\title{
REMOÇÃO DE CÉLULAS E SUBPRODUTOS DE MICROCYSTIS SPP. POR DUPLA FILTRAÇÃO, OXIDAÇÃO E ADSORÇÃO
}

Emília Kiyomi Kuroda

ORIENTADOR: Prof. Luiz Di Bernardo

Tese apresentada à Escola de Engenharia de São Carlos, da Universidade de São Paulo, como parte dos requisitos para obtenção do título de Doutor em Hidráulica e Saneamento

São Carlos

2006 


\section{DEDICATÓRIA}

Ao Mestre da vida,

Ao Mestre da sabedoria,

Ao Mestre dos mestres,

A minha capacidade vem do Senhor, por

isso, toda honra, toda glória, toda gratidão seja

dada ... somente a Ele! 


\section{AGRADECIMENTOS}

A Deus, por ter me capacitado de todas formas para a realização desse trabalho.

Ao Prof. Luiz Di Bernardo, pela orientação, pela oportunidade de aprendizado e confiança depositada na realização desse trabalho, pelos bons exemplos e, principalmente, pela inestimável amizade.

À minha valiosa mãe Somico e aos meus irmãos An, Guemi e Midori pelo apoio, carinho e compreensão, e de forma especial, à minha irmã Misae e toda sua família, por me acolherem com tanto amor quando precisei.

Ao meu pai Shigueo e minha avó Tomiko (in memorian) pelos exemplos de vida.

À Mirna, pela preciosa amizade.

À Marajainy, pelo companheirinho, presteza e amizade.

Aos Profs. Odete Rocha e Edson Rodrigues Filho, pelos trabalhos de colaboração técnica, apoios recebidos e incentivos para a continuidade da realização de pesquisas relacionadas ao tema.

Aos Professores do Departamento de Hidráulica e Saneamento da Escola de Engenharia de São Carlos pelos ensinamentos adquiridos. Aos Funcionários do Departamento, aos Técnicos de Laboratórios: Júlio, Paulo, Juliana, Janja, Bete e Luci, e aos Bolsistas: Patrícia e André, pelo apoio recebido na execução de experimentos e análises realizadas.

Às Profas. Maria do Carmo Calijuri, Eny Maria Vieira, Telma Franco, Sandra M. F. O. Azevedo e Célia Sant'Anna pelas colaborações técnicas e apoios de infra-estrutura laboratorial recebidos.

Aos parceiros de experimentos: Renata, Alessandro, Éden, Juliana e Alexandre.

À Renata, pela fundamental colaboração na execução dos ensaios em instalação piloto.

Aos Técnicos: “Gigante” do Departamento de Transportes e Oscar do Departamento de Geotecnia, pelos empréstimos de peneiras e equipamentos para preparação do material granular dos filtros, Flávio e Leny da Seção de Tratamento de Resíduos Químicos do Campus, pelos empréstimos de equipamentos e vidrarias. 
Ao Serviço Autônomo de Água e Esgoto de São Carlos por permitir a execução de experimentos na Instalação Piloto montada nas dependências da ETA 2 de São Carlos e aos Funcionários, pelo carinho, cuidado e atenção nunca negada.

À Fundação de Amparo à Pesquisa do Estado de São Paulo - FAPESP pela concessão de bolsa de doutorado (Proc. 01/13561-3) e auxílio financeiro (Proc. 02/08341-7).

À FINEP, CEF e CNPq, pelos recursos financeiros concedidos às pesquisas realizadas no âmbito do Programa de Pesquisa em Saneamento Básico- PROSAB Edital 4 Tema 1, que integrou este trabalho como um dos subprojetos.

Às Indústrias Tigre S.A. e Cardinali S.A. pelas doações de material para montagem da instalação piloto.

Aos colegas de trabalho da Universidade Estadual de Londrina - UEL, pela compreensão e apoio recebidos para finalização deste trabalho.

Aos colegas e às amizades que me acompanharam nestes anos e a todos aqueles que direta ou indiretamente contribuíram para a realização deste trabalho. 


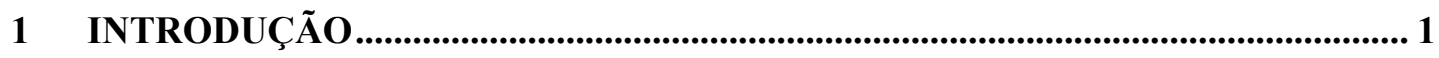

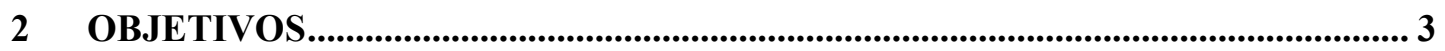

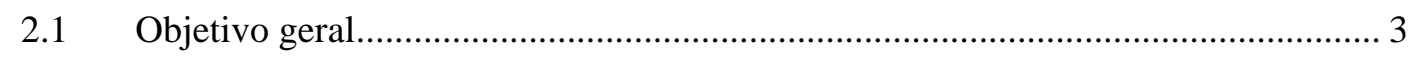

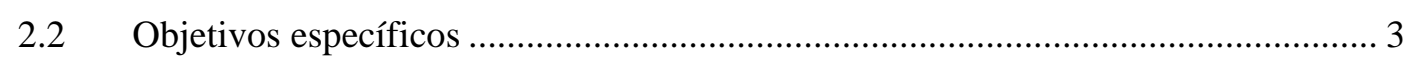

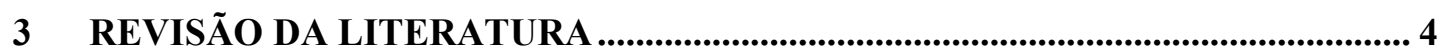

3.1 Efeitos da presença de organismos fitoplânctÔnicos em águas destinadas ao

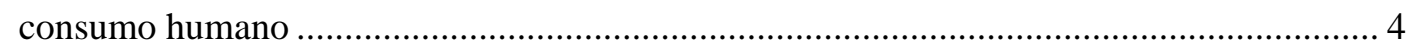

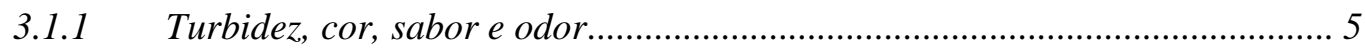

3.1.2 Formação de subprodutos organohalogenados - SPOs .................................. 6

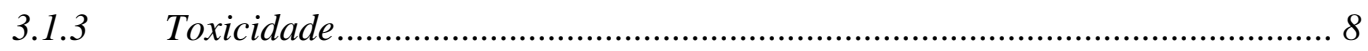

3.1.4 Obstrução do meio granular ....................................................................... 10

3.2 Água para consumo humano e Padrão de Potabilidade ......................................... 11

3.3 Dupla Filtração com Filtro Ascendente em Pedregulho ........................................ 13

3.4 Remoção de organismos fitoplânctônicos e subprodutos nos processos de tratamento de água para consumo humano ........................................................................ 16

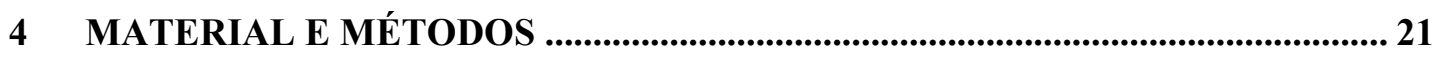

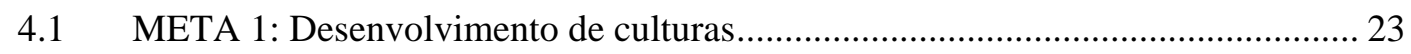

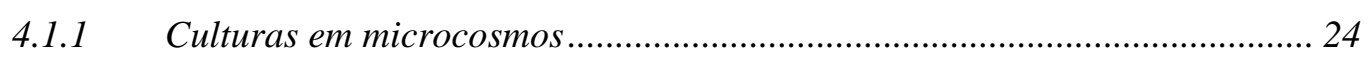

4.1.2 Culturas em mesocosmos e macrocosmos ..................................................... 25

4.2 META 2: Caracterização química e toxicológica de subprodutos.......................... 26

4.2.1 Caracterização química da principal microcistina produzida pela cepa

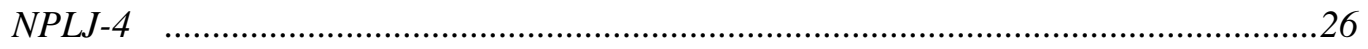

4.2.2 Caracterização toxicológica da cepa NPLJ-4 ............................................... 28

4.2.2.1 Preparação do extrato para o teste de toxicidade .......................................... 28

4.2.2.2 Teste de toxicidade aguda - 24h................................................................ 29

4.2.2.3 Análise de microcistinas MCs totais ............................................................ 30 
4.2.3 Avaliação do potencial de formação dos subprodutos organohalogenados PFSPOs 31

4.2.3.1 Experimento para obtenção das condições máximas de formação de SPOs 31

4.2.3.2 Caracterização física, química e microbiológica da AD e AE-A . 33

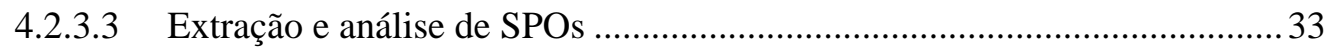

4.3 Estudo de métodos para análise de parâmetros de controle específicos...................34

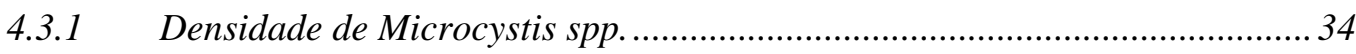

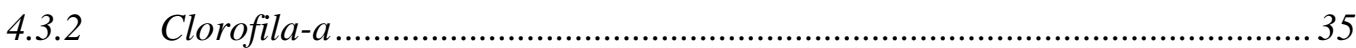

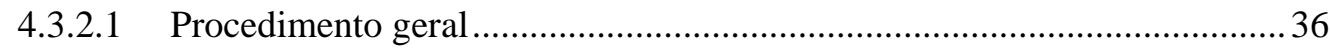

4.3.2.2 Testes realizados e principais resultados ......................................................... 37

4.3.2.3 Considerações em relação aos testes de extração de clorofila..................... 44

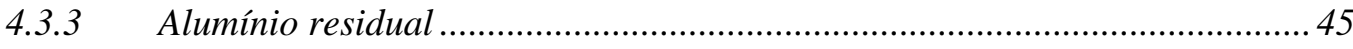

4.3.4 Subprodutos organohalogenados da oxidação - SPOs ................................... 48

4.3.4.1 Determinação de trihalometanos - TAMs, haloacetonitrilas - HANs, cloralhidrato - CH, halocetonas - HKs e halopicrinas - HPs .......................................... 48

4.3.4.2 Determinação dos ácidos haloacéticos - AHAs..............................................50

4.3.4.3 Cálculo do potencial de formação de subprodutos organohalogenados PFSPOs

4.3.5 Análise de microcistinas pelo método de imunoensaio ELISA (Enzyme-linked immunosorbent assay) .54

4.3.6 Análise de microcistinas por Cromatografia Líquida de Alta Eficiência com detector de UV e arranjo de diodos - HPLC-PDA (High Performance Liquid Chromatography - Photo Diode Array) .......................................................................... 56

4.3.6.1 Extração de microcistinas intracelulares - MC intra ...................................56

4.3.6.2 Purificação e concentração de microcistinas extracelulares - MC extra....57

4.3.6.3 Análise de microcistinas - MCs 59

4.4 META 4: Obtenção de parâmetros operacionais em ensaios de filtração direta em bancada. 63

4.4.1 Preparação da água de estudo tipo $1-A E-1$.................................................. 63

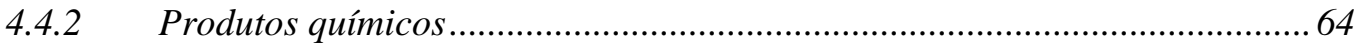

4.4.3 Equipamento jarteste e Filtros de laboratório de areia - FLAs ...................... 65

4.5 META 5: Obtenção de parâmetros operacionais em ensaios de oxidação em bancada 
4.6 META 6: Obtenção de parâmetros operacionais em ensaios de adsorção em bancada

4.6.1 Caracterização dos carvões ativados por meio dos índices de iodo e de azul de metileno.

4.6.2 Preparação do extrato de microcistinas - MCs ................................................ 71

4.6.3 Preparação das suspensões de carvão ativado ................................................ 72

4.6.4 Ensaio de adsorção de microcistinas - MCs.................................................. 73

4.6.5 Ajuste dos dados obtidos para iodo, azul de metileno e microcistina pelo modelo de adsorção de Freundlich.

4.7 METAs 7 e 8: Avaliação da remoção de células e subprodutos de Microcystis spp. com emprego de dupla filtração, oxidação e adsorção - ensaios em IP . 75

4.7.1 Fluxograma de distribuição de água ............................................................ 75

4.7.2 Descrição geral da instalação piloto - IP...................................................... 76

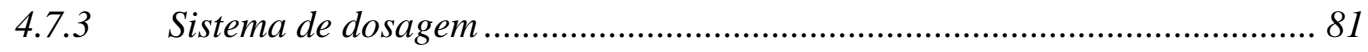

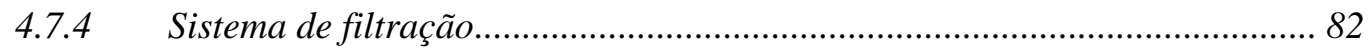

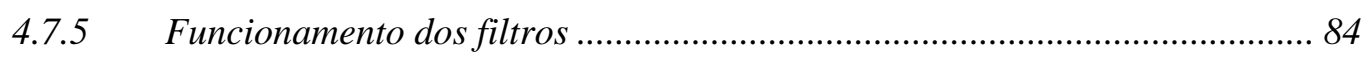

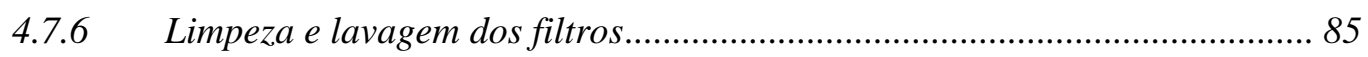

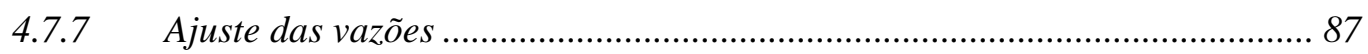

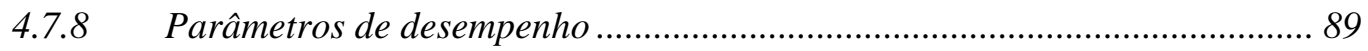

4.7.9 Testes de toxicidade aguda com dafinídeos (Ceriodaphnia dubia e Ceriodaphnia silvestrii) e biomonitoramento com peixes (Danio rerio)........................ 91

4.7.9.1 Cultivo de Ceriodaphnia spp ………........................................................... 91

4.7.9.2 Manutenção de Danio rerio (Teleostei, Cyprinidae) .................................. 92

4.7.9.3 Testes de toxicidade aguda e biomonitoramento ...................................... 93

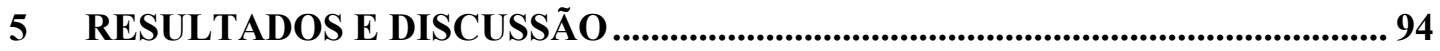

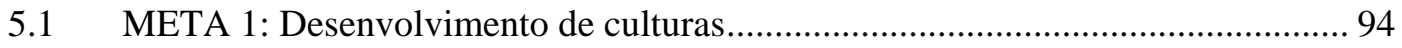

5.2 META 2: Caracterização química e toxicológica de subprodutos.......................... 97

5.2.1 Caracterização química da principal microcistina produzida pela cepa

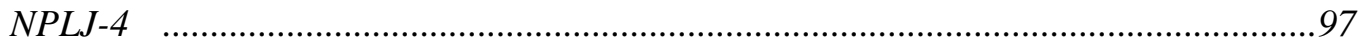

5.2.2 Caracterização toxicológica da cepa NPLJ-4 ............................................ 100

5.2.3 Avaliação do potencial de formação de subprodutos organohalogenados -

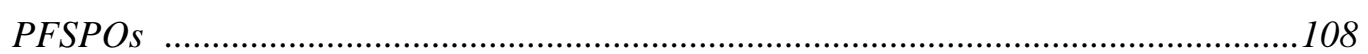

5.2.3.1 Caracterização física, química e microbiológica da AD e AE-A.............. 109 
5.2.3.2 Resultados do experimento para obtenção das condições máximas de formação de SPOs ....

5.2.3.3 Resultados do potencial de formação de subprodutos organohalogenados PFSPOs

5.3 META 4: Obtenção de parâmetros operacionais em ensaios de filtração direta em bancada

5.4 META 5: Obtenção de parâmetros operacionais em ensaios de oxidação em bancada

5.5 META 6: Obtenção de parâmetros operacionais em ensaios de adsorção em bancada

5.6 METAS 7 e 8: Avaliação da remoção de células e subprodutos de Microcystis spp. com emprego de dupla filtração, oxidação e adsorção - ensaios em IP

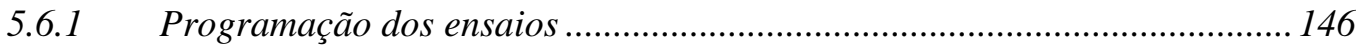

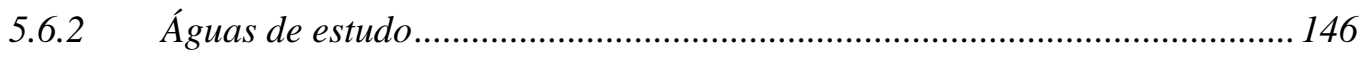

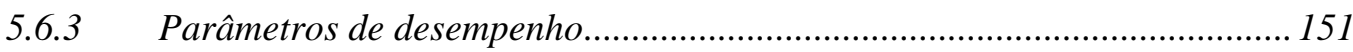

5.6.3.1 Remoção de células de Microcystis spp. ..................................................175

5.6.3.2 Remoção de partículas com tamanhos entre 1 e $10 \mu \mathrm{m}$...........................177

5.6.3.3 Remoção de microcistinas - MCs .............................................................. 180

5.6.3.4 Formação de subprodutos organohalogenados da oxidação.......................182

5.6.3.5 Testes de toxicidade aguda com dafinídeos e biomonitoramento com peixes .184

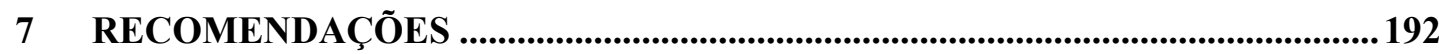

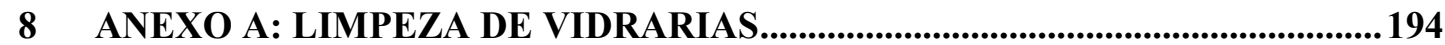

9 ANEXO B: PREPARAÇÃO DO MEIO ASM-1 ..................................................194

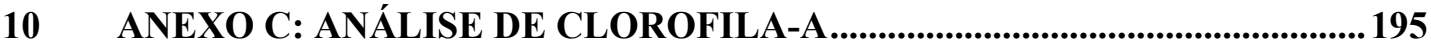

11 ANEXO D: ANÁLISE DE ALUMÍNIO RESIDUAL .............................................199

12 ANEXO E: RESULTADOS COMPLEMENTARES (PARÂMETROS DE CONTROLE OPERACIONAL E DE DESEMPENHO E TESTES 
ECOTÓXICOLÓGICOS COM MICROCRUSTÁCEOS) DOS ENSAIOS EM INSTALAÇÃO PILOTO - FASES 2 E 3 .......................................................................... 200

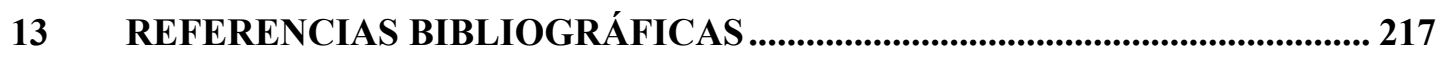




\section{LISTA DE FIGURAS}

Figura 3.1.1 - Aspectos de diferentes florações FONTE: http://www-

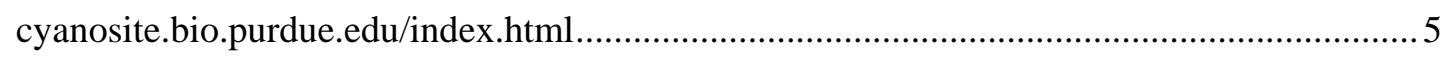
Figura 3.1.2 - Gêneros de cianobactérias potencialmente tóxicas freqüentemente encontrados em ecossistemas aquáticos continentais. FONTE: Brandão \& Azevedo, 2001 .......................10 Figura 3.2.1 - Distribuição de tamanhos das partículas na água ............................................11 Figura 3.4.1 - Diagrama de seleção de processos. FONTE: Janssens e Buekens, 1993 .........17 Figura 3.4.2 - Concentrações de microcistina nas águas bruta e tratada (Neenah, verão de 1998) e Porcentagem remanescente de microcistina nos processos de tratamento (Neenah,

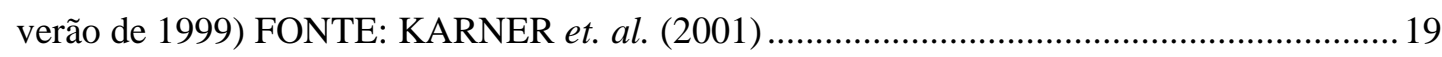
Figura 4.1.1 - Vista geral das culturas de Microcystis spp. em microcosmos - 15 dias após inoculação. 25

Figura 4.1.2 - Vista geral dos aspectos da cultura de Microcystis spp. em mesocosmos após inoculação em meio ASM-1 realizado em 30/01/2004 25

Figura 4.1.3- Vista geral da montagem do aquário com capacidade de $200 \mathrm{~L}$ pata cultivo de Microcystis spp em macrocosmos. 26

Figura 4.1.4 - Vista geral dos aspectos da cultura de Microcystis spp em macrocosmos após inoculação em meio ASM-1 .26 Figura 4.2.1 - Fluxograma das principais etapas realizadas para a caracterização química da principal microcistina produzida pela cepa toxigênica NPLJ4 27 Figura 4.2.2 - Vista geral da culturas de Microcystis spp. NPLJ-4 em diferentes fases do processo de concentração .29 Figura 4.2.3 - Vista geral da cultura de Microcystis spp. NPLJ-4 concentrada antes, durante e

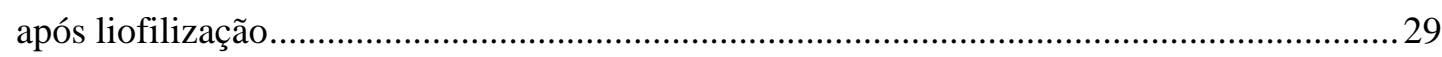

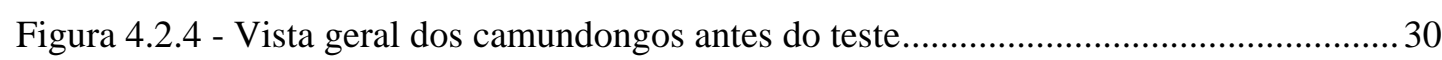
Figura 4.2.5 - Vista geral das águas de diluição e de estudo preparadas para o experimento de determinação do PFSPOs 31

Figura 4.2.6 - Planejamento experimental realizado para avaliação do potencial de formação dos subprodutos organohalogenados - PFSPOs. 32 
Figura 4.2.7 - Vista geral do experimento: incubação das amostras a $25^{\circ} \mathrm{C}$ por 3 e 7 dias no escuro

Figura 4.3.1 - Vista geral das câmaras de sedimentação e preparação das amostras para contagem

Figura 4.3.2 - Estrutura do Teste T2: três amostras contendo células de Microcystis spp., utilização de três solventes (etanol, metanol e acetona) e leitura em cubetas com caminho ótico diferentes (1 e $100 \mathrm{~mm}$ )

Figura 4.3.3 - Curvas de concentrações de clorofila em relação a densidade de células de Microcystis spp. nos três métodos de extração: acetona, etanol e metanol e respectivos índices de correlação obtidos no Teste T2

Figura 4.3.4 - Estrutura do Teste T3: seis amostras contendo células de Microcystis spp., utilização de três solventes (acetona, etanol e metanol) e leitura em cubetas com caminho ótico PL=10 mm

Figura 4.3.5- Curvas de concentrações de clorofila em relação a densidade de células de Microcystis spp. nos três métodos (acetona, etanol e metanol) e respectivos índices de correlação obtidos no Teste T3

Figura 4.3.6 - Estrutura do Teste T4: seis amostras contendo de células de Microcystis spp. utilização de quatro solventes (acetona, etanol, metanol e clorofórmio-metanol) e leitura em cubetas com caminho ótico PL=10 mm. 42 Figura 4.3.7- Curvas de concentrações de clorofila em relação a densidade de células de Microcystis spp. nos quatro métodos testados: acetona, etanol, metanol e metanolclorofórmio e respectivos índices de correlação obtidos no Teste T4

Figura 4.3.8- Estrutura do Teste T5: seis amostras contendo de células de Microcystis spp., utilização de metanol, leitura em cubetas com caminho ótico PL=10 mm, com e sem a adição de $\mathrm{MgCO}_{3}$.

Figura 4.3.9 - Concentrações de Clorofila-a extraídas por metanol, etanol, acetona e clorofórmio-metanol para água natural com 88,2\% de Microcystis spp. obtidos no Teste 644 Figura 4.3.10 - Estrutura do teste comparativo entre os métodos de análise de alumínio ..... 46 Figura 4.3.11 - Vista geral das amostras para o teste analítico comparativo para alumínio residual

Figura 4.3.12 - Cromatograma (típico) de um ponto da curva de calibração EPA 551 .......... 50

Figura 4.3.13 - Cromatograma (típico) de um ponto da curva de calibração EPA 552 ......... 52

Figura 4.3.14 - Exemplo ilustrativo do cálculo do PFSPOs de t dias .................................... 53

Figura 4.3.15 - Ilustração do processo de reação do método de imunoensaio ELISA........... 54 
Figura 4.3.16 - Fotos ilustrativas do material e equipamentos utilizados nas análises pelo método de imunoensaio ELISA ..... .55 Figura 4.3.17 - Curva de calibração e resultado da intercalibração laboratorial para MCs por ELISA. .56

Figura 4.3.18 - Vista geral dos extratos brutos de MCs em diferentes fases. .57

Figura 4.3.19 - Vista geral da bancada de concentração e purificação e dos cartuchos de C18 e de sílica. .58

Figura 4.3.20 - Vista geral dos extratos semipurificados após passagem em cartucho de C18 e purificado após passagem em cartucho de sílica .58

Figura 4.3.21 - Vista geral da etapa de concentração dos extratos de microcistinas. 59

Figura 4.3.22 - Fotos das etapas de concentração das amostras e dos extratos purificados .. 59 Figura 4.3.23 - Vista geral da etapa de filtração do extrato purificado concentrado ...............59 Figura 4.3.24 - Sobreposição dos cromatogramas resultantes para MC-RR, MC-LR e [DLeu ${ }^{1}$ MC-LR 60

Figura 4.3.25 - Planilha de cálculo e uma curva de calibração (típica) de MC-RR 61

Figura 4.3.26 - Planilha de cálculo e uma curva de calibração (típica) de MC-LR 61

Figura 4.3.27 - Planilha de cálculo e uma curva de calibração (típica) de [D-Leu ${ }^{1}$ MC-LR 62 Figura 4.3.28 - Fotos do HPLC e da coluna analítica de octadecil-silano ODS (C-18)..........62

Figura 4.4.1 - Esquema ilustrativo da preparação da AE 63

Figura 4.4.2 - Vista geral da cultura de Microcystis spp.NPLJ-4 e água de estudo da série A 64

Figura 4.4.3 - Curva de gradiente de velocidade em função da rotação aplicada e tabela de

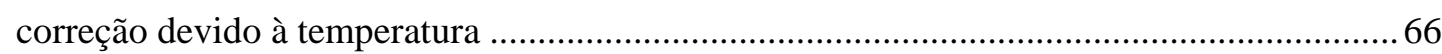

Figura 4.4.4 - Sistema de FLAs acoplado ao equipamento jarteste .......................................66

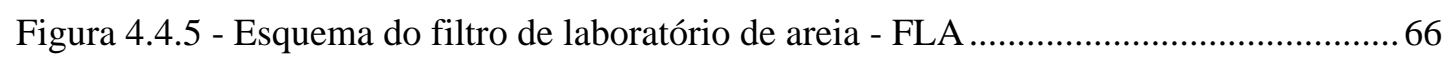

Figura 4.5.1 - Fotos da cultura de Microcystis spp.e da água de estudo AE-A .......................67

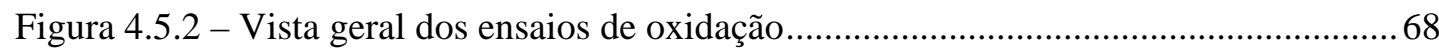

Figura 4.6.1 - Fluxograma das principais etapas realizadas para seleção e caracterização dos carvões ativados

Figura 4.6.2 - Vista geral das diferentes etapas do ensaio para determinação do índice ou

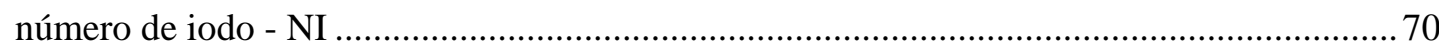

Figura 4.6.3 - Vista geral das diferentes etapas do ensaio para determinação do índice de azul

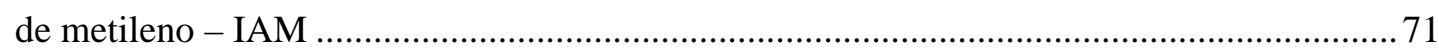

Figura 4.6.4 - Esquema da preparação do extrato bruto não purificado de microcistinas.......71 
Figura 4.6.5 - Vista geral dos extratos em diferentes etapas de preparação ........................... 72

Figura 4.6.6 - Vista geral das diferentes etapas de moagem do CA....................................... 73

Figura 4.6.7 - Vista geral das diferentes etapas do ensaio de adsorção de MCs .................... 74

Figura 4.7.1 - Fluxograma de distribuição de água na IP ....................................................... 76

Figura 4.7.2 - Vista geral do sistema de reservação e alimentação de água fitrada da ETA (sem cloro) para a Câmara de Nível Constante.....

Figura 4.7.3 - Fotos das Unidades de regularização de nível e preparação da água de estudo

Figura 4.7.4 - Fotos das colunas de oxidação e de adsorção 77

Figura 4.7.5 - Fotos das unidades de mistura rápida e de regularização / distribuição de vazão 79

Figura 4.7.6 b - Fotos da Instalação e do sistema de recepção e pós-tratamento dos efluentes gerados 80

Figura 4.7.7 - Tanques de produtos químicos e amostras de suspensão de carvão ativado em pó - CAP. 82

Figura 4.7.8 - Detalhes das unidades filtrantes que compõem a IP 83

Figura 4.7.9 - Curva granulométrica da areia do filtro descendente - FD. FONTE: KURODA, (2002). 84

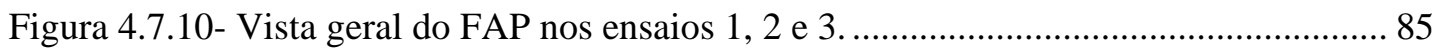

Figura 4.7.11 - Vista geral da execução de DFI no FAP nos ensaios 1, 2 e 3........................ 86

Figura 4.7.12 - Esquema da Câmara de Nível Constante - CNC ............................................. 87

Figura 4.7.13 - Esquema geral da IP contendo as adaptações realizadas............................... 88

Figura 4.7.14 - Fêmeas de (a) Ceriodaphnia dubia Richard e (b) e Ceriodaphnia silvestrii

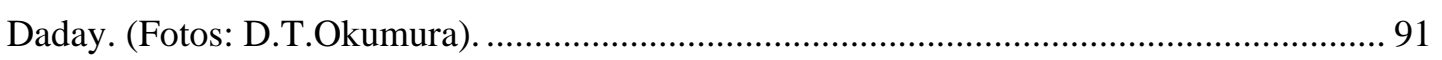

Figura 4.7.15 - a) Cultivo da alga cloroífcea Pseudokirchneriella subcapitata e, em detalhe, b) vista sob microscópio óptico. (Fotos: R.A.Takenaka e R.M.B.Sotero-Santos).................. 92 Figura 4.7.16 - a) Biomonitoramento de Danio rerio nos em ensaios na instalação piloto - IP e b) Danio rerio (Teleostei, Cyprinidae) (Foto da Internet) 93 Figura 5.1.1 - Vista geral do espaço reservado para as culturas em microcosmos e detalhes do aspecto das culturas de Microcystis spp. antes e 15 dias após a inoculação 95 Figura 5.1.2 - Imagem da cultura de Microcystis spp NPLJ4 (aumento 100x) mantida sob aeração 95

Figura 5.1.3 - Imagem da cultura de Microcystis spp. (aumento 100x) submetida à agitação manual diária. 
Figura 5.2.1 - Estrutura química da microcistina-LR (Z e X representam os dois Laminoácidos variáveis e R1 e R2 são os locais de possíveis metilações. FONTE: adaptado de CARMICHAEL (2006). 98

Figura 5.2.2 - Cromatogramas e espectros de UV a $238 \mathrm{~nm}$ do extrato semipurificado e do padrão de MC-LR. .99

Figura 5.2.3 - Espectros de massas do extrato semipurificado e do padrão de MC-LR....... 100 Figura 5.2.4 - Planejamento experimental realizado para avaliação da toxicidade da cepa NPLJ-4 101

Figura 5.2.5 - Hepatócitos e capilares sinusoidais antes e após a atuação de hepatotoxinas. FONTE: adaptado de CARMICHAEL (1994). 102

Figura 5.2.6 - Vista geral dos camundongos durante e após o teste. 102

Figura 5.2.7 - Concentração de MCs totais nos extratos e dosagens correspondentes de MCs

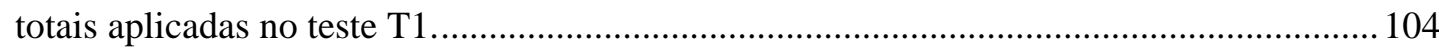

Figura 5.2.8 - Vista dos camundongos durante o teste T2 (17:00 h) .................................. 105

Figura 5.2.9 - Concentração de MCs totais nos extratos e dosagens correspondentes de MCs totais aplicadas no teste $\mathrm{T} 2$ 106

Figura 5.2.10 - Valores do potencial de formação de subprodutos organohalogenados PFSPOs das águas de estudo AE-A e AE-B, para os tempos de contato de 3 e 7 dias a $25^{\circ} \mathrm{C}$ 115

Figura 5.2.11 - Resultados de PFSPOs de 7 dias obtidos para as águas de estudo AE-A e AEB. 116

Figura 5.2.12 - Resultados de PFSPOs de 7 dias obtidos para a AE de Paschoalato (2005)116 Figura 5.3.1 - Condições de coagulação, turbidez e densidade de M.spp do Ensaio 8 / Série D 120

Figura 5.3.2 - Absorvância 254 nm, carbono orgânico total e alumínio residual do Ensaio 8 / Série D 121

Figura 5.3.3 - Número e distribuição de partículas do Ensaio 8 / Série D 122

Figura 5.3.4- Curvas de distribuição granulométrica preparadas para os FLAs 124 Figura 5.3.5 - Resultados de turbidez, número de partículas, potencial zeta, densidade de Microcystis spp., alumínio residual, carbono orgânico total e absorvância 254 nm dos efluentes filtrados para a dosagem de $0,45 \mathrm{mg} / \mathrm{L}$ de alumínio e diferentes valores de pH. .127 Figura 5.3.6 - Resultados dos ensaios da Série G. Diagrama de coagulação química com sulfato de alumínio / Potencial zeta (mV). ( • : pontos sem ajuste do pH de coagulação)...129 
Figura 5.3.7 - Resultados dos ensaios da Série G. Diagrama de coagulação química com sulfato de alumínio / Turbidez (uT). ( • : pontos sem ajuste do pH de coagulação).

Figura 5.3.8 - Resultados dos ensaios da Série G. Diagrama de coagulação química com sulfato de alumínio / Distribuição de partículas ( $\mathrm{N}^{\circ}$ Part. $(1$ a $10 \mu \mathrm{m})$ / mL). ( • : pontos sem ajuste do pH de coagulação)

Figura 5.3.9 - Resultados dos ensaios da Série G. Diagrama de coagulação química com sulfato de alumínio / Densidade de Microcystis spp. (cel/mL). ( • : pontos sem ajuste do pH de coagulação)

Figura 5.3.10 - Resultados dos ensaios da Série G. Diagrama de coagulação química com sulfato de alumínio / Alumínio residual (mg/L). ( • : pontos sem ajuste do pH de coagulação)

Figura 5.3.11 - Sistema de FLAs e FCAGs acoplados ao equipamento jarteste. 132

Figura 5.3.12 - Resultados dos ensaios da Série B: \% imobilidade dos dafinídeos Ceriodaphnia dubia e Ceriodaphnia silvestrii (Crustacea, Cladocera) para os ensaios 3 e 4 da série $\mathrm{B}$. ( $\mathrm{AD}$ = água de diluição; $\mathrm{AE}=$ água de estudo). 132

Figura 5.4.1 - Valores de demanda de oxidantes para os tempos de contato de 30, 60 e 120 minutos / Ensaio de oxidação da série-A

Figura 5.4.2 - Resultados de MCs totais do ensaio de oxidação da série-B. 138 Figura 5.4.3 - Decomposição de microcistinas - MCs pelo cloro para diferentes dosagens e concentração inicial de $100 \mu \mathrm{g} / \mathrm{L}$ 139

Figura 5.5.1 - Número de iodo e índice de azul de metileno dos carvões ativados granulares e pulverizados amostrados 141

Figura 5.5.2 - Isotermas de adsorção de microcistina não purificada para o carvão ativado granular 1 143

Figura 5.5.3 - Isotermas de adsorção de microcistina não purificada para o carvão ativado pulverizado 6 .

Figura 5.5.4 - Resumo dos resultados obtidos na caracterização dos carvões ativados granular e pulverizado selecionados 145

Figura 5.6.1 - Sistemas de tratamento utilizados nos ensaios para avaliação da remoção de células e subprodutos de Microcystis spp. 146 Figura 5.6.2 - Vista supeior da suspensão de células de Microcystis spp. e extrato de microcistinas - MCs 
Figura 5.6.4 - Densidade fitoplanctônica da amostragem pontual realizada em função da profundidade no Reservatório de Barra Bonita - SP. 149

Figura 5.6.5 - Densidade de Cyanophyceae da amostragem pontual realizada em função da profundidade no Reservatório de Barra Bonita - SP. 150

Figura 5.6.6 - Vista geral do material coletado no reservatório de Barra Bonita - SP e da suspensão empregada para compor a AE-3.

Figura 5.6.7 - Variação dos valores de turbidez em função do tempo nas águas de diluição e de estudo e nos efluentes de cada processo de tratamento do ENSAIO 1-IP 153 Figura 5.6.8 - Densidade de Microcystis spp. $\left(\mathrm{E}+0 \mathrm{x}=10^{\mathrm{x}}\right)$ na água de estudo e nos efluentes de cada processo de tratamento para diferentes tempos de amostragem do ENSAIO 1-IP .154 Figura 5.6.9 - Número de partículas (entre 1 e $10 \mu \mathrm{m}$ ) nas águas de diluição e de estudo e nos efluentes de cada processo de tratamento para diferentes tempos de amostragem do ENSAIO 1-IP 154

Figura 5.6.10 - Concentração de microcistinas - MCs extracelulares na água de estudo e nos efluentes de cada processo de tratamento para diferentes tempos de amostragem do ENSAIO 1-IP 155

Figura 5.6.11 - Concentração de subprodutos organohalogenados - SPOs formados na água de estudo e nos efluentes de cada processo de tratamento para amostragem de 6 h do ENSAIO 1-IP 155

Figura 5.6.12 - Variação dos valores de turbidez em função do tempo nas águas de diluição e de estudo e nos efluentes de cada processo de tratamento do ENSAIO 2-IP. 156 Figura 5.6.13 - Densidade de Microcystis spp. $\left(\mathrm{E}+0 \mathrm{x}=10^{\mathrm{x}}\right)$ na água de estudo e nos efluentes de cada processo de tratamento para diferentes tempos de amostragem do ENSAIO 2-IP 157

Figura 5.6.14 - Número de partículas (entre 1 e $10 \mu \mathrm{m}$ ) nas águas de diluição e de estudo e nos efluentes de cada processo de tratamento para diferentes tempos de amostragem do ENSAIO 2-IP 157 Figura 5.6.15 - Concentração de microcistinas - MCs extracelulares na água de estudo e nos efluentes de cada processo de tratamento para diferentes tempos de amostragem do ENSAIO 2-IP 158

Figura 5.6.16 - Concentração de subprodutos organohalogenados - SPOs formados na água de estudo e nos efluentes de cada processo de tratamento para amostragem de 6 h do ENSAIO 2-IP 158 
Figura 5.6.17 - Variação dos valores de turbidez em função do tempo nas águas de diluição e de estudo e nos efluentes de cada processo de tratamento do ENSAIO 3-IP 159 Figura 5.6.18 - Densidade de Microcystis spp. $\left(\mathrm{E}+0 \mathrm{x}=10^{\mathrm{x}}\right)$ na água de estudo e nos efluentes de cada processo de tratamento para diferentes tempos de amostragem do ENSAIO 3-IP.

Figura 5.6.19 - Número de partículas (entre 1 e $10 \mu \mathrm{m}$ ) nas águas de diluição e de estudo e nos efluentes de cada processo de tratamento para diferentes tempos de amostragem do ENSAIO 3-IP 160

Figura 5.6.20 - Concentração de microcistinas - MCs extracelulares na água de estudo e nos efluentes de cada processo de tratamento para diferentes tempos de amostragem do ENSAIO 3-IP

Figura 5.6.21 - Concentração de subprodutos organohalogenados - SPOs formados na água de estudo e nos efluentes de cada processo de tratamento para amostragem de $6 \mathrm{~h}$ do ENSAIO 3-IP 161

Figura 5.6.22 - Variação dos valores de turbidez em função do tempo nas águas de diluição e de estudo e nos efluentes de cada processo de tratamento do ENSAIO 4-IP (\#)..... 162 Figura 5.6.23 - Densidade de Microcystis spp. $\left(\mathrm{E}+0 \mathrm{x}=10^{\mathrm{x}}\right)$ na água de estudo e nos efluentes de cada processo de tratamento para diferentes tempos de amostragem do ENSAIO 4-IP (\#)

Figura 5.6.24 - Número de partículas (entre 1 e $10 \mu \mathrm{m}$ ) nas águas de diluição e de estudo e nos efluentes de cada processo de tratamento para diferentes tempos de amostragem do ENSAIO 4-IP (\#) 163

Figura 5.6.25 - Concentração de microcistinas - MCs extracelulares na água de estudo e nos efluentes de cada processo de tratamento para diferentes tempos de amostragem do ENSAIO 4-IP (\#) 164

Figura 5.6.26 - Concentração de subprodutos organohalogenados - SPOs formados na água de estudo e nos efluentes de cada processo de tratamento para amostragem de 6 h do ENSAIO 4-IP (\#) 164

Figura 5.6.27 - Variação dos valores de turbidez em função do tempo nas águas de diluição e de estudo e nos efluentes de cada processo de tratamento do ENSAIO 5-IP 165 Figura 5.6.28 - Densidade de Microcystis spp. $\left(\mathrm{E}+0 \mathrm{x}=10^{\mathrm{x}}\right)$ na água de estudo e nos efluentes de cada processo de tratamento para diferentes tempos de amostragem do ENSAIO 5-IP 166 
Figura 5.6.29 - Número de partículas (entre 1 e $10 \mu \mathrm{m}$ ) nas águas de diluição e de estudo e nos efluentes de cada processo de tratamento para diferentes tempos de amostragem do ENSAIO 5-IP 166

Figura 5.6.30 - Concentração de microcistinas - MCs extracelulares na água de estudo e nos efluentes de cada processo de tratamento para diferentes tempos de amostragem do ENSAIO 5-IP 167

Figura 5.6.31 - Concentração de subprodutos organohalogenados - SPOs formados na água de estudo e nos efluentes de cada processo de tratamento para amostragem de $6 \mathrm{~h}$ do ENSAIO 5-IP 167

Figura 5.6.32 - Variação dos valores de turbidez em função do tempo nas águas de diluição e de estudo e nos efluentes de cada processo de tratamento do ENSAIO 6-IP 168 Figura 5.6.33 - Densidade de Microcystis spp. $\left(\mathrm{E}+0 \mathrm{x}=10^{\mathrm{x}}\right)$ na água de estudo e nos efluentes de cada processo de tratamento para diferentes tempos de amostragem do ENSAIO 6-IP 169

Figura 5.6.34 - Número de partículas (entre 1 e $10 \mu \mathrm{m}$ ) nas águas de diluição e de estudo e nos efluentes de cada processo de tratamento para diferentes tempos de amostragem do ENSAIO 6-IP 169

Figura 5.6.35 - Concentração de subprodutos organohalogenados - SPOs formados na água de estudo e nos efluentes de cada processo de tratamento para amostragem de 6 h do ENSAIO 6-IP 170

Figura 5.6.36 - Variação dos valores de turbidez em função do tempo nas águas de diluição e de estudo e nos efluentes de cada processo de tratamento do ENSAIO 7-IP. 171 Figura 5.6.37 - Densidade de Microcystis spp. $\left(\mathrm{E}+0 \mathrm{x}=10^{\mathrm{x}}\right)$ na água de estudo e nos efluentes de cada processo de tratamento para diferentes tempos de amostragem do ENSAIO 7-IP 171

Figura 5.6.38 - Número de partículas (entre 1 e $10 \mu \mathrm{m}$ ) nas águas de diluição e de estudo e nos efluentes de cada processo de tratamento para diferentes tempos de amostragem do ENSAIO 7-IP 172

Figura 5.6.39 - Concentração de subprodutos organohalogenados - SPOs formados na água de estudo e nos efluentes de cada processo de tratamento para amostragem de $6 \mathrm{~h}$ do ENSAIO 7-IP ..... 172

Figura 5.6.40 - Variação dos valores de turbidez em função do tempo nas águas de diluição e de estudo e nos efluentes de cada processo de tratamento do ENSAIO 8-IP 173 
Figura 5.6.41 - Densidade de Microcystis spp. $\left(\mathrm{E}+0 \mathrm{x}=10^{\mathrm{x}}\right)$ na água de estudo e nos efluentes de cada processo de tratamento para diferentes tempos de amostragem do ENSAIO 8-IP 174

Figura 5.6.42 - Número de partículas (entre 1 e $10 \mu \mathrm{m}$ ) nas águas de diluição e de estudo e nos efluentes de cada processo de tratamento para diferentes tempos de amostragem do ENSAIO 8-IP 174

Figura 5.6.43 - Concentração de subprodutos organohalogenados - SPOs formados na água de estudo e nos efluentes de cada processo de tratamento para amostragem de 6 h do ENSAIO 8-IP 175

Figura 5.6.44 - \% imobilidade de Ceriodaphnia silvestrii para efluentes de processos de tratamento em diferentes tempos de amostragens dos Ensaios 5, 6, 7 e 8 - em IP, antes e após correção da dureza 185 


\section{LISTA DE TABELAS}

Tabela 3.1.1 - Características dos cinco principais compostos que conferem sabor e odor às águas. ADAPTADO de DI BERNARDO (1995) . 6

Tabela 3.1.2 - Subprodutos da oxidação para diferentes tipos de oxidantes. ADAPTADO de USEPA (1999). .8

Tabela 3.1.3 - Principais gêneros de cianobactérias produtoras de toxinas, suas toxinas específicas, qrupo químico e os tecidos / órgãos primeiramente afetados em humanos. ADAPTADO de CHORUS \& BARTRAM (1999). .9

Tabela 3.2.1 - Plano mínimo de amostragem para concentração de trihalometanos. ADAPTADO de Portaria 518/MS 2004. 13

Tabela 3.3.1 - Parâmetros de qualidade da água bruta para o emprego da dupla filtração e parâmetros de projeto. ADAPTADO de DI BERNARDO \& DANTAS (2005) 14 Tabela 3.3.2 - Características da água bruta observadas nos ensaios realizados por CEZAR et. al. (2000) 15

Tabela 3.3.3 -Valores de eficiência média de remoção de turbidez e clorofila-a e duração da carreira de filtração nos PFAP e FDAP obtidos por CEZAR et. al. (2000)..... 15

Tabela 4.2.1 - Condições experimentais empregadas para determinação do potencial de formação dos subprodutos organohalogenados - PFSPOs 32

Tabela 4.3.1 - Valores de constante de proporcionalidade utilizada no calculo da clorofila-a para cada solvente testado .37

Tabela 4.3.2 - Condições experimentais e principais resultados do Teste T1 .38 Tabela 4.3.3 - Densidade de células de Microcystis spp e concentrações de clorofila-a determinadas pelos métodos da Acetona 90\%, Metanol 100\% e Etanol 80\% a quente, com

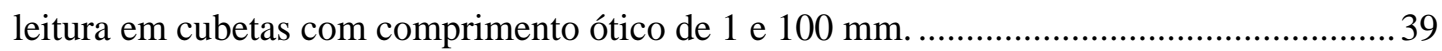

Tabela 4.3.4 - Classificação fitoplanctônica da amostra natural ............................................44

Tabela 4.3.5 - Concentrações de alumínio residual obtidos nos testes comparativos .............47

Tabela 4.3.6 - Concentrações de alumínio residual para diferentes tipos de água de diluição 48

Tabela 4.7.1 - Características do Material Granular do FAP. FONTE: KURODA, (2002)... 83 Tabela 4.7.2 - Características do Material Granular do FD. FONTE: KURODA, (2002) .... 84 
Tabela 4.7.3 - Parâmetros de desempenho e seus respectivos métodos de análise, pontos e freqüências de amostragem

Tabela 5.1.1 - Exemplo do monitoramento de contaminação das culturas em microcosmos (erlenmeyers de $250 \mathrm{~mL}$ )

Tabela 5.1.2 - Exemplo do monitoramento de contaminação da cultura em mesocosmos.... 97

Tabela 5.1.3 - Exemplo do monitoramento de contaminação da cultura em macrocosmos .. 97

Tabela 5.2.1 - Resultados do Teste T1 com camundongos................................................. 103

Tabela 5.2.2 - Resultados do Teste T2 com camundongos.................................................. 105

Tabela 5.2.3 - Resumo dos principais resultados obtidos nos testes T1 e T2 com camundongos 106

Tabela 5.2.4 - Limites de toxicidade de material seco e de toxinas propostos por LAWTON et. al. (1994b)

Tabela 5.2.5 - Caracterização física, química e microbiológica das águas de diluição - AD e de estudo da série A - AE-A

Tabela 5.2.6 - Resultados de cloro residual livre com tempo de contato de 3 e 7 dias a $25^{\circ} \mathrm{C}$ para obtenção das amostras representativas da condição máxima de formação de SPOs ... 111 Tabela 5.2.7 - Subprodutos organohalogenados - SPOs das águas de diluição e águas de estudo AE-A e AE-B, para o tempo de contato de 3 dias a $25^{\circ} \mathrm{C}$ 112 Tabela 5.2.8 - Subprodutos organohalogenados - SPOs das águas de diluição e águas de estudo AE-A e AE-B, para o tempo de contato de 7 dias a $25^{\circ} \mathrm{C}$

Tabela 5.2.9 - Valores absolutos do potencial de formação de subprodutos organohalogenados - PFSPOs das águas de estudo AE-A e AE-B, para o tempo de contato de 7 dias a $25^{\circ} \mathrm{C}$

Tabela 5.2.10 - Distribuição dos valores de potencial de formação de subprodutos organohalogenados - PFSPOs das águas de estudo AE-A e AE-B, para os tempos de contato de 3 e 7 dias a $25^{\circ} \mathrm{C}$ em porcentagem 115

Tabela 5.3.1 - Principais características físicas, químicas e microbiológicas das águas de estudo utilizadas. 117

Tabela 5.3.2 - Resultados do ensaio realizado para reprodução das melhores condições de coagulação obtidas para cada tipo de coagulante (Ensaio 8 / Série D) 119

Tabela 5.3.3 - Ensaio para avaliar a influência da variação das características da água de diluição (pH baixo) (Ensaio 9 / Série E)

Tabela 5.3.4 - Ensaio para avaliar a influência da variação das características da água de diluição (turbidez elevada) (Ensaio 10 / Série F). 
Tabela 5.3.5 - Valores de correlação obtidos entre os parâmetros analisados para efluentes filtrados, fixando-se a dosagem de coagulante e variando-se o $\mathrm{pH}$. 125 Tabela 5.3.6 - Valores de correlação entre os parâmetros analisados obtidos para efluentes filtrados. 126

Tabela 5.4.1 - Valores de demanda e de residual de oxidantes para os tempos de contato de 30, 60 e 120 minutos / Ensaio de oxidação da série-A. 134

Tabela 5.4.2 - Valores de densidade de $M$. spp., absorvância 254 nm e concentração de carbono orgânico total da AE-A e amostras após oxidação / Ensaio de oxidação da série A 136

Tabela 5.4.3 - Resultados do ensaio de oxidação da série-B 137

Tabela 5.5.1 - Parâmetros obtidos pela isoterma de adsorção de iodo e de azul de metileno dos carvões ativados granulares e pulverizados amostrados 141

Tabela 5.5.2 - Área da Superfície Específica BET-N2 e distribuição de poros dos carvões ativados granular e pulverizado selecionados 142

Tabela 5.5.3 - Parâmetros obtidos pelas isotermas de adsorção de microcictinas não purificadas para os carvões ativados granular e pulverizado selecionados. 143

Tabela 5.5.4 - Resumo dos principais resultados da caracterização de carvões ativados pulverizados em trabalhos citados.

Tabela 5.6.1 -Caracterização da água do Reservatório de Barra Bonita / Amostragem pontual em função da profundidade

Tabela 5.6.2 - Caracterização das águas de estudo empregadas nos ENSAIOS 1 a 8 151

Tabela 5.6.3 - Resumo das condições de funcionamento e dos parâmetros de desempenho para os controles operacional e qualitativo do ENSAIO 1-IP (em instalação piloto) 153 Tabela 5.6.4 - Resumo das condições de funcionamento e dos parâmetros de desempenho para os controles operacional e qualitativo do ENSAIO2-IP (em instalação piloto) 156 Tabela 5.6.5 - Resumo das condições de funcionamento e dos parâmetros de desempenho para os controles operacional e qualitativo do ENSAIO3-IP (em instalação piloto) 159 Tabela 5.6.6 - Resumo das condições de funcionamento e dos parâmetros de desempenho para os controles operacional e qualitativo do ENSAIO4-IP (em instalação piloto) 162 Tabela 5.6.7 - Resumo das condições de funcionamento e dos parâmetros de desempenho para os controles operacional e qualitativo do ENSAIO5-IP (em instalação piloto) 165 Tabela 5.6.8 - Resumo das condições de funcionamento e dos parâmetros de desempenho para os controles operacional e qualitativo do ENSAIO 6-IP (em instalação piloto) 168 
Tabela 5.6.9 - Resumo das condições de funcionamento e dos parâmetros de desempenho para os controles operacional e qualitativo do ENSAIO 7-IP (em instalação piloto)... 170

Tabela 5.6.10 - Resumo das condições de funcionamento e dos parâmetros de desempenho para os controles operacional e qualitativo do ENSAIO 8-IP (em instalação piloto)........... 173 Tabela 5.6.11 - Valores mínimo e máximo de densidade de Microcystis spp. e eficiências médias parcial e acumulada observados nos ENSAIOS 1 a 6

Tabela 5.6.12 - Tabela típica de dados de partículas para amostra coletada na $1^{\mathrm{a}}$ hora do ENSAIO 1

Tabela 5.6.13 - Valores mínimo e máximo de patículas (com tamanhos entre 1 e $10 \mu \mathrm{m}$ ) / $\mathrm{mL}$ e de eficiência acumulada observados nos ENSAIOS 1 a 8 .

Tabela 5.6.14 - Valores mínimo e máximo de concentração de microcistinas - MCs extracelulares e de eficiência e valores médios de eficiências parcial e acumulada dos ENSAIOS 1 a 5 181

Tabela 5.6.15 - Dados de funcionamento da instalação piloto de dupla filtração de água eutrofizada com pré-oxidação e pós-cloração FONTE: SALES (2005) 183

Tabela 5.6.16 - Dados de funcionamento da instalação piloto de dupla filtração de água eutrofizada com interoxidação e pós-cloração FONTE: SALES (2005)

Tabela 5.6.17- Observações de respostas locomotoras de indivíduos da espécie de peixe Danio rerio (Teleostei, Cyprinidae), realizadas durante os Ensaios 1 a 6 em IP. $\mathrm{H}=$ hiperatividade, $\mathrm{h}=$ hipoatividade, $\mathrm{a}=$ agrupamento, $\mathrm{c}=$ conflito entre indivíduos, $\mathrm{s}=$ superfície, $\mathrm{f}=$ fundo, $\mathrm{r}$ = rente à parede do aquário, $\mathrm{m}=$ mortos. 186 Tabela 5.6.1 - Parâmetros de controle - operação do ENSAIO 1-IP (em instalação piloto): temperatura, $\mathrm{pH}$, potencial zeta e residual de cloro livre das águas de diluição e de estudo e efluentes . 201

Tabela 5.6.2 - Parâmetros de controle - desempenho do ENSAIO 1-IP (em instalação piloto): carbono orgânico total, absorvância 254, oxigênio dissolvido, condutividade elétrica, dureza e turbidez das águas de diluição e de estudo e dos efluentes de cada processo de tratamento para diferentes tempos de amostragem 201 Tabela 5.6.3 - Resultados dos testes ecotoxicológicos com microcrustáceos (Ceriodaphnia dúbia - CD e Ceriodaphnia silvestri - CS) - ENSAIO 1-IP (em instalação piloto): total indivíduos imóveis / total indivíduos expostos, imobilidade, $\mathrm{pH}$, condutividade e dureza das águas de diluição e de estudo e efluentes. 202 
Tabela 5.6.4 - Parâmetros de controle - operação do ENSAIO 2-IP (em instalação piloto): temperatura, $\mathrm{pH}$, potencial zeta e residual de cloro livre das águas de diluição e de estudo e efluentes 203

Tabela 5.6.5 - Parâmetros de controle - desempenho do ENSAIO 2-IP (em instalação piloto): carbono orgânico total, absorvância 254, oxigênio dissolvido, condutividade elétrica, dureza e turbidez das águas de diluição e de estudo e dos efluentes de cada processo de tratamento para diferentes tempos de amostragem 203 Tabela 5.6.6 - Resultados dos testes ecotoxicológicos com microcrustáceos (Ceriodaphnia dúbia - CD e Ceriodaphnia silvestri - CS) - ENSAIO 2-IP (em instalação piloto): total indivíduos imóveis / total indivíduos expostos, imobilidade, $\mathrm{pH}$, condutividade e dureza das águas de diluição e de estudo e efluentes 204

Tabela 5.6.7 - Parâmetros de controle - operação do ENSAIO 3-IP (em instalação piloto): temperatura, $\mathrm{pH}$, potencial zeta e residual de cloro livre das águas de diluição e de estudo e efluentes 205

Tabela 5.6.8 - Parâmetros de controle - desempenho do ENSAIO 3-IP (em instalação piloto): carbono orgânico total, absorvância 254, oxigênio dissolvido, condutividade elétrica, dureza e turbidez das águas de diluição e de estudo e dos efluentes de cada processo de tratamento para diferentes tempos de amostragem 205 Tabela 5.6.9 - Resultados dos testes ecotoxicológicos com microcrustáceos (Ceriodaphnia dúbia - CD e Ceriodaphnia silvestri - CS) - ENSAIO 3-IP (em instalação piloto): total indivíduos imóveis / total indivíduos expostos, imobilidade, $\mathrm{pH}$, condutividade e dureza das águas de diluição e de estudo e efluentes 206

Tabela 5.6.10 - Parâmetros de controle - operação do ENSAIO 4-IP (em instalação piloto): temperatura, $\mathrm{pH}$, potencial zeta e residual de cloro livre das águas de diluição e de estudo e efluentes 207

Tabela 5.6.11 - Parâmetros de controle - desempenho do ENSAIO 4-IP (em instalação piloto): carbono orgânico total, absorvância 254, oxigênio dissolvido, condutividade elétrica, dureza e turbidez das águas de diluição e de estudo e dos efluentes de cada processo de tratamento para diferentes tempos de amostragem 207

Tabela 5.6.12 - Resultados dos testes ecotoxicológicos com microcrustáceos (Ceriodaphnia dúbia - CD e Ceriodaphnia silvestri - CS) - ENSAIO 4-IP (em instalação piloto): total indivíduos imóveis / total indivíduos expostos, imobilidade, $\mathrm{pH}$, condutividade e dureza das águas de diluição e de estudo e efluentes 208 
Tabela 5.6.13 - Parâmetros de controle - operação do ENSAIO 5-IP (em instalação piloto): temperatura, $\mathrm{pH}$, potencial zeta e residual de cloro livre das águas de diluição e de estudo e efluentes 209

Tabela 5.6.14 - Parâmetros de controle - desempenho do ENSAIO 5-IP (em instalação piloto): carbono orgânico total, absorvância 254, oxigênio dissolvido, condutividade elétrica, dureza e turbidez das águas de diluição e de estudo e dos efluentes de cada processo de tratamento para diferentes tempos de amostragem

Tabela 5.6.15 - Resultados dos testes ecotoxicológicos com microcrustáceos (Ceriodaphnia dúbia - CD e Ceriodaphnia silvestri - CS) - ENSAIO 5-IP (em instalação piloto): total indivíduos imóveis / total indivíduos expostos, imobilidade, $\mathrm{pH}$, condutividade e dureza das águas de diluição e de estudo e efluentes. 210

Tabela 5.6.16 - Parâmetros de controle - operação do ENSAIO 6-IP (em instalação piloto): temperatura, $\mathrm{pH}$, potencial zeta e residual de cloro livre das águas de diluição e de estudo e efluentes

Tabela 5.6.17 - Parâmetros de controle - desempenho do ENSAIO 6-IP (em instalação piloto): carbono orgânico total, absorvância 254, oxigênio dissolvido, condutividade elétrica, dureza e turbidez das águas de diluição e de estudo e dos efluentes de cada processo de tratamento para diferentes tempos de amostragem 211

Tabela 5.6.18 - Resultados dos testes ecotoxicológicos com microcrustáceos (Ceriodaphnia dúbia - CD e Ceriodaphnia silvestri - CS) - ENSAIO 6-IP (em instalação piloto): total indivíduos imóveis / total indivíduos expostos, imobilidade, $\mathrm{pH}$, condutividade e dureza das águas de diluição e de estudo e efluentes.

Tabela 5.6.19 - Parâmetros de controle - operação do ENSAIO 7-IP (em instalação piloto): temperatura, $\mathrm{pH}$, potencial zeta e residual de cloro livre das águas de diluição e de estudo e efluentes

Tabela 5.6.20 - Parâmetros de controle - desempenho do ENSAIO 7-IP (em instalação piloto): carbono orgânico total, absorvância 254, oxigênio dissolvido, condutividade elétrica, dureza e turbidez das águas de diluição e de estudo e dos efluentes de cada processo de tratamento para diferentes tempos de amostragem 213 Tabela 5.6.21 - Resultados dos testes ecotoxicológicos com microcrustáceos (Ceriodaphnia dúbia - CD e Ceriodaphnia silvestri - CS) - ENSAIO 7-IP (em instalação piloto): total indivíduos imóveis / total indivíduos expostos, imobilidade, $\mathrm{pH}$, condutividade e dureza das águas de diluição e de estudo e efluentes. 
Tabela 5.6.22 - Parâmetros de controle - operação do ENSAIO 8-IP (em instalação piloto): temperatura, $\mathrm{pH}$, potencial zeta e residual de cloro livre das águas de diluição e de estudo e efluentes 215

Tabela 5.6.23 - Parâmetros de controle - desempenho do ENSAIO 8-IP (em instalação piloto): carbono orgânico total, absorvância 254, oxigênio dissolvido, condutividade elétrica, dureza e turbidez das águas de diluição e de estudo e dos efluentes de cada processo de tratamento para diferentes tempos de amostragem 215 Tabela 5.6.24 - Resultados dos testes ecotoxicológicos com microcrustáceos (Ceriodaphnia dúbia - CD e Ceriodaphnia silvestri - CS) - ENSAIO 8-IP (em instalação piloto): total indivíduos imóveis / total indivíduos expostos, imobilidade, $\mathrm{pH}$, condutividade e dureza das águas de diluição e de estudo e efluentes 216 


\section{LISTA DE ABREVIATURAS E SIGLAS}

AC

$\mathrm{AD}$

$\mathrm{AE}$

AHAs

BCAA

BCAN

BDCAA

CA

CAG

CAP

CG-DCE

CG-EM

CM-AE

CMR

CNC

$\mathrm{CO}$

COT

DAl

DCL

DF

DFF

DFI

DHS

DSA

EESC

ELISA

ETA

ETASC 2

FAP
Água coagulada

água de diluição

água de estudo

Ácidos haloacéticos

Ácido bromocloroacético

Bromocloroacetonitrila

Ácido bromodicloroacético

coluna de adsorção

carvão ativado granular

carvão ativado em pó

Cromatrografia Gasosa - Detetor Captura de Eletrons

Cromatografia Gasosa - Espectrometria de Massas

câmara de mistura para água de estudo

câmara de mistura rápida

Câmara de nível constante

Coluna de oxidação

Carbono orgânico total

Dosagem de alumínio

Dosagem de cloro

Descarga de fundo

Descarga de fundo final

Descarga de fundo intermediária

Dosagem de hidróxido de sódio

Dosagem de sulfato de alumínio sólido

Escola de Engenharia de São Carlos

Enzyme-linked immunosorbent assay

Estação de tratamento de água

Estação de tratamento de água 2 de São Carlos

Filtro ascendente de pedregulho 
FCAG

FD

FLA

HKs

HPLC-PDA

HPs

INTER

IP

MC

MOE

MON

MTBE

PFSPOs

PÓS

PRÉ

PVDF

RAF

RPT

SPD

SSF

SST

SSV

TBAA

TBAN

TCAA

TCAN

THMs

Tmr

USP
Filtro de carvão ativado granular

Filtro descendente

Filtro de laboratório de areia

Halocetonas

High Performance Liquid Chromatography - Photo Diode Array

Halopicrinas

Intercloração

Instalação piloto

Microcistina

Matéria Orgânica Extracelular

Matéria Orgânica Natural

Metil-terc butílico éter

Potencial de formação de subprodutos organohalogenados

Pós-cloração

Pré-cloração

Fluoreto de polivinilideno

Reservatório de água filtrada

Reservatório de pós-tratamento

Subprodutos da desinfecção

Sólidos suspensos fixos

Sólidos suspensos totais

Sólidos suspensos voláteis

Ácido tribromoacético

Tribromoacetonitrila

Ácido tricloroacético

Tricloroacetonitrila

Trihalometranos

Tempo de mistura rápida

Universidade de São Paulo 


\section{LISTA DE SÍMBOLOS}

${ }^{\circ} \mathrm{C}$
$\mu \mathrm{g} / \mathrm{L}$
$\mu \mathrm{m}$
$\mathrm{Al}_{2}\left(\mathrm{SO}_{4}\right)_{3} \times 14,3 \mathrm{H}_{2} \mathrm{O}$
$\mathrm{Ca}(\mathrm{ClO})_{2}$
$\mathrm{CHBr}_{2} \mathrm{Cl}$
$\mathrm{CHBr}_{3}$
$\mathrm{CHCl}_{3}$
$\mathrm{ClO}_{2}$
$\mathrm{KI}^{\circ}$
$\mathrm{KMnO}$
$\mathrm{N}$
$\mathrm{NaOH}$
$\mathrm{nm}$
$\mathrm{P}$
$\mathrm{pH}$
$\mathrm{uH}$
$\mathrm{uT}$

Porcentagem

Grau Celsius

Microgramas por litro

Micrometro

Sulfato de alumínio

Hipoclorito de Cálcio

Dibromoclorometano

Bromofórmio

Clorofórmio

Dióxido de Cloro

Iodeto de Potássio

Permanganato de potássio

Nitrogênio

Hidróxido de sódio

Nanômetro

Fósforo

Potencial Hidrogeniônico

Unidade Hanzen de cor

Unidade Nefelométrica de turbidez 


\section{RESUMO}

KURODA, E. K. (2006). Remoção de células e subprodutos de Microcystis spp. por dupla filtração, oxidação e adsorção. São Carlos, 2006. 233 p. Tese (Doutorado) - Escola de Engenharia de São Carlos, Universidade de São Paulo.

Considerando o aumento da ocorrência de florações de cianobactérias e a possibilidade de formação de subprodutos em diversos mananciais destinados ao consumo humano, este trabalho teve como objetivo, avaliar a remoção de células e subprodutos de Microcystis spp. pelos processos de dupla filtração com filtração ascendente em pedregulho e de filtração descendente em areia, oxidação e adsorção com carvões ativados pulverizado e granular. $\mathrm{Na}$ fase 1 foram realizados ensaios de bancada para estabelecimento das condições operacionais dos ensaios a serem realizados em instalação piloto, utilizando-se água de estudo preparada com adição de cultura de cepa tóxica de Microcystis spp. e ou extrato de microcistinas. Em seguida, foram realizados ensaios em instalação piloto de escoamento contínuo para águas de estudo preparadas com adição de cultura de cepa tóxica de Microcystis spp. e de extrato de microcistinas - fase 2 e de material coletado no reservatório de Barra Bonita - SP - fase 3. A concepção de dupla filtração utilizada mostrou ser bastante eficiente na remoção de células de Microcystis spp.e, consequentemente, de microcistinas intracelulares, porém, a remoção ou degradação de microcistinas extracelulares só foi significativa com o emprego de processos complementares de oxidação e ou adsorção. Para as águas de estudo empregadas, não houve formação expressiva de subprodutos organohalogenados nos efluentes dos processos de tratamento, após serem submetidas à cloração e tempo de contato de 1 dia. Adicionalmente, foram realizados estudos prospectivos no sentido de avaliar a toxicidade de extrato, águas de estudo e efluentes dos processos de tratamento por meio de bioensaios com cladóceros e camundongos, além de biomonitoramento com a espécie de peixe Danio rerio.

Palavras-chave: tratamento de água, dupla filtração, filtração direta ascendente em pedregulho, cianobactérias, Microcystis, microcistinas, adsorção, carvão ativado, oxidação, cloro, PROSAB. 


\begin{abstract}
KURODA, E. K. (2006). Removal of cells and by-products of Microcystis spp. in double filtration, oxidation and adsorption processes. São Carlos, 2006. 233 p. Doctor’s Thesis School of Engineering of São Carlos, University of São Paulo.

Considering the increase in the frequency of cyanobacterial blooms and the possibilit'y of by-product formation in water supply sources for human consumption, this work was carried out in order to evaluate the removal of cells and by-products of Microcystis spp. using the processes of double filtration (gravel upflow filtration of coagulated water followed by rapid sand downflow filtration), oxidation and adsorption in powdered and granular activated carbons. Bench scale assays were performed in Phase 1 to determine the operational conditions of the tests to be performed in a continuous flow pilot plant, using a study water prepared with filtered water in the water treatment plant 2 of Sao Carlos and culture of a toxic strain of Microcystis spp. and/or microcystins extract. Based on the conditions stated in phase 1 , phase 2 was carried out by performing tests in the pilot plant for study waters prepared with culture of toxic strain of Microcystis spp. and phase 3 of microcystins extract from material collect in the de Barra Bonita - SP reservoir. The double filtration system used resulted very efficient concerning the removal of cells of Microcystis spp., but, on the other hand, the removal or degradation of extracellular microcystins was significant with the use of complementary processes such as oxidation and or activated carbon adsorption. With regards to the waters studied, there wasn't significant formation of by-products due to the oxidation of the effluent of each combination of processes, when submitted to chlorination with detention time of 1 day. Additionally, it was observed the toxicity effect by bioassays with crustaceans and mices, besides Danio rerio fish screening.
\end{abstract}

Key words: water treatment, double filtration, upflow gravel direct filtration, cyanobacteria, microcystis, microcystin, activated carbon adsorption, oxidation, chlorine, prosab. 



\section{INTRODUÇÃO}

O uso inadequado dos recursos hídricos, em decorrência do desenvolvimento de atividades agrícolas e industriais, aliado a fatores relativos à urbanização desordenada e ao crescimento populacional, têm provocado de forma abrangente, a poluição dos mananciais superficiais. O enriquecimento artificial dos corpos d'água com nitrogênio, fósforo e outros nutrientes em excesso, sob certas condições ambientais de temperatura, incidência de luz e velocidade de ventos, pode conduzir à quebra do equilíbrio biológico do meio aquático e favorecer o aparecimento de florações ou "blooms" de determinadas espécies fitoplanctônicas. As florações são caracterizadas pelo intenso crescimento e concentração desses microrganismos na superfície da água, formando uma densa camada de células que pode chegar a vários centímetros de profundidade.

A presença de florações de organismos fitoplantônicos e seus subprodutos em rios, lagos e reservatórios destinados ao abastecimento, interfere diretamente na qualidade da água, podendo introduzir efeitos negativos tanto de ordens estética e organoléptica pela produção de odor e sabor, como de saúde pública devido à produção de compostos potencialmente tóxicos e carcinogênicos. As alterações na qualidade da água para abastecimento, devido à presença desses organismos, introduzem dificuldades diversas, podendo comprometer seriamente o funcionamento das estações de tratamento de água ou sistemas de abastecimento, se estes não estiverem preparados para inativá-las e ou removêlas.

A situação torna-se mais crítica para os sistemas de tratamento que utilizam águas provenientes de lagos ou reservatórios, pois apesar de proporcionarem aparentemente, maior controle das características dos afluentes, apresentam, especificamente no caso do Brasil, condições ambientais favoráveis para o crescimento intenso de determinadas espécies de cianobactérias durante grande parte do ano.

Considerando o aumento, dos riscos à saúde, associados à presença de florações de cianobactérias e seus subprodutos em águas destinados ao abastecimento, a Fundação Nacional da Saúde (FUNASA), em colaboração com a Organização Panamericana da Saúde (OPAS), redigiu uma atualização da portaria 36/MS/90, incluindo a obrigatoriedade do monitoramento da ocorrência de cianobactérias potencialmente nocivas, testes de toxicidade e análises de microcistinas em mananciais destinados ao abastecimento e na água tratada 
para consumo humano (Portaria 1.469/MS, de 29 de dezembro de 2000 e revogação publicada em 25 de março de 2004 no Diário Oficial da União - Seção 1 pg 269 ISSN 16777042 dada pela Portaria 518/MS). É também recomendada a realização de análise de cilindrospermopsinas e saxitoxinas observando os valores limites de $15 \mu \mathrm{g} / \mathrm{L}$ e $3 \mu \mathrm{g} / \mathrm{L}$ respectivamente.

Por outro lado, vários estudos têm mostrado que os processos que envolvem o tratamento por ciclo completo, tecnologia que, segundo dados estatísticos do SNIS (2000), é empregada em aproximadamente 80 \% dos sistemas existentes no Brasil, não são efetivos na eliminação dos efeitos gerados pela presença de cianobactérias e seus subprodutos. Aliado a isso, fatores relacionados a problemas operacionais, como escolha inadequada de tecnologia, falta de mão-de-obra especializada e de recursos financeiros, entre outros, acarretam sérios prejuízos à qualidade da água produzida, tornando indispensável o desenvolvimento e domínio de tecnologias alternativas de tratamento, ou combinações destas, adequadas às condições técnicas, sociais, políticas e econômicas locais.

Seguindo esse princípio, pesquisas sobre tecnologias alternativas de tratamento de águas para consumo humano, aplicadas às pequenas e médias comunidades, vêm sendo desenvolvidas, com o intuito de melhor investigar as reais potencialidades e limitações dessas tecnologias. Vários estudos sobre a filtração direta foram realizados, considerando condições diferenciadas de qualidade de água bruta, como ocorrência de picos de turbidez, turbidez elevada, cor elevada e presença de algas; de funcionamento, como taxas de filtração, execução de descargas de fundo intermediárias, métodos de lavagem, produção efetiva de água e de diferentes concepções de composição granulométrica das unidades que compõe o sistema (MEGDA, 1999; GUSMÃO, 2001; AMARAL et. al. 2001; KURODA, 2002; WIECHETECK, 2003; SENS, 2003; BRANDÃO, 2003; DI BERNARDO, 2004; MONDARDO, 2004), enquadrando-se nessa linha de pesquisa, o estudo realizado. 


\section{OBJETIVOS}

\section{$2.1 \quad$ OBJETIVO GERAL}

Este trabalho teve como objetivo geral, avaliar a remoção de células de Microcystis spp. e subprodutos, presentes em águas de estudo, nos processos que envolvem a dupla filtração com filtro ascendente de pedregulho, precedida ou não de oxidantes e adsorvedores como carvão ativado em pó e granular.

\subsection{OBJETIVOS ESPECÍFICOS}

- Caracterização química e toxicológica de possíveis subprodutos de Microcystis spp..

- Obtenção de parâmetros de desempenho em ensaios de filtração direta realizados em bancada;

- Obtenção de parâmetros de desempenho em ensaios de oxidação, com cloro, dióxido de cloro e permanganato de potássio, realizados em bancada;

- Obtenção de parâmetros de desempenho em ensaios de adsorção, com carvão ativado pulverizado e granular, realizados em bancada;

- Avaliação da remoção de células e subprodutos de Microcystis spp. com emprego de dupla filtração, oxidação e adsorção, utilizando-se água de estudo tipo 2 AE -2 (água com adição de cultura de Microcystis spp. em macrocosmos e de extrato de microcistinas), em ensaios em instalação piloto - IP.

- Avaliação da remoção de células e subprodutos de Microcystis spp. com emprego de dupla filtração, oxidação e adsorção, utilizando-se água de estudo tipo 3 AE -3 (água com adição de material coletado no reservatório de Barra Bonita - SP), em ensaios em IP. 


\section{REVISÃO DA LITERATURA}

\subsection{EFEITOS DA PRESENÇA DE ORGANISMOS FITOPLÂNCTÔNICOS EM ÁGUAS DESTINADAS AO CONSUMO HUMANO}

Segundo DI BERNARDO (1995), a presença de organismos fitoplânctônicos em águas destinadas ao consumo humano pode trazer efeitos diretos na qualidade da água, tais como:

- aumento de matéria orgânica particulada (fitoplâncton, zooplâncton, bactérias , protozoários, fungos e detritos);

- aumento de substâncias orgânicas dissolvidas que podem incrementar a cor da água, conferir odor e sabor à água, ser precursores da formação de compostos organo-clorados, apresentar toxicidade, servir de substrato para o crescimento de bactérias na estação de tratamento e contribuir para aumentar a corrosão;

- aumento do pH e de suas flutuações diárias;

- diminuição do teor de oxigênio próximo ao sedimento, podendo ocorrer liberação de sulfeto de hidrogênio, amônia, ferro, manganês, fósforo, etc.

Por decorrência dessas alterações, dificuldades diversas são introduzidas nos processos de tratamento de águas para consumo humano, requerendo tratamentos específicos e implicando em custos adicionais. Dentre os principais problemas observados nos sistemas de abastecimento de água devido à presença de organismos fitoplanctônicos nos mananciais, DI BERNARDO et.al. (2000) destacam:

- aumento da dosagem de produtos químicos na coagulação devido à formação de flocos leves e necessidade do uso de polímeros para que ocorra sedimentação dos flocos, para sistemas que empregam o tratamento por ciclo completo;

- aumento da turbidez e do número de partículas na água decantada; colmatação rápida do meio filtrante, aumentando o consumo de água para lavagem;

- diminuição da eficiência da desinfecção e aumento no consumo de cloro;

- potencialidade de formação de subprodutos indesejáveis;

- ocorrência de sabor e odor; possibilidade de crescimento de bactérias na ETA e no sistema de distribuição, devido ao aumento de matéria orgânica que serve de substrato. 
Abordam-se nos itens seguintes, alguns desses problemas.

\subsubsection{Turbidez, cor, sabor e odor}

Segundo BRANCO (1986), os organismos fitoplânctônicos como partículas em suspensão podem constituir como fator diretamente responsável pela turbidez, especialmente nos casos em que ocorre o aparecimento de florações ou "blooms" de determinadas espécies de algas e de cianobactérias em que a turbidez pode atingir valores muito elevados. Possuindo ainda uma pigmentação verde-azulada ou mesmo parda ou avermelhada, atribuem coloração aparente (dada pela presença de compostos orgânicos naturais em solução ou dispersão, oriundos da degradação de plantas e animais) às águas, conforme apresentado na Figura 3.1.1.
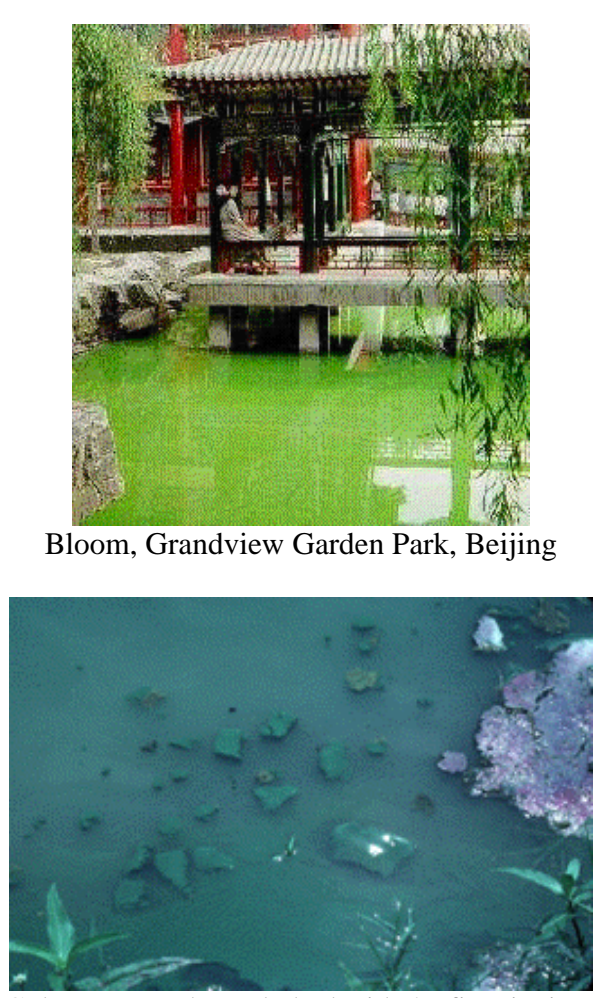

Coloração verde azulada devido às ficocianinas

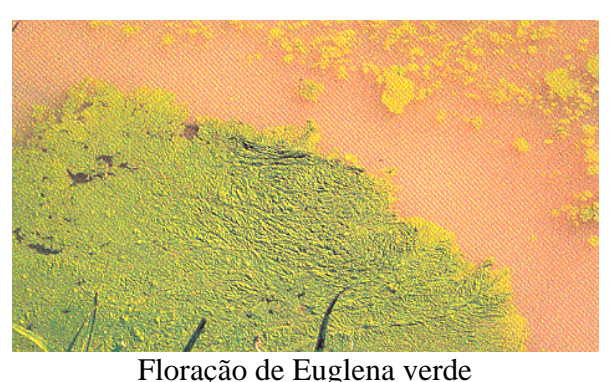

Floração de Euglena verde

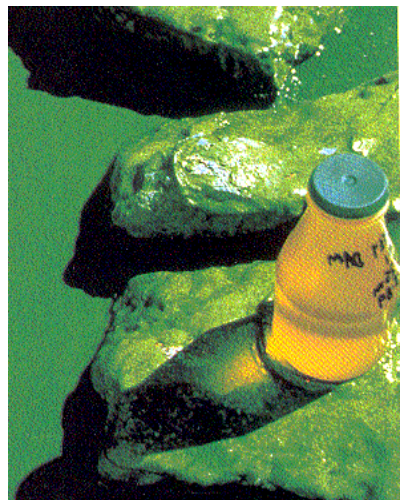

Espécies de Microcystis em Chaffey Dam, NSW.

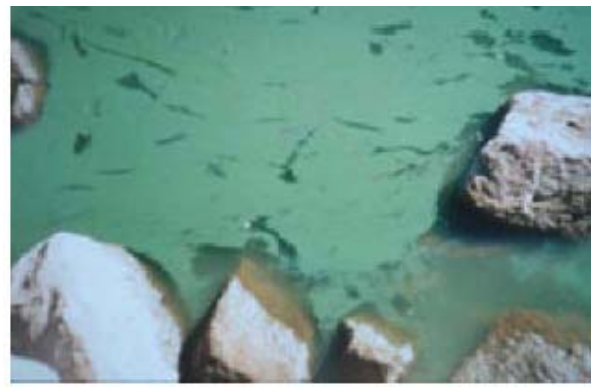

Floração de Cilindrospermopsis

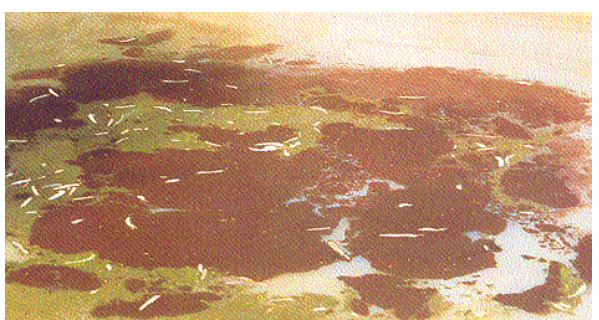

Floração de Euglena vermelha

Figura 3.1.1 - Aspectos de diferentes florações FONTE: http://www-cyanosite.bio.purdue.edu/index.html 
Os organismos fitoplânctônicos constituem um dos mais importantes fatores que causam sabor e odor nas águas de abastecimento. Certos organismos fitoplânctônicos ricos em compostos nitrogenados podem, ao entrar em decomposição, produzir intenso mau cheiro, como é o caso de certas cianobactérias (Microcystis por exemplo) que, embora possuam, enquanto vivas, odor característico de grama ou capim, passam a apresentar, depois que entram em putrefação, forte cheiro característico de esgoto séptico. Outras como Asterionella e Fragilaria apresentam, ao se decomporem, odor típico de peixe (Branco, 1986).

MEANS III et.al. (1984) identificaram como compostos responsáveis pelo odor acentuado de mofo e terra nos lagos Mathews e Skinner, o MIB (2-metil-isoborneol) e a geosmina (trans-1, 10-dimetil-trans-9-decalol), produzidos por Oscillatoria curviceps. Além do MIB e geosmina, há outros compostos que conferem sabor e odor de terra e mofo à água, descritos na Tabela 3.1.1.

Tabela 3.1.1 - Características dos cinco principais compostos que conferem sabor e odor às águas. ADAPTADO de

\begin{tabular}{c|c|c|c|c|c}
\hline \multicolumn{7}{c}{ DI BERNARDO (1995) } & TCA \\
\hline Característica & Geosmina & MIB & IPMP & IBMP & 168 \\
\hline Fórsa molecular (g) & 182 & 212 & 152 & 166 & $\mathrm{C}_{9} \mathrm{H}_{14} \mathrm{ON}_{2}$ \\
\hline Nome químico & $\begin{array}{c}\mathrm{C}_{12} \mathrm{H}_{22} \mathrm{O} \\
\text { trans-1,10- } \\
\text { dimetil-trans- } \\
\text { decalol }\end{array}$ & $\begin{array}{c}\mathrm{C}_{11} \mathrm{H}_{20} \mathrm{O} \\
\text { 2-metil- } \\
\text { isoborneol }\end{array}$ & $\begin{array}{c}\mathrm{C}_{8} \mathrm{H}_{12} \mathrm{ON}_{2} \\
\text { 2-isopropil-3- } \\
\text { metoxi } \\
\text { pirazina }\end{array}$ & $\begin{array}{c}2 \text {-isobutil-3- } \\
\text { metoxi } \\
\text { pirazina }\end{array}$ & $\begin{array}{c}2,3,6- \\
\text { tricloro- } \\
\text { anisole }\end{array}$ \\
\hline $\begin{array}{c}\text { Conc. limiar de percepção } \\
\text { (ng/L) }\end{array}$ & 10 & 30 & 2 & 2 & 7 \\
\hline
\end{tabular}

\subsubsection{Formação de subprodutos organohalogenados - SPOs}

O cloro devido aos seus atributos, é o agente desinfetante e oxidante mais utilizado no mundo, em sistemas de tratamento de água, principalmente por apresentar:

- Elevada efetividade na inativação de extensa gama dos patógenos geralmente encontrados na água;

- Possibilidade de manutenção de concentração residual na água;

- Simplicidade na medição e no controle;

- Baixo custo;

- Extenso registro de aplicação com segurança satisfatória.

Porém, a aplicação de cloro em águas com determinados constituintes pode levar à formação de subprodutos indesejáveis considerados potencialmente carcinogênicos, 
mutagênicos e teratogênicos. Segundo USEPA (1999), os subprodutos da oxidação podem ser classificados em:

Compostos orgânohalogenados como trihalometanos, ácidos haloacéticos, halocetonas e outros resultantes principalmente da cloração;

Compostos orgânicos oxidados como aldeídos, cetonas, carbono orgânico assimilável e carbono orgânico biodegradável, associados ao ozônio, ao cloro e aos processos de oxidação avançada (que utilizam fortes oxidantes);

Outros compostos inorgânicos como cloritos e cloratos, associados ao dióxido de cloro, (gerado com exposição à luz solar), e bromato, associado à ozonização de águas que apresentam elevada concentração de brometos.

Os principais fatores que influenciam a formação de subprodutos organohalogenados da oxidação são: $\mathrm{pH}$, tempo de contato, temperatura, natureza e concentração da matéria orgânica natural - MON, dosagem de cloro aplicada, residual de cloro livre e concentração de brometos. A MON é considerada o principal precursor de subprodutos da oxidação SPOs, sendo que a natureza do material orgânico depende da vegetação existente na bacia hidrográfica e das espécies de organismos fitoplânctônicos presentes na água. Assim, além das substâncias húmicas às quais, tradicionalmente se atribui a formação de SPOs, os organismos fitoplânctônicos também se constituem em potenciais precursores de SPOs.

Em estudos realizados por HOEHN et. al. (1980), foi observado que a concentração de trihalometanos - THMs está relacionada com o teor de clorofila-a e que a sua concentração aumentava com a idade das culturas inoculadas. Foi constatado também que, tanto as células como a matéria orgânica extracelular - MOE das algas são importantes precursoras de trihalometanos, sendo mais significativa a contribuição da MOE do que as células propriamente ditas.

Desde a descoberta da formação desses SPOs, têm-se buscado meios alternativos de oxidação no sentido de minimizar sua formação, dentre os quais destacam-se: dióxido de cloro, permanganato de potássio, ozônio, peróxido de hidrogênio, ácido peracético. Apresentam-se na Tabela 3.1.2 alguns SPOs gerados por diferentes oxidantes. 
Tabela 3.1.2 - Subprodutos da oxidação para diferentes tipos de oxidantes. ADAPTADO de USEPA (1999)

\begin{tabular}{|c|c|c|c|c|c|c|}
\hline Subprodutos da oxidação & $\frac{\circ}{\partial}$ & 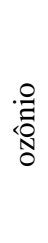 & 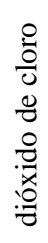 & 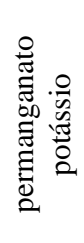 & 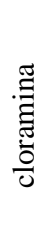 & 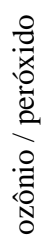 \\
\hline THM com MON & $\mathrm{s}$ & \pm & \pm & $\mathrm{n}$ & $\mathrm{s}$ & \pm \\
\hline Orgânicos oxidados & \pm & $\mathrm{s}$ & \pm & \pm & $\mathrm{n}$ & $\mathrm{s}$ \\
\hline Orgânicos halogenados & $\mathrm{s}$ & \pm & $\mathrm{n}$ & $\mathrm{n}$ & $\mathrm{s}$ & \pm \\
\hline Inorgânicos & $\mathrm{n}$ & \pm & $\mathrm{s}$ & $\mathrm{n}$ & $\mathrm{n}$ & \pm \\
\hline Matéria orgânica biodegradável & \pm & $\mathrm{s}$ & \pm & \pm & \pm & $\mathrm{s}$ \\
\hline
\end{tabular}

\subsubsection{Toxicidade}

CARMICHAEL (1992) define toxinas como compostos secundários que produzem efeitos nocivos em outros tecidos, células ou organismos. Compostos secundários referem-se àqueles que não são usados pelo organismo no metabolismo primário. Incluem os hormônios, antibióticos, aleloquímicos e toxinas.

Acredita-se que as características fisiológicas pelas quais as cianobactérias assimilam os nutrientes - nitrogênio e fósforo, do meio aquático, contribuem para que as cianobactérias predominem em sistemas eutrofizados de água doce (Brandão \& Azevedo, 2001).

Segundo SANT’ANNA \& AZEVEDO (2000) já foi registrada a ocorrência de pelo menos 20 espécies de cianobactérias potencialmente tóxicas, incluídas em 14 gêneros, em diferentes ambientes aquáticos brasileiros. A espécie Microcystis aeruginosa apresenta a distribuição mais ampla no Brasil e Anabaena é o gênero com o maior número de espécies potencialmente tóxicas (A. circinalis, A. flos-aquae, A. planctonica, A. solitaria e A. spiroides).

De acordo com suas estruturas químicas, as cianotoxinas podem ser distintas em três grandes grupos: os peptídeos cíclicos, os alcalóides e os lipopolissacarídeos. Os peptídeos cíclicos mais comumente encontrados em florações de cianobactérias tóxicas de águas doces e salobras são os das famílias da microcistina e nodularina. A microcistina é um heptapeptídeo e a nodularina, um pentapeptídeo.

Segundo SIVONEN \& JONES in CHORUS \& BARTRAM (1999), os alcalóides em geral, compreendem um grande grupo de compostos nitrogenados heterocíclicos. Dentre os alcalóides não sulfatados produzidos por cianobactérias de água doce destacam-se: as anatoxinas e as saxitoxinas. A cilindrospermopsina é um alcalóide sulfatado que bloqueia a síntese protéica com primeiro impacto nas células do fígado. Os lipopolissacarídeos são 
componentes integrais da parede celular de todas as bactérias gram-negativas, incluindo as cianobactérias e, podem causar irritações ao contato e respostas alérgicas em peles de humanos e mamíferos.

As toxinas de cianobactérias ou cianotoxinas apresentam mecanismos tóxicos específicos em vertebrados e podem ser classificados de acordo com o modo de ação em: neurotoxinas, caracterizadas por sua ação rápida, causando a morte de mamíferos por parada respiratória após poucos minutos de exposição (anatoxina-a, anatoxina-a(s), saxitoxinas), hepatotoxinas, que atuam menos rapidamente (microcistinas, nodularina e cilindrospermopsina) e endotoxinas ou dermatotoxinas que causam irritações ao contato (lipopolissacarídeos, lingybiatoxinas e aplisiatoxinas).

Na Tabela 3.1.3 são apresentados os principais gêneros de cianobactérias produtoras de toxinas, suas toxinas específicas e os tecidos / órgãos primeiramente afetados em humanos CHORUS \& BARTRAM (1999) e na Figura 3.1.2 são apresentados os gêneros de cianobactérias potencialmente tóxicas freqüentemente encontrados em ecossistemas aquáticos continentais.

Tabela 3.1.3 - Principais gêneros de cianobactérias produtoras de toxinas, suas toxinas específicas, qrupo químico e os tecidos / órgãos primeiramente afetados em humanos. ADAPTADO de CHORUS \& BARTRAM (1999)

\begin{tabular}{c|c|c|c}
\hline Gênero & Toxina & $\begin{array}{c}\text { Grupo } \\
\text { químico }\end{array}$ & Tecido/órgão afetado \\
\hline $\begin{array}{c}\text { Anabaena, Microcystis, Oscillatoria, } \\
\text { Planktothrix, Nostoc }\end{array}$ & microcistina & peptídeo & fígado \\
\hline Nodularia, & nodularina & peptídeo & fígado \\
\hline $\begin{array}{c}\text { Cylindrospermopsis, Umezakia, } \\
\text { Aphanizomenon }\end{array}$ & cilindrospermopsina & alcalóide & Fígado e rins \\
\hline $\begin{array}{c}\text { Anabaena, Oscillatoria, Planktothrix, } \\
\text { Aphanizomenon }\end{array}$ & anatoxina-a & alcalóide & SNC \\
\hline Anabaena, Aphanizomenon & anatoxina-a (S) & alcalóide & SNC \\
\hline $\begin{array}{c}\text { Anabaena, Aphanizomenon, Lyngbya, } \\
\text { Cylindrospermopsis }\end{array}$ & $\begin{array}{c}\text { saxitoxina e } \\
\text { neosaxitoxina }\end{array}$ & alcalóide & SNC \\
\hline Todas as cianobactérias & lipopolissacarídeo & LPS & pele / febre \\
\hline $\begin{array}{c}\text { Lyngbya, Schizothrix, Planktothrix } \\
\text { lingbiatoxina }\end{array}$ & alcalóide & tumores epiteliais \\
\hline Lyngbya, Oscillatoria, Schizothrix & debromoaplisiatoxina & - & tumores epiteliais \\
\hline
\end{tabular}

LPS: lipolissacarídeo; SNC: Sistema Nervoso Central. 


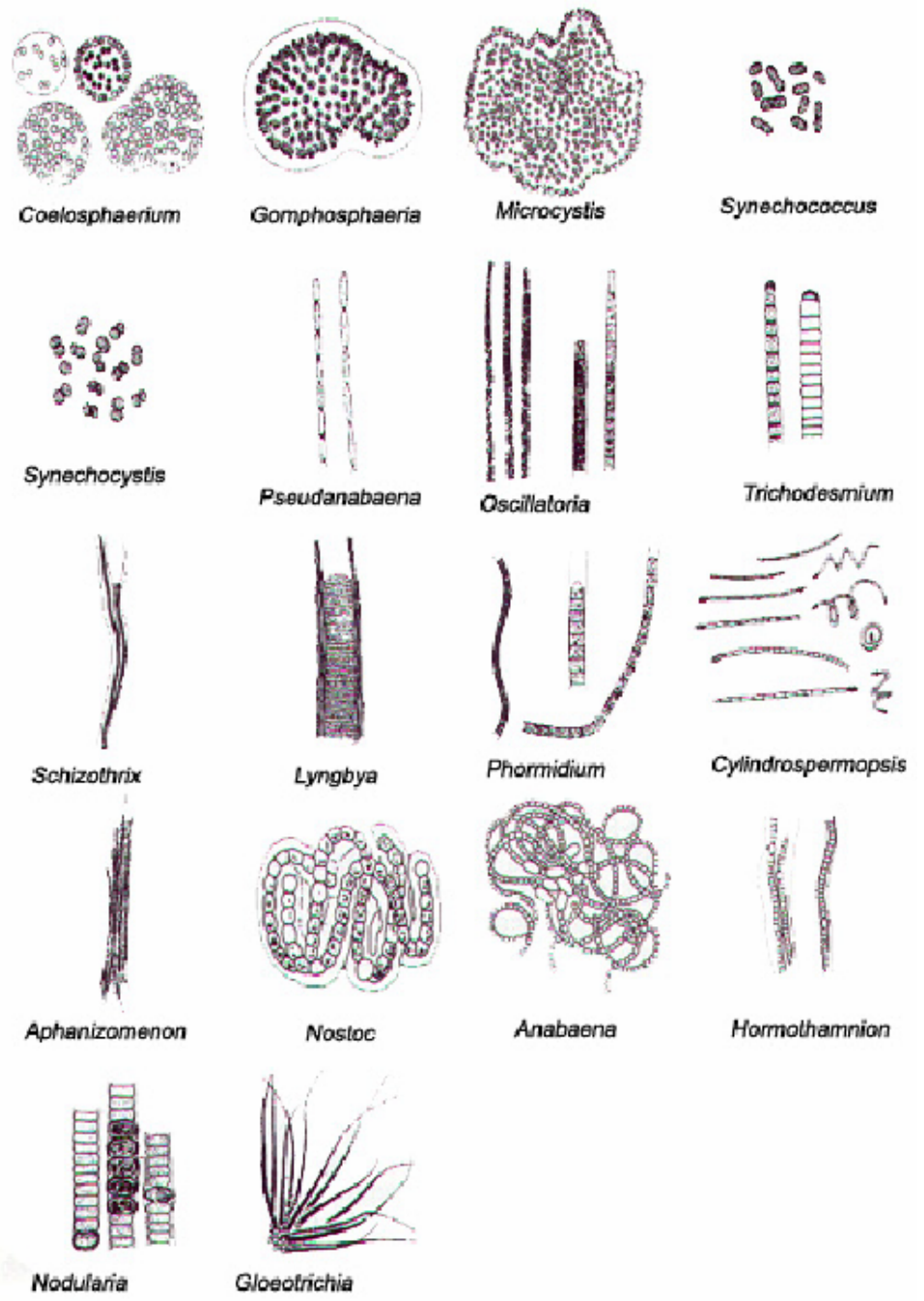

Figura 3.1.2 - Gêneros de cianobactérias potencialmente tóxicas freqüentemente encontrados em ecossistemas aquáticos continentais. FONTE: Brandão \& Azevedo, 2001

\subsubsection{Obstrução do meio granular}

A interferência da presença de organismos fitoplânctônicos em águas submetidas às tecnologias de tratamento que envolvem a floculação - decantação incide principalmente no fato de que os flocos formados, devido à baixa densidade e conseqüente baixa velocidade de sedimentação, resultam leves, reduzindo a eficiência de remoção na decantação e podendo ser carreados para os filtros, obstruindo-os em poucas horas de funcionamento, aumentando a freqüência de lavagens e,conseqüentemente, o consumo de água para lavagem. É comum nestes casos, empregar-se polímero como auxiliar de floculação para evitar a flotação dos mesmos.

Segundo DI BERNARDO (1995), o monitoramento do Lago Juturnaíba - RJ, em 1990, revelou, em dada ocasião, a presença sistemática de organismos fitoplanctônicos pertencentes às classes das Clorofíceas, Crisofíceas e Cianofíceas, com concentração 
variando entre $10^{4}$ e $2,5 \times 10^{5}$ ind/mL, exigindo a diminuição da vazão de água afluente à estação de tratamento de 900 para cerca de $500 \mathrm{~L} / \mathrm{s}$ e assim mesmo, causando o aumento do consumo de água para lavagem dos filtros para valores superiores a 10 \% do volume de água produzido.

O mesmo autor relata a ocorrência de florações algais em lagoas de várias regiões do Brasil, durante o período de estiagem prolongada entre maio e novembro de 1994, em que a estação de ciclo completo da cidade de São José do Rio Preto teve a vazão de água diminuída de 500 para 200L/s e apresentou redução na duração da carreira de filtração de 16 para 10 horas. A análise de amostras coletadas da água do lago revelou predominância de organismos fitoplanctônicos dos gêneros Melosira, Synedra, Cymbella, Pinullaria, Navícula, Pediastrum, Agmenellum, Scenedesmus e Dinobryon.

\section{2 ÁGUA PARA CONSUMO HUMANO E PADRÃO DE POTABILIDADE}

A água é por natureza um excelente solvente, o que torna praticamente impossível encontrá-la em estado de absoluta pureza. Desta forma, pode-se dizer que os constituintes da água são gases dissolvidos, compostos orgânicos e inorgânicos dissolvidos ou em suspensão, inclusive microrganismos e colóides. A distribuição de tamanhos desses constituintes é apresentada na Figura 3.2.1.

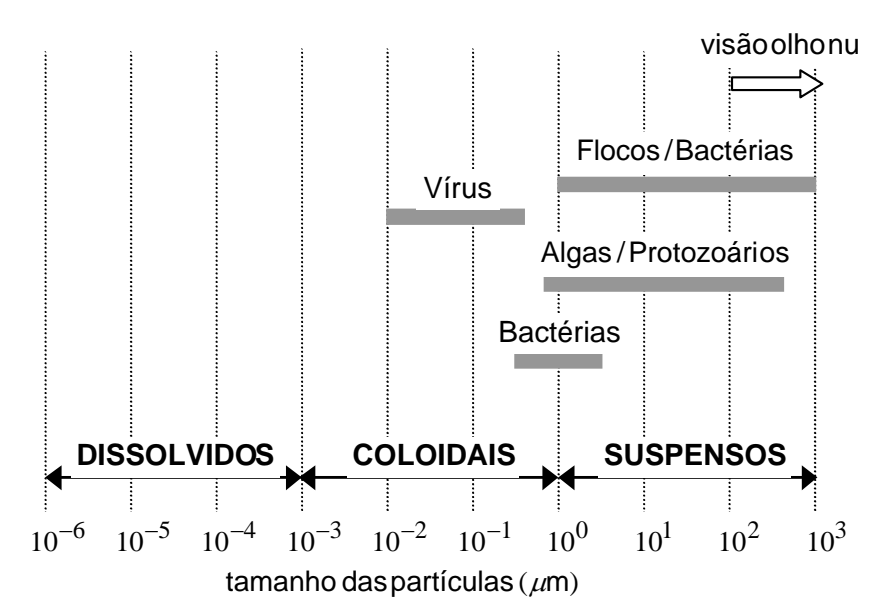

Figura 3.2.1 - Distribuição de tamanhos das partículas na água

A quantidade e qualidade desses constituintes ou impurezas na água dependem das condições climáticas, hidrológicas, geológicas, pedológicas, morfológicas e do grau de poluição, os quais caracterizam e condicionam as águas aos usos mais diversificados como de abastecimento, recreação, irrigação, navegação, entre outros. 
Após tratamento, a água destinada ao consumo humano deve respeitar certas restrições para que possa ser ingerida e utilizada para fins de higiene, sem provocar danos à saúde em curto e longo prazo, não apresentando microrganismos patogênicos, nem concentrações perigosas de substâncias tóxicas ou nocivas ao homem. É importante também que essa água apresente-se agradável ao consumo, através de suas propriedades estéticas e organolépticas, e que não produza danos ao sistema de distribuição, nem aos sistemas privados.

No Brasil, o controle de qualidade de águas para abastecimento é regulamentado pela Portaria 518 de 25 de março de 2004 do Ministério da Saúde. O padrão de potabilidade (Capítulo IV) estabelece concentrações limites para qualidade microbiológica, para turbidez da água filtrada, para substâncias químicas que representam risco à saúde, para constituintes radioativos e para o padrão de aceitação para consumo humano.

Devido à suscetibilidade aos riscos à saúde associados à formação de subprodutos da desinfecção / oxidação com cloro, bem como de evidências de intoxicações humanas por cianobactérias e existência de condições ambientais favoráveis ao desenvolvimento de florações de organismos fitoplânctônicos, foi proposto na Portaria 518/MS 2004, os valores limites para as concentrações de trihalometanos total e microcistina na água para consumo humano iguais a 0,1 mg/L e $1 \mu \mathrm{g} / \mathrm{L}$, respectivamente, sendo aceitáveis concentrações de até $10 \mu \mathrm{g} / \mathrm{L}$ de microcistina em até 3 amostras, consecutivas ou não, nas análises realizadas nos últimos 12 meses. É recomendado também, que nas análises para cianotoxinas sejam incluídas as determinações de cilindrospermopsinas e saxitoxinas, observando os valores limites de 15,0 e $3 \mu \mathrm{g} / \mathrm{L}$, respectivamente.

O plano mínimo de amostragem (Capítulo V) para a concentração de trihalometanos é apresentado na Tabela 3.2.1. O plano de amostragem prevê também, o monitoramento da presença de cianobactérias e de suas toxinas específicas nos pontos de captação de água, e estabelece que, quando a concentração de cianobactérias exceder 20.000 células/mL ou 2 $\mathrm{mm}^{3} / \mathrm{L}$ de biovolume, será exigida a análise semanal de cianotoxinas na água na saída do tratamento e nas entradas das clínicas de hemodiálise e indústrias de injetáveis, podendo ser dispensada esta análise quando não houver comprovação de toxicidade na água bruta por meio da realização semanal de bioensaios em camundongos (Cap. V / Art. $18 / \S 5^{\circ}$ ). Estabelece também, que o monitoramento de cianobactérias no ponto de captação do manancial deve obedecer a freqüência mensal, quando a concentração de cianobactérias não exceder 10.000 células $/ \mathrm{mL}$ ou $1 \mathrm{~mm}^{3} / \mathrm{L}$ de biovolume, e semanal, quando exceder este valor (Cap. V / Art. 19 / § 1º). 
Vale ressaltar que é vedado o uso de algicidas para o controle do crescimento de cianobactérias ou qualquer intervenção no manancial que provoque a lise das células desses microrganismos, quando a densidade das cianobactérias exceder 20.000 células/mL (ou 2 $\mathrm{mm}^{3} / \mathrm{L}$ de biovolume).

Tabela 3.2.1 - Plano mínimo de amostragem para concentração de trihalometanos. ADAPTADO de Portaria 518/MS

\begin{tabular}{|c|c|c|c|c|c|}
\hline \multicolumn{6}{|c|}{2004} \\
\hline \multirow{3}{*}{ Parâmetro } & \multirow{3}{*}{$\begin{array}{l}\text { Tipo de } \\
\text { manancial }\end{array}$} & \multirow{3}{*}{$\begin{array}{l}\text { Saída do Sistema } \\
\text { de Tratamento }\end{array}$} & \multirow{2}{*}{\multicolumn{3}{|c|}{$\begin{array}{c}\text { Sistema de Distribuição } \\
\text { População abastecida (hab) }\end{array}$}} \\
\hline & & & & & \\
\hline & & & $<50.000$ & 50.000 a 250.000 & $>250.000$ \\
\hline Trihalometanos & superficial & $\begin{array}{c}\mathrm{N}^{\circ} . \text { amostra }=1 \\
\text { Freqüência } \\
\text { quadrimestral } \\
\end{array}$ & $\begin{array}{c}\mathrm{N}^{\mathrm{o}} \text {. amostra }=1^{(*)} \\
\text { Freqüência } \\
\text { quadrimestral }\end{array}$ & $\begin{array}{c}\mathrm{N}^{\circ} . \text { amostra }=4^{(*)} \\
\text { Freqüência } \\
\text { quadrimestral }\end{array}$ & $\begin{array}{c}\mathrm{N}^{\circ} . \text { amostra }=4^{(*)} \\
\text { Freqüência } \\
\text { quadrimestral }\end{array}$ \\
\hline Trihalometanos & subterrâneo & 1 o & $\begin{array}{l}\mathrm{N}^{\mathrm{o}} \text {. amostra }=1^{(*)} \\
\text { Freqüência anual }\end{array}$ & $\begin{array}{c}\mathrm{N}^{\mathrm{o}} . \text { amostra }=1^{(*)} \\
\text { Freqüência } \\
\text { semestral }\end{array}$ & $\begin{array}{c}\mathrm{N}^{\mathrm{o}} \text {. amostra }=1^{(*)} \\
\text { Freqüência } \\
\text { semestral }\end{array}$ \\
\hline
\end{tabular}

${ }^{(*)}$ : as amostras devem ser coletadas, preferencialmente, em pontos de maior tempo de detenção da água no sistema de distribuição

\subsection{DUPLA FILTRAÇÃO COM FILTRO ASCENDENTE EM PEDREGULHO}

Dentre as principais tecnologias de tratamento que utilizam a coagulação química, tem-se a filtração direta ascendente que, apesar de requerer menor área para a implantação da estação, com custo de implantação e operação significativamente menor quando comparado ao de uma instalação na qual são usadas coagulação, floculação, decantação / flotação e filtração, apresenta limitações relativas à qualidade microbiológica da água bruta, sendo neste caso recomendado o tratamento complementar com filtro de escoamento descendente, compondo assim o sistema de dupla filtração. Além de permitir tratamento de água de pior qualidade, a dupla filtração possibilita o uso de taxas de filtração mais elevadas, oferece maior segurança com relação às variações bruscas de qualidade da água bruta, apresenta maior remoção global de microrganismos, além de dispensar o descarte de água pré-filtrada no início da carreira de filtração.

Na Tabela 3.3.1 são apresentadas as principais características da água bruta e os parâmetros de projeto recomendados para o emprego da dupla filtração com filtro ascendente em areia grossa e em pedregulho. 
Tabela 3.3.1 - Parâmetros de qualidade da água bruta para o emprego da dupla filtração e parâmetros de projeto. ADAPTADO de DI BERNARDO \& DANTAS (2005)

\begin{tabular}{|c|c|c|c|}
\hline & Condições & $\begin{array}{l}\text { Dupla Filtração com } \\
\text { Filtração Ascendente } \\
\text { em Areia Grossa }\end{array}$ & $\begin{array}{c}\text { Dupla Filtração com } \\
\text { Filtração Ascendente } \\
\text { em Pedregulho }\end{array}$ \\
\hline \multirow{11}{*}{$\begin{array}{l}\text { Características } \\
\text { da Água Bruta }\end{array}$} & Turbidez (uT) $(*)$ & & \\
\hline & $\begin{array}{l}90 \% \text { do tempo } \\
95 \% \text { do tempo } \\
100 \% \text { do tempo } \\
\end{array}$ & $\begin{array}{l}\leq 50 \\
\leq 100 \\
\leq 150\end{array}$ & $\begin{array}{l}\leq 100 \\
\leq 150 \\
\leq 200\end{array}$ \\
\hline & Cor verdadeira $(\mathrm{uH})(* *)$ & & \\
\hline & $\begin{array}{c}90 \% \text { do tempo } \\
95 \% \text { do tempo } \\
100 \% \text { do tempo } \\
\end{array}$ & $\begin{array}{l}\leq 50 \\
\leq 75 \\
\leq 100 \\
\end{array}$ & $\begin{array}{l}\leq 50 \\
\leq 75 \\
\leq 100\end{array}$ \\
\hline & Sólidos Suspensos Totais (mg/L) & & \\
\hline & $\begin{array}{l}95 \% \text { do tempo } \\
100 \% \text { do tempo }\end{array}$ & $\begin{array}{l}\leq 100 \\
\leq 150\end{array}$ & $\begin{array}{l}\leq 150 \\
\leq 200\end{array}$ \\
\hline & $\mathrm{DBO}_{5}(\mathrm{mg} / \mathrm{L})$ & $\leq 10$ & $\leq 10$ \\
\hline & NMP Escherichia coli (NMP/100 mL) & $\leq 2500(+)$ & $\leq 1500(+)$ \\
\hline & NMP de coliformes totais (NMP/100 mL) & $\leq 10000(+)$ & $\leq 5000(+)$ \\
\hline & Carbono orgânico total (mg/L) & $\leq 5$ & $\leq 5$ \\
\hline & Densidade fitoplanctônica (UPA/mL) & $\leq 1000$ & $\leq 2500$ \\
\hline \multirow{5}{*}{$\begin{array}{l}\text { Parâmetros de } \\
\text { Projeto }\end{array}$} & Taxa de filtração no filtro ascendente $\left(\mathrm{m}^{3} / \mathrm{m}^{2} \mathrm{~d}\right)$ & 120 a 240 & 80 a $180(* * *)$ \\
\hline & $\begin{array}{l}\text { Taxa de filtração no filtro descendente } \\
\left(\mathrm{m}^{3} / \mathrm{m}^{2} \mathrm{~d}\right)(* *)\end{array}$ & 200 a $400(++)$ & 120 a 240 \\
\hline & $\begin{array}{c}\text { Número de descargas de fundo intermediárias } \\
\text { no filtro ascendente durante a carreira de } \\
\text { filtração }\end{array}$ & $\geq 4$ & $\geq 4$ \\
\hline & $\begin{array}{l}\text { Taxa de aplicação de água na interface } \\
\left(\mathrm{m}^{3} / \mathrm{m}^{2} \mathrm{~d}\right)\end{array}$ & 600 a 1000 & - \\
\hline & Mecanismo de coagulação & neutralização de cargas & neutralização de cargas \\
\hline
\end{tabular}

(*) picos de até 300 uT com duração inferior a 12 h poderão ocorrer na água bruta;

(**) picos de até 150 uH com duração inferior a 12 horas podem ocorrer na água bruta;

(***) os valores superiores da taxa de filtração na filtração direta ascendente somente deverão ser adotados após a comprovação de sua viabilidade por meio de ensaios em instalação piloto;

(+) limites mais elevados podem ser adotados com o emprego da pré-desinfecção;

(++) para o filtro descendente com camada única de areia, a taxa de filtração deve ser inferior a $300 \mathrm{~m}^{3} / \mathrm{m}^{2} \mathrm{~d}$; para filtros de antracito e areia, a taxa de filtração pode ser maior.

A dupla filtração com filtro ascendente em pedregulho é uma variação do sistema de dupla filtração, cujo objetivo principal é de melhorar qualitativamente as características do afluente e adequá-lo ao tratamento subseqüente, porém com diferenças substanciais em relação às condições operacionais, ampliando assim seu campo de aplicação. Apresentam-se a seguir alguns estudos já realizados sobre a filtração direta ascendente em pedregulho.

MEGDA et. al. (1999) estudaram a aplicação da filtração direta ascendente em pedregulho (FDAP) como pré-tratamento à filtração rápida descendente (FRD). A turbidez da água bruta esteve comprendida entre 6 e 71 uT; foram aplicadas taxas de filtração entre 12 e $115 \mathrm{~m}^{3} / \mathrm{m}^{2}$.d. no filtro ascendente e de $250 \mathrm{~m}^{3} / \mathrm{m}^{2}$.d. no filtro descendente, obtendo-se água tratada com qualidade satisfatória em relação à eficiência na remoção de turbidez, cor aparente, ferro, manganês, coliformes totais e fecais, em todos os ensaios realizados.

CEZAR et. al. (2000) investigaram a pré-filtração em pedregulho (PFAP) precedida e não de coagulação química, como condicionamento para águas com presença significativa 
de algas, para diferentes taxas de filtração (12, 24 e $60 \mathrm{~m}^{3} / \mathrm{m}^{2}$.d.) e tratamento posterior com a FRD, para taxa de filtração igual a $300 \mathrm{~m}^{3} / \mathrm{m}^{2}$.d.. Dentre as principais constatações, destacou que a seqüência de tratamento, precedida de coagulação, FAP - FRD, constitui uma boa alternativa de tratamento para águas contendo algas em concentrações elevadas, sendo necessária, a realização de investigações de faixas granulométricas mais apropriadas e de combinações de taxas de filtração entre o filtro ascendente e o descendente, de forma a obter aumento da duração das carreiras de filtração no FAP. Apresentam-se na Tabela 3.3.2, as principais características da água bruta captada do Lago Paranoá em Brasília - DF, observados durante os ensaios, e na Tabela 3.3.3, um resumo dos resultados obtidos.

Tabela 3.3.2 - Características da água bruta observadas nos ensaios realizados por CEZAR et. al. (2000)

\begin{tabular}{c|c|c|c}
\hline Taxa de filtração $\left(\mathrm{m}^{3} / \mathrm{m}^{2} . \mathrm{d}.\right)$ & 12 & 24 & 60 \\
\hline Turbidez $(\mathrm{uT})$ & 2,5 a 40,0 & 2,8 a 8,0 & 2,3 a 13,0 \\
\hline Clorofila-a $(\mu \mathrm{g} / \mathrm{L})$ & 4,9 a 40,8 & 6,0 a 11,8 & 2,2 a 16,9 \\
\hline
\end{tabular}

Tabela 3.3.3 -Valores de eficiência média de remoção de turbidez e clorofila-a e duração da carreira de filtração nos PFAP e FDAP obtidos por CEZAR et. al. (2000)

\begin{tabular}{c|c|c|c|c}
\hline \multirow{2}{*}{ Unidade } & $\begin{array}{c}\text { Taxa de } \\
\text { filtração } \\
\left(\mathrm{m}^{3} / \mathrm{m}^{2} . \mathrm{d}\right)\end{array}$ & $\begin{array}{c}\text { Remoção de } \\
\text { turbidez } \\
(\%)\end{array}$ & $\begin{array}{c}\text { Remoção de } \\
\text { algas } \\
(\%)\end{array}$ & $\begin{array}{c}\text { Duração da carreira } \\
\text { de filtração } \\
(\mathrm{h}) *\end{array}$ \\
\cline { 2 - 5 } PFAP & 12 & 81,8 & 85,7 & $* *$ \\
\cline { 2 - 5 } (s/ coagulação) & 24 & 71,0 & 85,0 & $* *$ \\
\cline { 2 - 5 } & 60 & 63,6 & 71,6 & 456 \\
\cline { 2 - 5 } FDAP & 12 & 76,5 & 80,1 & 64 \\
\cline { 2 - 5 } (c/ coagulação) & 60 & 87,3 & 94,1 & 5 \\
\hline
\end{tabular}

* Considerando perda de carga limite de $60 \mathrm{~cm}$;

** Não atingiu perda de carga limite de 60 cm para carreiras de filtração superior a 36 dias.

Complementando o trabalho de MEGDA (1999), GUSMÃO (2001) estudou a aplicação da Filtração Direta Ascendente em Pedregulho e em Areia grossa como prétratamento à FRD, para água superficial natural com valores baixos de turbidez e cor e taxas de 80,110 e $190 \mathrm{~m}^{3} / \mathrm{m}^{2}$.d no filtro ascendente em pedregulho, e 120,180 e $240 \mathrm{~m}^{3} / \mathrm{m}^{2}$.d no filtro descendente em areia. Foi observada baixa taxa de crescimento de perda de carga no meio granular no filtro ascendente, além de significativa redução na perda de carga mediante execução de 2 e 3 descargas de fundo intermediárias - DFIs. A execução de descargas de fundo intermediárias - DFI com taxa de descarga entre 800 e $1000 \mathrm{~m}^{3} / \mathrm{m}^{2}$.d no filtro ascendente em pedregulho provocou redução média da ordem de 90 \% no valor da perda de carga devido à retenção de impurezas no meio granular; Em comparação realizada com os resultados obtidos com o sistema filtração ascendente em areia grossa seguida da filtração rápida descendente, o composto por filtração ascendente em pedregulho foi capaz de 
produzir efluente com qualidades equivalentes com a vantagem de requerer menor carga hidráulica e apresentar maior eficiência na produção de água tratada.

KURODA (2002) avaliou o desempenho da FDAP para água bruta com valores de turbidez entre 8,5 e 21,0 uT, cor verdadeira entre 19 e $74 \mathrm{uH}$, alcalinidade entre 6,7 e $10 \mathrm{mg}$ $\mathrm{CaCO}_{3} / \mathrm{L}$ e pH entre 6,5 e 7,5, tendo concluído que, para as condições estudadas, as taxas de filtração empregadas no FAP (180 e $\left.240 \mathrm{~m}^{3} / \mathrm{m}^{2} \mathrm{~d}\right)$ mostraram serem adequadas à execução de descargas de fundo intermediárias (DFIs) porém, os resultados indicaram que o número de DFIs (3 e 4) foi insuficiente. Adicionalmente, verificou que o sistema FDAP-FRD foi capaz de absorver picos de turbidez de até 380 uT, mediante a aplicação e controle adequados das condições de coagulação obtidas em laboratório. Foram obtidos valores de turbidez entre 0,3 e 5,7 uT para o efluente pré-filtrado, e para o efluente filtrado do FRD, valores consistentemente menores que $1 \mathrm{uT}$ e na maior parte do tempo menores que 0,1 uT.

\subsection{REMOÇÃO DE ORGANISMOS FITOPLÂNCTÔNICOS E SUBPRODUTOS NOS PROCESSOS DE TRATAMENTO DE ÁGUA PARA CONSUMO HUMANO}

Estudos intensivos com relação à remoção de organismos fitoplânctônicos de uma forma geral vêm sendo realizados, abordando as mais variadas tecnologias, desde a filtração lenta até a adoção de etapas de oxidação utilizando cloro, ozônio, permanganato de potássio e outros oxidantes. As eficiências na remoção desses organismos pelos processos de ciclo completo, utilizando a flotação por ar dissolvido e sedimentação, variam de caso a caso, podendo ser influenciadas pelas demais características da água, bem como condições de outros processos envolvidos. O gênero ou mais precisamente, características como forma, estrutura, tamanho e organização dos organismos fitoplânctônicos têm influência direta na eficiência do tratamento, atribuindo comportamentos diferenciados para uma mesma tecnologia.

VLASKI et. al. (1996) utilizando cultura de Microcystis aeruginosa, comparou por meio de ensaios de bancada, o desempenho da sedimentação e da flotação por ar dissolvido, tendo obtido eficiências de remoção de células de 87 e 71 \%, respectivamente. No mesmo trabalho, a adição de polieletrólito catiônico como auxiliar de floculação resultou em aumento significativo na eficiência de remoção de Microcystis aeruginosa (da ordem de $99 \%)$.

Em geral, independentemente do tipo de agente oxidante utilizado, a pré-oxidação apresentou efeitos positivos na eficiência de remoção de células. Segundo PETRUSEVSKY 
et.al.(1996), eficiências de remoção de células da ordem de 90 \%, comumente atingidas por filtração direta, passaram a valores maiores que 99 \% após pré-oxidação com permanganato de potássio e adição de polímero.

A partir da compilação de resultados obtidos sobre eficiência de diversas tecnologias visando a remoção física de biomassa fitoplanctônica (tratamento de ciclo completo com sedimentação - SED, com flotação por ar dissolvido - FAD, filtração direta - FD e dupla filtração - FDD), JANSSENS \& BUEKENS (1993) propuseram o diagrama de seleção em função da concentração de clorofila-a e turbidez (Figura 3.4.1), limitando a aplicação da filtração direta e dupla filtração para concentrações de clorofila-a infeiores a $10 \mu \mathrm{g} / \mathrm{L}$.

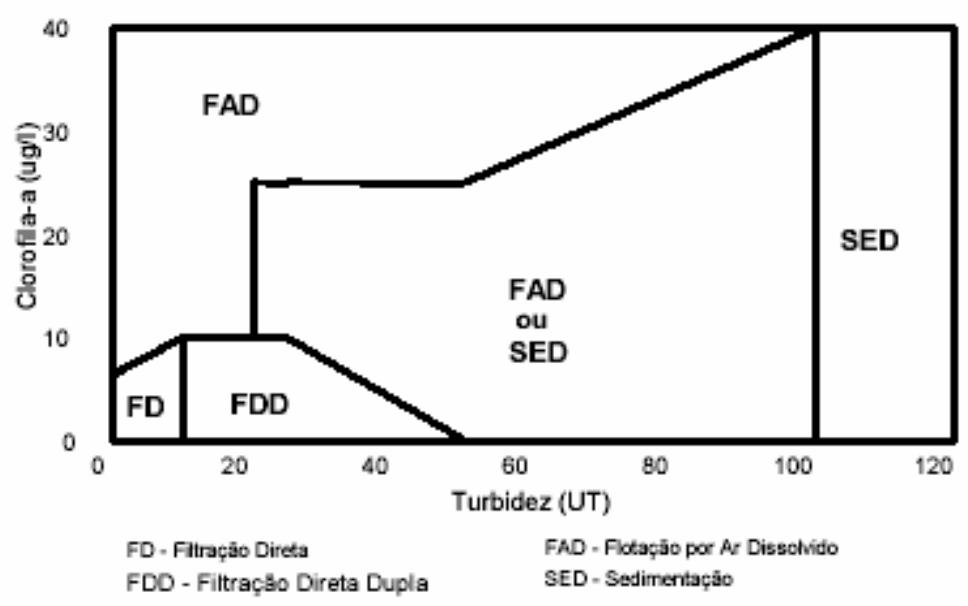

Figura 3.4.1 - Diagrama de seleção de processos. FONTE: Janssens e Buekens, 1993

DRIKAS et. al. (2001) simulou o tratamento por ciclo completo e obteve eficiências de remoções de células de microalgas entre 70 e $83 \%$ em experimentos de bancada e supeiores a 99,9 \% em escala piloto.

Quando dissolvidas na água, as toxinas de cianobactérias ou cianotoxinas geralmente não são removidas pelo tratamento por ciclo completo (HART et. al. 1998; HOFFMAN, 1976;) e podem ter a concentração aumentada durante tal processo devido à lise celular (Chow et. al., 1998).

A aplicação de carvão ativado granular - CAG e carvão ativado em pó - CAP, em conjunto com o tratamento convencional, tem mostrado ser efetiva na remoção de microcistina, particularmente de extracelulares presentes na água de abastecimento.

HART et.al.(1998) estudaram a adsorção de microcistina por CAG e CAP em instalação piloto e concluíram que para absorver 85\% das microcistinas a dose requerida de CAP era excessiva e que, portanto, a aplicação de doses usuais em ETAs (5 a 20 mg / L), serviria apenas para contribuir para a remoção dessas toxinas mas dificilmente promoveria 
sua remoção completa. Ressaltaram ainda, que a efetividade do CAP é altamente dependente do tipo de carvão e dosagem aplicada.

KEIJOLA et. al. (1988) apresentou o CAG como um processo efetivo para remoção de hepato e neurotoxinas e relata não ter obtido bons resultados com o emprego de CAP. Porém, a dosagem aplicada foi baixa (5 mg/L) e nenhum estudo sobre as propriedades do carvão foi realizado.

KEIJOLA et. al.. (1988) e HIMBERG et. al. (1989) analisando a cloração dentro dos processos usuais de tratamento (convencional e filtração direta) sugerem que essa etapa não foi eficaz na remoção de toxinas. Porém, a demanda de cloro exercida por outros orgânicos e a influência do valor do $\mathrm{pH}$, associados à baixa dosagem $(0,5 \mathrm{mg} / \mathrm{L}$ de cloro) utilizada, podem explicar a baixa efetividade do cloro observada por esses autores.

NICHOLSON et. al. (1994) observaram eficiência de 95\% com a aplicação de 1 mg/L de cloro e hipoclorito de cálcio (cloro ativo) após 30 minutos. Observou também que a remoção fica comprometida para valores de pH superiores a 8,0.

Com o objetivo de elucidar a eficiência dos processos quanto à remoção de microcistina na tecnologia de tratamento por ciclo completo acrescido de pré-oxidação com permanganato de potássio, adsorção em CAP ou CAG e desinfecção por cloraminas, KARNER et. al. (2001) realizaram uma pesquisa em que monitoraram a concentração de microcistinas em diversos pontos no processo de tratamento de água a fim de determinar quais os passos que efetivamente removeram as toxinas, tendo obtido as seguintes conclusões:

- Houve redução de 90 a 99,9\% da concentração de microcistina durante os 5 tratamentos de água testados (Figura 3.4.2);

- A adição de permanganato de potássio, ou outros pré-tratamentos químicos como CAP, apresentaram reduções no nível de microcistina da ordem de $61 \%$.

Porém, deve-se observar que a água bruta em questão apresentou baixos valores de concentração de microcistinas (valores entre 01 e $1 \mu \mathrm{g} / \mathrm{L}$ ). 

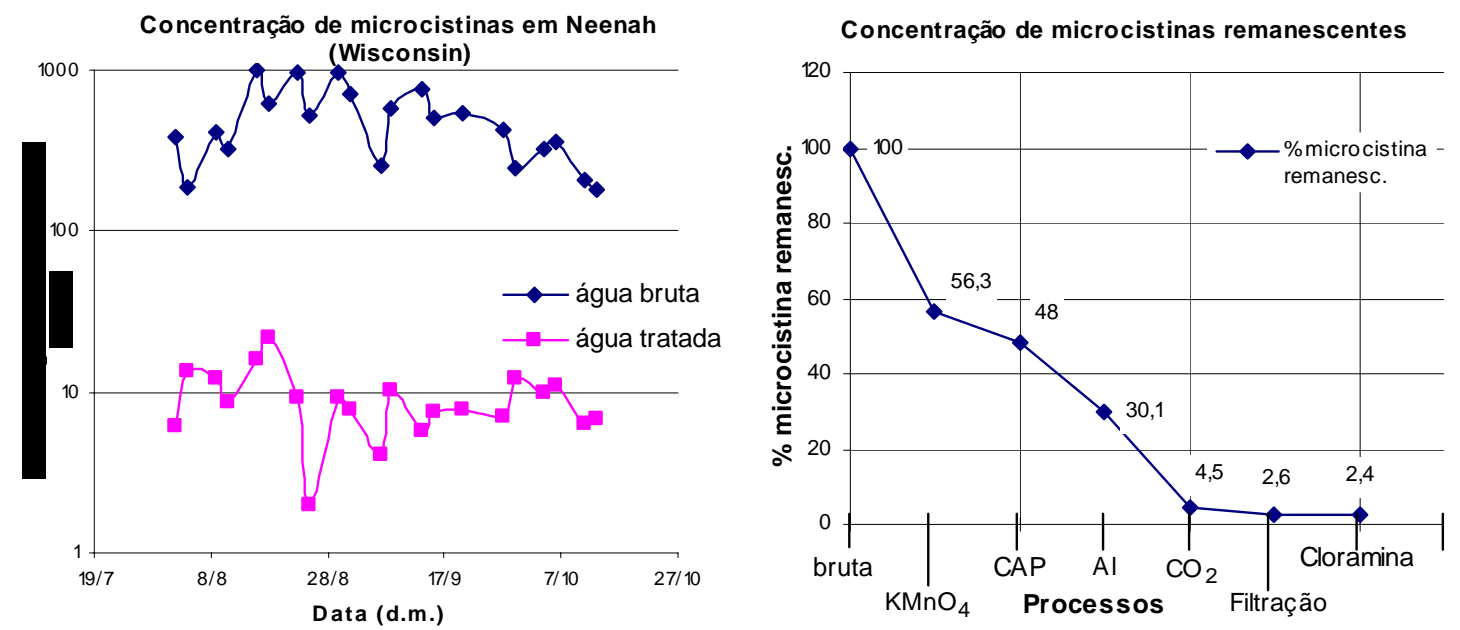

Figura 3.4.2 - Concentrações de microcistina nas águas bruta e tratada (Neenah, verão de 1998) e Porcentagem remanescente de microcistina nos processos de tratamento (Neenah, verão de 1999) FONTE: KARNER et. al. (2001)

LALEZARY et. al. (1986) realizaram estudos com água contendo subprodutos que conferem sabor e odor à água empregando como oxidantes o cloro, dióxido de cloro, permanganato de potássio e ozônio, obtendo as seguintes conclusões:

- Odores causados por diferentes espécies dos gêneros Synura, Synedra, Dinobryon, Anabaena, Asterionella, Ceratium e Anacystis foram controlados por meio de précloração com residuais de 1 a 5 mg/L de cloro livre;

- Dosagem da ordem de $4 \mathrm{mg} \mathrm{Cl}_{2} / \mathrm{L}$ mostrou-se efetiva no controle de odores de terra, peixe e outros associados aos gêneros Mallomonas, Anabaena, Asterionella, Synura e Vorticella, além de actinomicetos, fontes de MIB e Geosmina ;

- O permanganato de potássio tem sido considerado efetivo para a remoção de sabor e odor, e é também usado como algicida e bactericida. Na faixa de pH de 3,5 e 11, há produção do precipitado que adsorve grande parte dos compostos orgânicos presentes na água;

- Dosagem de cerca de $4 \mathrm{mg} \mathrm{O}_{3} / \mathrm{L}$ e tempo de contato de 10 minutos, têm sido efetivos na redução de odor e sabor de terra e mofo em água bruta;

- Após realização de experimentos com água contendo MIB, Geosmina, TCA, IBMP, IPMP, verificaram, para os oxidantes utilizados, maior eficiência de remoção seguindo a ordem MIB $<$ Geosmina $<$ TCA $<$ IBMP $<$ IPMP, a menos do permanganato de potássio, para o qual houve inversão de IBMP com IPMP. Dentre os quatro oxidantes utilizados, o dióxido de cloro revelou ser o mais eficiente e o permanganato de potássio o menos eficiente. 
Após realização de experimentos com água contendo MIB, Geosmina, TCA, IBMP, IPMP, verificaram para os oxidantes utilizados, maior eficiência de remoção seguindo a ordem $\mathrm{MIB}<$ Geosmina $<$ TCA $<$ IBMP $<$ IPMP, a menos do permanganato de potássio para o qual houve inversão de IBMP com IPMP. Dentre os quatro oxidantes utilizados, o dióxido de cloro revelou ser o mais eficiente e o permanganato de potássio o menos eficiente 


\section{MATERIAL E MÉTODOS}

Neste capítulo são apresentados primeiramente, os fundamentos que delinearam a forma de desenvolvimento do trabalho. Envolve a busca de informações para o estabelecimento do tipo de água a ser estudada - água de estudo ${ }^{1}$, de forma que as características resultantes fossem representativas de mananciais destinados ao abastecimento - META 1. Em seguida, são relatadas as investigações realizadas no sentido de caracterizar os possíveis subprodutos formados com a água de estudo - META 2.

Um tópico foi reservado para apresentação dos estudos efetuados com o objetivo de definir os parâmetros de desempenho, empregados no controle operacional e no monitoramento de qualidade dos efluentes gerados, e os respectivos métodos de análise, a fim de viabilizar a avaliação dos processos de tratamento na pesquisa proposta - META 3. Adicionalmente, são apresentados nos Anexos A, B, C e D, os protocolos utilizados para limpeza de vidrarias, preparação do meio de cultura ASM-1, análise de clorofila-a e análise de alumínio residual, respectivamente.

Nos itens seguintes, são finalmente, apresentados os procedimentos empregados para avaliação dos processos de tratamento, organizada em três fases.

Fase 1: refere-se aos ensaios de filtração direta, oxidação e adsorção, realizados em bancada, com o intuito de fornecer subsídios para a determinação prévia das condições operacionais desses processos nos ensaios em instalação piloto - IP. Contempla as METAS 4, 5 e 6;

\footnotetext{
${ }^{1}$ água especificamente preparada com adição de compostos ou microrganismos, em concentração imprópria ao uso a que se destina, utilizada no estudo (por isso denominada água de estudo) em ensaios de tratabilidade e experimentos. Sinônimo: água teste, água de desafio.
} 
Fase 2: refere-se aos ensaios realizados em IP, om emprego de água de estudo tipo 2 - AE-2 (água com adição de cultura de Microcystis spp. em macrocosmos e de extrato de microcistinas - MCs): META 7;

Fase 3: refere-se aos ensaios realizados em IP, om emprego de água de estudo tipo 3 - AE-3 (água com adição de material coletado no reservatório de Barra Bonita - SP, manancial eutrofizado da região): META 8.

Na Figura 4.1. são esquematizados os experimentos e ensaios realizados para avaliação da remoção de células e subprodutos de Microcystis spp. com emprego de filtração direta, dupla filtração, oxidação e adsorção nas diferentes fases do trabalho.

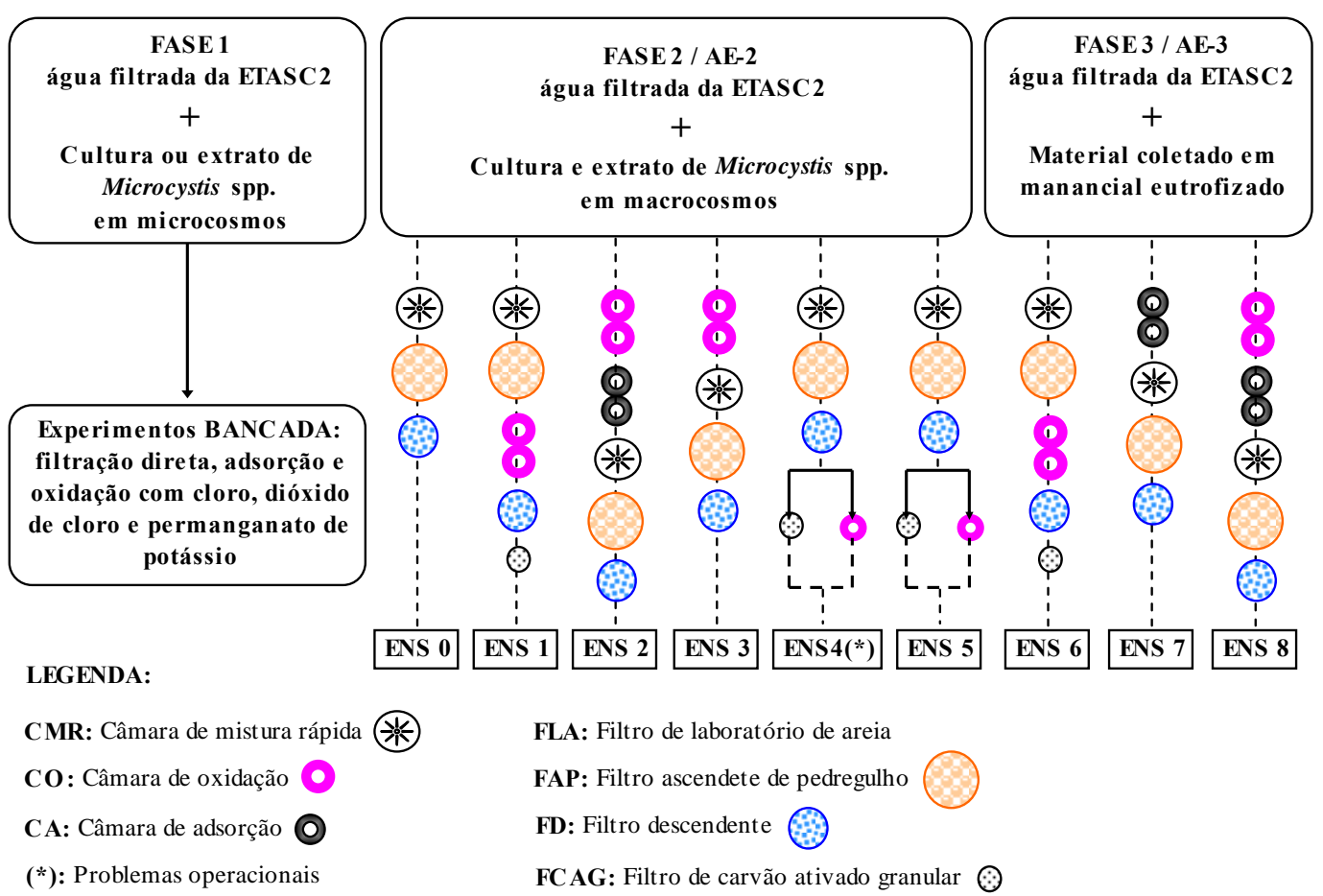

Figura 4.1 - Esquema das fases experimentais para avaliação da remoção de células e subprodutos de Microcystis spp.

Assim, o estudo proposto foi organizado de acordo com as metas apresentadas a seguir.

META 1: Desenvolvimento de culturas;

META 2: Caracterização química e toxicológica de subprodutos;

META 3: Estudo de métodos para análise de parâmetros de desempenho específicos;

META 4: Obtenção de parâmetros de desempenho em ensaios de filtração direta em bancada - FASE 1;

META 5: Obtenção de parâmetros de desempenho em ensaios de oxidação em bancada FASE 1; 
META 6: Obtenção de parâmetros de desempenho em ensaios de adsorção em bancada FASE 1;

META 7: Avaliação da remoção de células e subprodutos de Microcystis spp. com emprego de dupla filtração, oxidação e adsorção utilizando-se AE -2 em ensaios em IP - FASE 2;

META 8: Avaliação da remoção de células e subprodutos de Microcystis spp. com emprego de dupla filtração, oxidação e adsorção utilizando-se AE-3 em ensaios em IP - FASE 3.

\subsection{META 1: DESENVOLVIMENTO DE CULTURAS}

Baseado em bioensaios e em análises por cromatografia líquida de alta eficiência HPLC, pelo menos 50 a 75\% das amostras tem-se mostrado tóxicas (Cood, 2000). O tipo mais comum de intoxicação envolvendo cianobactérias é ocasionado por hepatotoxinas. As espécies já identificadas como produtoras de hepatotoxinas estão incluídas nos gêneros Microcystis, Anabaena, Nodularia, Oscillatoria, Nostoc e Cylindrospermopsis (Carmichael, 1994).

Para SANT'ANNA E AZEVEDO (2000), a espécie Microcystis aeruginosa é considerada a de distribuição mais ampla no território nacional, e a Anabaena, o gênero com maior número de espécies potencialmente tóxicas (A. circinalis, A. flos-aquae, A. planctonica, A. solitaria e A. spiroides).

Aproximadamente $82 \%$ das cepas isoladas, de ambientes eutrofizados, pelo Laboratório de Ecofisiologia e Toxicologia de Cianobactérias do Instituto de Biofísica Carlos Chagas Filho - Universidade Federal do Rio de Janeiro - LETC-IBCCF-UFRJ mostram-se tóxicas quando testadas em bioensaios de toxicidade ou por análises químicas, sendo 52\% dessas, pertencentes ao gênero Microcystis (Brandão \& Azevedo, 2001).

Segundo MATTHIENSEN et.al. 1999, diversas florações de Microcystis aeruginosa foram observadas nas águas do estuário da Lagoa dos Patos - RS nos últimos 15 anos. O autor relata a ocorrência desta espécie após monitoramento realizado ao longo de 12 meses, a 
partir de agosto de 1994, com densidades entre $1,5 \times 10^{2}$ e $1,3 \times 10^{3} \mathrm{cel} / \mathrm{mL}$. Extratos da floração apresentaram elevada toxicidade em camundongos com valores de DL50 $24 \mathrm{~h}^{2}$ menores que $100 \mathrm{mg} / \mathrm{kg}$ p.c. ${ }^{3}$ (mg de material seco / kg de peso médio corpóreo dos camundongos) e concentrações de microcistinas - MCs no material seco, maiores que 1,0 $\mu \mathrm{g} / \mathrm{mg}$ p.s. ${ }^{4}$. ( $\mu \mathrm{g}$ de MCs / mg de peso seco do material). Diversas variantes de MCs foram encontradas, sendo a MC-LR, a mais abundante.

Diante das constatações apresentadas, para obtenção das águas de estudo - AEs, optou-se pelo desenvolvimento de culturas em micro, meso e macrocosmos, de cepa toxigênica de Microcystis spp., cujo inóculo NPLJ-4 foi gentilmente cedido pelo LETCIBCCF-UFRJ. Segundo OLIVEIRA (2003), a cepa NPLJ-4, produtora de microcistinas, foi isolada em 1996 da Lagoa de Jacarepaguá, situada na zona oeste da cidade do Rio de Janeiro

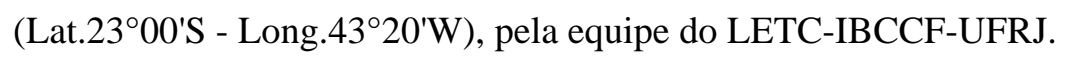

\subsubsection{Culturas em microcosmos}

As culturas foram mantidas (em triplicata) em meio ASM-1 autoclavado em tubos de ensaios de $20 \mathrm{~mL}$ e erlenmeyers de $250 \mathrm{~mL}$ (Figura 4.1.1) sob agitação manual diária, temperatura de $22 \pm 1^{\circ} \mathrm{C}$, fotoperíodo de $12 \mathrm{~h}$ e intensidade luminosa da ordem de 55 ( $\mu \mathrm{E}$. $\left.\mathrm{m}^{-2} \cdot \mathrm{s}^{-1}\right)$.

A inoculação das culturas foi realizada quinzenalmente, seguindo a proporção de inóculo : meio (1 : 9). Para assegurar a predominância de Microcystis spp. em relação aos demais organismos fitoplanctônicos, foi realizado monitoramento periódico de contaminação das culturas a cada 1 a 2 meses. Toda vidraria utilizada na pesquisa foi limpa e tratada segundo protocolo descrito no Anexo A. O Anexo B refere-se ao protocolo para preparação do meio de cultura ASM-1.

\footnotetext{
${ }^{2}$ dose letal para 50\% dos animais que foram sujeitos à administração em $24 \mathrm{~h}$

${ }^{3} \mathrm{mg}$ de material seco / kg de peso médio corpóreo dos camundongos

${ }^{4} \mu \mathrm{g}$ de MCs / mg de peso seco do material
} 

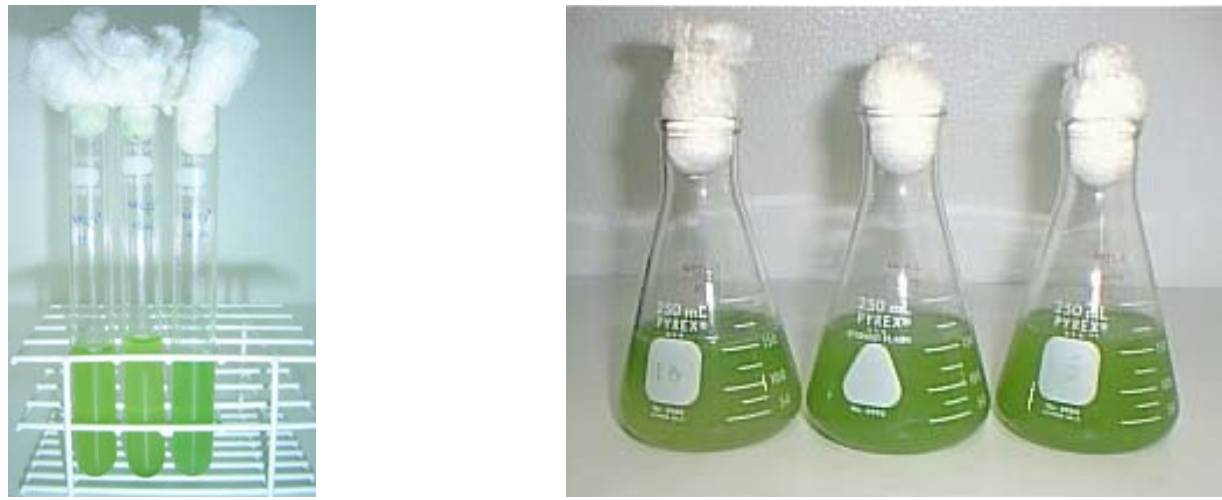

Figura 4.1.1 - Vista geral das culturas de Microcystis spp. em microcosmos - 15 dias após inoculação

\subsubsection{Culturas em mesocosmos e macrocosmos}

As culturas de Microcystis spp. em meso e macrocosmos foram realizadas em meio ASM-1 não autoclavado, preparado com água deionizada, em 3 aquários com capacidade de 30 L (mesocosmos) e 3 de 200 L (macrocosmos), sob as mesmas condições de temperatura e iluminação. Para isso, foram adaptados aos aquários, um banho termostatizado, com reservatório de 16 L e recirculação externa em serpentina de contato em aço inoxidável 316, para controle da temperatura, e um sistema de aeração contínua adaptado a filtros de algodão autoclavados e saída com vários terminais.

Na Figura 4.1.2 são mostradas fotos da cultura em mesocosmos após inoculação em meio ASM-1. Somente após análise de contaminação, as culturas de mesocosmos foram utilizadas como inóculo para as culturas em macrocosmos.

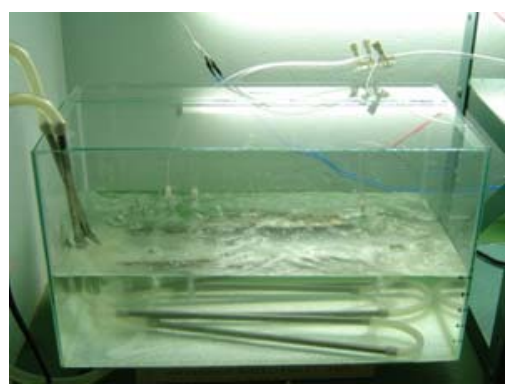

$30 / 01 / 2004$

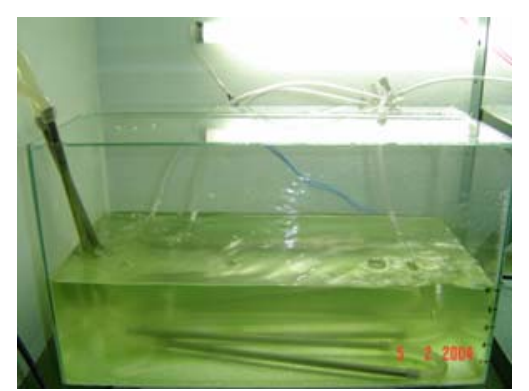

$05 / 02 / 2004$

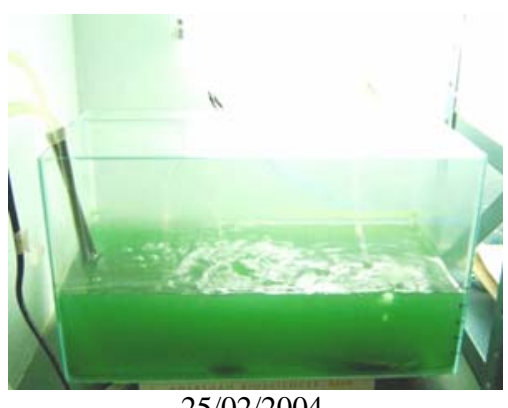

$25 / 02 / 2004$

Figura 4.1.2 - Vista geral dos aspectos da cultura de Microcystis spp. em mesocosmos após inoculação em meio ASM-1 realizado em 30/01/2004

Os aquários de 200 L para culturas em macrocosmos foram montados na Instalação Piloto - IP e possuíam adaptações para o sistema de bombeamento da suspensão de Microcystis spp. à caixa de mistura para preparação da água de estudo - CM-AE, utilizada nos experimentos em escoamento contínuo. Nas Figuras 4.1.3 e 4.1.4 são mostradas fotos da 
montagem do aquário e do aspecto da cultura de Microcystis spp em macrocosmos, respectivamente.

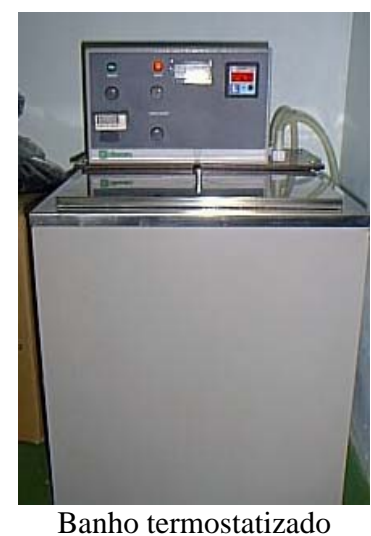

Figura 4.1.3- Vista geral da montagem do aquário com capacidade de 200 L pata cultivo de Microcystis spp em

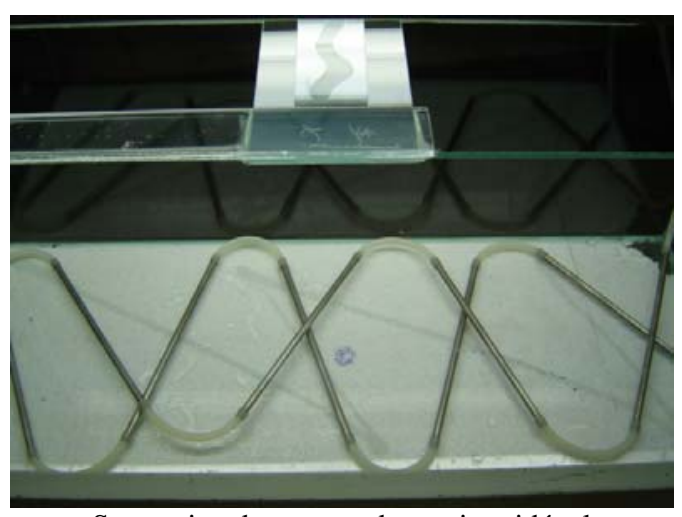

Serpentina de contato de aço inoxidável

\section{macrocosmos}

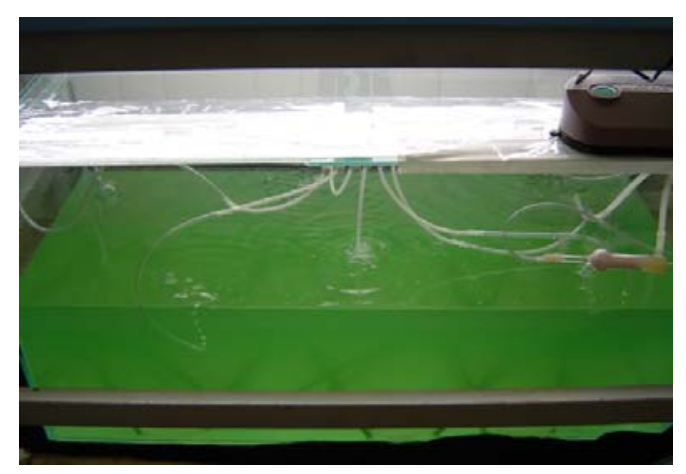

10 dias após inoculação em meio ASM-1

Figura 4.1.4 - Vista geral dos aspectos da cultura de Microcystis spp em macrocosmos após inoculação em meio ASM-1

\subsection{META 2: CARACTERIZAÇÃO QUÍMICA E TOXICOLÓGICA DE SUBPRODUTOS}

\subsubsection{Caracterização química da principal microcistina produzida pela cepa NPLJ-4}

A caracterização química das microcistinas - MCs produzidas pela cepa foi realizada com a água de estudo - AE preparada com densidade de $2 \times 10^{5}$ cél/mL, por meio da adição de cultura de Microcystis spp. NPLJ-4, na fase final do crescimento exponencial, em água filtrada sem cloração da ETASC 2.

Primeiramente, $500 \mathrm{~mL}$ da $\mathrm{AE}$ foram submetidos ao processo de congelamento e descongelamento (3 vezes) para extração de toxinas intracelulares para o meio aquoso e de filtração em membrana tipo GF/C. Após pré-purificação do filtrado em fase sólida (cartuchos de C18), o extrato semipurificado foi concentrado, ressuspenso em $1 \mathrm{~mL}$ de água : metanol 
$100 \%(1: 1 \mathrm{v} / \mathrm{v})$ e filtrado em filtro de fluoreto de polivinilideno - PVDF com porosidade de $0,45 \mu \mathrm{m}$. As etapas de extração - purificação - concentração são descritas com detalhes no Item 4.3.6, referente à análise de MCs. O extrato semipurificado de microcistinas foi analisado por cromatografia líquida de alta eficiência com detector de UV e arranjo de diodos - HPLC-PDA (High Performance Liquid Chromatography - Photo Diode Array) e por espectrometria de massas com ionização por electrospray MS-ESI (Electrospray Ionisation Mass Spectrometry).

As análises por HPLC-PDA foram realizadas de acordo com o Item 4.3.6.3. As análises por MS-ESI foram feitas, por trabalho de colaboração, no Laboratório de Espectrometria de Massas do Departamento de Química da Universidade Federal de São Carlos - DQ - UFSCar, sob responsabilidade do Prof. Edson Rodrigues Filho, em espectrômetro do tipo triplo-quadrupolo (QuattroLC da Micromass) equipado com fontes API. Foi utilizada a ionização por electrospray - ESI no modo positivo, usando um potencial de 3,6 kV no capilar, $46 \mathrm{~V}$ no cone de amostragem e $8 \mathrm{~V}$ no cone extrator. A aquisição dos dados foi feita na região de m/z 300 a 1400. O extrato foi inserido na fonte de ionização por meio de uma bomba tipo seringa (Carlo Erba Phoenix 40), usando metanol : água (7:3 v/v) como solventes e fluxo de 150 (L/min. Na Figura 4.2.1 é apresentado um fluxograma ilustrando as principais etapas para a caracterização química realizada.

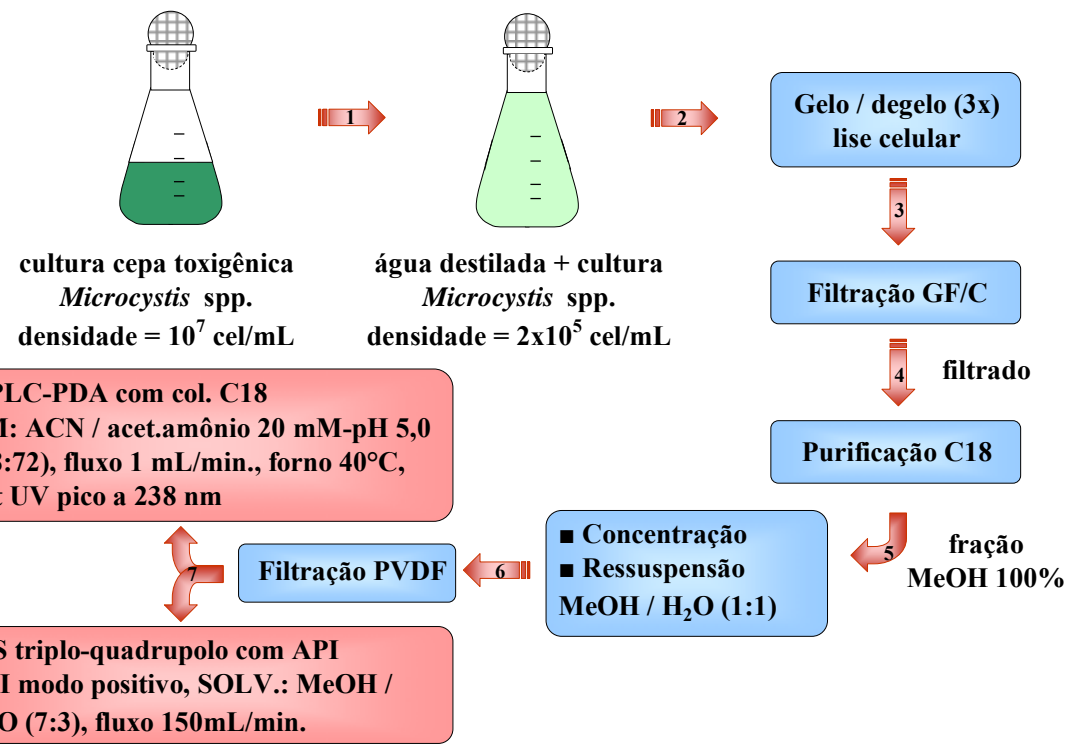

Figura 4.2.1 - Fluxograma das principais etapas realizadas para a caracterização química da principal microcistina produzida pela cepa toxigênica NPLJ4 


\subsubsection{Caracterização toxicológica da cepa NPLJ-4}

A fim de complementar a caracterização da toxicidade da cepa de Microcystis spp. NPLJ-4, após caracterização química preliminar de microcictinas - MCs realizada por HPLC-PDA e MS-ESI, foram realizados testes de toxicidade aguda com camundongos. Os testes de toxicidade foram realizados, por trabalho de colaboração, no Laboratório de Ecotoxicologia do Departamento de Ecologia e Biologia Evolutiva da Universidade Federal de São Carlos - DEBE-UFSCar, sob a supervisão da Profa. Odete Rocha.

\subsubsection{Preparação do extrato para o teste de toxicidade}

Para obtenção dos extratos para o teste de toxicidade, foram preparadas culturas da cepa toxigênica de Microcystis spp. NPLJ-4 e de cepa não toxigênica de Microcystis aeruginosa, sob condições descritas no Item 4.1.1. Após 15 a 20 dias, as culturas na fase final do crescimento exponencial foram concentradas (Figura 4.2.2) e quantificadas pelo método de sedimentação de UTHERMÖHL (1958). Em seguida, os concentrados foram congelados, liofilizados (liofilizador LB 5000 TT da Terroni-Fauvel) e mantidos congelados até o uso (Figura 4.2.3). 


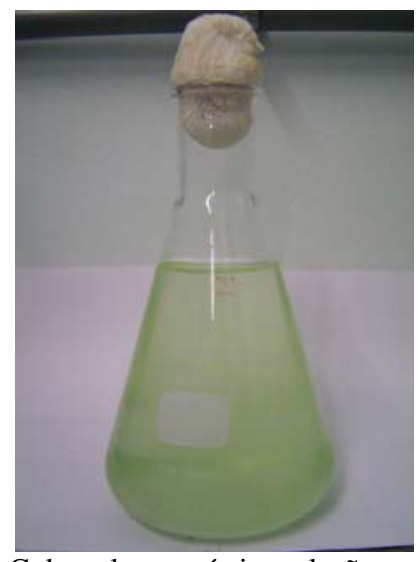

Cultura logo após inoculação em meio ASM1

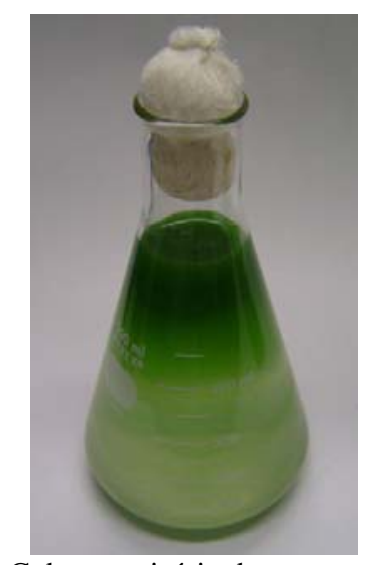

Cultura no início do processo de concentração

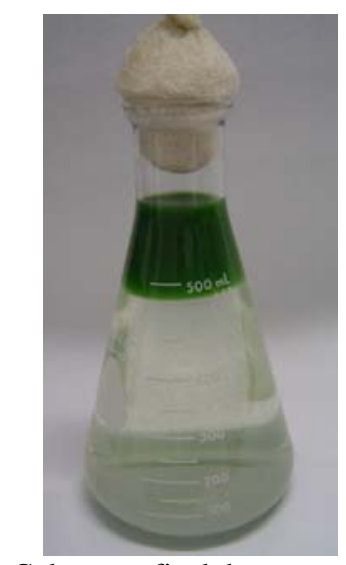

Cultura no final do processo de concentração

Figura 4.2.2 - Vista geral da culturas de Microcystis spp. NPLJ-4 em diferentes fases do processo de concentração

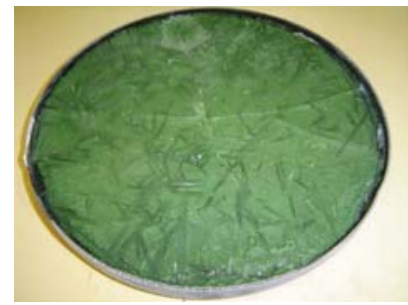

Cultura congelada antes da liofilização

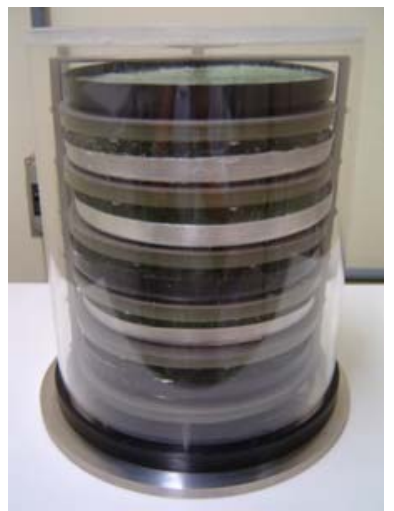

Cultura congelada durante a liofilização
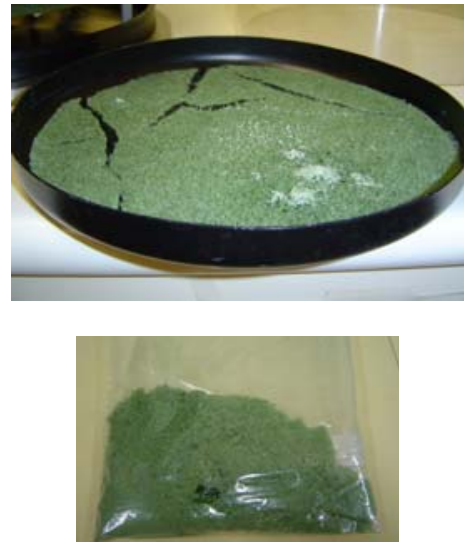

Cultura após liofilização

Figura 4.2.3 - Vista geral da cultura de Microcystis spp. NPLJ-4 concentrada antes, durante e após liofilização

Os extratos foram preparados misturando-se porções do material liofilizado e solução salina $(\mathrm{NaCl}-0,09 \%)$, de forma a obter as concentrações correspondentes às dosagens previstas para cada peso médio corpóreo dos animais previamente selecionados e volume de injeção. Após homogeneização, os extratos foram submetidos ao processo de congelamento / descongelamento e alíquotas dos extratos foram separadas e mantidas congeladas para análise posterior de microcistinas - MCs totais por imunoensaio ELISA (Enzyme-linked immunosorbent assay).

\subsubsection{Teste de toxicidade aguda $-24 \mathrm{~h}$}

Os testes de toxicidade aguda foram realizados segundo método CETESB (1993) com adaptações, empregando-se camundongos machos da espécie Swiss albino com peso corpóreo entre 16,4 e 28,2 g, fornecidos pelo Biotério da UFSCar (Figura 5.2.4 a). Os animais foram identificados e separados em grupos de 3 animais em função do peso 
corpóreo, com o intuito de equalizar os efeitos por dosagem aplicada e facilitar a interpretação dos resultados (Figura 5.2.4 b).

Para cada dosagem testada foram utilizados 3 camundongos, tendo sido aplicados volumes, que variaram em função do peso médio dos animais, entre 0,880 e $1 \mathrm{~mL}$ no teste T1 e entre 0,355 e 1,0 mL no teste T2, por meio de injeções intraperitoniais (i.p). Após as injeções, os animais foram mantidos em local arejado com ração e água, sob observação contínua durante as 5 primeiras horas e posteriormente, em intervalos de 3 a 6 h até 24 horas.

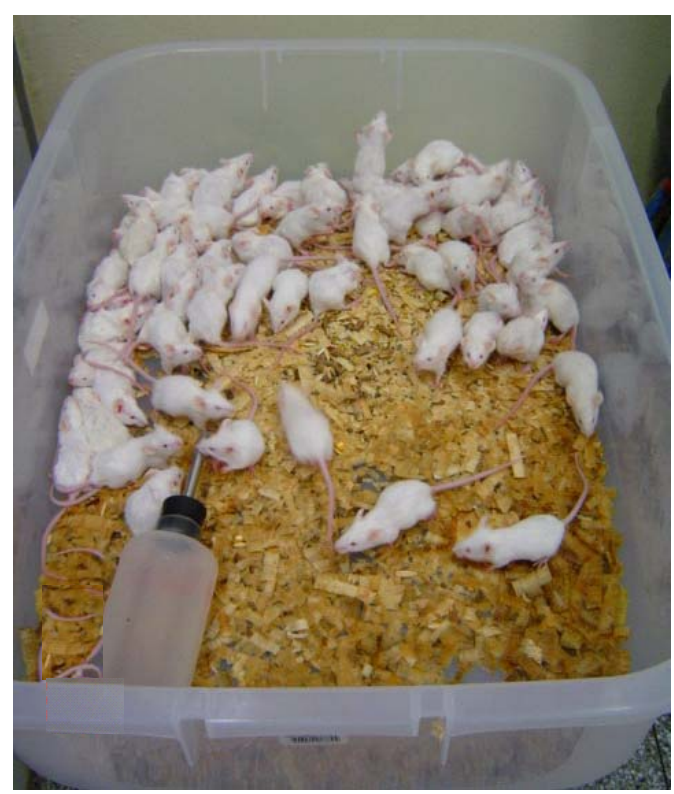

a) camundongos machos da espécie Swiss albino

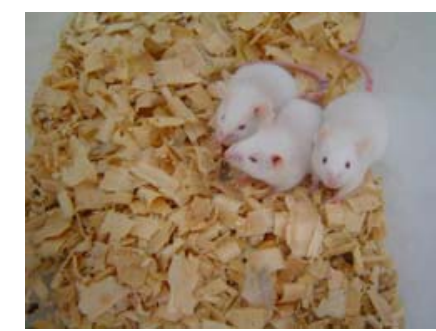

b) camundongos separados para aplicação de uma dosagem (tréplica)

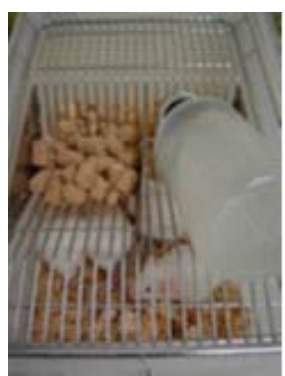

c) acondicionamento dos camundongos com água e ração

Figura 4.2.4 - Vista geral dos camundongos antes do teste

\subsubsection{Análise de microcistinas MCs totais}

A análise de microcistinas - MCs totais (intra e extracelulares) foi realizada por imunoensaio ELISA de placas da Beacon Analytical Systems Inc.. O princípio do método de análise e o procedimento adotado são detalhados no Item 4.3.5.

As alíquotas dos extratos foram previamente filtradas (pré-filtro GF/C) e em seguida diluídas em água deionizada em proporções variadas, de forma a possibilitar a quantificação pela curva de calibração construída especificamente para o lote de amostras. Para o cálculo estatístico da DL50 24h de extrato seco foi usado o programa Trimmed Spearman-Karber (Hamilton et. al. 1977) com intervalo de confiança de 95\%. 


\subsubsection{Avaliação do potencial de formação dos subprodutos organohalogenados - PFSPOs}

\subsubsection{Experimento para obtenção das condições máximas de formação de SPOs}

O experimento para avaliação do potencial de formação de subprodutos organohalogenados - PFSPOs com cloro foi realizado segundo método 5710 A e B de APHA, AWWA, WEF (1999) com adaptações, para os tempos de 3 e 7 dias.

A água de estudo tipo A, representado por AE-A, foi preparada, diluindo-se volumes de cultura de Microcystis spp., com densidade previamente conhecida e especialmente preparada para esse fim, em água filtrada sem cloração da ETASC 2, de forma a resultar em densidades da ordem de $10^{5}$ cél $/ \mathrm{mL}$. Com o intuito de avaliar o efeito da densidade de Microcystis spp. na formação de SPOs, optou-se nesse experimento, pelo emprego adicional de outro tipo de água de estudo, tipo B AE-B..

As águas de estudo A e B foram então preparadas com densidades de $1,4 \times 10^{5}$ $\mathrm{cel} / \mathrm{mL}$ e de $5,5 \times 10^{5} \mathrm{cel} / \mathrm{mL}$, respectivamente, por meio da adição de cultura de Microcystis spp. NPLJ-4, na fase final do crescimento exponencial, em água filtrada sem cloração da ETASC 2 (Figura 4.2.5).
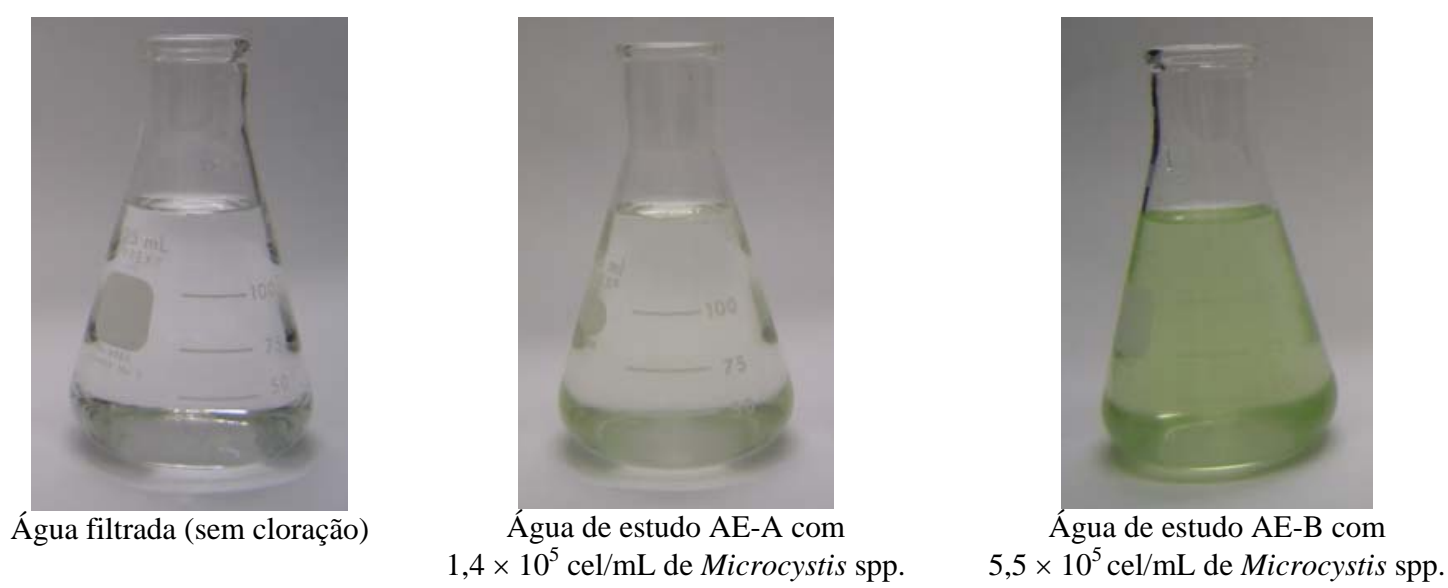

Figura 4.2.5 - Vista geral das águas de diluição e de estudo preparadas para o experimento de determinação do PFSPOs

De acordo com o referido método, as águas de diluição e de estudo A e B foram submetidas a várias dosagens de cloro (hipoclorito de cálcio) em pH 7,0 (corrigido por meio de adição de tampão fosfato a $2 \%$ ) e mantidas no escuro à temperatura de $25^{\circ} \mathrm{C}$, a fim de possibilitar a obtenção das condições máximas de formação de SPOs e as respectivas amostras. Segundo o método, as amostras selecionadas devem apresentar, sob as condições descritas acima, residuais de cloro livre entre 3 e $5 \mathrm{mg} / \mathrm{L}$ após os tempos de contato previstos 
de 3 e 7 dias. As condições experimentais empregadas são relacionadas na Tabela 4.2.1. Na

Figura 4.2.6 é apresentada uma ilustração do planejamento experimental realizado.

Tabela 4.2.1 - Condições experimentais empregadas para determinação do potencial de formação dos subprodutos organohalogenados - PFSPOs

\begin{tabular}{c|c|c|c}
\hline Tipos de água & $\begin{array}{c}\text { Água de diluição } \\
\text { AD }\end{array}$ & $\begin{array}{c}\text { Água de estudo - A } \\
\text { AE-A }\end{array}$ & $\begin{array}{c}\text { Água de estudo - B } \\
\text { AE-B }\end{array}$ \\
\hline $\begin{array}{c}\text { Densidade de Microcystis spp. } \\
\text { (cel/mL) }\end{array}$ & 0 & $1,4 \times 10^{5}$ & $5,5 \times 10^{5}$ \\
\hline $\begin{array}{c}\text { Dosagem de cloro } \\
\text { (hipoclorito de cálcio) }(\mathrm{mg} / \mathrm{L})\end{array}$ & 5,$0 ; 6,0$ e 8,0 & $10 ; 12,5 ; 15$ e 20 & $50 ; 55 ; 65$ e 75 \\
\hline Volume de amostra (mL) & 400 \\
\hline Temperatura $\left({ }^{\circ} \mathrm{C}\right)$ & $25 \pm 0,2$ \\
\hline Volume de tampão pH $7,0(\mathrm{~mL})$ & 8 & 3 e 7 \\
\hline Tempo de contato (dia) & \multicolumn{3}{c}{ tiosulfato de sódio 5\% } \\
\hline Desclorante & \multicolumn{3}{c}{$|c|$}
\end{tabular}

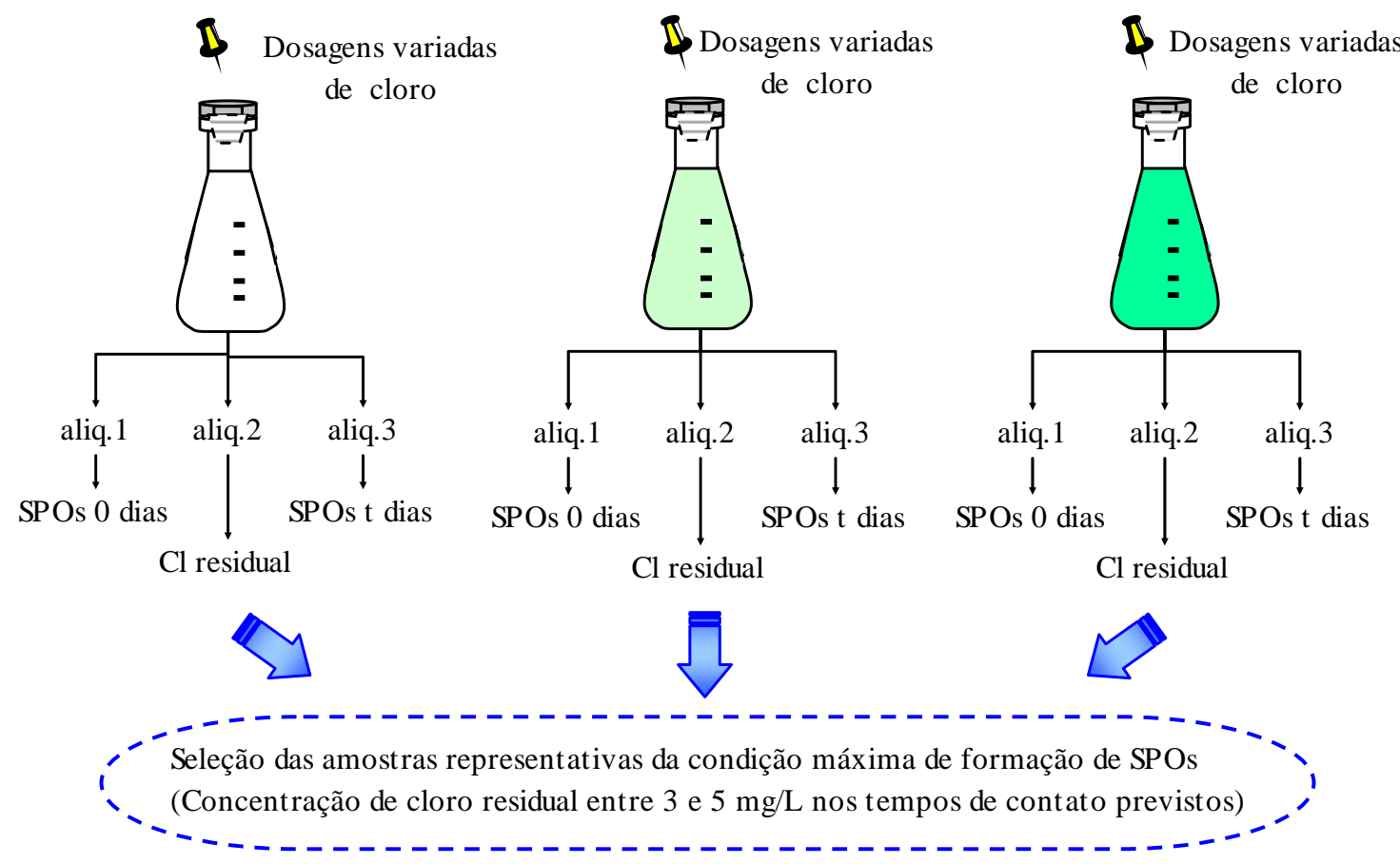

Figura 4.2.6 - Planejamento experimental realizado para avaliação do potencial de formação dos subprodutos organohalogenados - PFSPOs

Após cada dosagem, as amostras foram rápida e cuidadosamente separadas, evitando-se a formação de bolhas e preenchendo-se totalmente os frascos, em 3 alíquotas de $100 \mathrm{~mL}$ :

Alíquota 1: destinada à determinação do PFSPOs no tempo zero, sendo imediatamente desclorada, com adição de $200 \mu \mathrm{L}$ de solução de tiosulfato de sódio $5 \%$, devidamente fechada e mantida a $4^{\circ} \mathrm{C}$; 
Alíquota 2: destinada à medida do residual de cloro livre nos tempos previstos de 3 e 7 dias, sendo mantida sob as mesmas condições da terceira alíquota;

Alíquota 3: destinada à análise dos SPOs formados nos tempos previstos, após seleção.

As alíquotas 2 e 3 foram mantidas em frascos âmbar fechados com tampa de pressão, tampa roscável e selo de silicone em banho termostatizado a $25^{\circ} \mathrm{C} \pm 0,2$ (Figura 4.2.6) durante os tempos de contato previstos, de 3 e 7 dias.

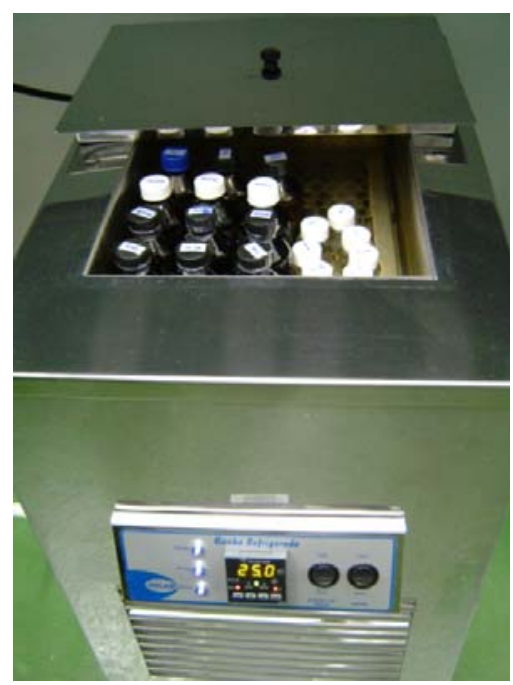

Figura 4.2.7 - Vista geral do experimento: incubação das amostras a $25^{\circ} \mathrm{C}$ por 3 e 7 dias no escuro

\subsubsection{Caracterização física, química e microbiológica da AD e AE-A}

Com exceção dos parâmetros específicos (densidade de Microcystis spp., clorofila-a, e microcistinas), a caracterização das águas AD e AE-A foi realizada, por trabalho de colaboração, pelos técnicos do laboratório do SHS-EESC-USP, segundo metodologias analíticas indicadas em APHA, AWWA, WEF (1999).

\subsubsection{Extração e análise de SPOs}

Após determinação dos residuais de cloro das amostras nos tempos de contato previstos, foram selecionadas as condições máximas de formação de SPOs para as águas de diluição e de estudo A e B com concentrações de cloro residual entre 3 e 5 mg/L, conforme prescreve o método. As terceiras alíquotas das amostras foram então descloradas, extraídas em fase líquida e analisadas por cromatografia gasosa com detector de captura de elétrons CG-DCE, de acordo com descrição apresentada no Item 4.3.4. As extrações e análises foram feitas, por prestação de serviços, pelo Laboratório de Recursos Hídricos da Universidade de Ribeirão Preto - UNAERP, sob responsabilidade da Profa Cristina Paschoalato. 


\subsection{ESTUdo DE MÉtodos PARA ANÁlise DE PARÂMETROS DE CONTROLE ESPECÍFICOS}

Neste item, são apresentados os procedimentos e métodos empregados e os estudos realizados com o objetivo de:

- definir os parâmetros de desempenho, a serem empregados no controle e monitoramento de qualidade dos efluentes gerados nos experimentos;

- definir os procedimentos e metodologias de análise a serem empregadas, considerando a qualidade dos resultados (precisão e reprodutibilidade) e infra-estrutura disponível;

- estabelecer correlações entre os parâmetros de desempenho propostos para avaliação dos processos de tratamento - densidade de células e concentração de subprodutos e outros mais simplificados com curto tempo de resposta, para serem empregados na detecção de variações de qualidade dos efluentes gerados e no controle operacional da instalação piloto;

- fornecer subsídios científicos para possibilitar a análise mais criteriosa dos resultados, bem como a realização de comparações entre dados reportados na literatura.

Devido às especificidades desses estudos metodológicos, estes serão apresentados integralmente neste capítulo, uma vez que correspondem aos testes e comparações realizados, visando a definição do método a ser empregado nos experimentos de processos de tratamento.

A avaliação das correlações entre os parâmetros turbidez, número de partículas e densidade de Microcystis spp., e entre os parâmetros carbono orgânico total e absorvância $254 \mathrm{~nm}$ foram investigados nos estudos de filtração direta em bancada e portanto, serão abordadas no Item 5.3 correspondente.

\subsubsection{Densidade de Microcystis spp.}

A determinação da densidade de Microcystis spp. nas culturas, água de estudo e efluentes do tratamento foi realizada pelos bolsistas do Laboratório de Biotoxicologia em Águas Continentais e Efluentes - BIOTACE do SHS - EESC-USP, sob responsabilidade da Profa. Maria do Carmo Calijuri,.

A densidade de Microcystis spp. foi determinada pelo emprego do método de sedimentação de UTHERMÖHL (1958) em microscópio invertido. Neste método, são utilizadas câmaras de sedimentação de diferentes volumes (de $2 \mathrm{~mL}$ a $40 \mathrm{~mL}$ - Figura 4.3.1), em função da densidade fitoplanctônica da amostra. O tempo de sedimentação está diretamente relacionado com a altura da câmara, e é, no mínimo, três vezes (em horas) a 
altura da câmara (em centímetros), o que resultou em tempos de sedimentação de 1,5 h para a câmara de 2 mL, 12 horas, para câmara de 20 mL, e de 21 horas, para a câmara de 40 mL.

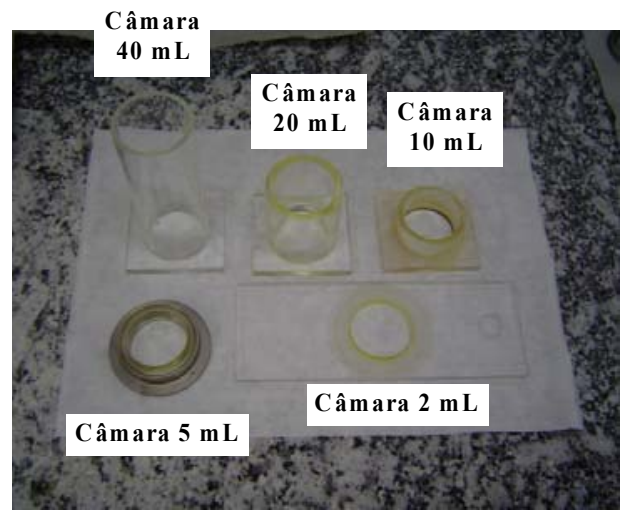

Câmaras de sedimentação para amostras de 2,0; 5,0; 10 ; 20 e $40 \mathrm{~mL}$

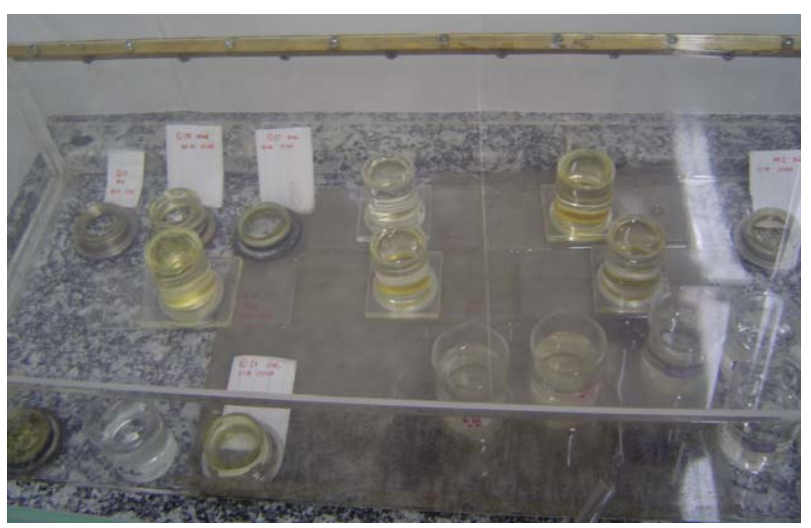

Preparação das amostras para contagem

Figura 4.3.1 - Vista geral das câmaras de sedimentação e preparação das amostras para contagem

As câmaras de volumes mais elevados (20 mL e $40 \mathrm{~mL}$ ) são montadas sobre a câmara de $2 \mathrm{~mL}$ e requer aplicação de silicone em pasta na superfície de contato para união e vedação das câmaras (Figura 4.3.1).

A estimativa da densidade de Microcystis spp.para definição da diluição e do volume da câmara a ser empregada foi realizada pela medida de turbidez e contagem de partículas com tamanhos entre 2 e $10 \mu \mathrm{m}$, dadas as correlações obtidas e apresentadas no Item 5.3. Após coleta das amostras em frascos de vidro âmbar, fez-se a fixação com solução de lugol a base de ácido acético ou com formol (4\%).

Vale ressaltar que as baixas densidades de Microcystis spp. encontradas nos efluentes dos processos de tratamento pesquisados inviabilizaram a contagem direta por outros métodos tais como Sedgwick Rafter, Neubauer, Fuchs Rosenthal, Thoma, Sêmen, Bürker, entre outros, pois o volume de amostra requerido resultaria na perda de precisão na contagem.

\subsubsection{Clorofila-a}

Desde a década de 60, diversas metodologias foram propostas quanto ao modo de extração (agitação, maceração, liofilização, sonificação e imersão), tipo de solvente (acetona $90 \%$, etanol $80 \%$, metanol $100 \%$, clorofórmio-metanol $2: 1 \mathrm{v} / \mathrm{v}$, metanol e sulfeto de hidrogênio, entre outros) a frio / quente e análise (espectrofotometria e fluorimetria) com ou sem separação cromatográfica desses pigmentos, em função do objetivo do estudo, 
diversidade e composição fitoplanctônica, equipamentos disponíveis, tipos de reagentes, qualidade da água, entre outros.

Considerando o tipo de estudo proposto e a infra-estrutura disponível, decidiu-se pela implementação do método espectrofotométrico. Este método requer a extração preliminar do pigmento, utilizando-se um dos solventes. Sabe-se que a seleção do solvente depende de avaliação preliminar com relação ao tipo de organismo fitoplanctônico presente na amostra - espécie, bem como, da diversidade, que pode ser elevada, em águas naturais, e baixa, em culturas puras.

\subsubsection{Procedimento geral}

Os primeiros métodos espectrofotométricos indicam a acetona como o solvente para amostras de clorofila (LORENZEN, 1967). O uso da acetona como solvente é indicado como padrão pela APHA, AWWA, WEF (1999) e pela EPA - ARAR (1997). Porém vários autores discutem a eficiência de extração da clorofila pela acetona (HOLM-HANSEN \& RIEMANN, 1978; MOED \& HALLEGRAEFF, 1978, MARKER et al, 1980).

Assim, foram realizados testes comparativos com o objetivo de possibilitar a escolha do solvente mais adequado a ser empregado para determinação da concentração de clorofilaa na água de estudo e efluentes dos tratamentos. No estudo, foram utilizados os seguintes solventes:

- Acetona 90\% a frio com maceração segundo descrito em APHA, AWWA, WEF (1999)

- Método 10200 H, LORENZEN (1967) e ARAR (1997);

- Metanol 100\% a frio sem maceração (MARKER, 1972);

- Etanol 80\% a quente sem maceração (NUSH, 1980);

- Clorofórmio-Metanol (2:1) a frio sem maceração (WOOD, 1985).

O volume final dos extratos, para todos os solventes, foi de $12 \mathrm{~mL}$. Os extratos foram submetidos a centrifugação (3000 rpm por 15 min) e a leitura no espectrofotômetro foi feito com o sobrenadante. A fórmula utilizada para os três métodos foi a proposta por LORENZEN (1965), com a correção para feopigmentos dada por:

$$
\text { Clorofila }-\mathrm{a}\left(\mu\left(\mu \mathrm{g}^{-1}\right)=\mathrm{P} \times\left(\mathrm{A}_{665}-\mathrm{A}_{750}\right) \times \frac{1.000 \times \mathrm{V}}{\mathrm{S} \times \mathrm{PL}}\right.
$$

em que:

$\mathrm{P}$ = Constante de proporcionalidade derivado do coeficiente molar de extinção (Tabela 4.3.1); 
$\mathrm{A}_{665}=$ Absorbância do extrato no comprimento de onda $665 \mathrm{~nm}$, corrigida com a absorbância do extrato acidificado em 665 nm;

$A_{750}=$ Absorbância do extrato no comprimento de onda $750 \mathrm{~nm}$, corrigida com a absorbância do extrato acidificado em 750 nm;

$\mathrm{V}=$ Volume do extrato em $\mathrm{mL}$;

$\mathrm{S}=$ Volume da amostra filtrada em $\mathrm{mL}$;

$\mathrm{PL}=$ Comprimento ótico da cubeta.

Vale ressaltar que os erros associados ao estado fisiológico e a composição taxonômica são minimizados neste estudo pois teve-se o cuidado de utilizar culturas com o predomínio de Microcystis spp. e amostras retiradas no mesmo período de crescimento.

Os procedimentos utilizados para cada método de extração são detalhados no protocolo do Anexo C.

Tabela 4.3.1 - Valores de constante de proporcionalidade utilizada no calculo da clorofila-a para cada solvente testado

\begin{tabular}{c|c|c}
\hline Solvente & Constante de Proporcionalidade (P) & Referência \\
\hline Acetona $90 \%$ a frio & $26,7 \mathrm{mg} . \mathrm{cm} / . \mathrm{L}$ & ARAR, 1997 \\
\hline Metanol 100\% & $29,6 \mathrm{mg} . \mathrm{cm} / . \mathrm{L}$ & MARKER, 1972 \\
\hline Clorofórmio-Metanol (2:1) & $13,2 \mathrm{mg} . \mathrm{cm} / . \mathrm{L}$ & WOOD, 1985 \\
\hline Etanol 80\% a quente & $27,9 \mathrm{mg} . \mathrm{cm} / . \mathrm{L}$ & NUSH, 1980 \\
\hline
\end{tabular}

As concentrações de clorofila-a obtidas foram analisadas através de:

- correlação com os dados de densidade (células $/ \mathrm{mL}$ ) de Microcystis spp, para determinar qual das metodologias representava melhor a densidade de células;

- teste $\mathrm{t}$ (student) entre os testes para determinar se há diferença significativa entre os métodos.

\subsubsection{Testes realizados e principais resultados}

\section{TESTE 1 - T1}

Objetivo do teste: definição das melhores condições de extração de clorofila-a utilizando-se acetona $90 \%$ como solvente.

Dos resultados obtidos no teste T1, observou-se que o volume mínimo necessário de amostra filtrada para determinação de clorofila deve ser estabelecido em função da densidade de cianobactérias, no caso, de Microcystis spp., tendo-se obtido resultados 
satisfatórios com volumes da ordem de 30; 500 e $1000 \mathrm{~mL}$ para as águas com densidades de $10^{7}, 10^{5}$ e $10^{3}$ cél/mL, respectivamente. Para a amostra com densidade estimada de 10 cél/mL, o volume de $1000 \mathrm{~mL}$ foi insuficiente para detecção.

Em geral, a aplicação por 15 minutos, das rotações de 500, 1000 e 1500 rpm correspondentes a 50,3, 201,2 e 452,7 gravidades não foram suficientes para eliminar o efeito da turbidez na ocasião da leitura espectrofotométrica, em função dos elevados valores de absorvância obtidos no comprimento de onda de $750 \mathrm{~nm}$. Os resultados obtidos com o tempo de extração de 2 h não foram satisfatórios, sendo recomendado o tempo mínimo de 12 h, e o máximo, de 24 h. Os valores calculados de clorofila apresentaram significativas variações, tendo resultado para as águas com densidades de $10^{7}, 10^{5}$ e $10^{3}$ cél $/ \mathrm{mL}$, valores da ordem de 175; 30 e 2,5 $\mu \mathrm{g} / \mathrm{L}$, respectivamente, de acordo com a Tabela 4.3.2.

Tabela 4.3.2 - Condições experimentais e principais resultados do Teste T1

\begin{tabular}{|c|c|c|c|c|c|c|}
\hline Amostra & $\begin{array}{c}\text { Densidade de } \\
\text { Microcystis spp. } \\
\text { estimada (céls/mL) }\end{array}$ & $\begin{array}{c}\text { Volume } \\
\text { filtrado } \\
(\mathrm{mL})\end{array}$ & $\begin{array}{l}\text { Tempo de } \\
\text { extração } \\
\text { (h) } \\
\end{array}$ & $\begin{array}{l}\text { Grau de } \\
\text { agitação } \\
\text { (rpm) }\end{array}$ & $\begin{array}{c}\text { Tempo } \\
\text { agitação } \\
(\text { min) }\end{array}$ & $\begin{array}{c}\text { Clorofila-a } \\
(\mu \mathrm{g} / \mathrm{L})\end{array}$ \\
\hline 1 & $10^{7}$ & 30 & \multirow{4}{*}{2 e,12 h' } & \multirow{4}{*}{1500 e } & \multirow{4}{*}{ ' } & 175 \\
\hline 2 & $10^{5}$ & $100 \rightarrow \mathrm{X}$ & & & & 30 \\
\hline 3 & $10^{3}$ & $500 \rightarrow X$ & & & & 2,5 \\
\hline 4 & 10 & $1000 \rightarrow X$ & & & & - \\
\hline
\end{tabular}

\section{TESTE $2-$ T2}

Objetivo do teste: definição do volume de amostra a ser filtrada e emprego de cubetas de caminho ótico diferente (10 e $100 \mathrm{~mm}$ ), utilizando-se os solventes acetona, etanol e metanol, segundo as metodologias já citadas, para três densidades $\left(10^{1}, 10^{3}\right.$ e $10^{5}$ células de Microcystis spp/mL), de acordo com a Figura 4.3.2.

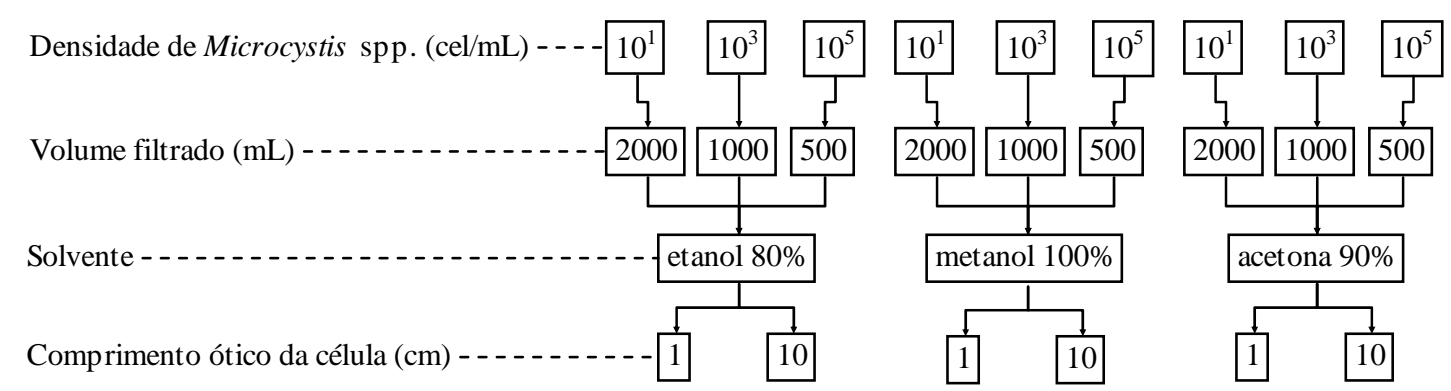

Figura 4.3.2 - Estrutura do Teste T2: três amostras contendo células de Microcystis spp., utilização de três solventes (etanol, metanol e acetona) e leitura em cubetas com caminho ótico diferentes (1 e $100 \mathrm{~mm}$ ) 
O teste $\mathrm{t}$ de Student aplicado aos valores de clorofia-a obtidos em cubetas de $10 \mathrm{~mm}$ e em de 100 mm, nos três tratamentos, indicou não haver diferença entre as concentrações obtidas ( $\mathrm{P}=0,434$ para nível de confiança de 0,05$)$.

O teste $\mathrm{t}$ de Student aplicado aos valores de clorofila-a não indicou diferenças significativas para os três métodos testados. Porém, as maiores concentrações médias foram observadas com a utilização da extração com metanol. Comparando-se os resultados, as concentrações obtidas com etanol e acetona foram respectivamente, $6 \%$ e $41 \%$ menores em relação aos obtidos com metanol (Tabela 4.3.3). Os três métodos tiveram grande correlação com as concentrações de células de cianobactérias (Figura 4.3.3).

Os volumes de amostragem adotados em função da densidade de $M$. spp. foram considerados suficientes para a quantificação de clorofila-a.

Tabela 4.3.3 - Densidade de células de Microcystis spp e concentrações de clorofila-a determinadas pelos métodos da Acetona 90\%, Metanol 100\% e Etanol 80\% a quente, com leitura em cubetas com comprimento ótico de 1 e 100

\begin{tabular}{|c|c|c|c|c|c|c|c|}
\hline \multirow{2}{*}{ Amostra } & \multirow{2}{*}{$\begin{array}{c}\text { Densidade } \\
\text { Microcystis spp. } \\
\text { (cél/mL) }\end{array}$} & \multicolumn{6}{|c|}{ Clorofila com extração em metanol $100 \%$} \\
\hline & & $\begin{array}{c}\text { Metanol } \\
\mathrm{PL}=10 \mathrm{~mm}\end{array}$ & média & $\begin{array}{l}\text { desvio } \\
\text { padrão }\end{array}$ & $\begin{array}{c}\text { Metanol } \\
\mathrm{PL}=100 \mathrm{~mm}\end{array}$ & média & $\begin{array}{l}\text { desvio } \\
\text { padrão }\end{array}$ \\
\hline 1 & \multirow{2}{*}{$1,4 \times 10^{5} \pm 15 \%$} & 21,46 & \multirow{2}{*}{24,42} & \multirow{2}{*}{4,19} & 19,76 & \multirow{2}{*}{22,83} & \multirow{2}{*}{4,34} \\
\hline $1^{\prime}$ & & 27,38 & & & 25,90 & & \\
\hline 2 & \multirow{2}{*}{$2,9 \times 10^{3} \pm 15 \%$} & 2,22 & \multirow{2}{*}{2,41} & \multirow{2}{*}{0,26} & 2,15 & \multirow{2}{*}{2,05} & \multirow{2}{*}{0,13} \\
\hline $2^{\prime}$ & & 2,59 & & & 1,96 & & \\
\hline 3 & \multirow{2}{*}{$7,6 \times 10^{1} \pm 15 \%$} & 1,97 & \multirow{2}{*}{1,73} & \multirow{2}{*}{0,35} & 0,89 & \multirow{2}{*}{1,00} & \multirow{2}{*}{0,16} \\
\hline 3' & & 1,48 & & & 1,11 & & \\
\hline \multirow[b]{2}{*}{ Amostra } & \multirow{2}{*}{$\begin{array}{c}\text { Densidade } \\
\text { Microcystis spp. } \\
\text { (cél/mL) }\end{array}$} & \multicolumn{6}{|c|}{ Clorofila com extração em etanol $80 \%$} \\
\hline & & $\begin{array}{c}\text { Etanol } \\
\mathrm{PL}=10 \mathrm{~mm}\end{array}$ & média & $\begin{array}{l}\text { desvio } \\
\text { padrão }\end{array}$ & $\begin{array}{c}\text { Etanol } \\
\mathrm{PL}=100 \mathrm{~mm}\end{array}$ & média & $\begin{array}{l}\text { desvio } \\
\text { padrão }\end{array}$ \\
\hline 1 & \multirow{2}{*}{$1,4 \times 10^{5} \pm 15 \%$} & 23,02 & \multirow{2}{*}{23,72} & \multirow{2}{*}{0,99} & 23,16 & \multirow{2}{*}{24,62} & \multirow{2}{*}{2,07} \\
\hline $1^{\prime}$ & & 24,41 & & & 26,09 & & \\
\hline 2 & \multirow{2}{*}{$2,9 \times 10^{3} \pm 15 \%$} & 3,49 & \multirow{2}{*}{3,14} & \multirow{2}{*}{0,49} & 2,30 & \multirow{2}{*}{2,88} & \multirow{2}{*}{0,81} \\
\hline $2^{\prime}$ & & 2,79 & & & 3,45 & & \\
\hline 3 & \multirow{2}{*}{$7,6 \times 10^{1} \pm 15 \%$} & 1,16 & \multirow{2}{*}{1,74} & 087 & 0,65 & 150 & 120 \\
\hline $3^{\prime}$ & & 2,33 & & 0,02 & 2,35 & 1,00 & $1, \angle U$ \\
\hline & Densidade & & Clorof & $\operatorname{com}$ ext & ção em aceto & $90 \%$ & \\
\hline Amostra & $\begin{array}{l}\text { Microcystis spp. } \\
\text { (cél/mL) }\end{array}$ & $\begin{array}{c}\text { Acetona } \\
\mathrm{PL}=10 \mathrm{~mm}\end{array}$ & média & $\begin{array}{l}\text { desvio } \\
\text { padrão }\end{array}$ & $\begin{array}{c}\text { Acetona } \\
\mathrm{PL}=100 \mathrm{~mm}\end{array}$ & média & $\begin{array}{l}\text { desvio } \\
\text { padrão }\end{array}$ \\
\hline 1 & & 16,02 & & مه & 16,15 & & (nog \\
\hline $1^{\prime}$ & $1,4 \times 10^{\circ} \pm 15 \%$ & 16,02 & 16,02 & 0,00 & 16,29 & 16,22 & 0,09 \\
\hline 2 & & 0,67 & & 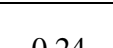 & 0,50 & (1) & (1) \\
\hline 2' & $2,9 \times 10^{\circ} \pm 15 \%$ & 0,33 & 0,50 & 0,24 & 0,33 & 0,42 & 0,12 \\
\hline 3 & & 0,22 & רכ & م 0 م & 0,24 & 023 & 00 \\
\hline $3{ }^{\prime}$ & $7,6 \times 10^{7} \pm 15 \%$ & 0,22 & 0,22 & 0,00 & 0,22 & 0,23 & 0,02 \\
\hline
\end{tabular}

PL: comprimento ótico. 
Em função da constatação de que o pequeno número de amostras e a grande diferença na densidade de Microcystis spp favoreceram as correlações obtidas entre as densidades de células de Microcystis spp e de clorofila-a, planejou-se o terceiro teste.

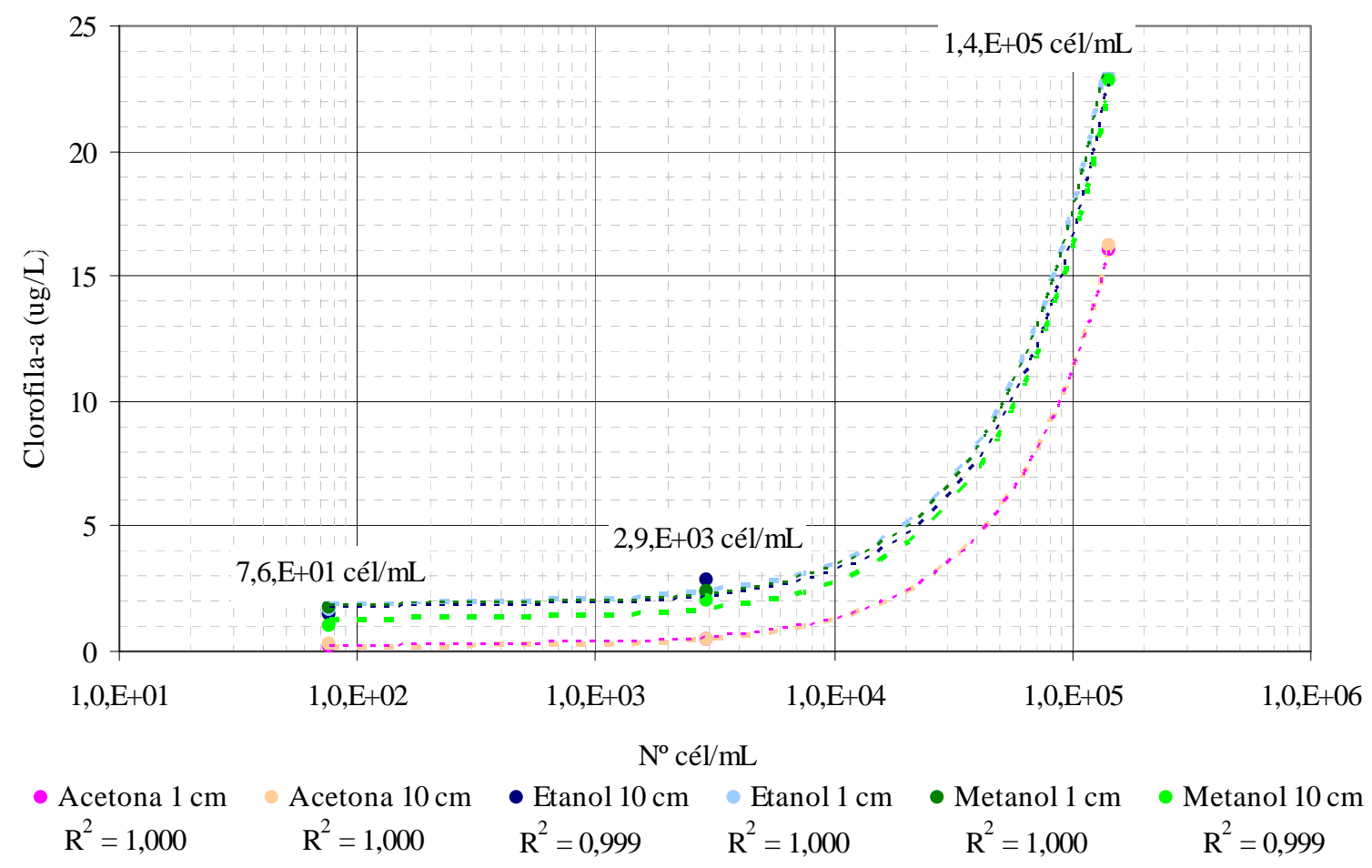

Figura 4.3.3 - Curvas de concentrações de clorofila em relação a densidade de células de Microcystis spp. nos três métodos de extração: acetona, etanol e metanol e respectivos índices de correlação obtidos no Teste T2

\section{TESTE 3 - T3}

Objetivo do teste: estabelecimento de correlações para um número maior de amostras e emprego de cubetas de caminho ótico PL $=10 \mathrm{~mm}$, utilizando-se os solventes acetona, etanol e metanol, segundo as metodologias já citadas, de acordo com a Figura 4.3.4.

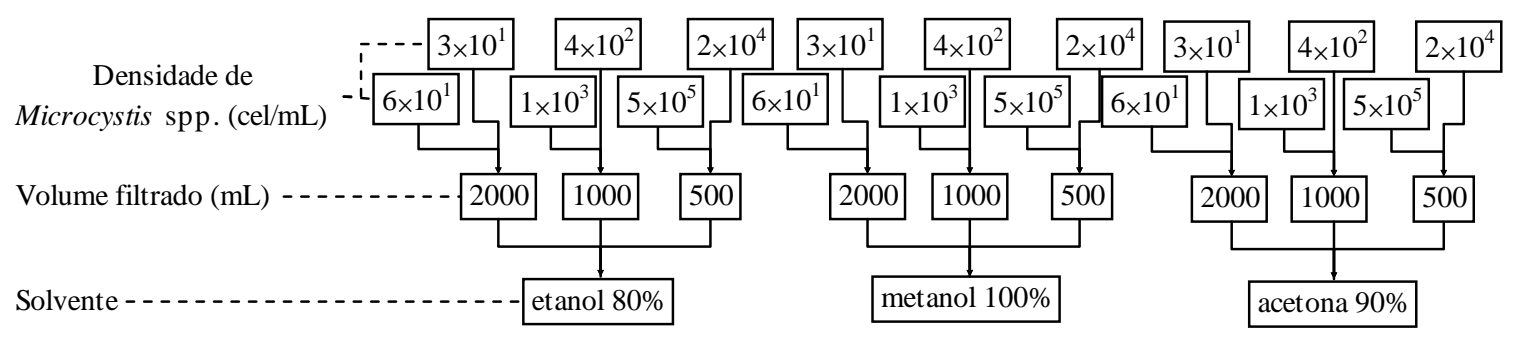

Figura 4.3.4 - Estrutura do Teste T3: seis amostras contendo células de Microcystis spp., utilização de três solventes (acetona, etanol e metanol) e leitura em cubetas com caminho ótico PL=10 mm

Novamente, as concentrações obtidas foram maiores no método do metanol. Estas concentrações foram, em média, $9 \%$ maiores que as obtidas no método do etanol e $1 \%$ 
maiores que as obtidas pelo método da acetona. A diferença entre os métodos foi maior para menores densidades de Microcystis spp. Enquanto as diferenças chegam a 108\% e 125\% para acetona e etanol, respectivamente, em relação ao metanol nas menores concentrações ( $<10^{2}$ células.mL $\mathrm{mL}^{-1}$ ) é somente de $3 \%$ e $5 \%$ na concentração de $10^{5}$.

O teste $\mathrm{t}$ de Student, comparando os métodos dois a dois, para variâncias semelhantes e com nível de decisão alfa de 0,01, também não indicou diferença entre os métodos testados. A correlação com a densidade de células foi novamente muito próxima para os três métodos testados, com diferenças somente próximas a quarta casa decimal (Figura 4.3.5).

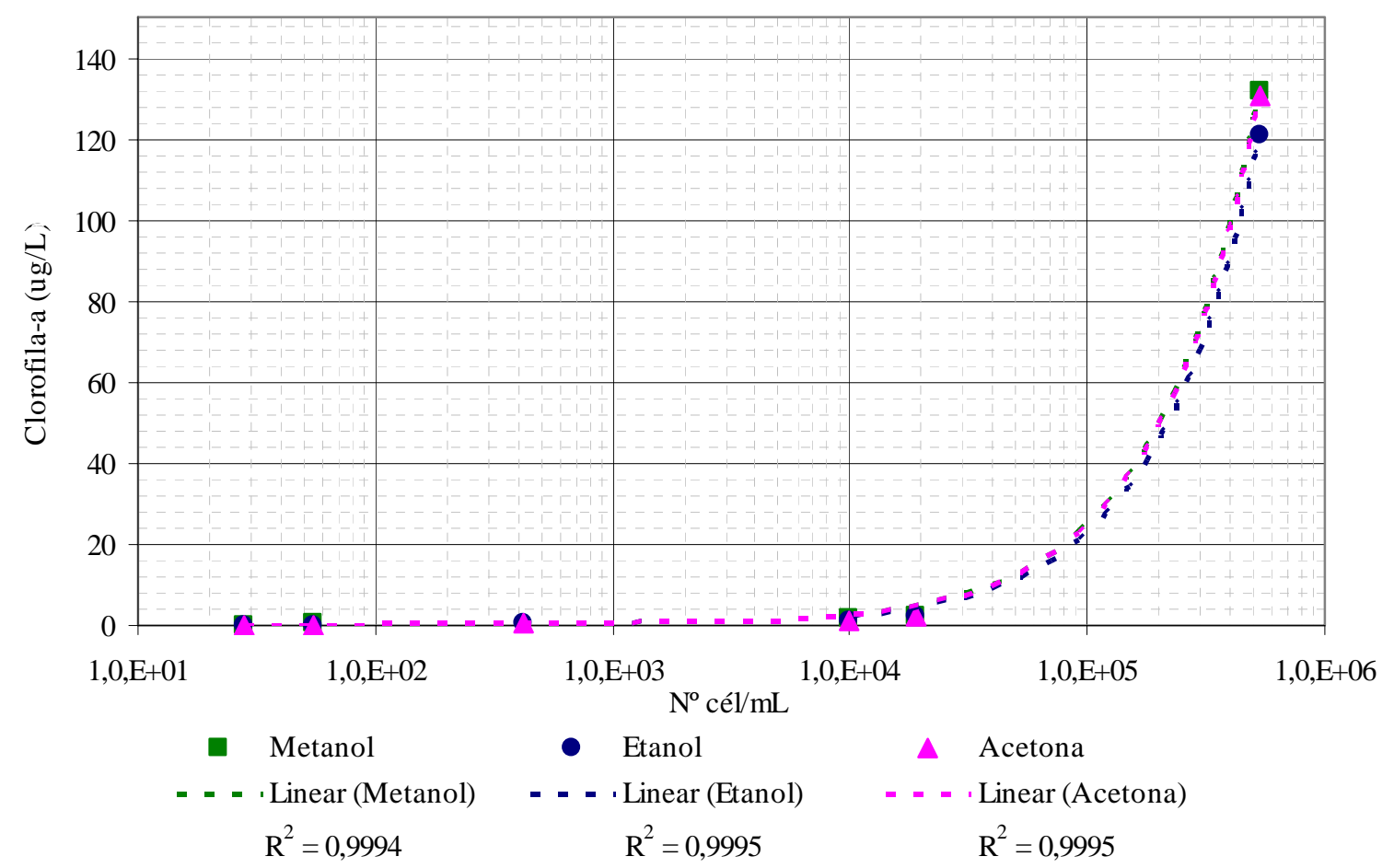

Figura 4.3.5- Curvas de concentrações de clorofila em relação a densidade de células de Microcystis spp. nos três métodos (acetona, etanol e metanol) e respectivos índices de correlação obtidos no Teste T3

Baseado nas constatações feitas por WOOD (1985) e LLOYD \& TUCKER (1988) de que o uso de Clorofórmio-Metanol (2:1) é mais eficiente que a acetona e o metanol na extração de clorofila-a, foi realizado o quarto teste.

\section{TESTE 4 - T4}

Objetivo do teste: estabelecimento de correlações para seis amostras com emprego de cubetas de caminho ótico PL = $10 \mathrm{~mm}$, utilizando-se os solventes acetona, etanol, metanol e clorofórmio-metanol, segundo as metodologias já citadas, de acordo com a Figura 4.3.6. 


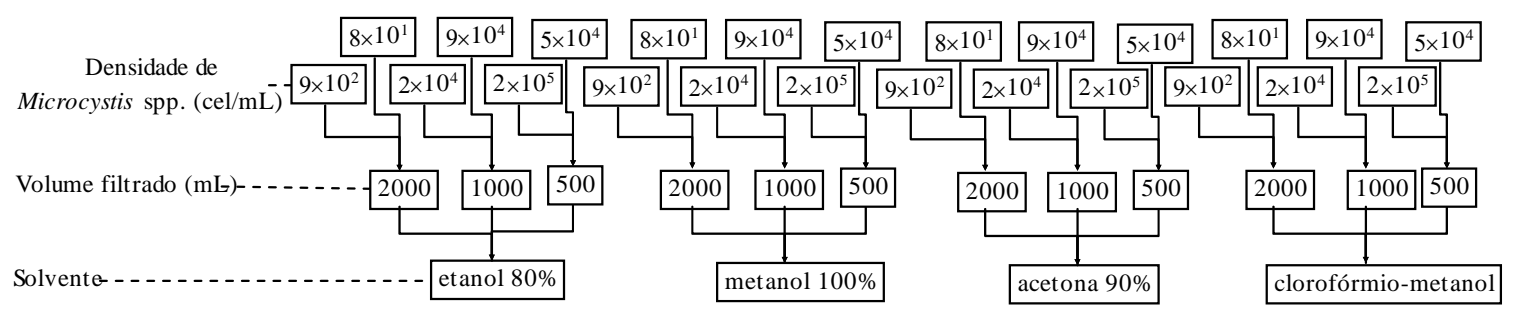

Figura 4.3.6 - Estrutura do Teste T4: seis amostras contendo de células de Microcystis spp. utilização de quatro solventes (acetona, etanol, metanol e clorofórmio-metanol) e leitura em cubetas com caminho ótico PL=10 mm

As concentrações médias obtidas foram maiores para o método do etanol. As concentrações obtidas nos outros métodos foram 13\%, 37\% e 63\% menores para o metanol, acetona e clorofórmio-metanol respectivamente. O teste t de Student também não indicou diferenças significativas entre os quatro métodos testados. A correlação com os dados de concentração de células, apesar de terem valor de $\mathrm{R}^{2}$ menores são muito significativos. As maiores correlações foram observadas com os dados de clorofila-a obtidos pelos métodos que usam como solvente etanol e metanol (Figura 4.3.7).

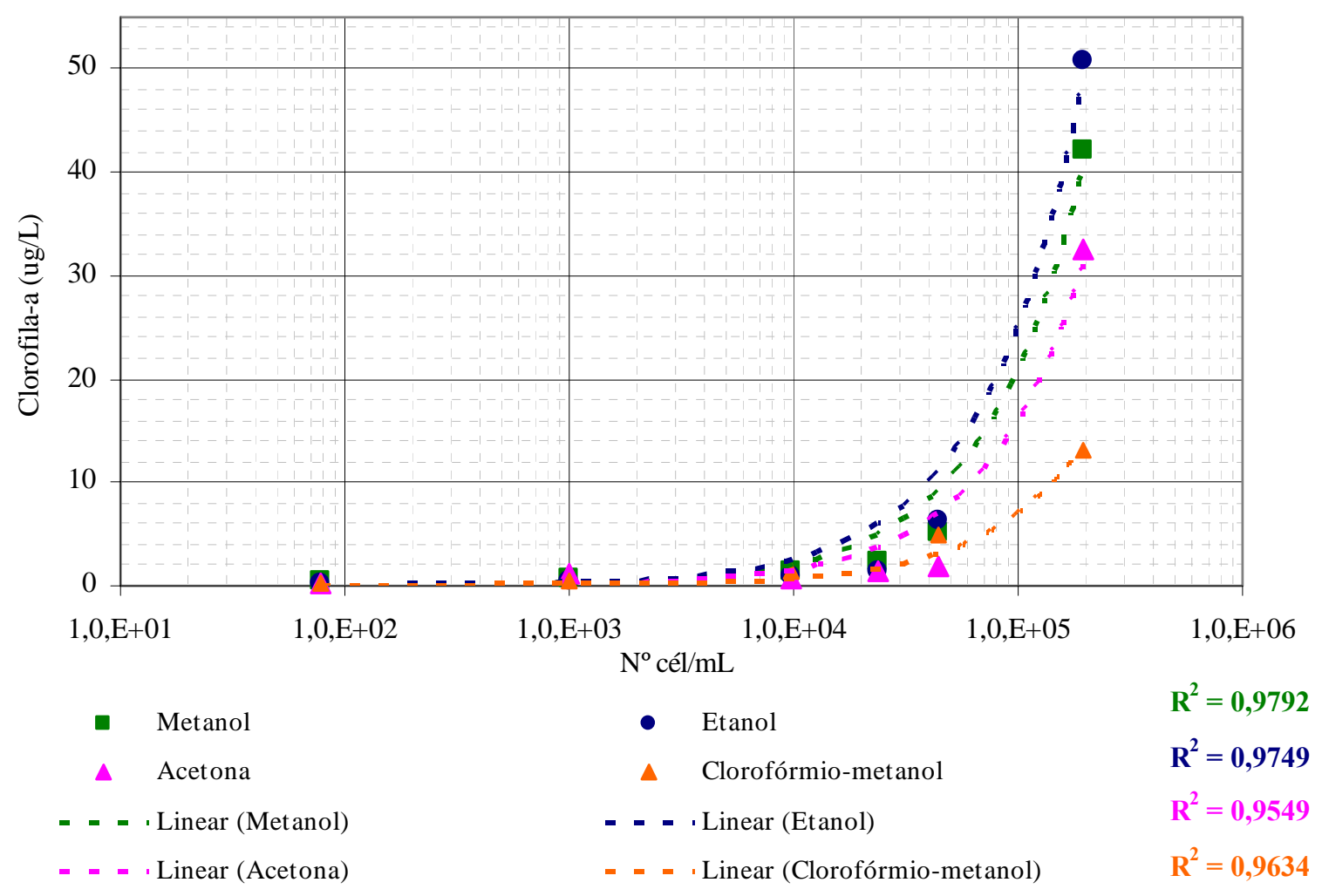

Figura 4.3.7- Curvas de concentrações de clorofila em relação a densidade de células de Microcystis spp. nos quatro métodos testados: acetona, etanol, metanol e metanol-clorofórmio e respectivos índices de correlação obtidos no Teste T4 
Objetivo do teste: avaliação da influência da adição de carbonato de magnésio $\mathrm{MgCO}_{3}$, conforme recomendações feitas por alguns autores (APHA, AWWA, WEF (1999) - Método 10200 H, ASFA (1999), STRICLAND \& PARSON, (1972)) e Companhias de Saneamento no Brasil, utilizando-se o metanol, de acordo com a Figura 4.3.8.

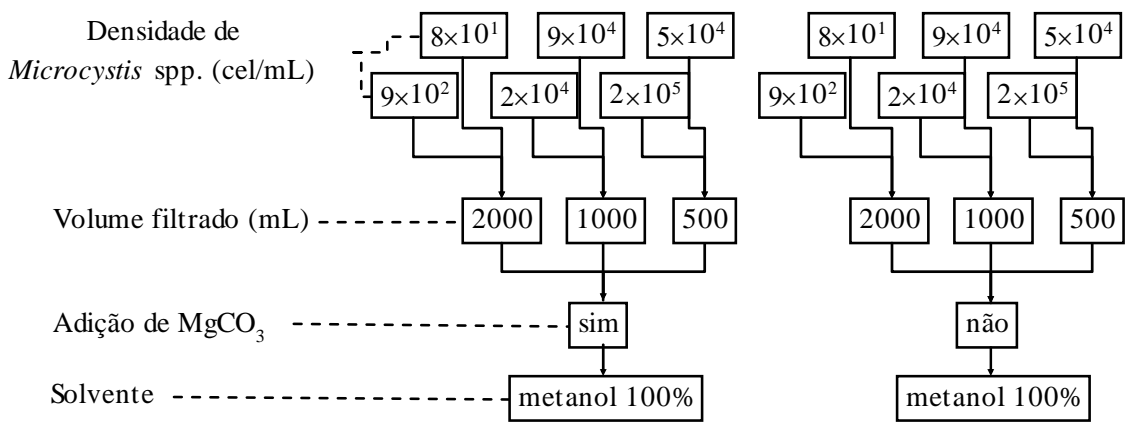

Figura 4.3.8- Estrutura do Teste T5: seis amostras contendo de células de Microcystis spp., utilização de metanol, leitura em cubetas com caminho ótico PL=10 mm, com e sem a adição de $\mathrm{MgCO}_{3}$.

As concentrações de clorofila sem a adição de $\mathrm{MgCO}_{3}$ foram $15 \%$ maiores do que aquelas obtidas com a adição. Não houve diferenças significativas entre os dois métodos segundo os resultados do teste $\mathrm{t}(\mathrm{p}>0,01)$. Porém, deve-se observar, que após preparação, as amostras foram imediatamente submetidas ao processo de extração, o que pode ter contribuído para a similaridade dos resultados.

\section{TESTE 6 - T6}

Objetivo do teste: avaliação das diferenças de resposta com o emprego dos solventes utilizados entre águas preparadas com adição de cultura e água natural com predomnância de Microcystis spp.

Para tanto, foi realizada uma coleta na represa de Salto Grande, cuja classificação fitoplanctônica é apresentada na Tabela 4.3.4.

Como pode ser observado na Figura 4.3.9, para densidades de Microcystis spp. da mesma ordem de grandeza, os valores de clorofila obtidos com a água natural foram bem superiores em relação aos obtidos com as águas de estudo preparadas por meio de adição de cultura de Microcystis spp.. Este fato pode ser explicado pela presença na água natural, de outros organismos com características diferenciadas em relação ao tamanho celular e conteúdo de pigmento fotossintetizante por célula, podendo, mesmo em quantidades não expressivas, terem contribuído para o aumento da concentração de clorofila-a da amostra em questão. 
Tabela 4.3.4 - Classificação fitoplanctônica da amostra natural

\begin{tabular}{c|c|c|c}
\hline & Número & cél/mL & Abundância \% \\
\hline Celulas Microcystis & 16 & $1,1, \mathrm{E}+03$ & 2,5 \\
\hline Colônia de Microcystis & 3 & $2,1, \mathrm{E}+02$ & 0,5 \\
\hline Células de Microcystis em colonia & 557 & & 88,2 \\
\hline Microcystis Total & 573 & $4,1, \mathrm{E}+04$ & 0,5 \\
\hline Outras Cyanobactérias & 3 & $2,1, \mathrm{E}+02$ & 2,5 \\
\hline Diatomáceas & 16 & $1,1, \mathrm{E}+03$ & 4,9 \\
\hline Cloroficeas & 32 & $2,3, \mathrm{E}+03$ & 0,9 \\
\hline Cryptofícea & 6 & $4,3, \mathrm{E}+02$ & 0,2 \\
\hline Outras & 1 & $7,1, \mathrm{E}+01$ & 100,0 \\
\hline Total & & $4,6, \mathrm{E}+04$ & \\
\hline
\end{tabular}

A resposta quanto à eficiência de extração para a água natural foi mantida, isto é, a extração a metanol $100 \%$ e a etanol $80 \%$ produziram valores de concentração de clorofila similares e bem superiores quando comparados com os valores obtidos com a extração a acetona 90\% e clorofórmio-metanol 2:1 v:v.

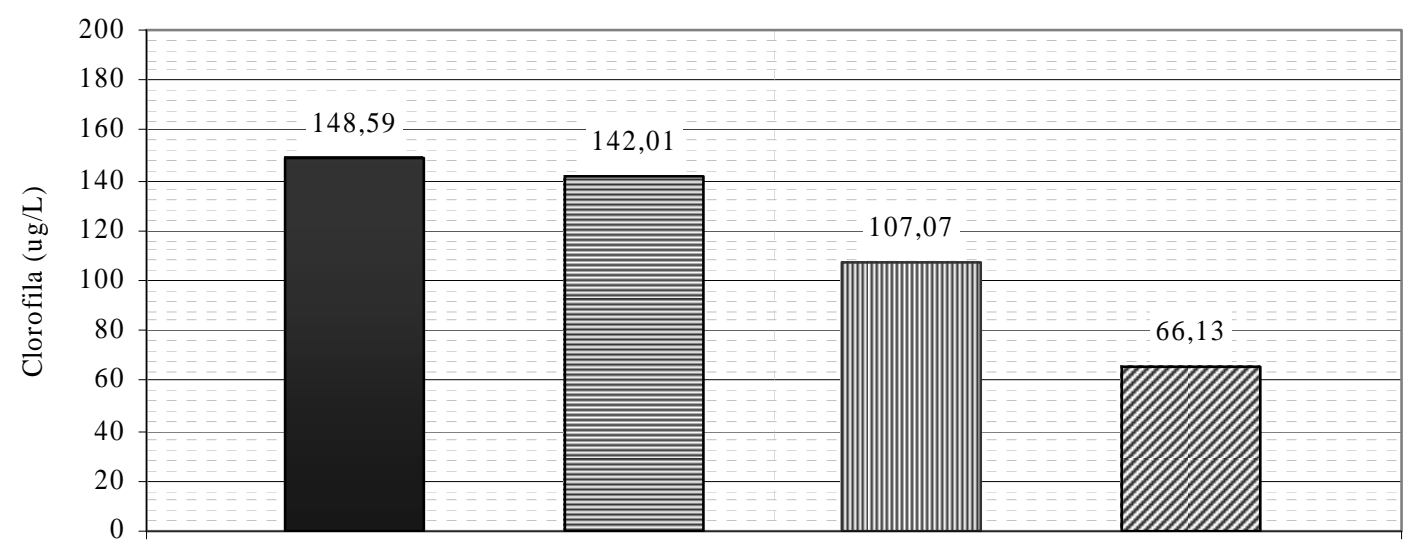

Amostra natural com 88,2 \% (4,1 x 104 cél/mL) de Microcystis spp.

Metanol

目Etanol

m Acetona

๑ Clorofórmio metanol

Figura 4.3.9 - Concentrações de Clorofila-a extraídas por metanol, etanol, acetona e clorofórmio-metanol para água natural com 88,2\% de Microcystis spp. obtidos no Teste 6

\subsubsection{Considerações em relação aos testes de extração de clorofila}

Não foram encontradas diferenças significativas entre o uso de cubetas de $10 \mathrm{~mm}$ e 100 mm de caminho ótico para os três métodos testados; 
Os resultados obtidos com todos os métodos (solventes) testados tiveram grande correlação $\left(\mathrm{R}^{2}>0,9\right)$ com as densidades de células de Microcytis spp.;

Não foram encontrados diferenças estatísticas significativas entre a extração realizada com acetona $90 \%$, metanol $100 \%$, etanol $80 \%$ a quente e Clorofórmio-metanol (2:1), porém, o metanol $100 \%$ e etanol $80 \%$ foram mais eficientes (resultaram em concentrações maiores de clorofila-a), quando comparados aos outros solventes, principalmente nas amostras com menores densidades de células $\left(<10^{4}\right.$ celulas $\left./ \mathrm{mL}\right)$;

$\mathrm{O}$ uso de $\mathrm{MgCO}_{3}$ não produziu diferenças significativas nas concentrações de clorofila-a , porém, deve-se observar, que após preparação, as amostras foram imediatamente submetidas ao processo de extração, o que pode ter contribuído para a similaridade dos resultados.

Os valores de clorofila-a obtidos para água natural com densidades de Microcystis spp. da mesma ordem de grandeza, foram bem superiores em relação aos obtidos com as águas de estudo preparadas por meio de adição de cultura de Microcystis spp. devido, possivelmente, à presença de outros organismos com características diferenciadas em relação ao tamanho celular e conteúdo de pigmento fotossintetizante por célula, podendo, mesmo em quantidades não expressivas, terem contribuído para o aumento da concentração de clorofilaa da amostra em questão.

\subsubsection{Alumínio residual}

Em função da infra-estrutura disponível, utilizou-se o método espectrofotométrico para determinação da concentração de alumínio residual na água de diluição (água filtrada sem cloro, da ETASC 2) e nos efluentes dos processos de tratamento. A implementação foi baseada na metodologia proposta por APHA, AWWA, WEF (1999) - 3500 Al B Eriochrome Cyanine R Method. Os procedimentos utilizados para construção da curva de calibração e análise de alumínio residual são descritos no protocolo do Anexo D.

Os valores escolhidos para construção da curva foram selecionados em função do valor limite preestabelecido em $0,2 \mathrm{mg} / \mathrm{L}$ de alumínio residual na água para consumo humano (Cap. IV / Art. 16 / Tabela 5) da Portaria MS/518/2004.

Após implementação do método espectrofotométrico para análise de alumínio residual, foram conduzidos testes comparativos entre os métodos espectrofotométricos (3500 B Eriochrome Cyanine R Method e o 8012 com emprego de kits da HACH) e o espectrométrico de absorção atômica, de acordo com a Figura 4.3.10. 


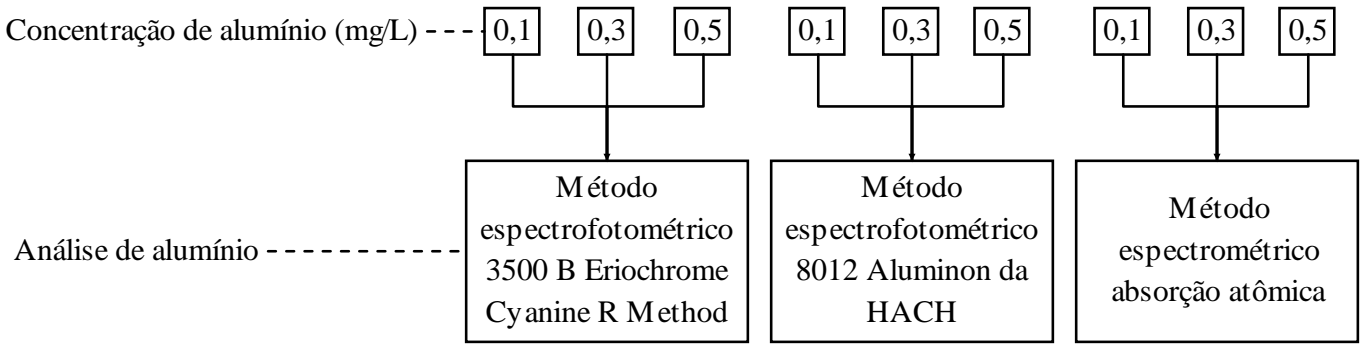

Figura 4.3.10 - Estrutura do teste comparativo entre os métodos de análise de alumínio

As análises por espectrometria de absorção atômica foram realizadas, por trabalho de colaboração, no laboratório do Departamento de Química da UFSCar em equipamento da Gemini Intralab mod AA 12/1475 com curva de calibração na faixa de 0 a 5 mg/L. O teste foi realizado com amostras preparadas por meio de diluição de padrão de alumínio em água deionizada, de forma a resultar nas concentrações teóricas de 0,1; 0,3 e 0,5 mg/L de alumínio (Figura 4.3.11).

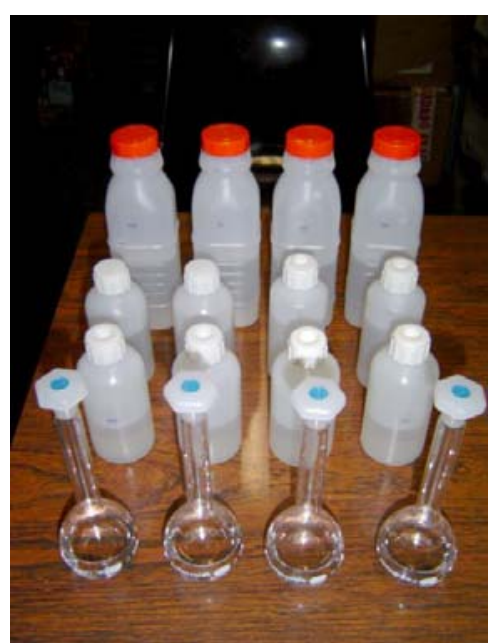

Amostras para os 3 métodos testados

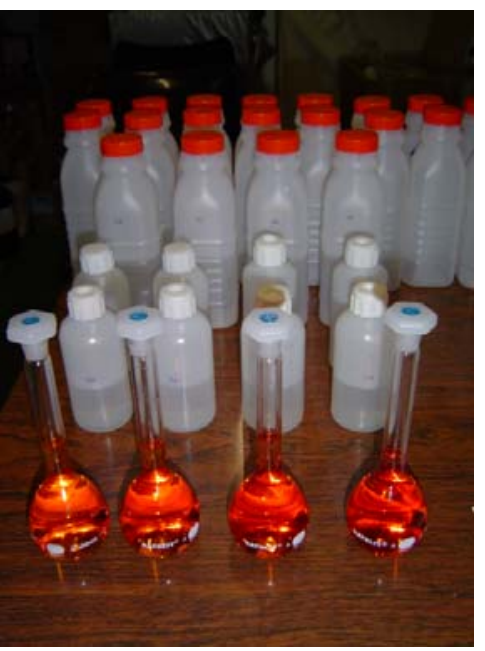

Análise pelo método espectrofotométrico 3500 B

Figura 4.3.11 - Vista geral das amostras para o teste analítico comparativo para alumínio residual

Em função dos resultados obtidos (Tabela 4.3.5), o método espectrofotométrico 3500 B foi o que apresentou valores com maior confiabilidade para as concentrações residuais testadas. Deve-se considerar que as concentrações teóricas de alumínio nas amostras corresponderam a valores da ordem de $10 \%$ da faixa ótima de trabalho para a análise por espectrometria de absorção atômica, o que pode ter contribuído para a ocorrência de perda de precisão dos resultados obtidos. 
Tabela 4.3.5 - Concentrações de alumínio residual obtidos nos testes comparativos

\begin{tabular}{c|c|c|c|c}
\hline $\begin{array}{c}\text { Concentração } \\
\text { teórica de } \\
\text { alumínio }(\mathrm{mg} / / \mathrm{L})\end{array}$ & $\begin{array}{c}\text { Espectrofotométric } \\
\text { o método 3500 B }\end{array}$ & $\begin{array}{c}\text { Espectrofotométrico } \\
\text { método 3500 B }(*)\end{array}$ & $\begin{array}{c}\text { Espectrofotométrico } \\
\text { método 8012 HACH }\end{array}$ & $\begin{array}{c}\text { Espectrométrico } \\
\text { Absorção atômica }\end{array}$ \\
\hline 0,1 & $\mathbf{0 , 0 9 8}$ & $\mathbf{0 , 0 9 2}$ & 0,01 & 0,073 \\
\hline 0,3 & $\mathbf{0 , 2 9}$ & $\mathbf{0 , 3 1 8}$ & 0,2 & 0,154 \\
\hline 0,5 & $\mathbf{0 , 4 3 6}$ & $\mathbf{0 , 4 7 8}$ & 0,41 & 0,345 \\
\hline
\end{tabular}

(*): Leitura realizada 1 semana após preparação da amostra

A análise realizada uma semana após a preparação das amostras, mantidas sem cuidados especiais, revelou que este parâmetro é bastante estável para a condição testada, uma vez que a água utilizada na diluição (água deionizada) era desprovida de compostos que pudessem interferir no resultado, como compostos orgânicos que complexam o alumínio.

Para avaliar a interferência da qualidade da água na quantificação de alumínio residual pelo método $3500 \mathrm{~B}$, foi realizado um teste com amostras preparadas por meio de diluição do padrão de alumínio para as concentrações de 0,1; 0,2; 0,3 e 0,5 mg/L e diferentes tipos de águas para diluição:

- Água deionizada;

- água da ETA 2 de São Carlos (com concentração inicial de alumínio de 0,025 mgAl/L) a ser utilizada nos ensaios em IP;

- água com nutrientes (com concentração inicial de alumínio de 0,016 mgAl/L): sulfato de cálcio, cloreto de potássio, bicarbonato de sódio e sulfato de magnésio, para correção da condutividade, a ser utilizada nos bioensaios;

- água natural com matéria orgânica utilizada nos bioensaios para investigar a ocorrência de complexação do alumínio.

Os resultados obtidos são apresentados na Tabela 4.3.6. De uma maneira geral, não houve interferências significativas na determinação de alumínio para as amostras preparadas com as águas da ETA e com nutrientes. Por outro lado, as amostras preparadas com concentrações previstas de 0,1; 0,2; 0,3 e 0,5 mg/L, com água contendo matéria orgânica, resultaram em valores de concentração de alumínio reduzidas de 1,0;4,2; 5,3; e 8,0\%, respectivamente. 
Tabela 4.3.6 - Concentrações de alumínio residual para diferentes tipos de água de diluição

\begin{tabular}{c|c|c|c|c|c}
\hline \multirow{4}{*}{$\begin{array}{c}\text { Água } \\
\text { de } \\
\text { diluição }\end{array}$} & $\begin{array}{c}\text { Água deionizada com concentração inicial } \\
\text { de alumínio = 0,00 mgAl/L }\end{array}$ & 0,10 & 0,20 & 0,30 & 0,50 \\
\cline { 2 - 5 } & $\begin{array}{c}\text { Água da ETASC com concentração inicial } \\
\text { de alumínio = 0,025 mgAl/L }\end{array}$ & 0,121 & 0,229 & 0,327 & $>0,5$ \\
\cline { 2 - 6 } & $\begin{array}{c}\text { Água com nutrientes com concentração } \\
\text { inicial de alumínio = 0,016 mgAl/L }\end{array}$ & 0,114 & 0,216 & 0,316 & $>0,5$ \\
\cline { 2 - 6 } & Água com matéria orgânica & 0,099 & 0,192 & 0,285 & 0,463 \\
\hline
\end{tabular}

\subsubsection{Subprodutos organohalogenados da oxidação - SPOs}

As extrações e análises dos SPOs foram feitas por prestação de serviço, no Laboratório de Recursos Hídricos da Universidade de Ribeirão Preto - UNAERP, sob responsabilidade da Profa Cristina Paschoalato.

\subsubsection{Determinação de trihalometanos - TAMs, haloacetonitrilas - HANs, cloralhidrato - CH, halocetonas - HKs e halopicrinas - HPs}

O método utilizado para extração e análise de trihalometanos - TAMs, haloacetonitrilas - HANs, cloralhidrato - $\mathrm{CH}$, halocetonas - HKs e halopicrinas - HPs foi baseado no procedimento descrito pela USEPA 551.1 (1995) e adaptado por PASCHOALATO (2005).

\subsection{Extração de trihalometanos - THMs, haloacetonitrilas - HANs, cloralhidrato} - CH, halocetonas - HKs e halopicrinas - HPs em fase líquida

Primeiramente, adicionou-se $10 \mu \mathrm{L}$ de padrão interno (diclorometano $1 \%$ grau cromatográfico, marca J.T. Baker) em $10 \mathrm{~mL}$ de amostra contida em frasco vial de $25 \mathrm{~mL}$, para corrigir o efeito da injeção manual. A extração em fase líquida foi realizada com adição de $4 \mathrm{~mL}$ de metil-terc-butírico-éter - MTBE, mantido a $4^{\circ} \mathrm{C}$, e aproximadamente $1,0 \pm 0,010$ g de sulfato de sódio puro, utilizado como agente secante da fase orgânica. O frasco vial foi agitado vigorosamente por 2 minutos e imediatamente acondicionado em freezer à - $4^{\circ} \mathrm{C}$.

Após decantação, foram formadas duas fases bem definidas: a fase orgânica superior, chamada de extrato, e a fase inferior, chamada de fase aquosa. A fase orgânica foi retirada e transferida para um frasco vial de $4 \mathrm{~mL}$, acondicionada em freezer e conservada para análise por cromatografia gasosa com detector de captura de elétrons - CG-DCE por um período máximo de 7 dias, sendo a fase aquosa, descartada. Durante todo o procedimento de manipulação com padrões e solventes para diluição e preparo da curva de calibração, teve-se o cuidado de colocar gelo em uma bandeja plástica onde os reagentes e vidrarias em uso permaneceram apoiados para evitar perdas por evaporação. 


\subsection{Analise de trihalometanos - THMs, haloacetonitrilas - HANs, cloralhidrato - CH, halocetonas - HKs e halopicrinas - HPs por cromatografia gasosa com detector de captura de elétrons - CG-DCE}

As análises de trihalometanos, haloacetonitrilas, cloralhidrato, halocetonas e cloropicrina por CG-DCE foram realizadas em cromatógrafo a gás da Varian, modelo 3600CX, com detetor de captura de elétrons sob condições cromatográficas relacionadas a seguir.

- Coluna J\&W-DB-1, 30m x 0,32mm ID e 5 $\mu \mathrm{m}$ filme;

- Gás de arraste nitrogênio 5.0 ECD com fluxo de 3,6 mL/min, 74 cm/s com pressão de 15 psi (1,071 atm);

- Temperatura do injetor a $160^{\circ} \mathrm{C}$ e temperatura do detector a $290^{\circ} \mathrm{C}$;

- Temperatura inicial de $40^{\circ} \mathrm{C}$ por $1 \mathrm{~min}$, rampa de aquecimento até $125^{\circ} \mathrm{C}$ numa razão de $5^{\circ} \mathrm{C} / \mathrm{min}$ por $2 \mathrm{~min}$, rampa de aquecimento até $150^{\circ} \mathrm{C}$ numa razão de $35^{\circ} \mathrm{C} / \mathrm{min}$ e permanece em $150^{\circ} \mathrm{C}$ por $10 \mathrm{~min}$;

- Com divisão de amostra de $2 \mathrm{~mL} / \mathrm{min}$ e sensibilidade 10 ;

- Tempo total aproximado de 25 min para cada análise;

- Volume de extrato injetado de $1 \mu \mathrm{L}$.

Os padrões de calibração utilizados para esse método foram:

- Padrão misto de trihalometanos, marca Supelco (48140-U) para THMs;

- Padrão puro de grau cromatográfico de bromofórmio, marca MERCK.

- Padrão misto de halogenados voláteis (EPA 551 B), marca Supelco (48046), para haloacetonitrilas, cloropicrina e haloacetonas;

- Padrão puro de cloralhidrato, marca Supelco (47335-U).

Por este método foram determinados os seguintes compostos:

- Trihalometanos - THMs: clorofórmio, bromodiclorometano, dibromoclorometano, bromofórmio;

- Cloralhidrato - $\mathrm{CH}$;

- Haloacetonitrilas - HANs: dicloroacetonitrila, tricloroacetonitrila, dibromoacetonitrila, tribromoacetonitrila, bromocloroacetonitrila;

- Halopicrinas - HPs: cloropicrina;

- Haloacetonas - HKs: 1,1-dicloropropanona, 1,1,1-tricloropropanona. 
Na Figura 4.3.12 é apresentado o cromatograma (típico) de um ponto da curva de calibração EPA 551 construída.

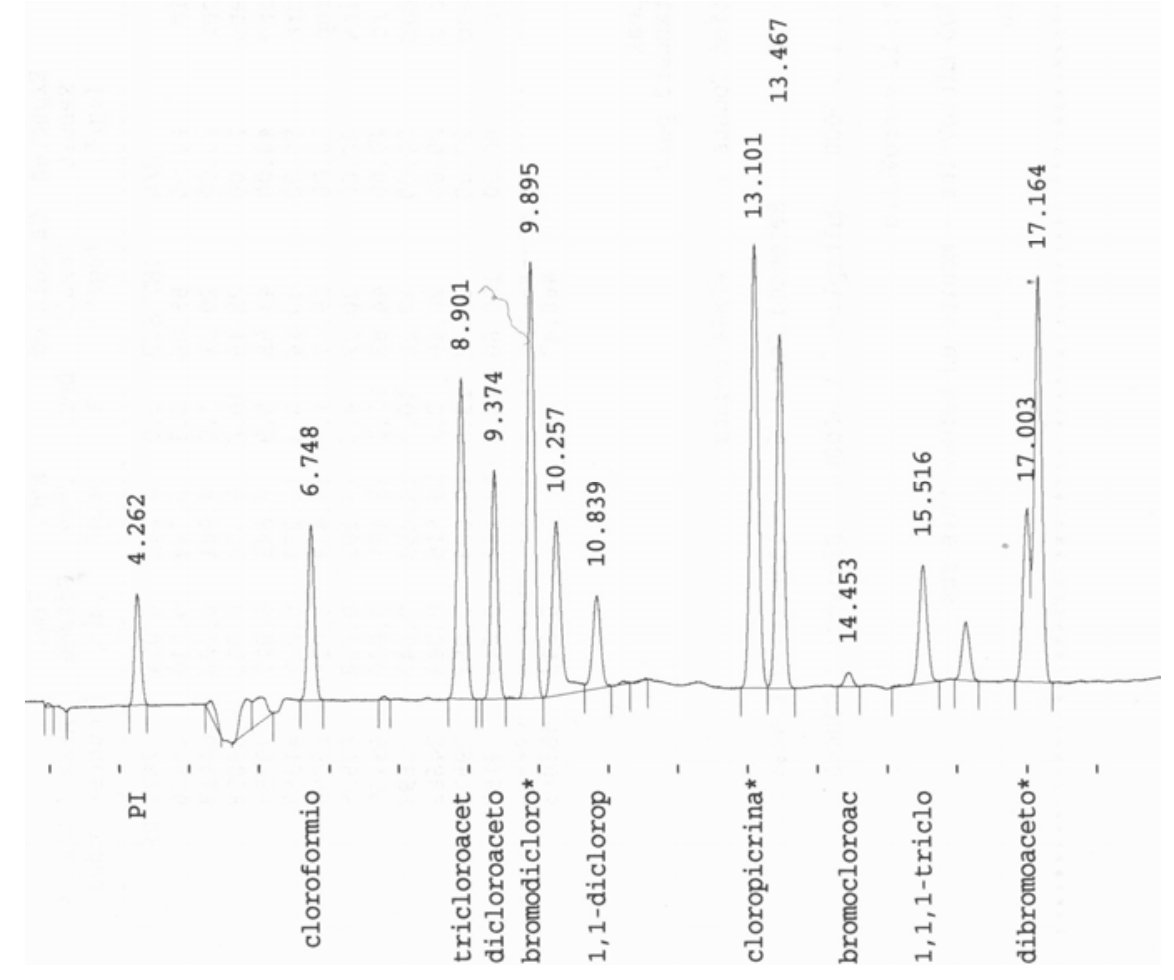

Figura 4.3.12 - Cromatograma (típico) de um ponto da curva de calibração EPA 551

\subsubsection{Determinação dos ácidos haloacéticos - AHAs}

O método utilizado para extração e análise de ácidos haloacéticos - AHAs foi baseado no procedimento descrito pela USEPA 552.2 (1995) e adaptado por PASCHOALATO (2005).

\subsection{Extração dos ácidos haloacéticos - AHAs com derivatização}

Primeiramente, adicionou-se $50 \mu \mathrm{L}$ de padrão interno (2,3-ácido dibrompropiônico, $10 \mathrm{mg} / \mathrm{L}$ ) em $50 \mathrm{~mL}$ de amostra, contida em balão volumétrico de $50 \mathrm{~mL}$, para corrigir o efeito da injeção manual. Em seguida, a amostra foi acidificada com $1 \mathrm{~mL}$ de ácido sulfúrico concentrado e acrescentou-se $2 \mathrm{~g}$ de sulfato de cobre e $16 \mathrm{~g}$ de sulfato de sódio. O frasco foi tampado, agitado por 10 min e em seguida, foi resfriado em geladeira até temperatura de $4^{\circ} \mathrm{C}$. Após completa dissolução e resfriamento da amostra, foram adicionados $5 \mathrm{~mL}$ de MTBE mantido a $4^{\circ} \mathrm{C}$. A amostra foi submetida a agitação por 10 min seguida de repouso para separação das fases.

Com auxílio de uma pipeta, transferiu-se $3 \mathrm{~mL}$ da fase orgânica para um tubo de vidro com tampa roscável, no qual foi adicionado $1 \mathrm{~mL}$ de solução ácida de metanol 10\%. 
Após fechamento do frasco, o mesmo foi mantido sob aquecimento imerso em banho termostatizado a $50^{\circ} \mathrm{C}$ por $2 \mathrm{~h}$.

Finalmente, o frasco foi resfriado e adicionaram-se $4 \mathrm{~mL}$ de solução saturada de bicarbonato de sódio em incrementos de $1 \mathrm{~mL}$. O extrato obtido foi transferido para um frasco vial de $4 \mathrm{~mL}$ e acondicionado em freezer à - $4^{\circ} \mathrm{C}$ para análise posterior por CG-DCE por um período máximo de 14 dias.

\subsection{Analise dos ácidos haloacéticos - AHAs por cromatografia gasosa com detector de captura de elétrons - CG-DCE}

As análises dos ácidos haloacéticos por CG-DCE foram realizadas em cromatógrafo a gás da Varian, modelo 3600CX, com detetor de captura de elétrons sob condições cromatográficas relacionadas a seguir.

- Coluna capilar DB-1701, 30m, 0,32mm ID, 0,25 $\mu \mathrm{m}$ de filme;

- Gás de arraste nitrogênio;

- Temperatura do injetor $250^{\circ} \mathrm{C}$, temperatura do detector $300^{\circ} \mathrm{C}$;

- Fluxo de 1,4 mL/min, velocidade de $29 \mathrm{~cm} / \mathrm{s}$ em 6 psi (0,428 atm);

- Sem divisão de amostras, sensibilidade 10 ;

- Temperatura isoterma de $40^{\circ} \mathrm{C}$ por $3 \mathrm{~min}$, aquecimento a $130^{\circ} \mathrm{C}$ numa razão de $4^{\circ} \mathrm{C} / \mathrm{min}$ durante 5 min, aquecimento a $180^{\circ} \mathrm{C}$ numa razão de $20^{\circ} \mathrm{C} / \mathrm{min}$ durante $3 \mathrm{~min}$;

- Tempo total aproximado de corrida analítica 36,1 min.

- Volume de extrato injetado de $1 \mu \mathrm{L}$.

Para elaboração da curva de calibração foi utilizada uma mistura de padrões da marca Supelco (4-7787), originalmente dissolvido em MTBE, com os seguintes compostos de ácidos haloacéticos (AHAs): ácido monocloroacético, ácido dicloroacético, ácido tricloroacético, ácido monobromoacético, ácido dibromoacético, ácido tribromoacético, ácido bromocloroacético, ácido bromodicloroacético, ácido dibromocloracético.

Na Figura 4.3.13 é apresentado o cromatograma (típico) de um ponto da curva de calibração EPA 552 construída. 


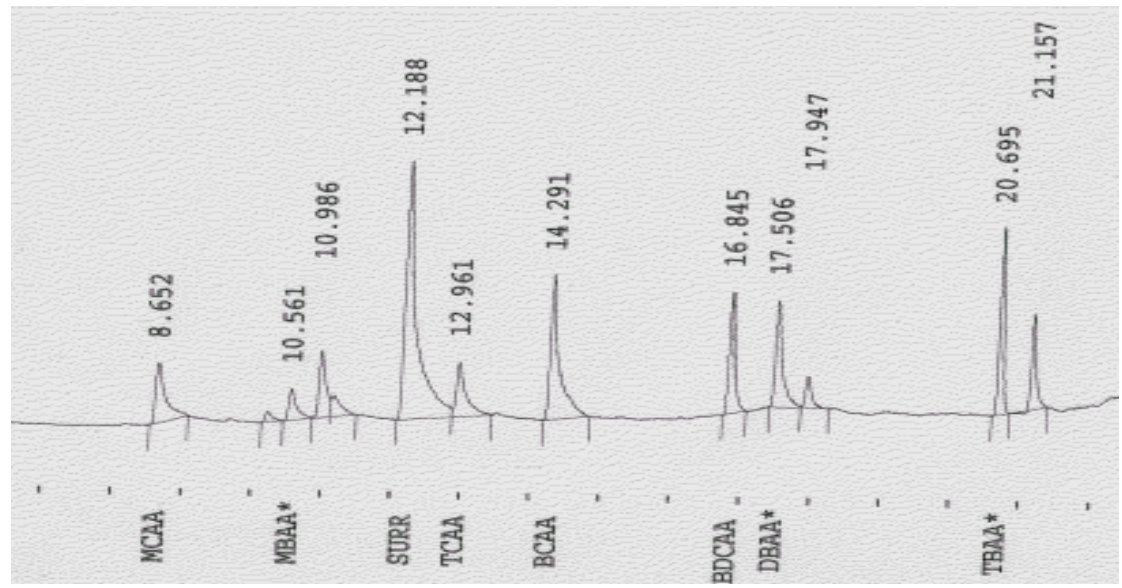

Figura 4.3.13 - Cromatograma (típico) de um ponto da curva de calibração EPA 552

As curvas de calibração denominadas EPA551 para determinação de trihalometanos - THMs, haloacetonitrilas - HANs, cloralhidrato - $\mathrm{CH}$, halocetonas - HKs e halopicrinas HPs e curva EPA 552, para determinação dos ácidos haloacéticos AHAs foram construídas e checadas por meio de injeção de padrão externo com concentrações teóricas conhecidas antes de cada bateria de análise.

\subsubsection{Cálculo do potencial de formação de subprodutos organohalogenados - PFSPOs}

A concentração total de trihalometanos - Total THMs foi calculada conforme equação apresentada a seguir.

Total THMs $=\left[\mathrm{CHCl}_{3}\right]+\left[\mathrm{CHBrCl}_{2}\right]+\left[\mathrm{CHBr}_{2} \mathrm{Cl}\right]+\left[\mathrm{CHBr}_{3}\right]$

em que:

$\left[\mathrm{CHCl}_{3}\right](\mu \mathrm{g} / \mathrm{L})$ : concentração de clorofórmio;

$\left[\mathrm{CHBrCl}_{2}\right](\mu \mathrm{g} / \mathrm{L})$ : concentração de bromodiclorometano;

[CHBr $\left.{ }_{2} \mathrm{Cl}\right](\mu \mathrm{g} / \mathrm{L})$ : concentração de dibromoclorometano;

$\left[\mathrm{CHBr}_{3}\right](\mu \mathrm{g} / \mathrm{L})$ : concentração de bromofórmio.

A concentração total de ácidos haloacéticos - Total AHAs foi calculada conforme equação apresentada a seguir.

Total AHAs $=[$ MCAA $]+[$ MBAA $]+[$ DCAA $]+[$ TCAA $]+[$ BCAA $]+[$ BDCAA $]+$ $[\mathrm{DBAA}]+[\mathrm{CDBAA}]+[\mathrm{TBAA}]$

em que:

[MCAA] $(\mu \mathrm{g} / \mathrm{L})$ : concentração de ácido monocloroacético;

[MBAA] ( $\mu \mathrm{g} / \mathrm{L})$ : concentração de ácido monobromoacético;

[DCAA] ( $\mu \mathrm{g} / \mathrm{L})$ : concentração de ácido dicloroacético; 
[TCAA] $(\mu \mathrm{g} / \mathrm{L})$ : concentração de ácido tricloroacético;

[BCAA] ( $\mu \mathrm{g} / \mathrm{L})$ : concentração de ácido bromocloroacético;

[BDCAA] ( $\mu \mathrm{g} / \mathrm{L})$ : concentração de ácido bromodicloroacético;

[DBAA] $(\mu \mathrm{g} / \mathrm{L})$ : concentração de ácido dibromoacético;

[CDBAA] $(\mu \mathrm{g} / \mathrm{L})$ : concentração de ácido clorodibromoacético;

[TBAA] $(\mu \mathrm{g} / \mathrm{L})$ : concentração de ácido tribromoacético.

O potencial de formação de subprodutos organohalogenados - PFSPOs foi calculado pela diferença entre as concentrações de SPOs formados no tempo de contato previsto (3 e 7 dias) e no tempo zero, descontando-se os possíveis SPOs formados com a água de diluição (branco) nos respectivos tempos, conforme equação apresentada a seguir.

PFSPOs $_{\mathrm{t} \text { dias }}=\left[\left(\mathrm{SPOs}_{\mathrm{t} \text { dias }}-\mathrm{SPOs}_{0 \text { dias }}\right)-\left(\mathrm{SPOs}_{\mathrm{b}} \mathrm{b}_{\mathrm{t} \text { dias }}-\mathrm{SPOs} \mathrm{b}_{0 \text { dias }}\right)\right]$

em que:

SPOs $_{\mathrm{t} \text { dias }}(\mu \mathrm{g} / \mathrm{L})$ : concentração de SPOs formados na amostra após t dias;

$\operatorname{SPOs}_{0 \text { dias }}(\mu \mathrm{g} / \mathrm{L})$ : concentração de SPOs formados na amostra no tempo = 0 dias;

SPOs,b t dias $(\mu \mathrm{g} / \mathrm{L})$ : concentração de SPOs formados no branco após t dias;

SPOs $_{0 \text { dias }}(\mu \mathrm{g} / \mathrm{L})$ : concentração de SPOs formados no branco no tempo $=0$ dias.

Na Figura 4.3.14 é apresentado um exemplo ilustrativo de acordo com a equação proposta para o cálculo do potencial de formação de subprodutos organohalogenados de $t$ dias.

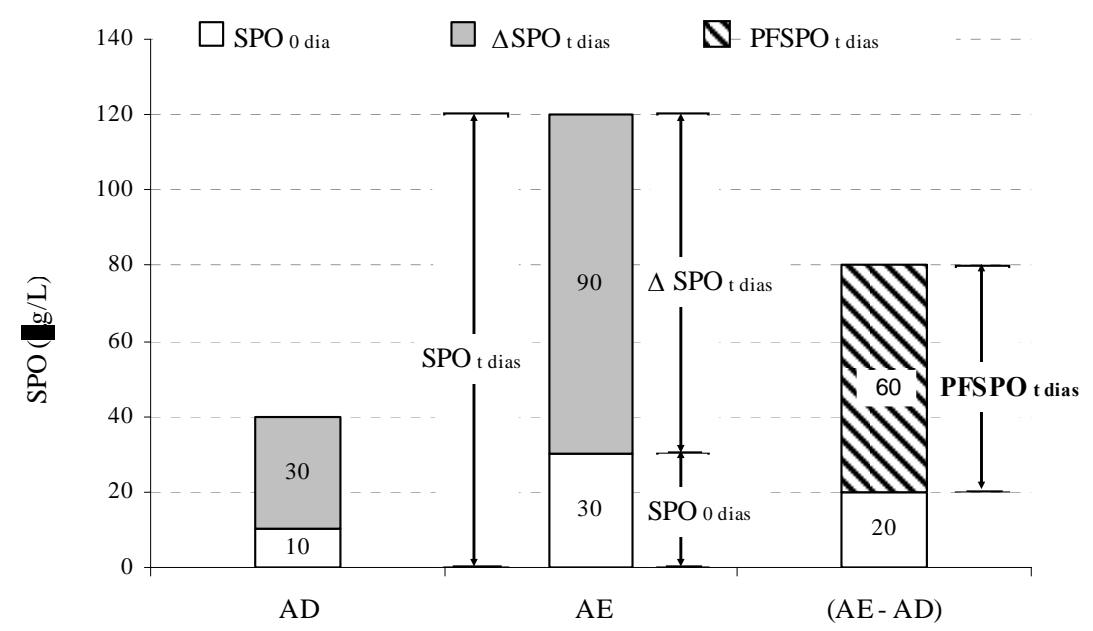

Figura 4.3.14 - Exemplo ilustrativo do cálculo do PFSPOs de t dias 


\subsubsection{Análise de microcistinas pelo método de imunoensaio ELISA (Enzyme-linked immunosorbent assay)}

A análise de microcistinas - MCs totais por imunoensaio ELISA foi realizada com o kit de placas da Beacon Analytical Systems Inc.. O método de imunoensaio ELISA utilizado baseia-se na competição direta entre dois tipos de antígenos (a possível microcistina - MC presente na amostra, e em seguida, o antígeno marcador ligado a uma enzima, neste caso, a peroxidase), sobre um número limitado de anticorpos policlonais de coelho anti-MC-LR, com reatividade cruzada também, contra vários congêneres de microcistinas (100 \% para MC-LR, 87\% para a MC-RR e 48\% para a MC-YR), adsorvidos na parede dos poços para reação. Assim, os resultados das análises por imunoensaio ELISA são expressas, neste caso, na forma de equivalentes de MCs totais. O processo de reação do método é ilustrado na Figura 4.3.15.

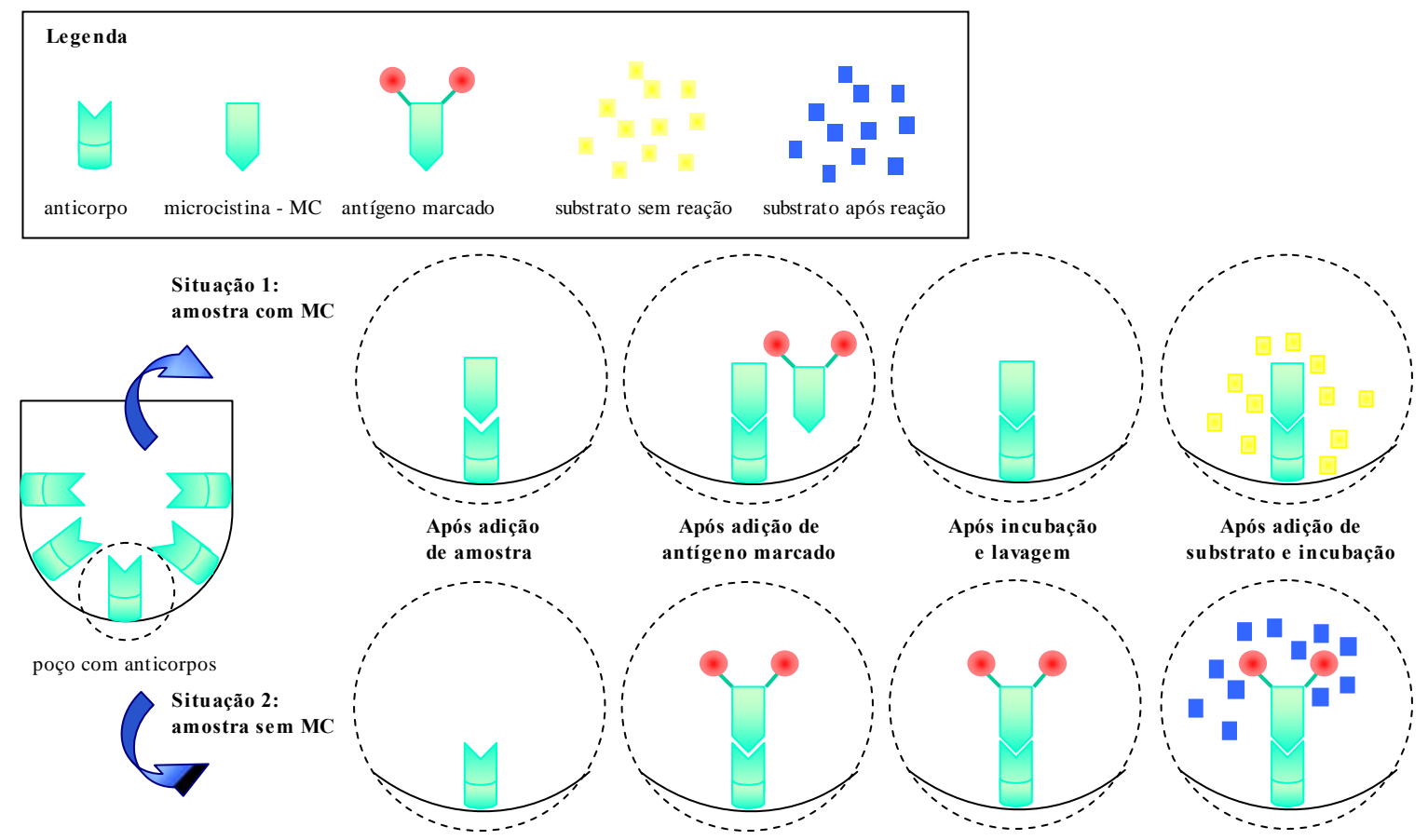

Figura 4.3.15 - Ilustração do processo de reação do método de imunoensaio ELISA

Antes da análise, as amostras foram previamente filtradas em filtro tipo GF/C ou similar e em seguida, diluídas com água deionizada em proporções variadas, de forma a possibilitar a quantificação pela curva de calibração construída para a faixa entre 0 e 2,0 $\mu \mathrm{g} / \mathrm{L}$ de MCs totais. O limite de detecção do método é estimado pelo fabricante em torno de $0,16 \mu \mathrm{g} / \mathrm{L}$. A placa de reação contém 96 poços, o volume requerido de amostra é de $50 \mu \mathrm{L}$ por poço e o tempo médio gasto no processo para análise após preparação das amostras é da ordem de $90 \mathrm{~min}$. 
Após os processos de adição de antígeno marcador - $1^{\mathrm{a}}$ incubação - lavagem da placa - adição de substrato da enzima - $2^{\mathrm{a}}$ incubação, procedeu-se a análise por absorção espectrofotométrica a $450 \mathrm{~nm}$ em leitora de microtiras Quick Elisa. A coloração azul resultante ao final dessa reação enzimática é inversamente proporcional à concentração da toxina presente na amostra analisada. Na Figura 4.3.16 são mostradas fotos ilustrativas do material e equipamentos utilizados durante a realização das análises.

Para assegurar a confiabilidade do método, as curvas de calibração foram construídas e validadas, antes de cada bateria de análise, com o emprego de padrão externo com concentração previamente conhecida, se a porcentagem de recuperação resultasse entre 80 e 130 \% (faixa estabelecida pelo fabricante para validação da curva de calibração). As análises foram realizadas no mínimo em duplicata e preferencialmente em triplicata, sendo estas consideradas válidas, se os valores de coeficiente de variação - CV máximo resultassem inferiores a 15\%. As análises foram realizadas com emprego de micropipetas automáticas de volume variável devidamente calibradas e reservadas especificamente para esse uso.

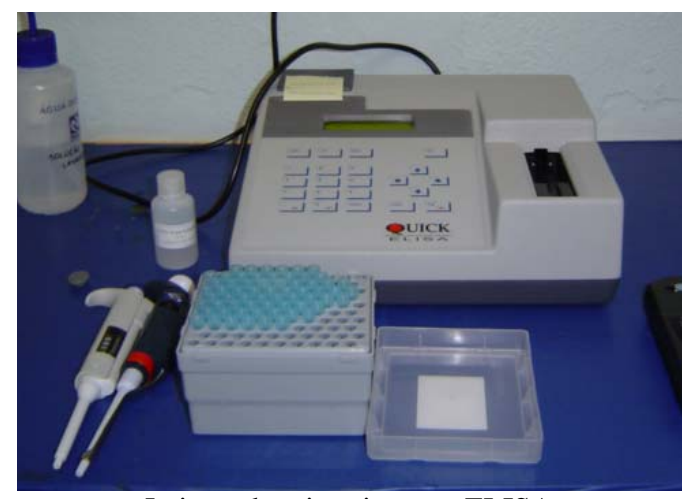

Leitora de microtiras por ELISA

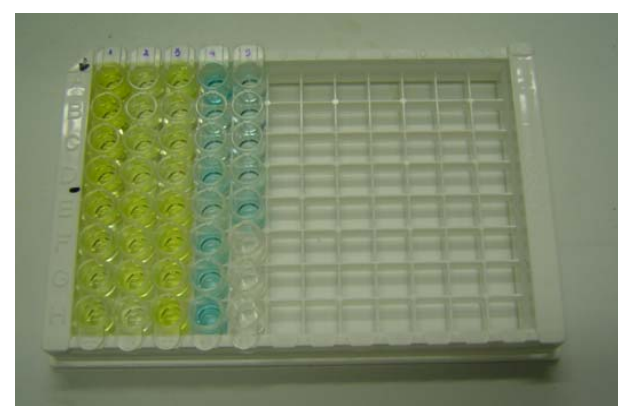

Placa de reação

Figura 4.3.16 - Fotos ilustrativas do material e equipamentos utilizados nas análises pelo método de imunoensaio ELISA

Na Figura 4.3.17 é apresentada a planilha de cálculo contendo a curva de calibração construída para a análise, tendo esta, apresentado correlação entre \%Bo e concentração de MCs $\mathrm{R}^{2}=0$,9913. A curva de calibração foi devidamente validada com o emprego de padrão externo o qual apresentou concentração de 1,187 $\mu \mathrm{g} / \mathrm{L}$ e porcentagem de recuperação de 118 \%. O resultado obtido na análise da amostra cega foi de 1,061 $\pm 0,023 \mu \mathrm{g} / \mathrm{L}$ com CV de $2,94 \%$. 


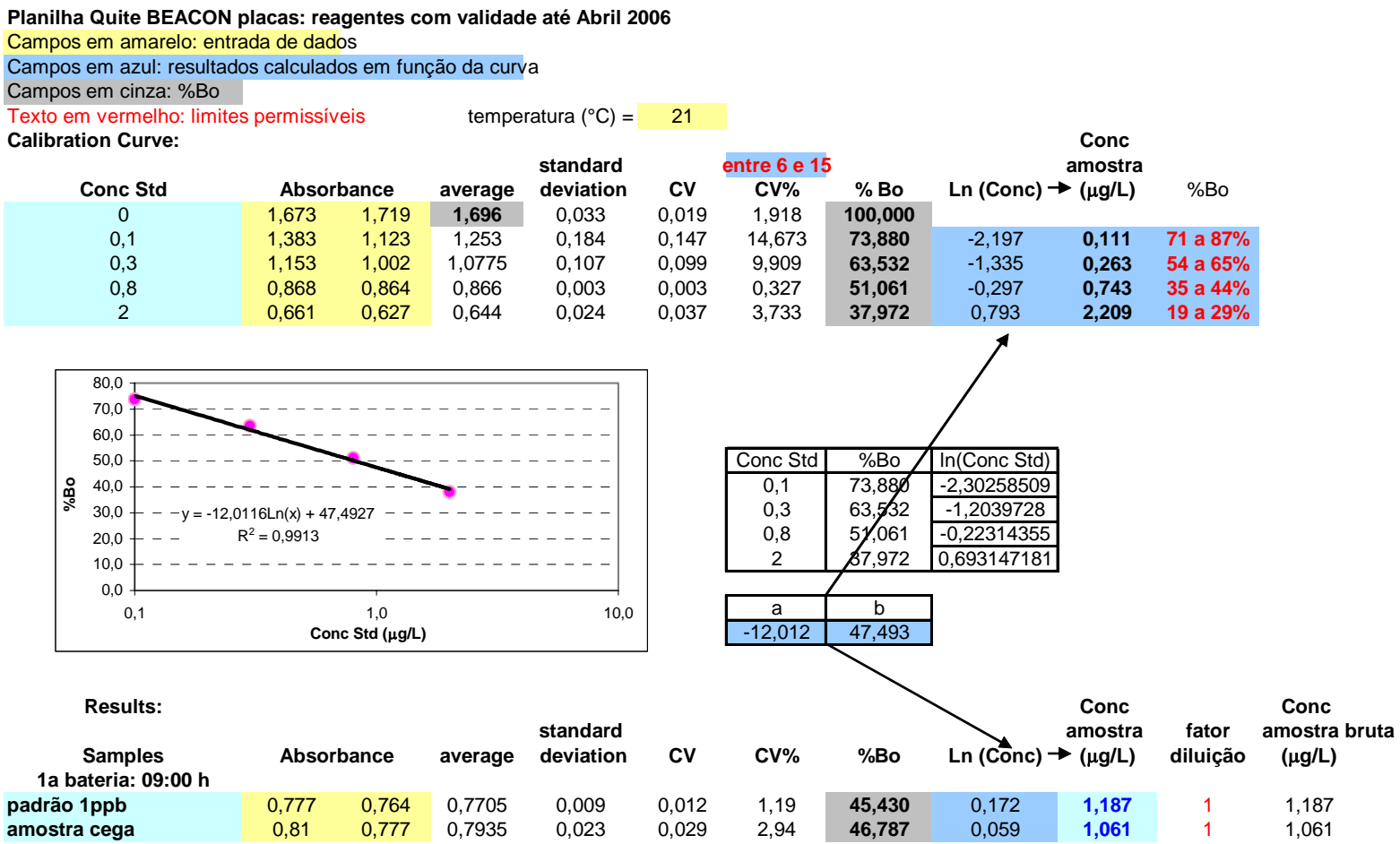

Figura 4.3.17 - Curva de calibração e resultado da intercalibração laboratorial para MCs por ELISA

\subsubsection{Análise de microcistinas por Cromatografia Líquida de Alta Eficiência com detector de UV e arranjo de diodos - HPLC-PDA (High Performance Liquid Chromatography - Photo Diode Array)}

A análise por HPLC requer a execução de etapas preliminares para extração e purificação das possíveis toxinas presentes na amostra, cujos processos são específicos para cada tipo de toxina. O procedimento para extração e purificação de microcistinas - MCs foi baseado em KRISHNAMURTHY et. al (1986), ENVVIRONMENT AGENCY (1998), LAWTON et. al (1994a), TSUJI et. al (1994), COYLE \& LAWTON (1996) e HARADA et. al in CHORUS \& BARTRAM (1999) e é descrita resumidamente a seguir.

\subsubsection{Extração de microcistinas intracelulares - MC intra}

As microcistinas - MCs intracelulares contidas nas amostras foram separadas das extracelulares por meio de filtração em membrana tipo GF/C. Após seca, a membrana foi submetida à extração em $20 \mathrm{~mL}$ de metanol 70\% sob agitação constante durante 1 hora. Em seguida, o extrato foi centrifugado por 15 minutos a $5000 \mathrm{rpm}$ e o sobrenadante foi reservado. Após 3 extrações seguidas, os sobrenadantes foram homogeneizados, concentrados e submetidos ao tratamento estabelecido para purificação e concentração de 
MCs extracelulares apresentado no item a seguir. Na Figura 4.3.18 são mostradas fotos ilustrativas dos extratos brutos de MCs em diferentes fases.

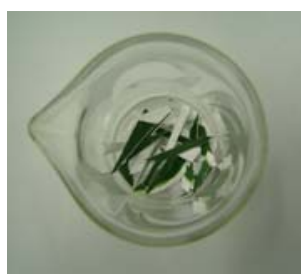

a) Início da extração

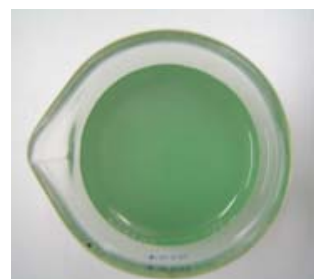

b) Final da $1^{\mathrm{a}}$ extração

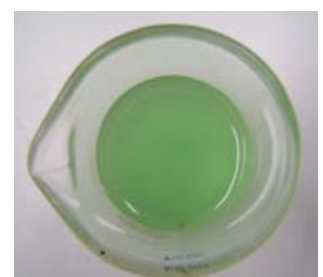

c) Final da $2^{\mathrm{a}}$ extração

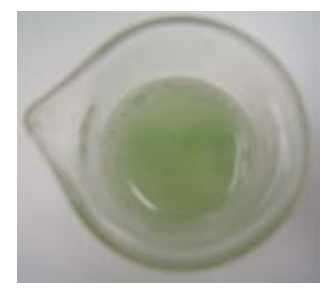

d) Final da $3^{\mathrm{a}}$ extração

Figura 4.3.18 - Vista geral dos extratos brutos de MCs em diferentes fases

\subsubsection{Purificação e concentração de microcistinas extracelulares - MC extra}

A porção filtrada da amostra contendo as MCs extracelulares (ou o extrato de MCs) foi passada em cartucho de octadecilsilano - C18 (500 mg, $6 \mathrm{~mL}$ marca J.T.Baker ou Supelco) para concentração e semi-purificação em fase sólida, com vazão controlada entre 0,5 e 1,0 mL/min, mediante ativação do mesmo, realizada com $20 \mathrm{~mL}$ de metanol 100\%, seguida de $20 \mathrm{~mL}$ de água deionizada. O cartucho de C18 foi então lavado com $20 \mathrm{~mL}$ de água deionizada e $20 \mathrm{~mL}$ de metanol $20 \%$ e, finalmente, eluído com $20 \mathrm{~mL}$ de metanol 100\% (extrato semipurificado).

A purificação das MCs foi realizada, quando necessária, com a passagem do extrato semipurificado, com vazão controlada entre 0,5 e $1,0 \mathrm{~mL} / \mathrm{min}$, em cartucho de sílica previamente ativada com $20 \mathrm{~mL}$ de metanol 100\%. Em seguida, o cartucho de sílica foi eluído com $30 \mathrm{~mL}$ de metanol 100\% e $20 \mathrm{~mL}$ de solução água:TFA:metanol 100\% $(10: 0,1: 89,9 \mathrm{v} / \mathrm{v})$ (extrato purificado).

O extrato purificado foi evaporado à secura em evaporador rotativo, ressuspenso em $1 \mathrm{~mL}$ de solução metanol 100\% : água (1:1 v/v) e mantido em repouso por 1 hora. Em seguida, o extrato purificado concentrado em $1 \mathrm{~mL}$ foi filtrado em membrana de PVDF ou nylon com porosidade de $0,45 \mu \mathrm{m}$ e acondicionado em frasco vial de $2 \mathrm{~mL}$ em freezer à - $4^{\circ} \mathrm{C}$ para análise posterior por HPLC-PDA. Nas Figuras 4.3.19 a 4.3.23 são mostradas fotos ilustrativas das etapas de concentração e purificação de MCs. 

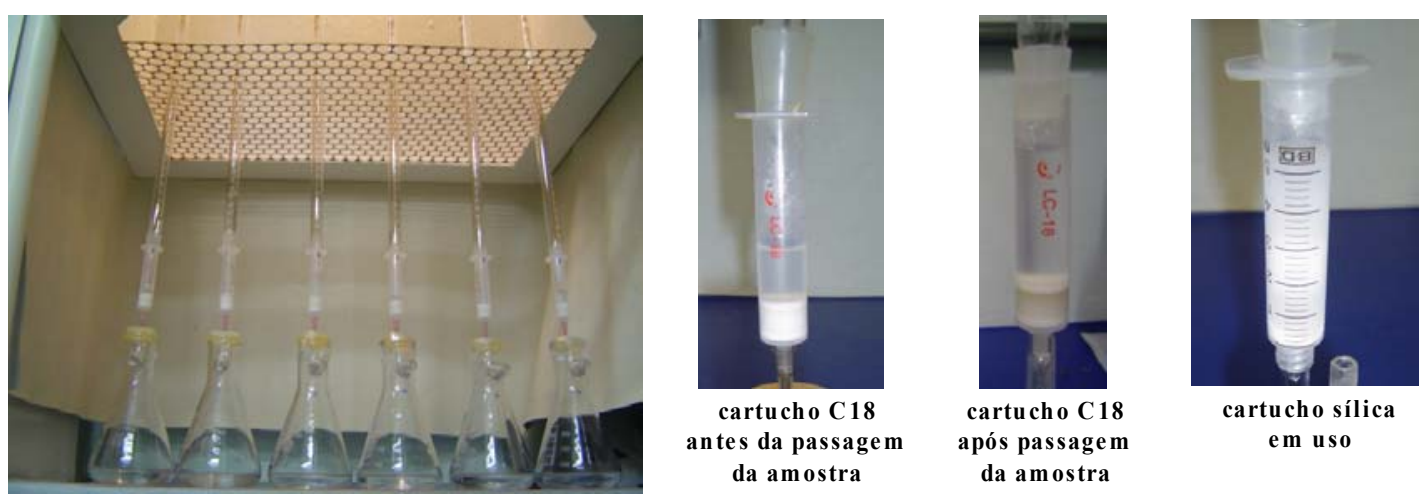

Figura 4.3.19 - Vista geral da bancada de concentração e purificação e dos cartuchos de C18 e de sílica
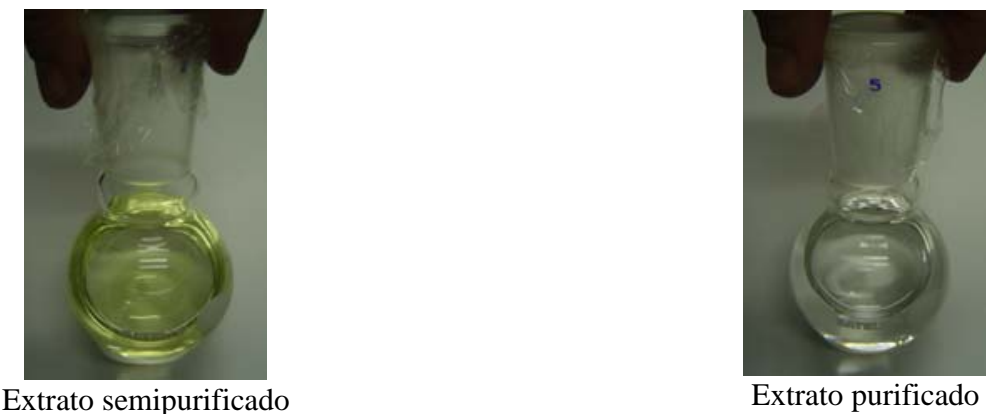

Extrato purificado

Figura 4.3.20 - Vista geral dos extratos semipurificados após passagem em cartucho de C18 e purificado após passagem em cartucho de sílica

Vale ressaltar que para definição do procedimento empregado e descrito, foram realizados vários estudos preliminares com objetivos específicos de:

- Avaliar a influência da vazão empregada e aplicação de vácuo na passagem da amostra no cartucho de C18 para extração em fase sólida;

- Avaliar a necessidade de purificação complementar do extrato semipurificado em cartucho de sílica gel, confome recomendação feita por TSUJI et. al (1994);

- Avaliar a reprodutibilidade dos resultados após extração e purificação simultânea de 3 amostras de $500 \mathrm{~mL}$;

- Otimizar o processo de concentração dos extratos após purificação com emprego de evaporador rotativo;

- Avaliar a influência do emprego de diferentes solventes (água, metanol 50\%, metanol 70\% e metanol 100\%) para ressuspensão final das MCs purificadas em relação ao tempo de retenção dos picos de MCs nos cromatogramas;

- Avaliar a ocorrência de interferências na extração, purificação e análise de amostras após adição de tampão fosfato $(\mathrm{pH}=7,0)$ e de desclorantes diversos nos ensaios de bancada. 

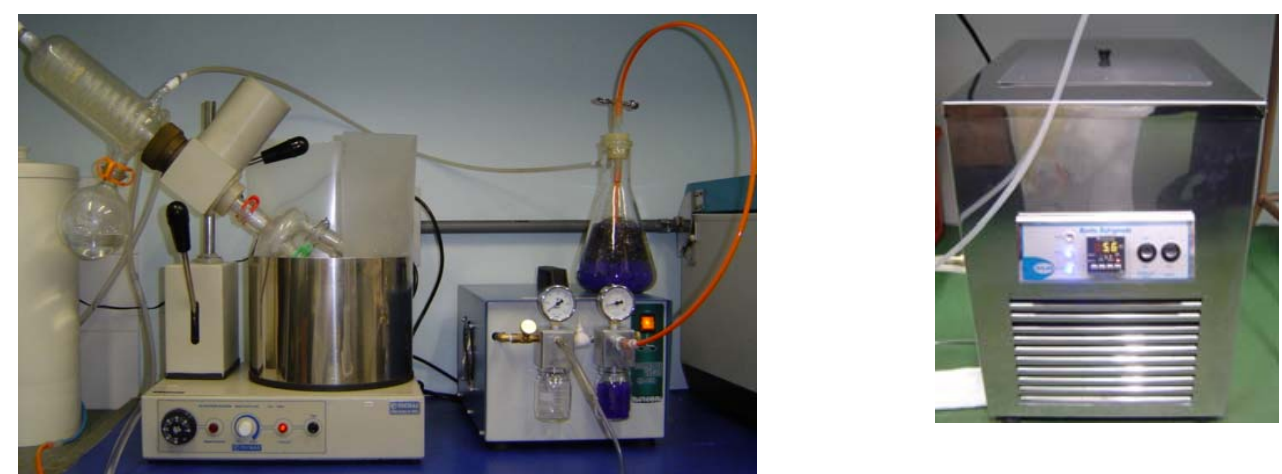

Evaporador rotativo acoplado ao sistema de vácuo e ao banho tesrmostatizado

Figura 4.3.21 - Vista geral da etapa de concentração dos extratos de microcistinas

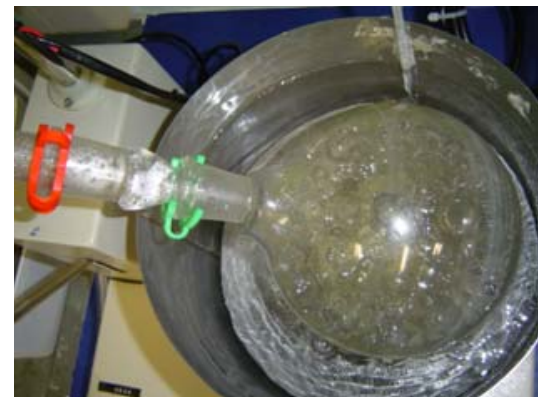

b) Concentração inicial da amostra de $1 \mathrm{~L}$

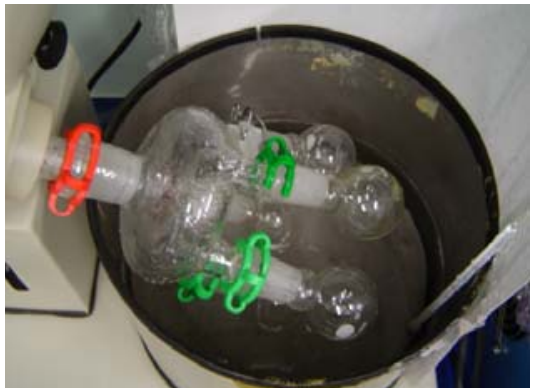

c) Concentração final dos extratos purificados

Figura 4.3.22 - Fotos das etapas de concentração das amostras e dos extratos purificados

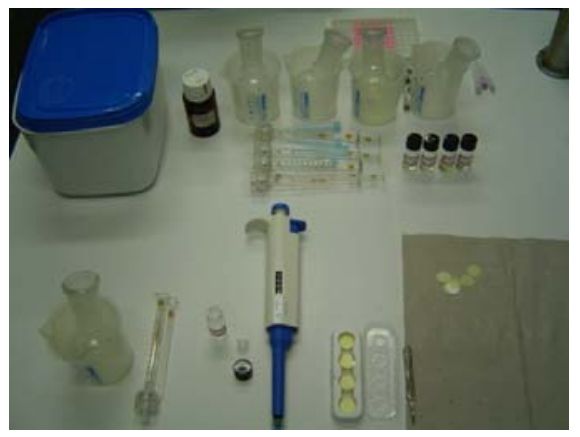

Figura 4.3.23 - Vista geral da etapa de filtração do extrato purificado concentrado

\subsubsection{Análise de microcistinas - MCs}

As análises de microcistinas - MCs por HPLC - PDA foram realizadas em cromatógrafo Shimadzu modelo LC-10AD com detector de diodo UV/VIS modelo SPDM10A sob condições cromatográficas relacionadas a seguir.

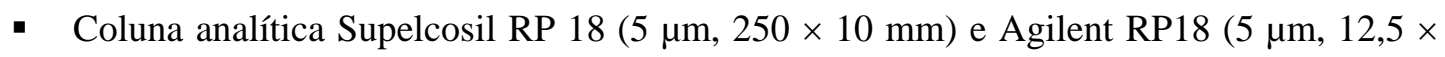
$10 \mathrm{~mm})$;

- Fase móvel de acetonitrila : acetato de amônio (28:72 v/v) 20 mM, pH 5,0, fluxo = $1 \mathrm{~mL}$ /min em condições isocráticas; 
- Faixa de absorção entre 195 e 300 nm a 2 nm com e pico entre 238 e 239 nm;

- Forno a $40^{\circ} \mathrm{C}$ modelo CTO-10A;

- Tempo total aproximado de 25 min para cada corrida / análise;

- Volume de extrato injetado: loop de $20 \mu \mathrm{L}$.

Os padrões de calibração utilizados para esse método foram:

- Padrão de MC-LR (Sigma M2912 Lot 31K 1647) com pureza >95\%;

- Padrão de MC-RR (Aléxis 350-043-C250 Lot L15250) com 95,2 \% de pureza;

- Padrão de [D-Leu $\left.{ }^{1}\right] \mathrm{MC}-\mathrm{LR}$, produzida e disponibilizada pela FURG.

Nas Figuras 4.3.24 a 4.3.27 são apresentadas a sobreposição dos cromatogramas onde podem ser observados os tempos de retenção de 3,7; 4,0 e 6,8 min, para MC-RR, MCLR e [D-Leu ${ }^{1}$ MC-LR, respectivamente, seguida de exemplos das planilhas de cálculo e curvas de calibração (típicas).

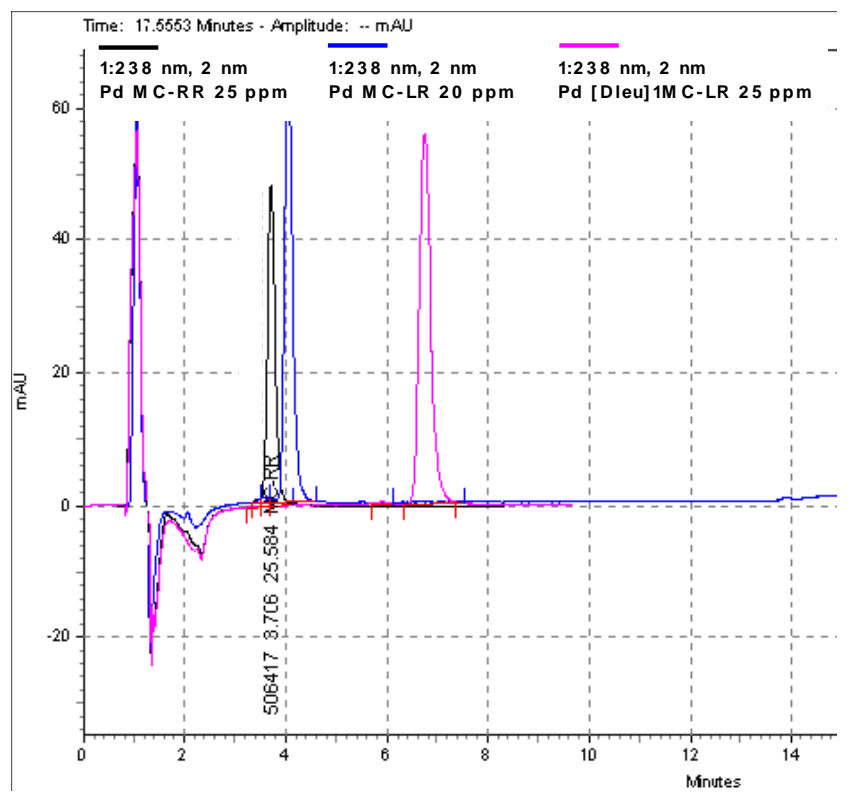

Figura 4.3.24 - Sobreposição dos cromatogramas resultantes para MC-RR, MC-LR e [D-Leu ${ }^{1}$ MC-LR 


\begin{tabular}{|c|c|c|c|c|c|c|}
\hline \multicolumn{7}{|c|}{ Curva de calibração com Pd MC-RR (loop 20uL e C18 nova de 12,5 cm) } \\
\hline Concentração (mg/L) & $\begin{array}{c}\text { Tempo de } \\
\text { retenção } \\
(\mathbf{m i n})\end{array}$ & Área & $\begin{array}{c}\text { Concentração } \\
\text { calculada } \\
(\mathbf{m g} / \mathbf{L})\end{array}$ & $\begin{array}{c}\text { IS } \\
\text { MICYST- } \\
\text { LR }\end{array}$ & $\begin{array}{c}\text { Coeficientes } \\
\text { calculados }\end{array}$ & $\begin{array}{c}\text { Amplitude do } \\
\text { pico (mAU) }\end{array}$ \\
\hline $\mathbf{0 , 3 9 0 6}$ & 3,716 & $\mathbf{9 . 6 9 5}$ & 0,74 & & $\mathrm{a}=$ & \\
\hline $\mathbf{0 , 7 8 1 2}$ & 3,707 & $\mathbf{1 8 . 8 7 7}$ & 1,20 & & $5,00102 \mathrm{E}-05$ & \\
\hline $\mathbf{1 , 5 6 2 5}$ & 3,707 & $\mathbf{2 2 . 5 1 0}$ & 1,38 & & & \\
\hline $\mathbf{3 , 1 2 5}$ & 3,709 & $\mathbf{6 1 . 9 6 3}$ & 3,36 & & $\mathrm{R} 2=$ & \\
\hline $\mathbf{6 , 2 5}$ & 3,712 & $\mathbf{1 2 3 . 7 4 9}$ & 6,45 & & 0,993034786 & \\
\hline $\mathbf{1 2 , 5}$ & 3,713 & $\mathbf{2 1 2 . 6 1 9}$ & 10,89 & & $\mathrm{~b}=$ & \\
\hline $\mathbf{2 5}$ & 3,706 & $\mathbf{5 0 6 . 4 1 7}$ & 25,58 & 0,9996 & 0,258290539 & \\
\hline
\end{tabular}

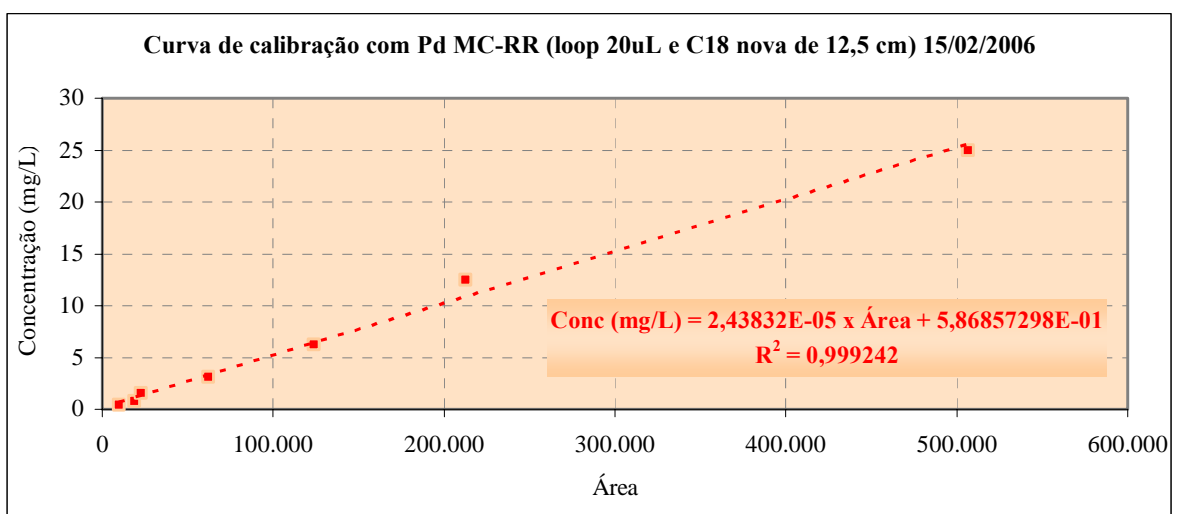

Figura 4.3.25 - Planilha de cálculo e uma curva de calibração (típica) de MC-RR

\begin{tabular}{|c|c|c|c|c|c|c|}
\hline \multicolumn{7}{|c|}{ Curva de calibração com Pd MC-LR (loop 20uL e C18 nova de 12,5 cm) } \\
\hline Concentração (mg/L) & $\begin{array}{c}\text { Tempo de } \\
\text { retenção } \\
(\mathbf{m i n})\end{array}$ & Área & $\begin{array}{c}\text { Concentração } \\
\text { calculada } \\
(\mathbf{m g} / \mathbf{L})\end{array}$ & $\begin{array}{c}\text { IS } \\
\text { MICYST- } \\
\text { LR }\end{array}$ & $\begin{array}{c}\text { Coeficientes } \\
\text { calculados }\end{array}$ & $\begin{array}{c}\text { Amplitude do } \\
\text { pico (mAU) }\end{array}$ \\
\hline $\mathbf{0 , 3 1 2 5}$ & 4,164 & $\mathbf{1 3 . 6 8 6}$ & 0,80 & & $\mathrm{a}=$ & \\
\hline $\mathbf{0 , 6 2 5}$ & 4,1 & $\mathbf{2 0 . 2 6 4}$ & 0,97 & & $2,50068 \mathrm{E}-05$ & \\
\hline $\mathbf{1 , 2 5}$ & 3,996 & $\mathbf{4 7 . 8 6 2}$ & 1,66 & & & \\
\hline $\mathbf{2 , 5}$ & 4,13 & $\mathbf{7 0 . 4 8 6}$ & 2,22 & & $\mathrm{R} 2=$ & \\
\hline $\mathbf{5}$ & 4,098 & $\mathbf{1 8 4 . 1 0 3}$ & 5,06 & & 0,999163365 & \\
\hline $\mathbf{1 0}$ & 4,122 & $\mathbf{3 4 4 . 3 8 3}$ & 9,07 & & & \\
\hline $\mathbf{2 0}$ & 4,038 & $\mathbf{7 6 6 . 2 0 9}$ & 19,62 & & $\mathrm{~b}=$ & \\
\hline $\mathbf{5 0}$ & 4,086 & $\mathbf{1 . 9 9 2 . 9 2 2}$ & 50,29 & 0,9990 & 0,458285089 & \\
\hline
\end{tabular}

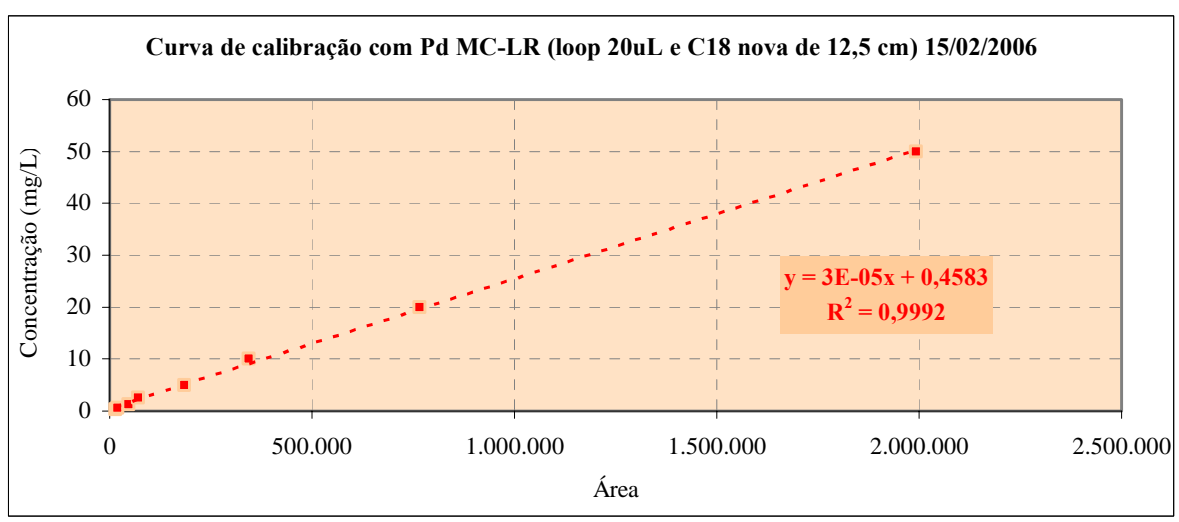

Figura 4.3.26 - Planilha de cálculo e uma curva de calibração (típica) de MC-LR 


\begin{tabular}{|c|c|c|c|c|c|c|}
\hline \multicolumn{7}{|c|}{ Curva de calibração com Pd [DLeu1]MC-LR (loop 20uL e C18 nova de 12,5 cm) } \\
\hline Concentração $(\mathbf{m g} / \mathbf{L})$ & $\begin{array}{c}\text { Tempo de } \\
\text { retenção } \\
(\mathbf{m i n})\end{array}$ & Área & $\begin{array}{c}\text { Concentração } \\
\text { calculada (mg/L) }\end{array}$ & $\begin{array}{c}\text { IS MC- } \\
\text { LR }\end{array}$ & $\begin{array}{c}\text { Coeficientes } \\
\text { calculados }\end{array}$ & $\begin{array}{c}\text { Amplitude do pico } \\
\text { (mAU) }\end{array}$ \\
\hline $\mathbf{0 , 3 9 0 6}$ & 7,037 & $\mathbf{6 . 7 2 3}$ & 0,75 & & $\mathrm{a}=$ & 0,5 \\
\hline $\mathbf{0 , 7 8 1 2}$ & 6,99 & $\mathbf{2 1 . 2 5 3}$ & 1,11 & & $2,43832 \mathrm{E}-05$ & 1,2 \\
\hline $\mathbf{1 , 5 6 2 5}$ & 6,974 & $\mathbf{4 5 . 1 4 0}$ & 1,69 & & & 2,5 \\
\hline $\mathbf{3 , 1 2 5}$ & 7,1 & $\mathbf{1 0 8 . 2 4 5}$ & 3,23 & & $\mathrm{R} 2=$ & 5,9 \\
\hline $\mathbf{6 , 2 5}$ & 7,019 & $\mathbf{2 2 0 . 0 6 3}$ & 5,95 & & 0,999241944 & 12,7 \\
\hline $\mathbf{1 2 , 5}$ & 6,78 & $\mathbf{4 8 2 . 4 3 5}$ & 12,35 & & & 20,5 \\
\hline $\mathbf{2 5}$ & 6,728 & $\mathbf{9 6 1 . 2 0 3}$ & 24,02 & & $\mathrm{~b}=$ & 56,0 \\
\hline $\mathbf{5 0}$ & 6,86 & $\mathbf{2 . 0 4 7 . 5 5 0}$ & 50,51 & 0,9996 & 0,586857298 & 121,3 \\
\hline
\end{tabular}

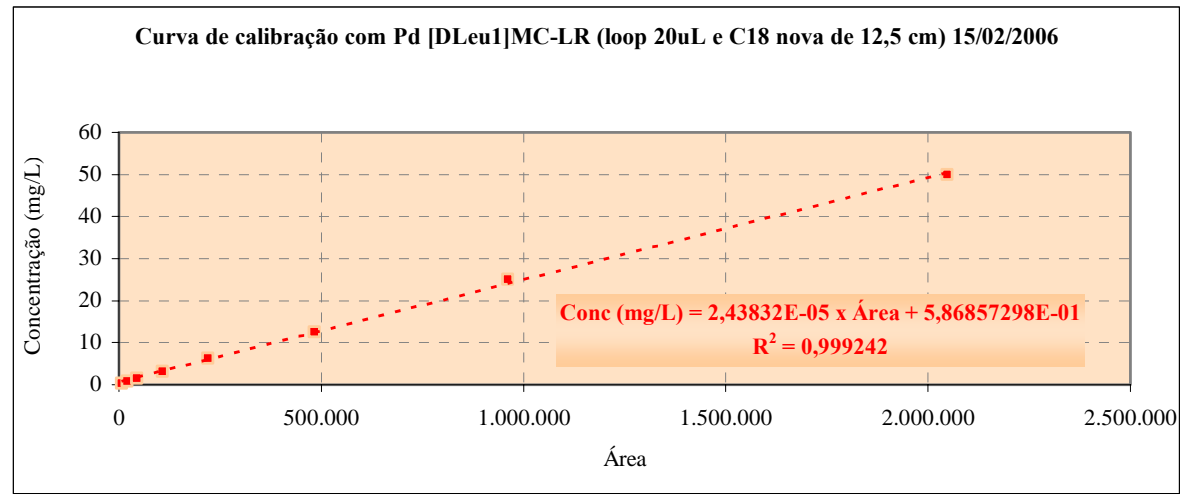

Figura 4.3.27 - Planilha de cálculo e uma curva de calibração (típica) de [D-Leu $\left.{ }^{1}\right] \mathrm{MC}-\mathrm{LR}$

Antes de cada bateria de análise, as curvas de calibração eram checadas por meio de injeção de padrões externos de MC-LR, MC-RR e MC do extrato obtido da cepa NPLJ-4 com concentrações teóricas conhecidas. Na Figura 4.3.28 são mostradas fotos do equipamento utilizado.
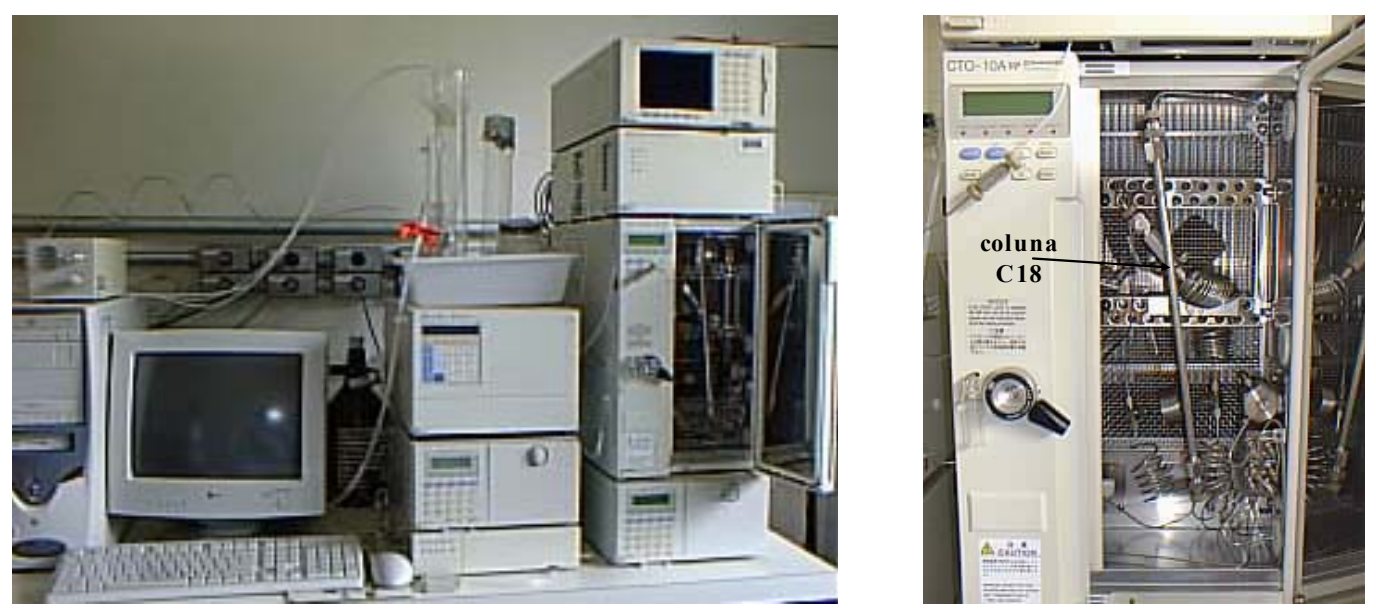

Figura 4.3.28 - Fotos do HPLC e da coluna analítica de octadecil-silano ODS (C-18)

HARADA et. al in CHORUS \& BARTRAM (1999) relata considerações feitas por FASTNER (dados não publicados) que quantificou diretamente outras MCs, porém, esclarece a simplificação adotada no trabalho: "For a tentative assessment of the toxicity of this sample, a "worst case" approach was chosen by calculating the sum of all of the nine 
microcystins and assuming them to be as toxic as $-L R$ and $-Y R$, the most toxic variants currently known.”

\subsection{META 4: OBTENÇÃO DE PARÂMETROS OPERACIONAIS EM ENSAIOS DE FILTRAÇÃO DIRETA EM BANCADA}

Esses experimentos de bancada foram realizados para dar subsídios para a determinação prévia das condições de coagulação química empregadas nos ensaios em instalação piloto - IP.

Com o intuito adicional de estudar a aplicabilidade de testes de toxicidade aguda com dafinídeos (Ceriodaphnia dubia e Ceriodaphnia silvestrii) na avaliação qualitativa do desempenho dos processos empregados, foi realizado um trabalho em colaboração com a doutoranda Renata Akemi Takenaka sob orientação da Profa. Odete Rocha do Departamento de Ecologia e Biologia Evolutiva - DEBE da Universidade Federal de São Carlos - UFSCar. Assim, informações específicas relacionadas aos cultivos de dafinídeos e testes de toxicidade foram compartilhadas a fim de possibilitar a visão globalizada do estudo realizado. Detalhes específicos sobre a metodologia utilizada são apresentados no Item 4.7.9.

\subsubsection{Preparação da água de estudo tipo 1 - AE-1}

As águas de estudo tipo 1 - AE-1 foram preparadas, diluindo-se volumes de cultura de Microcystis spp., com densidade previamente conhecida e especialmente preparada para esse fim, em água filtrada sem cloração da ETASC 2, de forma a resultar em densidades da ordem de $10^{5}$ cél $/ \mathrm{mL}$. Vale ressaltar que o uso de água filtrada na ETASC 2 como água de diluição é justificado, considerando as condições dos ensaios em instalação piloto, uma vez que o sistema montado localiza-se nas dependências da ETA 2 (Figura 4.4.1).

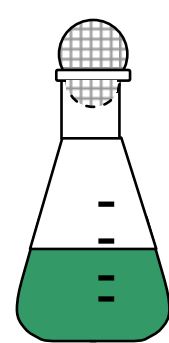

Culturas de cepa tóxica de Microcystis spp. NPLJ4 (cedida pelo LECT-UFRJ) densidade $=10^{7} \mathrm{cel} / \mathrm{mL}$

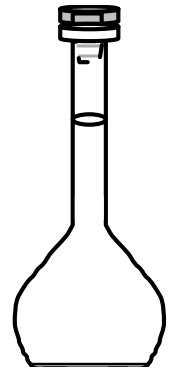

Água filtrada ET ASC 2 sem cloração
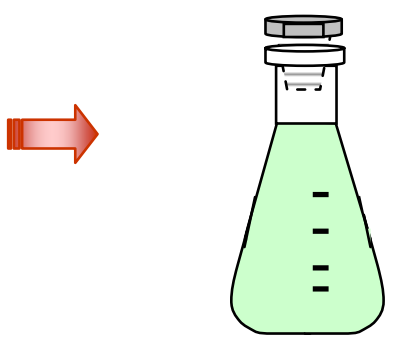

Água de estudo - AE com células e microcistinas de Microcystis spp. densidade $=10^{5} \mathrm{cel} / \mathrm{mL}$

Figura 4.4.1 - Esquema ilustrativo da preparação da AE 
Na Figura 4.4.2 são mostradas fotos da suspensão de Microcystis spp. NPLJ-4 e da água de estudo preparada, por ocasião da realização dos ensaios da série A.

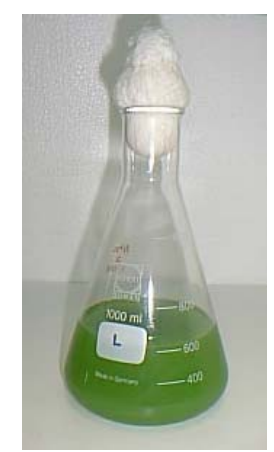

Cultura de Microcystis spp.NPLJ-4 com densidade de $1,33 \times 10^{7} \mathrm{cel} / \mathrm{mL}$

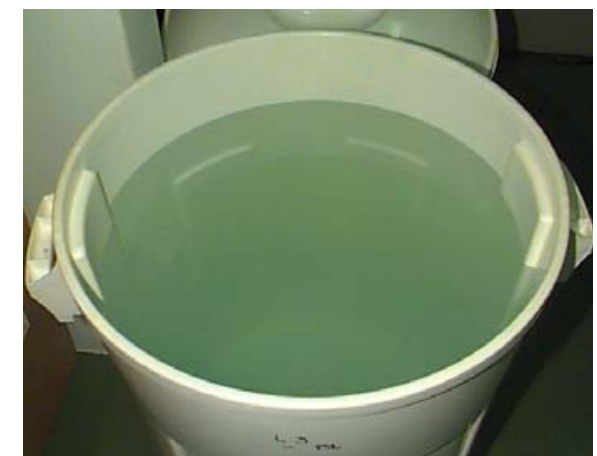

Água de estudo da série A - AE-A preparada com diluição da Cultura de Microcystis spp.NPLJ-4 resultando em densidade de $1,5 \times 10^{5} \mathrm{cel} / \mathrm{mL}$

Figura 4.4.2 - Vista geral da cultura de Microcystis spp.NPLJ-4 e água de estudo da série A

\subsubsection{Produtos químicos}

Para realização dos ensaios foram utilizados os seguintes produtos químicos:

a) Alcalinizante e Acidificante:

- Hidróxido de sódio (sólido) com massa específica = 1,013 kg/L;

- Solução comercial de ácido clorídrico com concentração de 37\% (em massa) e massa específica $=1,187 \mathrm{~kg} / \mathrm{L}$.

b) Coagulantes:

- Tipo 1: solução comercial de sulfato de alumínio isento de ferro com 6,0 \% de $\mathrm{Al}_{2} \mathrm{O}_{3}$, teor de $\mathrm{Fe}^{2+} \leq 0,1 \%$, $\mathrm{pH} \leq 2,5$, massa específica = 1,3 kg/L e cor âmbar;

- Tipo 2: solução comercial de sulfato de alumínio líquido ferroso com 6,0 \% de $\mathrm{Al}_{2} \mathrm{O}_{3}$, teor de $\mathrm{Fe}^{2+} \leq 1,0 \%$, $\mathrm{pH} \leq 4,0$, massa específica = 1,3 kg/L e cor marrom alaranjado;

- Tipo 3: solução comercial de hidroxicloreto de alumínio líquido com 11,0 \% de $\mathrm{Al}_{2} \mathrm{O}_{3}$, $\mathrm{pH} \geq 2,0$, massa específica $=1,1 \mathrm{~kg} / \mathrm{L}$ e cor âmbar clara;

- Tipo 4: solução comercial de hidroxicloreto de alumínio líquido com 10,7 \% de $\mathrm{Al}_{2} \mathrm{O}_{3}$, massa específica $=1,3 \mathrm{~kg} / \mathrm{L}$ e cor castanha;

- Tipo 5: solução comercial de hidroxicloreto de alumínio líquido com 17,5 \% de $\mathrm{Al}_{2} \mathrm{O}_{3}$, massa específica $=1,35 \mathrm{~kg} / \mathrm{L}$ e cor castanha;

- Tipo 6: solução comercial de hidroxicloreto de alumínio líquido com 22,6 \% de $\mathrm{Al}_{2} \mathrm{O}_{3}$, massa específica $=1,325 \mathrm{~kg} / \mathrm{L}$ e cor âmbar claro;

- Tipo 7: solução comercial de sulfato de alumínio com 7,2 \% de $\mathrm{Al}_{2} \mathrm{O}_{3}$ e massa específica $=1,304 \mathrm{~kg} / \mathrm{L}$. 


\subsubsection{Equipamento jarteste e Filtros de laboratório de areia - FLAs}

O equipamento jarteste utilizado é composto de 6 jarros de acrílico transparente de 2 L, tacômetro digital para visualização da rotação (até $600 \mathrm{rpm} \pm 2$ \%), o que confere gradiente de velocidade de até $1.200 \mathrm{~s}^{-1}$, dispositivo para aplicação de produtos químicos e coleta de água nos 6 jarros simultaneamente. Apresenta-se na Figura 4.4.2, a curva característica do aparelho relacionando o gradiente de velocidade com a rotação aplicada e tabela de correção devido à temperatura.

O sistema de FLAs é constituído por seis filtros, cada um contendo corpo em acrílico transparente de $19 \mathrm{~mm}$ de diâmetro, $40 \mathrm{~cm}$ de altura e areia aderida na parede interna, de modo a evitar formação de correntes preferenciais durante a filtração. A cota de saída de água filtrada foi posicionada, aproximadamente, $1 \mathrm{~cm}$ acima do topo da camada de areia com espessura de $15 \mathrm{~cm}$.

Na Figura 4.4.3 é mostrado uma foto do sistema de filtros de laboratório de areia FLAs acoplado ao equipamento jarteste e na Figura 4.4.4, um esquema contendo detalhes construtivos dos FLAs. Para controle automático da taxa de filtração foi utilizado um dispositivo com regulagem programável acoplado ao braço de coleta. 


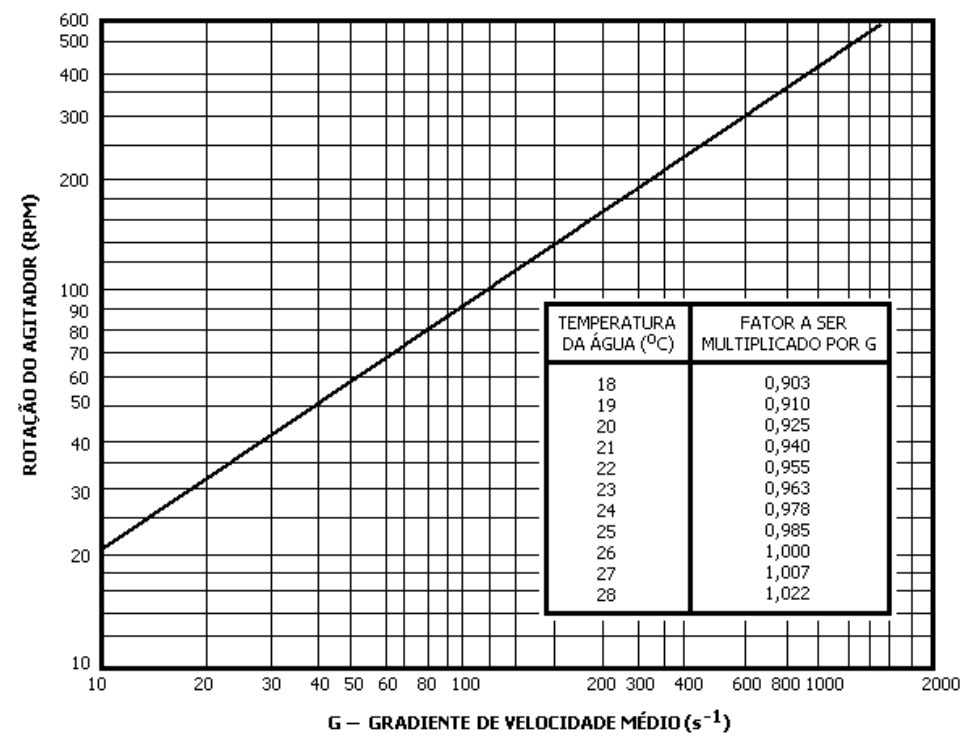

Figura 4.4.3 - Curva de gradiente de velocidade em função da rotação aplicada e tabela de correção devido à temperatura

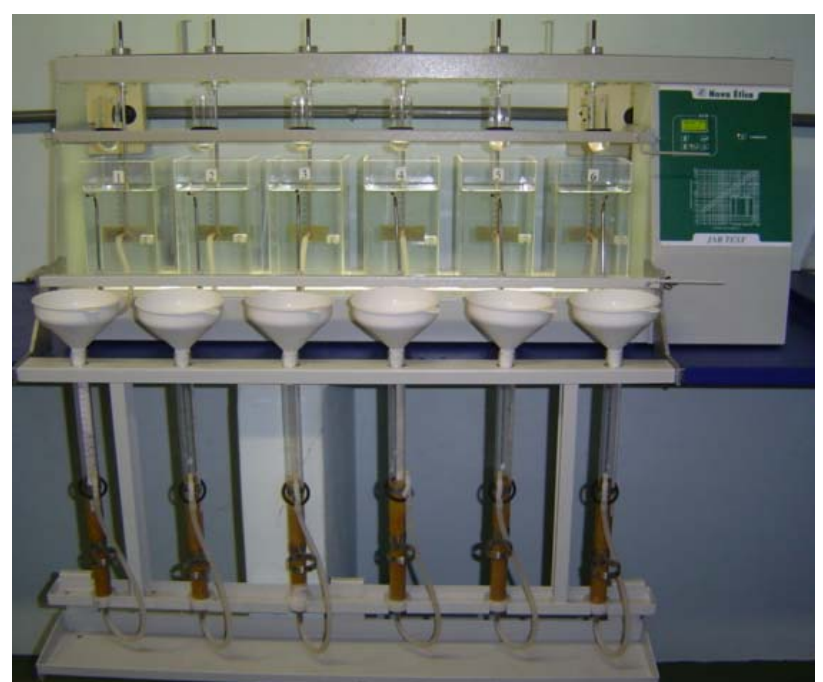

Figura 4.4.4 - Sistema de FLAs acoplado ao equipamento jarteste

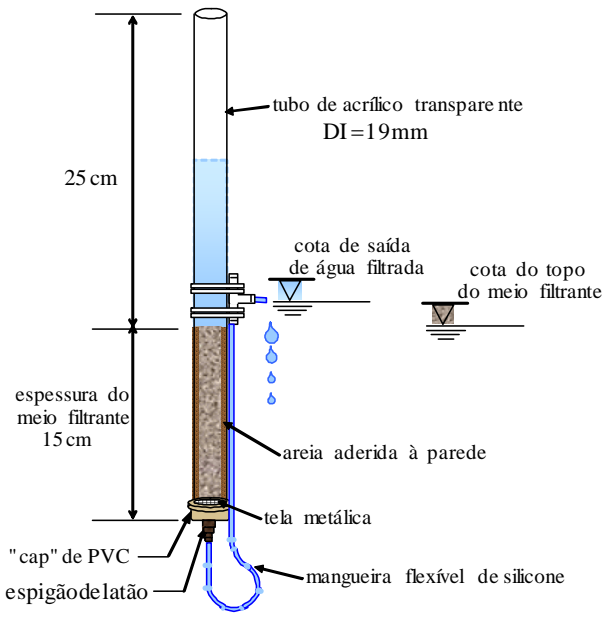

Figura 4.4.5 - Esquema do filtro de laboratório de areia - FLA

Considerando a estrutura física e as condições de funcionamento da instalação piloto, o tempo médio de mistura rápida foi fixado em $\mathrm{Tmr}=1 \mathrm{~min}$ e o gradiente médio de velocidade de mistura rápida em $\mathrm{Gmr}=800 \mathrm{~s}^{-1}$.

Todos os efluentes produzidos nos ensaios de bancada realizados foram armazenados em tanque de polietileno de $500 \mathrm{~L}$ e submetidos à dosagem de cloro (hipoclorito de sódio) de forma a resultar em concentração mínima de cloro residual $5 \mathrm{mg} / \mathrm{L}$ após tempo de contato de 2 dias. 


\subsection{META 5: OBTENÇÃO DE PARÂMETROS OPERACIONAIS EM ENSAIOS DE OXIDAÇÃO EM BANCADA}

Para a realização desse estudo foram desenvolvidas, previamente, as seguintes atividades:

- implementação dos métodos espectrofotométricos para análise dos residuais de oxidantes (cloro, dióxido de cloro e permanganato de potássio);

- estudo preliminar da relação agente desoxidante (tiosulfato de sódio e ácido ascórbico) / oxidante necessária e eficaz para paralisar a reação no tempo desejado para cada tipo de oxidante;

- verificação da interferência da adição de agente desoxidante e de de tampão de fosfato (pH 7,0) nas análises a serem efetuadas (contagem celular e microcistinas);

As águas de estudo foram preparadas diluindo-se volumes de cultura de Microcystis spp., com densidade previamente conhecida e especialmente preparada para esse fim, em água filtrada sem cloração da ETASC 2, de forma a resultar em densidades da ordem de $10^{5}$ cél $/ \mathrm{mL}$.

Em função das dificuldades encontradas na reprodução das águas de estudo, fato que dificultaria a comparação dos resultados, os ensaios de oxidação em bancada com o emprego de cloro (hipoclorito de cálcio), dióxido de cloro e permanganato de potássio foram realizados seqüencialmente, utilizando-se a mesma água de estudo AE-A com densidade de Microcystis spp.de $1,2 \times 10^{5} \mathrm{cel} / \mathrm{mL}$ (Figura 4.5.1).
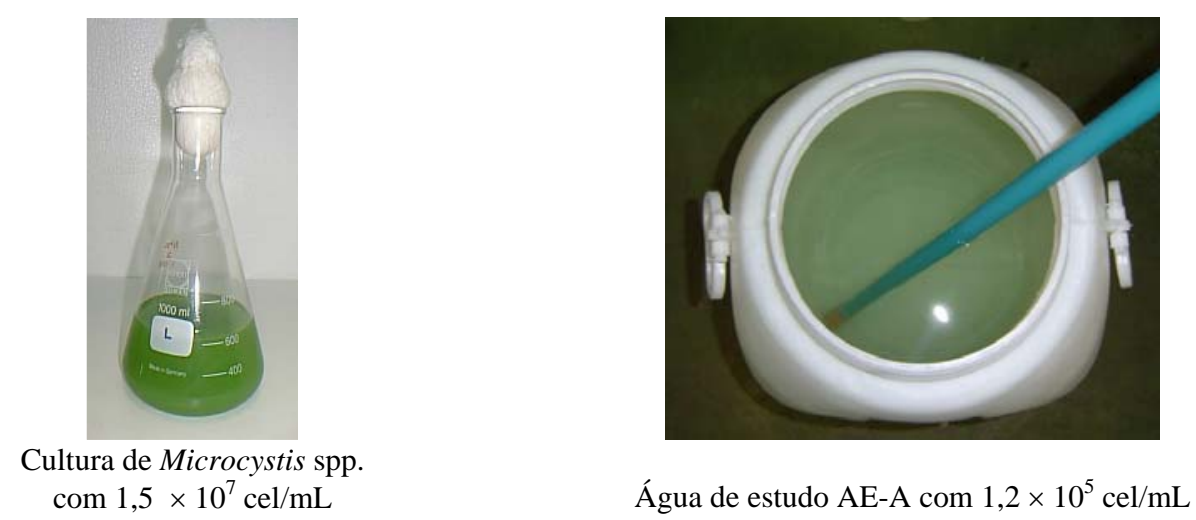

Figura 4.5.1 - Fotos da cultura de Microcystis spp.e da água de estudo AE-A

Primeiramente, foram realizados ensaios a fim de obter os valores de demanda de cada oxidante considerando as condições de aplicação nos ensaios em instalação piloto - IP 
e o atendimento aos valores limites de residuais estabelecidos pela Portaria MS 518/2004 para as seguintes situações:

- Situação 1: Pré-oxidação seguida de adsorção com carvão ativado pulverizado - CAP

Nesse caso, o critério para escolha da dosagem de oxidante baseou-se produção de residuais próximos de zero para o tempo de contato previsto de $30 \mathrm{~min}$;

- Situação 2: Pré-oxidação seguida de filtração direta.

Nesse caso, o critério para escolha da dosagem de oxidante baseou-se produção de residuais (cloro, dióxido de cloro, clorito e manganês total) aceitáveis segundo legislações vigentes para o tempo de contato previsto de 60 min.;

- Situação 3: Pré-oxidação com o dobro da dosagem obtida na situação 2, seguida de filtração direta.

Nesse caso, pretendeu-se avaliar o efeito da oxidação com dosagem elevada na degradação de microcistinas.

Os ensaios foram realizados a $25^{\circ} \mathrm{C}$ em mesa agitadora orbital regulada para 150 opm, com o emprego de tampão (pH 7,0) a 2\%. O uso do tampão $(\mathrm{pH} 7,0)$ é justificado pelas condições resultantes e pré-determinadas dos processos empregados nos ensaios em instalação piloto. Na Figura 4.5.2 são mostradas fotos tiradas durante os ensaios realizados com cloro e com permanganato de potássio.

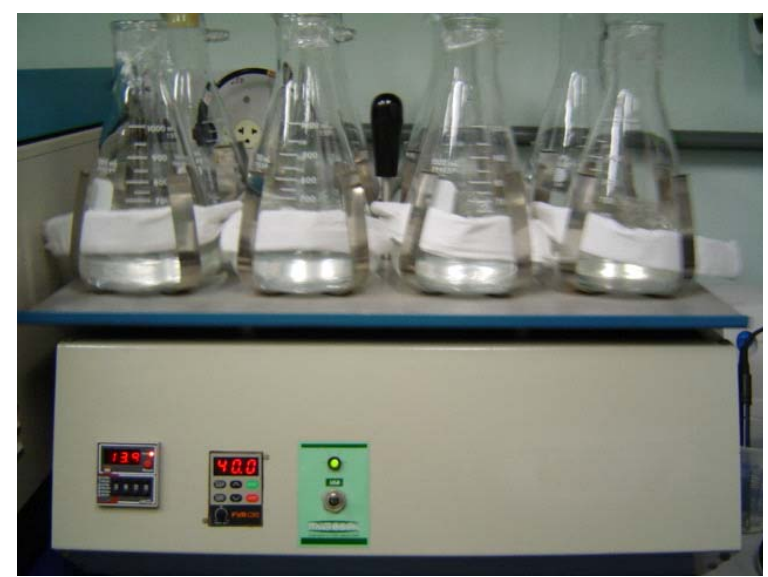

Ensaio de oxidação com cloro (hipoclorito de cálcio)

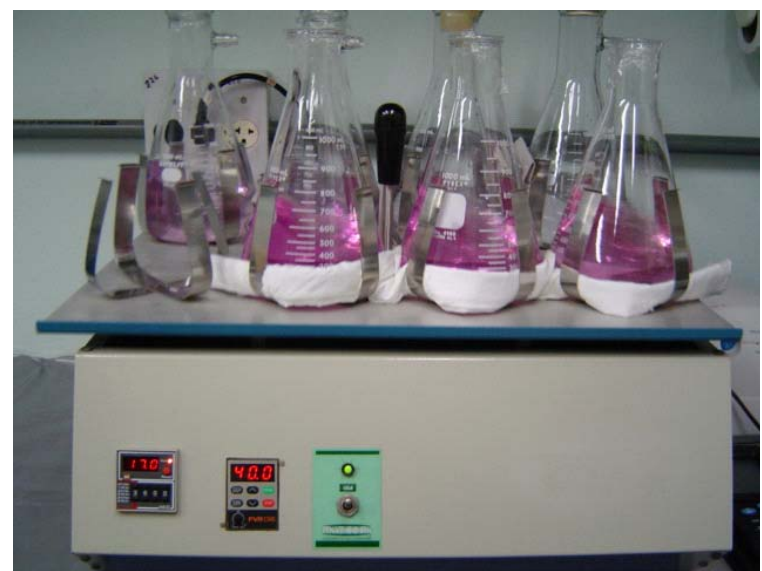

Ensaio de oxidação com permanganato de potássio

Figura 4.5.2 - Vista geral dos ensaios de oxidação

Para os tempos de contato previstos, foram coletadas 2 amostras, sendo uma, destinada à análise imediata do residual de oxidante, e a outra, à caracterização posterior realizada por análise de MCs, densidade de Microcystis spp , absorvância 254 e COT, mediante adição prévia de solução de tiosulfato de sódio 5\%, em volumes definidos em função da concentração residual de oxidante esperada. 


\subsection{META 6: OBTENÇÃO DE PARÂMETROS OPERACIONAIS EM ENSAIOS DE ADSORÇÃO EM BANCADA}

Esses experimentos de bancada foram realizados para dar subsídios para determinação prévia das condições de adsorção a serem empregadas nos ensaios em instalação piloto - IP.

Inicialmente, foi realizada a avaliação prévia da capacidade adsortiva de carvões produzidos e disponíveis comercialmente no Brasil, e em seguida, realizada a caracterização dos carvões selecionados (um granular e um pulverizado), por meio de determinação da distribuição do volume de poros e construção das isotermas de adsorção para MC não purificada, visando sua aplicação em sistemas de tratamento de água para consumo humano.

Na Figura 4.6.1 é apresentado um fluxograma ilustrando as principais etapas realizadas para seleção e caracterização dos carvões ativados utilizados nos ensaios em instalação piloto - IP.

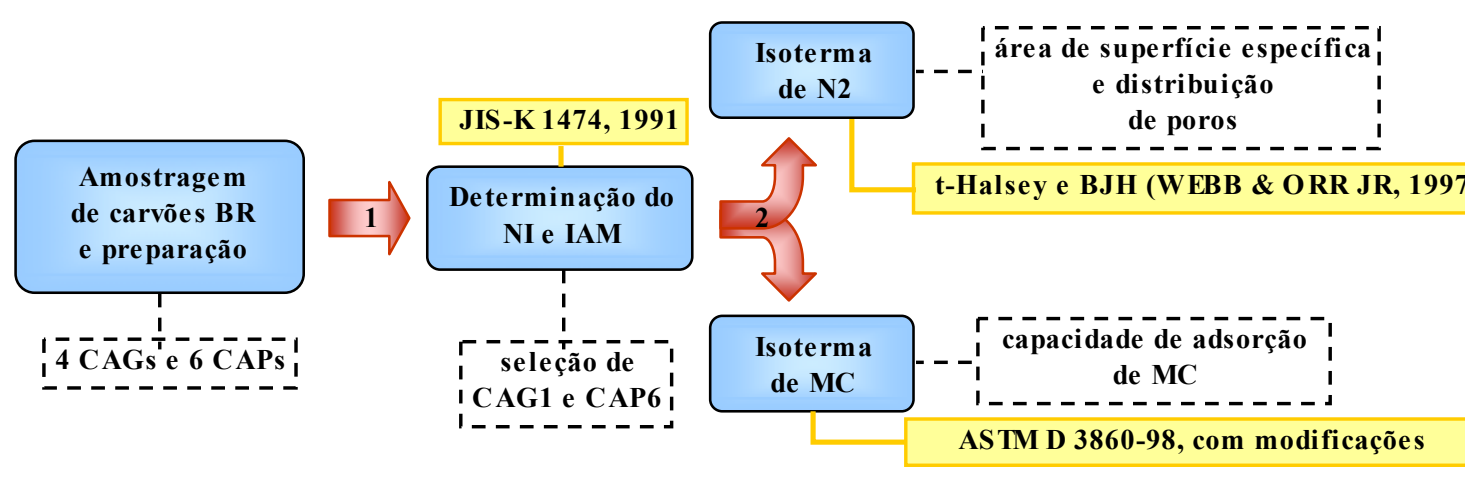

Figura 4.6.1 - Fluxograma das principais etapas realizadas para seleção e caracterização dos carvões ativados NI: número ou índice de iodo; IAM: índice de azul de metileno;

\subsubsection{Caracterização dos carvões ativados por meio dos índices de iodo e de azul de metileno}

Primeiramente, foram amostrados 10 tipos de carvão ativado granulares (4) e pulverizados (6) provenientes do endocarpo do côco, madeira e osso, destinados ao uso em sistemas de tratamento de águas, disponíveis comercialmente em 4 fabricantes do Brasil. Com o intuito de estimar a capacidade adsortiva dos carvões ativados na fase líquida e assim possibilitar a seleção para determinação da área superficial BET-N2, distribuição de poros e construção das isotermas de adsorção para microcistinas - MCs, optou-se pela determinação prévia do número ou índice de iodo e, especialmente, do índice de azul de metileno, de acordo com a norma JIS-K 1474, 1991. 
As concentrações residuais das soluções de iodo e de azul de metileno foram determinadas por titulação volumétrica com tiosulfato de sódio e por espectrofotometria no comprimento de onda de $665 \mathrm{~nm}$, respectivamente. Esses índices foram determinados pelo ajuste à equação de Freundlich, sendo o número de iodo definido como a quantidade de iodo adsorvido em mg por g de carvão quando a concentração de iodo total no equilíbrio é de 2,5 g/L, e da mesma forma, o índice de azul de metileno, definido como a quantidade de azul de metileno adsorvido quando a concentração residual é de 0,24 mg/L. Esses experimentos foram realizados em duplicata. Nas Figuras 4.6.2 e 4.6 .3 são mostradas fotos tiradas durante a determinação dos índices de iodo e de azul de metileno.

Os carvões que apresentaram a melhor capacidade de adsorção em fase líquida para o azul de metileno tiveram sua capacidade de adsorção em fase gasosa avaliada, onde se pode estimar as áreas de suas superfícies especificas bem como a distribuição do tamanho de seus poros. Para este objetivo foram realizadas isotermas de adsorção de nitrogênio gasoso a -196 ${ }^{\circ} \mathrm{C}$ (equipamento NOVA 1200 - Quantachrome Corporation). Antes de serem analisadas, as amostras foram degaseificadas a $140{ }^{\circ} \mathrm{C}$ por no mínimo 4 h, a um vácuo de $100 \mathrm{~mm} \mathrm{Hg}$. A área da superfície específica de cada carvão ativado foi estimada empregando-se o método de BET. Os cálculos das áreas e dos volumes de microporos e de mesoporos foram realizados utilizando os métodos $t$-Halsey e BJH, respectivamente (WEBB \& ORR JR, 1997).
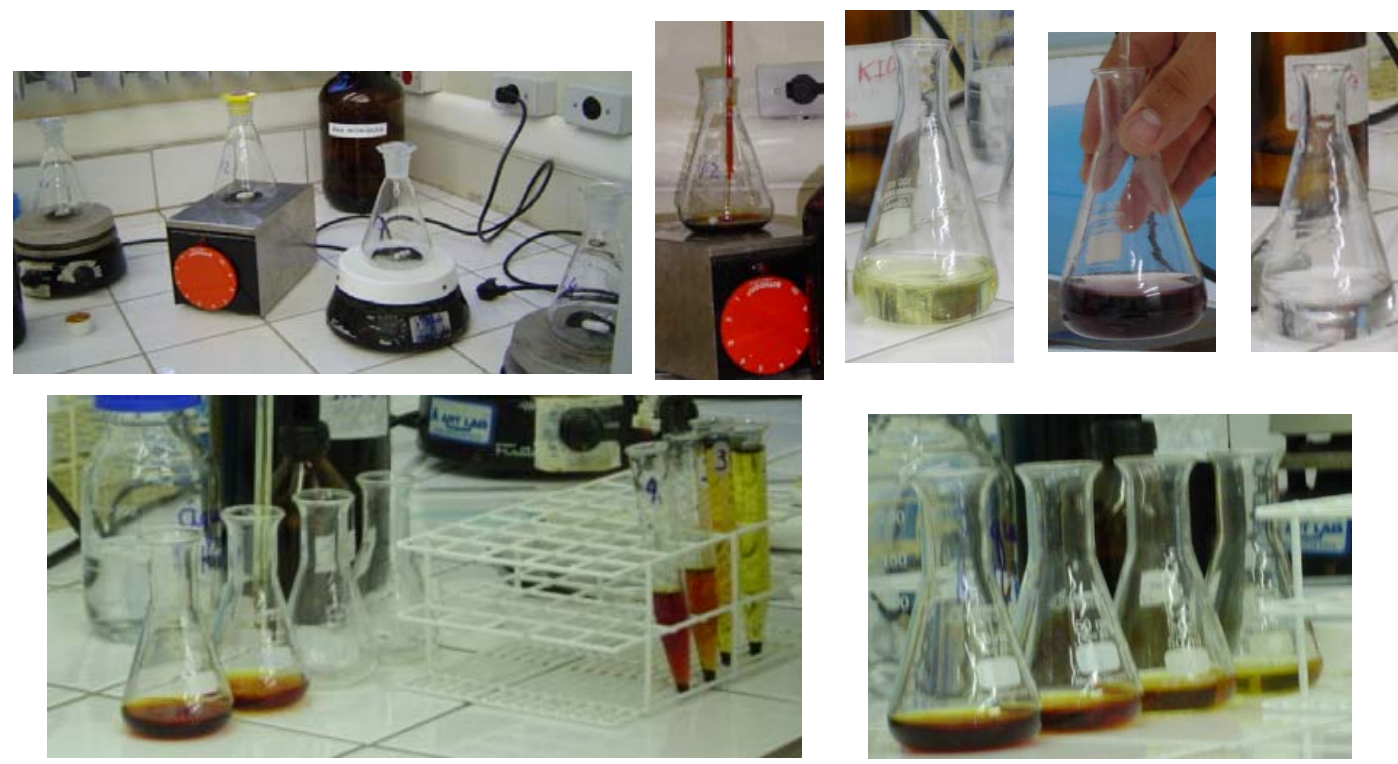

Figura 4.6.2 - Vista geral das diferentes etapas do ensaio para determinação do índice ou número de iodo - NI 

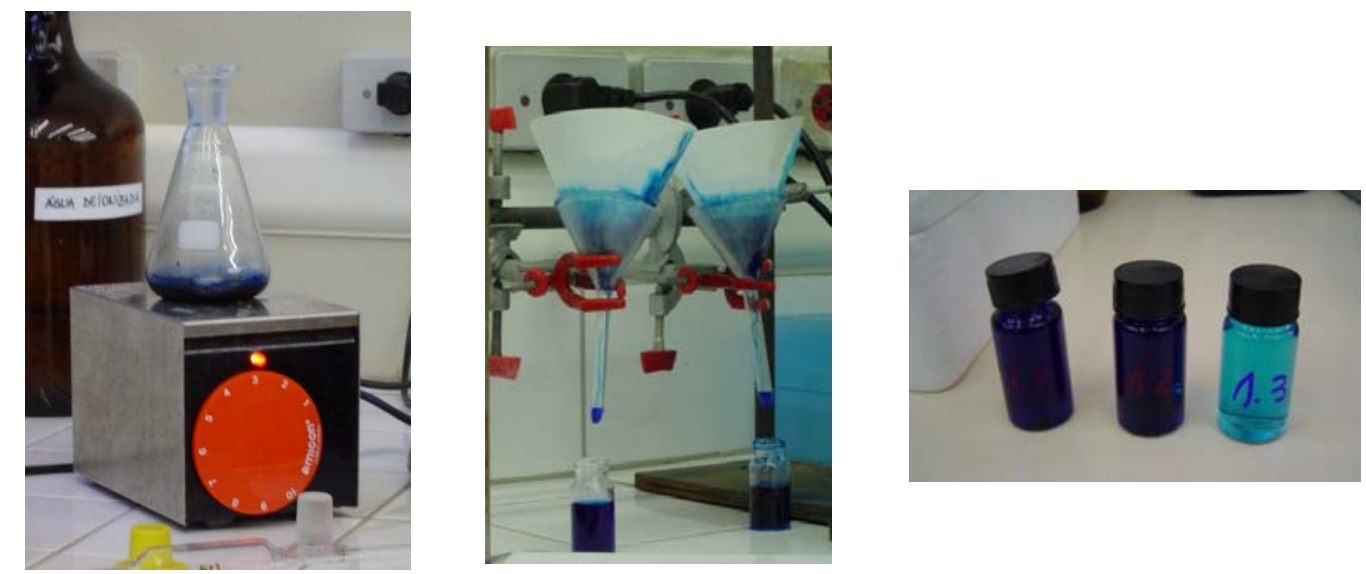

Figura 4.6.3 - Vista geral das diferentes etapas do ensaio para determinação do índice de azul de metileno - IAM

\subsubsection{Preparação do extrato de microcistinas - MCs}

Para obtenção dos extratos de microcistinas - MCs, foram preparadas culturas da cepa toxigênica de Microcystis spp. NPLJ-4 sob condições descritas no Item 4.1.1. Após 15 a 20 dias (fase final do crescimento exponencial), as culturas foram submetidas ao processo de congelamento e descongelamento (3 vezes), para extração de MCs intracelulares para o meio, e de filtração em membrana tipo GF/C para separação de material suspenso, de acordo com as Figuras 4.6.4 e 4.6.5.
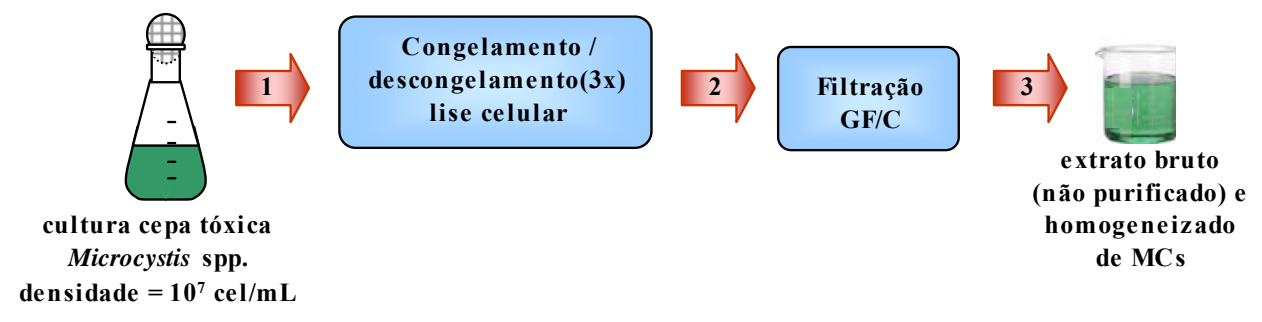

Figura 4.6.4 - Esquema da preparação do extrato bruto não purificado de microcistinas

Após homogeneização dos extratos, estes foram divididos em alíquotas de $300 \mathrm{~mL}$ e mantidos em freezer $-4^{\circ} \mathrm{C}$. Todos os experimentos de adsorção foram realizados com o mesmo lote de extrato. 


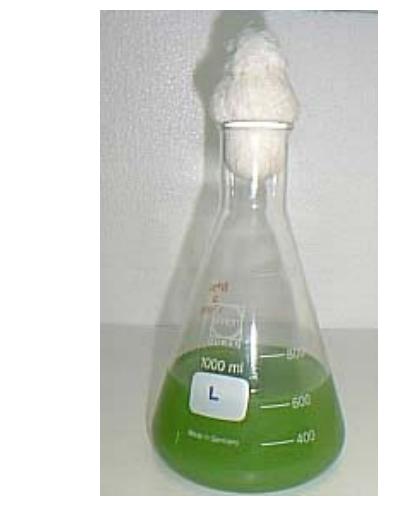

Cultura de Microcystis spp.NPLJ-4

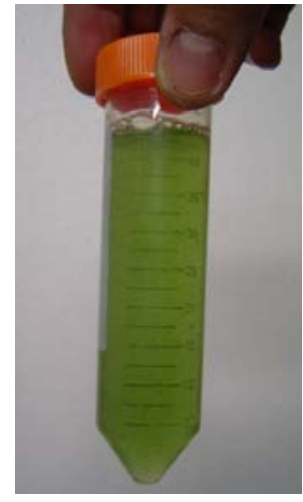

Extrato bruto após lise celular congelamento e descongelamento (3 vezes)

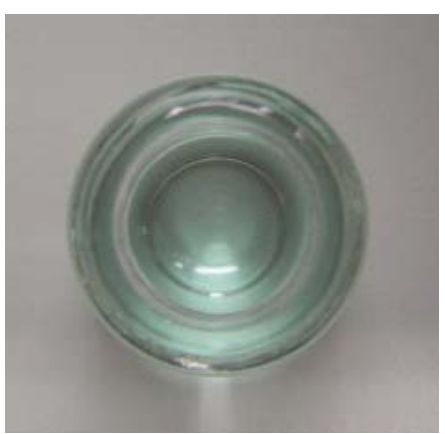

Extrato bruto após lise celular e filtração

Figura 4.6.5 - Vista geral dos extratos em diferentes etapas de preparação

\subsubsection{Preparação das suspensões de carvão ativado}

De acordo com a norma ASTM D 3860-98 e JIS-K 1474, 1991, os carvões ativados tiveram primeiramente suas granulometrias reduzidas, de modo que, no mínimo, 95\% em massa, passassem na peneira 325 mesh $(0,044 \mathrm{~mm})$. Essa etapa foi realizada no Laboratório Interdisciplinar de Eletroquímica e Cerâmica - LIEC da UFSCar, por trabalho de colaboração, sob responsabilidade do Prof. Élson Longo. A redução da granulometria dos carvões foi realizada em moinho de alta energia SPEX modelo Certi Prep 8000 M Mixer/Mill, por meio de agitação por 10 min, de 5 g de CA granular seco e 30 esferas de zircônia com 5 mm de diâmetro (Figura 4.6.6).

Testes preliminares indicaram a necessidade da utilização de solução tampão nas suspensões de carvão ativado devido à constatação do aumento dos valores de $\mathrm{pH}$ da mistura com a adição da massa de carvão ativado, tendo resultado em variações significativas na eficiência do processo de adsorção. Desta forma, para preparação das suspensões de carvão ativado, adicionou-se à massa correspondente dos carvões em solução tampão fosfato ( $\mathrm{pH}$ = $7,0)$ previamente filtrado em membrana de acetato de celulose com porosidade de 0,45 $\mu \mathrm{m}$, de forma a obter as concentrações desejadas para o experimento. Em seguida, a suspensão de carvão ativado foi submetida à agitação (250 rpm) sob vácuo de $600 \mathrm{~mm}$ Hg por 3 h. Antes de cada experimento, os carvões foram mantidos em estufa a $110^{\circ} \mathrm{C}$ por $24 \mathrm{~h}$ e resfriados em dessecador sob vácuo de $300 \mathrm{~mm} \mathrm{Hg}$. 


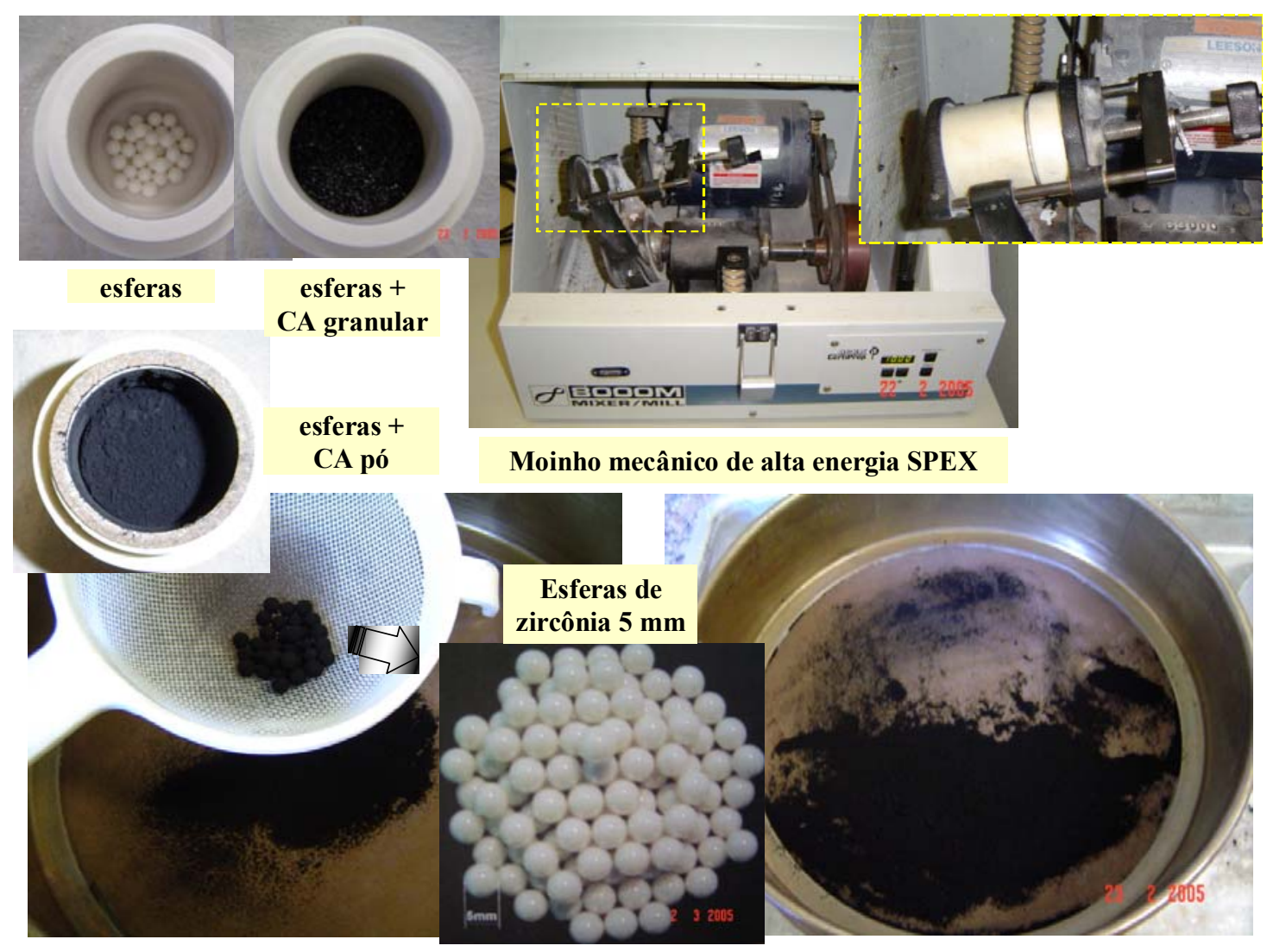

Figura 4.6.6 - Vista geral das diferentes etapas de moagem do CA

\subsubsection{Ensaio de adsorção de microcistinas - MCs}

Os ensaios de adsorção para construção das isotermas foram realizados a temperatura de $25,5 \pm 1,0^{\circ} \mathrm{C}$, com volumes totais de mistura de $50 \mathrm{~mL}$, em erlenmeyers de $250 \mathrm{~mL}$ devidamente fechados sob mesa agitadora orbital com 250 opm modelo MA 140 com temporizador programável por 3 h, uma vez que, fixada a massa de carvão e volume de extrato bruto, testes preliminares com 2 e 12 h de tempo de agitação apresentaram valores similares da concentração residual de MCs. Assim como os ensaios para determinação dos índices de iodo e de azul de metileno, estes também foram realizados em duplicata. Após agitação, as misturas foram imediatamente filtradas em membrana com abertura de poros de 0,45 $\mu \mathrm{m}$ para separação do material suspenso. Na Figura 4.6.7 são mostradas fotos tiradas durante o ensaio de adsorção de MCs.

Para evitar interferências relativas às diferenças no tempo de contato devido à etapa de filtração, o início do ensaio foi realizado por grupos de pontos (erlenmeyers) de forma defasada (30 min). Em seguida, os volumes filtrados foram devidamente preparados para análise e quantificação por cromatografia líquida de alta eficiência com detector de diodo HPLC-PDA, conforme descrito no Item 4.3.6. 

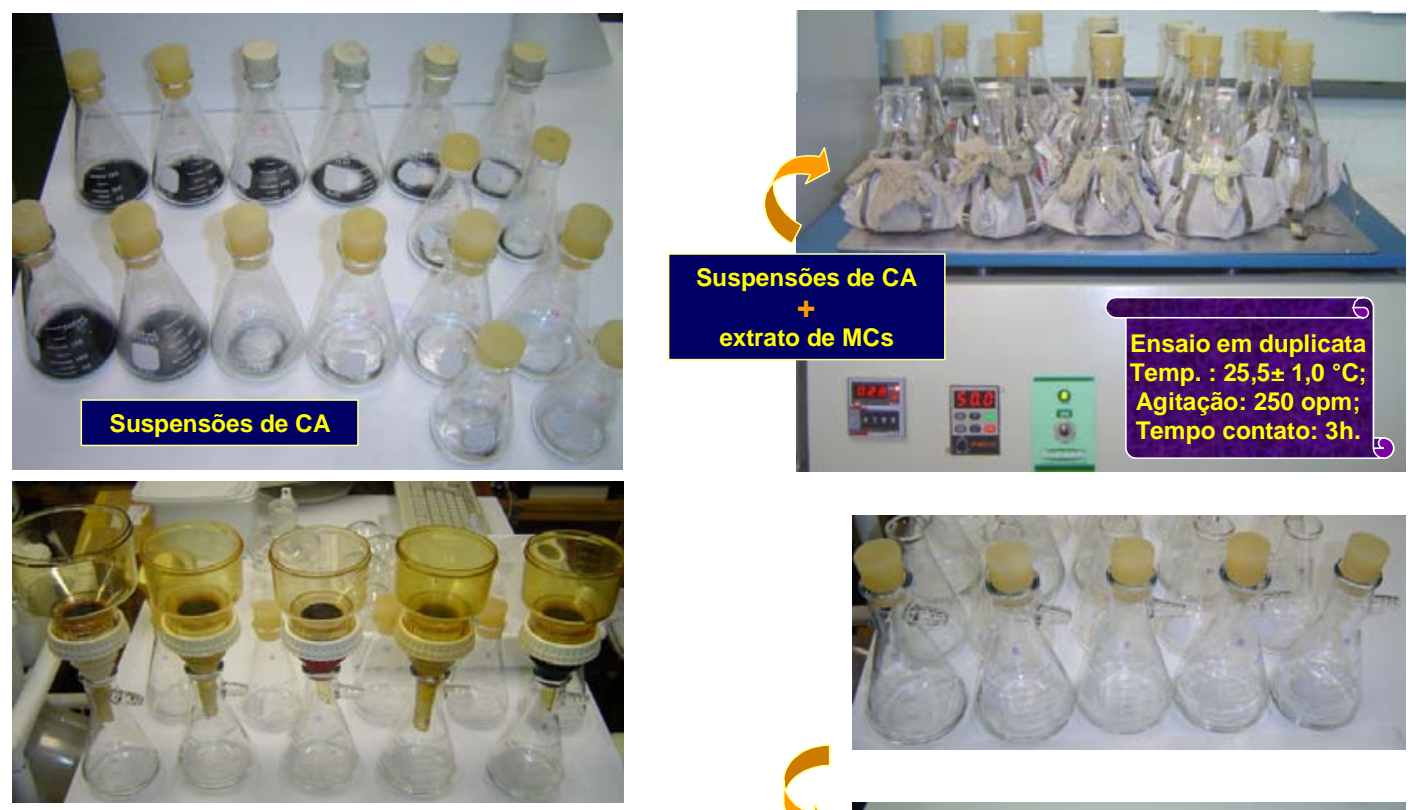

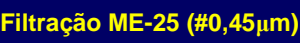
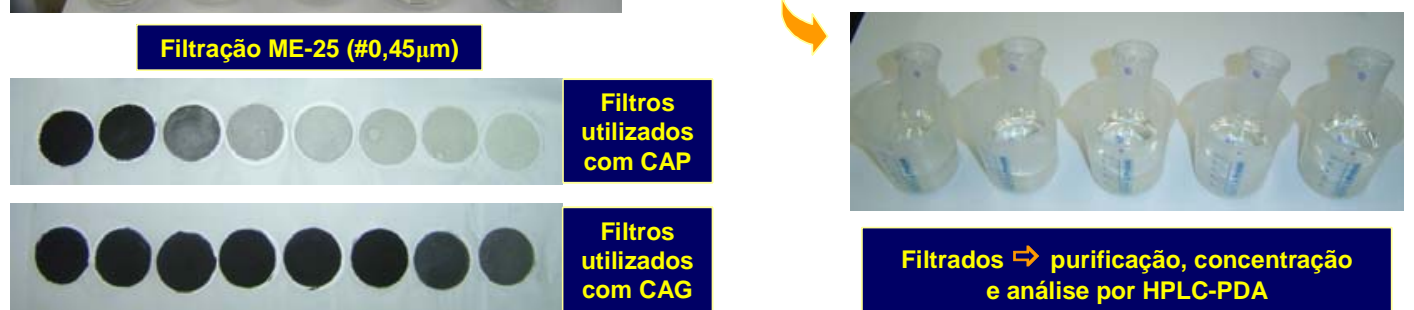

Filtrados $\Rightarrow$ purificação, concentração e análise por HPLC-PDA

Figura 4.6.7 - Vista geral das diferentes etapas do ensaio de adsorção de MCs

\subsubsection{Ajuste dos dados obtidos para iodo, azul de metileno e microcistina pelo modelo de adsorção de Freundlich}

O modelo de adsorção de Freundlich é uma equação empírica sem base teórica, na qual se assume uma variação exponencial da energia nos sítios energéticos de adsorção. Ela é utilizada em sistemas simples e é baseada na distribuição do soluto entre as fases sólida e líquida no equilíbrio (Ng et. al., 2002).

$\mathrm{q}_{\mathrm{e}}=\mathrm{K}_{\mathrm{f}} \times \mathrm{C}_{\mathrm{e}}^{1 / \mathrm{n}}$, ou na forma linearizada, $\log \left(\mathrm{q}_{\mathrm{e}}\right)=\log \left(\mathrm{K}_{\mathrm{f}}\right)+\frac{1}{\mathrm{n}} \log \left(\mathrm{C}_{\mathrm{e}}\right)$, em que:

$\mathrm{q}_{\mathrm{e}}(\mathrm{mg} / \mathrm{g}$ ou $\mu \mathrm{g} / \mathrm{mg}$ ): massa do composto (iodo, azul de metileno e microcistina) adsorvido por unidade de massa de carvão ativado;

Ce (mg/L ou $\mu \mathrm{g} / \mathrm{L})$ : concentração do composto (iodo, azul de metileno e microcistina) no equilíbrio;

$\mathrm{K}_{\mathrm{f}}$ e $\mathrm{n}$ : constantes empíricas. 
Os coeficientes do modelo $\left(\mathrm{K}_{\mathrm{f}}\right.$ e $\left.\mathrm{n}\right)$ podem ser determinados para cada sistema específico estudado. Um grande valor para 1/n indica uma grande mudança na eficácia sobre diferentes concentrações de equilíbrio, ou seja, quanto menor o valor de $1 / n$, mais afinidade o adsorbato terá pelo adsorvente (Aygüun et. al., 2003).

\subsection{METAS 7 E 8: AVALIAÇÃO DA REMOÇÃO DE CÉLULAS E SUBPRODUTOS DE MICROCYSTIS SPP. COM EMPREGO DE DUPLA FILTRAÇÃO, OXIDAÇÃO E ADSORÇÃO - ENSAIOS EM IP}

A fim de facilitar e simplificar o entendimento da descrição e funcionamento da instalação piloto - IP serão utilizadas as abreviações relacionadas na Figura 4.7.1.

Com o intuito adicional de estudar a aplicabilidade de testes de toxicidade aguda com dafinídeos (Ceriodaphnia dubia e Ceriodaphnia silvestrii) e biomonitoramento com peixes (Danio rerio) na avaliação qualitativa do desempenho dos processos empregados, foi realizado este trabalho em colaboração com a doutoranda Renata Akemi Takenaka sob orientação da Profa. Odete Rocha do Departamento de Ecologia e Biologia Evolutiva DEBE da Universidade Federal de São Carlos - UFSCar. Assim, informações específicas relacionadas aos cultivos de dafinídeos, manutenção de peixes, testes de toxicidade e biomonitoramento foram compartilhadas a fim de possibilitar a visão globalizada do estudo realizado.

\subsubsection{Fluxograma de distribuição de água}

Apresenta-se na Figura 4.7.1, o fluxograma de distribuição de água nas unidades da IP montada nas dependências da ETASC 2, localizada no Distrito Industrial da cidade CEAT de São Carlos. 


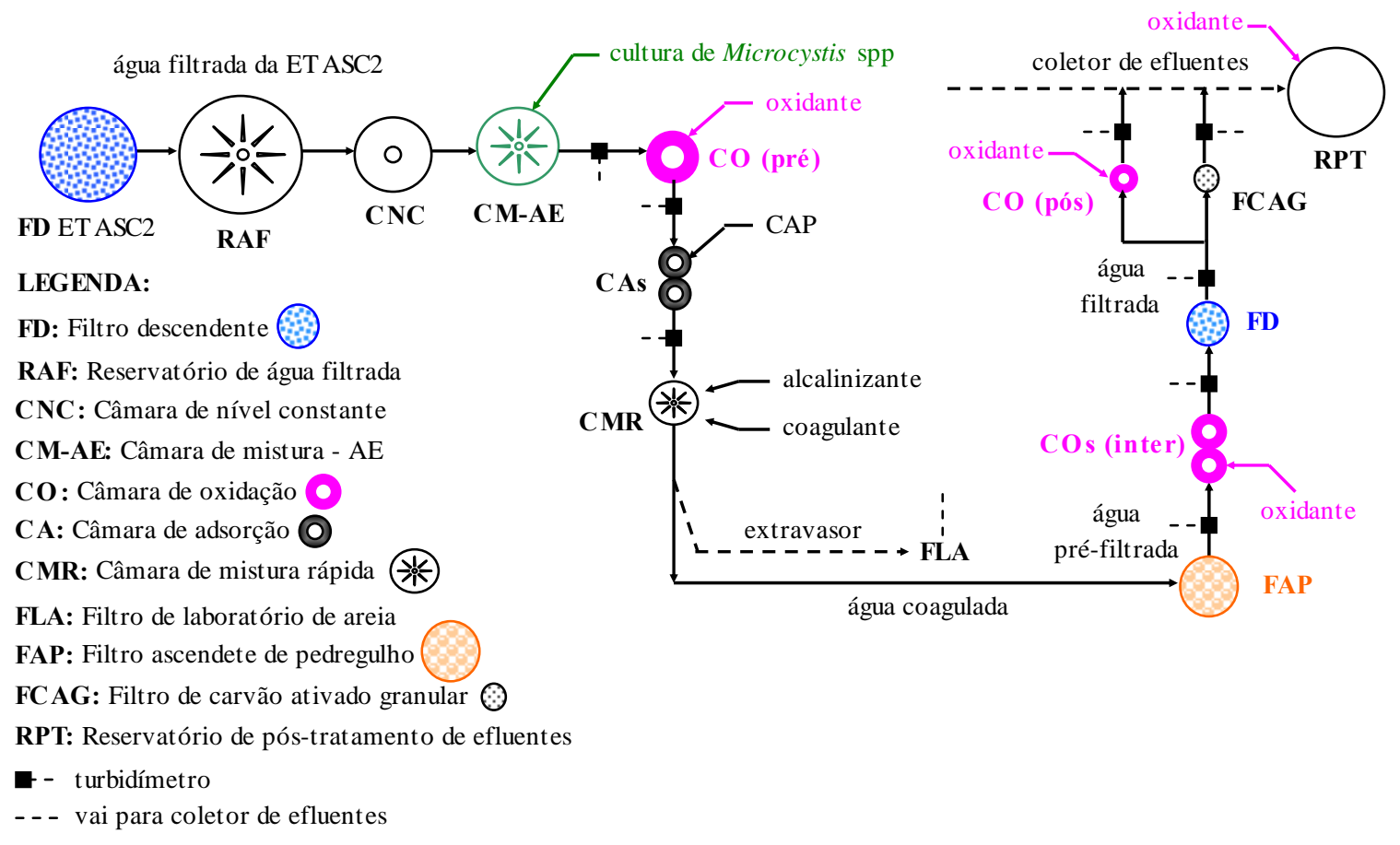

Figura 4.7.1 - Fluxograma de distribuição de água na IP

\subsubsection{Descrição geral da instalação piloto - IP}

Primeiramente, uma bomba centrífuga recalcava água filtrada sem cloro das caixas individuais de saída dos filtros descendentes - FD da ETASC 2 ao reservatório de água filtrada - RAF da IP (Figura 4.7.2). Este, por sua vez, estava ligado a um sistema de bombeamento à câmara de nível constante - CNC, para regularização da vazão de entrada de água no sistema. Em seguida, a água era encaminhada à câmara de mistura para preparação da água de estudo - CM-AE, onde recebia a suspensão de Microcystis spp. e o extrato de MCs para obtenção das características desejadas de água de estudo - AE (Figura 4.7.3).

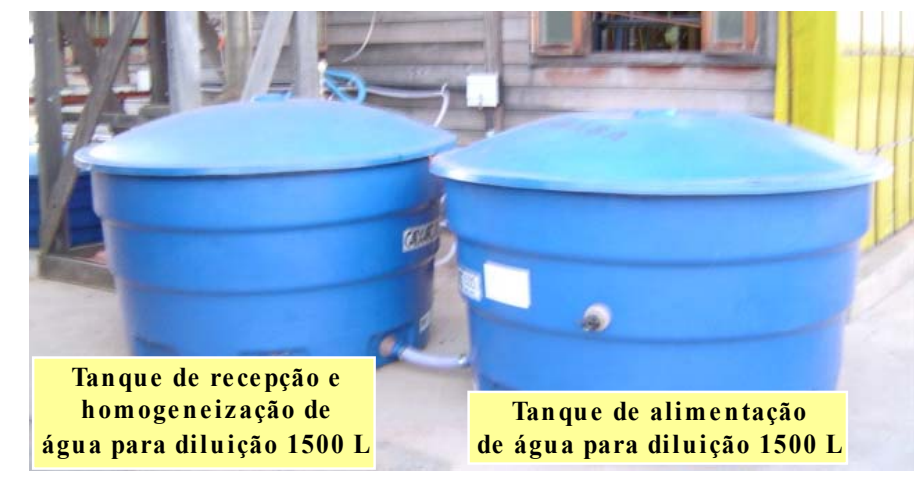

Reservatórios de água filtrada da ETA - RAF (sem cloro) (3000 L)

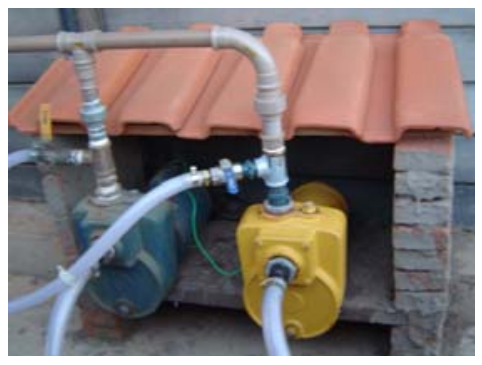

Sistema de bombeamento de água para diluição

Figura 4.7.2 - Vista geral do sistema de reservação e alimentação de água fitrada da ETA (sem cloro) para a Câmara de Nível Constante 

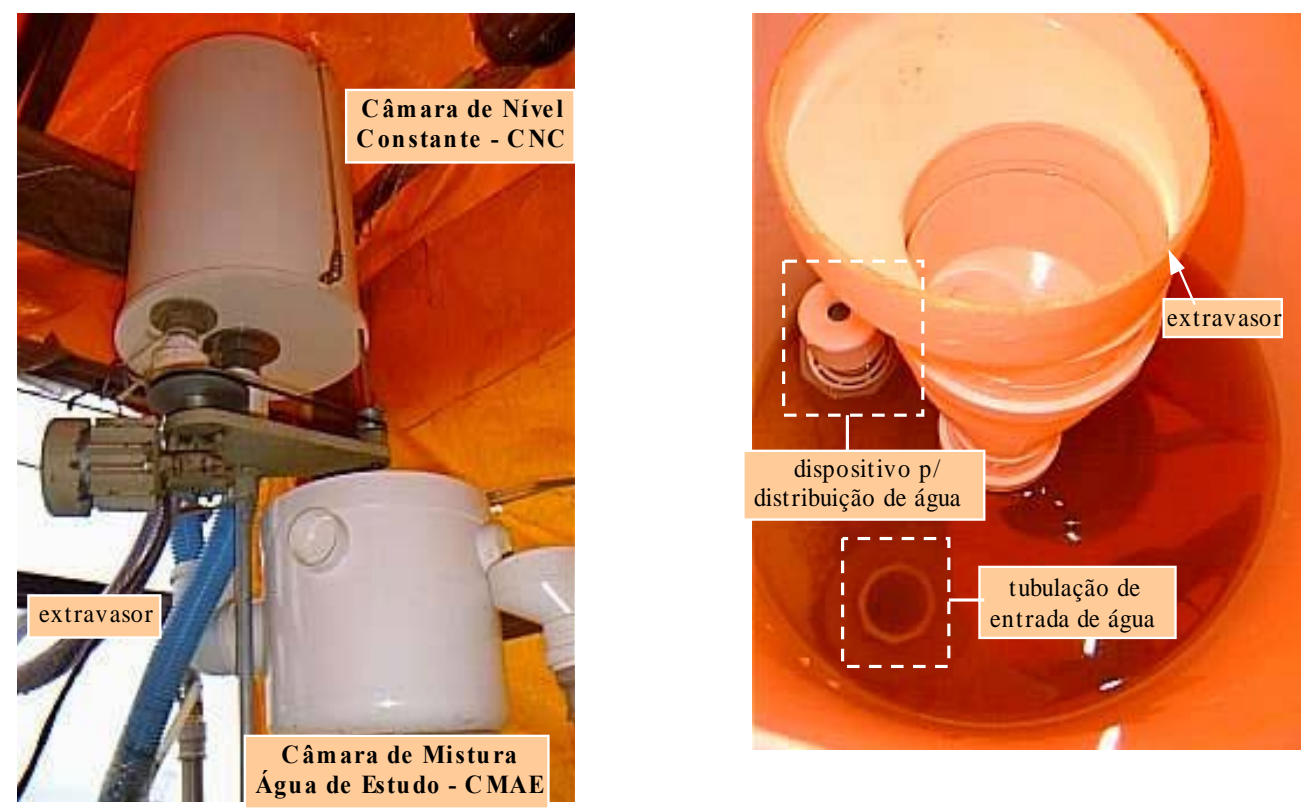

Câmaras de Nível Constante e de Mistura de Água de Estudo

Vista superior da Câmara de Nível Constante

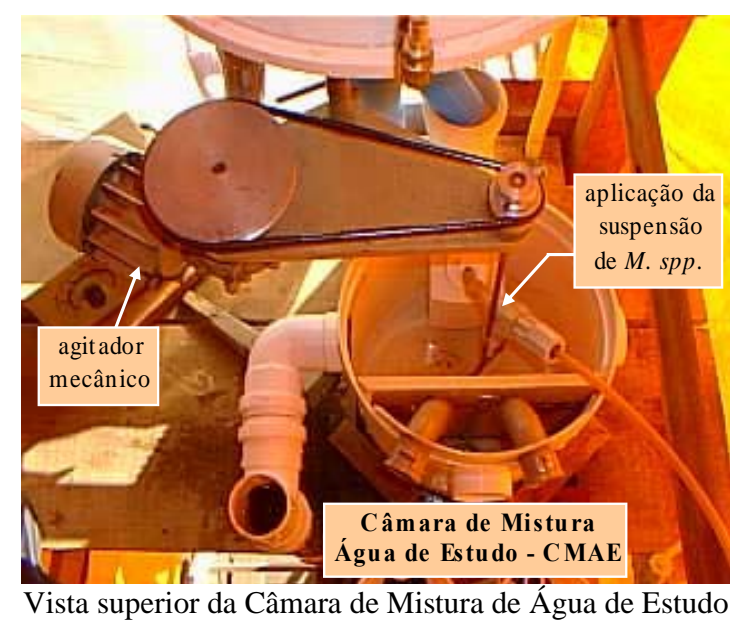

Figura 4.7.3 - Fotos das Unidades de regularização de nível e preparação da água de estudo

Em seguida, a AE já preparada, poderia ser encaminhada à coluna de pré-oxidação CO, para aplicação de cloro e, em seguida, receber aplicação de suspensão de carvão em pó ativado - CAP na coluna de adsorção -CA (Figura 4.7.4). 

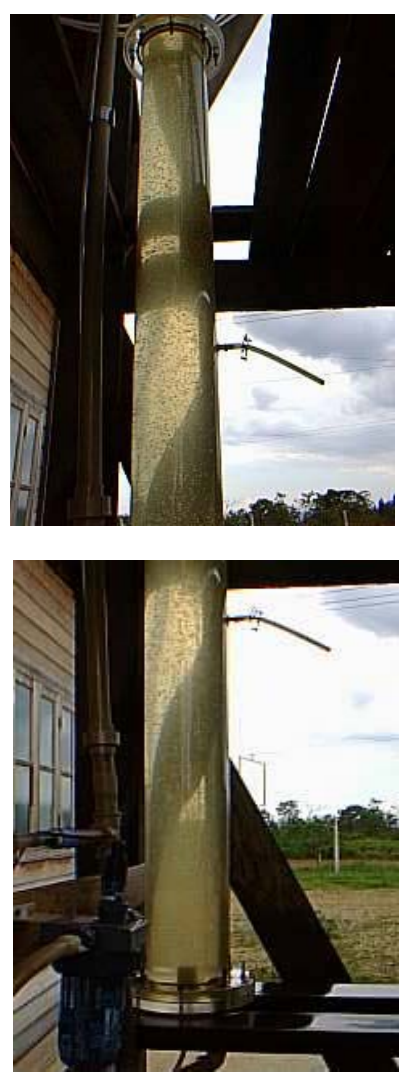

Coluna de pré-oxidação
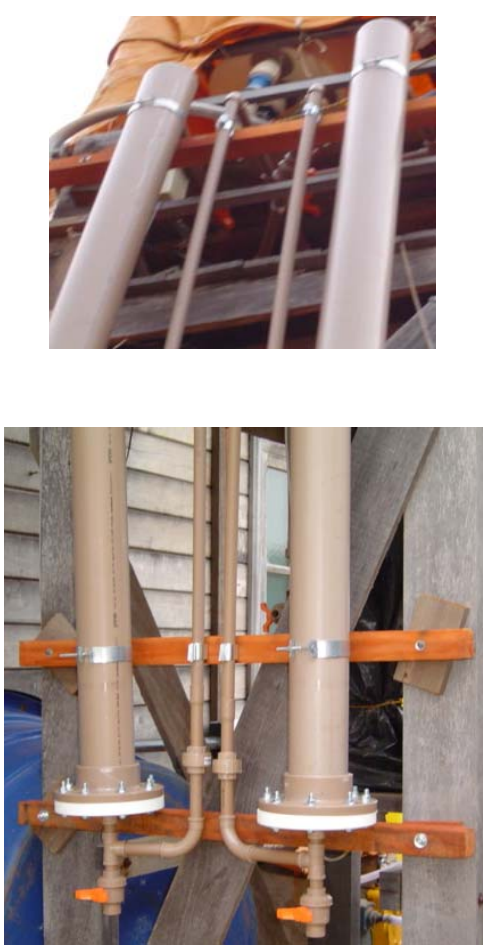

Colunas de adsorção
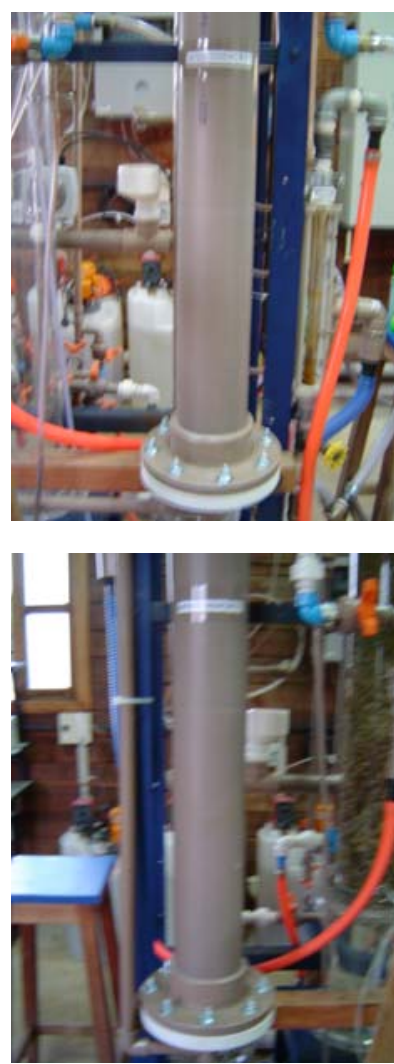

Colunas de interoxidação

Figura 4.7.4 - Fotos das colunas de oxidação e de adsorção

Na entrada da Câmara de Mistura Rápida - CMR, era adicionado o alcalinizante ou acidificante (quando necessário), seguido do coagulante químico - sulfato de alumínio (Figura 4.7.5). A CMR (Figura 4.7.5) possuía as mesmas dimensões do jarro utilizado no jarteste, a fim de garantir as condições de mistura rápida preestabelecidas nos ensaios de bancada da fase 1; era provida de agitador para mistura do coagulante à água de estudo e uma placa com orifícios na parte superior para verter a água coagulada à câmara de regularização / distribuição de vazão - CRDV. 


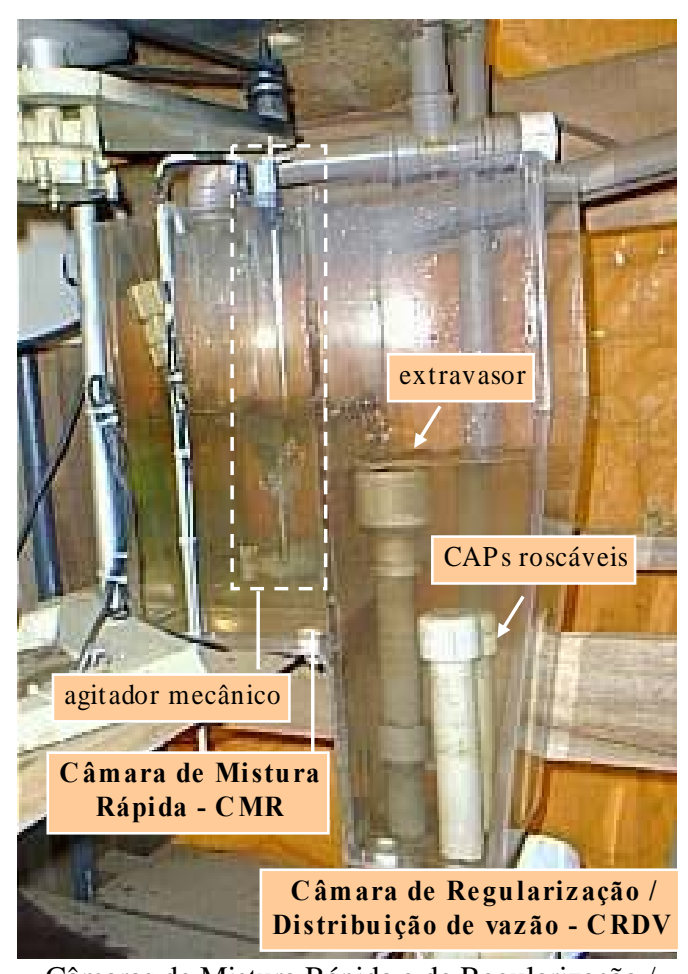

Câmaras de Mistura Rápida e de Regularização / Distribuição de Vazão

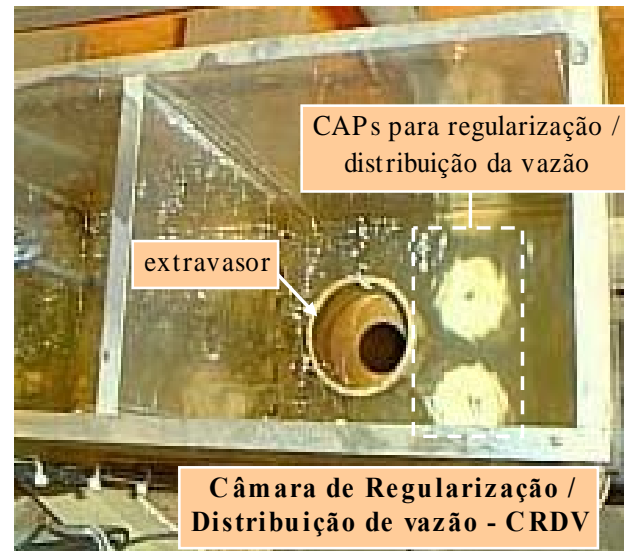

Vista superior da Câmara de Regularização / Distribuição da vazão a ser encaminhada aos filtros ascendentes

Figura 4.7.5 - Fotos das unidades de mistura rápida e de regularização / distribuição de vazão

Como a vazão máxima a ser utilizada no sistema de filtração era inferior à de recalque, uma parcela da água coagulada (aproximadamente $30 \mathrm{~L} / \mathrm{h}$ ) era extravasada continuamente por uma tubulação junto ao sistema, permitindo a realização da otimização e controle da dosagem de coagulante e o respectivo pH de coagulação, utilizando-se filtro de laboratório de areia - FLA de material granular adequado às características da água em questão. Para tanto, a tubulação de alimentação do sistema de filtração possuiu uma derivação para desvio da água coagulada até que fossem ajustadas as condições de coagulação no início do ensaio. Vale ressaltar que somente após o ajuste das condições de coagulação foi dado o início do ensaio, encaminhando a água coagulada à parte inferior do filtro ascendente de pedregulho - FAP.

A água pré-filtrada poderia ser encaminhada à coluna de interoxidação - CO para aplicação de cloro e em seguida, ao filtro descendente de areia - FD. A água filtrada, por sua vez poderia ser conduzida ao filtro descendente de carvão ativado granular - FCAG ou à coluna de pós-oxidação - CO.

O sistema era provido de medidores eletromagnéticos e rotâmetros para controle de vazão, tomadas de amostragem contínua, que conduziram uma pequena parcela (vazão aproximada de 30L/h) dos efluentes de cada processo aos turbidímetros de processo, tacômetros para monitoramento da rotação aplicada nas câmaras da torre, além de 
piezômetros, que permitiram verificar a penetração de impurezas no meio granular e controlar as operações de descargas de fundo intermediárias.

As saídas de processo foram direcionadas aos turbidímetros de escoamento contínuo HACH modelo 1720C e 1720D. Esses, por sua vez, eram interligados aos aquários com capacidade de 20 L para a realização de biomonitoramento com peixes da espécie Danio rerio (Figura 4.7.6a). Todos os efluentes do sistema eram coletados e direcionados ao reservatório de recepção e pós-tratamento de efluentes - RPT, a fim de evitar a ocorrência de proliferação de cianobactérias em cursos de água da região. O pós-tratamento foi efetuado por meio da adição de solução de hipoclorito de sódio em tanques de $1500 \mathrm{~L}$, resultando em tempo médio de contato de 10 h (tempo superior ao recomendado na literatura (30 min)) e concentração mínima de cloro residual livre igual a 5 mg/L (Figura 4.7.6b).

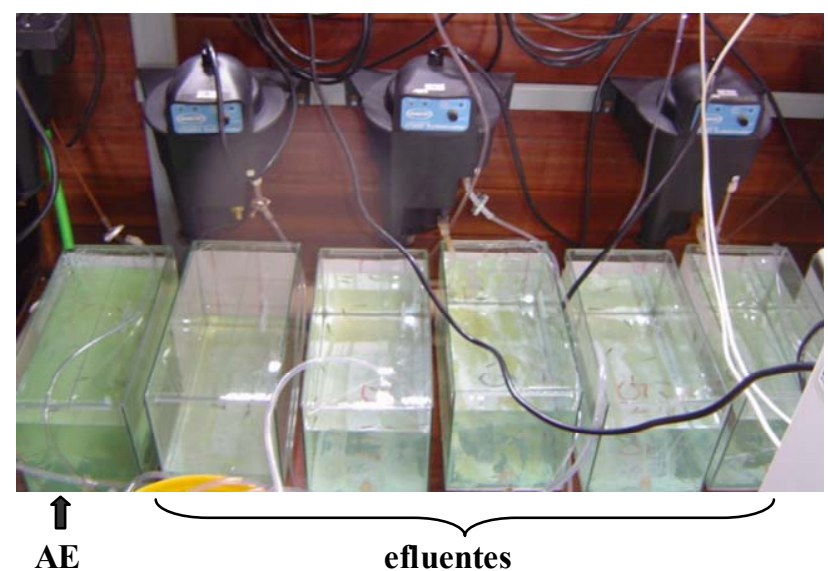

Figura 4.7.6a - Turbidímetros de escoamento contínuo e aquários para biomonitoramento
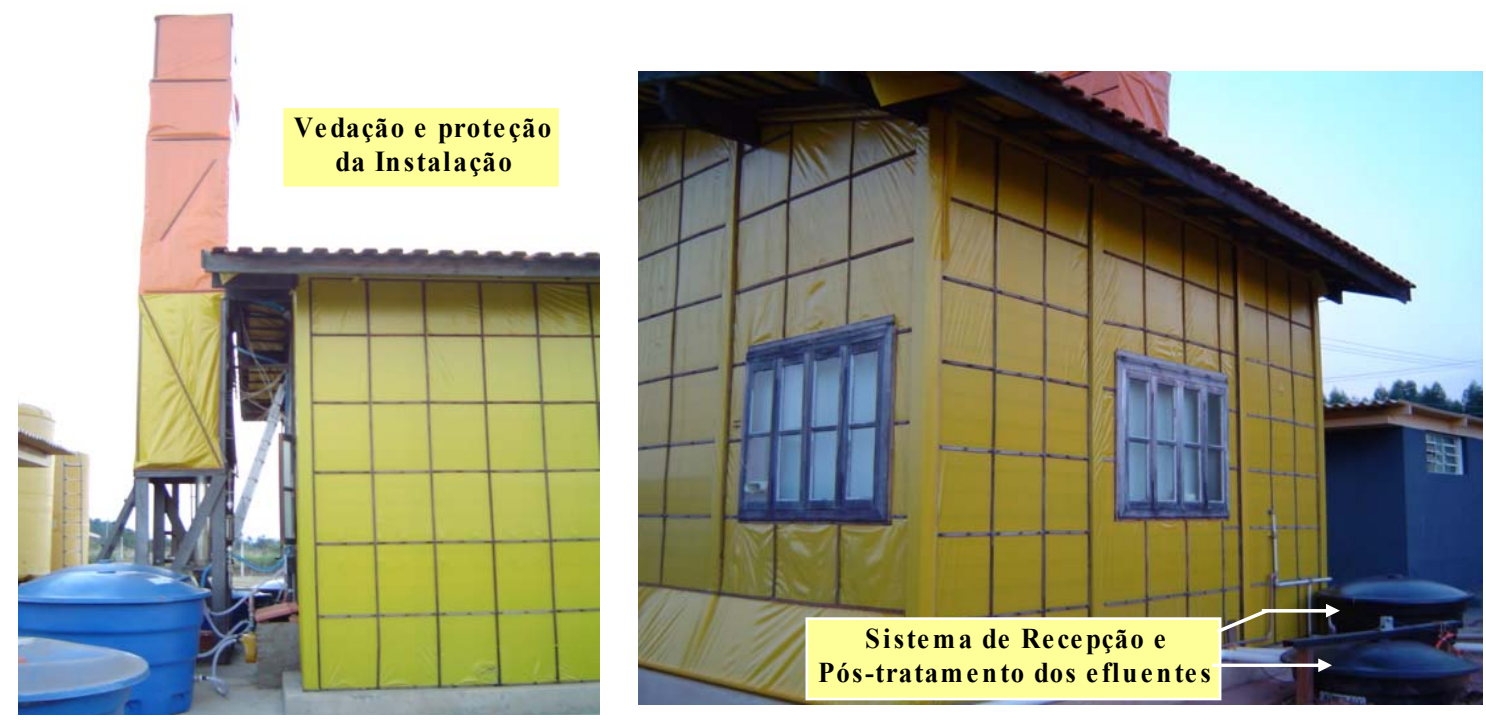

Figura 4.7.6 b - Fotos da Instalação e do sistema de recepção e pós-tratamento dos efluentes gerados 


\subsubsection{Sistema de dosagem}

Para cada ensaio, as soluções de produtos químicos - alcalinizante (hidróxido de sódio-sólido), coagulante (sulfato de alumínio líquido comercial) e cloro (hipoclorito de cálcio-pó) foram preparadas, diluindo-se o produto comercial em água filtrada da ETA 2 sem cloração, de forma a obter concentrações adequadas em relação à precisão desejada para realização de ajustes das dosagens empregadas, vazões correspondentes ao bom desempenho da bomba dosadora (entre 0,2 a 0,8 L/h), considerando a vazão afluente à CMR e a dosagem preestabelecida e volumes adequados para alimentação contínua durante a carreira. A preparação da suspensão de carvão ativado pulverizado - CAP foi realizada da mesma forma, porém, com 1 dia de antecedência e mantida sob agitação intermitente por períodos de $6 \mathrm{~h}$.

Para preparação e aplicação das soluções e suspensões de produtos químicos dispunha-se para cada tipo de reagente, de tanques graduados com volume útil de $50 \mathrm{~L}$ cada, providos de bomba dosadora de membrana com regularizador de pulsos, de motoredutor e agitador e aplicador com válvula de contrapressão. As bombas dosadoras apresentavam as seguintes especificações: marca ProMinent, modelo CONB 1601, 230 V, 60/60 Hz 16 W, 1 A, com amplitude de dosagem de até 1,0 L/h e altura manométrica de 16 m.c.a. (Figura 4.7.7a).

Para facilitar a regulagem das dosagens de produtos químicos e da suspensão de células e extrato de microcistinas - MCs os comandos das bombas dosadoras foram automatizadas. Para isso, foi necessário realizar a fixação das mangueiras e a calibração das vazões resultantes para cada sistema de dosagem.

Durante os ensaios, amostras de 25 e $50 \mathrm{~mL}$ da suspensão de CAP foram coletadas na saída do sistema de dosagem, para verificação posterior, pelo método gravimétrico (Figura 4.7.7b), das concentrações empregadas nos ensaios. 


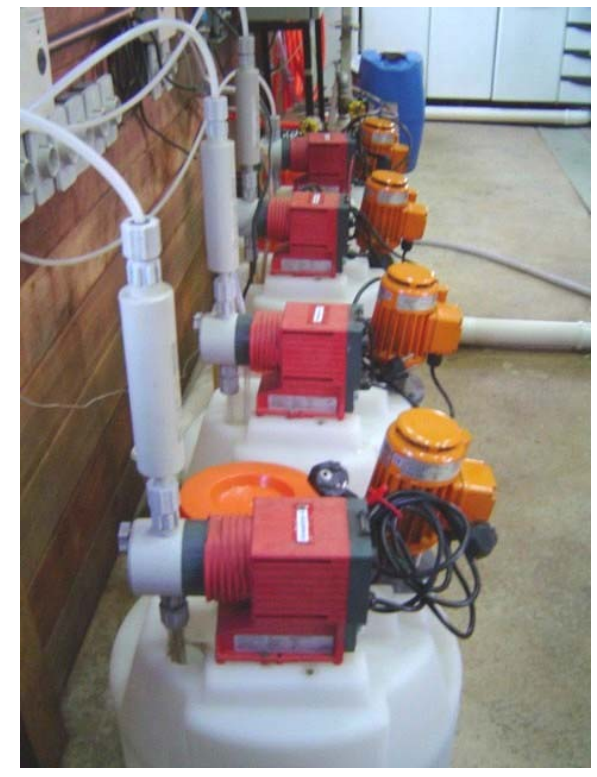

a) Tanques de produtos químicos providos de bombas dosadoras e agitador

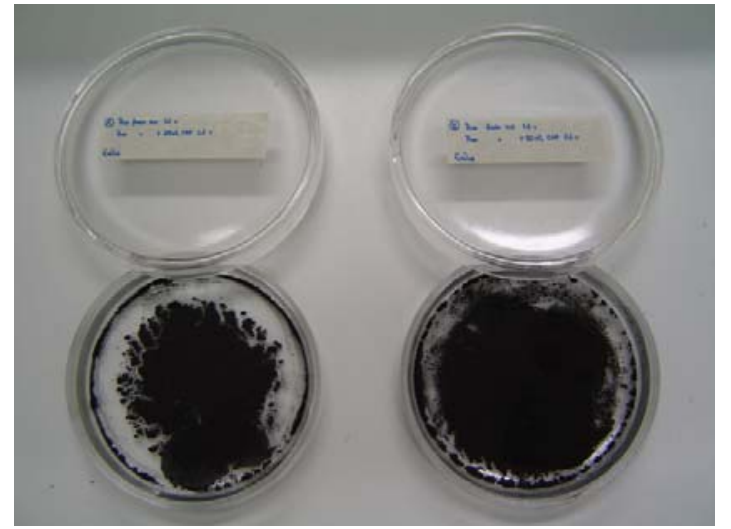

b) Amostras de 25 e $50 \mathrm{~mL}$ da suspensão de carvão ativado em pó - CAP após secura preparadas para pesagem

Figura 4.7.7 - Tanques de produtos químicos e amostras de suspensão de carvão ativado em pó - CAP

\subsubsection{Sistema de filtração}

O Sistema de Dupla Filtração composto pelos filtros ascendente de pedregulho FAP e descendentes de areia - FD foram os mesmos utilizados por KURODA (2002). Foram montados pela superposição adequada de segmentos de tubos cilíndricos, com diâmetros externos iguais a $153 \mathrm{~mm}(\mathrm{DI}=141 \mathrm{~mm})$ e $100 \mathrm{~mm}(\mathrm{DI}=92 \mathrm{~mm})$, respectivamente, além de placas de fundo e placas perfuradas para uniformização da distribuição da vazão de entrada e saída, construídos em acrílico transparente. A estanqueidade do conjunto foi garantida pela colocação de anéis de vedação (de borracha) entre os flanges de cada segmento de tubo, sendo, estes, devidamente conectados por meio de parafusos de latão com porca tipo borboleta.. Na Figura 4.7.8 são apresentadas as principais características das unidades filtrantes que compõem o sistema.

O FAP possuía altura total de 1,97 m e foi apoiado sobre outro segmento de tubo de 1,5 m de altura. O material granular era composto por quatro subcamadas de pedregulho de $30 \mathrm{~cm}$ de altura cada, com granulometria variando entre 1,41 e $25,4 \mathrm{~mm}$, dispostos, estratificadamente, sobre uma placa perfurada, em ordem decrescente no sentido do escoamento. As faixas granulométricas do FAP são relacionadas na Tabela 4.7.1. 
Tabela 4.7.1 - Características do Material Granular do FAP. FONTE: KURODA, (2002)

\begin{tabular}{c|c}
\hline Tamanho dos grãos $(\mathrm{mm})$ & Espessura da subcamada $(\mathrm{mm})$ \\
\hline 19,0 a 25,4 & 300 \\
\hline 9,6 a 15,9 & 300 \\
\hline 3,2 a 6,4 & 300 \\
\hline 1,41 a 2,4 & 300
\end{tabular}

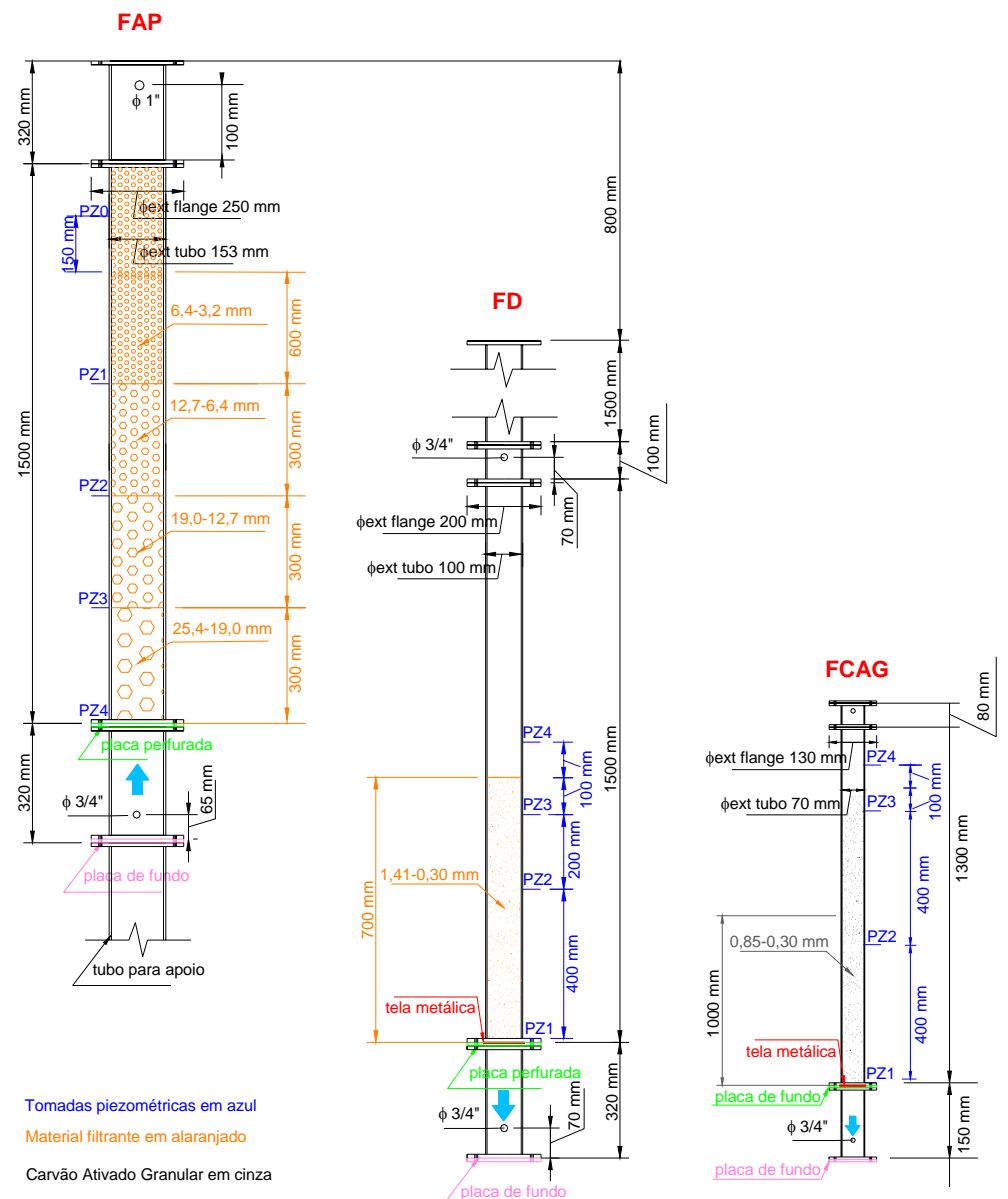

Figura 4.7.8 - Detalhes das unidades filtrantes que compõem a IP

O FD possuía altura total de 3,42 m e dispunha de uma tela metálica com abertura de malha de, aproximadamente, \# 0,2 $\mathrm{mm}$ apoiada sobre a placa perfurada, o que possibilitou a disposição do material filtrante, constituído unicamente de areia, diretamente sobre a mesma, dispensando, assim, o uso de camada suporte. As características do meio filtrante são apresentadas na Tabela 4.7.2. Na Figura 4.7.9 é apresentada a curva de distribuição granulométrica resultante da areia do FD. 
Tabela 4.7.2 - Características do Material Granular do FD. FONTE: KURODA, (2002)

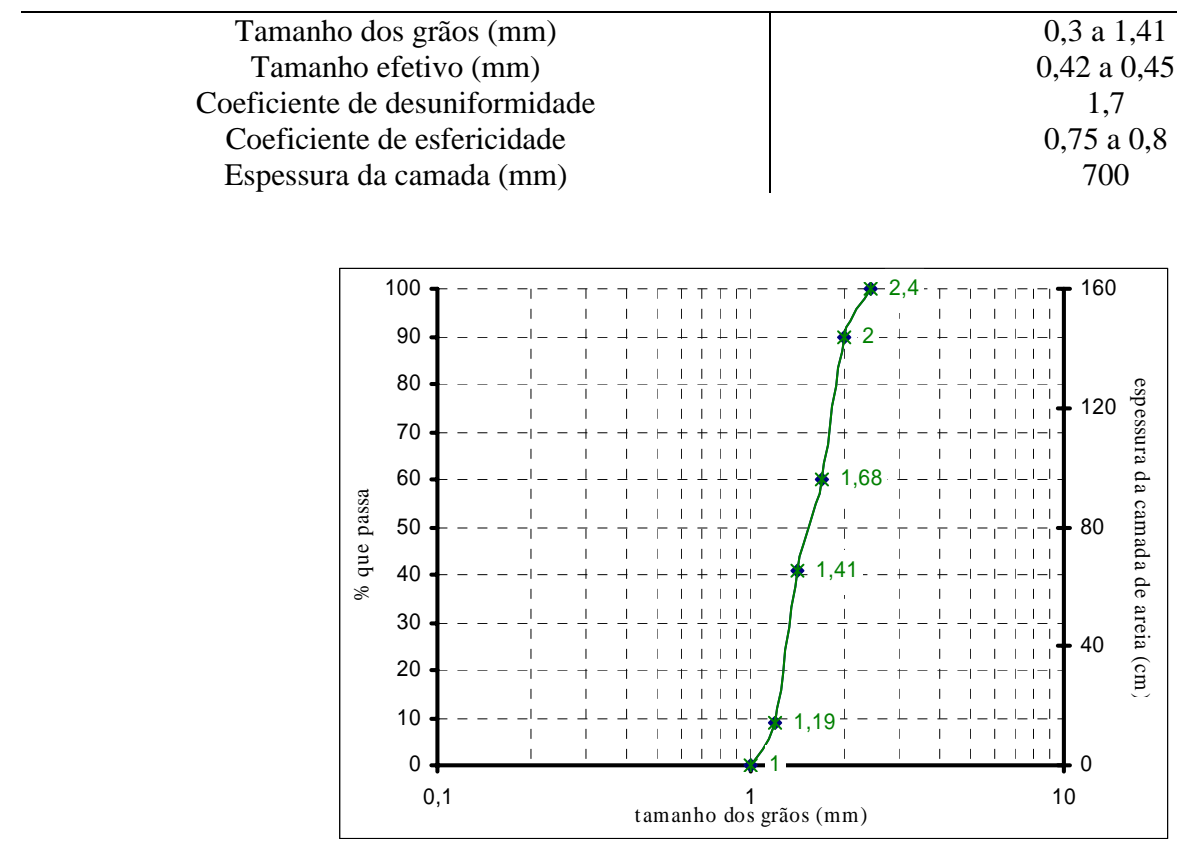

Figura 4.7.9 - Curva granulométrica da areia do filtro descendente - FD. FONTE: KURODA, (2002)

O FCAG possuía altura total de 1,10 m, diâmetro interno igual a 64 mm e dispunha de uma tela metálica com abertura de malha de, aproximadamente, \# 0,2 $\mathrm{mm}$ apoiada sobre a placa perfurada, o que possibilitou a disposição do material adsorvente diretamente sobre a mesma. Segundo especificações técnicas do fornecedor de carvão ativado granular - CAG tipo Bcarbon 350 (20x50), lote 5813, Bahiacarbon Agro Industrial Ltda, as características do material utilizado são: diâmetro médio igual a 0,6 mm, tamanho efetivo igual a 0,35 mm,porcentagem retida na \#20 igual a 2,98\%, porcentagem passante na \#50 igual a 3,01\%, número de iodo da ordem de $860 \mathrm{mg}$ I / g carvão, coeficiente de desuniformidade igual a 1,68 , umidade de $1,2 \%$ e massa específica aparente $\left(\mathrm{g} / \mathrm{cm}^{3}\right)$ igual a 0,52 . Os fundamentos utilizados para a escolha do CAG e sua caracterização são descritos em detalhes, nos Itens 4.6 e 5.5 .

\subsubsection{Funcionamento dos filtros}

Baseado em dados obtidos por KURODA (2002), que estudou o desempenho do sistema de dupla filtração com Filtro ascendente de Pedregulho, o FAP foi submetido à taxa de filtração de $120 \mathrm{~m}^{3} / \mathrm{m}^{2}$.d, o filtro descendente - FD à taxa de filtração de $180 \mathrm{~m}^{3} / \mathrm{m}^{2}$.d. e o FCAG, à taxa de filtração de $110 \mathrm{~m}^{3} / \mathrm{m}^{2}$.d..

Em função do grande volume de cultura e de extrato liofilizado utilizado nos ensaios, não foi possível encerrar a carreira de filtração pelo critério de perda de carga limite 
nos meios granulares do FAP e do FD. Desta forma, os ensaios foram encerrados com tempos de funcionamento fixados de $12 \mathrm{~h}$ para o Ensaio 1, de $10 \mathrm{~h}$ para os Ensaios 2 a 6 e de 6 h para os Ensaios 7 e 8.

Na Figura 4.7.10, são mostradas fotos do FAP durante os ensaios 1, 2 e 3.

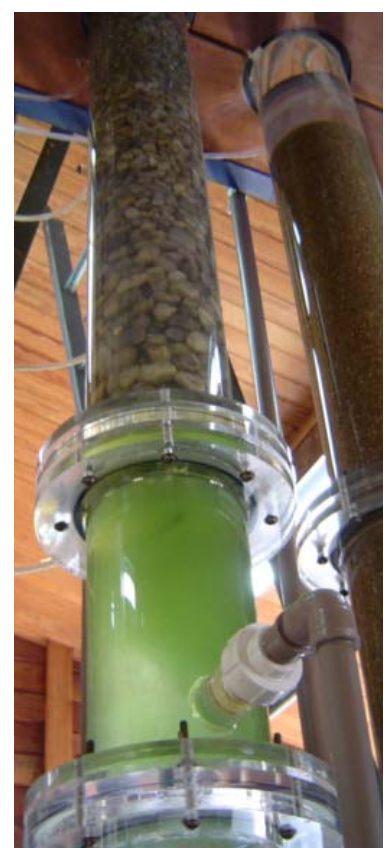

FAP - ENSAIO 1

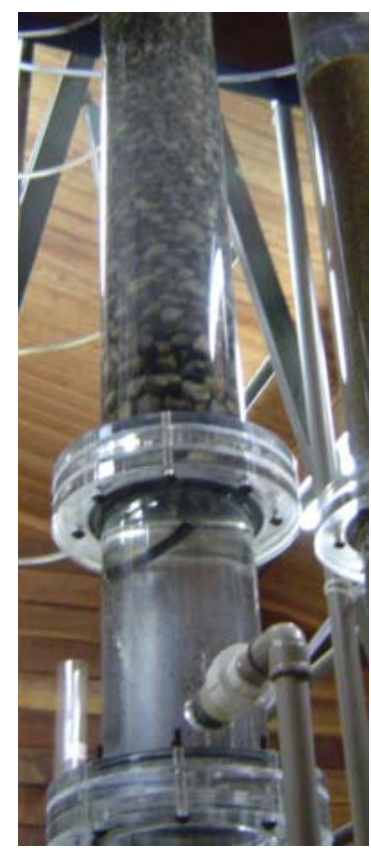

FAP - ENSAIO 2

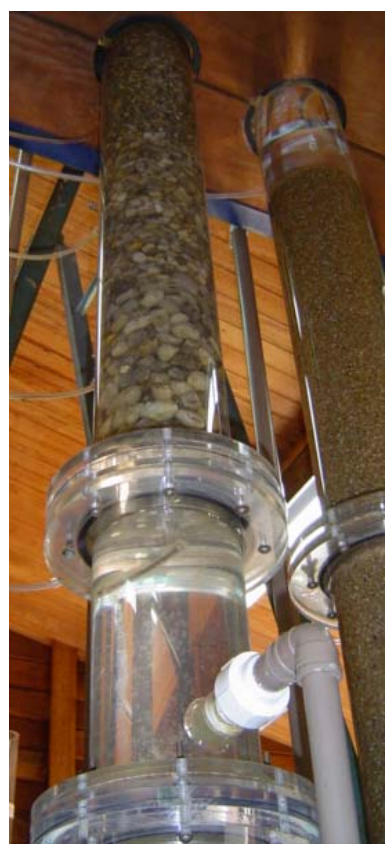

FAP - ENSAIO 3

Figura 4.7.10- Vista geral do FAP nos ensaios 1 , 2 e 3.

\subsubsection{Limpeza e lavagem dos filtros}

O sistema de lavagem e limpeza dos filtros foi composto por sistema de bombeamento acoplado a um reservatório de 500 L para armazenamento de água para lavagem, alimentado com água filtrada da ETASC 2. A bomba centrífuga utilizada possuía as seguintes características: bomba centrífuga monoestágio da série MB-12 (para água limpa), modelo M0B-12X, potência de 0,25 HP, capacidade de bombear até 4,8 $\mathrm{m}^{3} / \mathrm{h}$ a altura manométrica máxima de 21 m.c.a, motor Weg.

O sistema de aplicação de ar para lavagem auxiliar era composto por motocompressor de ar, tubulação principal provida de rotâmetro e ramificações dessa tubulação, adaptadas na parte inferior dos filtros, abaixo da placa perfurada, cujas vazões eram controlados por registros de agulha. A distribuição do ar dentro dos filtros era efetuado por um tubo em cobre de, aproximadamente, $3 \mathrm{~mm}$ de diâmetro, contendo orifícios distribuídos ao longo do seu comprimento. 
No FAP, a limpeza foi efetuada primeiramente com execução de 1 descarga de fundo com taxas de descargas da ordem de 800 a $1200 \mathrm{~m}^{3} / \mathrm{m}^{2} . \mathrm{d}$ e tempo necessário para esvaziamento total do filtro, o que correspondeu a aproximadamente 1,5 min, seguida da introdução simultânea de ar com taxa de aplicação da ordem de $10 \mathrm{~L} / \mathrm{s} \cdot \mathrm{m}^{2}$ e água com velocidade ascensional de $0,5 \mathrm{~m} / \mathrm{min}$ durante $5 \mathrm{~min}$; a operação era finalizada com aplicação de água com velocidade ascensional de aproximadamente 1,4 m/min por $5 \mathrm{~min}$, ou durante o período necessário para que a turbidez do efluente resultasse inferior a 5 uT.

No FD, a lavagem foi realizada por meio de insuflação de ar durante 3 min., com taxa de aplicação da ordem de 15 L / s.m², seguida de água para promover expansão de, aproximadamente, 30 \% na camada de areia, correspondente à velocidade ascensional de aproximadamente $0,6 \mathrm{~m} / \mathrm{min}$ ou taxa de aplicação de $850 \mathrm{~m}^{3} / \mathrm{m}^{2}$.d., durante cerca de $7 \mathrm{~min}$. ou período necessário para que a turbidez do efluente resultasse inferior a 5 uT.

Para garantir a mesma capacidade adsortiva do FCAG nos ensaios realizados, optouse pela substituição integral do material para cada condição testada.

Em geral, a execução de descarga de fundo intermediária - DFI foi realizada após 6 h de operação, com esvaziamento total do filtro, taxas de descargas da ordem de 800 a 1200 $\mathrm{m}^{3} / \mathrm{m}^{2}$.d. e duração de aproximadamente 1,5 min.. Na Figura 4.7.11, são mostradas fotos da execução de DFI dos ensaios 1, 2 e 3.

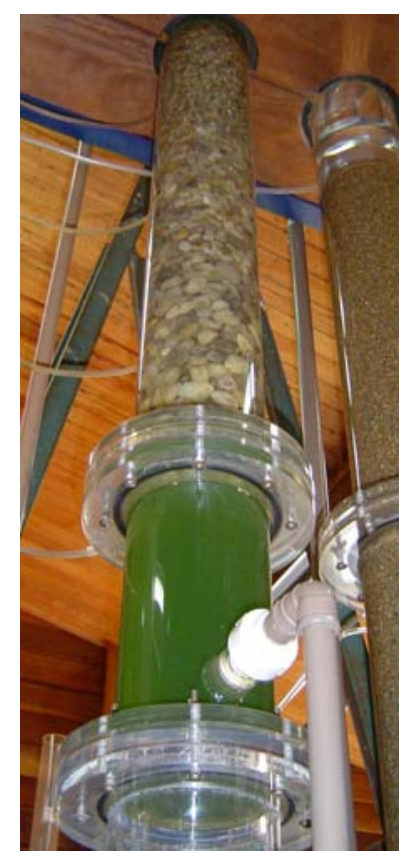

ENSAIO 1: DFI no FAP

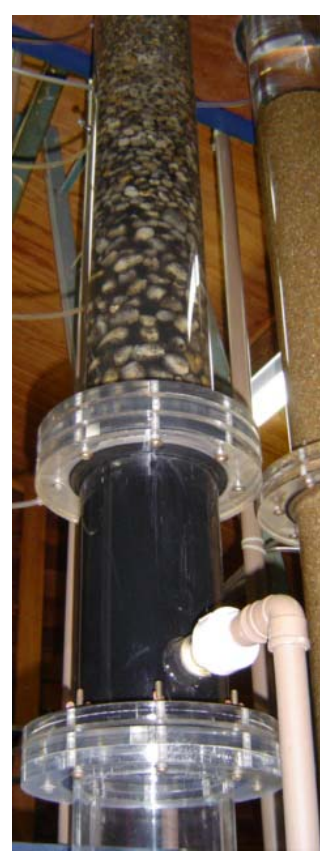

ENSAIO 2: DFI no FAP

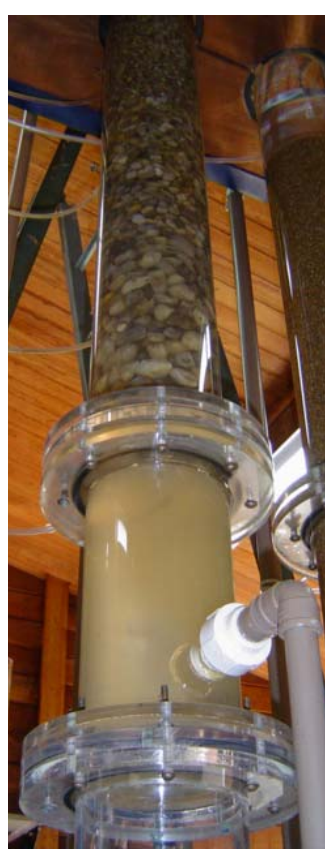

ENSAIO 3: DFI no FAP

Figura 4.7.11 - Vista geral da execução de DFI no FAP nos ensaios 1, 2 e 3. 


\subsubsection{Ajuste das vazões}

O ajuste da vazão afluente ao sistema foi efetuado na câmara de nível constante CNC constituída por tubulação de entrada de água bruta de 19 mm de diâmetro, extravasor de água de dimensões relativamente grandes a fim de atenuar as variações de nível de água na CNC, tubulação de saída de água para a CMR, de $38 \mathrm{~mm}$ de diâmetro, provido de dispositivo de distribuição de vazão e de visor externo para controle do nível de água na câmara. O dispositivo de distribuição de vazão consistiu na adaptação de um cap roscável com um furo central de 12,7 mm à extremidade afogada da tubulação de saída de água, permitindo a realização de ajustes da lâmina líquida sobre o furo para obtenção das vazões requeridas pelo sistema, uma vez que o nível permanece praticamente constante. O cálculo da lâmina líquida sobre o furo pode ser feito considerando a equação da lei dos orifícios e coeficiente de vazão Cd (para orifícios circulares de parede fina) igual a 0,6, conforme é apresentado na Figura 4.7.12.

Os ajustes das vazões parciais foram efetuados por meio de válvulas de esfera e de agulha, rotâmetros e medidores de vazão eletromagnéticos, instalados nas tubulações de entrada ou saída do FAP, FD e FCAG.

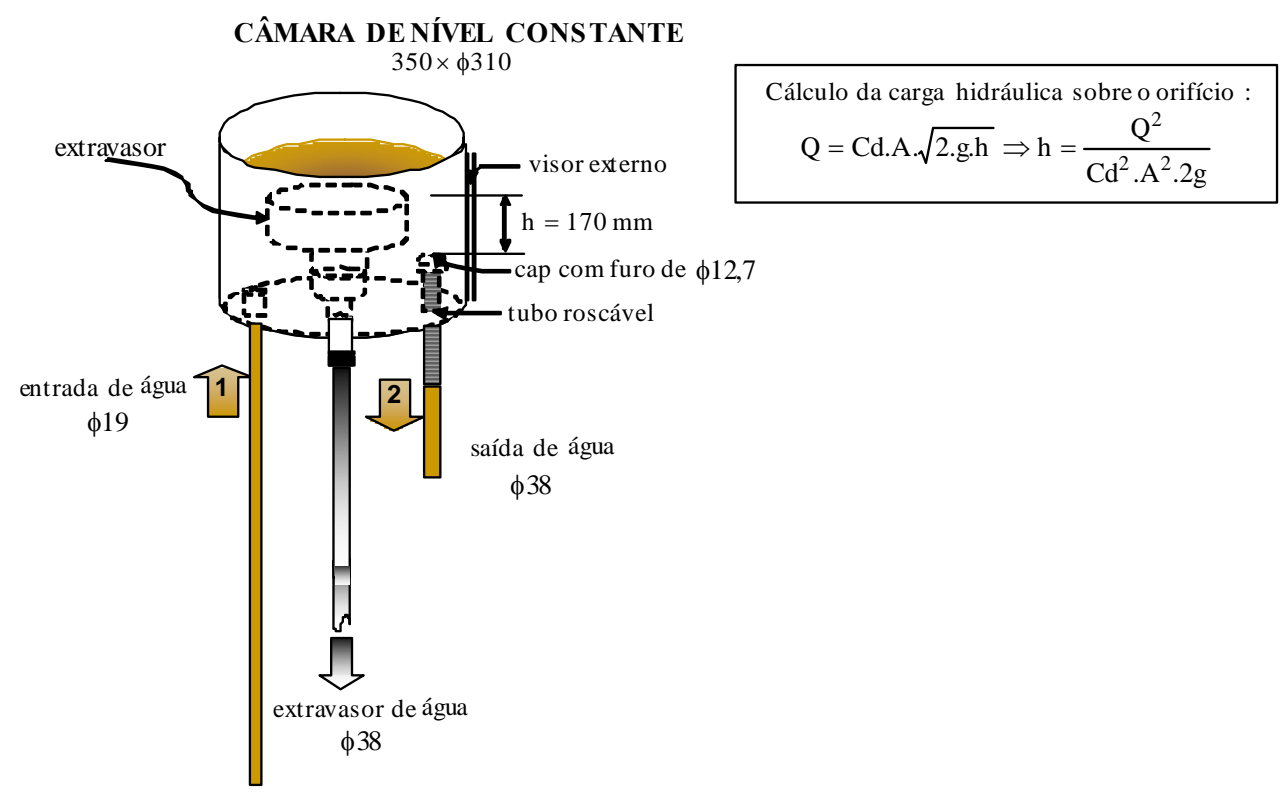

Figura 4.7.12 - Esquema da Câmara de Nível Constante - CNC

Apresenta-se na Figura 4.7.13, o esquema da IP contendo as adaptações realizadas. 


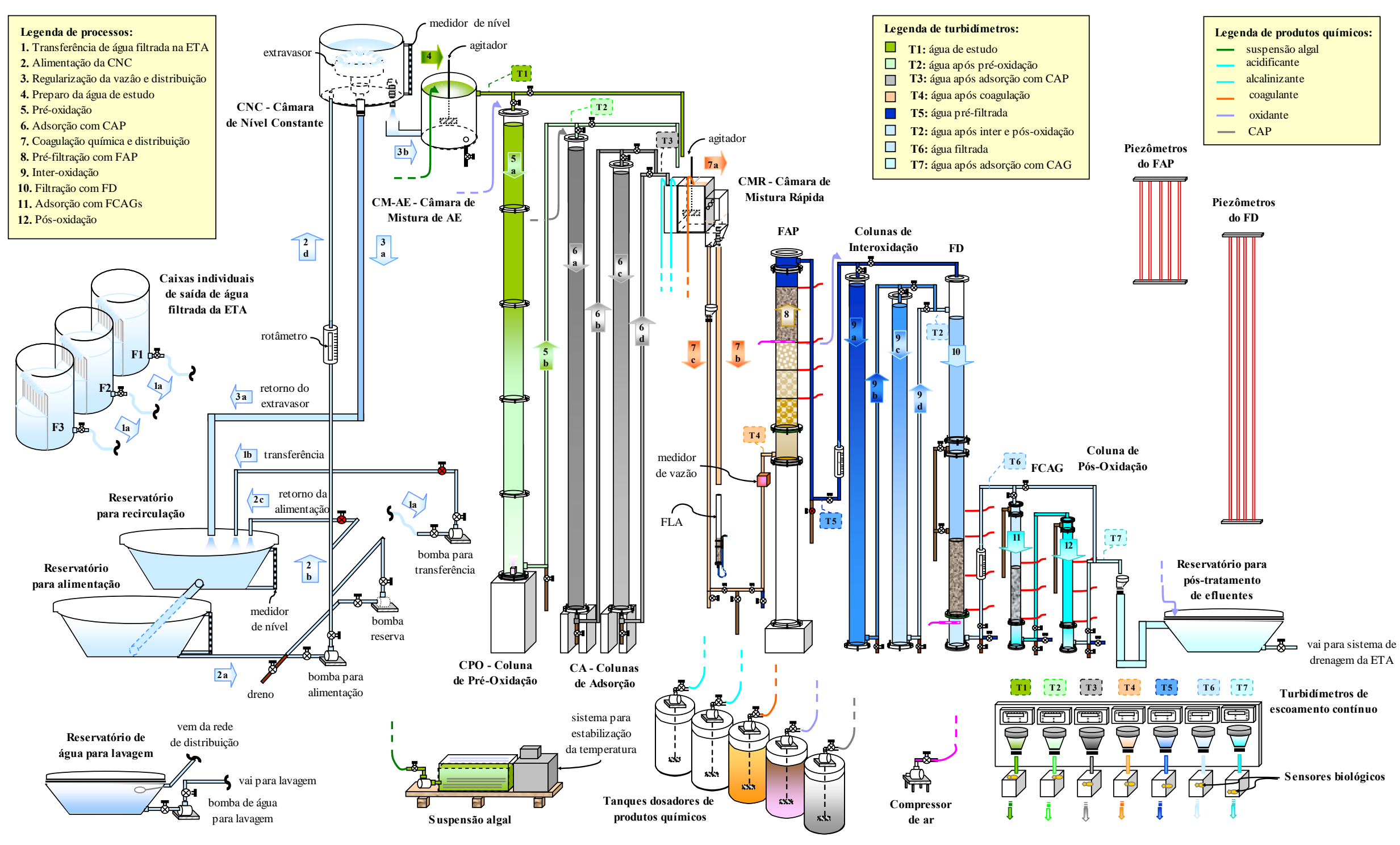

Figura 4.7.13 - Esquema geral da IP contendo as adaptações realizadas 


\subsubsection{Parâmetros de desempenho}

A operação dos vários sistemas de tratamento testados foi realizada por meio de monitoramento sistemático com freqüência horária de amostragem e análise de parâmetros de controle operacional previamente definidos. São listados a seguir os parâmetros de controle operacional adotados e suas respectivas funções.

- Vazão da AE e dos efluentes de cada processo: de forma a garantir as taxas de filtração aplicadas, tempos de contato de adsorção / oxidação preestabelecidos e dosagem de produtos químicos;

- Turbidez da AE: para detectar variações de qualidade da AE e determinar estratégias operacionais para assegurar o desempenho do sistema de tratamento;

- pH e potencial zeta da água coagulada: para controle do processo de coagulação química;

- Concentração de cloro residual nos efluentes da pré, inter e pós-cloração: para estabelecer o critério de aplicação do processo de oxidação para as situações 1 , 2 e 3 (Item 4.5);

- Perda de carga: para acompanhar a evolução da frente de impurezas no meio granular dos filtros.

Para a avaliação do desempenho dos sistemas propostos em relação à qualidade dos efluentes produzidos, com exceção do ensaio I, foi programada a realização de coletas defasadas em função do tempo de residência de cada processo, com freqüência de amostragem preestabelecida de 3 h, e análise dos seguintes parâmetros: carbono orgânico total - COT, absorvância $\lambda=254$ nm, densidade de Microcystis spp. e microcistinas - MCs.

Em virtude do estudo sobre a aplicabilidade do uso de testes de toxicidade aguda com dafinídeos (Ceriodaphnia dubia e Ceriodaphnia silvestrii) e biomonitoramento com peixes (Danio rerio) na avaliação qualitativa do desempenho dos processos empregados, foi necessária a realização de análises de parâmetros adicionais como oxigênio dissolvido, condutividade, dureza e alumínio das mesmas amostras.

Os principais parâmetros de desempenho e seus respectivos métodos de análise, pontos e freqüências de amostragem utilizados são relacionados na Tabela 4.7.3. 
Tabela 4.7.3 - Parâmetros de desempenho e seus respectivos métodos de análise, pontos e freqüências de amostragem

\begin{tabular}{|c|c|c|c|}
\hline Parâmetros & Equipamento / método & Pontos de amostragem & Frequência \\
\hline Vazão (L/h) & $\begin{array}{c}\text { Volumétrico, rotâmetro e } \\
\text { eletromagnético }\end{array}$ & $\mathrm{AD}, \mathrm{AE}, \mathrm{AC},(*)$ & $1 \mathrm{~h}$ \\
\hline Concentração residual de cloro (mg/L) & espectrofotométrico & $\begin{array}{l}\text { Eflu. PRÉ, INTER e } \\
\text { PÓS }\end{array}$ & $1 \mathrm{~h}$ \\
\hline Temperatura $\left({ }^{\circ} \mathrm{C}\right)$ & termômetro de $\mathrm{Hg}$ & $\mathrm{AE}$ & $3 \mathrm{~h}$ \\
\hline $\mathrm{pH}$ & Potenciômetro Orion / 420A & $\mathrm{AD}, \mathrm{AE}, \mathrm{AC},(*)$ & $1 \mathrm{~h}$ \\
\hline Potencial Zeta & $\begin{array}{l}\text { Medida de mobilidade eletroforética: } \\
\text { Zetamaster particle eletrophoresis } \\
\text { analyser / Malvern Instruments Ltd. }\end{array}$ & $\mathrm{AD}, \mathrm{AE}, \mathrm{AC},\left(^{*}\right)$ & $1 \mathrm{~h}$ \\
\hline Carbono orgânico total - COT (mg/L) & $\begin{array}{c}\text { TOC } 5000 \text { A; Combustão; Radiação } \\
\text { infra-vermelho: Total organic carbon } \\
\text { analyser Shimadzu / TOC } 5000 \text { A }\end{array}$ & $\mathrm{AE},(*)$ & $3 \mathrm{~h}$ \\
\hline Absorvância $\lambda=254 \mathrm{~nm}$ & Espectrofotométrico UV & $\mathrm{AE},(*)$ & $3 \mathrm{~h}$ \\
\hline Cor aparente e verdadeira $(\mathrm{uH})$ & espectrofotométrico & $\mathrm{AE}$ & $6 \mathrm{~h}$ \\
\hline Oxigênio dissolvido - OD (mg/L) & Winkler, sonda Horiba U-10 & $\mathrm{AD}, \mathrm{AE},(*)$ & $3 \mathrm{~h}$ \\
\hline Condutividade elétrica ( $\mu \mathrm{S} / \mathrm{cm})$ & sonda Horiba U-10 & $\mathrm{AD}, \mathrm{AE},(*)$ & $3 \mathrm{~h}$ \\
\hline Alcalinidade $\left(\mathrm{mgCaCO}_{3} / \mathrm{L}\right)$ & Titulação potenciométrica & $\mathrm{AE}$ & $6 / \mathrm{d}$ \\
\hline Alumínio residual (mg Al/L) & espectrofotômetro & $\mathrm{AD}, \mathrm{AE},(*)$ & 3h \\
\hline Perda de carga $(\mathrm{mm})$ & piezômetro & FA, FD & $1 \mathrm{~h}$ \\
\hline Turbidez (uT) & $\begin{array}{c}\text { Turbidímetro } \\
\text { 1720C, 1720D e 2100P }\end{array}$ & $\mathrm{AD}, \mathrm{AE}, \mathrm{AC},\left(^{*}\right)$ & $\begin{array}{c}\text { 3h, } \\
\text { contínuo }\end{array}$ \\
\hline Partículas $(1-20 \mu \mathrm{m}) / \mathrm{mL}$ & $\begin{array}{l}\text { 3000A Liquid Syringe Sample; } \\
\text { MicroCount 05 Sensor; 8000A } \\
\text { Counter }\end{array}$ & $\mathrm{AD}, \mathrm{AE},\left(^{*}\right)$ & $3 \mathrm{~h}$ \\
\hline $\begin{array}{l}\text { Subprodutos organohalogenados - } \\
\text { SPOs }(\mu \mathrm{g} / \mathrm{L})\end{array}$ & CG- DCE & $\mathrm{AD}, \mathrm{AE},(*)$ & $3 \mathrm{~h}$ \\
\hline Microcistinas - MCs ( $\mu \mathrm{g} / \mathrm{L})$ & $\begin{array}{c}\text { Imunensaio ELISA, } \\
\text { HPLC-PDA }\end{array}$ & $\mathrm{AE},(*)$ & $3 h$ \\
\hline Densidade Microcystis spp. (cel/mL) & Microscópio invertido / Uthermohl & $\mathrm{AE},(*)$ & $3 \mathrm{~h}$ \\
\hline
\end{tabular}

AD: água de diluição; AE: água de estudo, AC: água coagulada, Eflu: Efluentes; (*):PRÉ: pré-cloração, CAP: adsorção em carvão ativado em pó, FAP: filtro ascendente de pedregulho, INTER: intercloração; FD: filtro descendente; FCAG: filtro com carvão ativado granular; PÓS: pós-cloração.

A quantificação de microcistinas - MCs extracelulares foi realizada por imunoensaio ELISA de placas da Beacon Analytical Systems Inc.. A análise de MCs intracelulares foi realizada por HPLC-PDA, porém, em função da elevada remoção de células de Microcystis spp nos filtros ou do emprego de oxidantes, dependendo do ensaio, várias amostras apresentaram concentrações inferiores ao limite de detecção do método. Análises posteriores de MCs totais (intra e extracelulares), após submeter as amostras ao processo de congelamento e descongelamento (3 vezes), por imunoensaio ELISA, confirmaram este fato, tendo resultado em concentrações próximas às obtidas para MCs extracelulares.

Para avaliação da formação de subprodutos organohalogenados da oxidação - SPOs, foi utilizada, em geral, a amostragem da $3^{\text {a }}$ hora de funcionamento. Essas amostras foram ajustadas para $\mathrm{pH}=7,0$ por meio de adição de solução tampão fosfato, submetidas à 
dosagem de $2 \mathrm{mg} / \mathrm{L}$ de cloro e incubadas em frascos âmbar fechados com tampa de pressão e tampa roscável em banho termostatizado a $25^{\circ} \mathrm{C} \pm 0,2$ por $24 \mathrm{~h}$.

\subsubsection{Testes de toxicidade aguda com dafinídeos (Ceriodaphnia dubia e Ceriodaphnia silvestrii) e biomonitoramento com peixes (Danio rerio)}

\subsubsection{Cultivo de Ceriodaphnia spp}

Ceriodaphnia dubia Richard é oriunda de regiões temperadas e Ceriodaphnia silvestrii Daday, espécie nativa (Figura 4.7.14). Esses dafinídeos foram cultivados e mantidos no Laboratório de Cultivo e Ecotoxicologia do Departamento de Ecologia e Biologia Evolutiva da Universidade Federal de São Carlos -DEBE-UFSCar.

Os organismos foram cultivados, seguindo normas padronizadas (ABNT, 2005), em água reconstituída (com dureza total de 40 a 48 mg $\mathrm{CaCO}_{3} / \mathrm{L}$, pH 7,0 - 7,6) em béquer de 2 $\mathrm{L}$ e mantidos em incubadora a $25^{\circ} \mathrm{C}$ e fotoperíodo de $16 / 8 \mathrm{~h}$ claro/escuro. A renovação da água de cultivo das culturas-estoque foi realizada três vezes por semana, com auxílio de pipetas de diâmetro adequado e ponta arredondada para não danificar os organismos, mantendo-se cerca de 120 indivíduos por béquer, a fim de controlar a densidade e evitar interferências causadas por superpopulação.

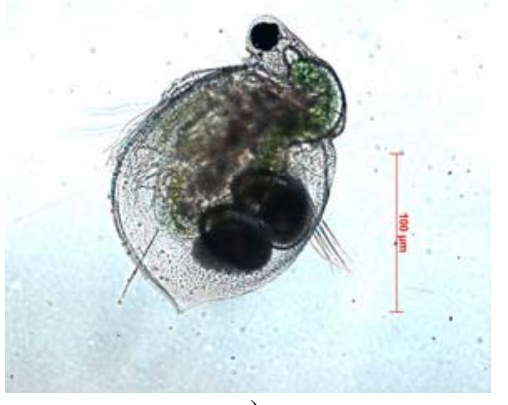

a)

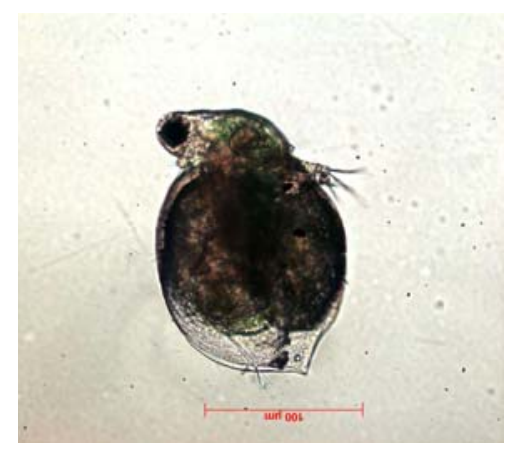

b)

Figura 4.7.14 - Fêmeas de (a) Ceriodaphnia dubia Richard e (b) e Ceriodaphnia silvestrii Daday. (Fotos: D.T.Okumura).

Os organismos foram alimentados com $1 \mathrm{~mL} / \mathrm{L}$ de uma mistura de leveduras (fermento biológico seco Fleishmann ${ }^{\circledR}$ dissolvido em água destilada) e ração de peixe fermentada $\left(\right.$ Tetramin $\left.^{\circledR}\right)$ na proporção de 1:1, bem como com suspensão da alga clorofícea Pseudokirchneriella subcapitata (anteriormente conhecida como Selenastrum capricornutum), em fase exponencial de crescimento, cultivada em meio CHU-12, sob 
iluminação e aeração constantes (Figura 4.7.15). Para eliminar nutrientes do meio não aproveitados pela alga ou metabólitos da mesma, o sobrenadante foi descartado após decantação em geladeira e o precipitado, ressuspendido com água de cultivo dos dafinídeos.

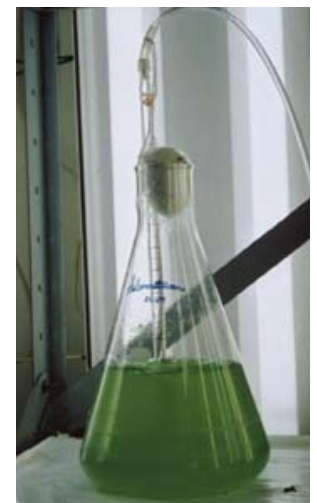

a)

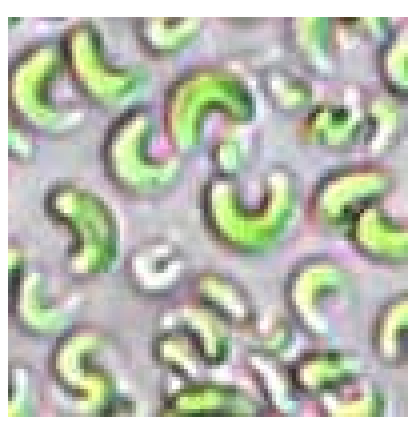

b)

Figura 4.7.15 - a) Cultivo da alga cloroífcea Pseudokirchneriella subcapitata e, em detalhe, b) vista sob microscópio óptico. (Fotos: R.A.Takenaka e R.M.B.Sotero-Santos).

A densidade de células da suspensão algácea foi, então, determinada por meio de contagem em Câmara de Neubauer, sob microscópio óptico. A partir desse dado, calculou-se o volume a ser adicionado às culturas-estoque, para que a concentração fornecida fosse de 1 $\times 10^{5}$ céls $/ \mathrm{mL}$.

O cultivo de Daphnia similis seguiu os mesmos procedimentos do cultivo de Ceriodaphnia spp, diferindo apenas na concentração de suspensão algácea $1 \times 10^{6}$ céls/mL (ABNT, 2004a).

\subsubsection{Manutenção de Danio rerio (Teleostei, Cyprinidae)}

Danio rerio Hamilton-Buchanan é originário da Índia e tem sido utilizado mundialmente em estudos ecotoxicológicos (DOMINGURES; BERTOLETTI, 2006). Espécimes adultos de D. rerio foram adquiridos em lojas especializadas. A aclimatação e a manutenção dos organismos em laboratório seguiram procedimentos descritos em normas padronizadas (ABNT, 2004b). Os peixes foram mantidos em aquários (40 e 60 L) com água da torneira, mantendo-se a relação de $1 \mathrm{~g}$ de organismo por litro de água, e alimentados com ração TETRAMIN ${ }^{\circledR}$, duas vezes ao dia. A água da torneira foi reconstituída com soluções específicas para apresentar dureza total de 40 a 50 mg $\mathrm{CaCO}_{3} / \mathrm{L}$ e pH de 6,5 a 7,5. 


\subsubsection{Testes de toxicidade aguda e biomonitoramento}

Em função de resultados prévios de bancada, foram adotados procedimentos específicos com adição de soluções de tiosulfato de sódio e de EDTA para neutralizar os efeitos do cloro e do alumínio, respectivamente, nesses organismos.

Para todos os dafinídeos, cinco neonatas $(<24$ h) foram colocadas, em três réplicas, em tubos de ensaio contendo $10 \mathrm{~mL}$ das amostras de água, sem diluição, oriundas dos ensaios de bancada e da instalação piloto. As amostras de água foram mantidas sob refrigeração até o início dos testes. Durante o período de exposição (48 h), os organismos foram mantidos em incubadora a $25^{\circ} \mathrm{C}$, sem iluminação e sem alimentação. Foram medidos $\mathrm{pH}$, condutividade e dureza no início e ao final dos testes. Após 48h, registrou-se o número de indivíduos imóveis ou mortos para cada amostra. Quando a porcentagem de organismos imóveis no controle excedeu 10\%, o resultado não foi considerado válido (ABNT, 2004a).

Para o biomonitoramento, os peixes foram transportados até a instalação piloto - IP em sacos plásticos, separados aleatoriamente em lotes de 15 ou 20 organismos e colocados nos aquários previamente delimitados em zonas (Figrua 4.7.16). Cada aquário era alimentado continuamente pelos efluentes dos processos empregados mantendo-se o volume de $15 \mathrm{~L}$, com tempo de residência de $1 \mathrm{~h}$. Os peixes não foram alimentados $24 \mathrm{~h}$ antes nem durante os ensaios. Foram realizadas observações diretas de respostas comportamentais de locomoção dos organismos para cada processo de tratamento nos ensaios I a VI em instalação piloto - IP.

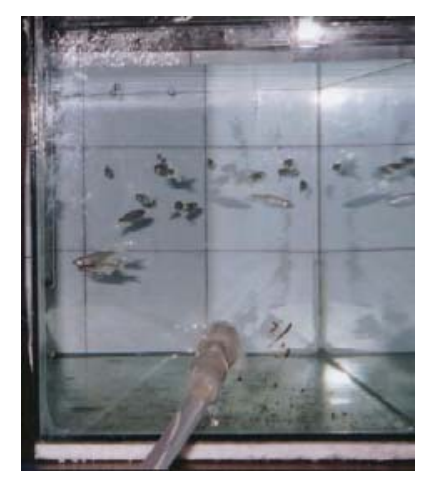

a)

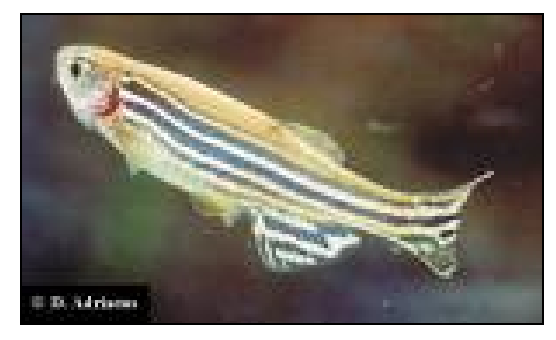

b)

Figura 4.7.16 - a) Biomonitoramento de Danio rerio nos em ensaios na instalação piloto - IP e b) Danio rerio (Teleostei, Cyprinidae) (Foto da Internet) 


\section{RESULTADOS E DISCUSSÃO}

Neste capítulo são apresentados os resultados obtidos e as discussões contendo as considerações pertinentes a cada meta da investigação experimental. Resultados complementares referentes aos parâmetros de controle operacional e de desempenho e testes ecotóxicológicos com microcrustáceos dos ensaios realizados em instalação piloto - fases 2 e 3 são apresentados no Anexo E.

\subsection{META 1: DESENVOLVIMENTO DE CULTURAS}

Conforme já relatado, para avaliação dos diferentes processos de tratamento, optouse pelo desenvolvimento de culturas, em micro, meso e macrocosmos, de cepa toxigênica de Microcystis spp. NPLJ-4, de forma a que as características resultantes fossem representativas de mananciais eutrofizados destinados ao abastecimento.

O estabelecimento das culturas de Microcystis spp. NPLJ-4 em microcosmos foi realizado em meados de junho de 2003 e desde então, vem sendo mantidas no laboratório de apoio do Departamento de Hidráulica e Saneamento da Escola de Engenharia de São Carlos da Universidade de São Paulo - SHS-EESC-USP, adaptado para essa pesquisa (Figura 5.1.1).

Em geral, mantendo-se as condições de cultivo descritas no Item 4.1.1 e a proporção de inóculo : meio ASM-1 (1 : 9), a inoculação das culturas de Microcystis spp. em microcosmos foi realizada quinzenalmente. A densidade de Microcystis spp. após 15 dias, quando a cultura encontrava-se no final da fase exponencial, foi da ordem de $10^{7}$ cél//mL, e a predominância desta, em relação aos demais organismos fitoplanctônicos, mantida superior a 99 \% por meio de monitoramento mensal de contaminação. Não foi constatada a formação de colônias nas culturas mantidas sob aeração constante, havendo predominância de células com tamanhos entre 3 e $7 \mu \mathrm{m}$ (Figura 5.1.2). 

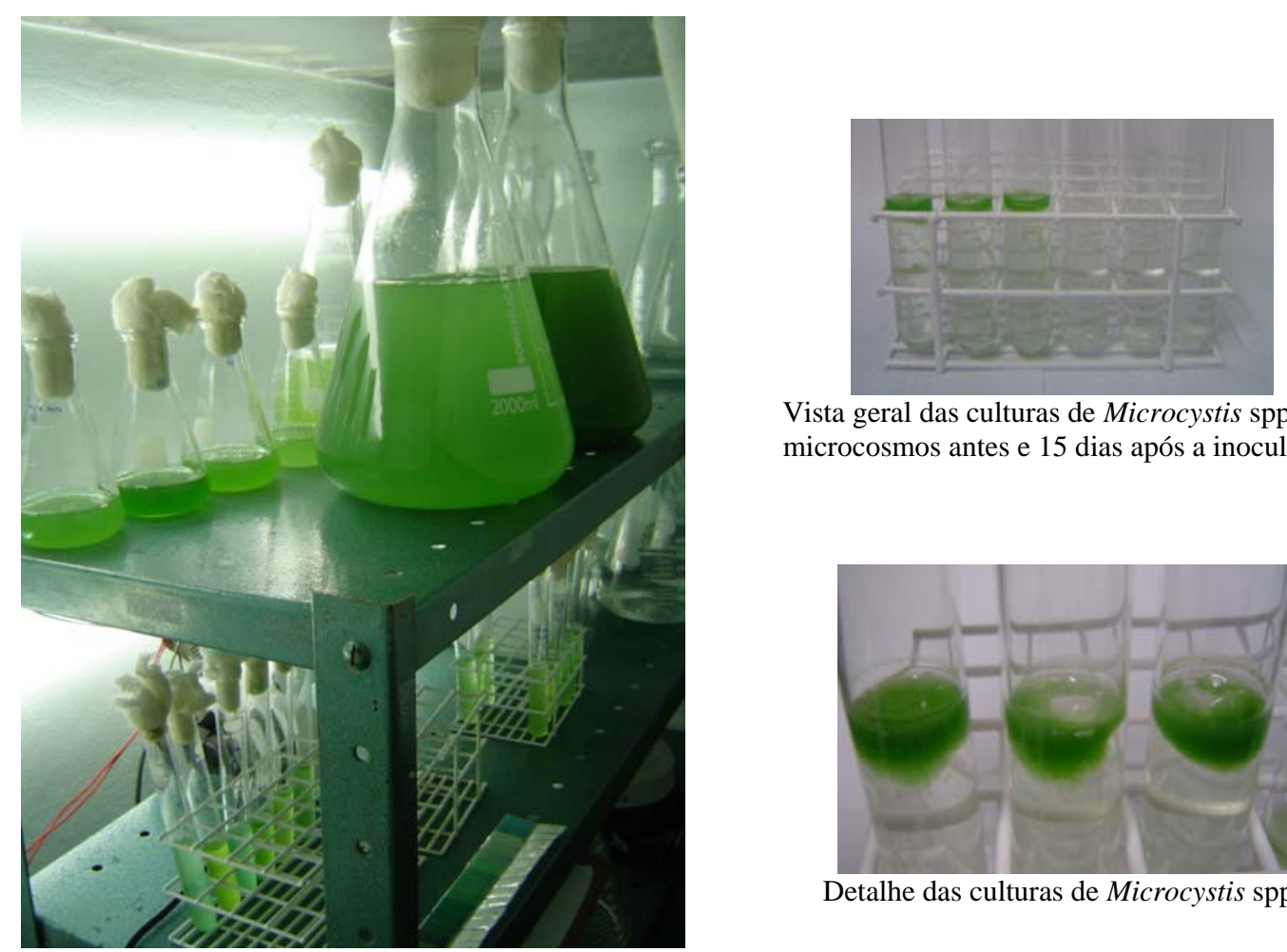

Vista geral das culturas de Microcystis spp. em microcosmos antes e 15 dias após a inoculação

Figura 5.1.1 - Vista geral do espaço reservado para as culturas em microcosmos e detalhes do aspecto das culturas de Microcystis spp. antes e 15 dias após a inoculação

A agitação manual diária das culturas em erlenmeyers favoreceu, em alguns casos, a formação de colônias com até $100 \mu$ m (Figura 5.1.3) e de bainha de mucilagem, conforme resultados do monitoramento de contaminação da Tabela 5.1.1.

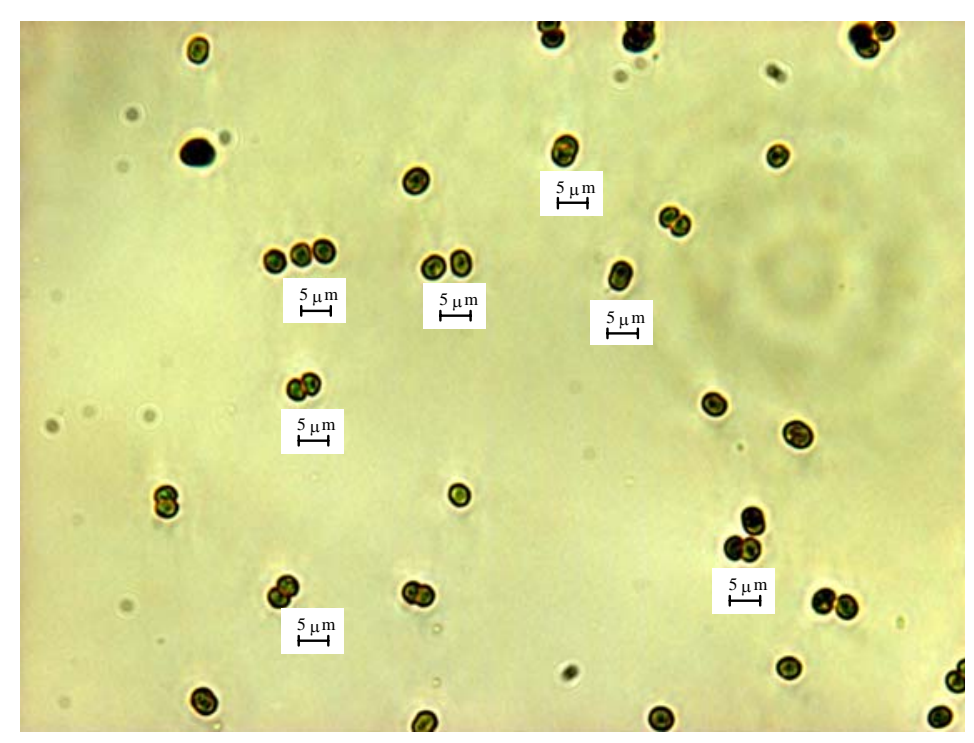

Figura 5.1.2 - Imagem da cultura de Microcystis spp NPLJ4 (aumento 100x) mantida sob aeração 
Tabela 5.1.1 - Exemplo do monitoramento de contaminação das culturas em microcosmos (erlenmeyers de $250 \mathrm{~mL}$ )

\begin{tabular}{c|c|c|c|c|c|c}
\hline \multirow{2}{*}{ Amostra } & \multicolumn{2}{|c|}{ NPLJ-4 (erlenmeyer 1) } & \multicolumn{2}{c|}{ NPLJ-4 (erlenmeyer 2) } & \multicolumn{2}{c}{ NPLJ-4 (erlenmeyer 3) } \\
\hline Microcystis spp & cel/mL & Abund. (\%) & cel/mL & Abund. (\%) & cel/mL & Abund. (\%) \\
\hline Células & $6,58, \mathrm{E}+06$ & 100,0 & $3,92, \mathrm{E}+06$ & 99,7 & $6,86, \mathrm{E}+05$ & 99,3 \\
\hline $\begin{array}{c}\text { Colonias } \\
\text { Média de } \\
\text { Cel/Colônia }\end{array}$ & $0,00, \mathrm{E}+00$ & 0,0 & $1,14, \mathrm{E}+04$ & 0,3 & $4,88, \mathrm{E}+03$ & 0,7 \\
\hline Sub-Total & 0 & & 9 & & 8 & \\
\hline Outras & $0,00, \mathrm{E}+00$ & 0,0 & $8,13, \mathrm{E}+03$ & 0,2 & $1,63, \mathrm{E}+03$ & 0,2 \\
\hline Total Geral & $6,58, \mathrm{E}+06$ & & $4,03, \mathrm{E}+06$ & & $7,28, \mathrm{E}+05$ & \\
\hline
\end{tabular}

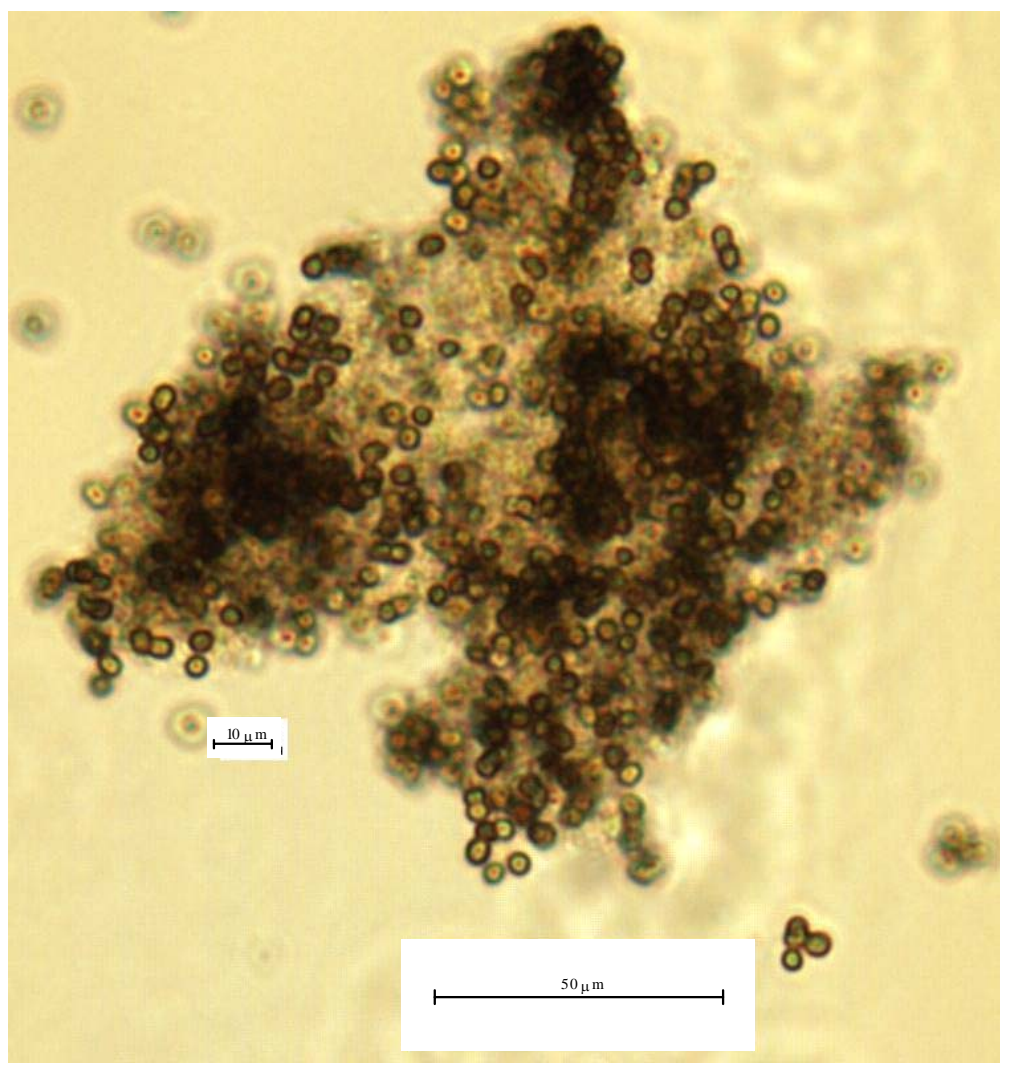

Figura 5.1.3 - Imagem da cultura de Microcystis spp. (aumento 100x) submetida à agitação manual diária

Em geral, a inoculação das culturas de Microcystis spp. em meso e macrocosmos foram realizadas em intervalos mais longos, da ordem de 30 dias, possivelmente, devido à fase de adaptação requerida pelas condições de cultivo. A predominância de Microcystis spp. em relação aos demais organismos fitoplanctônicos foi mantida superior a 95 \%, conforme exemplos de resultados típicos do monitoramento de contaminação das culturas em meso e macrocosmos (Tabelas 5.1.2 e 5.1.3). 
Tabela 5.1.2 - Exemplo do monitoramento de contaminação da cultura em mesocosmos

\begin{tabular}{c|c|c}
\hline Amostra & NPLJ-4 / Aquário / 26 dias após inoculação \\
\hline Microcystis spp & cel/mL & Abundância (\%) \\
\hline Células & $3,47, \mathrm{E}+06$ & 99,1 \\
\hline Colônias & $0,00, \mathrm{E}+00$ & 0,0 \\
\hline Outras & $3,25, \mathrm{E}+04$ & 0,9 \\
\hline Sub-Total & $3,47, \mathrm{E}+06$ & 99,1 \\
\hline
\end{tabular}

Tabela 5.1.3 - Exemplo do monitoramento de contaminação da cultura em macrocosmos

\begin{tabular}{c|c|c}
\hline \multirow{2}{*}{ Amostra } & NPLJ-4 / Aquário 10 dias após inoculação \\
\hline Microcystis spp & cel/mL & Abundância (\%) \\
\hline Células & $9,21 \mathrm{E}+05$ & 99,8 \\
\hline Colônias & $0,00 \mathrm{E}+00$ & 0 \\
\hline Outras & $2,17 \mathrm{E}+03$ & 0,2 \\
\hline Sub-Total & $9,21 \mathrm{E}+05$ & 99,8 \\
\hline
\end{tabular}

A manutenção de aeração constante nessas culturas resultou na eliminação das formas coloniais, as quais são mais facilmente removidas nos processos de tratamento, devido, principalmente, às suas características físicas. Assim, a água de estudo utilizada nos experimentos foi preparada para a condição desfavorável de tratamento, com emprego de culturas de células individualizadas, o que possibilitou por outro lado maior precisão na contagem para avaliação da eficiência obtida na remoção de células de Microcystis spp..

O desenvolvimento de culturas de cepa toxigênica de Microcystis spp. sob condições controladas em micro, meso e macrocosmos, possibilitou o controle das características das AEs nos experimentos realizados nas fases 1 e 2, especialmente com relação à densidade de células de Microcystis spp. e concentração de MCs, favorecendo assim, a avaliação comparativa entre as eficiências obtidas nos variados processos de tratamento pesquisados.

\subsection{META 2: CARACTERIZAÇÃO QUÍMICA E TOXICOLÓGICA DE SUBPRODUTOS}

\subsubsection{Caracterização química da principal microcistina produzida pela cepa NPLJ-4}

A estrutura geral das microcistinas é Ciclo (D-alanina ${ }^{1}-\mathrm{X}^{2}-\mathrm{D}-\mathrm{MeAsp}^{3}-\mathrm{Z}^{4}-$ Adda $^{5}$ - D-glutamato ${ }^{6}-$ Mdha $^{7}$ ) (Figura 5.2.1), onde X e Z representam os dois L aminoácidos variáveis, D-MeAsp é o D-eritro- $\beta$-metil ácido aspártico e Mdha é a N-metildeidroalanina. O 
aminoácido menos comum é o Adda, (2S,3S,8S,9S)-3amino-9-metoxi-2,6,8-trimetil-10fenil-4,6-ácido decadienóico. Variações estruturais nos sete aminoácidos, destacando-se a ocorrência de substituições dos L aminoácidos das posições 2 e 4 e de desmetilações dos aminoácidos das posições 3 e ou 7, têm sido reportados na literatura, para designar os mais de 60 tipos de MCs.

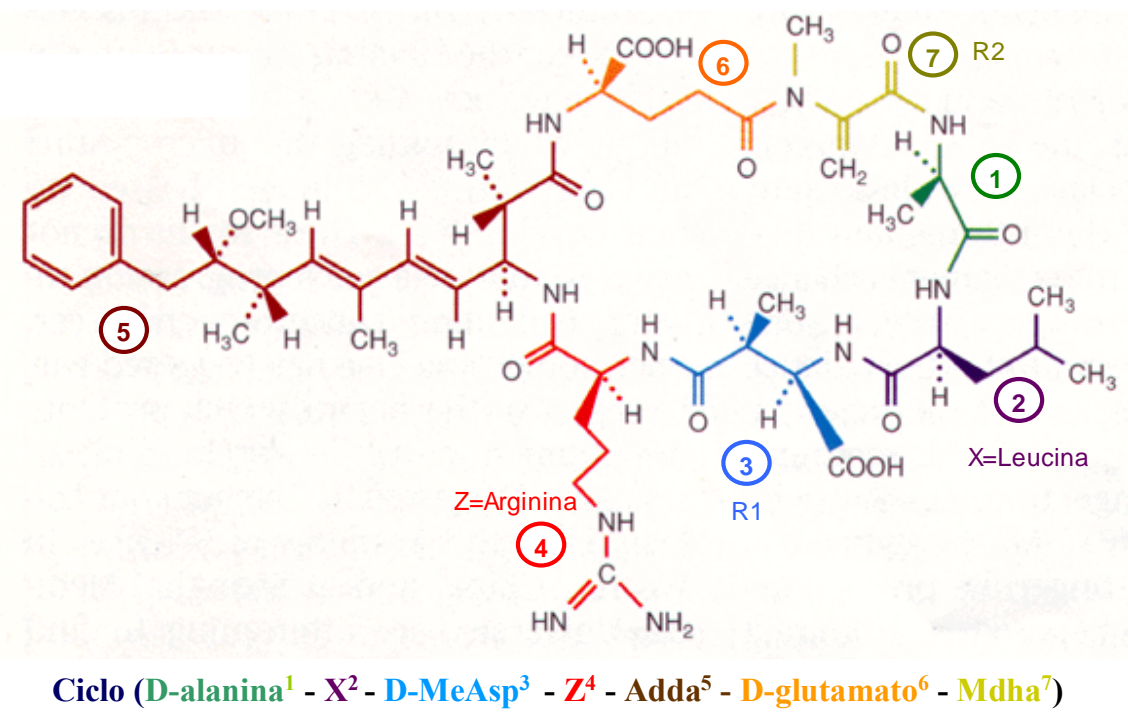

Figura 5.2.1 - Estrutura química da microcistina-LR (Z e X representam os dois L-aminoácidos variáveis e R1 e R2 são os locais de possíveis metilações. FONTE: adaptado de CARMICHAEL (2006)

As análises por HPLC-PDA permitiram concluir que embora os valores de índice de similaridade obtidos entre os espectros de UV a $238 \mathrm{~nm}$ dos picos da principal microcistina MC dos extratos semipurificados e do padrão de MC-LR (Sigma M2912 Lot 31K 1647) tenham resultados elevados, com valores de até 0,9999, os tempos de retenção dos picos correspondentes às MCs dos extratos variaram entre 9,8 e 10,4 min e foram bem diferentes dos tempos de retenção obtidos pelo pico do padrão de MC -LR, entre 7,3 a 7,8 min (Figura 5.2.2). 

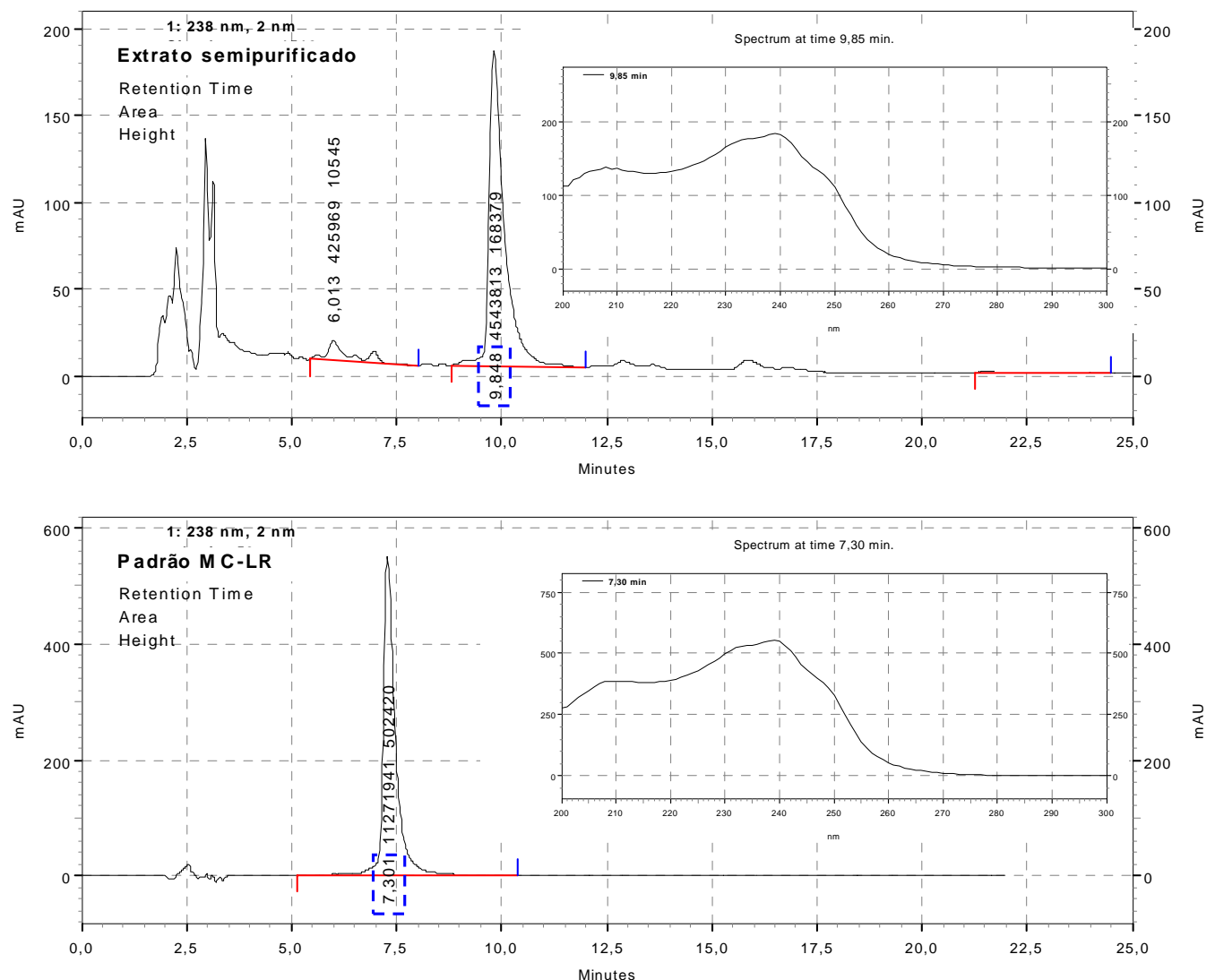

Figura 5.2.2 - Cromatogramas e espectros de UV a $238 \mathrm{~nm}$ do extrato semipurificado e do padrão de MC-LR

A análise posterior do extrato por MS-ESI no modo positivo revelou um espectro com $[\mathrm{M}+\mathrm{H}]^{+}$a $m / \mathrm{z} 1037,8$, indicando tratar-se de outro tipo de MC, possivelmente, alguma variante da MC -LR como a [D-Leu ${ }^{1}$ ]MC-LR encontrada por MATTHIENSEN et. al., 2000, ou outra desconhecida, pois o espectro do padrão de MC-LR apresentou [M+H $]^{+}$a m/z 995,7 (Figura 5.2.3).

Desta forma, pôde-se constatar que embora a principal MC presente no extrato e a MC-LR do padrão sejam quimicamente diferentes, os grupos cromóforos parecem ser muito similares ou coincidentes, o que explica os elevados índices de similaridade obtidos. 


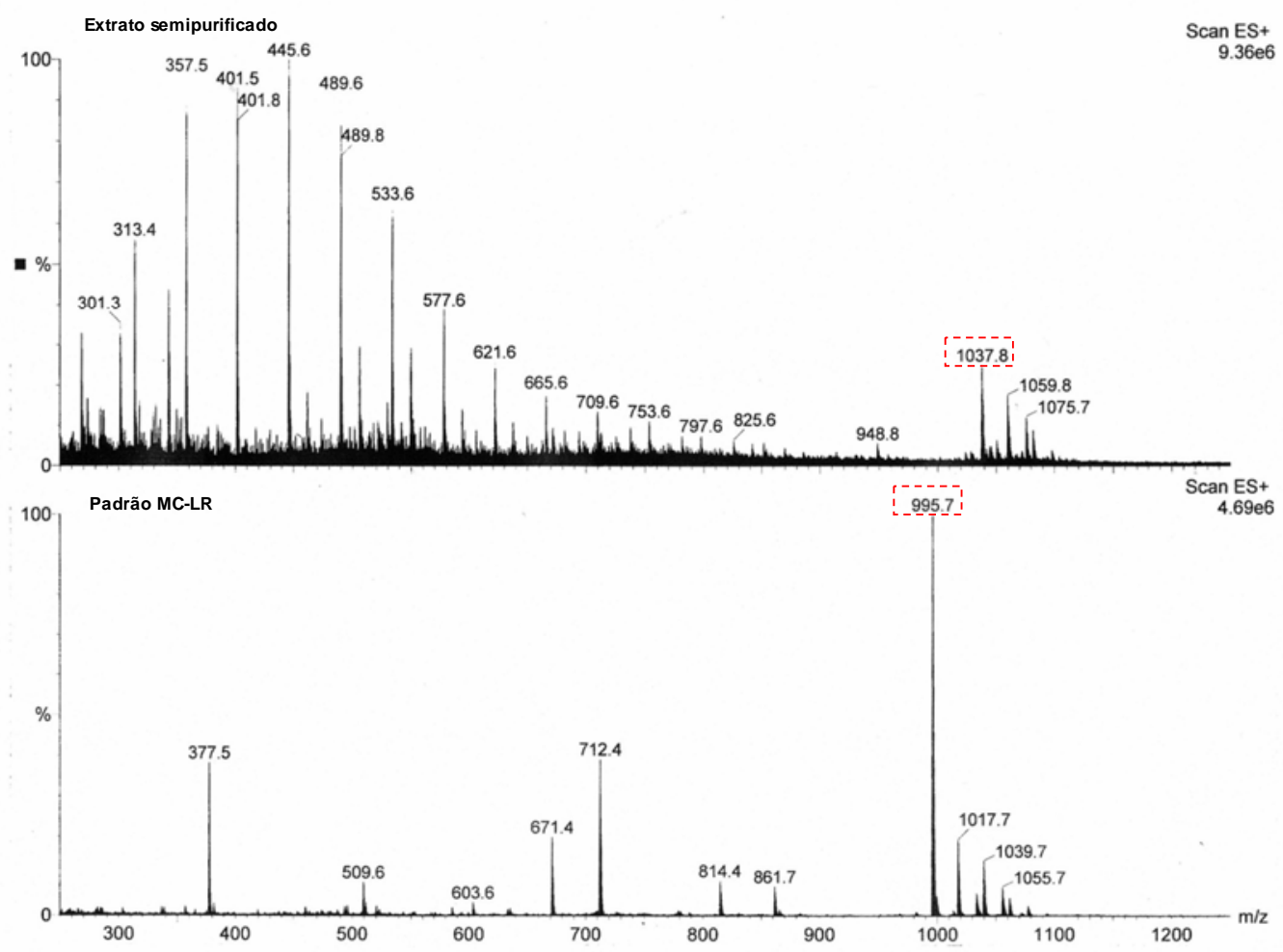

Figura 5.2.3 - Espectros de massas do extrato semipurificado e do padrão de MC-LR

Além da especiação química da molécula poder interferir na quantificação dos vários tipos de microcistinas - MCs, deve-se considerar que pequenas variações na estrutura podem levar a diferenças pronunciadas na toxicidade. Os valores da DL50 (i.p.) para camundongos de 60 diferentes MCs são reportados em SIVONEN E JONES (1999) e variaram em média entre 50 e $300 \mu \mathrm{g} / \mathrm{kg}$ de peso corpóreo. Valores reportados de DL50 (i.p.) foram de 250 e $180 \mu \mathrm{g} / \mathrm{kg}$ para [D-Asp ${ }^{3}$ MC-RR e [Dha $\left.{ }^{7}\right]$ MC-RR, respectivamente, mas de $600 \mu \mathrm{g} / \mathrm{kg}$ para MC-RR. Em contraste, a [D-Asp $\left.{ }^{3}\right]$ MC-LR é uma variante com menor toxicidade (DL50 entre 90 e $300 \mu \mathrm{g} / \mathrm{kg}$ ) do que MC-LR (DL50 entre 25 e $150 \mu \mathrm{g} / \mathrm{kg}$ ). Nesse sentido foram realizados testes de toxicidade aguda com camundongos a fim de avaliar o efeito toxicológico das microcistinas produzidas pela cepa NPLJ-4.

\subsubsection{Caracterização toxicológica da cepa NPLJ-4}

Após processo de concentração, as culturas toxigênica NPLJ-4 e não toxigênica, apresentaram densidades de $3,8 \times 10^{7} \mathrm{cel} / \mathrm{mL}$ e de $1,1 \times 10^{7} \mathrm{cel} / \mathrm{mL}$, respectivamente, e abundância relativa de 100 \% em relação a outros organismos.

Visando o enquadramento da cepa de acordo com a classificação sugerida por LAWTON et. al. (1994b) (Tabela 5.2.4), o teste T1 foi realizado com dosagens de 125, 250, 
500, e $1000 \mathrm{mg} / \mathrm{kg}$ p.c. (mg de material seco / kg de peso médio corpóreo dos camundongos), para a cepa toxigênica NPLJ-4, e com a dosagem mais elevada (de 1000 mg/kg p.c.) para a cepa não toxigênica utilizada como controle tipo A. Além deste controle, foi estabelecido o controle tipo B, realizado com aplicação de $1 \mathrm{~mL}$ de solução salina. A Figura 5.2.4 ilustra os testes realizados, com os principais resultados assinalados.

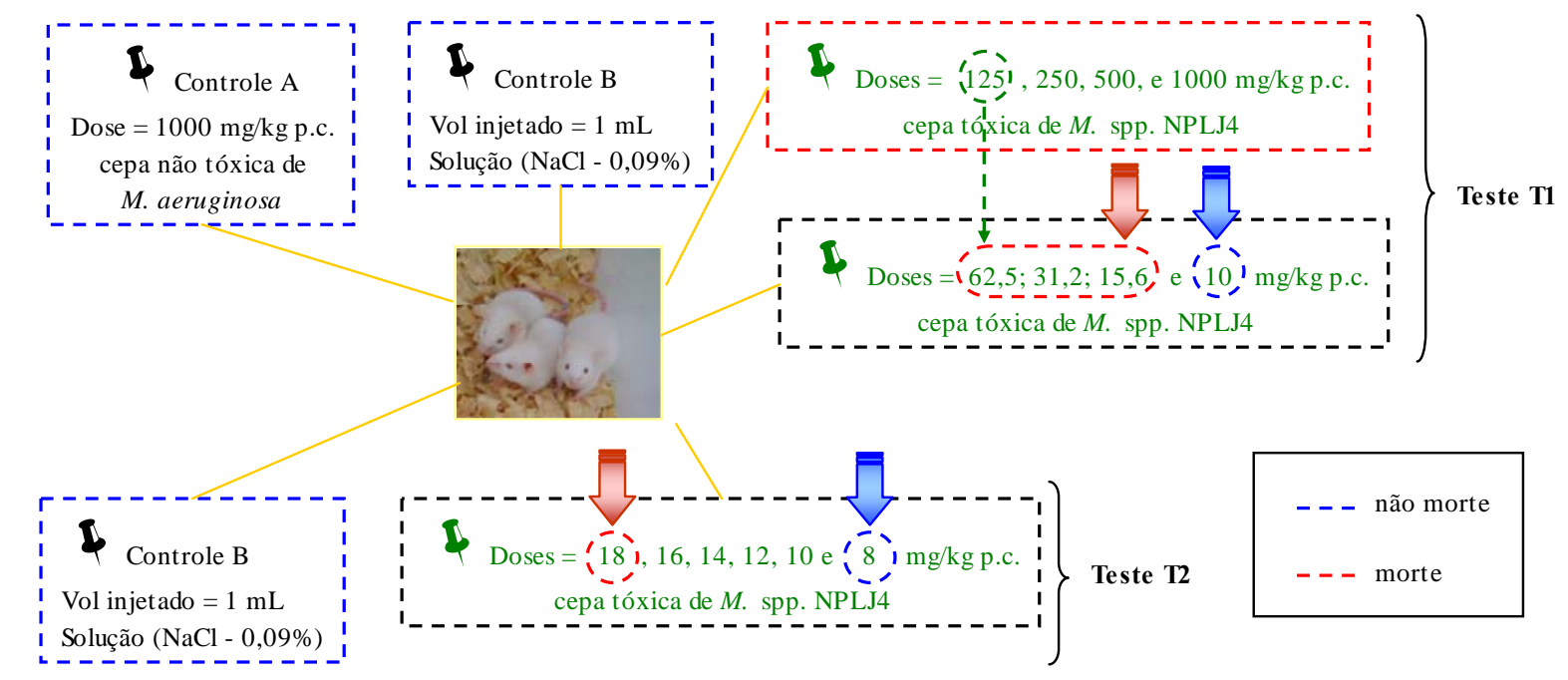

Figura 5.2.4 - Planejamento experimental realizado para avaliação da toxicidade da cepa NPLJ-4

Para as dosagens de extrato da cepa NPLJ-4 aplicadas, todos os camundongos morreram em menos de 1 h e manifestaram efeitos comumente descritos em intoxicações por hepatotoxinas (Falconer (1991) e Carmichael (1992)), como baixa mobilidade, fotofobia e prostração logo nos primeiros 15 minutos e, posteriormente, perda de brilho nos olhos e inchaço da região abdominal (Figura 5.2.6).

As microcistinas - MCs consumidas e presentes no intestino delgado são levados, através do mecanismo de transporte da bile, para o fígado, onde são absorvidos. As MCs causam a inibição bioquímica das proteínas fosfatases tipo 1 e 2A, o que afeta a manutenção das proteínas do citoesqueleto, resultando na desorganização da estrutura dos hepatócitos e como conseqüência, o fígado perde sua arquitetura e desenvolve graves lesões internas (Figura 5.2.5) (Carmichael, 1994). A perda de contato entre as células cria espaços internos que são preenchidos pelo sangue que passa a fluir dos capilares para esses locais, provocando acúmulo de sangue neste órgão e inchaço da região abdominal, condição esta que pôde ser observada na maioria dos casos de cobaias que tiveram a morte em poucas horas dos ensaios realizados. 

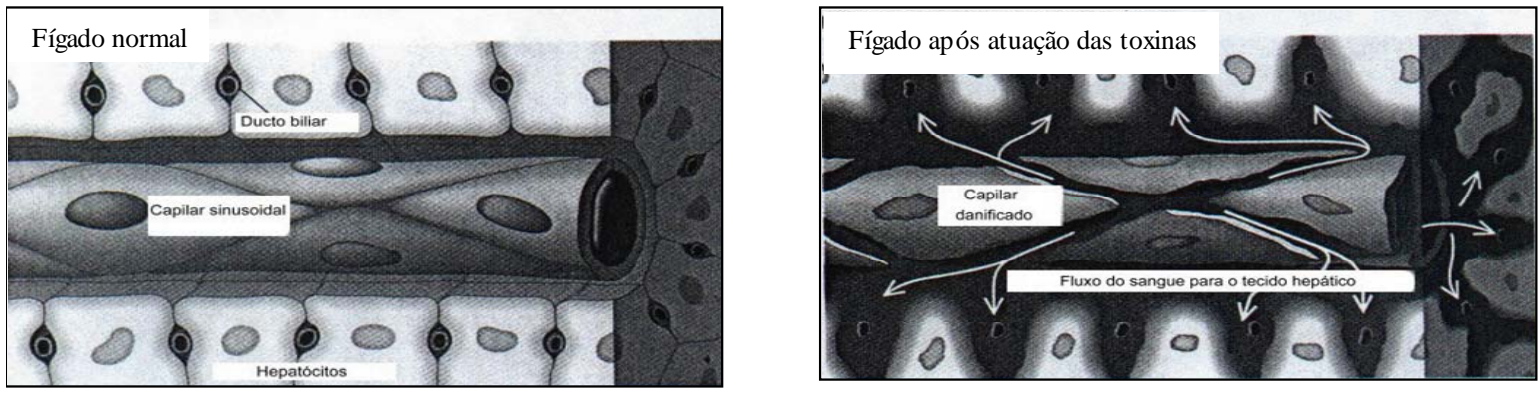

Figura 5.2.5 - Hepatócitos e capilares sinusoidais antes e após a atuação de hepatotoxinas. FONTE: adaptado de CARMICHAEL (1994)

O protocolo da CETESB (1993) recomenda que, com ocorrência de morte, o fígado deve ser retirado e pesado, sendo que um valor elevado (superior a 7 \%) da relação entre o peso do fígado e o peso corporal é considerado como indicador de hepatotoxicidade. Porém, não foi possível a realização dessa etapa na avaliação apresentada.
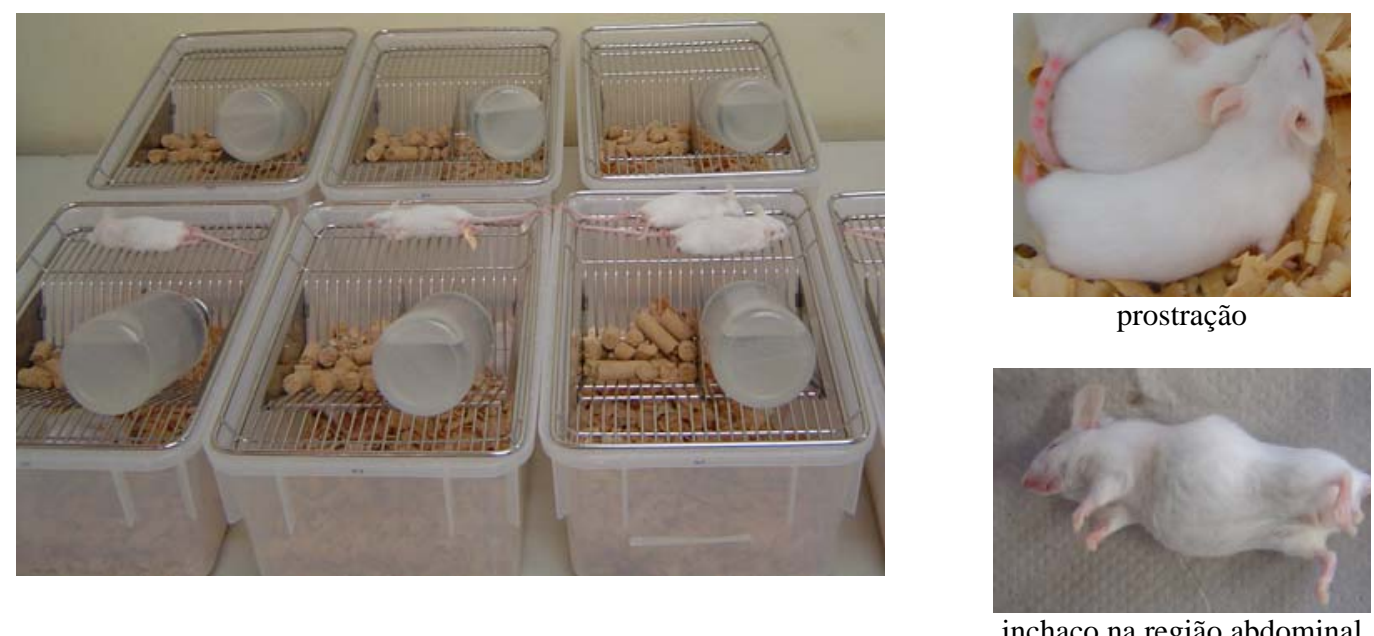

Figura 5.2.6 - Vista geral dos camundongos durante e após o teste

Em função dos resultados obtidos foram preparadas, logo em seguida, diluições do extrato de $125 \mathrm{mg} / \mathrm{kg}$ p.c. e novo extrato para dosagem de $10 \mathrm{mg} / \mathrm{kg}$ p.c., de forma a possibilitar a continuidade do teste com as dosagens de 62,5, 31,25, 15,625 e $10 \mathrm{mg} / \mathrm{kg}$ p.c. (mg de material seco / kg de peso médio corpóreo dos camundongos). Como o peso médio dos camundongos selecionados para essas dosagens diferiu do peso médio considerado na preparação do extrato de $125 \mathrm{mg} / \mathrm{kg}$ p.c., aplicou-se um fator de correção no volume a ser injetado para cada dose. Os resultados de interesse obtidos no teste T1 são apresentados na Tabela 5.2.1. 


\begin{tabular}{|c|c|c|c|c|c|c|c|}
\hline \multirow{3}{*}{ Tipo extrato } & \multicolumn{7}{|c|}{ Tabela 5.2.1 - Resultados do Teste T1 com camundongos } \\
\hline & \multirow{2}{*}{$\begin{array}{l}\text { Dose extrato }^{(*)} \\
\text { (mg/kg p.c.) }\end{array}$} & \multirow{2}{*}{$\begin{array}{c}\text { Peso do } \\
\text { animal (g) }\end{array}$} & \multirow{2}{*}{$\begin{array}{l}\text { Peso } \\
\text { médio } \\
(\mathrm{g})\end{array}$} & \multirow{2}{*}{$\begin{array}{l}\text { Desvio } \\
\text { padrão }\end{array}$} & \multicolumn{3}{|c|}{ Hora de $(\mathrm{h})$} \\
\hline & & & & & injeção & morte & vida após injeção \\
\hline \multirow{3}{*}{$\begin{array}{l}\text { Controle A } \\
\text { cepa não } \\
\text { toxigênica }\end{array}$} & \multirow{3}{*}{1000} & 20,78 & \multirow{3}{*}{20,4} & \multirow{3}{*}{0,512} & $17: 33$ & - & $24: 00$ \\
\hline & & 20,61 & & & $17: 35$ & - & $24: 00$ \\
\hline & & 19,82 & & & $17: 37$ & - & $24: 00$ \\
\hline \multirow{3}{*}{$\begin{array}{c}\text { Controle B } \\
\mathrm{NaCl} \text { 0,09\% }\end{array}$} & \multirow{3}{*}{0} & 24,58 & \multirow{3}{*}{21,8} & \multirow{3}{*}{4,643} & 18:15 & - & $24: 00$ \\
\hline & & 24,38 & & & 18:16 & - & $24: 00$ \\
\hline & & 16,44 & & & $18: 17$ & - & $24: 00$ \\
\hline \multirow{3}{*}{$\begin{array}{c}\text { Cepa } \\
\text { toxigênica } \\
\text { NPLJ-4 }\end{array}$} & \multirow{3}{*}{10} & 22,78 & \multirow{3}{*}{22,0} & \multirow{3}{*}{0,775} & $17: 52$ & - & $24: 00$ \\
\hline & & 21,99 & & & $17: 54$ & - & 24:00 \\
\hline & & 21,23 & & & $17: 56$ & - & $24: 00$ \\
\hline \multirow{3}{*}{$\begin{array}{c}\text { Cepa } \\
\text { toxigênica } \\
\text { NPLJ-4 }\end{array}$} & \multirow{3}{*}{15,625} & 21,18 & \multirow{3}{*}{21,0} & \multirow{3}{*}{0,197} & $17: 42$ & 22:10 & 04:28 \\
\hline & & 21,08 & & & $17: 45$ & 19:15 & 01:30 \\
\hline & & 20,8 & & & $17: 47$ & $19: 45$ & $01: 58$ \\
\hline
\end{tabular}

${ }^{(*)}$ : mg de material seco / kg de peso médio corpóreo dos camundongos

Os camundongos do controle A, realizado com dosagem de $1000 \mathrm{mg} / \mathrm{kg}$ p.c. de extrato da cepa não toxigênica ficaram imóveis após as injeções intraperitoniais mas começaram a apresentar sinais de restabelecimento após cerca de $5 \mathrm{~h}$.

A curva de calibração construída para análise de microcistinas - MCs apresentou correlação (\%Bo e concentração de MCs) $\mathrm{R}^{2}=0,9913$ e foi devidamente validada com o emprego de padrão externo com concentração previamente conhecida, apresentando porcentagem de recuperação de 118 \% (80 a 130 \% - faixa estabelecida pelo fabricante para validação da análise). As análises apresentaram valores de coeficiente de variação relativa máxima de 8,3 \%. Na Figura 5.2.7 são apresentadas as concentrações de microcistinas - MCs totais $(\mu \mathrm{g} / \mathrm{L})$ dos extratos analisados por imunoensaio ELISA e as correspondentes dosagens de MCs totais ( $\mu \mathrm{g} / \mathrm{kg}$ ) ( $\mu \mathrm{g}$ de MCs totais / kg de peso médio corpóreo dos camundongos) calculadas em função do volume injetado e do peso médio corpóreo dos camundongos. 


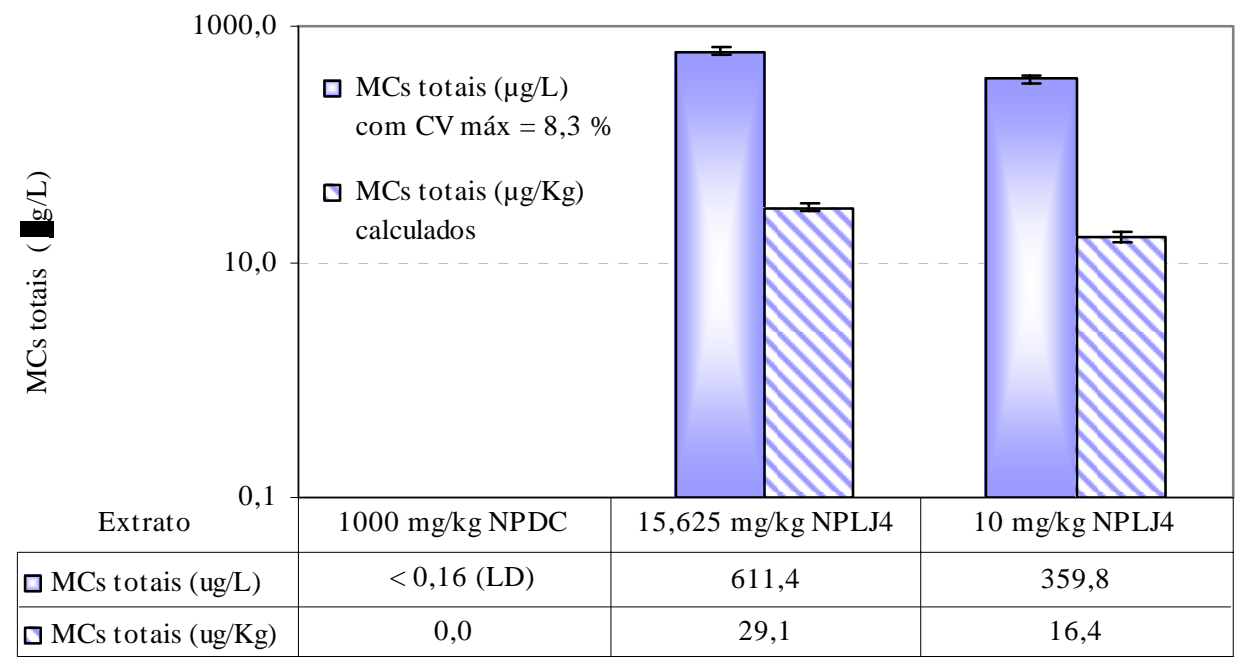

Figura 5.2.7 - Concentração de MCs totais nos extratos e dosagens correspondentes de MCs totais aplicadas no teste T1.

De acordo com resultados obtidos, um novo teste T2 foi realizado, aplicando-se as dosagens de 8, 10, 12, 14, 16 e $18 \mathrm{mg} / \mathrm{kg}$ p.c. (mg de material seco / kg de peso médio corpóreo dos camundongos) do extrato da cepa toxigênica NPLJ-4, com o intuito de obter maior precisão da DL50 24h.

Neste ensaio utilizou-se o mesmo extrato e variou-se o volume aplicado entre 0,355 e $1 \mathrm{~mL}$ por meio de injeções intraperitoniais (i.p), a fim de resultar nas dosagens preestabelecidas. Os resultados obtidos são apresentados na Tabela 5.2.2. Na Figura 5.2.8 são apresentadas fotos dos camundongos do controle (ativos) e das dosagens de $8 \mathrm{mg} / \mathrm{kg}$ p.c. (imobilidade) e $18 \mathrm{mg} / \mathrm{kg}$ p.c. (imobilidade e fotofobia). Na Figura 5.2 .9 são apresentadas as concentrações de MCs totais ( $\mu \mathrm{g} / \mathrm{L}$ ) do extrato analisado por imunoensaio ELISA e as correspondentes dosagens de MCs totais $(\mu \mathrm{g} / \mathrm{kg}$ ) ( $\mu \mathrm{g}$ de MCs totais / $\mathrm{kg}$ de peso médio corpóreo dos camundongos) calculadas em função do volume injetado e do peso médio corpóreo. 


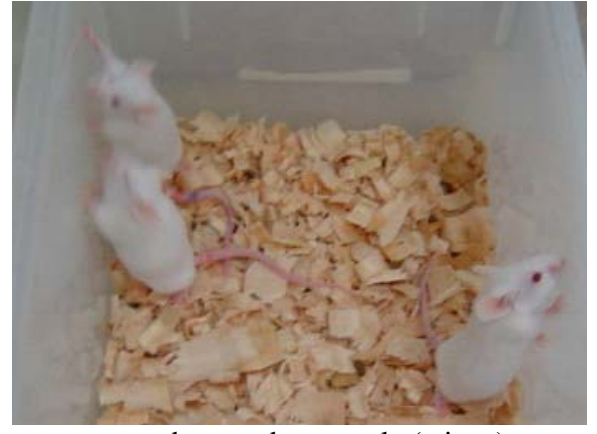

camundongos do controle (ativos)

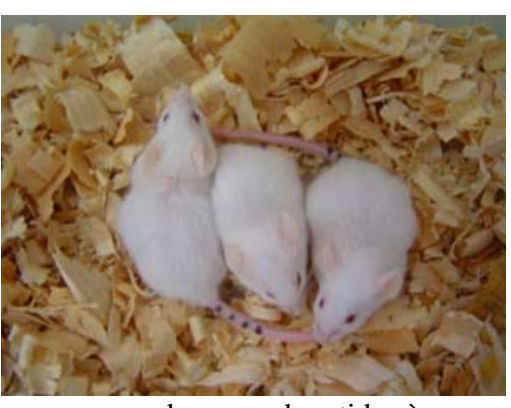

camundongos submetidos à dosagem de $8 \mathrm{mg} / \mathrm{kg}$ p.c. (imobilidade)

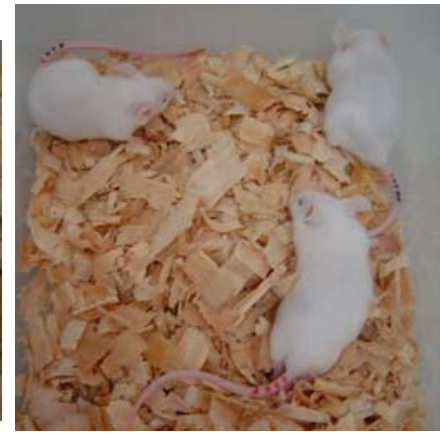

camundongos submetidos à dosagem de $18 \mathrm{mg} / \mathrm{kg}$ p.c. (imobilidade e fotofobia)

Figura 5.2.8 - Vista dos camundongos durante o teste T2 (17:00 h)

Tabela 5.2.2 - Resultados do Teste T2 com camundongos

\begin{tabular}{|c|c|c|c|c|c|c|c|}
\hline \multirow{2}{*}{ Tipo extrato } & \multirow{2}{*}{$\begin{array}{c}\text { Dose extrato } \\
\left({ }^{*}\right) \\
\text { (mg/kg p.c.) }\end{array}$} & \multirow{2}{*}{$\begin{array}{l}\text { Peso do } \\
\text { animal (g) }\end{array}$} & \multirow{2}{*}{$\begin{array}{l}\text { Peso } \\
\text { médio } \\
(\mathrm{g})\end{array}$} & \multirow{2}{*}{$\begin{array}{l}\text { Desvio } \\
\text { padrão }\end{array}$} & \multicolumn{3}{|c|}{ Hora de (h) } \\
\hline & & & & & injeção & morte & vida após injeção \\
\hline \multirow{3}{*}{$\begin{array}{c}\text { Controle } \\
\mathrm{NaCl} 0,09 \%\end{array}$} & \multirow{3}{*}{0} & 28,2 & \multirow{3}{*}{21,2} & \multirow{3}{*}{6,167} & $16: 25$ & - & $24: 00$ \\
\hline & & 19,1 & & & $16: 26$ & - & $24: 00$ \\
\hline & & 16,44 & & & $16: 27$ & - & $24: 00$ \\
\hline \multirow{18}{*}{$\begin{array}{c}\text { Cepa } \\
\text { toxigênica } \\
\text { NPLJ-4 }\end{array}$} & \multirow{3}{*}{8} & 19,61 & \multirow{3}{*}{20,3} & \multirow{3}{*}{0,787} & $15: 38$ & - & $24: 00$ \\
\hline & & 20,1 & & & $15: 41$ & - & $24: 00$ \\
\hline & & 21,15 & & & $15: 40$ & - & $24: 00$ \\
\hline & \multirow{3}{*}{10} & 22,21 & \multirow{3}{*}{21,9} & \multirow{3}{*}{0,405} & $15: 47$ & - & $24: 00$ \\
\hline & & 22,1 & & & $15: 46$ & $18: 33$ & $02: 47$ \\
\hline & & 21,46 & & & $15: 48$ & - & $24: 00$ \\
\hline & \multirow{3}{*}{12} & 22,5 & \multirow{3}{*}{22,7} & \multirow{3}{*}{0,208} & $15: 54$ & $18: 12$ & 02:18 \\
\hline & & 22,8 & & & $15: 53$ & - & $24: 00$ \\
\hline & & 22,9 & & & $15: 56$ & - & $24: 00$ \\
\hline & \multirow{3}{*}{14} & 22,51 & \multirow{3}{*}{23,0} & \multirow{3}{*}{0,440} & $16: 02$ & 18:11 & 02:09 \\
\hline & & 23,24 & & & $16: 00$ & - & $24: 00$ \\
\hline & & 23,3 & & & 16:01 & - & $24: 00$ \\
\hline & \multirow{3}{*}{16} & 23,62 & \multirow{3}{*}{24,2} & \multirow{3}{*}{0,516} & 16:09 & - & $24: 00$ \\
\hline & & 24,2 & & & $16: 08$ & - & $24: 00$ \\
\hline & & 24,65 & & & $16: 13$ & $18: 17$ & 02:04 \\
\hline & \multirow{3}{*}{18} & 25 & \multirow{3}{*}{25,4} & \multirow{3}{*}{0,361} & $16: 19$ & $17: 26$ & 01:07 \\
\hline & & 25,5 & & & $16: 17$ & $18: 35$ & $02: 18$ \\
\hline & & 25,7 & & & $16: 21$ & $17: 41$ & 01:20 \\
\hline
\end{tabular}

${ }^{(*)}$ : mg de material seco / kg de peso médio corpóreo dos camundongos

De acordo com os resultados obtidos da Tabela 5.2.2, foi observada a morte de todos os animais submetidos à dosagem de $18 \mathrm{mg} / \mathrm{kg}$ p.c. do extrato e a resistência de todos os animais submetidos à dosagem de $8 \mathrm{mg} / \mathrm{kg}$ p.c., o que confirma a faixa de sensibilidade obtida no teste T1. 
A faixa de sensibilidade encontrada no teste T1 é bastante similar à encontrada no teste T2 em relação às dosagens de extrato seco T1 (10 a 15,625 mg/kg p.c.) e T2 (8 e 18 mg/kg p.c.), e especialmente, em relação às dosagens de MCs totais: T1 (16,4 e 29,1 $\mu \mathrm{g} / \mathrm{kg})$ e T2 (14,1 e 31,7 $\mu \mathrm{g} / \mathrm{kg}$ ) (Figuras 5.2.7, 5.2.9 e Tabela 5.2.3).

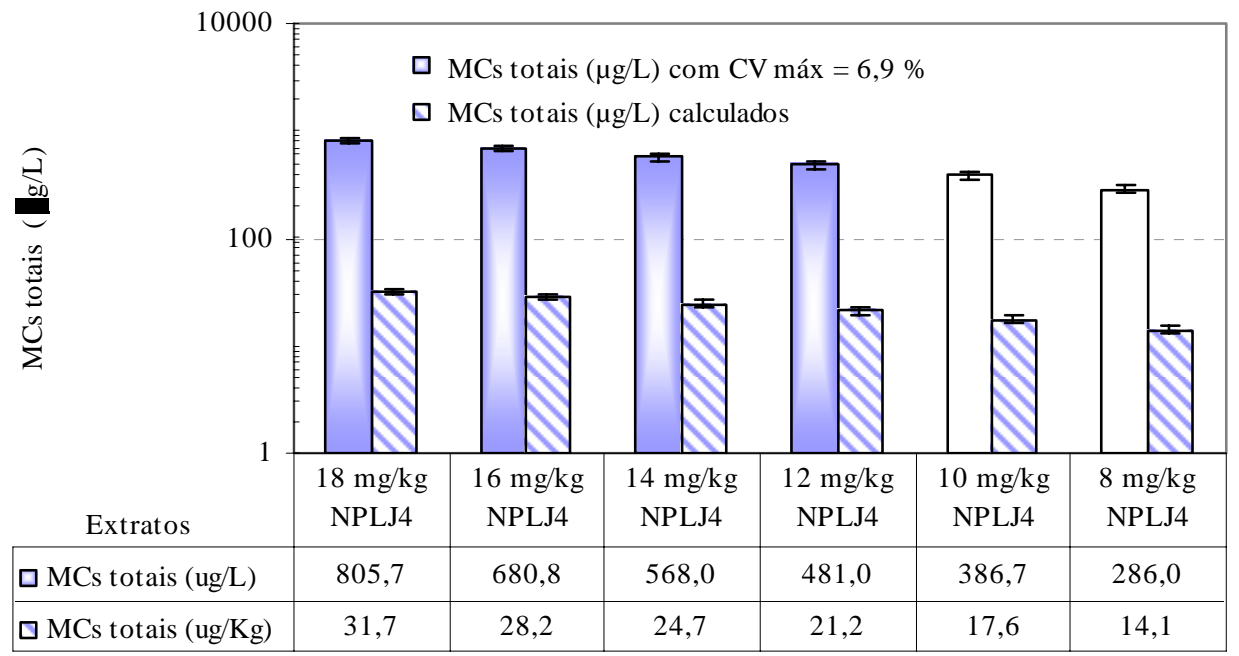

Figura 5.2.9 - Concentração de MCs totais nos extratos e dosagens correspondentes de MCs totais aplicadas no teste $\mathrm{T} 2$

Tabela 5.2.3 - Resumo dos principais resultados obtidos nos testes T1 e T2 com camundongos

\begin{tabular}{|c|c|c|c|c|c|c|c|}
\hline Teste & $\begin{array}{c}\text { Dose extrato } \\
\text { NPLJ-4 } \\
\text { (mg/kg p.c.) }\end{array}$ & $\begin{array}{l}\text { Concentração } \\
\text { MCs totais nos } \\
\text { extratos }(\mu \mathrm{g} / \mathrm{L})\end{array}$ & $\begin{array}{c}\text { Concentração MCs } \\
\text { totais no material } \\
\text { seco }(\mu \mathrm{g} / \mathrm{mg} \text { p.s. })\end{array}$ & $\begin{array}{l}\text { Peso } \\
\text { médio } \\
\text { (g) }\end{array}$ & $\begin{array}{l}\text { Desvio } \\
\text { padrão }\end{array}$ & $\begin{array}{l}\text { Dose MCs } \\
\text { totais } \\
\text { ( } \mu \mathrm{g} / \mathrm{kg} \text { p.c.) }\end{array}$ & $\begin{array}{l}\text { Horas de } \\
\text { vida após } \\
\text { injeção (h) }\end{array}$ \\
\hline \multirow{6}{*}{$\mathrm{T} 1$} & \multirow{3}{*}{10} & \multirow{3}{*}{359,8} & \multirow{3}{*}{1,64} & \multirow{3}{*}{22,0} & \multirow{3}{*}{0,775} & \multirow{3}{*}{16,4} & $24: 00$ \\
\hline & & & & & & & $24: 00$ \\
\hline & & & & & & & $24: 00$ \\
\hline & \multirow{3}{*}{15,625} & \multirow{3}{*}{611,4} & \multirow{3}{*}{1,86} & \multirow{3}{*}{21,0} & \multirow{3}{*}{0,197} & \multirow{3}{*}{29,1} & 04:28 \\
\hline & & & & & & & $01: 30$ \\
\hline & & & & & & & 01:58 \\
\hline \multirow{6}{*}{$\mathrm{T} 2$} & \multirow{3}{*}{8} & \multirow{3}{*}{286,0} & \multirow{3}{*}{$1,76(*)$} & \multirow{3}{*}{20,3} & \multirow{3}{*}{0,787} & \multirow{3}{*}{14,1} & $24: 00$ \\
\hline & & & & & & & $24: 00$ \\
\hline & & & & & & & 24:00 \\
\hline & \multirow{3}{*}{18} & \multirow{3}{*}{805,7} & \multirow{3}{*}{1,76} & \multirow{3}{*}{25,4} & \multirow{3}{*}{0,361} & \multirow{3}{*}{31,7} & 01:07 \\
\hline & & & & & & & 02:18 \\
\hline & & & & & & & 01:20 \\
\hline
\end{tabular}

As correlações entre as dosagens de extrato utilizados nos testes e os resultados obtidos de MCs totais analisados nos extratos apresentaram elevada correlação ( $R=0,988$ e $\left.\mathrm{R}^{2}=0,976\right)$, o que assegura a confiabilidade do procedimento experimental empregado. Esses valores aumentam $\left(\mathrm{R}=0,992\right.$ e $\left.\mathrm{R}^{2}=0,984\right)$ com a inclusão dos dados calculados. 
Os valores das DL50 ${ }_{24 \mathrm{~h}}$ encontrados nos ensaios foram de $13,7 \mathrm{mg} / \mathrm{kg}$ p.c. de extrato seco e de $24,2 \mu \mathrm{g} / \mathrm{kg}$ p.c. de MCs totais estimada e revelaram a elevada toxicidade da cepa NPLJ-4, o que pode ser explicada pela elevada concentração de MCs totais presentes nos extratos (Figuras 5.2.7, 5.2.9 e Tabela 5.2.2).

A DL50 24h de MC - LR via intraperitonial (i.p) em camundongos é estimada entre 25 e $150 \mu \mathrm{g} / \mathrm{kg}$. Para as demais microcistinas, os limites de toxicidade variam entre $50 \mathrm{a}$ $1.200 \mu \mathrm{g} / \mathrm{kg}$, influenciados pelas modificações químicas dos aminoácidos individuais ou de variação na composição de aminoácidos (Rinehart et. al., 1994).

As concentrações calculadas de MCs no material seco utilizado para preparação de extratos com diferentes concentrações resultaram entre 1,64 e 1,86 $\mu \mathrm{g} / \mathrm{mg}$ p.s. ( $\mu \mathrm{g}$ de MCs totais / mg do material seco) (Tabela 5.2.3), o que condiz com a classificação proposta por LAWTON et. al. (1994b), apresentada na Tabela 5.2.4. Segundo os autores, o material contendo cianobactérias é considerado altamente tóxico se a DL50 24h para camundongos for menor que $100 \mathrm{mg} / \mathrm{kg}$ p.c. ou se a concentração de MCs totais no material seco for superior a 1,0 $\mu \mathrm{g} / \mathrm{mg}$ p.s. Assim, pôde-se verificar que a cepa NPLJ-4 testada enquadra-se no grau 3, de elevada toxicidade, e que a cepa não toxigênica utilizada como controle tipo A, com concentração de MCs totais inferior a 0,00016 $\mu \mathrm{g} / \mathrm{mg}$ p.s. não foi tóxica para as cobaias utilizadas.

Tabela 5.2.4 - Limites de toxicidade de material seco e de toxinas propostos por LAWTON et. al. (1994b)

\begin{tabular}{c|c|c}
\hline Grau de toxicidade & $\begin{array}{c}\text { DL50 em camundongos } \\
(\mathrm{mg} / \mathrm{kg} \text { p.c. })\end{array}$ & $\begin{array}{c}\text { Concentração toxinas } \\
(\mu \mathrm{g} / \mathrm{mg} \text { p.s. })\end{array}$ \\
\hline não & $>1000$ & $<0,01$ \\
\hline 1 - baixa & 500 a 1000 & 0,01 a 0,1 \\
\hline 2 - média & 100 a 500 & 0,1 a 1,0 \\
\hline 3 - alta & $<100$ & $>1,0$ \\
\hline
\end{tabular}

Os resultados encontrados neste ensaio demonstraram que a cepa utilizada apresentou toxicidade superior quando comparada com outras culturas mantidas em laboratório, por exemplo, ao reportado por AZEVEDO et. al. (1994), com a cepa de $M$. aeruginosa (NPJB-1) isolada do Lago das Garças, São Paulo - SP, cujo valor da DL100 24h foi de $31 \mathrm{mg} / \mathrm{kg}$ p.c. de extrato seco. Uma toxicidade menor foi descrita por HONDA et. al. (2001), com cepas não axênicas de M. panniformis (SPC 686 e 702), também isoladas no Lago das Garças, São Paulo - SP, com valores da DL100 24h entre 100 e 316 mg/kg p.c. de extrato seco.

Estudos com amostras naturais realizados por MATTHIENSEN (1999) em região integrante do Estuário da Lagoa dos Patos reportaram valores de DL50 24h menores que 100 
mg/kg p.c., variando entre 35 e 140 mg/kg p.c. e concentrações de MCs, no material seco, maiores que $1,0 \mu \mathrm{g} / \mathrm{mg}$ p.s. em amostras dominadas por Microcystis aeruginosa neste ambiente. A cultura de Microcystis aeruginosa PCC7813 apresentou DL50 24h.de 70,7 mg/kg p.c. e teve maior concentração de MCs no material seco em relação às florações (1,145 $\mu \mathrm{g} / \mathrm{mg}$ p.s.).

Níveis próximos a estes também foram reportados por OLIVEIRA et. al. (2003), com valores de DL100 24h entre 28,44 e 62,90 mg/kg p.c., em amostras de água no reservatório do Funil, Rio de Janeiro, dominadas por florações de Microcystis spp., Cylindrospermopsis sp e Anabaena spiroides.

Estudos realizados por VASCONCELOS (1999), com florações de cianobactérias coletadas em lagos e reservatórios na região Norte e Central de Portugal, demonstraram a alta toxicidade de duas amostras, com valores de $\mathrm{DL}_{50}$ entre 30 e $175 \mu \mathrm{g} / \mathrm{kg}$, enquanto cepas isoladas e cultivadas destes florescimentos causaram uma maior ação tóxica, com valores de $\mathrm{DL}_{50}$ de 15 a $75 \mu \mathrm{g} / \mathrm{kg}$.

Os resultados obtidos no estudo revelaram sobretudo, a importância e necessidade da realização de testes de toxicidade com organismos como complemento às sofisticadas técnicas qualitativas e quantitativas, por possibilitar a aquisição de importantes informações sobre a potencialidade tóxica de uma amostra, especialmente nos casos em que os padrões dessas toxinas não são comercialmente disponíveis.

\subsubsection{Avaliação do potencial de formação de subprodutos organohalogenados - PFSPOs}

De acordo com SINGER (1994), os principais fatores que influenciam a formação de subprodutos organohalogenados - SPOs são: $\mathrm{pH}$, tempo de contato, temperatura, natureza e concentração da matéria orgânica natural - MON, dosagem de cloro aplicada, residual de cloro livre e concentração de brometos. A MON é considerada a principal precursora de SPOs, sendo que a natureza do material orgânico depende da vegetação existente na bacia hidrográfica e das espécies de organismos fitoplanctônicos presentes na água. Assim, além das substâncias húmicas às quais, tradicionalmente se atribui a formação de SPOs, os organismos fitoplanctônicos também se constituem em potenciais precursores de SPOs.

A determinação do potencial de formação de subprodutos organohalogenados PFSPO é uma ferramenta importante a ser utilizada no tratamento de água para consumo humano pois possibilita a previsão qualitativa e quantitativa dos possíveis subprodutos formados após oxidação de águas contendo diferentes composições de matéria orgânica e os riscos associados à sua presença em águas para consumo humano. 
Desta forma, este experimento foi realizado com o objetivo principal de avaliar o potencial de formação de subprodutos organohalogenados - PFSPOs para a água de estudo AE-A com densidade de Microcystis spp. de 1,4 × 10 $\mathrm{cel} / \mathrm{mL}$. Com o intuito de investigar o efeito da densidade de Microcystis spp. na formação de SPOs, foi acrescentada ao experimento, a água de estudo AE-B, apenas com acréscimo da densidade de Microcystis spp. para $5,5 \times 10^{5} \mathrm{cel} / \mathrm{mL}$.

\subsubsection{Caracterização física, química e microbiológica da AD e AE-A}

A fim de assegurar a qualidade dos resultados obtidos em relação aos SPOs formados e fornecer possíveis subsídios para avaliação dos mesmos, foi realizada a caracterização física, química e microbiológica das águas de diluição - AD e de estudo - AEA (Tabela 5.2.5).

Como era esperado, a adição de cultura de Microcystis spp. para obtenção da AE-A foi refletida no incremento de vários parâmetros indiretos relacionados a compostos orgânicos, tais como absorvância a 254 nm, oxigênio consumido, carbono orgânico total, além dos parâmetros comumente utilizados para estimativa de biomassa fitoplanctônica. As variações observadas nos valores relativos aos parâmetros inorgânicos podem ser justificadas pela composição do meio de nutrientes utilizado (ASM1) para manutenção das culturas de Microcystis spp.. De acordo com a Tabela 5.2.5, não foi constatada nenhuma característica que possa interferir ou mascarar os resultados de SPOs formados. 
Tabela 5.2.5 - Caracterização física, química e microbiológica das águas de diluição - AD e de estudo da série A - AE-A

\begin{tabular}{|c|c|c|}
\hline \multirow[b]{2}{*}{ Parâmetros } & \multicolumn{2}{|c|}{ Amostras } \\
\hline & Água de diluição - AD & $\begin{array}{c}\text { Água de estudo - AE- } \\
\text { A }\end{array}$ \\
\hline Densidade de Microcystis spp. (cel/mL) & - & $1,2 \times 10^{5}$ \\
\hline Clorofila-a $(\mu \mathrm{g} / \mathrm{L})$ & - & 91,51 \\
\hline Microcistinas totais extracelulares $(\mu \mathrm{g} / \mathrm{L})$ & - & $1,65 \pm 0,03$ \\
\hline Microcistinas totais intra + extra celulares $(\mu \mathrm{g} / \mathrm{L})$ & - & $13,46 \pm 0,04$ \\
\hline $\mathrm{pH}$ & 6,74 & 6,79 \\
\hline Cor aparente (uH) & 1 & 26 \\
\hline Cor verdadeira $(\mathrm{uH})$ & $<1$ & 4 \\
\hline Turbidez (uT) & 0,56 & 5,12 \\
\hline Alcalinidade total $(\mathrm{mg} \mathrm{CaCO} / \mathrm{L})$ & 6 & 7 \\
\hline Condutividade elétrica $(\mu \mathrm{S} / \mathrm{cm})$ & 24,3 & 26,2 \\
\hline Dureza total $(\mathrm{mg} \mathrm{CaCO} / \mathrm{L})$ & 5 & 6 \\
\hline Absorvância 254 nm & 0,003 & 0,017 \\
\hline Nitrogênio amoniacal (mg N/L) & 0,01 & 0,02 \\
\hline Nitrogênio nitrato (mg N/L) & 0,31 & 0,43 \\
\hline Nitrogênio nitrito (mg N/L) & $<0,001$ & 0,002 \\
\hline Cloretos (mg Cl$\left.{ }^{-} / \mathrm{L}\right)$ & 1,1 & 2,0 \\
\hline Fluoretos (mg F- /L) & 0,35 & 0,40 \\
\hline Oxigênio consumido (mg $\mathrm{O}_{2} / \mathrm{L}$ ) & 0,3 & 1,4 \\
\hline Sólidos dissolvidos totais (mg/L) & 21 & 23 \\
\hline Sílica (mg $\left.\mathrm{SiO}_{2} / \mathrm{L}\right)$ & 9,9 & 9,9 \\
\hline Sulfatos $\left(\mathrm{mg} \mathrm{SO}_{4}{ }^{2-} / \mathrm{L}\right)$ & 4 & 4 \\
\hline Sódio (mg Na /L) & 1,7 & 2,0 \\
\hline Potássio (mg K /L) & 0,9 & 1,0 \\
\hline Carbono orgânico total (mg C/L) & 0,962 & 3,152 \\
\hline Fosfato total $\left(\mathrm{mg} \mathrm{PO}_{4}^{3-} / \mathrm{L}\right)$ & 0,03 & 0,18 \\
\hline Coliformes totais (UFC/100 mL) & 10 & 7 \\
\hline E. coli (UFC/100 mL) & Ausente & Ausente \\
\hline Zinco (mg Zn /L) & $<0,002$ & $<0,002$ \\
\hline Chumbo (mg Pb /L) & $<0,02$ & $<0,02$ \\
\hline Cádmio (mg Cd /L) & $<0,0006$ & $<0,0006$ \\
\hline Níquel (mg Ni /L) & $<0,008$ & $<0,008$ \\
\hline Ferro total (mg Fe /L) & $<0,005$ & 0,93 \\
\hline Manganês total (mg Mn /L) & $<0,003$ & 0,03 \\
\hline Cobre (mg Cu /L) & $<0,003$ & $<0,003$ \\
\hline Cromo total (mg Cr /L) & $<0,005$ & $<0,005$ \\
\hline
\end{tabular}




\subsubsection{Resultados do experimento para obtenção das condições máximas de formação de SPOs}

Os resultados obtidos no experimento realizado para obtenção das amostras representativas da condição máxima de formação de SPOs para as águas de diluição - AD e de estudo AE-A e AE-B são relacionados na Tabela 5.2.6.

Tabela 5.2.6 - Resultados de cloro residual livre com tempo de contato de 3 e 7 dias a $25^{\circ} \mathrm{C}$ para obtenção das amostras representativas da condição máxima de formação de SPOs

\begin{tabular}{|c|c|c|c|c|c|c|}
\hline Amostra & $\begin{array}{c}\text { Dosagem } \\
\text { de cloro } \\
(\mathrm{mg} / \mathrm{L})\end{array}$ & $\begin{array}{l}\text { Conc. cloro } \\
\text { residual após } 3 \\
\text { dias }(\mathrm{mg} / \mathrm{L})\end{array}$ & $\begin{array}{l}\text { Demanda de } \\
\text { cloro após } 3 \\
\text { dias }(\mathrm{mg} / \mathrm{L})\end{array}$ & $\begin{array}{l}\text { Conc. cloro } \\
\text { residual após } 7 \\
\text { dias }(\mathrm{mg} / \mathrm{L})\end{array}$ & $\begin{array}{l}\text { Demanda de } \\
\text { cloro após } 7 \\
\text { dias (mg/L) } \\
\end{array}$ & $\mathrm{pH}$ \\
\hline \multirow{3}{*}{$\begin{array}{c}\text { Água de } \\
\text { diluição } \\
\text { AD }\end{array}$} & 5 & 1,99 & 3,01 & - & - & - \\
\hline & 6 & $3,61^{(*)}$ & 2,39 & - & - & 7,01 \\
\hline & 8 & 5,54 & 2,46 & $4,67^{(*)}$ & 3,33 & 7,10 \\
\hline \multirow{4}{*}{$\begin{array}{c}\text { Água de } \\
\text { estudo } \\
\text { AE-A }\end{array}$} & 10 & 1,21 & 8,79 & - & - & - \\
\hline & 12,5 & 2,24 & 10,26 & - & - & - \\
\hline & 15 & $3,8^{(*)}$ & 11,20 & - & - & 7,12 \\
\hline & 20 & 7,12 & 12,88 & $2,5^{(*)}$ & 17,50 & 7,16 \\
\hline \multirow{4}{*}{$\begin{array}{l}\text { Água de } \\
\text { estudo } \\
\text { AE-B }\end{array}$} & 50 & 0,26 & 49,74 & - & - & - \\
\hline & 55 & 1,25 & 53,75 & - & - & - \\
\hline & 65 & $3,66^{(*)}$ & 61,34 & 1,25 & 63,75 & 7,14 \\
\hline & 75 & 9,28 & 65,72 & $2,9^{(*)}$ & 72,10 & 7,15 \\
\hline
\end{tabular}

${ }^{(*)}$ : condições selecionadas para determinação do PFSPOs de 3 e 7 dias.

Os valores de concentração de cloro residual das amostras de AE-B selecionadas para representar a capacidade máxima de formação de SPOs em 7 dias resultaram levemente inferiores ao limite mínimo recomendado pelo método de $3 \mathrm{mg} / \mathrm{L}$, o que pode ter contribuído para a subestimação dos valores encontrados de PFSPOs.

\subsubsection{Resultados do potencial de formação de subprodutos organohalogenados - PFSPOs}

Os resultados de análises das amostras representativas da condição máxima de formação de cada SPOs para os tempos de contato de 3 e 7 dias são relacionados nas Tabelas 5.2.7 e 5.2 .8 respectivamente. 
Tabela 5.2.7 - Subprodutos organohalogenados - SPOs das águas de diluição e águas de estudo AE-A e AE-B,

\begin{tabular}{|c|c|c|c|c|c|c|c|c|c|}
\hline \multirow{3}{*}{ SPOs } & \multicolumn{3}{|c|}{ Água de diluição AD } & \multicolumn{3}{|c|}{$\begin{array}{c}\text { Água de estudo } \\
\text { AE-A }\end{array}$} & \multicolumn{3}{|c|}{$\begin{array}{c}\text { Água de estudo } \\
\text { AE-B }\end{array}$} \\
\hline & \multicolumn{9}{|c|}{ Tempo de contato (dia) } \\
\hline & 0 & 3 & $(3-0)$ & 0 & 3 & $(3-0)$ & 0 & 3 & $(3-0)$ \\
\hline clorofórmio & 14,3 & 25,7 & 11,4 & 15,2 & 28,7 & 13,5 & 40,5 & 166,4 & 125,9 \\
\hline bromodiclorometano & 1,8 & 4,3 & 2,5 & 2,0 & 1,8 & $<1,0$ & 3,0 & 20,2 & 17,3 \\
\hline dibromoclorometano & $<1,0$ & $<1,0$ & $<1,0$ & $<1,0$ & $<1,0$ & $<1,0$ & $<1,0$ & $<1,0$ & $<1,0$ \\
\hline bromofórmio & $<1,0$ & $<1,0$ & $<1,0$ & $<1,0$ & $<1,0$ & $<1,0$ & $<1,0$ & $<1,0$ & $<1,0$ \\
\hline Total THMs $(\mu \mathrm{g} / \mathrm{L})$ & 16,0 & 30,0 & 13,9 & 17,2 & 30,5 & 13,3 & 43,5 & 186,6 & 143,1 \\
\hline tricloroacetonitrila & $<1,0$ & 2,0 & 2,0 & $<1,0$ & $<1,0$ & $<1,0$ & $<1,0$ & $<1,0$ & $<1,0$ \\
\hline dicloroacetonitrila & $<1,0$ & $<1,0$ & $<1,0$ & $<1,0$ & 3,6 & 3,6 & 8,6 & 16,3 & 7,7 \\
\hline bromocloroacetonitrila & $<1,0$ & $<1,0$ & $<1,0$ & $<1,0$ & $<1,0$ & $<1,0$ & 13,8 & 5,5 & $<1,0$ \\
\hline dibromoacetonitrila & $<1,0$ & $<1,0$ & $<1,0$ & $<1,0$ & $<1,0$ & $<1,0$ & 1,1 & 1,6 & 0,5 \\
\hline Total HANs $(\mu \mathrm{g} / \mathrm{L})$ & $<1,0$ & 2,0 & 2,0 & $<1,0$ & 3,6 & 3,6 & 24,0 & 24,2 & $<1,0$ \\
\hline cloralhidrato & $<1,0$ & 12,6 & 12,6 & $<1,0$ & 18,4 & 18,4 & 42,1 & 109,3 & 67,1 \\
\hline Total CH $(\mu \mathrm{g} / \mathrm{L})$ & $<1,0$ & 12,6 & 12,6 & $<1,0$ & 18,4 & 18,4 & 42,1 & 109,3 & 67,1 \\
\hline 1,1-dicloropropanona & $<1,0$ & $<1,0$ & $<1,0$ & $<1,0$ & $<1,0$ & $<1,0$ & $<1,0$ & $<1,0$ & $<1,0$ \\
\hline 1,1,1tricloropropanona & $<1,0$ & 2,5 & 2,5 & $<1,0$ & 1,1 & 1,1 & 4,8 & 3,1 & $<1,0$ \\
\hline Total HKs $(\mu \mathrm{g} / \mathrm{L})$ & $<1,0$ & 2,5 & 2,5 & $<1,0$ & 1,1 & 1,1 & 4,8 & 3,1 & $<1,0$ \\
\hline cloropicrinas & $<0,1$ & $<0,1$ & $<0,1$ & $<0,1$ & $<0,1$ & $<0,1$ & 1,3 & 0,6 & $<1,0$ \\
\hline Total HPs $(\mu \mathrm{g} / \mathrm{L})$ & $<0,1$ & $<0,1$ & $<\mathbf{0 , 1}$ & $<\mathbf{0 , 1}$ & $<0,1$ & $<0,1$ & 1,3 & 0,6 & $<0,1$ \\
\hline MCAA & $<1,0$ & 1,1 & 1,1 & $<1,0$ & 38,2 & 38,2 & 83,7 & 275,3 & 191,6 \\
\hline MBAA & 9,2 & 7,3 & $<1,0$ & 26,9 & 76,4 & 49,5 & 348,7 & 54,0 & $<1,0$ \\
\hline DCAA & $<1,0$ & 21,7 & 21,7 & 24,9 & 293,9 & 269,0 & 222,6 & 1964,2 & 1741,6 \\
\hline TCAA & $<1,0$ & $<1,0$ & $<1,0$ & $<1,0$ & $<1,0$ & $<1,0$ & $<1,0$ & $<1,0$ & $<1,0$ \\
\hline BCAA & 2,2 & 34,8 & 32,6 & 49,0 & 395,4 & 346,4 & 236,5 & 1815,2 & 1578,7 \\
\hline BDCAA & 3,3 & $<1,0$ & $<1,0$ & 78,2 & 11,1 & $<1,0$ & 145,7 & 161,8 & 16,1 \\
\hline DBAA & $<1,0$ & 1,3 & 1,3 & 3,2 & $<1,0$ & $<1,0$ & $<1,0$ & 6,1 & 6,1 \\
\hline CDBAA & $<1,0$ & $<1,0$ & $<1,0$ & 39,9 & $<1,0$ & $<1,0$ & 48,3 & 66,1 & 17,8 \\
\hline TBAA & $<1,0$ & $<1,0$ & $<1,0$ & $<1,0$ & $<1,0$ & $<1,0$ & $<1,0$ & $<1,0$ & $<1,0$ \\
\hline Total AHAs $(\mu \mathrm{g} / \mathrm{L})$ & 14,7 & 66,2 & 51,6 & 222,1 & 815,0 & 592,9 & 1085,5 & 4342,7 & 3257,2 \\
\hline
\end{tabular}

Total THMs $(\mu \mathrm{g} / \mathrm{L})$ : concentração total de trihalometanos;

Total HANs $(\mu \mathrm{g} / \mathrm{L})$ : concentração total de haloacetonitrilas;

Total CH ( $\mu \mathrm{g} / \mathrm{L})$ : concentração total de cloralhidrato;

Total HKs $(\mu \mathrm{g} / \mathrm{L})$ : concentração total de halocetonas;

Total HPs ( $\mu \mathrm{g} / \mathrm{L})$ : concentração total de halopicrinas;

Total AHAs $(\mu \mathrm{g} / \mathrm{L})$ : concentração total de ácidos haloacéticos. 
Tabela 5.2.8 - Subprodutos organohalogenados - SPOs das águas de diluição e águas de estudo AE-A e AE-B,

\begin{tabular}{|c|c|c|c|c|c|c|c|c|c|}
\hline \multirow{3}{*}{ SPOs } & \multicolumn{3}{|c|}{ Água de diluição AD } & \multicolumn{3}{|c|}{$\begin{array}{c}\text { Água de estudo } \\
\text { AE-A }\end{array}$} & \multicolumn{3}{|c|}{$\begin{array}{c}\text { Água de estudo } \\
\text { AE-B }\end{array}$} \\
\hline & \multicolumn{9}{|c|}{ Tempo de contato (dia) } \\
\hline & 0 & 7 & $(7-0)$ & 0 & 7 & $(7-0)$ & 0 & 7 & $(7-0)$ \\
\hline clorofórmio & 12,3 & 23,9 & 11,6 & 10,2 & 53,3 & 43,2 & 29,5 & 222,4 & 192,9 \\
\hline bromodiclorometano & 2,1 & 3,5 & 1,4 & 2,0 & 3,0 & 1,0 & 2,2 & 5,4 & 3,2 \\
\hline dibromoclorometano & $<1,0$ & $<1,0$ & $<1,0$ & $<1,0$ & $<1,0$ & $<1,0$ & $<1,0$ & $<1,0$ & $<1,0$ \\
\hline bromofórmio & $<1,0$ & $<1,0$ & $<1,0$ & $<1,0$ & $<1,0$ & $<1,0$ & $<1,0$ & $<1,0$ & $<1,0$ \\
\hline Total THMs $(\mu \mathrm{g} / \mathrm{L})$ & 14,4 & 27,4 & 13,0 & 12,2 & 56,4 & 44,2 & 31,7 & 227,8 & 196,1 \\
\hline tricloroacetonitrila & $<1,0$ & $<1,0$ & $<1,0$ & $<1,0$ & $<1,0$ & $<1,0$ & $<1,0$ & 3,3 & 3,3 \\
\hline dicloroacetonitrila & $<1,0$ & $<1,0$ & $<1,0$ & $<1,0$ & 2,0 & 2,0 & 7,1 & 15,6 & 8,5 \\
\hline bromocloroacetonitrila & $<1,0$ & $<1,0$ & $<1,0$ & $<1,0$ & $<1,0$ & $<1,0$ & $<1,0$ & $<1,0$ & $<1,0$ \\
\hline dibromoacetonitrila & $<1,0$ & $<1,0$ & $<1,0$ & $<1,0$ & $<1,0$ & $<1,0$ & 1,5 & 1,2 & $<1,0$ \\
\hline Total HANs $(\mu \mathrm{g} / \mathrm{L})$ & $<1,0$ & $<1,0$ & $<1,0$ & $<1,0$ & 2,0 & 2,0 & 8,6 & 20,1 & 11,5 \\
\hline cloralhidrato & $<1,0$ & 17,8 & 17,8 & $<1,0$ & 40,5 & 40,5 & 33,2 & 234,3 & 201,1 \\
\hline Total CH $(\mu \mathrm{g} / \mathrm{L})$ & $\mathbf{0 , 0}$ & 17,8 & 17,8 & $\mathbf{0 , 0}$ & $\mathbf{4 0 , 5}$ & 40,5 & 33,2 & 234,3 & 201,1 \\
\hline 1,1-dicloropropanona & $<1,0$ & $<1,0$ & $<1,0$ & $<1,0$ & $<1,0$ & $<1,0$ & $<1,0$ & $<1,0$ & $<1,0$ \\
\hline 1,1,1tricloropropanona & $<1,0$ & $<1,0$ & $<1,0$ & $<1,0$ & 1,6 & 1,6 & 2,0 & 7,8 & 5,8 \\
\hline Total HKs $(\mu \mathrm{g} / \mathrm{L})$ & $<\mathbf{1 , 0}$ & 2,5 & 2,5 & $<1,0$ & 1,1 & 1,1 & 4,8 & 3,1 & $<1,0$ \\
\hline cloropicrinas & $<0,1$ & $<0,1$ & $<0,1$ & $<0,1$ & 0,5 & 0,5 & 0,4 & 1,4 & 1,0 \\
\hline Total HPs $(\mu \mathrm{g} / \mathrm{L})$ & $<\mathbf{0 , 1}$ & $<0,1$ & $<0,1$ & $<0,1$ & 0,5 & 0,5 & 0,4 & 1,4 & 1,0 \\
\hline MCAA & $<1,0$ & $<1,0$ & $<1,0$ & $<1,0$ & 25,0 & 25,0 & 46,6 & 41,7 & $<1,0$ \\
\hline MBAA & 28,2 & $<1,0$ & $<1,0$ & $<1,0$ & $<1,0$ & 0,0 & 224,1 & 68,2 & $<1,0$ \\
\hline DCAA & 25,2 & 54,7 & 29,5 & & 665,9 & 665,9 & 243,6 & 2885,1 & 2641,5 \\
\hline TCAA & $<1,0$ & $<1,0$ & 0,0 & $<1,0$ & $<1,0$ & 0,0 & $<1,0$ & $<1,0$ & 0,0 \\
\hline BCAA & 28,8 & 97,6 & 68,8 & 14,5 & 492,0 & 477,5 & 336,6 & 2423,4 & 2086,9 \\
\hline BDCAA & $<1,0$ & 5,3 & 5,3 & $<1,0$ & 23,5 & 23,5 & 26,0 & 4,7 & $<1,0$ \\
\hline DBAA & $<1,0$ & 4,0 & 4,0 & $<1,0$ & $<1,0$ & $<1,0$ & $<1,0$ & $<1,0$ & $<1,0$ \\
\hline CDBAA & $<1,0$ & $<1,0$ & $<1,0$ & $<1,0$ & $<1,0$ & $<1,0$ & $<1,0$ & $<1,0$ & $<1,0$ \\
\hline TBAA & $<1,0$ & $<1,0$ & $<1,0$ & $<1,0$ & $<1,0$ & $<1,0$ & $<1,0$ & $<1,0$ & $<1,0$ \\
\hline Total AHAs $(\mu \mathrm{g} / \mathrm{L})$ & 82,2 & 161,6 & 79,4 & 14,5 & 1206,4 & 1191,9 & 876,9 & 5423,2 & 4546,3 \\
\hline
\end{tabular}

Total THMs $(\mu \mathrm{g} / \mathrm{L})$ : concentração total de trihalometanos;

Total HANs $(\mu \mathrm{g} / \mathrm{L})$ : concentração total de haloacetonitrilas;

Total CH $(\mu \mathrm{g} / \mathrm{L})$ : concentração total de cloralhidrato;

Total HKs $(\mu \mathrm{g} / \mathrm{L})$ : concentração total de halocetonas;

Total HPs $(\mu \mathrm{g} / \mathrm{L})$ : concentração total de halopicrinas;

Total AHAs $(\mu \mathrm{g} / \mathrm{L})$ : concentração total de ácidos haloacéticos.

De acordo com a Tabela 5.2.9 e Figura 5.2.10, a capacidade máxima de formação de trihalometanos - PFTHMs de 7 dias, para a água de estudo AE-A com $1,4 \times 10^{5} \mathrm{cel} / \mathrm{mL}$ de Microcystis spp. foi de $31 \mu \mathrm{g} / \mathrm{L}$, valor inferior ao limitado pela Portaria MS/518/2004, de 0,1 mg/L. O PFTHMs de 3 e 7 dias, para a água de estudo AE-B com 5,5 $\times 10^{5} \mathrm{cel} / \mathrm{mL}$ de Microcystis spp. foi de 129 e $183 \mu \mathrm{g} / \mathrm{L}$, respectivamente, valores superiores ao limitado pela Portaria MS 518/2004. Esses valores indicam uma ordem de grandeza da relação entre a densidade de Microcystis spp. e a capacidade máxima de formação de THMs. No entanto, 
deve-se considerar o tipo de organismo fitoplanctônico, ou mais precisamente, o conteúdo celular, uma vez que, segundo constatação feita por HOEHN et al (1980), tanto as células como a matéria orgânica extracelular das algas - MOE, mostraram-se importantes precursores de THMs, sendo mais significativa a contribuição da MOE do que as células propriamente ditas.

Em relação à água de estudo AE-A, os PFSPOs de 7 dias que apresentaram valores mais significativos em ordem decrescente foram: ácidos haloacéticos com $1112 \mu \mathrm{g} / \mathrm{L}$ (95,0\%); trihalometanos com $31 \mu \mathrm{g} / \mathrm{L}$ (2,7\%); cloralhidrato com $23 \mu \mathrm{g} / \mathrm{L}(1,9 \%)$; haloacetonitrila com $2 \mu \mathrm{g} / \mathrm{L}(0,2 \%)$ e halocetonas com 1,6 $\mu \mathrm{g} / \mathrm{L}(<0,1 \%)$ (Figura.5.2.11a).

Em relação à água de estudo AE-B, o PFSPOs de 7 dias que apresentaram valores mais significativos em ordem decrescente foram: ácidos haloacéticos com $4467 \mu \mathrm{g} / \mathrm{L}$ (92\%);. cloralhidrato com $183 \mu \mathrm{g} / \mathrm{L}$ (3,8\%); trihalometanos com $183 \mu \mathrm{g} / \mathrm{L}$ (3,8\%); haloacetonitrila com $12 \mu \mathrm{g} / \mathrm{L}(0,2 \%)$ e halocetonas com $6 \mu \mathrm{g} / \mathrm{L}(<0,1 \%)$ (Figura.5.2.11b). Vale ressaltar que na Portaria MS 518/2004, nenhuma menção é feita em relação aos demais SPOs.

Como pode ser observado nas Figura.5.2.11 a e b, a tendência de formação preferencial dos SPOs mais significativos foi mantida, seguindo proporções diretas e bem definidas em relação à densidade de Microcystis spp. (1,4 : 5,5), independentemente da densidade fitoplanctônica e do tempo de contato. Esse fato comprova a hipótese de que os organismos fitoplanctônicos também se constituem em potenciais precursores de SPOs.

Tabela 5.2.9 - Valores absolutos do potencial de formação de subprodutos organohalogenados - PFSPOs das águas de estudo AE-A e AE-B, para o tempo de contato de 7 dias a $25^{\circ} \mathrm{C}$

\begin{tabular}{c|c|c|c|c}
\hline \multirow{2}{*}{ PFSPOs } & \multicolumn{3}{|c|}{$\begin{array}{c}\text { Água de estudo } \\
\text { AE-A }\end{array}$} & \multicolumn{3}{c}{ Aempo de contato (dia) } \\
\cline { 2 - 5 } & 3 & 7 & 3 & 7 \\
\cline { 2 - 5 } & \multicolumn{3}{|c|}{ AE-B } \\
\hline Total THMs $(\boldsymbol{\mu g} / \mathbf{L})$ & $<1,0$ & 31,2 & 129,2 & 183,1 \\
\hline Total HANs $(\boldsymbol{\mu g} / \mathbf{L})$ & 1,6 & 2,0 & $<1,0$ & 11,5 \\
\hline Total CH $(\boldsymbol{\mu g} / \mathbf{L})$ & $<1,0$ & 1,6 & $<1,0$ & 5,8 \\
\hline Total HKs $(\boldsymbol{\mu g} / \mathbf{L})$ & 5,8 & 22,7 & 54,5 & 183,3 \\
\hline Total HPs $(\boldsymbol{\mu g} / \mathbf{L})$ & $<1,0$ & $<1,0$ & $<1,0$ & 1,0 \\
\hline Total AHAs $(\boldsymbol{\mu g} / \mathbf{L})$ & 541,4 & 1112,5 & 3205,6 & 4466,9 \\
\hline
\end{tabular}


Tabela 5.2.10 - Distribuição dos valores de potencial de formação de subprodutos organohalogenados PFSPOs das águas de estudo AE-A e AE-B, para os tempos de contato de 3 e 7 dias a $25^{\circ} \mathrm{C}$ em porcentagem

\begin{tabular}{c|c|c|c|c}
\hline \multirow{2}{*}{ SPOs } & \multicolumn{3}{|c}{$\begin{array}{c}\text { Água de estudo } \\
\text { AE-A }\end{array}$} & \multicolumn{3}{c}{$\begin{array}{c}\text { Água de estudo } \\
\text { AE-B }\end{array}$} \\
\cline { 2 - 5 } & \multicolumn{4}{|c}{ Tempo de contato (dia) } \\
\cline { 2 - 5 } & 3 & 7 & 3 & 7 \\
\hline Total THMs $(\boldsymbol{\mu g} / \mathbf{L})$ & $<1,0$ & 2,7 & 3,8 & 3,8 \\
\hline Total HANs $(\boldsymbol{\mu g} / \mathbf{L})$ & $<1,0$ & $<1,0$ & $<1,0$ & $<1,0$ \\
\hline Total CH $(\boldsymbol{\mu g} / \mathbf{L})$ & $<1,0$ & $<1,0$ & 1,0 & $<1,0$ \\
\hline Total HKs $(\boldsymbol{\mu g} / \mathbf{L})$ & 1,1 & 1,9 & $<1,0$ & $<1,0$ \\
\hline Total HPs $(\boldsymbol{\mu g} / \mathbf{L})$ & $<1,0$ & $<1,0$ & 94,8 & 92,1 \\
\hline Total AHAs $(\boldsymbol{\mu g} / \mathbf{L})$ & 99,0 & 95,0 & & \\
\hline
\end{tabular}

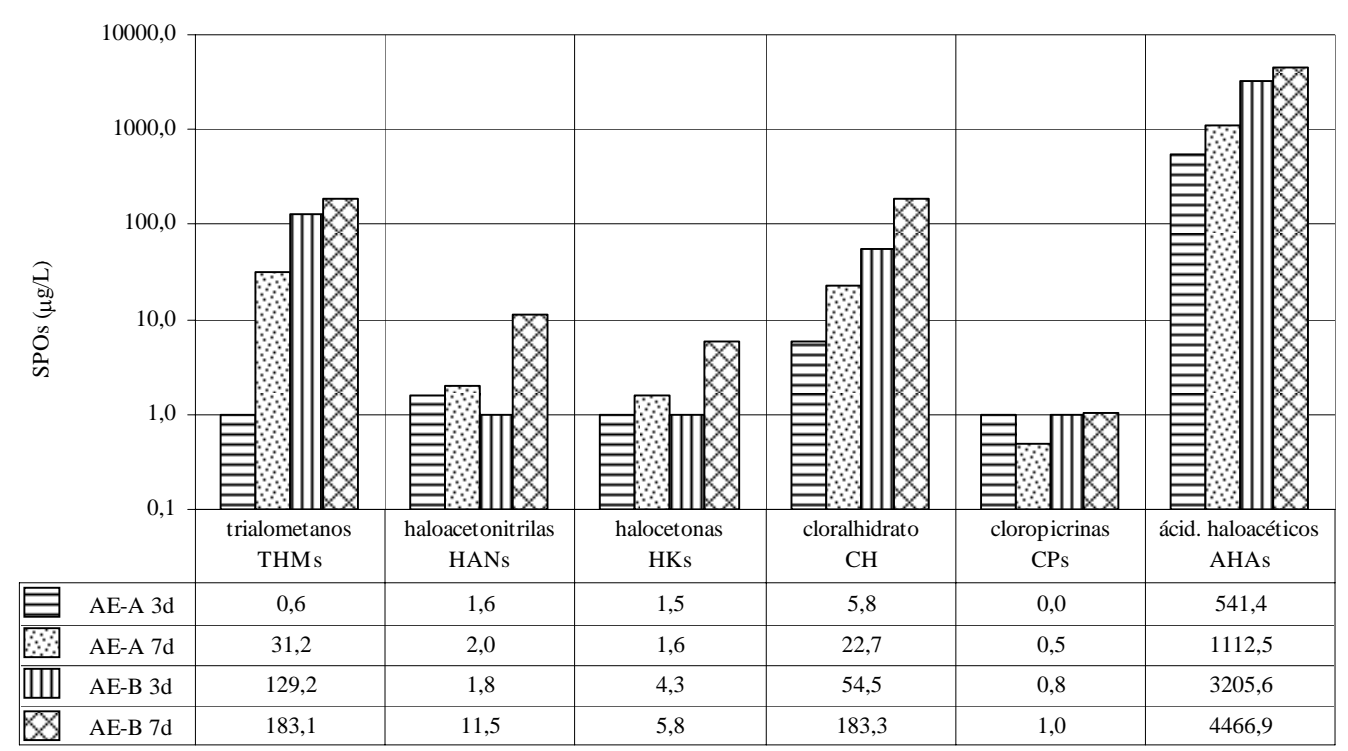

Figura 5.2.10 - Valores do potencial de formação de subprodutos organohalogenados - PFSPOs das águas de estudo AEA e AE-B, para os tempos de contato de 3 e 7 dias a $25^{\circ} \mathrm{C}$ 


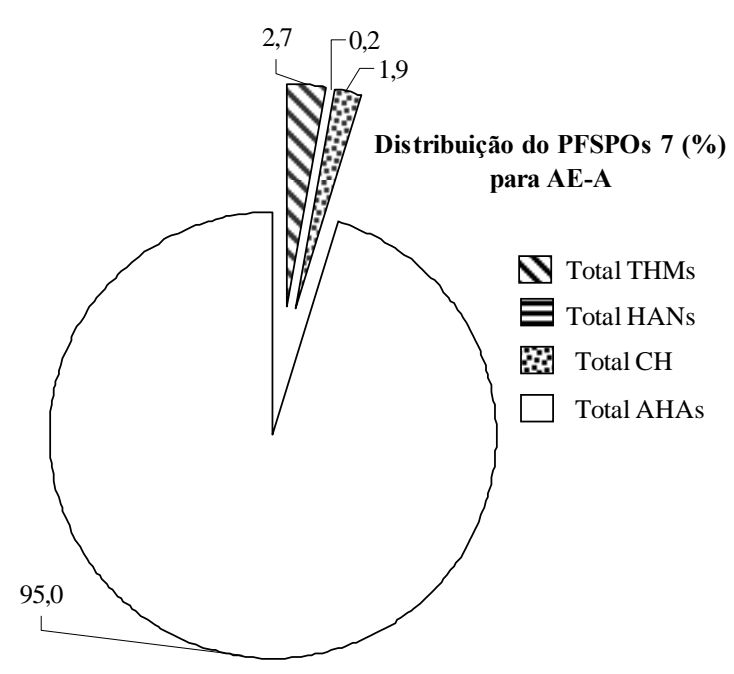

a) AE-A

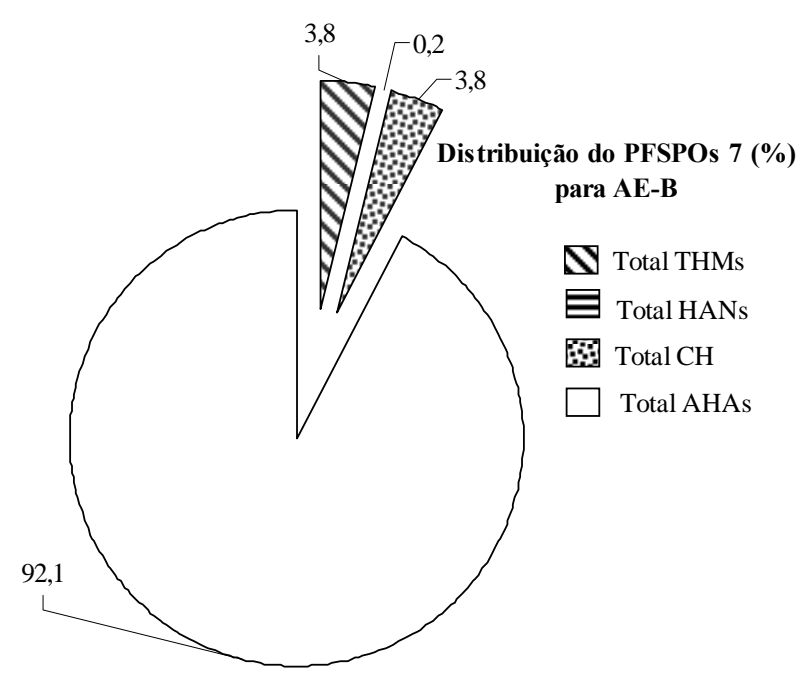

a) AE-B

Figura 5.2.11 - Resultados de PFSPOs de 7 dias obtidos para as águas de estudo AE-A e AE-B.

PASCHOALATO (2005) determinou o PFSPOs de 7 dias para água com cor verdadeira de 200 uH, preparada por meio de adição de substância húmica extraída de turfa, sob condições experimentais similares e obteve a seguinte distribuição: ácidos haloacéticos

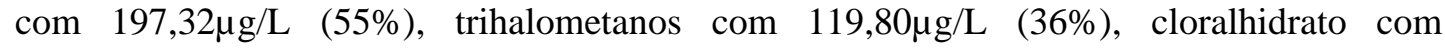

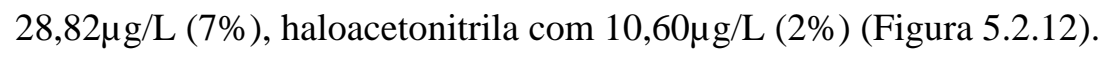

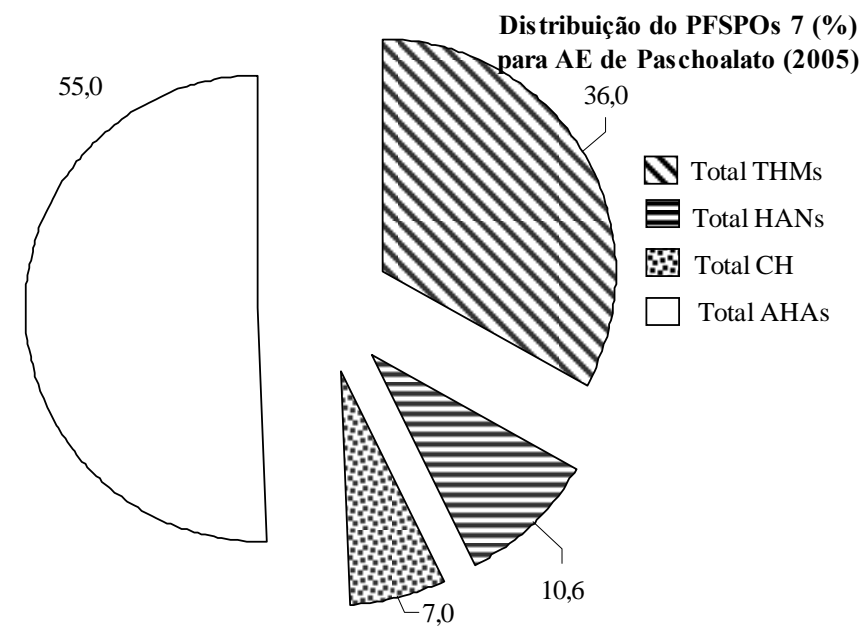

Figura 5.2.12 - Resultados de PFSPOs de 7 dias obtidos para a AE de Paschoalato (2005)

Esses dados sugerem que a formação preferencial de determinados tipos de SPOs depende diretamente da constituição dos precursores presentes na água. 


\subsection{META 4: OBTENÇÃO DE PARÂMETROS OPERACIONAIS EM ENSAIOS DE FILTRAÇÃO DIRETA EM BANCADA}

Conforme já relatado, as séries dos ensaios foram estabelecidas em função do lote preparado de água de estudo, sendo as principais características das águas de estudo de cada série, apresentadas de forma resumida, na Tabela 5.3.1.

Tabela 5.3.1 - Principais características físicas, químicas e microbiológicas das águas de estudo utilizadas

\begin{tabular}{c|c|c|c|c|c|c|c}
\hline \multirow{2}{*}{ Parâmetros } & \multicolumn{7}{c}{ Águas de Estudo } \\
\cline { 2 - 8 } & $\begin{array}{c}\text { Série A } \\
\text { AE-A }\end{array}$ & $\begin{array}{c}\text { Série B } \\
\text { AE-B }\end{array}$ & $\begin{array}{c}\text { Série C } \\
\text { AE-C }\end{array}$ & $\begin{array}{c}\text { Série D } \\
\text { AE-D }\end{array}$ & $\begin{array}{c}\text { Série E } \\
\text { AE-E }\end{array}$ & $\begin{array}{c}\text { Série F } \\
\text { AE-F }\end{array}$ & $\begin{array}{c}\text { Série G } \\
\text { AE-G }\end{array}$ \\
\hline Turbidez (uT) & 5,18 & 4,43 & 2,86 & 2,35 & 2,37 & 4,32 & 11,5 \\
\hline Temperatura $\left({ }^{\circ} \mathrm{C}\right)$ & 24,0 & 22,0 & 24,0 & 24,0 & 24,0 & 24,0 & 25,0 \\
\hline $\mathrm{pH}$ & 6,53 & 6,10 & 5,70 & 6,63 & 5,94 & 5,83 & 6,15 \\
\hline $\begin{array}{c}\text { Alumínio Residual } \\
(\mathrm{mg} / \mathrm{L})\end{array}$ & - & - & 0,33 & - & 0,026 & 0,026 & 0,12 \\
\hline $\begin{array}{c}\text { Alcalinidade } \\
(\mathrm{mg} \text { CaCO } / \mathrm{mL})\end{array}$ & 6,44 & 4,60 & 4,00 & 7,00 & 3,50 & 4,00 & 6,48 \\
\hline Condutividade $(\mathrm{mS} / \mathrm{cm})$ & 20,50 & 21,80 & 31,00 & 33,80 & 27,00 & 28,60 & 46,50 \\
\hline Potencial Zeta $(\mathrm{mV})$ & $-23,30$ & $-21,50$ & $-17,40$ & $-17,40$ & $-16,00$ & $-16,30$ & $-15,3$ \\
\hline Cor Aparente $(\mathrm{uH})$ & 33,00 & 26,00 & 12,00 & 12,00 & 9,00 & 18,00 & - \\
\hline Cor Verdadeira $(\mathrm{uH})$ & $<1$ & $<1$ & $<1$ & - & - & - & - \\
\hline $\begin{array}{c}\text { COT }(\mathrm{mg} / \mathrm{L}) \\
\text { Absorbância }(254 \mathrm{~nm})\end{array}$ & 3,748 & 2,098 & 2,396 & 3,421 & 3,255 & 3,473 & 2,370 \\
\hline $\begin{array}{c}\text { Densidade } M . \mathrm{spp} \\
(\mathrm{cel} / \mathrm{mL})\end{array}$ & $1,5 \times 10^{5}$ & $5,9 \times 10^{4}$ & $6,3 \times 10^{4}$ & $2,1 \times 10^{5}$ & $2,1 \times 10^{5}$ & $2,1 \times 10^{5}$ & $2,0 \times 10^{5}$ \\
\hline $\begin{array}{c}\text { Partículas } \\
(1 \text { a } 10 \mu \mathrm{m}) / \mathrm{mL}\end{array}$ & $2,08 \mathrm{E}+05$ & $1,86 \mathrm{E}+05$ & - & $6,40 \mathrm{E}+04$ & - & - & $1,3 \mathrm{E}+05$ \\
\hline AE-i: refere-se à água de estudo da série i.
\end{tabular}

Em função da quantidade de dados relativos aos ensaios realizados para determinação das condições de coagulação química para as águas de estudo, apresenta-se a seguir a síntese dos objetivos e resultados correspondentes dos principais ensaios de coagulação química seguida de filtração em filtros de laboratório de areia - FLAs.

Ensaios da série A: ensaios (1 e 2 / Série A) de coagulação química seguida de filtração em FLAs realizados para avaliação da influência da dosagem do coagulante químico - sulfato de alumínio utilizado na ETASC 2, com dosagens entre 0 e 5,5 $\mathrm{mg}\left(\mathrm{Al}_{2}\left(\mathrm{SO}_{4}\right)_{3} \times 14,3 \mathrm{H}_{2} \mathrm{O}\right) / \mathrm{L}$.

As condições selecionadas para a coagulação química foram: dosagem de alumínio $\mathrm{DAl}=0,23 \mathrm{mg} / \mathrm{L}$ (dosagem de sulfato de alumínio DSA = 2,5 $\mathrm{mg} \mathrm{Al} \mathrm{Al}_{2}\left(\mathrm{SO}_{4}\right)_{3} \times 14,3 \mathrm{H}_{2} \mathrm{O} / \mathrm{L}$ ), $\mathrm{pH}$ de coagulação $=6,18$; potencial zeta da água coagulada $=+0,6 \mathrm{mV}$; efluente filtrado com turbidez $=0,17 \mathrm{uT}$, número de partículas entre 1 e $10 \mu \mathrm{m}=660 \mathrm{part} / \mathrm{mL}$, densidade de Microcystis spp. $=613 \mathrm{cel} / \mathrm{mL}$ (com emprego do FLA 1 - areia com tamanho dos grãos entre $0,30$ e $0,59 \mathrm{~mm})$. 
Ensaios da série B: ensaios (1 e 2 / Série B) de coagulação química seguida de filtração em FLAs 1, realizados para avaliação da reprodutibilidade do preparo da água de estudo e dos melhores resultados obtidos nos ensaios da série A.

A variação de densidade de Microcystis spp. de 1,5 × $10^{5} \mathrm{cel} / \mathrm{mL}$ (água de estudo da série A) para 5,9 × $10^{4}$ (água de estudo da série B) foi suficiente para alterar as condições de coagulação química devido os baixos valores do pH de coagulação $(5,7)$ e valores positivos do potencial zeta da água coagulada $(+7,0 \mathrm{mV})$.

Comparando-se os resultados dos ensaios da série A e B, observou-se que a aplicação das condições de coagulação obtidas nos ensaios da série A, na água de estudo da série $\mathrm{B}$, conduziu à produção de efluentes filtrados com qualidade similar em relação aos parâmetros físicos e químicos, porém, com densidade de Microcystis spp. significativamente menor para a condição selecionada (30 cel/mL, com emprego do FLA 1).

Continuação dos ensaios da série B: ensaio 3 / Série B de coagulação química seguida de filtração para a condição de coagulação selecionada nos ensaios 1 e 2 / Série B, realizado para avaliar a influência de 3 diferentes granulometrias FLA1, FLA2 e FLA3 e ensaios 4 / Série B, de caráter proscpectivo, utilizando filtros com carvão ativado granular como póstratamento aos efluentes do ensaio 3 / Série B.

Ensaios da série C: ensaios (1 a 7 / Série C) de coagulação química seguida de filtração em FLAs realizados para determinação das condições de coagulação química sem adição de alcalizante ou acidificante para diferentes tipos de coagulantes a base alumínio (7 tipos especificados no Item 4.4.2).

As condições de coagulação selecionadas para os diferentes tipos de coagulantes corresponderam a valores de pH de coagulação da ordem de 6,3 a 6,5 e dosagem de alumínio entre 0,09 e $0,14 \mathrm{mg} / \mathrm{L}$ para todos os coagulantes testados. As dosagens dos produtos comerciais variaram entre $1,13 \mathrm{mg} / \mathrm{L}$, para a solução comercial de hidróxi-cloreto de alumínio líquido com 22,6 \% de $\mathrm{Al}_{2} \mathrm{O}_{3}$, e 4,25 mg/L para as soluções comerciais de sulfato de alumínio com $6,0 \%$ de $\mathrm{Al}_{2} \mathrm{O}_{3}$.

Ensaios da série D: (8 / Série D) ensaios de coagulação química seguida de filtração em FLAs realizados para reprodução dos melhores resultados obtidos para cada tipo de coagulante nos ensaios realizados previamente na série C.

As densidades de células de Microcystis spp. dos efluentes filtrados variaram entre 20 e $1159 \mathrm{cel} / \mathrm{mL}$ e os melhores resultados corresponderam ao emprego dos coagulantes tipo 4 (solução comercial de hidroxicloreto de alumínio líquido com 10,7 \% de $\mathrm{Al}_{2} \mathrm{O}_{3}$ ) com 75 
cel/mL e tipo 7 (solução comercial de sulfato de alumínio com 7,2 \% de $\mathrm{Al}_{2} \mathrm{O}_{3}$ ) com 20 cel/mL. Apresentam-se na Tabela 5.3.2, os resultados obtidos no ensaio e nas Figuras 5.3.1 a

5.3.3, as principais representações gráficas correspondentes.

Tabela 5.3.2 - Resultados do ensaio realizado para reprodução das melhores condições de coagulação obtidas para cada tipo de coagulante (Ensaio 8 / Série D)

\begin{tabular}{c|c|c|c|c|c|c|c}
\hline Parâmetros & Jarro 1 & Jarro 2 & Jarro 3 & Jarro 4 & Jarro 5 & Jarro 6 & Jarro 7 \\
\hline Dosagem de alumínio (mg/L) & 0,14 & 0,14 & 0,14 & $\mathbf{0 , 1 4}$ & 0,14 & 0,14 & $\mathbf{0 , 1 4}$ \\
\hline Dosagem do produto comercial (mg/L) & 4,25 & 4,25 & 2,32 & $\mathbf{2 , 3 9}$ & 1,46 & 1,13 & $\mathbf{3 , 5 5}$ \\
\hline pH coagulação & 6,29 & 6,36 & 6,38 & $\mathbf{6 , 4 2}$ & 6,34 & 6,43 & $\mathbf{6 , 4 8}$ \\
\hline Potencial Zeta água coagulada (mV) & $-2,10$ & $-1,80$ & 2,10 & $\mathbf{- 1 , 3 0}$ & 2,50 & $-0,30$ & $\mathbf{0 , 0 0}$ \\
\hline Turbidez do efluente filtrado (uT) & 0,24 & 0,22 & 0,28 & $\mathbf{0 , 2 2}$ & 0,24 & 0,31 & $\mathbf{0 , 2 1}$ \\
\hline Cor aparente do efluente filtrado (uH) & $<1$ & $<1$ & $<1$ & $<\mathbf{1}$ & $<1$ & $<1$ & $<\mathbf{1}$ \\
\hline COT do efluente filtrado (mg/L) & 1,826 & 1,591 & 1,896 & $\mathbf{1 , 4 1 7}$ & 1,397 & 1,654 & $\mathbf{1 , 6}$ \\
\hline $\begin{array}{c}\text { Absorv. (254 nm) do efluente filtrado } \\
\text { Densidade Microcystis spp. do efluente } \\
\text { filtrado (cel/mL) }\end{array}$ & 0,028 & 0,021 & 0,020 & $\mathbf{0 , 0 2 2}$ & 0,026 & 0,023 & $\mathbf{0 , 0 2 3}$ \\
\hline $\begin{array}{c}\left.\mathrm{N}^{\circ} \text { Partículas (entre 1 e 10 } \mu \mathrm{m}\right) / \mathrm{mL} \text { do } \\
\text { efluente filtrado }\end{array}$ & 191 & 95 & 218 & $\mathbf{7 5}$ & 1159 & 460 & $\mathbf{2 0}$ \\
\hline
\end{tabular}

Jarro i (i $=1$ a 7 , conforme especificações apresentadas no Item 4.4.2): refere-se à aplicação do coagulante tipo i. 

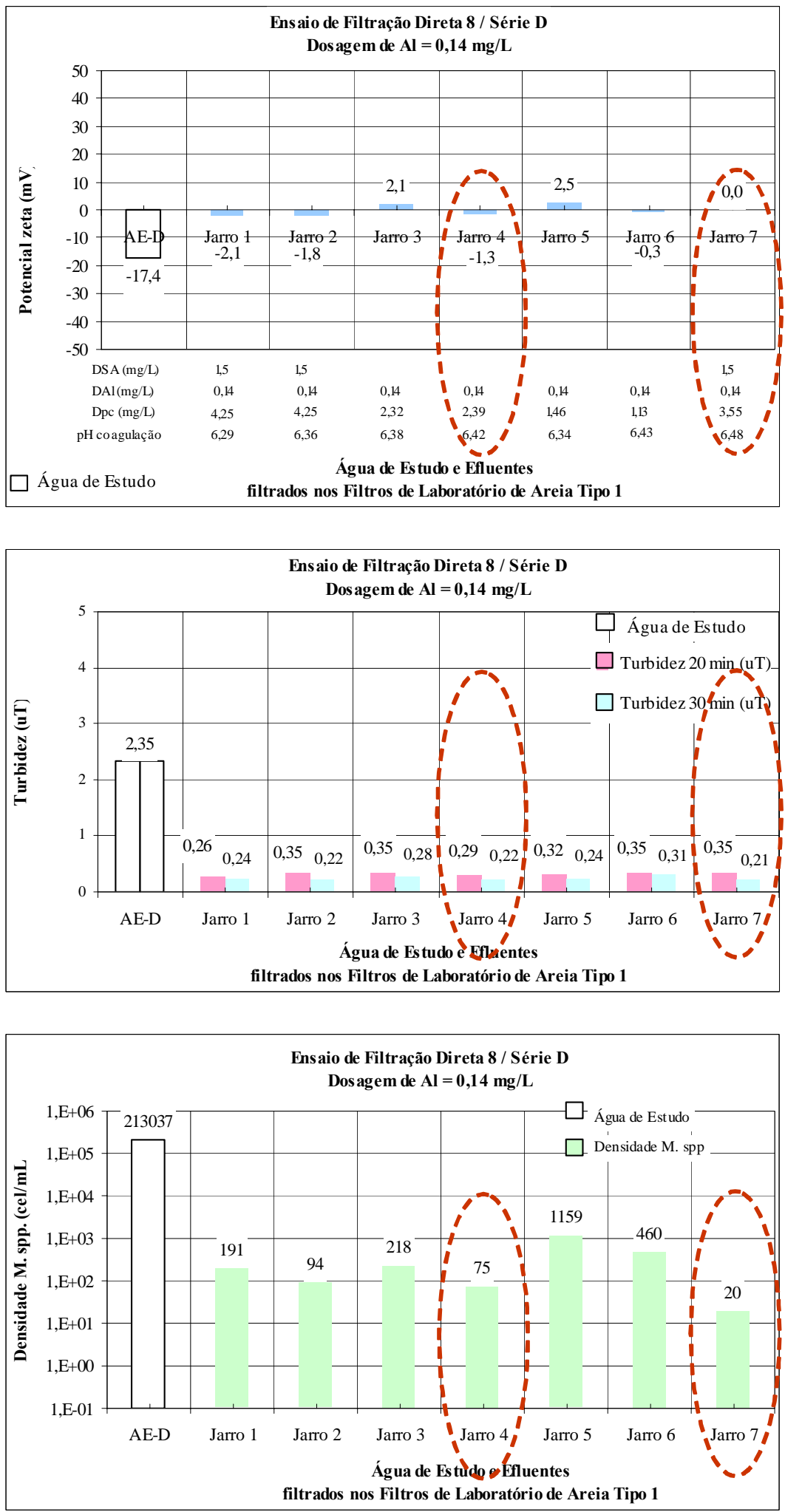

Figura 5.3.1 - Condições de coagulação, turbidez e densidade de M.spp do Ensaio 8 / Série D DSA: dosagem de $\mathrm{Al}_{2}(\mathrm{SO} 4)_{3} \times 14,3 \mathrm{H}_{2} \mathrm{O}$; DAl: dosagem de Al; Dpc: dosagem do prod. comercial 

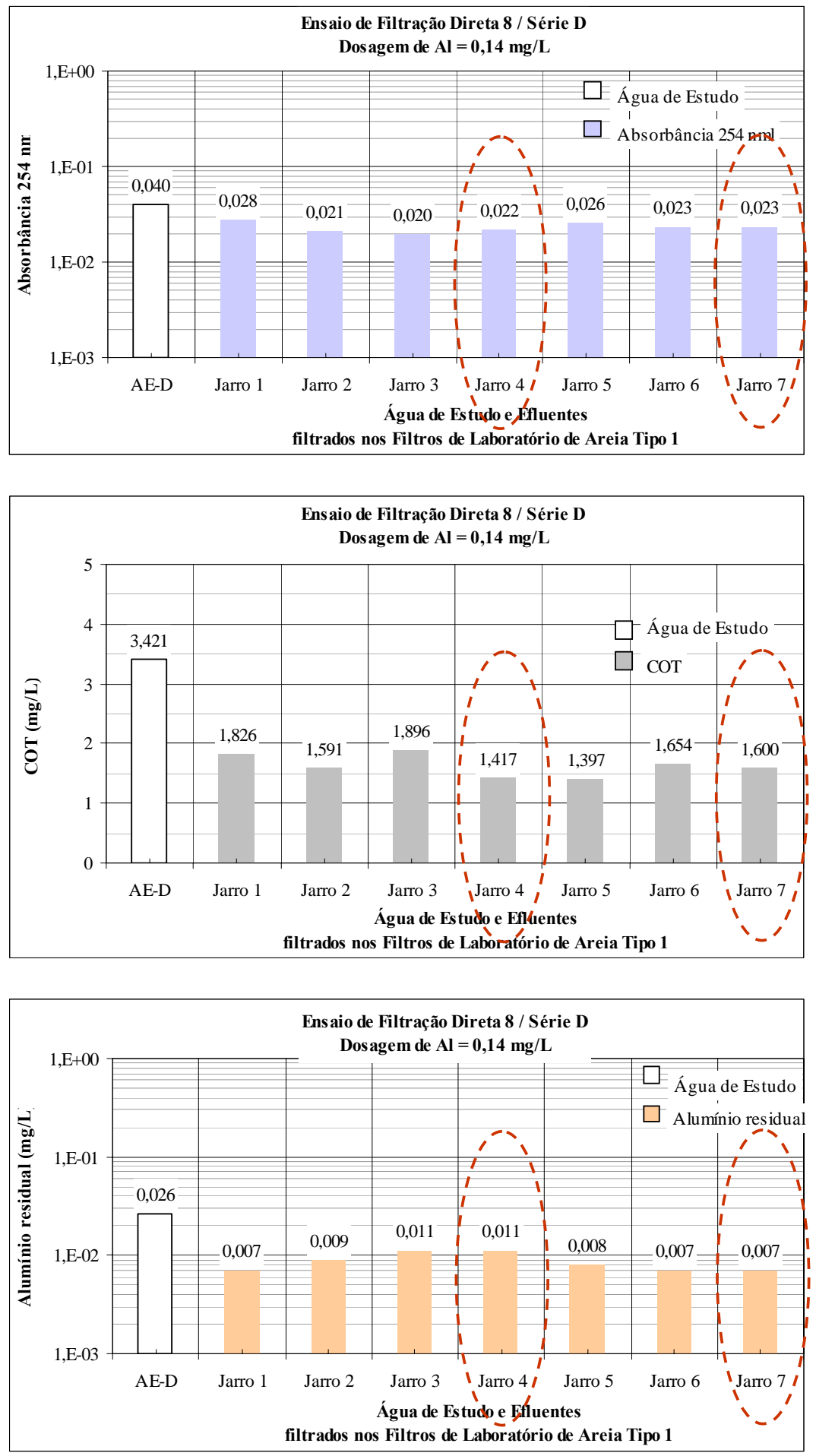

Figura 5.3.2 - Absorvância 254 nm, carbono orgânico total e alumínio residual do Ensaio 8 / Série D DSA: dosagem de $\mathrm{Al}_{2}(\mathrm{SO} 4)_{3} \times 14,3 \mathrm{H}_{2} \mathrm{O}$; DAl: dosagem de $\mathrm{Al}$; Dpc: dosagem do prod. comercial 

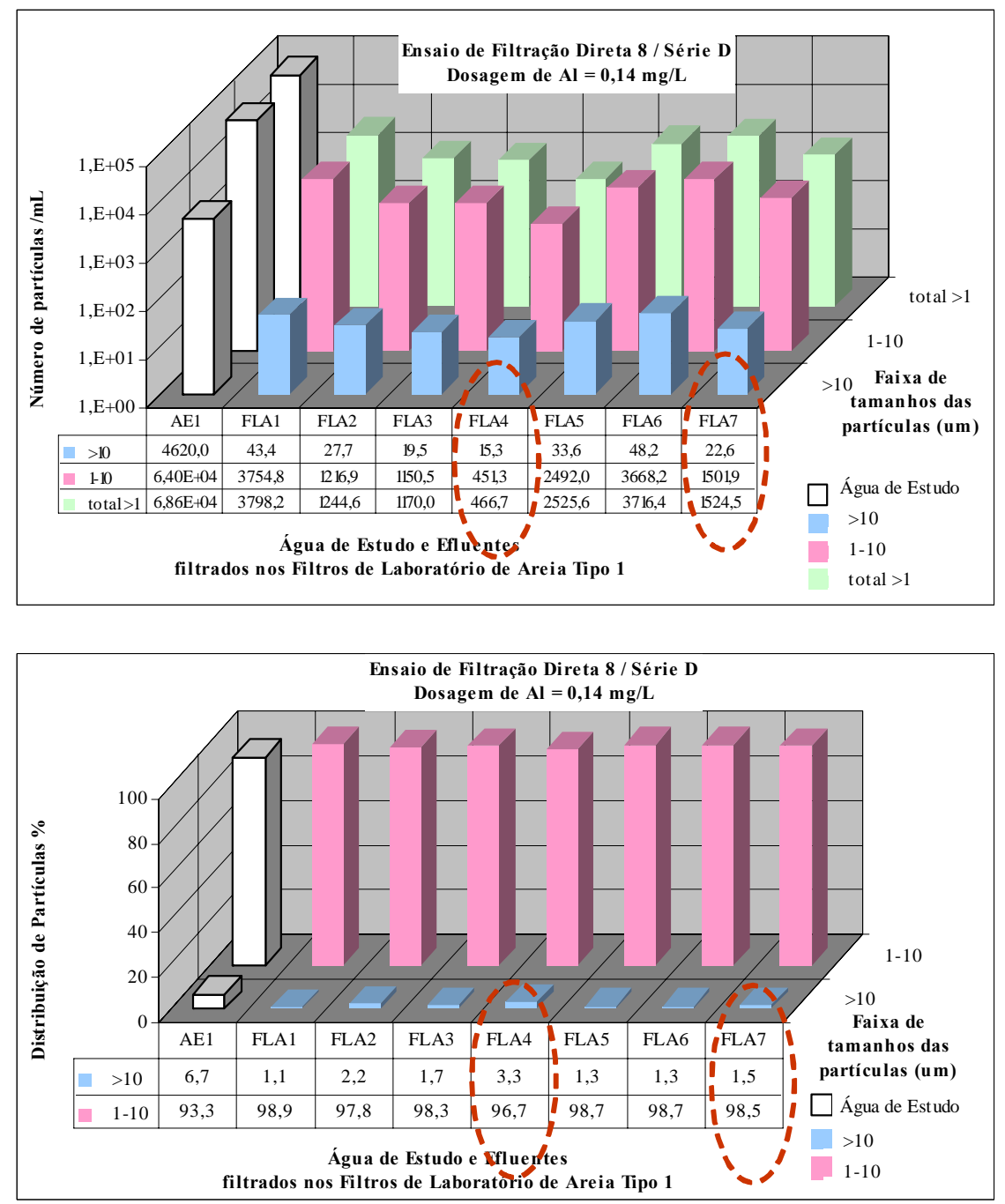

Figura 5.3.3 - Número e distribuição de partículas do Ensaio 8 / Série D

DSA: dosagem de $\mathrm{Al}_{2}(\mathrm{SO} 4)_{3} \times 14,3 \mathrm{H}_{2} \mathrm{O}$; DAl: dosagem de Al; Dpc: dosagem do prod. comercial

Ensaios das séries E e F: ensaios de coagulação química seguida de filtração em FLAs 1, realizados com o objetivo de avaliar a influência da variação do pH (da ordem de 5,8) (Ensaio 9 / Série E) e da turbidez (da ordem de 5,0) (Ensaio 10 / Série F) da água de diluição, utilizando-se as condições de coagulação selecionadas previamente nos ensaios das séries C e D. Em função dos resultados obtidos nos ensaios da série C e D, o coagulante tipo 5 foi descartado neste estudo.

Considerando as variações das características da água de diluição observadas nas diversas coletas realizadas, mais especificamente, em relação aos valores de pH (baixo) e de turbidez (elevado), foram obtidos valores de turbidez do efluente filtrado (valor máximo de 0,64 uT) superiores aos obtidos para as condições otimizadas (Ensaio 8D, Tabela 5.3.2), porém, de qualidade aceitável em relação ao limite estabelecido pela Portaria MS/518/2004 de 1,0 uT. No entanto, a análise dos demais parâmetros e especialmente de densidade de 
Microcystis spp. e da distribuição de partículas, refletem claramente a perda de eficiência ocorrida (Tabelas 5.3.3.e 5.3.4). Este fato comprova a necessidade e importância do emprego de parâmetros mais diretos em relação aos comumente utilizados, como turbidez e cor, para avaliação do desempenho das tecnologias de tratamento para a água de estudo em questão.

Em função dessa constatação, foram providenciados reservatórios para água filtrada sem cloração da ETASC 2 com capacidade suficiente para suprir a demanda prevista para cada ensaio em instalação piloto - IP, e desta forma, eliminar as possíveis interferências causadas pela variação da qualidade de água de diluição.

Tabela 5.3.3 - Ensaio para avaliar a influência da variação das características da água de diluição (pH baixo) (Ensaio 9 / Série E)

\begin{tabular}{c|c|c|c|c|c|c}
\hline Parâmetros & Jarro 1 & Jarro 2 & Jarro 3 & Jarro 4 & Jarro 6 & Jarro 7 \\
\hline Dosagem de alumínio (mg/L) & 0,14 & 0,14 & 0,14 & 0,14 & 0,14 & 0,14 \\
\hline Dosagem do produto comercial (mg/L) & 4,25 & 4,25 & 2,39 & 1,46 & 1,13 & 2,32 \\
\hline pH coagulação & 5,56 & 5,56 & 5,77 & 5,81 & 5,84 & 5,61 \\
\hline Potencial Zeta água coagulada (mV) & $-5,4$ & $-3,1$ & 0,4 & 5,3 & $-9,3$ & $-7,0$ \\
\hline Turbidez do efluente filtrado (uT) & 0,57 & 0,33 & 0,33 & 0,31 & 0,39 & 0,45 \\
\hline COT do efluente filtrado (mg/L) & 1,071 & 1,14 & 1,425 & 0,809 & 0,864 & 1,093 \\
\hline Absorv. (254 nm) do efluente filtrado & 0,029 & 0,027 & 0,028 & 0,028 & 0,031 & 0,028 \\
\hline $\begin{array}{c}\text { Densidade Microcystis spp. do efluente } \\
\text { filtrado (cel/mL) }\end{array}$ & 4920,2 & 2975,3 & 1790,3 & 1816,1 & 1964,2 & 6684,8 \\
\hline
\end{tabular}

Jarro i (i = 1 a 7, conforme especificações apresentadas): refere-se à aplicação do coagulante tipo i.

Tabela 5.3.4 - Ensaio para avaliar a influência da variação das características da água de diluição (turbidez elevada) (Ensaio 10 / Série F)

\begin{tabular}{c|c|c|c|c|c|c}
\hline Parâmetros & Jarro 1 & Jarro 2 & Jarro 3 & Jarro 4 & Jarro 6 & Jarro 7 \\
\hline Dosagem de alumínio (mg/L) & 0,14 & 0,14 & 0,14 & 0,14 & 0,14 & 0,14 \\
\hline Dosagem do produto comercial (mg/L) & 4,25 & 4,25 & 2,39 & 1,46 & 1,13 & 2,32 \\
\hline pH coagulação & 6,51 & 6,26 & 6,03 & 5,97 & 5,88 & 6,12 \\
\hline Potencial Zeta água coagulada (mV) & $-4,00$ & $-4,00$ & 1,60 & 2,00 & $-0,90$ & $-5,40$ \\
\hline Turbidez do efluente filtrado (uT) & 0,40 & 0,46 & 0,64 & 0,64 & 0,54 & 0,46 \\
\hline COT do efluente filtrado (mg/L) & 1,573 & 1,759 & 0,91 & 1,582 & 1,73 & 1,78 \\
\hline Absorv. (254 nm) do efluente filtrado & 0,037 & 0,038 & 0,036 & 0,036 & 0,037 & 0,037 \\
\hline $\begin{array}{c}\text { Densidade Microcystis spp. do efluente } \\
\text { filtrado (cel/mL) }\end{array}$ & 6762,1 & 8629,7 & 15275,8 & 9595,7 & 3460,5 & 8166,0 \\
\hline
\end{tabular}

Jarro i (i = 1 a 7, conforme especificações apresentadas): refere-se à aplicação do coagulante tipo i.

Baseado nos estudos preliminares apresentados, os ensaios de bancada para determinação das condições de coagulação química, aplicadas nos experimentos em escoamento contínuo, na instalação piloto de dupla filtração (Ensaios da série G), foram realizados com o coagulante tipo 7 - sulfato de alumínio, devido ao seu largo emprego nas Estações de Tratamento de Água - ETAs do Brasil e por apresentar menor custo em relação aos demais coagulantes estudados. 
Ensaios da série G: ensaios ( 1 a 14 / Série G) de coagulação química com o coagulante tipo 7 (solução comercial de sulfato de alumínio com 7,2 \% de $\mathrm{Al}_{2} \mathrm{O}_{3}$ e massa específica =1,304 kg/L) com adição de alcalinizante ou acidificante para ajuste do pH de coagulação, seguida de filtração em FLAs realizados para determinação das condições de coagulação química, a serem aplicadas nos experimentos em escoamento contínuo, na instalação piloto de dupla filtração.

Para realização dos ensaios da série $G$, foram preparados novos materiais granulares para preenchimento dos Filtros de Laboratório de Areia - FLAs mantendo-se as faixas granulométricas correspondentes a cada tipo de areia, de acordo com as curvas granulométricas apresentadas na Figura 5.3.4.

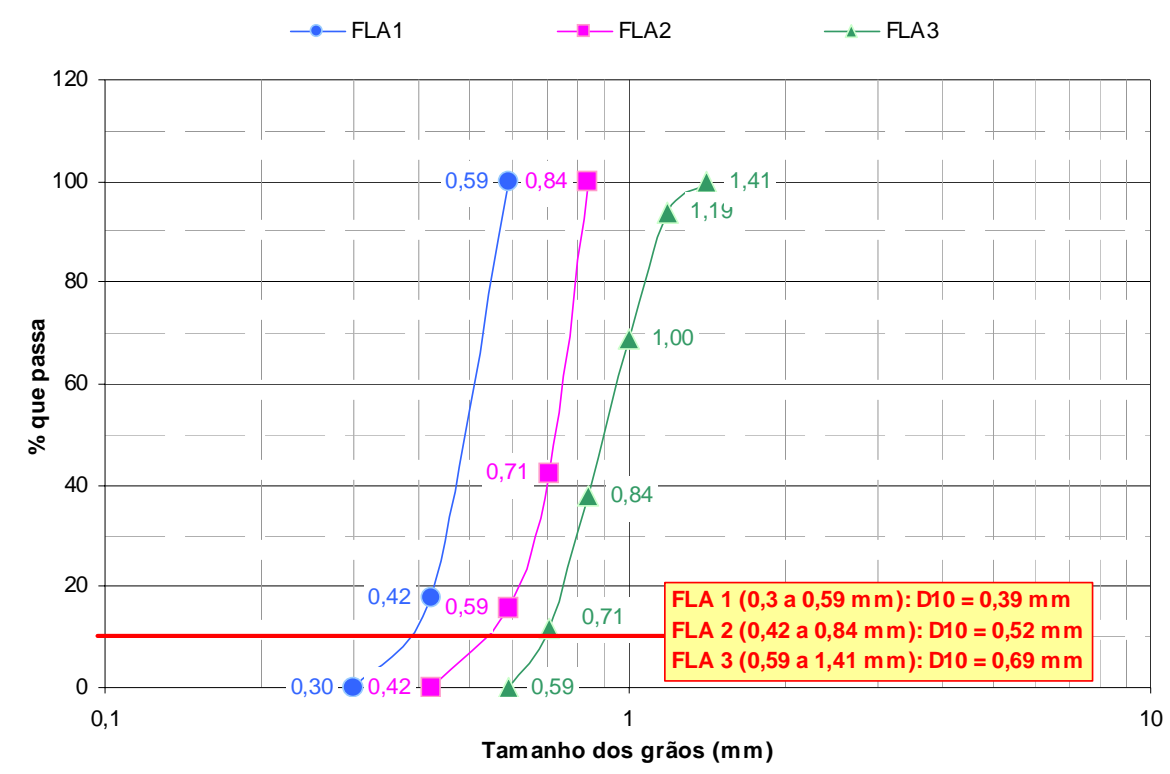

Figura 5.3.4- Curvas de distribuição granulométrica preparadas para os FLAs

Testes preliminares com a areia tipo 1 para a água de estudo preparada, indicaram a ocorrência de retenção superficial nos FLAs 1, inviabilizando seu uso, pois, a variação das condições de coagulação não era refletida na qualidade dos efluentes produzidos em relação aos parâmetros de qualidade medidos. Assim, os ensaios da série $G$ foram realizados com a areia tipo 2.

Foram preparados $250 \mathrm{~L}$ de água de estudo AE-G em tanque de polietileno. Os ensaios da série $G$ foram realizados no prazo de 2 dias, tendo sido verificada a manutenção das principais características da água de estudo. Os ensaios foram realizados à temperatura de $23 \pm 1,0^{\circ} \mathrm{C}$. As principais características da água de estudo - AE-G encontram-se apresentadas na Tabela 5.3.1. 
Na Tabela 5.3.5 são apresentados os valores de correlação obtidos para os efluentes filtrados entre os parâmetros analisados, para cada dosagem de coagulante aplicado.

Tabela 5.3.5 - Valores de correlação obtidos entre os parâmetros analisados para efluentes filtrados, fixando-se a dosagem de coagulante e variando-se o $\mathrm{pH}$

\begin{tabular}{|c|c|c|c|c|c|}
\hline \multicolumn{2}{|c|}{ Dosagem (mg/L) } & \multicolumn{4}{|c|}{ Correlação } \\
\hline Alumínio & $\begin{array}{c}\mathrm{Al}_{2}\left(\mathrm{SO}_{4}\right)_{3} \\
\times \\
\left.14,3 \mathrm{H}_{2} \mathrm{O}\right)\end{array}$ & $\begin{array}{c}\text { Turbidez } \\
(\mathrm{uT}) \\
\times \\
\mathrm{N}^{\mathrm{o}} \text { partíc. } \\
(1 \mathrm{a} 10 \mu \mathrm{m}) / \mathrm{mL}\end{array}$ & $\begin{array}{c}\text { Turbidez } \\
\text { (uT) } \\
\times \\
\text { Densidade } M \text {. spp. } \\
\text { (cel } / \mathrm{mL} \text { ) }\end{array}$ & $\begin{array}{c}\mathrm{N}^{\mathrm{o}} \text {. partíc. } \\
(1 \mathrm{a} 10 \mu \mathrm{m}) / \mathrm{mL} \\
\times \\
\text { Densidade } M . \text { spp. } \\
\text { (cel/mL) }\end{array}$ & $\begin{array}{c}\text { Absorvância } \\
\text { 254nm } \\
\times \\
\text { Carbono Orgânico } \\
\text { Total }(\mathrm{mg} / \mathrm{L}) \\
\end{array}$ \\
\hline \multirow{2}{*}{0,09} & \multirow{2}{*}{1,0} & $\mathrm{R}=0,977$ & 0,961 & 0,939 & 0,431 \\
\hline & & $\mathrm{R}^{2}=0,955$ & 0,923 & 0,883 & 0,186 \\
\hline \multirow{2}{*}{0,18} & \multirow{2}{*}{2,0} & $\mathrm{R}=0,973$ & 0,938 & 0,927 & $-0,209$ \\
\hline & & $\mathrm{R}^{2}=0,947$ & 0,880 & 0,859 & 0,044 \\
\hline \multirow{2}{*}{0,27} & \multirow{2}{*}{3,0} & $\mathrm{R}=0,981$ & 0,903 & 0,923 & 0,847 \\
\hline & & $\mathrm{R}^{2}=0,963$ & 0,815 & 0,852 & 0,718 \\
\hline \multirow{2}{*}{0,36} & \multirow{2}{*}{4,0} & $\mathrm{R}=0,877$ & 0,533 & 0,799 & 0,124 \\
\hline & & $\mathrm{R}^{2}=0,769$ & 0,284 & 0,638 & 0,015 \\
\hline \multirow{2}{*}{0,45} & \multirow{2}{*}{5,0} & $\mathrm{R}=0,890$ & 0,767 & 0,760 & $-0,526$ \\
\hline & & $\mathrm{R}^{2}=0,792$ & 0,588 & 0,577 & 0,276 \\
\hline \multirow{2}{*}{0,54} & \multirow{2}{*}{6,0} & $\mathrm{R}=0,915$ & 0,721 & 0,779 & 0,874 \\
\hline & & $\mathrm{R}^{2}=0,837$ & 0,520 & 0,607 & 0,763 \\
\hline
\end{tabular}

Apesar da absorção UV a 254 nm ser considerada uma boa técnica para avaliar a presença de COD, os resultados obtidos de carbono orgânico total e absovância 254 nm dos efluentes filtrados apresentaram grande variabilidade e, conseqüentemente, baixa correlação e não foram apresentados no trabalho (Tabela 5.3.5), o que indica a necessidade da realização de pesquisas complementares em relação à preparação da amostra e caracterização desses parâmetros.

Analisando os resultados obtidos de forma generalizada, verificou-se que mesmo para efluentes filtrados produzidos nos ensaios de bancada sob condições diversas de coagulação química, com dosagens de alumínio entre 0,09 e 0,54 mg/L (1,0 e 6,0 mg $\left.\left(\mathrm{Al}_{2}\left(\mathrm{SO}_{4}\right)_{3} \times 14,3 \mathrm{H} 2 \mathrm{O}\right) / \mathrm{L}\right)$ e $\mathrm{pH}$ de coagulação entre 4,6 e 8,0, as correlações obtidas entre os valores de turbidez, contagem de partículas com tamanhos entre 1 e $10 \mu \mathrm{m}$ e densidade de Microcystis spp. foram satisfatórias, conforme coeficientes apresentados na Tabela 5.3.6. Porém, deve-se considerar que as características da água de estudo utilizada foram mantidas durante os ensaios, fato que raramente ocorre em situações reais de tratamento. 
Tabela 5.3.6 - Valores de correlação entre os parâmetros analisados obtidos para efluentes filtrados

\begin{tabular}{c|c|c|c}
\hline \multirow{2}{*}{ Correlação } & $\begin{array}{c}\text { Turbidez (uT) } \\
\times\end{array}$ & $\begin{array}{c}\text { Turbidez (uT) } \\
\times\end{array}$ & $\begin{array}{c}\left.\mathrm{N}^{\circ} \text {. partíc. (1 a } 10 \mu \mathrm{m}\right) / \mathrm{mL} \\
\times\end{array}$ \\
& $\mathrm{N}^{\text {o }}$ partíc. $(1 \mathrm{a} 10 \mu \mathrm{m}) / \mathrm{mL}$ & $\begin{array}{c}\text { Densidade } M . \text { spp. (cel/mL) } \\
\text { Densidade } M . \text { spp. (cel/mL) }\end{array}$ \\
\hline $\mathrm{R}$ & 0,881 & 0,786 & 0,869 \\
\hline $\mathrm{R} 2$ & 0,777 & 0,617 & 0,755 \\
\hline
\end{tabular}

FERREIRA et. al. (2003) verificaram boa correlação entre turbidez e contagem fitoplanctônica com predomínio de 73\% de Planktothrix agardhii, para águas (água bruta) do açude Gavião (CE) ( $\mathrm{R}^{2}$ entre 0,87 e 0,93). Porém, ressaltaram que a água tratada, com valores de turbidez inferiores a 1,0 uT e portanto, em conformidade à Portaria 518/MS 2004 com relação a este parâmetro, apresentou densidades de cianobactérias de até $30.000 \mathrm{cel} / \mathrm{mL}$. Vale lembrar que de acordo com o Cap.5 Art.19 § $1^{\circ}$ da referida portaria, o monitoramento de cianobactérias na água do manancial, no local de captação, deve obedecer freqüência mensal quando o número de cianobactérias não exceder $10.000 \mathrm{cel} / \mathrm{mL}$, e semanal, quando o número de cianobactérias exceder este valor, sendo vedado, no $§ 2^{\circ}$, o uso de algicidas para o controle do crescimento de cianobactérias ou qualquer intervenção no manancial que provoque a lise celular, quando a densidade das cianobactérias exceder $20.000 \mathrm{cel} / \mathrm{mL}$.

Na Figura 5.3.5 é apresentado um gráfico típico em que pode ser observada a concordância de tendência entre os valores de turbidez, número de partículas e densidade de células de Microcystis spp. dos efluentes filtrados para a dosagem de 0,45 mg/L de alumínio (5,0 mg $\left.\left(\mathrm{Al}_{2}\left(\mathrm{SO}_{4}\right)_{3} \times 14,3 \mathrm{H}_{2} \mathrm{O}\right) / \mathrm{L}\right)$ e diferentes valores de $\mathrm{pH}$. 


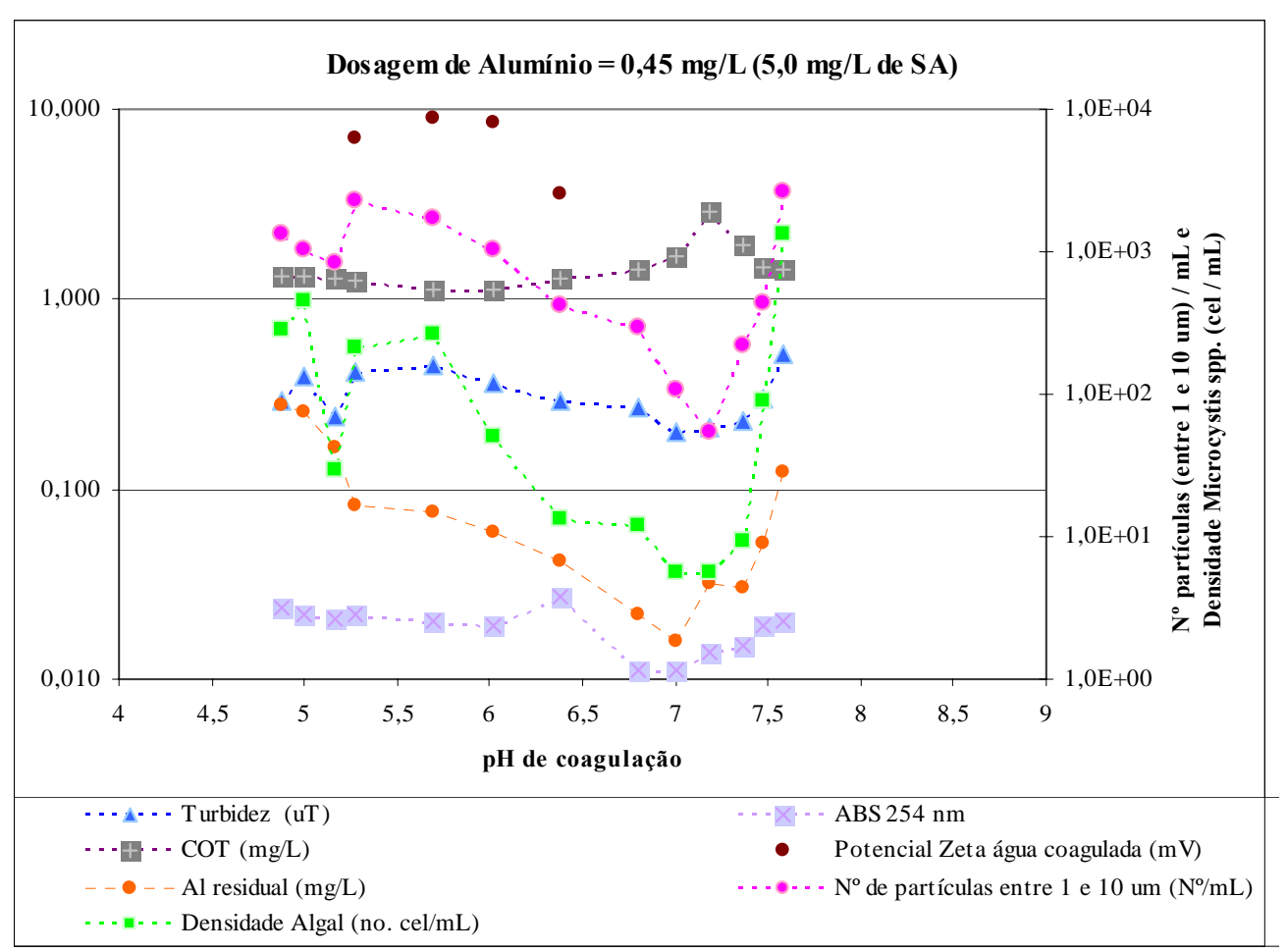

Figura 5.3.5 - Resultados de turbidez, número de partículas, potencial zeta, densidade de Microcystis spp., alumínio residual, carbono orgânico total e absorvância $254 \mathrm{~nm}$ dos efluentes filtrados para a dosagem de $0,45 \mathrm{mg} / \mathrm{L}$ de alumínio e diferentes valores de $\mathrm{pH}$.

Apresentam-se nas Figuras 5.3.6 a 5.3.10 os resultados dos ensaios da série G em forma de diagramas de coagulação química para potencial zeta da água coagulada (mV), turbidez (uT), número de partículas (1 e $10 \mu \mathrm{m}$ )/mL, densidade de Microcystis spp. (cel/mL) e alumínio residual do efluente filtrado, respectivamente.

Analisando os resultados obtidos e as Figuras 5.3.6 a 5.3.10, pôde-se distinguir basicamente, as seguintes regiões:

Região (I) (tracejada em vermelho): região em que foram obtidos os melhores resultados dos efluentes filtrados em relação à densidade de Microcystis spp. (1 a $19 \mathrm{cel} / \mathrm{mL}$ ) e número de partículas (57 a 420 part / mL). Corresponde às dosagens iguais ou superiores a 0,36 mg/L de alumínio (4,0 mg $\mathrm{Al}_{2}\left(\mathrm{SO}_{4}\right)_{3} \times 14,3 \mathrm{H}_{2} \mathrm{O} / \mathrm{L}$ ), $\mathrm{pH}$ de coagulação entre 6,5 e 7,0 (ajustado com dosagens entre 1,5 a 4,0 mg/L de $\mathrm{NaOH}$ ) e valores de potencial zeta da água coagulada entre 0 e - 8,0 mV;

Região (II): região em que foram obtidos resultados aceitáveis dos efluentes filtrados em relação à densidade de Microcystis spp. (20 a $80 \mathrm{cel} / \mathrm{mL}$ ) e número de partículas (400 a 800 part/mL). Corresponde às dosagens entre 0,18 e 0,36 mg/L de alumínio (2,0 e 4,0 mg $\mathrm{Al}_{2}\left(\mathrm{SO}_{4}\right)_{3} \times 14,3 \mathrm{H}_{2} \mathrm{O} / \mathrm{L}$ ), pH de coagulação entre 5,5 e 7,0 (ajustado com dosagens entre 0 e 2,0 mg/L de $\mathrm{NaOH}$ ) e valores de potencial zeta da água coagulada entre 0 e - 15,0 mV. 
Região (III): valores de $\mathrm{pH}$ maiores que 7,0 para dosagens de até $0,18 \mathrm{mg} / \mathrm{L}$ de alumínio (2,0 mg Al $2\left(\mathrm{SO}_{4}\right)_{3} \times 14,3 \mathrm{H}_{2} \mathrm{O} / \mathrm{L}$ ) e maiores que 7,5 para dosagens superiores a 0,18 mg/L delimitaram a região (III) correspondente à produção de efluentes filtrados com qualidade insatisfatória e com grandes variações em termos de turbidez, número de partículas (1 e 10 $\mu \mathrm{m})$ e densidade de Microcystis spp., tendo apresentado valores de até 0,6 uT; 5200 part/mL e $2274 \mathrm{cel} / \mathrm{mL}$.

Região (IV): região ampla de dosagem e valores baixos de pH de coagulação situados entre 4,6 e 5,5, produziram efluentes com valores dos parâmetros de qualidade dos efluentes filtrados intermediários entre os obtidos nas regiões II e III, o que não justifica a aplicação dessas condições de coagulação. Adicionalmente, as concentrações de alumínio residual resultaram superiores ao limite estabelecido pela Portaria 518/MS 2004 (0,2 mg/L de alumínio) para valores de pH inferiores a 5,0.

Com os resultados obtidos pela variação da dosagem de alumínio 0,09 e 0,54 mg/L (1,0 e 6,0 mg $\left.\mathrm{Al}_{2}\left(\mathrm{SO}_{4}\right)_{3} \times 14,3 \mathrm{H}_{2} \mathrm{O}\right) / \mathrm{L}$ ) sem o ajuste do $\mathrm{pH}$ de coagulação, representada nas Figuras 5.3.6 a 5.3.10 por pontos em vermelho nas regiões II e IV, verificou-se a importância da realização de ensaios de bancada com ajuste do pH de coagulação para determinação das condições de coagulação, devido às diferenças qualitativas dos filtrados entre esses pontos e aqueles obtidos com a coagulação química realizada na região I. 


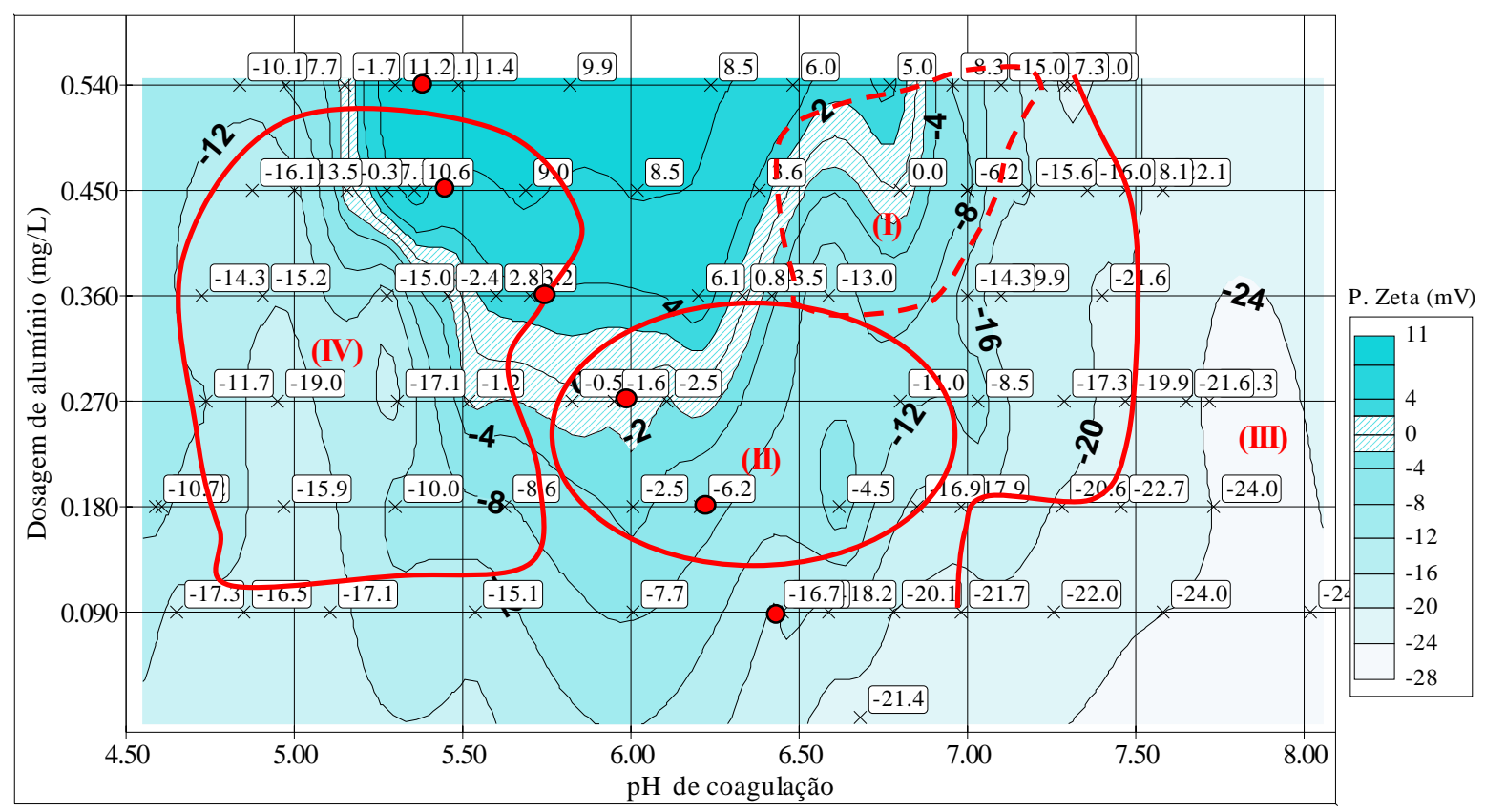

Figura 5.3.6 - Resultados dos ensaios da Série G. Diagrama de coagulação química com sulfato de alumínio / Potencial zeta $(\mathrm{mV}) .(\bullet:$ pontos sem ajuste do pH de coagulação)

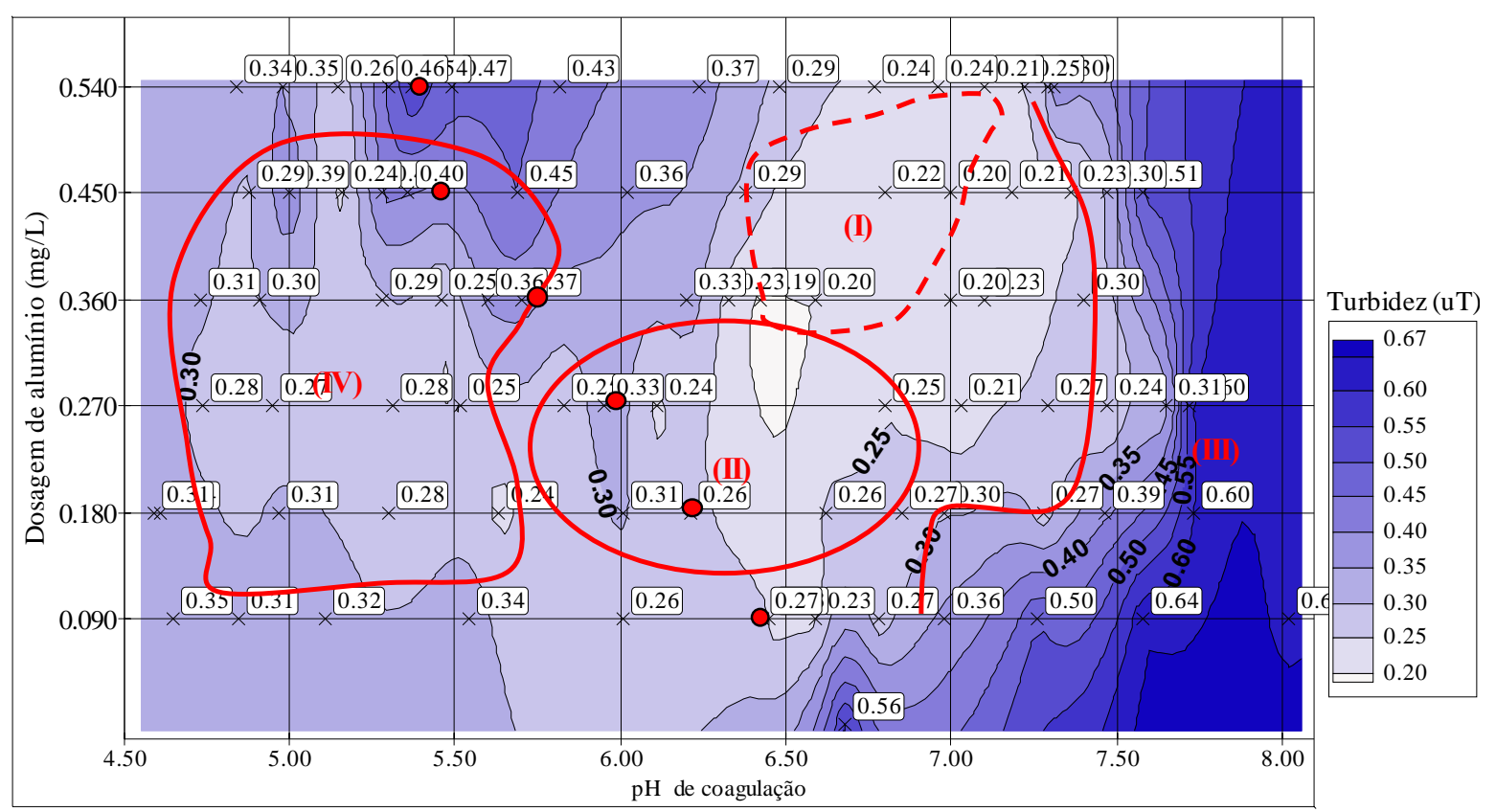

Figura 5.3.7 - Resultados dos ensaios da Série G. Diagrama de coagulação química com sulfato de alumínio / Turbidez (uT). ( • : pontos sem ajuste do pH de coagulação) 


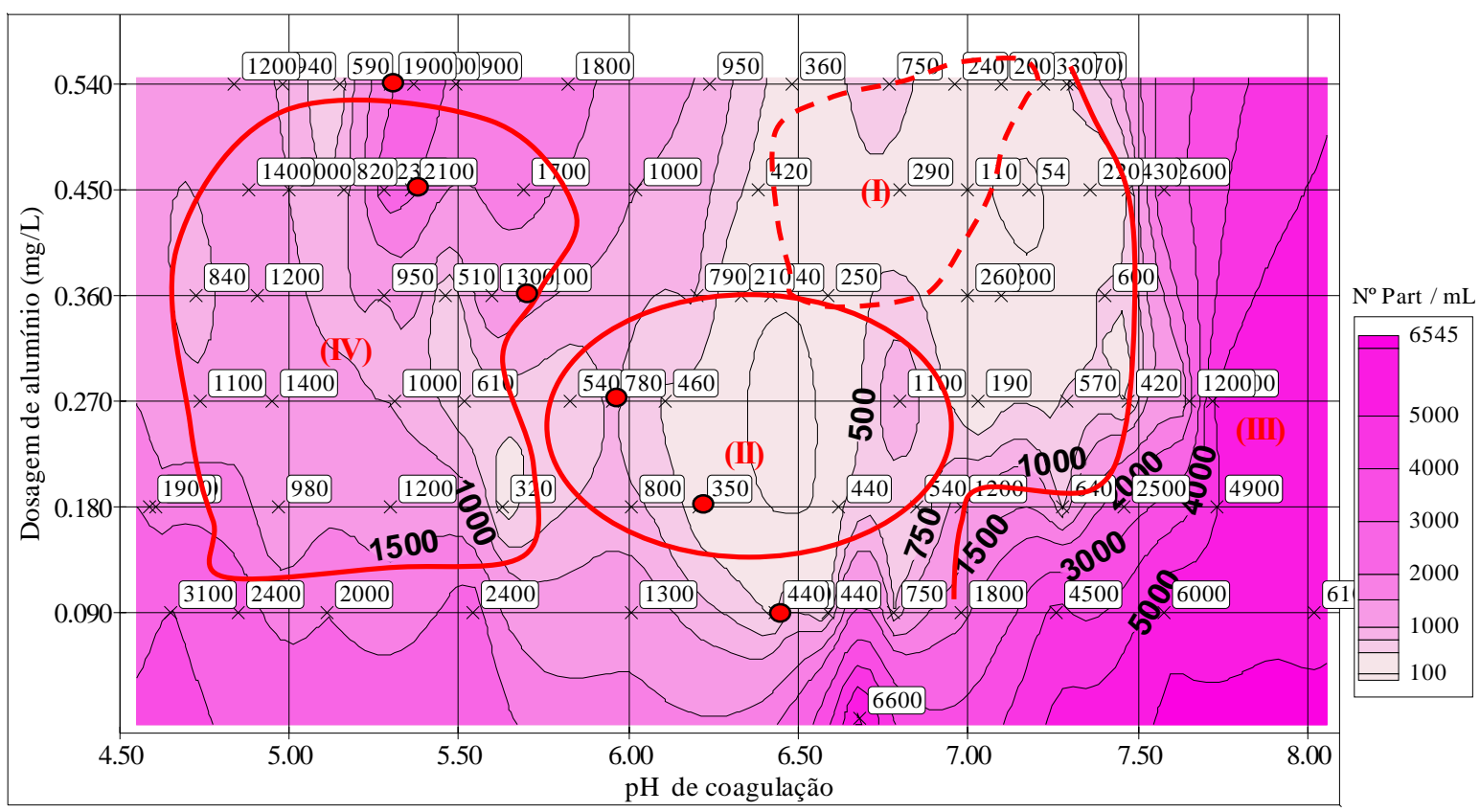

Figura 5.3.8 - Resultados dos ensaios da Série G. Diagrama de coagulação química com sulfato de alumínio / Distribuição de partículas ( $\mathrm{N}^{\circ}$ Part. $(1$ a $10 \mu \mathrm{m}) / \mathrm{mL}$ ). ( • pontos sem ajuste do $\mathrm{pH}$ de coagulação)

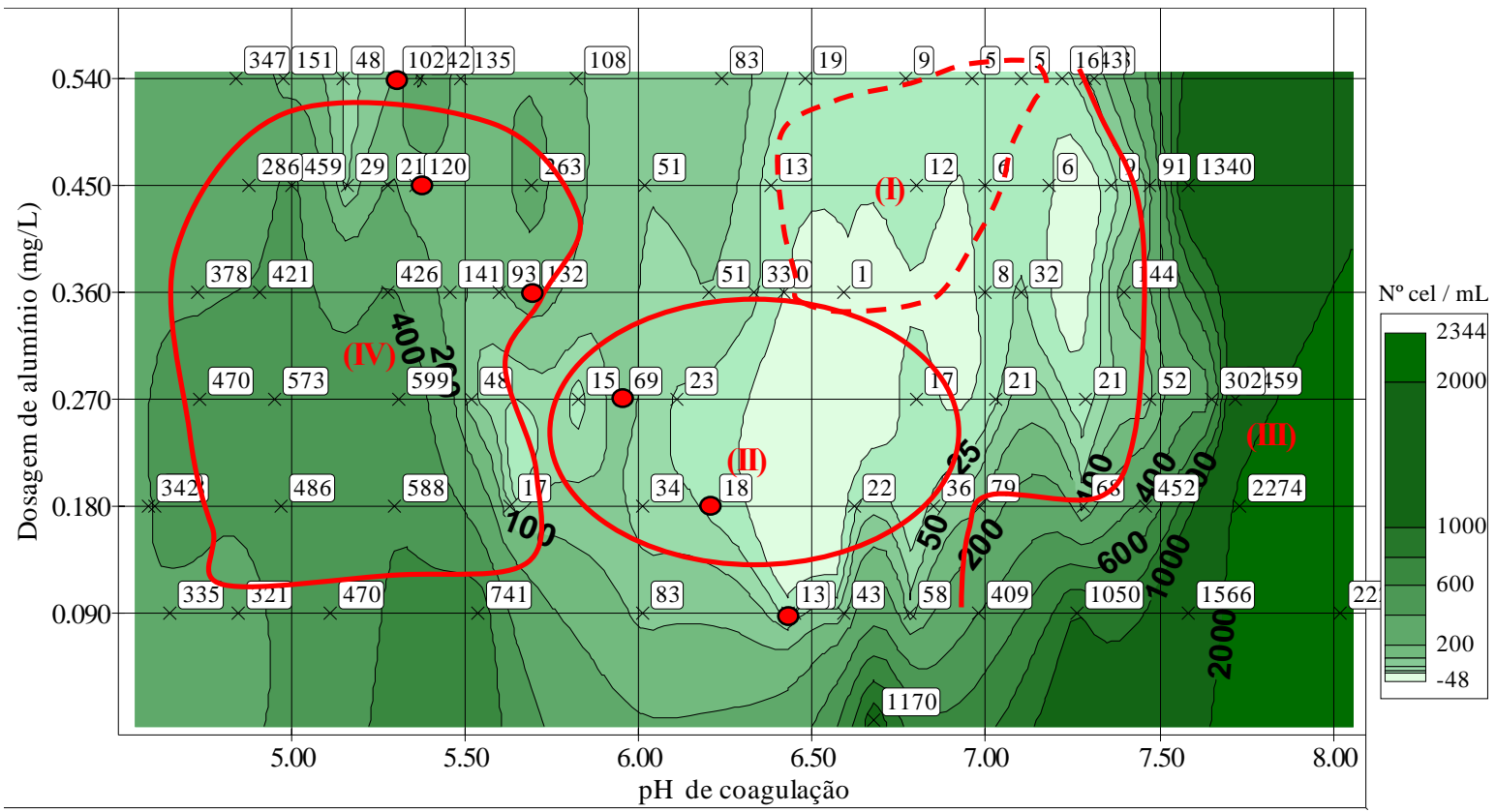

Figura 5.3.9 - Resultados dos ensaios da Série G. Diagrama de coagulação química com sulfato de alumínio / Densidade de Microcystis spp. (cel/mL). ( • : pontos sem ajuste do $\mathrm{pH}$ de coagulação) 


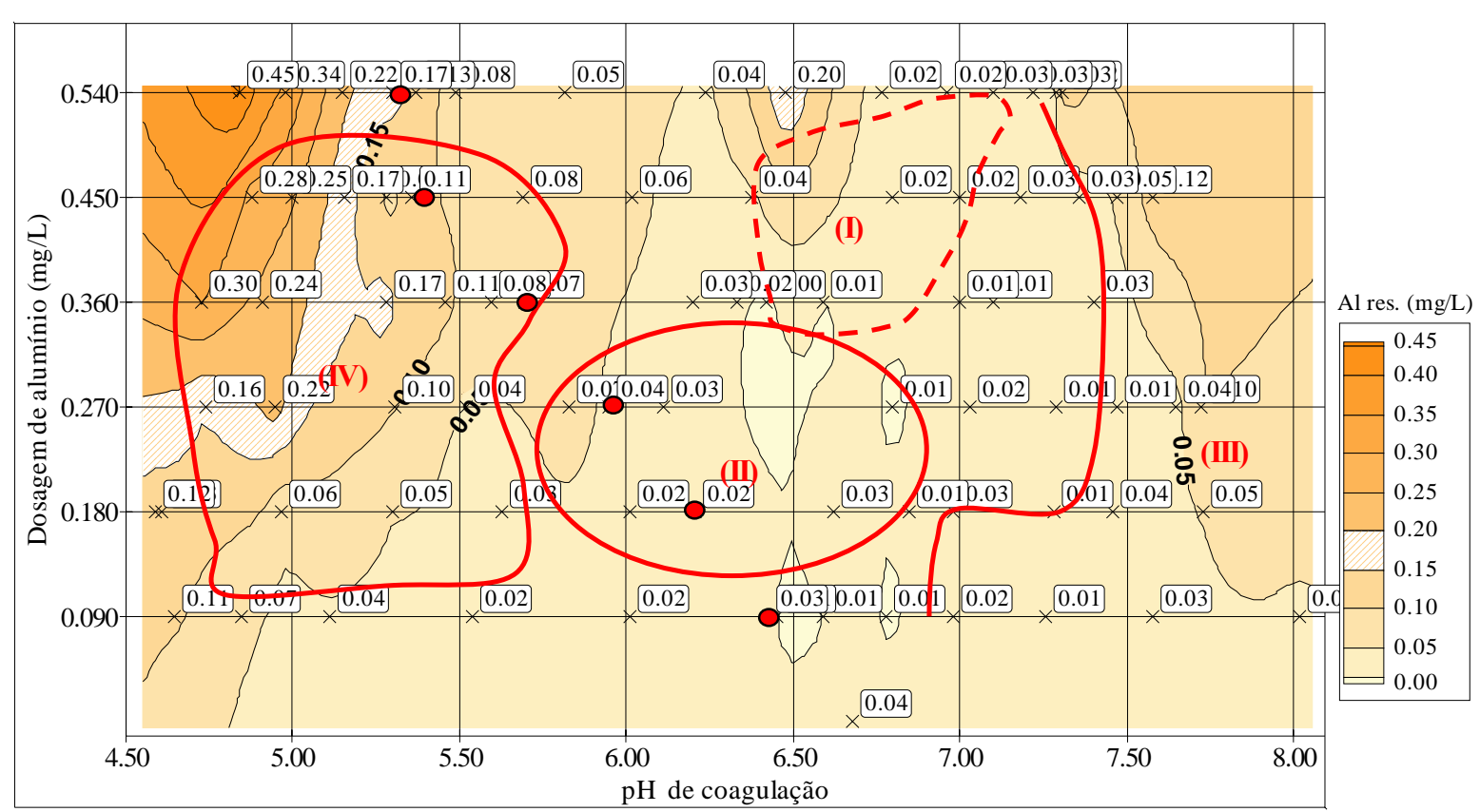

Figura 5.3.10 - Resultados dos ensaios da Série G. Diagrama de coagulação química com sulfato de alumínio / Alumínio residual (mg/L). ( • : pontos sem ajuste do pH de coagulação)

Dos estudos sobre a aplicabilidade de testes de toxicidade aguda com dafinídeos na avaliação qualitativa do desempenho dos processos empregados, pôde-se observar que, em geral, as águas de estudo empregadas não apresentaram efeitos tóxicos aos dafinídeos. Testes adicionais revelaram ser necessárias concentrações superiores a $1 \times 10^{6}$ céls $/ \mathrm{mL}$ de Microcystis spp. (NPLJ-4), na forma de extrato (com MCs extracelulares) para causar efeito tóxico agudo aos dafinídeos. DEMOTT et. al. (1991) observaram rápida mortalidade (48h) de Daphnia pulex em baixa concentração $\left(1 \times 10^{4}\right.$ céls $\left./ \mathrm{mL}\right)$ de uma linhagem toxigênica de Microcystis aeruginosa (PCC7820).

Em geral, os efluentes da filtração direta e a água filtrada na ETASC 2, utilizada para compor as águas de estudo - AEs, causaram toxicidade aguda aos dafinídeos, provavelmente, devido à concentração residual de alumínio ou impurezas resultantes do processo de coagulação química emprgada na ETASC - 2.

Ensaios de caráter proscpectivo utilizando filtros de laboratório com carvão ativado granular Figura 5.3.11) como pós-tratamento (ensaio 4 / Série B), mostraram ser eficientes para a remoção da toxicidade (Figura 5.3.12). A água de diluição causou toxicidade aguda a C. silvestrii, talvez por esta ser uma espécie mais sensível. 


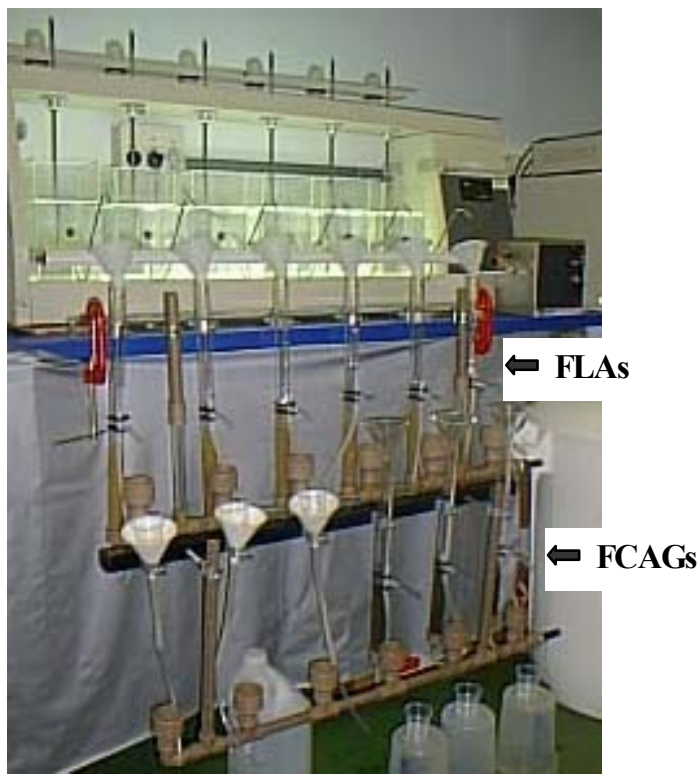

Figura 5.3.11 - Sistema de FLAs e FCAGs acoplados ao equipamento jarteste

Ceriodaphnia dubia Tempo de exposição $\square 24 \mathrm{~h} \quad 048 \mathrm{~h}$
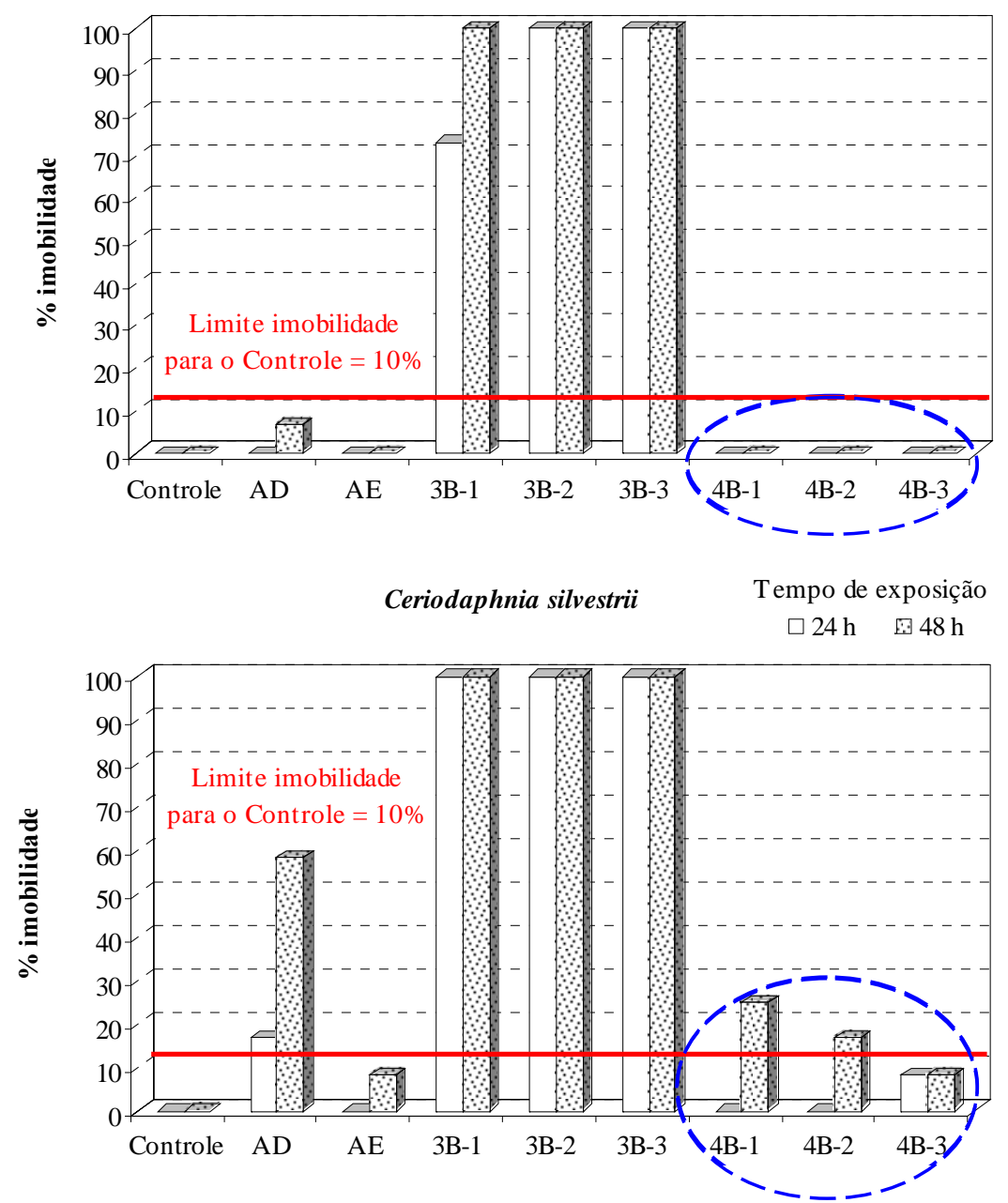

Figura 5.3.12 - Resultados dos ensaios da Série B: \% imobilidade dos dafinídeos Ceriodaphnia dubia e Ceriodaphnia silvestrii (Crustacea, Cladocera) para os ensaios 3 e 4 da série B. (AD = água de diluição; $\mathrm{AE}$ = água de estudo). 


\subsection{META 5: OBTENÇÃO DE PARÂMETROS OPERACIONAIS EM ENSAIOS DE OXIDAÇÃO EM BANCADA}

Apresentam-se na Tabela 5.4.1, os valores de demanda e de residual de cloro, dióxido de cloro e permanganato de potássio obtidos no ensaio de oxidação da série A para os tempos de contato de 30, 60 e 120 minutos, de acordo com as situações de oxidação previstas (Item 4.5). Na Figura 5.4.1 são apresentados os gráficos de demanda resultantes.

Os valores de $\mathrm{pH}$ das amostras após $2 \mathrm{~h}$ de tempo de contato variaram entre 7,11 a 7,22. As demais características da AE-A encontram-se apresentadas na Tabela 5.2.5. 
Tabela 5.4.1 - Valores de demanda e de residual de oxidantes para os tempos de contato de 30, 60 e 120 minutos / Ensaio de oxidação da série-A

\begin{tabular}{|c|c|c|c|c|c|c|}
\hline \multirow{3}{*}{$\begin{array}{c}\text { Dosagem } \\
\text { (mg/L) }\end{array}$} & \multicolumn{6}{|c|}{ Cloro (hipoclorito de cálcio) } \\
\hline & \multicolumn{2}{|c|}{ Tempo de contato $=30 \mathrm{~min}$} & \multicolumn{2}{|c|}{ Tempo de contato $=60 \mathrm{~min}$} & \multicolumn{2}{|c|}{ Tempo de contato $=120 \mathrm{~min}$} \\
\hline & $\begin{array}{c}\text { Demanda } \\
(\mathrm{mg} / \mathrm{L})\end{array}$ & $\begin{array}{c}\begin{array}{c}\text { Residual } \\
(\mathrm{mg} / \mathrm{L})\end{array} \\
\end{array}$ & $\begin{array}{c}\text { Demanda } \\
(\mathrm{mg} / \mathrm{L})\end{array}$ & $\begin{array}{c}\begin{array}{c}\text { Residual } \\
(\mathrm{mg} / \mathrm{L})\end{array} \\
\end{array}$ & $\begin{array}{c}\text { Demanda } \\
(\mathrm{mg} / \mathrm{L})\end{array}$ & $\begin{array}{c}\text { Residual } \\
(\mathrm{mg} / \mathrm{L})\end{array}$ \\
\hline 0,50 & 0,420 & 0,08 & 0,430 & 0,07 & 0,460 & 0,04 \\
\hline 1,00 & 0,660 & $0,34^{(*)}$ & 0,730 & 0,27 & 0,830 & 0,17 \\
\hline 1,50 & 0,880 & 0,62 & 0,990 & 0,51 & 1,040 & 0,46 \\
\hline 2,00 & 1,150 & 0,85 & 0,910 & 1,09 & 1,030 & 0,97 \\
\hline 2,50 & 0,950 & 1,55 & 1,050 & $1,45^{(*)}$ & 1,430 & 1,07 \\
\hline 3,00 & 1,020 & 1,98 & 1,170 & 1,83 & 1,310 & 1,69 \\
\hline 4,00 & 1,090 & 2,91 & 1,030 & 2,97 & 1,210 & 2,79 \\
\hline 5,00 & 1,170 & 3,83 & 1,080 & 3,92 & 1,370 & $3,63^{(*)}$ \\
\hline \multirow{3}{*}{$\begin{array}{c}\text { Dosagem } \\
\text { (mg/L) }\end{array}$} & \multicolumn{6}{|c|}{ Dióxido de cloro } \\
\hline & \multicolumn{2}{|c|}{ Tempo de contato $=30 \mathrm{~min}$} & \multicolumn{2}{|c|}{ Tempo de contato $=60 \mathrm{~min}$} & \multicolumn{2}{|c|}{ Tempo de contato $=120 \mathrm{~min}$} \\
\hline & $\begin{array}{c}\text { Demanda } \\
(\mathrm{mg} / \mathrm{L})\end{array}$ & $\begin{array}{c}\text { Residual } \\
(\mathrm{mg} / \mathrm{L})\end{array}$ & $\begin{array}{c}\text { Demanda } \\
(\mathrm{mg} / \mathrm{L})\end{array}$ & $\begin{array}{c}\text { Residual } \\
(\mathrm{mg} / \mathrm{L})\end{array}$ & $\begin{array}{c}\text { Demanda } \\
(\mathrm{mg} / \mathrm{L})\end{array}$ & $\begin{array}{c}\text { Residual } \\
\text { (mg/L) }\end{array}$ \\
\hline 0,25 & 0,14 & $0,11^{(*)}$ & 0,15 & 0,10 & 0,17 & 0,08 \\
\hline 0,50 & 0,23 & 0,27 & 0,25 & $0,25^{(*)}$ & 0,33 & 0,17 \\
\hline 1,00 & 0,28 & 0,72 & 0,43 & 0,57 & 0,53 & $0,48^{(*)}$ \\
\hline 1,50 & 0,28 & 1,22 & 0,38 & 1,12 & 0,65 & 0,86 \\
\hline 2,00 & 0,56 & 1,44 & 0,71 & 1,29 & 1,18 & 0,82 \\
\hline 3,00 & 0,72 & 2,28 & 1,01 & 2,00 & 1,46 & 1,54 \\
\hline 4,00 & 1,09 & 2,91 & 1,21 & 2,79 & 1,89 & 2,11 \\
\hline 5,00 & 1,49 & 3,52 & 1,62 & 3,38 & 2,80 & 2,20 \\
\hline \multirow{3}{*}{$\begin{array}{c}\text { Dosagem } \\
(\mathrm{mg} / \mathrm{L})\end{array}$} & \multicolumn{6}{|c|}{ Permanganato de potássio } \\
\hline & \multicolumn{2}{|c|}{ Tempo de contato $=30 \mathrm{~min}$} & \multicolumn{2}{|c|}{ Tempo de contato $=60 \mathrm{~min}$} & \multicolumn{2}{|c|}{ Tempo de contato $=120 \mathrm{~min}$} \\
\hline & $\begin{array}{c}\text { Demanda } \\
(\mathrm{mg} / \mathrm{L})\end{array}$ & $\begin{array}{c}\text { Residual } \\
(\mathrm{mg} / \mathrm{L})\end{array}$ & $\begin{array}{c}\text { Demanda } \\
(\mathrm{mg} / \mathrm{L})\end{array}$ & $\begin{array}{c}\text { Residual } \\
\text { (mg/L) }\end{array}$ & $\begin{array}{c}\text { Demanda } \\
\text { (mg/L) }\end{array}$ & $\begin{array}{c}\text { Residual } \\
(\mathrm{mg} / \mathrm{L})\end{array}$ \\
\hline 0,25 & 0,24 & $0,01^{(*)}$ & 0,25 & 0,0 & 0,25 & 0 \\
\hline 0,50 & 0,26 & 0,24 & 0,25 & $0,25^{(*)}$ & 0,28 & 0,22 \\
\hline 1,00 & 0,27 & 0,73 & 0,29 & 0,71 & 0,33 & $0,67^{(*)}$ \\
\hline 1,50 & 0,46 & 1,04 & 0,37 & 1,13 & 0,44 & 1,06 \\
\hline 2,00 & 0,37 & 1,63 & 0,46 & 1,54 & 0,55 & 1,45 \\
\hline 3,00 & 0,38 & 2,62 & 0,49 & 2,51 & 0,59 & 2,41 \\
\hline 4,00 & 0,46 & 3,54 & 0,51 & 3,49 & 0,63 & 3,37 \\
\hline 5,00 & 0,51 & 4,49 & 0,61 & 4,39 & 0,68 & 4,32 \\
\hline
\end{tabular}

\footnotetext{
${ }^{(*)}$ : Residuais aceitáveis para cada situação.
} 

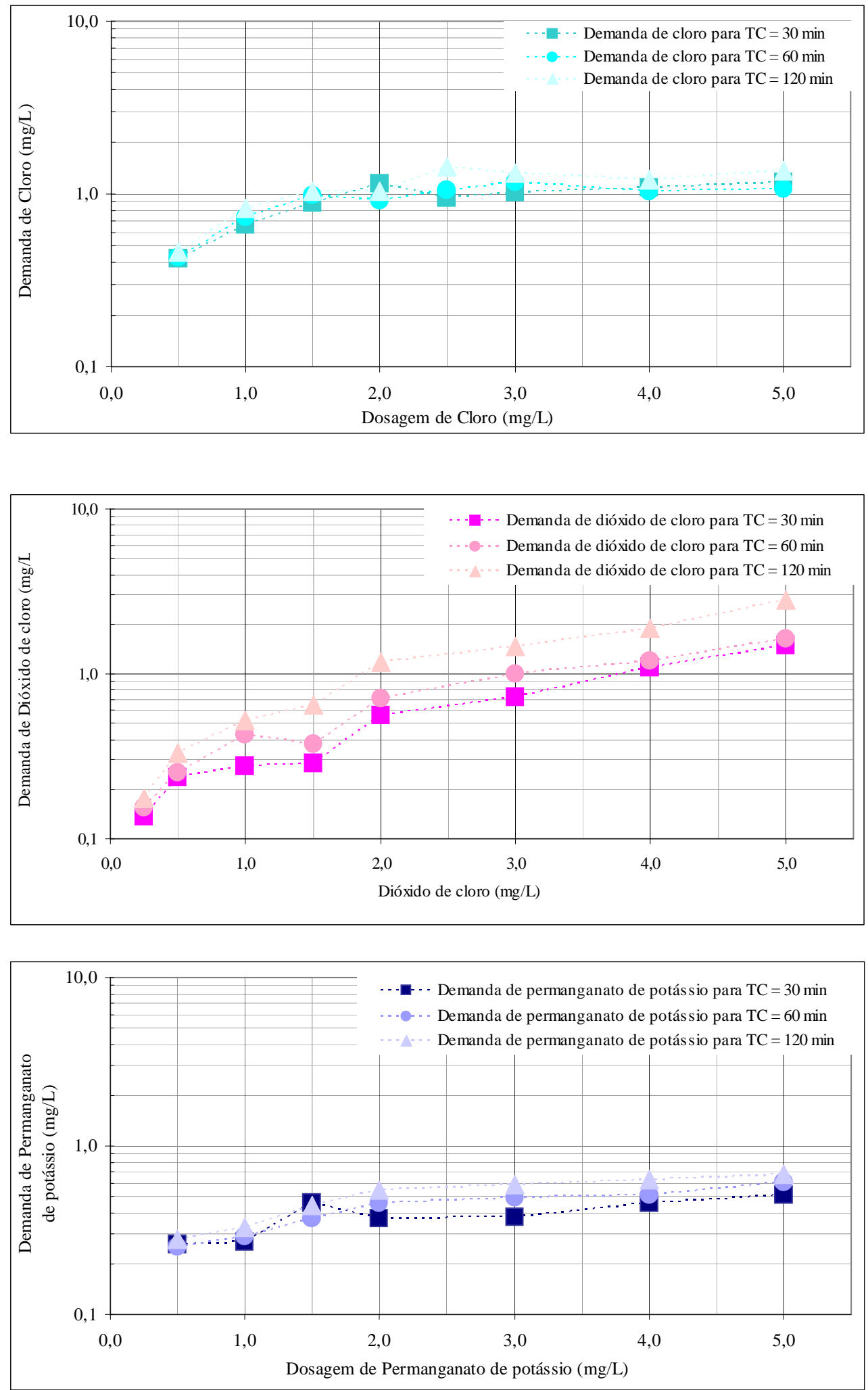

Figura 5.4.1 - Valores de demanda de oxidantes para os tempos de contato de 30, 60 e 120 minutos / Ensaio de oxidação da série-A 
Na Tabela 5.4.2 são apresentadas as faixas de valores de densidade de Microcystis spp., absorvância 254 nm e carbono orgânico total da água de estudo AE-A e das amostras após oxidação.

Tabela 5.4.2 - Valores de densidade de M. spp., absorvância 254 nm e concentração de carbono orgânico total da AE-A e amostras após oxidação / Ensaio de oxidação da série A

\begin{tabular}{|c|c|c|c|c|}
\hline \multirow[b]{2}{*}{ Parâmetros } & \multirow[b]{2}{*}{ AE-A } & \multicolumn{3}{|c|}{ Amostras após oxidação } \\
\hline & & Cloro & Dióxido de cloro & $\begin{array}{l}\text { Permanganato de } \\
\text { potássio }\end{array}$ \\
\hline $\begin{array}{l}\text { Densidade de } M \text {. spp. } \\
\text { (cel } / \mathrm{mL} \text { ) }\end{array}$ & $1,2 \times 10^{5}$ & $3,4 \times 10^{4}$ a $1,7 \times 10^{5}$ & $8,1 \times 10^{3}$ a $5,8 \times 10^{4}$ & $4,0 \times 10^{3}$ a $1,4 \times 10^{4}$ \\
\hline Absorvância 254 nm (UA) & 0,017 & 0,020 a 0,069 & 0,019 a 0,079 & 0,027 a 0,136 \\
\hline $\begin{array}{c}\text { Carbono orgânico total - } \\
\text { COT }(\mathrm{mg} / \mathrm{L})\end{array}$ & 3,152 & 1,396 a 3,241 & 1,456 a 2,545 & 0,845 a 2,523 \\
\hline
\end{tabular}

Embora os dados obtidos em relação a remoção de células de Microcystis spp., absorvância 254 nm e carbono orgânico total no ensaio de oxidação da série A não sejam indicativos de elevada eficiência em relação a esses aspectos, os ensaios da série B revelaram que a ação oxidante, especialmente do cloro, pode ser relativamente efetiva na degradação de MCs.

Com o intuito de comparar os efeitos da oxidação com cloro, dióxido de cloro e permanganato de potássio sobre as microcistinas - MCs, foram realizados ensaios com volumes reduzidos de água de estudo AE-B, preparada especialmente para análise de MCs por imunoensaio ELISA com adição de células de Microcystis spp. e extrato de MCs. A densidade de Microcystis spp. da água de estudo da série B foi de $1,4 \times 10^{5} \mathrm{cel} / \mathrm{mL}$. Na Tabela 5.4.3 são apresentados os resultados do ensaio de oxidação da série B e na Figura 5.4.2, os resultados de MCs totais (intra e extracelulares) para os tempos de contato de $30 \mathrm{e}$ 60 minutos, correspondentes às situações 1 e 2 previstas.

De acordo com a Tabela 5.4.3 para a situação 1de oxidação: pré-oxidação seguida de adsorção com carvão ativado pulverizado - CAP, com produção de residuais próximos de zero ao final de 30 minutos de contato, as dosagens de cloro, dióxido de cloro e permanganato de potássio, passíveis de aplicação, foram de 1,0; 0,25 e 0,25 mg/L; e resultaram em eficiências de remoção de MCs da ordem de 84, 34 e 13 \%, respectivamente.

Para a situação 2 de oxidação: pré-oxidação seguida de filtração direta, com produção de residuais aceitáveis segundo legislações vigentes para o tempo de contato previsto de $60 \mathrm{~min}$, as dosagens de cloro, dióxido de cloro e permanganato de potássio, foram de 2,5; 0,5 e 0,5 mg/L; correspondentes em eficiências de remoção de MCs de 97, 46 e $50 \%$, respectivamente. 
A principal restrição encontrada ao emprego de permanganato de potássio como oxidante está relacionada à limitada eficiência observada para as dosagens passíveis de aplicação, devido às concentrações de residuais de manganês nas águas tratadas com esse oxidante. Outro fator a ser considerado refere-se à coloração resultante após aplicação deste oxidante, uma vez que concentrações residuais superiores a $0,3 \mathrm{mg} / \mathrm{L}$ conferem coloração rósea à água.

Já com relação ao dióxido de cloro, além da limitada eficiência, deve-se considerar os custos, as dificuldades para obtenção do produto e os riscos associados quanto à geração e formação dos subprodutos clorito e clorato.

Tabela 5.4.3 - Resultados do ensaio de oxidação da série-B

\begin{tabular}{|c|c|c|c|c|c|c|}
\hline \multirow{3}{*}{$\begin{array}{l}\text { Dosagem } \\
\text { (mg/L) }\end{array}$} & \multicolumn{6}{|c|}{ Cloro (hipoclorito de cálcio) } \\
\hline & \multicolumn{3}{|c|}{ Tempo de contato $=30 \mathrm{~min}$} & \multicolumn{3}{|c|}{ Tempo de contato $=60 \mathrm{~min}$} \\
\hline & $\begin{array}{c}\text { Demanda } \\
\text { (mg/L) }\end{array}$ & $\begin{array}{c}\text { Residual } \\
\text { (mg/L) }\end{array}$ & $\begin{array}{l}\text { Remoção } \\
\text { MCs (\%) }\end{array}$ & $\begin{array}{c}\text { Demanda } \\
\text { (mg/L) }\end{array}$ & $\begin{array}{c}\text { Residual } \\
\text { (mg/L) }\end{array}$ & $\begin{array}{l}\text { Remoção } \\
\text { MCs (\%) }\end{array}$ \\
\hline 0,50 & 0,410 & 0,09 & 46,9 & 0,430 & 0,07 & 45,9 \\
\hline 1,00 & 0,820 & $0,18^{(*)}$ & 83,5 & 0,890 & 0,11 & 87,2 \\
\hline 2,50 & 1,400 & 1,10 & 94,3 & 1,600 & $0,90^{(*)}$ & 96,8 \\
\hline 5,00 & 1,710 & 3,29 & 98,2 & 1,970 & 3,03 & 99,2 \\
\hline \multirow{3}{*}{$\begin{array}{l}\text { Dosagem } \\
\text { (mg/L) }\end{array}$} & \multicolumn{6}{|c|}{ Dióxido de Cloro } \\
\hline & \multicolumn{3}{|c|}{ Tempo de contato $=30 \mathrm{~min}$} & \multicolumn{3}{|c|}{ Tempo de contato $=60 \mathrm{~min}$} \\
\hline & $\begin{array}{c}\text { Demanda } \\
\text { (mg/L) }\end{array}$ & $\begin{array}{c}\text { Residual } \\
\text { (mg/L) }\end{array}$ & $\begin{array}{l}\text { Remoção } \\
\text { MCs (\%) }\end{array}$ & $\begin{array}{c}\text { Demanda } \\
\text { (mg/L) }\end{array}$ & $\begin{array}{c}\text { Residual } \\
\text { (mg/L) }\end{array}$ & $\begin{array}{l}\text { Remoção } \\
\text { MCs (\%) }\end{array}$ \\
\hline 0,25 & 0,14 & $0,11^{(*)}$ & 34,1 & 0,16 & 0,10 & 37,3 \\
\hline 0,50 & 0,23 & 0,27 & 51,6 & 0,25 & $0,25^{(*)}$ & 45,9 \\
\hline 1,00 & 0,28 & 0,72 & 36,3 & 0,43 & 0,57 & 56,6 \\
\hline 2,00 & 0,56 & 1,44 & 48,2 & 0,71 & 1,29 & 58,1 \\
\hline \multirow{3}{*}{$\begin{array}{l}\text { Dosagem } \\
\text { (mg/L) }\end{array}$} & \multicolumn{6}{|c|}{ Permanganato de potássio } \\
\hline & \multicolumn{3}{|c|}{ Tempo de contato $=30 \mathrm{~min}$} & \multicolumn{3}{|c|}{ Tempo de contato $=60 \mathrm{~min}$} \\
\hline & $\begin{array}{c}\text { Demanda } \\
\text { (mg/L) }\end{array}$ & $\begin{array}{c}\text { Residual } \\
\text { (mg/L) }\end{array}$ & $\begin{array}{l}\text { Remoção } \\
\text { MCs (\%) }\end{array}$ & $\begin{array}{c}\text { Demanda } \\
\text { (mg/L) }\end{array}$ & $\begin{array}{c}\text { Residual } \\
\text { (mg/L) }\end{array}$ & $\begin{array}{l}\text { Remoção } \\
\text { MCs (\%) }\end{array}$ \\
\hline 0,25 & 0,22 & $0,03^{(*)}$ & 13,7 & 0,23 & 0,02 & 40,6 \\
\hline 0,50 & 0,22 & 0,28 & 39,5 & 0,29 & $0,21^{(*)}$ & 49,9 \\
\hline 1,00 & 0,27 & 0,73 & 58,9 & 0,37 & 0,63 & 66,2 \\
\hline 2,00 & 0,40 & 1,60 & 54,4 & 0,56 & 1,44 & 46,7 \\
\hline
\end{tabular}

$\left.{ }^{*}\right)$ : Residuais aceitáveis para cada situação. 

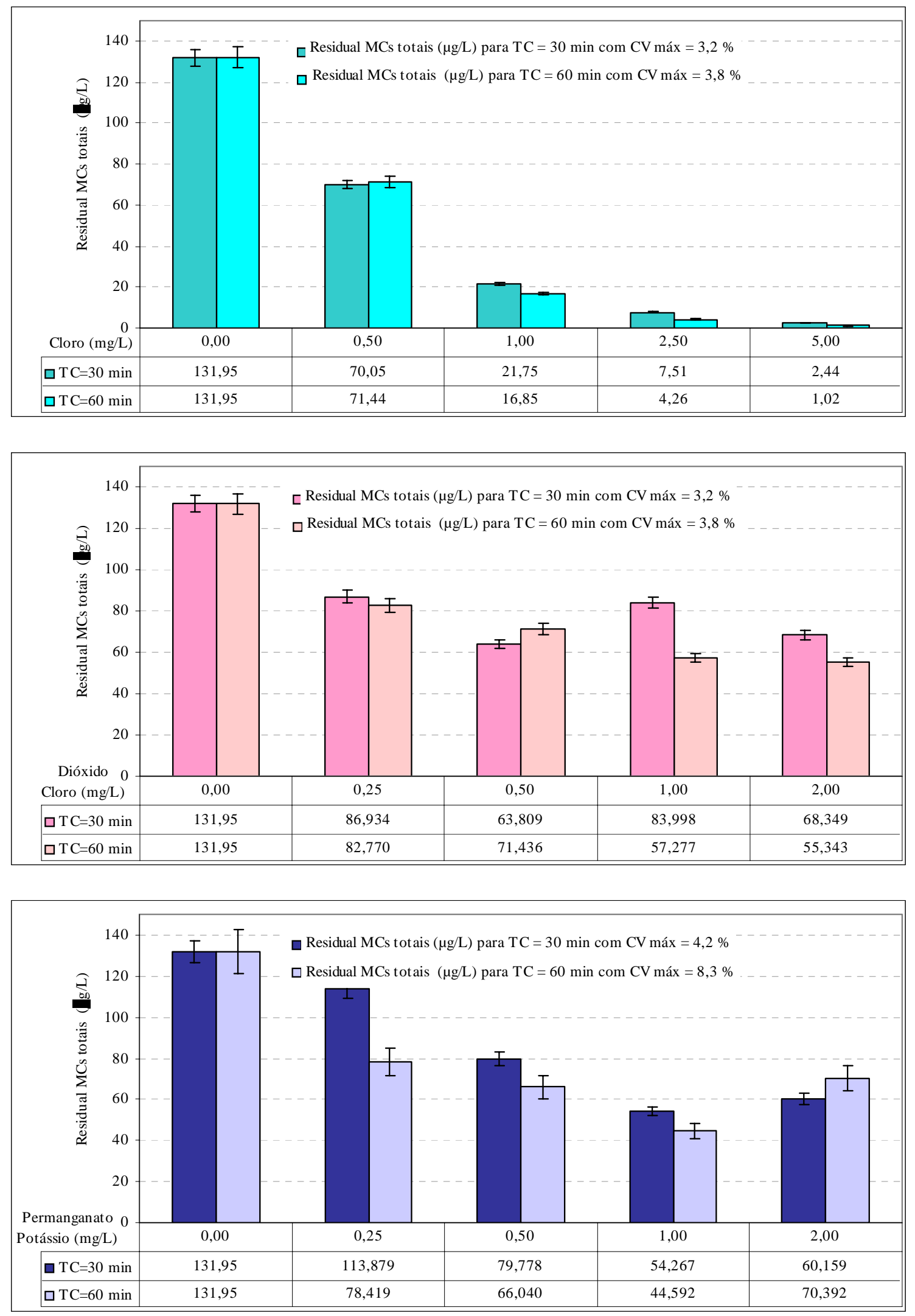

Figura 5.4.2 - Resultados de MCs totais do ensaio de oxidação da série-B 
PEGORER (2006) testou em bancada, as dosagens fixas de 1,6; 3,0 e 5;0 mg/L de hipoclorito de sódio (como $\mathrm{Cl}_{2}$ ), de ferrato(VI) de potássio (como $\mathrm{K}_{2} \mathrm{FeO}_{4}$ ) e de permanganato de potássio (como $\left.\mathrm{KMnO}_{4}\right)$ na remoção de microcistinas - MCs diluídas em água ultra-pura, com concentração inicial da ordem de $100 \mu \mathrm{g} / \mathrm{L}$, ao longo de 30 minutos de tempo de contato.

Para a dosagem de 1,6 mg/L cloro, a eficiência média de remoção de MCs variou de $25 \%$ no início do tempo de contato, chegando a quase $75 \%$ ao final dos 30 minutos de ensaio. Já para as concentrações de 3,0 e 5,0 mg/L, esse valor alcançou os 95\%, sendo ligeiramente superior para a maior concentração (Figura 5.4.3).

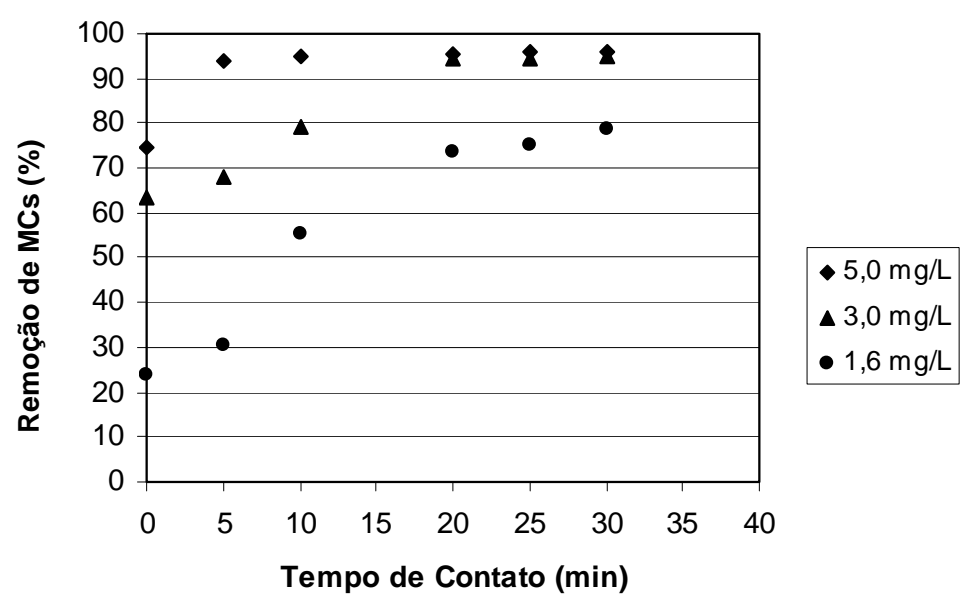

Figura 5.4.3 - Decomposição de microcistinas - MCs pelo cloro para diferentes dosagens e concentração inicial de $100 \mu \mathrm{g} / \mathrm{L}$

Segundo a autora, os resultados de remoção de MCs ao final de 30 minutos de contato resultaram em eficiências de oxidação para permanganato, hipoclorito e ferrato iguais, respectivamente, a 91,5; 79 e 68\% para a dosagem de 1,6 mg/L; 93, 95 e 75\% para a dosagem de 3,0 mg/L e 95, 96; 95,5 \% para para a dosagem de 5,0 mg/L. O pH médio inicial das soluções foi da ordem de 6,0 a 6,5, aumentando para uma faixa de 7,0 a 7,5 ao final dos ensaios.

Porém, deve-se ressaltar, que embora nos ensaios realizados com permanganato de potássio não tenha sido analisada a concentração residual de manganês, esse pode ser um fator limitante da aplicabilidade desse oxidante, uma vez que o valor limite estabelecido pela Portaria MS 518/2004 é de 0,1 mg/L para águas a serem distribuídas para consumo humano. De forma similar, nos ensaios realizados com o ferrato de potássio, as concentrações de ferro total residual resultaram entre 1,2 a 1,8 mg/L, valores bem superiores ao limite de $0,2 \mathrm{mg} / \mathrm{L}$ estabelecido pela referida Portaria. 
Em função dos resultados obtidos e dos atributos inerentes ao emprego de cloro especialmente com relação ao baixo custo, simplicidade de uso e manutenção de residual, os ensaios em instalação piloto foram realizados com o emprego do cloro como oxidante.

\subsection{META 6: OBTENÇÃO DE PARÂMETROS OPERACIONAIS EM ENSAIOS DE ADSORÇÃO EM BANCADA}

O carvão ativado é um tipo de material carbonáceo, caracterizado por possuir área superficial interna elevada e porosidade altamente desenvolvida (COUTINHO et.al., 2000), de forma a possibilitar a adsorção de moléculas tanto em fase líquida como gasosa.

A capacidade adsortiva do carvão ativado em relação a um contaminante específico depende de fatores intrínsecos do adsorvente, resultantes basicamente, da forma de ativação e do material de produção, tais como: volume e distribuição de poros, forma dos poros, existência de grupos funcionais de superfície, $\mathrm{pH}$, teor de cinzas entre outros. Por outro lado, as condições experimentais como $\mathrm{pH}$, temperatura, tempo de contato requerido, agitação e presença de compostos que competem pelos mesmos sítios de adsorção, atuam diretamente na eficiência da adsorção, podendo favorecer ou dificultar o processo. PENDLETON et. al. (2001) investigaram vários fatores que controlam a adsorção de MC-LR em solução e como era esperado, de acordo com DONATI et.al. 1994 e MOHAMED et.al. 1998, o carvão de madeira apresentou maior capacidade adsortiva para MC-LR. Porém, a variação do $\mathrm{pH}$ da solução de 6,5 para 2,5 aumentou a afinidade da molécula em $400 \%$ e $100 \%$ para os carvões de côco e madeira, respectivamente.

DONATI et.al. 1994 caracterizaram 8 carvões de diversos materiais (minério, côco, madeira e turfa), e concluíram que a adsorção de MC-LR está relacionada ao volume de mesoporos do carvão. De acordo com a união internacional de química pura e aplicada (IUPAC), os poros podem ser classificados em função do diâmetro como: macroporos (> 50 $\mathrm{nm})$, mesoporos (2-50 nm), microporos secundários (0,8-2 nm) e microporos primários (< $0,8 \mathrm{~nm}$ ). Vale ressaltar que os índices de referência comumente utilizados na caracterização indireta dos carvões, tais como número de iodo, fenol e área superficial, estão relacionados com a porção microporosa do carvão e portanto, não são suficientes para avaliar a capacidade adsortiva dos carvões ativados para MCs.

Os resultados obtidos na estimativa da capacidade adsortiva dos carvões ativados na fase líquida pela determinação do número e ou índice de iodo e especialmente, do índice de azul de metileno, são apresentados na Tabela 5.5.1 e Figura 5.5.1. A escolha dessas moléculas está relacionada à possibilidade de associação desses índices à distribuição do volume de poros do adsorvente. O número ou índice de iodo está relacionado à 
microporosidade do carvão ativado, uma vez que requer poros com abertura inferior a $1 \mathrm{~nm}$ para ser adsorvida. Estima-se que $1 \mathrm{mg}$ de iodo adsorvido corresponde a $1 \mathrm{~m}^{2}$ de superfície interna (EL-HENDAWY et. al., 2001). Embora a molécula de azul de metileno $\left(\mathrm{C}_{16} \mathrm{H}_{18} \mathrm{ClN}_{3} \mathrm{~S} \times 3 \mathrm{H}_{2} \mathrm{O}\right)$ apresente diâmetro médio da ordem de 0,8 nm, ela requer, para ser adsorvida, poros com abertura mínima de $1,3 \mathrm{~nm}$ (BARTON, 1987), sendo, preferencialmente adsorvida, por poros com abertura próxima a 2,0 nm (WARHURST et. al., 1997). Assim, conclui-se que a mesoporosidade do carvão pode ser estimada indiretamente pelo índice de azul de metileno (BAÇAOUI et. al., 2001).

Tabela 5.5.1 - Parâmetros obtidos pela isoterma de adsorção de iodo e de azul de metileno dos carvões ativados granulares e pulverizados amostrados

\begin{tabular}{|c|c|c|c|c|c|c|c|c|}
\hline \multirow{2}{*}{$\begin{array}{l}\text { Carvão } \\
\text { ativado }\end{array}$} & \multirow{2}{*}{$\begin{array}{c}\text { matéria- } \\
\text { prima }\end{array}$} & \multirow{2}{*}{ forma } & \multicolumn{3}{|c|}{ Número de Iodo - NI } & \multicolumn{3}{|c|}{ Índice de Azul de Metileno - IAM } \\
\hline & & & $\begin{array}{c}\text { NI } q_{\mathrm{e}} \text { médio } \\
(\mathrm{mg} / \mathrm{g})\end{array}$ & $\mathrm{K}_{\mathrm{f}}$ & $1 / \mathrm{n}$ & $\begin{array}{c}\text { IAM } q_{\mathrm{e}} \text { médio } \\
(\mathrm{mg} / \mathrm{g})\end{array}$ & $\mathrm{K}_{\mathrm{f}}$ & $1 / \mathrm{n}$ \\
\hline $1^{(*)}$ & $\begin{array}{c}\text { endocarpo } \\
\text { côco }\end{array}$ & granular & $844,77 \pm 2,17$ & 693,3 & 0,22 & $80,82 \pm 2,24$ & 85,6 & 0,05 \\
\hline 2 & $\begin{array}{l}\text { endocarpo } \\
\text { côco }\end{array}$ & pulverizado & $770,09 \pm 3,22$ & 636,8 & 0,21 & $132,60 \pm 3,95$ & 189,9 & 0,24 \\
\hline 3 & Osso & granular & $21,00 \pm 0,29$ & 5,4 & 14,63 & $11,42 \pm 0,32$ & 15,6 & 0,23 \\
\hline 4 & Osso & pulverizado & $12,10 \pm 0,06$ & 2,2 & 18,36 & $15,79 \pm 0,44$ & 20,9 & 0,21 \\
\hline 5 & $\begin{array}{c}\text { endocarpo } \\
\text { côco }\end{array}$ & granular & $909,72 \pm 5,74$ & 759,0 & 0,19 & $78,94 \pm 2,19$ & 83,3 & 0,05 \\
\hline $6^{(*)}$ & madeira & pulverizado & $1018,99 \pm 0,27$ & 861,5 & 0,18 & $170,94 \pm 4,74$ & 198,4 & 0,12 \\
\hline 7 & madeira & pulverizado & $765,30 \pm 3,71$ & 664,6 & 0,15 & $116,07 \pm 3,22$ & 190,9 & 0,36 \\
\hline 8 & madeira & pulverizado & $620,66 \pm 1,81$ & 537,9 & 0,16 & $97,89 \pm 2,71$ & 103,9 & 0,06 \\
\hline 9 & madeira & pulverizado & $465,07 \pm 2,31$ & 396,7 & 0,17 & $66,55 \pm 1,85$ & 69,7 & 0,05 \\
\hline 10 & $\begin{array}{c}\text { endocarpo } \\
\text { côco }\end{array}$ & granular & $936,33 \pm 4,39$ & 810,3 & 0,16 & $54,11 \pm 1,50$ & 56,6 & 0,05 \\
\hline
\end{tabular}

${ }^{(*)}$ : Carvões ativados selecionados

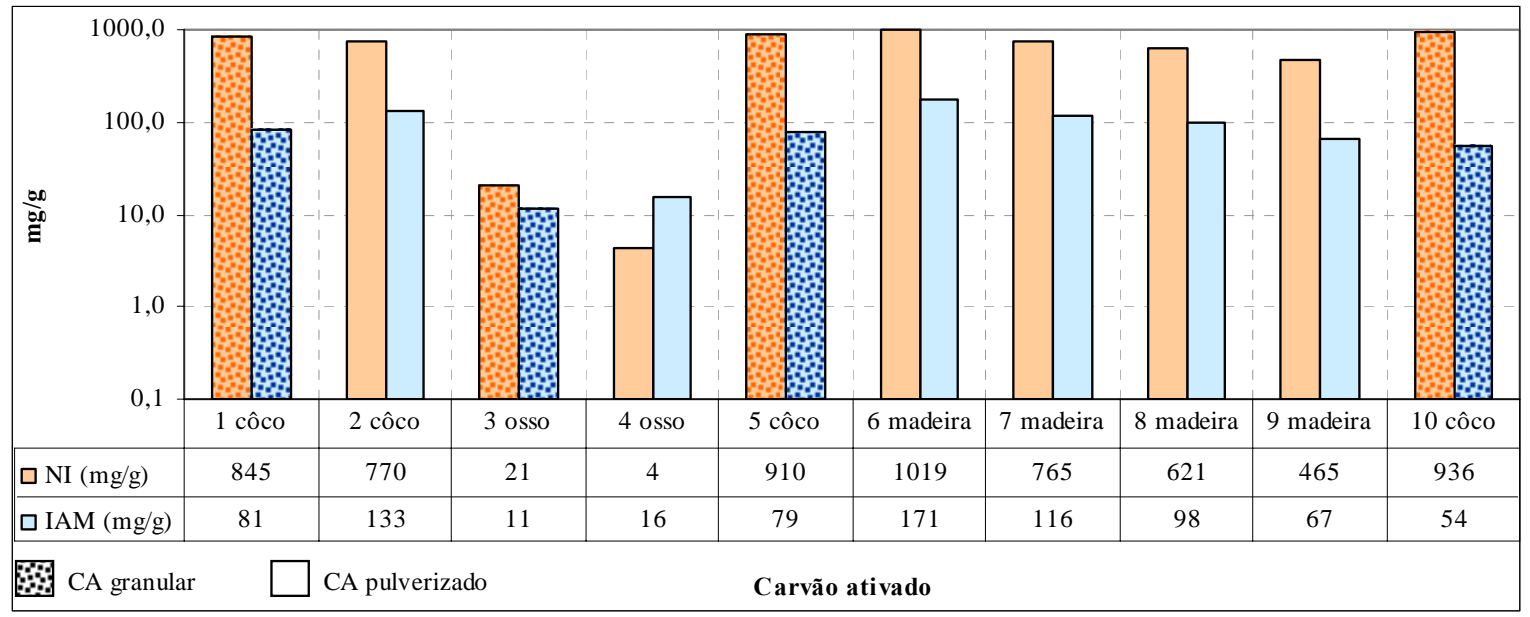

Figura 5.5.1 - Número de iodo e índice de azul de metileno dos carvões ativados granulares e pulverizados amostrados

DONATI et.al., 1994 e PENDLETON et. al., 2001 concluíram que a adsorção de MC-LR está relacionada ao volume de mesoporos do carvão, tendo obtido coeficientes de 
correlação de $r=0,96$ e $r^{2}=0,93$, respectivamente. Baseado nesses resultados, a seleção dos carvões para adsorção de MCs foi feita principalmente em função dos valores obtidos do índice de azul de metileno - IAM: carvão granular 1 com IAM = $81 \mathrm{mg} / \mathrm{g}$ e carvão pulverizado 6 com IAM = $171 \mathrm{mg} / \mathrm{g}$. De uma forma geral pôde-se verificar que os carvões amostrados apresentaram índices de azul de metileno - IAMs relativamente baixos. BAÇAOUI et. al., 2001 otimizaram as condições de ativação física por vapor, de carvões produzidos do caroço de azeitona e obtiveram índices de azul de metileno entre 115 e 490 $\mathrm{mg} / \mathrm{g}$ (Tabela 5.5.4).

No Brasil, segundo a especificação EB-2133,199, o limite mínimo do número de iodo - NI para carvões a serem utilizados em Estações de Tratamento de Águas é de $600 \mathrm{mg} / \mathrm{g}$ e nenhuma menção é feita em relação ao índice de azul de metileno - IAM. Vale ressaltar que em Marrocos, o limite mínimo de adsorção de azul de metileno é estabelecido em 180 mg/g (BAÇAOUI et.al., 2001).

Examinando-se os resultados da Tabela 5.5.2 com aqueles encontrados na predição da capacidade adsortiva feita com azul de metileno e iodo, para estimativa dos volumes de micro e mesoporos, pôde-se constatar, como era esperada, a predominância de microporos nos carvões ativados selecionados no estudo, fato confirmado pelos resultados de número de iodo relativamente elevado e índice de azul de metileno de medianos a baixo.

Tabela 5.5.2 - Área da Superfície Específica BET-N2 e distribuição de poros dos carvões ativados granular e pulverizado selecionados

\begin{tabular}{c|c|c|c|c|c|c}
\hline $\begin{array}{c}\text { Carvão } \\
\text { ativado }\end{array}$ & $\begin{array}{c}\text { Área da Superfície } \\
\text { Específica BET-N2 } \\
\left(\mathrm{m}^{2} / \mathrm{g}\right)\end{array}$ & $\begin{array}{c}\text { Volume } \\
\text { microporos } 1^{\text {ários }} \\
\left(\mathrm{cm}^{3} / \mathrm{g}\right)\end{array}$ & $\begin{array}{c}\text { Volume } \\
\text { microporos 2ários } \\
\left(\mathrm{cm}^{3} / \mathrm{g}\right)\end{array}$ & $\begin{array}{c}\text { Volume } \\
\text { microporos } \\
\left(\mathrm{cm}^{3} / \mathrm{g}\right)\end{array}$ & $\begin{array}{c}\text { Volume } \\
\text { mesoporos } \\
\left(\mathrm{cm}^{3} / \mathrm{g}\right)\end{array}$ & $\begin{array}{c}\text { Volume total } \\
\text { poros } \\
\left(\mathrm{cm}^{3} / \mathrm{g}\right)\end{array}$ \\
\hline $1^{(*)}$ & 789,55 & 0,14 & 0,30 & 0,44 & 0,04 & 0,48 \\
\hline $6^{(*)}$ & 821,30 & 0,16 & 0,30 & 0,46 & 0,09 & 0,55 \\
\hline
\end{tabular}

Considerando que na prática, a água contendo MCs utilizada em processos de tratamento para produção de água para consumo humano será também provida de outros constituintes (matéria orgânica e inclusive restos celulares) que competirão pelos mesmos sítios de adsorção do carvão ativado, optou-se pelo uso direto do extrato bruto (sem purificação das toxinas). Foram construídas 4 isotermas de adsorção para a principal MC não purificada contida no extrato ( 2 para cada carvão), conforme Figuras 5.5.2 e 5.5.3 e resultados apresentados na Tabela 5.5.3. 
Tabela 5.5.3 - Parâmetros obtidos pelas isotermas de adsorção de microcictinas não purificadas para os carvões ativados granular e pulverizado selecionados

\begin{tabular}{c|c|c|c|c|c|c|c|c|c|c|c|c}
\hline \multirow{2}{*}{$\begin{array}{c}\text { Carvão } \\
\text { ativado }\end{array}$} & \multicolumn{5}{|c|}{ Microcictina - Isoterma 1} & \multicolumn{6}{c}{ Microcictina - Isoterma 2} \\
\cline { 2 - 12 } & $\begin{array}{c}\mathrm{Co} / \mathrm{L}) \\
(\mu \mathrm{pH}\end{array}$ & $\begin{array}{c}\text { MC qe, } \\
\text { máx } \\
(\mu \mathrm{g} / \mathrm{mg})\end{array}$ & $\mathrm{R} 2$ & $\mathrm{Kf}$ & $1 / \mathrm{n}$ & $\begin{array}{c}\text { Co } \\
(\mu \mathrm{g} / \mathrm{L})\end{array}$ & $\mathrm{pH}$ & $\begin{array}{c}\text { MC qe, } \\
\text { máx } \\
(\mu \mathrm{g} / \mathrm{mg})\end{array}$ & $\mathrm{R} 2$ & $\mathrm{Kf}$ & $1 / \mathrm{n}$ \\
\hline $1\left(^{*}\right)$ & 747 & $\begin{array}{c}7,02 \mathrm{a} \\
7,09\end{array}$ & 3,2 & 0,83 & 1,193 & 0,148 & 1129 & $\begin{array}{c}6,98 \\
\mathrm{a} \\
7,05\end{array}$ & 2,8 & 0,84 & 0,766 & 0,182 \\
\hline $6\left(^{*}\right)$ & 747 & $\begin{array}{c}6,99 \mathrm{a} \\
7,04\end{array}$ & 10,1 & 0,83 & 0,803 & 0,383 & 1208 & $\begin{array}{c}6,86 \\
\mathrm{a} \\
7,10\end{array}$ & 10,7 & 0,92 & 1,066 & 0,325 \\
\hline
\end{tabular}

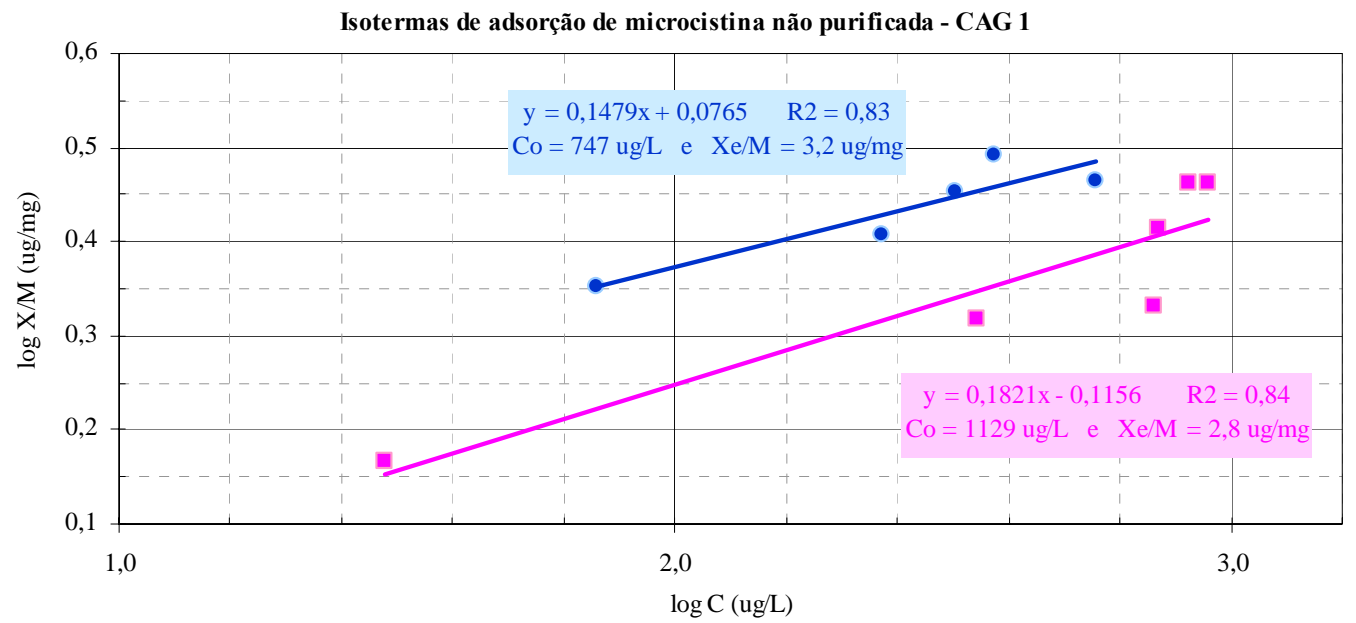

Figura 5.5.2 - Isotermas de adsorção de microcistina não purificada para o carvão ativado granular 1

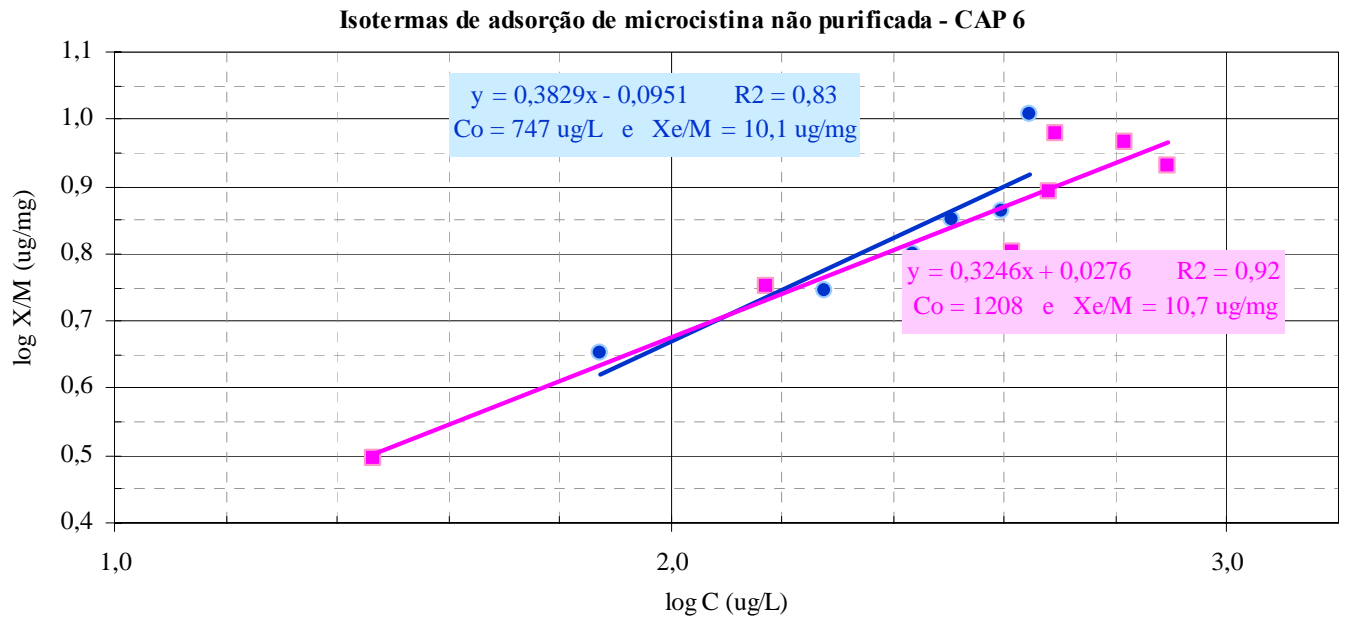

Figura 5.5.3 - Isotermas de adsorção de microcistina não purificada para o carvão ativado pulverizado 6

Considerando os resultados da caracterização prévia realizada, com baixos valores de IAM e volumes de mesoporos entre 0,04 e $0,09 \mathrm{~cm}^{3} / \mathrm{g}$, constatou-se, a baixa capacidade adsortiva dos carvões selecionados para adsorção de microcistina não purificada, tendo 
resultado em valores de capacidade máxima de adsorção de MCs da ordem de 3,0 $\mu \mathrm{g} / \mathrm{mg}$ para o carvão ativado granular - CAG1 e da ordem de $10 \mu \mathrm{g} / \mathrm{mg}$ para o carvão ativado pulverizado - CAP6. Vale ressaltar que os melhores carvões dos trabalhos citados (Tabela 5.5.4), com mesoporosidade bem desenvolvida (volume de mesoporos entre 0,19 e 0,5 $\mathrm{cm}^{3} / \mathrm{g}$ ), apresentaram valores de capacidade máxima de adsorção de MC-LR entre 100 e 200 $\mu \mathrm{g} / \mathrm{mg}$. Porém, deve-se considerar que esses trabalhos foram desenvolvidos com o emprego de padrões certificados de MC-LR dissolvidas em água ultra-pura. Na Tabela 5.5.4 é apresentado um resumo dos principais resultados da caracterização de carvões ativados em trabalhos citados.

Tabela 5.5.4 - Resumo dos principais resultados da caracterização de carvões ativados pulverizados em trabalhos citados

\begin{tabular}{|c|c|c|c|c|c|c|c|c|}
\hline Autores & $\begin{array}{l}\text { matéria- } \\
\text { prima }\end{array}$ & $\begin{array}{l}\text { Índice de } \\
\text { Azul } \\
\text { Metileno } \\
\text { (mg/g) }\end{array}$ & $\begin{array}{c}\text { Número } \\
\text { de Iodo } \\
\text { (mg/g) }\end{array}$ & $\begin{array}{c}\text { Área } \\
\text { Superfície } \\
\text { Específica } \\
\text { BET-N2 } \\
\left(\mathrm{m}^{2} / \mathrm{g}\right) \\
\end{array}$ & \multicolumn{2}{|c|}{$\begin{array}{l}\text { Volume } \\
\text { microporos } \\
\left(\mathrm{cm}^{3} / \mathrm{g}\right)\end{array}$} & $\begin{array}{l}\text { Volume } \\
\text { mesoporos } \\
\left(\mathrm{cm}^{3} / \mathrm{g}\right)\end{array}$ & $\begin{array}{c}\text { qe, máx MC- } \\
\text { LR } \\
(\mu \mathrm{g} / \mathrm{mg})\end{array}$ \\
\hline $\begin{array}{l}\text { Baçaoui et. } \\
\text { al., } 2001\end{array}$ & $\begin{array}{l}\text { caroço de } \\
\text { azeitona }\end{array}$ & 115 a 490 & $\begin{array}{l}741 \mathrm{a} \\
1495\end{array}$ & 514 a 1271 & \multicolumn{2}{|c|}{0,225 a 0,377} & $\begin{array}{c}0,217 \text { a } \\
0,557 \\
\varnothing>3,7 \mathrm{~nm}\end{array}$ & - \\
\hline \multirow{8}{*}{$\begin{array}{l}\text { DONATI } \\
\text { et.al. } 1994\end{array}$} & 1-mineral & - & 688 & 863 & \multicolumn{2}{|c|}{0,39} & 0,1 & 70 \\
\hline & 2-côco & - & 991 & 991 & \multicolumn{2}{|c|}{0,42} & 0,02 & 40 \\
\hline & 3-madeira & - & 964 & 1197 & \multicolumn{2}{|c|}{0,6} & 0,49 & 280 \\
\hline & 4-mineral & - & 929 & 1000 & \multicolumn{2}{|c|}{0,44} & 0,05 & 75 \\
\hline & 5-côco & - & 956 & 1067 & \multicolumn{2}{|c|}{0,45} & 0,03 & 20 \\
\hline & 6-turfa & - & 590 & 493 & \multicolumn{2}{|c|}{0,23} & 0,06 & 20 \\
\hline & 7-madeira & - & 953 & 1366 & \multicolumn{2}{|c|}{0,72} & 0,27 & 220 \\
\hline & 8-mineral & - & 1023 & 1329 & \multicolumn{2}{|c|}{0,66} & 0,19 & 116 \\
\hline \multirow{5}{*}{$\begin{array}{l}\text { PENDLE- } \\
\text { TON et. al. } \\
\quad 2001\end{array}$} & 1-madeira & \multirow{3}{*}{\multicolumn{3}{|c|}{$\begin{array}{l}\text { ativados quimicamente com ácido } \\
\text { fosfórico }\end{array}$}} & $0,52^{(1)}$ & $0,33^{(2)}$ & 0,4 & 189 \\
\hline & 2-madeira & & & & $0,46^{(1)}$ & $0,5^{(2)}$ & 0,38 & 200 \\
\hline & 3-madeira & & & & $0,42^{(1)}$ & $029^{(2)}$ & 0,26 & 161 \\
\hline & 4-côco & \multirow{2}{*}{\multicolumn{3}{|c|}{ ativados fisicamente com vapor }} & $0,68^{(1)}$ & $0,13^{(2)}$ & 0,05 & 22 \\
\hline & 5-côco & & & & $0,29^{(1)}$ & $0,1^{(2)}$ & 0,07 & 7 \\
\hline
\end{tabular}

${ }^{(1)}$ : microporos primários; ${ }^{(2)}$ : microporos secundários.

Na Figura 5.5.4 é apresentado um resumo dos resultados obtidos na caracterização realizada para os carvões CAG1 e CAP6 selecionados. 


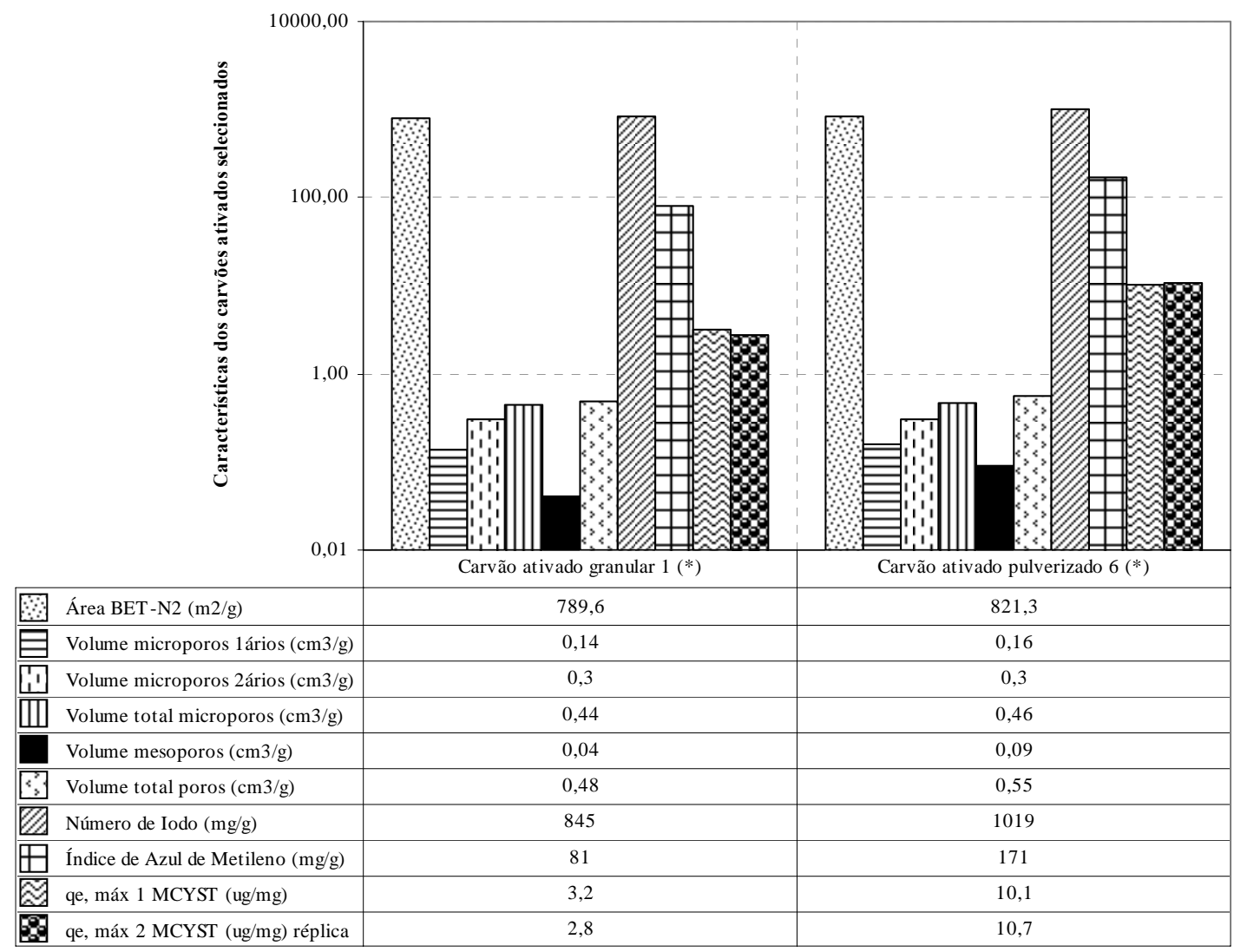

Figura 5.5.4 - Resumo dos resultados obtidos na caracterização dos carvões ativados granular e pulverizado selecionados

Com a conclusão deste trabalho, as relações estabelecidas em trabalhos citados entre a capacidade adsortiva dos carvões ativados para MC-LR, o volume de mesoporos e o índice de azul de metileno puderam ser verificadas.

Foi possível constatar que a determinação dos índices de iodo e de azul de metileno como estimativa dos volumes de micro e mesoporos, respectivamente, mostrou ser uma ferramenta eficiente e de simples execução para controle da qualidade dos carvões ativados destinados ao uso em sistemas de tratamento de águas para consumo humano. Assim, este trabalho ressalta a importância da realização de outras análises, além das regulamentadas, para caracterização dos carvões ativados, devido à necessidade cada vez mais premente, de remoção de contaminantes específicos presentes em águas destinadas ao consumo humano. 


\subsection{METAS 7 E 8: AVALIAÇÃO DA REMOÇÃO DE CÉLULAS E SUBPRODUTOS DE MICROCYSTIS SPP. COM EMPREGO DE DUPLA FILTRAÇÃO, OXIDAÇÃO E ADSORÇÃO - ENSAIOS EM IP}

\subsubsection{Programação dos ensaios}

Na Figura 5.6.1 são esquematizados os ensaios realizados para avaliação da remoção de células e subprodutos de Microcystis spp. com emprego de dupla filtração, oxidação e adsorção nas diferentes fases.

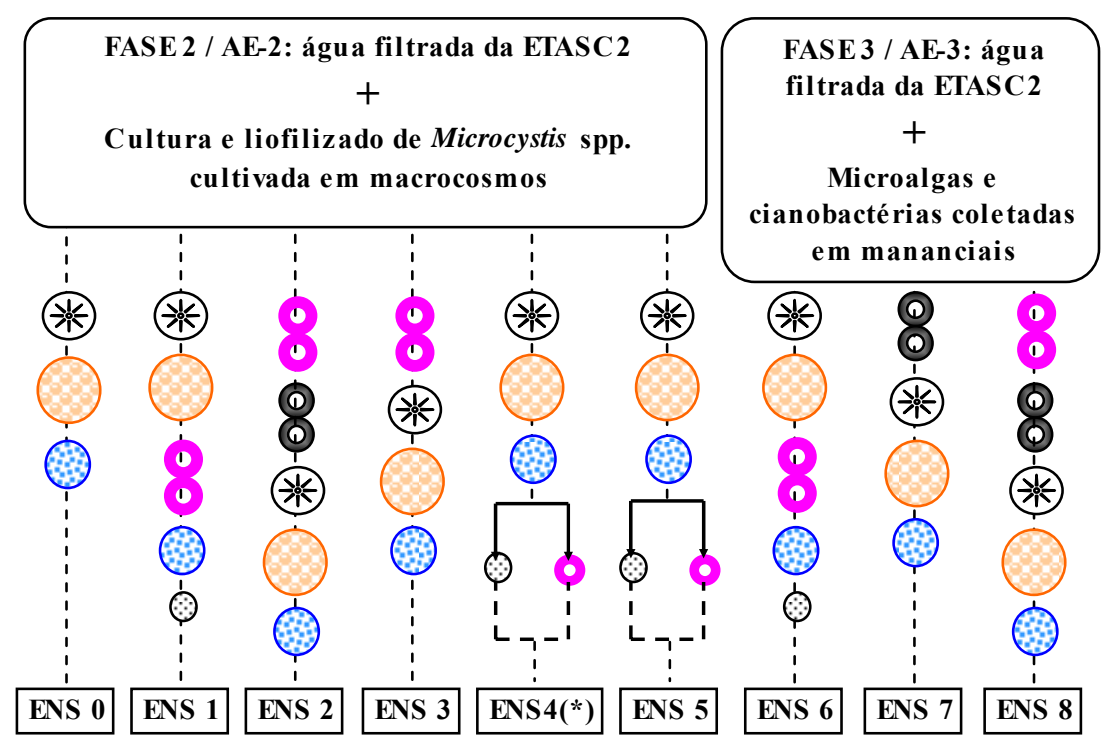

\section{LEGENDA:}

CMR: Câmara de mistura rápida 東

FLA: Filtro de laboratório de areia

CO : Câmara de oxidação

FAP: Filtro ascendente de pedregulho

CA: Câmara de adsorção (?)

FD: Filtro descendente

(*): Ensaio com problemas operacionais

FCAG: Filtro de carvão ativado granular $\bigcirc$

Figura 5.6.1 - Sistemas de tratamento utilizados nos ensaios para avaliação da remoção de células e subprodutos de Microcystis spp.

\subsection{2 Águas de estudo}

Em geral, as águas de estudo tipo 1 - AE-1 (água com adição de cultura de Microcystis spp.) com densidades de Microcystis spp. próximas de $10^{5} \mathrm{cel} / \mathrm{mL}$ resultaram em concentrações de microcistinas - MC extracelulares inferiores a 1,0 $\mu \mathrm{g} / \mathrm{L}$, e totais (intra e extracelulares), da ordem de $10 \mu \mathrm{g} / \mathrm{L}$.

Nos ensaios preliminares realizados em IP, com emprego de AE-1, foi observada elevada eficiência da filtração ascendente em pedregulho em relação à remoção de células, e consequentemente, de MCs intracelulares. Esse fato inviabilizaria a avaliação dos processos 
subseqüentes do tratamento por oxidação e adsorção, a serem empregados nos próximos ensaios, uma vez que as concentrações de MCs extracelulares após adição das culturas resultaram baixas.

Concentrações elevadas de toxinas totais (intra e extracelulares) de até $25000 \mu \mathrm{g} / \mathrm{L}$ de microcistinas e de $3300 \mu \mathrm{g} / \mathrm{L}$ de anatoxina-a(s) presentes em águas superficiais são reportadas por SIVONEN E JONES (1999), porém, deve-se considerar que esses valores correspondem, provavelmente, à escuma de florações ou ao material de coleta previamente concentrado. DONATI et.al. 1994 relatam concentrações típicas de MCs em florações naturais da ordem de $50 \mu \mathrm{g} / \mathrm{L}$.

No entanto, considerando a possibilidade de manejo de florações e de adequação dos sistemas de captação, os contatos realizados com alguns sistemas produtores de águas para abastecimento / consumo humano no Brasil, com histórico de freqüente ocorrência de florações no manancial de captação e a quantidade de material (suspensão de células de Microcystis spp. e extrato de MCs) necessária para a realização dos ensaios em instalação piloto - IP, optou-se pelo emprego de águas de estudo tipo 2 - AE-2, com densidades de Microcystis spp. próximas de $10^{5} \mathrm{cel} / \mathrm{mL}$ e concentrações de MCs totais entre 10 e $20 \mu \mathrm{g} / \mathrm{L}$ nos ensaios em IP da fase 2 deste trabalho.

Assim, para a realização dos ensaios em IP, foi necessário aumentar, significativamente, o volume previsto de culturas em macrocosmos (3 aquários de 200 L) em função da necessidade de preparação dos extratos de MCs, além do volume previsto para a suspensão de células de Microcystis spp., aplicada para manutenção da densidade de Microcystis spp..

Para preparação dos extratos, as culturas foram concentradas, liofilizadas e ressuspensas na cultura reservada para compor a AE-2 em proporções previamente definidas, de forma a resultar em concentrações de MCs extracelulares próximas às desejadas (Figura 5.6.2).

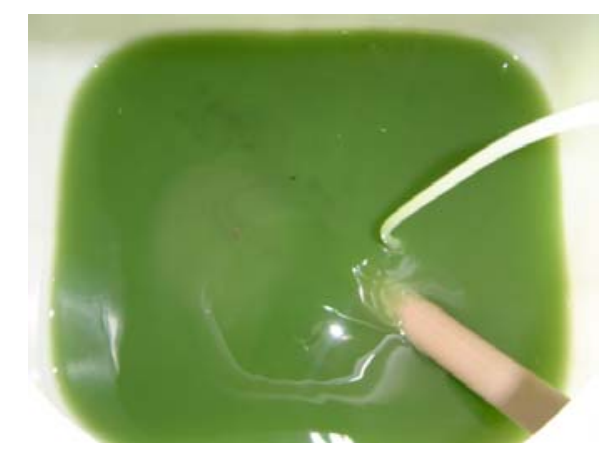

Figura 5.6.2 - Vista supeior da suspensão de células de Microcystis spp. e extrato de microcistinas - MCs 
Para avaliar a aplicabilidade dos resultados obtidos nos ensaios com a AE-2, foi programada a realização de uma bateria de ensaios em IP, utilizando-se a AE-3, obtida com a adição de material coletado em manancial eutrofizado da região - Reservatório de Barra Bonita - SP / Médio Tietê em 15/07/2006, uma vez que vários estudos têm demonstrado a ocorrência de florações toxigênicas no reservatório de Barra Bonita, por meio de testes de toxicidade com cladóceros e camundongos (Minillo, 2005; Sotero-Santos et. al., 2006; Okumura et. al., 2006)

Na Figura 5.6.3 são apresentadas fotos do local de coleta e da amostragem pontual realizada para caracterização da água do Reservatório em função da profundidade, cujos dados complementares encontram-se na Tabela 5.6.1.

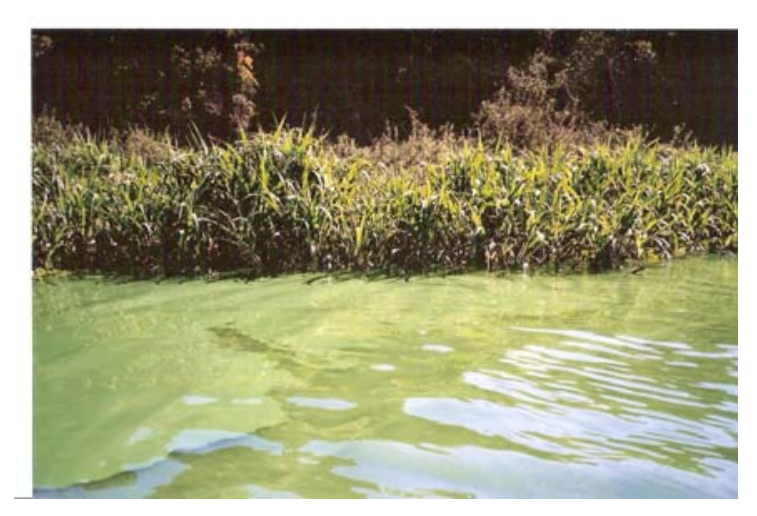

Local de coleta: Reservatório de Barra Bonita - SP

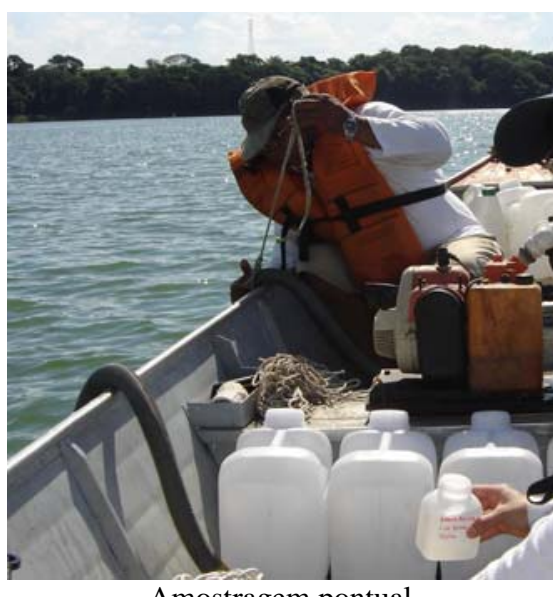

Amostragem pontual

Figura 5.6.3 - Vista geral do local de coleta e do material para compor a AE-3

As concentrações de microcistinas - MCs totais de todas as amostras coletadas no ponto de amostragem resultaram inferiores a $0,16 \mu \mathrm{g} / \mathrm{L}$ (limite de detecção do método), o que fundamenta o planejamento experimental empregado com adoção de concentrações de MCs substancialmente menores em relação às reportadas na literatura.

Os dados de contagem e identificação fitoplanctônica da amostragem pontual (Figuras 5.6.4 e 5.6.5) indicaram predominância de cianofíceas (cianobactérias), com valores de abundância relativa entre 70 e 82 \%, para profundidades de até 10 m. Nessas primeiras subcamadas, pôde-se observar a predominância do gênero Aphanotece em relação às demais cianofíceas, cabendo ao gênero Microcystis, valores de abundância relativa entre 24 e 43 \%, o que pode ter contribuído para a baixa concentração de microcistinas encontrada. 
Tabela 5.6.1 -Caracterização da água do Reservatório de Barra Bonita / Amostragem pontual em função da profundidade

PONTO DE AMOSTRAGEM: GPS: $22^{\circ}$ 31,408' S e 48 31,887' W; disco de Secchi: 0,80 m; horário: 12:25 h; Observações: dia ensolarado, sem nuvens, com ventos; muitas pessoas pescando às margens da represa e barcos de turismo passando (sábado)

\begin{tabular}{l|c|c|c|c|c|c}
\hline \multirow{2}{*}{ PARÂMETROS } & \multicolumn{7}{c}{ Profundidade (m) } \\
\cline { 2 - 7 } & $\mathbf{0}$ & $\mathbf{5}$ & $\mathbf{1 0}$ & $\mathbf{1 5}$ & $\mathbf{2 0}$ & $\mathbf{2 5}$ \\
\hline $\mathrm{pH}$ & 6,93 & 6,47 & 6,15 & 5,87 & 5,69 & 5,33 \\
\hline Temperatura $\left({ }^{\circ} \mathrm{C}\right)$ & 20,8 & 20,2 & 20,1 & 19,4 & 19,2 & 19,2 \\
\hline Condutividade elétrica $(\mu \mathrm{S} / \mathrm{cm})$ & 0,182 & 0,184 & 0,184 & 0,177 & 0,174 & 0,193 \\
\hline Clorofila-a $(\mu \mathrm{g} / \mathrm{L})$ & 73,68 & 69,78 & 37,53 & 1,67 & 1,9 & 0 \\
\hline Feofitina $(\mu \mathrm{g} / \mathrm{L})$ & 5,51 & 4,95 & 4,96 & 3,01 & 0,49 & 2,93 \\
\hline N-amoniacal $(\mu \mathrm{g} / \mathrm{L})$ & 17,43 & 17,43 & 17,82 & 20,54 & 25,20 & 11,21 \\
\hline N-nitrato $(\mu \mathrm{g} / \mathrm{L})$ & 645,46 & 610,52 & 806,02 & 543,93 & 646,88 & 626,57 \\
\hline N-nitrito $(\mu \mathrm{g} / \mathrm{L})$ & 41,91 & 38,33 & 46,22 & 9,21 & 6,83 & 9,55 \\
\hline N-Total $(\mu \mathrm{g} / \mathrm{L})$ & 1351,90 & 1345,37 & 821,58 & 908,33 & 830,06 & 734,17 \\
\hline Fosfato-inorgânico $(\mu \mathrm{g} / \mathrm{L})$ & 7,97 & 10,90 & 5,63 & 15,60 & 13,84 & 16,48 \\
\hline Fosfato-orgânico $(\mu \mathrm{g} / \mathrm{L})$ & 2,98 & 3,41 & 8,38 & 2,08 & 5,67 & 4,56 \\
\hline Fosfato-Total $(\mu \mathrm{gg} / \mathrm{L})$ & 10,95 & 14,32 & 14,01 & 17,68 & 19,51 & 21,04 \\
\hline P-Total $(\mu \mathrm{g} / \mathrm{L})$ & 160,59 & 147,22 & 111,66 & 65,01 & 64,35 & 61,74 \\
\hline Silicato $(\mathrm{mg} / \mathrm{L})$ & 6,87 & 6,70 & 6,51 & 6,75 & 6,87 & 6,79 \\
\hline SST (mg/L) & 18,67 & 14,33 & 7,11 & 2,40 & 3,20 & 4,00 \\
\hline SSF (mg/L) & 0,00 & 3,00 & 1,11 & 0,00 & 1,60 & 1,80 \\
\hline SSV (mg/L) & 18,67 & 11,33 & 6,00 & 2,40 & 1,60 & 2,20 \\
\hline
\end{tabular}

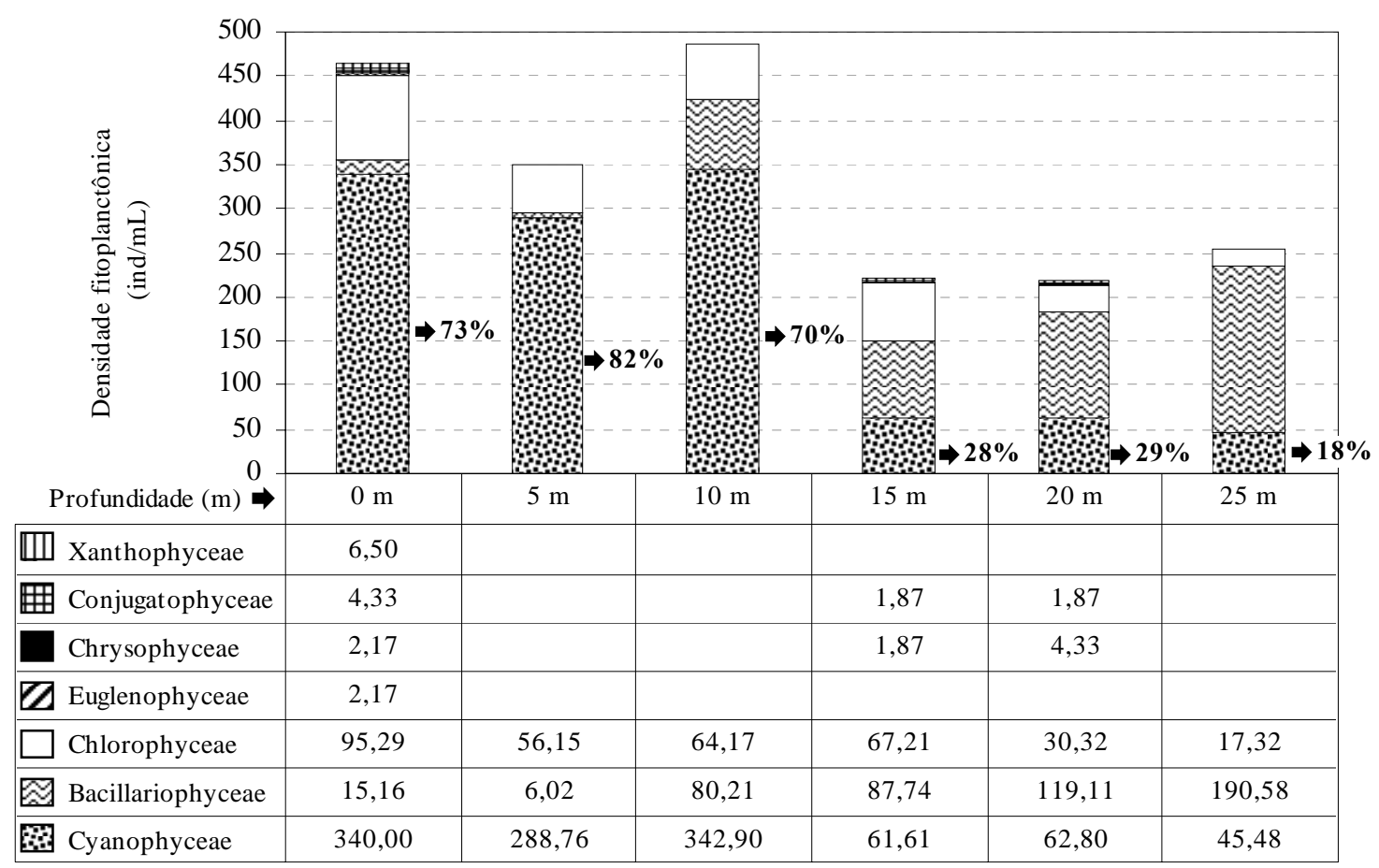

Figura 5.6.4 - Densidade fitoplanctônica da amostragem pontual realizada em função da profundidade no Reservatório de Barra Bonita - SP 


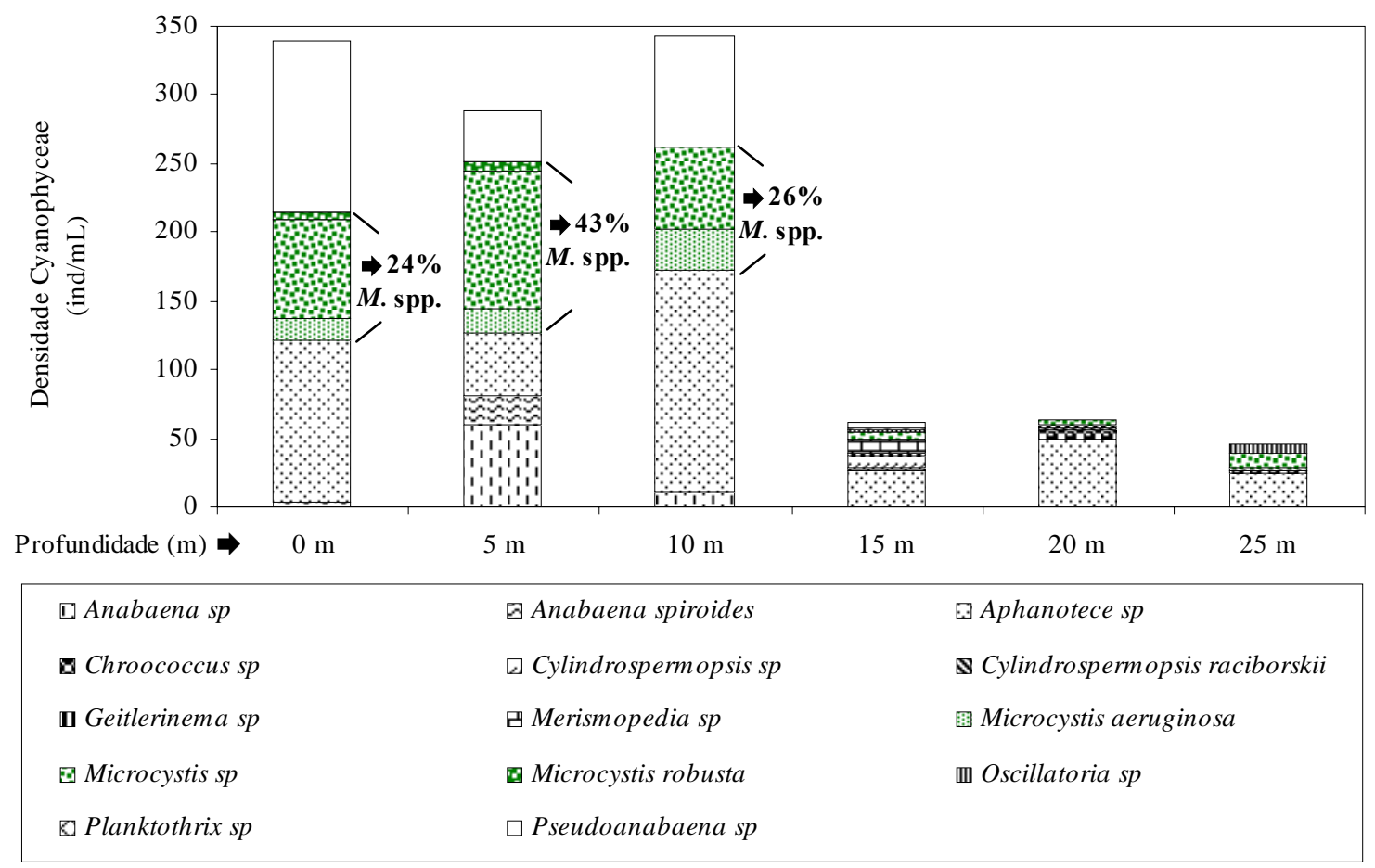

Figura 5.6.5 - Densidade de Cyanophyceae da amostragem pontual realizada em função da profundidade no Reservatório de Barra Bonita - SP

Na Figura 5.6.6 pode-se observar a aparência do material concentrado coletado com densidade de Microcystis spp. da ordem de $10^{8}$ cél/mL e da suspensão diluída com densidade de Microcystis spp. da ordem de $10^{7}$ cél/mL aplicada nos ensaios 6, 7 e 8 para compor a AE3.

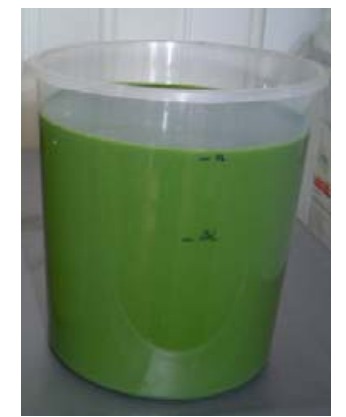

Densidade $M$. spp. da ordem de $10^{8}$ cél $/ \mathrm{mL}$ Material concentrado coletado

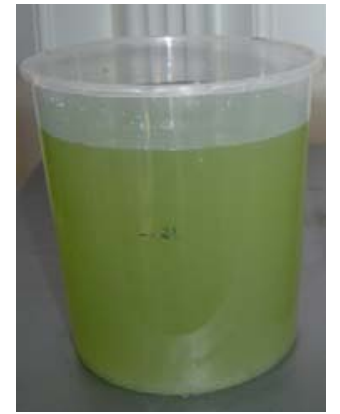

Densidade $M$. spp. da ordem de $10^{7}$ cél $/ \mathrm{mL}$ Suspensão diluída empregada nos ensaios

Figura 5.6.6 - Vista geral do material coletado no reservatório de Barra Bonita - SP e da suspensão empregada para compor a AE-3

Desta forma, as composições das águas de estudo empregadas na avaliação da remoção de células e subprodutos de Microcystis spp. nos ensaios em IP, nas diferentes fases, são descritas a seguir. 
- Água de estudo tipo 2 - AE-2: água filtrada sem cloração da ETASC2 com adição de cultura de Microcystis spp. e extrato de MCs não purificadas $\Rightarrow$ FASE 2;

- Água de estudo tipo 3 - AE-3: água filtrada sem cloração da ETASC2 com adição de material coletado no Reservatório de Barra Bonita - SP $\Rightarrow$ FASE 3.

Na Tabela 5.6.2 são apresentados os resultados da caracterização complementar das águas de estudo empregadas nos ensaios realizados.

Tabela 5.6.2 - Caracterização das águas de estudo empregadas nos ENSAIOS 1 a 8

\begin{tabular}{|c|c|c|c|c|c|c|c|}
\hline FASES $\Rightarrow$ & & & FASE 2 & & & & E 3 \\
\hline ÁGUAS $\Rightarrow$ & & Água de & tudo ti & $2 \mathrm{AE}-$ & & $\begin{array}{r}\text { Água } \\
\text { tipo }\end{array}$ & $\begin{array}{l}\text { estudo } \\
\text { AE-3 }\end{array}$ \\
\hline PARÂMETROS $\quad$ ENSAIOS $\Rightarrow$ & 1 & 2 & 3 & 4 & 5 & 6 & 7 e 8 \\
\hline $\mathrm{pH}$ & 6,71 & 6,64 & 7,23 & 6,63 & 6,41 & 7,55 & 7,67 \\
\hline Cor aparente (uH) & 24 & 24 & 25 & 23 & 31 & 23 & 23 \\
\hline Cor verdadeira $(\mathrm{uH})$ & - & 2,0 & 1,0 & 1,0 & 6,0 & 1,0 & 6,0 \\
\hline Turbidez (uT) & 3,01 & 2,36 & 2,62 & 2,97 & 2,15 & 4,35 & 3,91 \\
\hline Alcalinidade total $\left(\mathrm{mg} \mathrm{CaCO}_{3} / \mathrm{L}\right)$ & 4,0 & 6,0 & 7,0 & 7,0 & 7,0 & 7,0 & 7,0 \\
\hline Dureza total $(\mathrm{mg} \mathrm{CaCO} / \mathrm{L})$ & 8,0 & 20 & 20 & 22,0 & 16 & 13,0 & 15,0 \\
\hline Condutividade elétrica $(\mu \mathrm{S} / \mathrm{cm})$ & 44,5 & 46,9 & 54,8 & 38,2 & 36,4 & 24,5 & 39,4 \\
\hline Carbono orgânico total (mg C/L) & 1,227 & 2,767 & 3,949 & 3,336 & 2,988 & 1,739 & 2,899 \\
\hline Absorvância 254 nm (UA) & 0,023 & 0,052 & 0,037 & 0,037 & 0,017 & 0,011 & 0,024 \\
\hline $\mathrm{N}$ amoniacal $(\mu \mathrm{g} / \mathrm{L})$ & 50 & 120 & 150 & 150 & 80 & 10 & 60 \\
\hline $\mathrm{N}$ nitrato $(\mu \mathrm{g} / \mathrm{L})$ & 633 & 777 & 820 & 437 & 747 & 206 & 789 \\
\hline $\mathrm{N}$ nitrito $(\mu \mathrm{g} / \mathrm{L})$ & 39 & ND & ND & 188 & 125 & 2 & ND \\
\hline Cloro livre (mg/L) & ND & ND & ND & ND & ND & ND & ND \\
\hline Cloretos (mg/L) & - & - & 3,0 & 1,4 & 1,2 & 0,8 & ND \\
\hline Sulfatos (mg/L) & - & 5,0 & 7,0 & 5,0 & 1,0 & ND & ND \\
\hline Acidez & - & 3,0 & 3,0 & 5,0 & 10,0 & 3,0 & 3,0 \\
\hline Fosfato total $(\mu \mathrm{g} / \mathrm{L})$ & - & - & - & - & 390 & 50 & 70 \\
\hline
\end{tabular}

(*): amostra coletada no final do ensaio e caracterização realizada no dia seguinte; ND: não detectado

\subsubsection{Parâmetros de desempenho}

São apresentados a seguir, um resumo das condições de funcionamento, dos parâmetros de desempenho para controles operacional e qualitativo complementar (carbono orgânico total - COT, absorvância $\lambda=254$ nm, oxigênio dissolvido, condutividade e dureza) nos ensaios realizados nas fases 2 e 3. Com as taxas de filtração do FAP e FD fixadas, as condições de funcionamento resultantes para os outros processos são apresentadas no topo das tabelas seguintes, dispostas na forma seqüencial de aplicação estabelecida para cada ensaio / sistema de tratamento. 
Em seguida, são apresentados os gráficos de variação de turbidez dos efluentes em função do tempo, medidos por turbidímetros de escoamento contínuo, onde é possível observar a amplitude das instabilidades geradas decorrentes da execução de descarga de fundo intermediária - DFI no FAP e das variações de qualidade dos afluentes de cada processo. Posteriormente, são apresentados os resultados gráficos e tabelados dos parâmetros de desempenho para controle qualitativo (densidade de Microcystis spp., equivalentes de microcistinas - MCs extracelulares e subprodutos organohalogenados - SPOs) dos efluentes de cada processo de tratamento para diferentes tempos de amostragem. 
Tabela 5.6.3 - Resumo das condições de funcionamento e dos parâmetros de desempenho para os controles operacional e qualitativo do ENSAIO 1-IP (em instalação piloto)

\section{ENSAIO1-IP: Sistema MR $\rightarrow$ FAP $\rightarrow$ INTER $\rightarrow$ FD $\rightarrow$ FCAG}

\begin{tabular}{c|c|c|c|c}
\hline TC-MR $=50 \mathrm{~s}$ & $\begin{array}{c}\text { TxF-FAP }=120 \\
\mathrm{~m}^{3} / \mathrm{m}^{2} . \mathrm{d}\end{array}$ & TC-INTER $=44 \mathrm{~min}$ & $\begin{array}{c}\text { TxF-FD }=180 \\
\mathrm{~m}^{3} / \mathrm{m}^{2} . \mathrm{d}\end{array}$ & TCv FCAG $=12 \mathrm{~min}$ \\
\hline
\end{tabular}

PARÂMETROS CONTROLE OPERACIONAL: DSA: 6 a 7 mg/L; DHS: 1 a 1,5 mg/L; pH da AC: 6,3 a 6,6; potencial zeta da AC: -6,4 a +3,2 mV; cloro residual do efluente da intercloração (mantido próximo de 0,5 mg/L): 0,1 a $0,78 \mathrm{mg} / \mathrm{L}$, temperatura: 20,5 a $24,5^{\circ} \mathrm{C}$; DFI realizada na $6^{\mathrm{a}} \mathrm{h}$, duração do ensaio: $12 \mathrm{~h}$

\begin{tabular}{|c|c|c|c|c|c|c|}
\hline \multirow{2}{*}{$\begin{array}{l}\text { PARÂMETROS } \\
\text { CONTROLE } \\
\text { QUALITATIVO }\end{array}$} & \multicolumn{6}{|c|}{ Águas de diluição - AD, de estudo - AE e Efluentes } \\
\hline & $\mathrm{AD}$ & $\mathrm{AE}$ & FAP & INTER & FD & FCAG \\
\hline $\mathrm{pH}$ & 6,3 a 6,8 & 6,5 a 7,3 & 6,2 a 6,4 & 6,2 a 6,5 & 6,3 a 6,5 & 8,8 a 9,3 \\
\hline Potencial Zeta (mV) & $-1,2$ a $-1,5$ & $\begin{array}{c}-32,5 \mathrm{a} \\
-35,1 \\
\end{array}$ & - & - & - & - \\
\hline $\begin{array}{c}\text { Carbono orgânico total - COT } \\
(\text { mg C / L) }\end{array}$ & - & 1,3 a 2,4 & 1,01 a 2,4 & 1,0 a 2,0 & 1,0 a 1,4 & 0,4 a 3,2 \\
\hline Absorvância $\lambda=254$ nm & - & $\begin{array}{c}0,026 \mathrm{a} \\
0,032\end{array}$ & $\begin{array}{c}0,015 \mathrm{a} \\
0,018\end{array}$ & $\begin{array}{l}0,02 \mathrm{a} \\
0,046\end{array}$ & $\begin{array}{c}0,019 \mathrm{a} \\
0,021\end{array}$ & $\begin{array}{c}0,006 \mathrm{a} \\
0,011\end{array}$ \\
\hline $\begin{array}{c}\text { Oxigênio dissolvido - OD } \\
(\mathrm{mg} / \mathrm{L})\end{array}$ & 7,4 a 7,5 & 7,0 a 7,7 & 7,2 a 7,7 & 7,2 a 7,8 & 7,7 a 7,7 & 6,6 a 7,2 \\
\hline $\begin{array}{c}\text { Condutividade elétrica } \\
(\mu \mathrm{S} / \mathrm{cm})\end{array}$ & 19,7 a 20,5 & 24,7 a 25,6 & 29,4 a 30,5 & 28,5 a 32,2 & 24,4 a 32,2 & 23,4 a 34,1 \\
\hline Dureza $\left(\mathrm{mgCaCO}_{3} / \mathrm{L}\right)$ & 6 a 7 & 7 a 9 & 7 a 9 & 8 а 10 & 8 a 9 & 9 а 10 \\
\hline Turbidez $^{\left({ }^{*}\right)}$ (uT) & - & 2,4 a 4,2 & 0,19 a 0,23 & 0,25 a 0,36 & 0,18 a 0,3 & 0,19 a 0,34 \\
\hline Turbidez $^{(* *)}$ (uT) & - & 2,1 a 2,9 & 0,02 a 0,1 & 0,01 a 0,5 & 0,01 a 0,05 & 0,03 a 0,07 \\
\hline $\begin{array}{l}\text { TC: tempo médio de contato; TxF } \\
\text { filtro ascendente de pedregulho; } \\
\text { DSA: dosagem de sulfato de alum } \\
\text { água de diluição; AE: água de es } \\
\text { HACH: }(* *) \text { leitura em turbidíme }\end{array}$ & $\mathrm{l}_{2}(\mathrm{SC}$ & ração; TCv: & $\begin{array}{l}\text { apo médio de } \\
\text { descendente; } \\
\text { dosagem de h }\end{array}$ & $\begin{array}{l}\text { ontato em vazi } \\
\text { CAG: filtro ce } \\
\text { dróxido de sód }\end{array}$ & $\begin{array}{l}\text {; MR: mistura } \\
\text { m carvão ativa } \\
\text {; AC: água coa }\end{array}$ & $\begin{array}{l}\text { ápida; FAP: } \\
\text { do granular; } \\
\text { gulada; AD: } \\
\text { icada } 2100 \mathrm{P}\end{array}$ \\
\hline
\end{tabular}

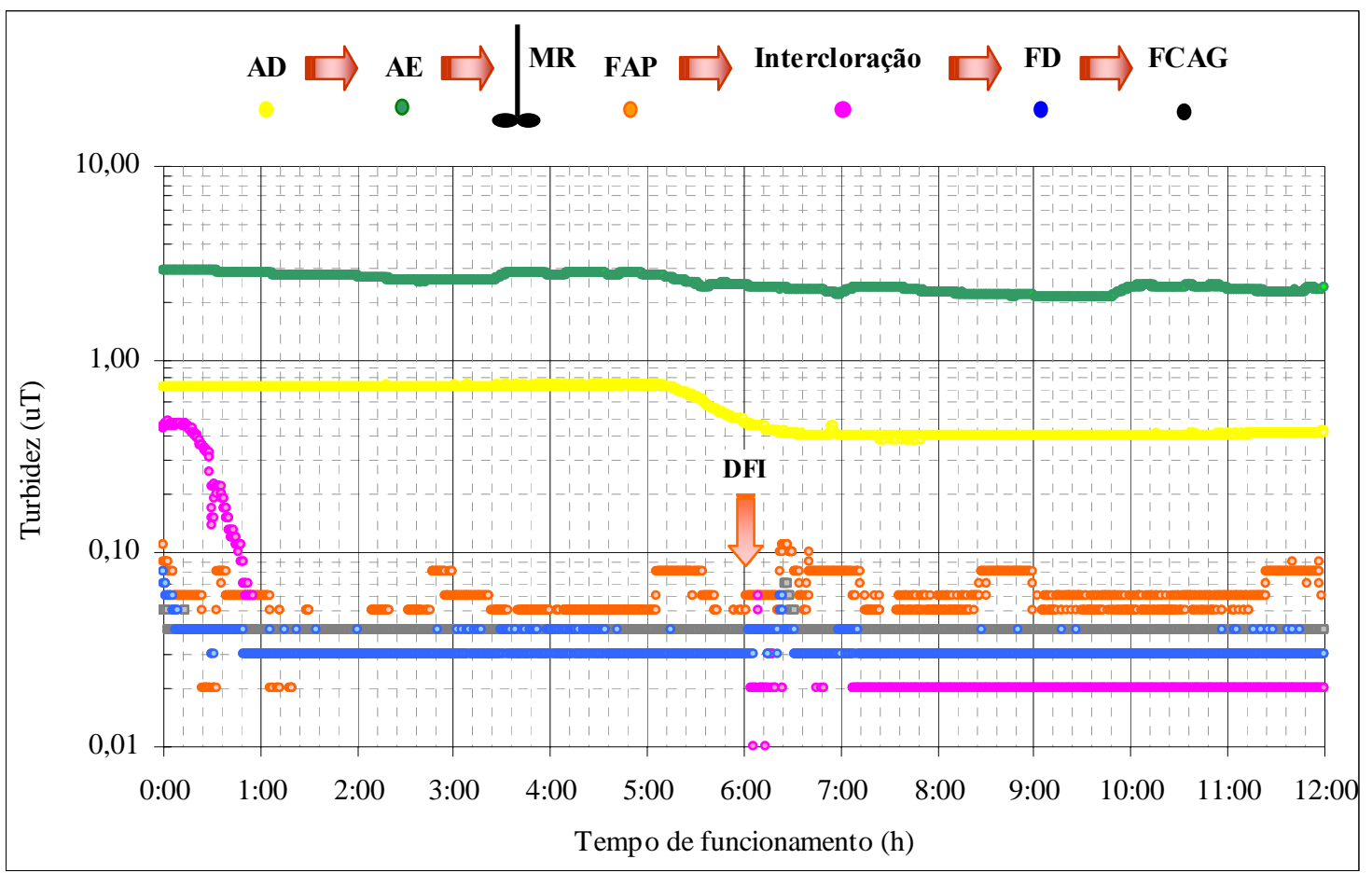

Figura 5.6.7 - Variação dos valores de turbidez em função do tempo nas águas de diluição e de estudo e nos efluentes de cada processo de tratamento do ENSAIO 1-IP 


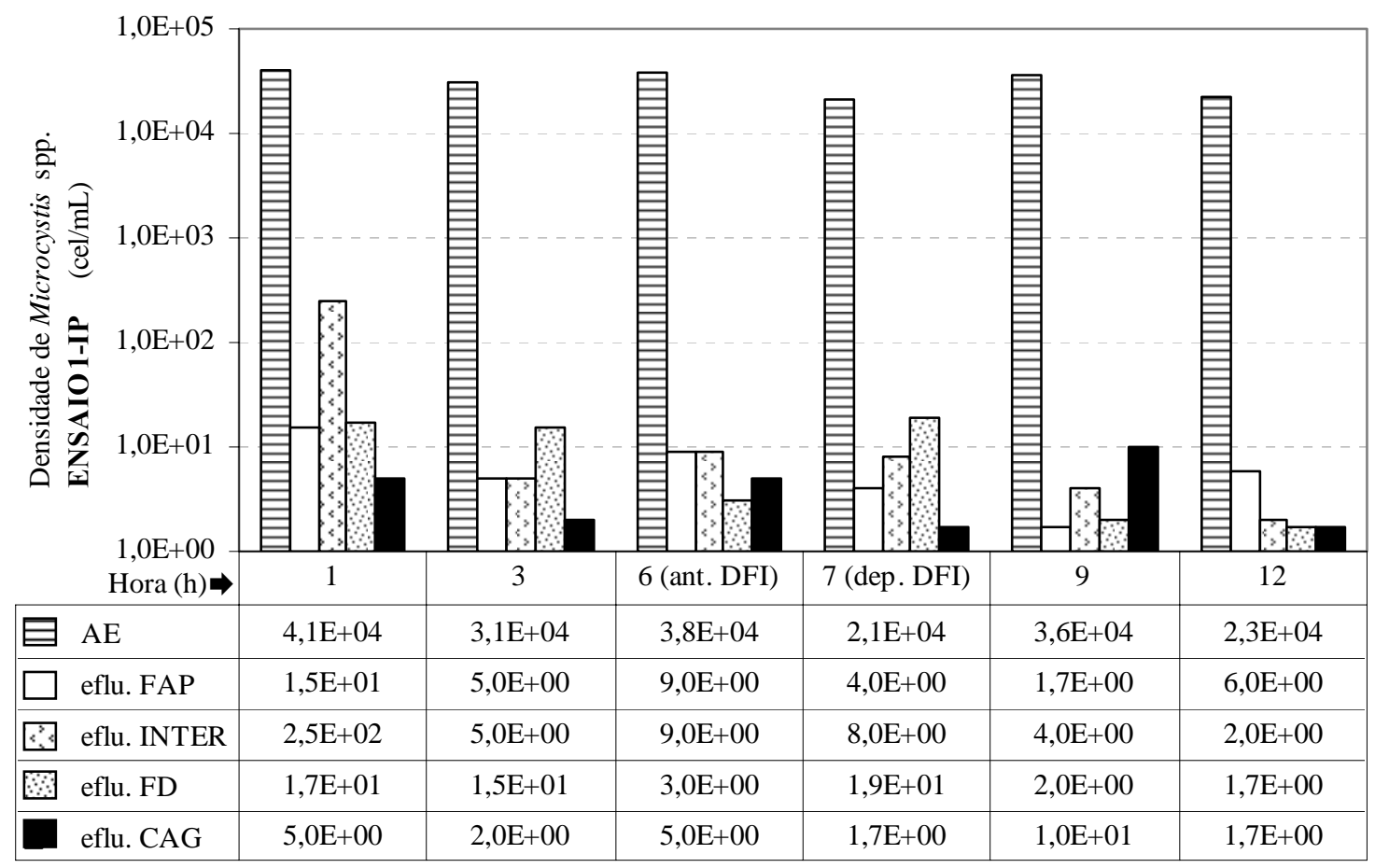

Figura 5.6.8 - Densidade de Microcystis spp. $\left(\mathrm{E}+0 \mathrm{x}=10^{\mathrm{x}}\right)$ na água de estudo e nos efluentes de cada processo de tratamento para diferentes tempos de amostragem do ENSAIO 1-IP

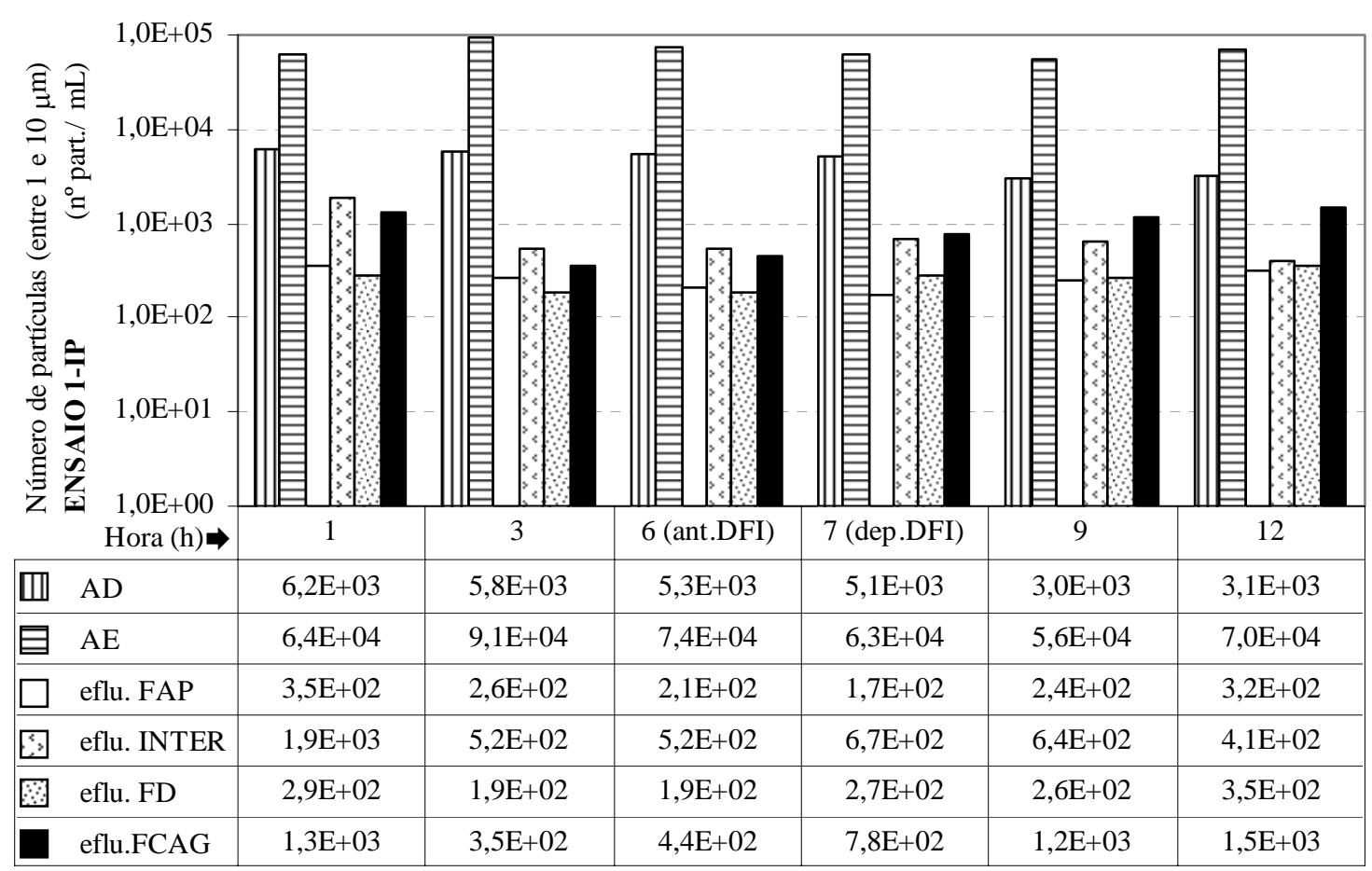

Figura 5.6.9 - Número de partículas (entre 1 e $10 \mu \mathrm{m}$ ) nas águas de diluição e de estudo e nos efluentes de cada processo de tratamento para diferentes tempos de amostragem do ENSAIO 1-IP 


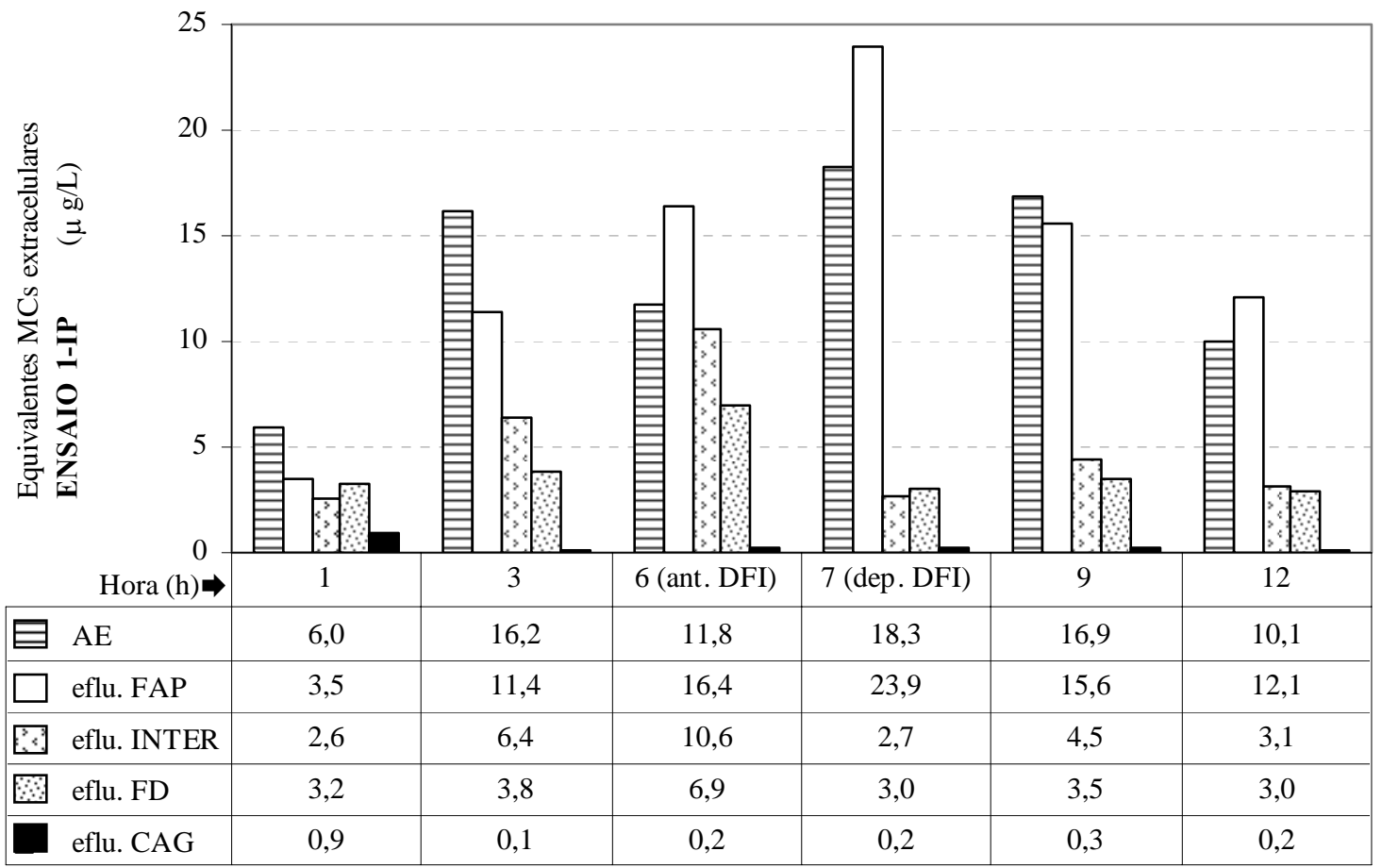

Figura 5.6.10 - Concentração de microcistinas - MCs extracelulares na água de estudo e nos efluentes de cada processo de tratamento para diferentes tempos de amostragem do ENSAIO 1-IP

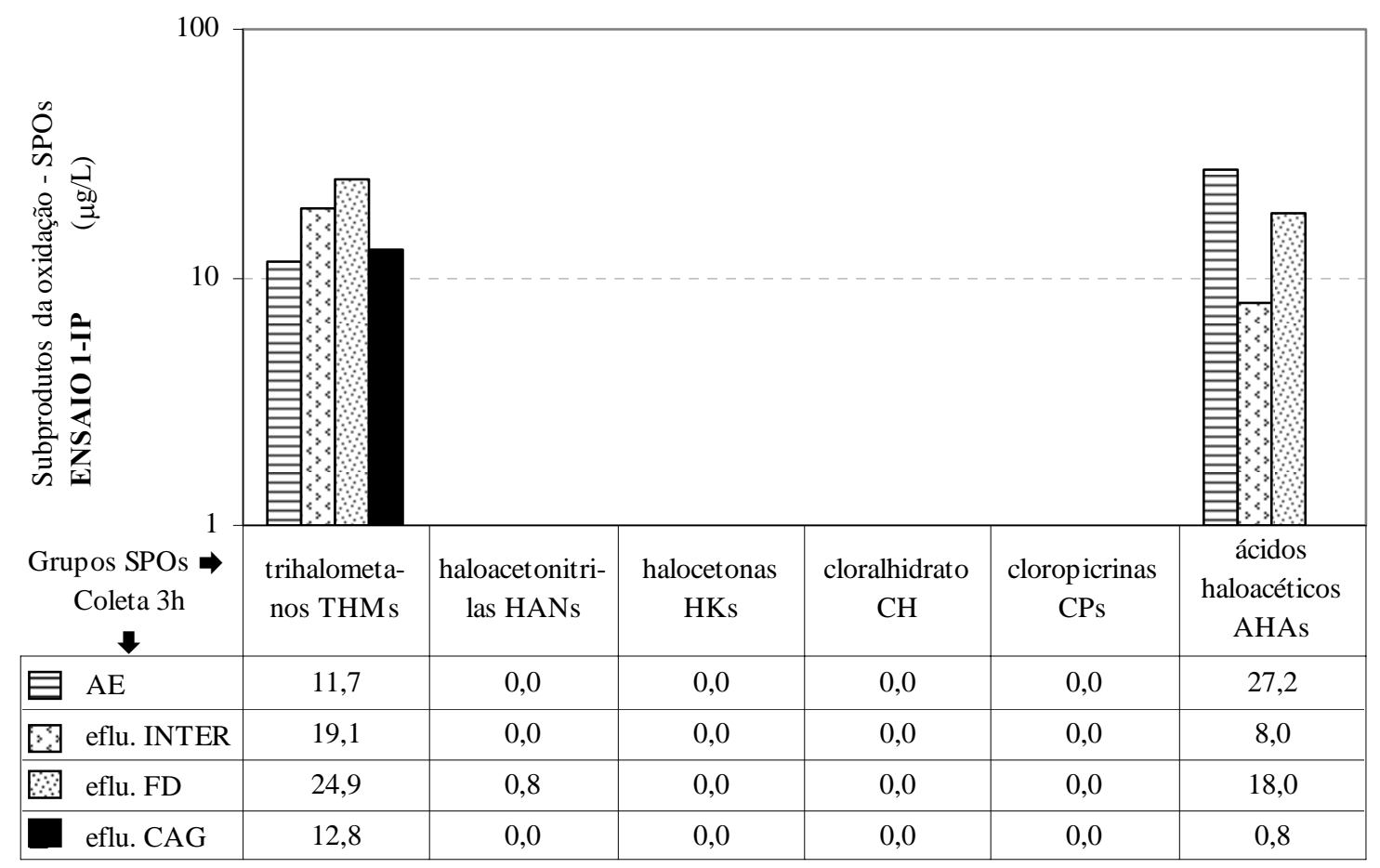

Figura 5.6.11 - Concentração de subprodutos organohalogenados - SPOs formados na água de estudo e nos efluentes de cada processo de tratamento para amostragem de $6 \mathrm{~h}$ do ENSAIO 1-IP 
Tabela 5.6.4 - Resumo das condições de funcionamento e dos parâmetros de desempenho para os controles operacional e qualitativo do ENSAIO2-IP (em instalação piloto)

ENSAIO2-IP: Sistema PRÉ $\rightarrow$ CAP $\rightarrow$ MR $\rightarrow$ FAP $\rightarrow$ FD

\begin{tabular}{c|c|c|c|c}
\hline $\begin{array}{c}\text { TC-PRÉ }=35 \\
\text { min }\end{array}$ & TC-CAP $=20 \mathrm{~min}$ & TC-MR $=60 \mathrm{~s}$ & $\begin{array}{c}\text { TxF-FAP }=120 \\
\mathrm{~m}^{3} / \mathrm{m}^{2} \cdot \mathrm{d}\end{array}$ & $\begin{array}{c}\text { TxF-FD }=180 \\
\mathrm{~m}^{3} / \mathrm{m}^{2} \cdot \mathrm{d}\end{array}$ \\
\hline
\end{tabular}

PARÂMETROS CONTROLE OPERACIONAL: DSA: 5 a 7 mg/L; DHS: 1 a 1,5 mg/L; pH da AC: 6,9 a 7,0; cloro residual do efluente da i pré-oxidação: 0,05 a 0,20 mg/L, DCAP: $20 \mathrm{mg} / \mathrm{L}$; temperatura: 21 a 22,5 ${ }^{\circ} \mathrm{C}$; DFI realizada na $6^{\mathrm{a}} \mathrm{h}$, duração do ensaio: $10 \mathrm{~h}$

\begin{tabular}{|c|c|c|c|c|c|c|}
\hline \multirow{2}{*}{$\begin{array}{c}\text { PARÂMETROS } \\
\text { CONTROLE } \\
\text { QUALITATIVO }\end{array}$} & \multicolumn{6}{|c|}{ Águas de diluição - AD, de estudo - AE e Efluentes } \\
\hline & $\mathrm{AD}$ & $\mathrm{AE}$ & PRÉ & CAP & FAP & FD \\
\hline $\mathrm{pH}$ & 6,9 a 7,1 & 7,0 a 7,2 & 6,8 a 7,1 & 6,9 a 7,5 & 6,7 a 7,1 & 6,7 a 7,1 \\
\hline Potencial Zeta (mV) & $-4,1 \mathrm{a}-2,5$ & $\begin{array}{l}-34,6 \mathrm{a} \\
-24,9 \mathrm{a}\end{array}$ & - & - & $-2,5$ a $-1,2$ & $-2,1$ a $-1,8$ \\
\hline $\begin{array}{c}\text { Carbono orgânico total - COT } \\
\text { (mg C / L) }\end{array}$ & - & 1,45 a 4,48 & 1,48 а 3,99 & 1,75 a 4,3 & 0,63 a 2,39 & 0,68 а 2,27 \\
\hline Absorvância $\lambda=254$ nm & - & $\begin{array}{c}0,026 \mathrm{a} \\
0,033\end{array}$ & $\begin{array}{c}0,015 \text { a } \\
0,033\end{array}$ & $\begin{array}{c}0,015 \mathrm{a} \\
0,026\end{array}$ & $\begin{array}{c}0,007 \mathrm{a} \\
0,013\end{array}$ & $\begin{array}{c}0,005 \text { a } \\
0,012\end{array}$ \\
\hline $\begin{array}{c}\text { Oxigênio dissolvido - OD } \\
(\mathrm{mg} / \mathrm{L})\end{array}$ & 7,3 a 8,1 & 7,4 a 8,1 & 7,3 a 8,0 & 7,0 a 7,9 & 7,6 a 8,4 & 7,2 a 8,2 \\
\hline $\begin{array}{c}\text { Condutividade elétrica } \\
(\mu \mathrm{S} / \mathrm{cm})\end{array}$ & 17,4 a 17,9 & 24,3 a 24,9 & 24,3 a 25 & 25,3 a 25,6 & 18,9 a 29,8 & 21,1 a 30,1 \\
\hline Dureza $\left(\mathrm{mgCaCO}_{3} / \mathrm{L}\right)$ & 6 a 7 & 7 а 9 & 7 a 9 & 7 а 9 & 7 a 9 & 8 a a10 \\
\hline Turbidez $^{(*)}$ (uT) & - & 2,4 a 4,0 & 1,7 a 2,6 & 1,5 a 4,0 & 0,3 a 0,4 & 0,3 a 0,4 \\
\hline Turbidez $^{\left({ }^{* *}\right)}$ (uT) & 0,7 а 0,9 & 2,3 a 3,6 & 2,3 a 3,3 & 2,8 а 4,7 & 0,03 а 0,5 & 0,04 а 0,2 \\
\hline
\end{tabular}

TC: tempo médio de contato; TxF: taxa média de filtração; TCv: tempo médio de contato em vazio; MR: mistura rápida; FAP: filtro ascendente de pedregulho; PRÉ: pré-cloração; FD: filtro descendente; CAP: carvão ativado em pó; DSA: dosagem de sulfato de alumínio $\mathrm{Al}_{2}\left(\mathrm{SO}_{4}\right)_{3} \times 14,3 \mathrm{H}_{2} \mathrm{O} / \mathrm{L}$; DHS: dosagem de hidróxido de sódio; AC: água coagulada; AD: água de diluição; AE: água de estudo; DFI: descarga de fundo intermediária; (*): leitura em turbidímetro de bancada 2100P HACH; (**): leitura em turbidímetro de escoamento contínuo.

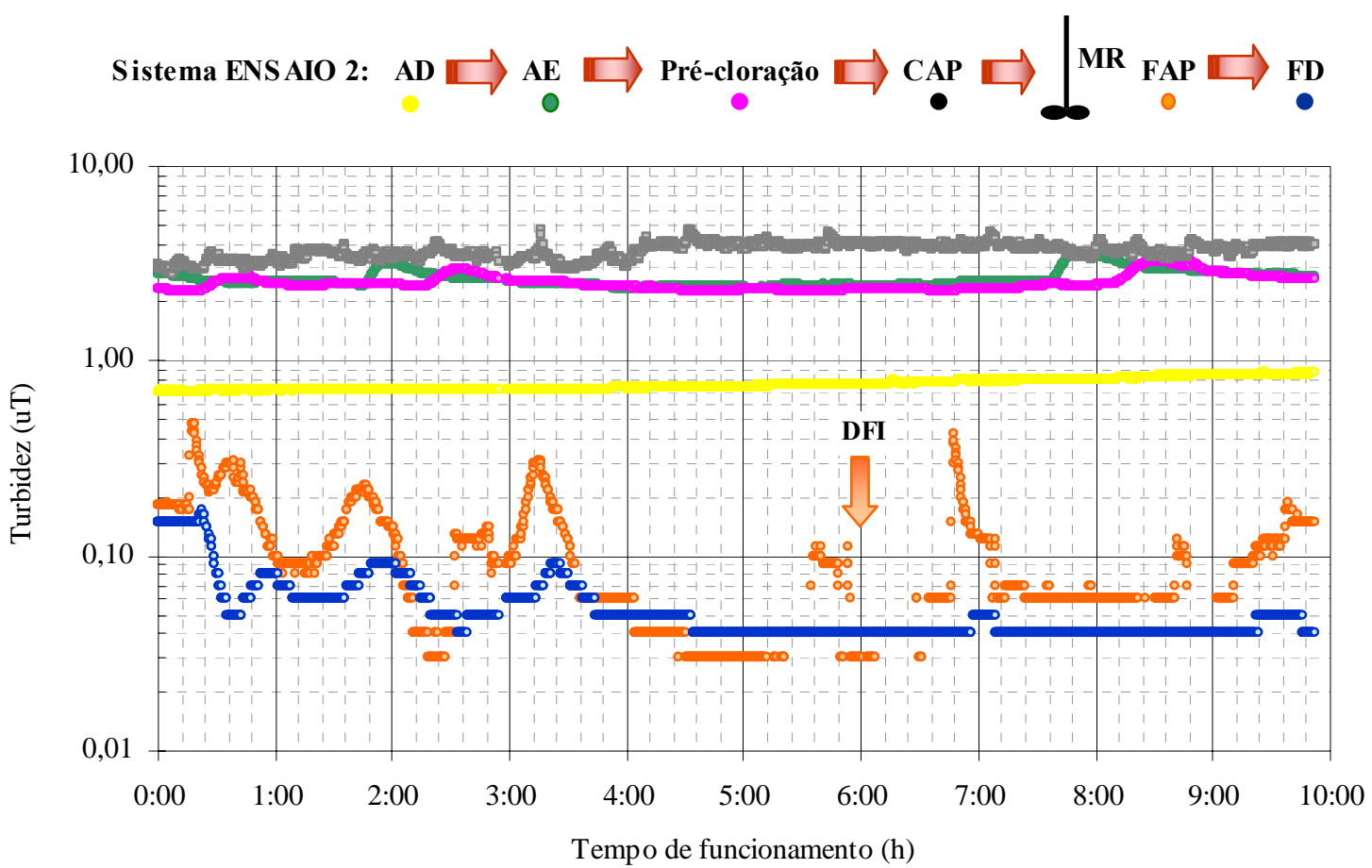

Figura 5.6.12 - Variação dos valores de turbidez em função do tempo nas águas de diluição e de estudo e nos efluentes de cada processo de tratamento do ENSAIO 2-IP 


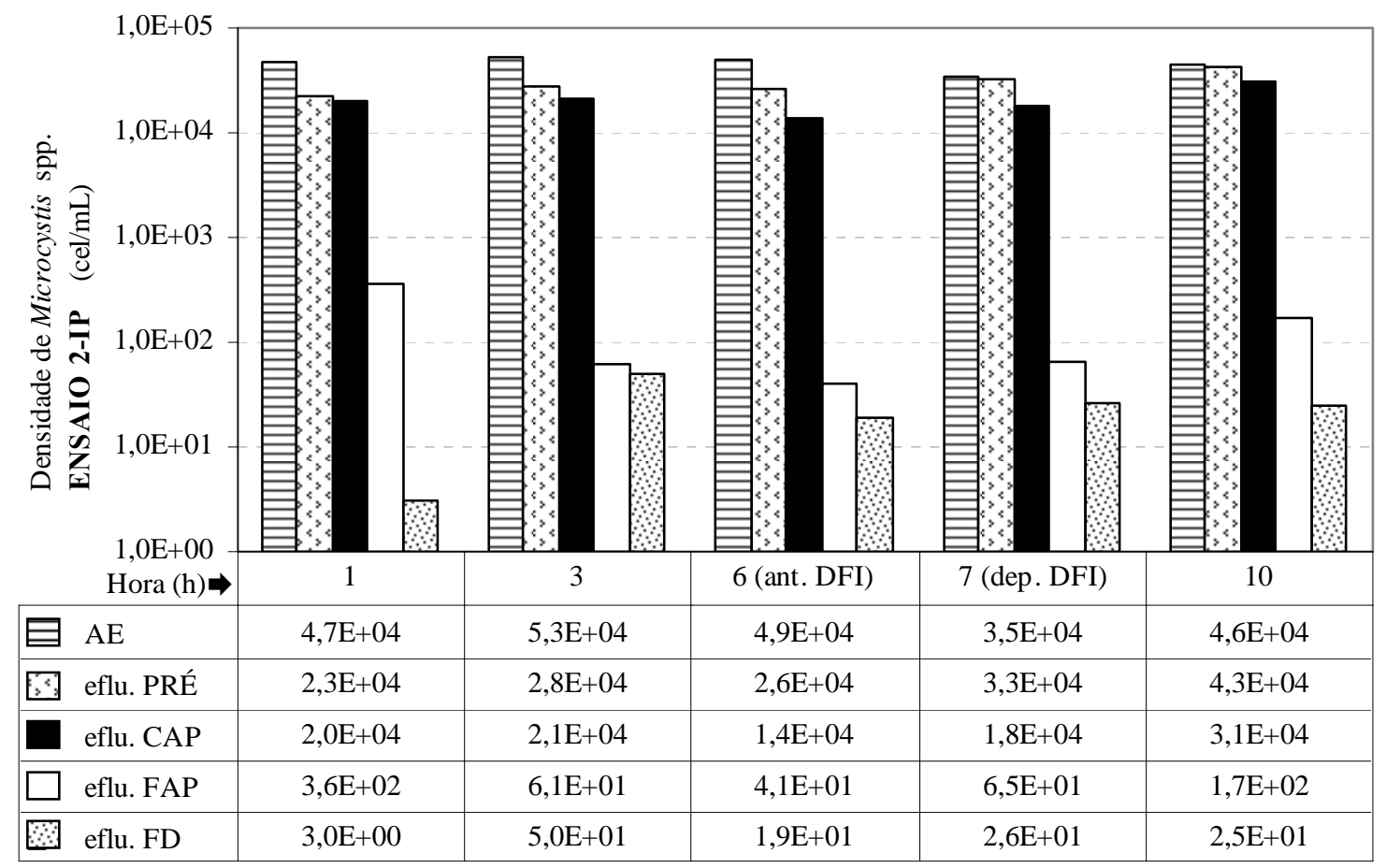

Figura 5.6.13 - Densidade de Microcystis spp. $\left(\mathrm{E}+0 \mathrm{x}=10^{\mathrm{x}}\right)$ na água de estudo e nos efluentes de cada processo de tratamento para diferentes tempos de amostragem do ENSAIO 2-IP

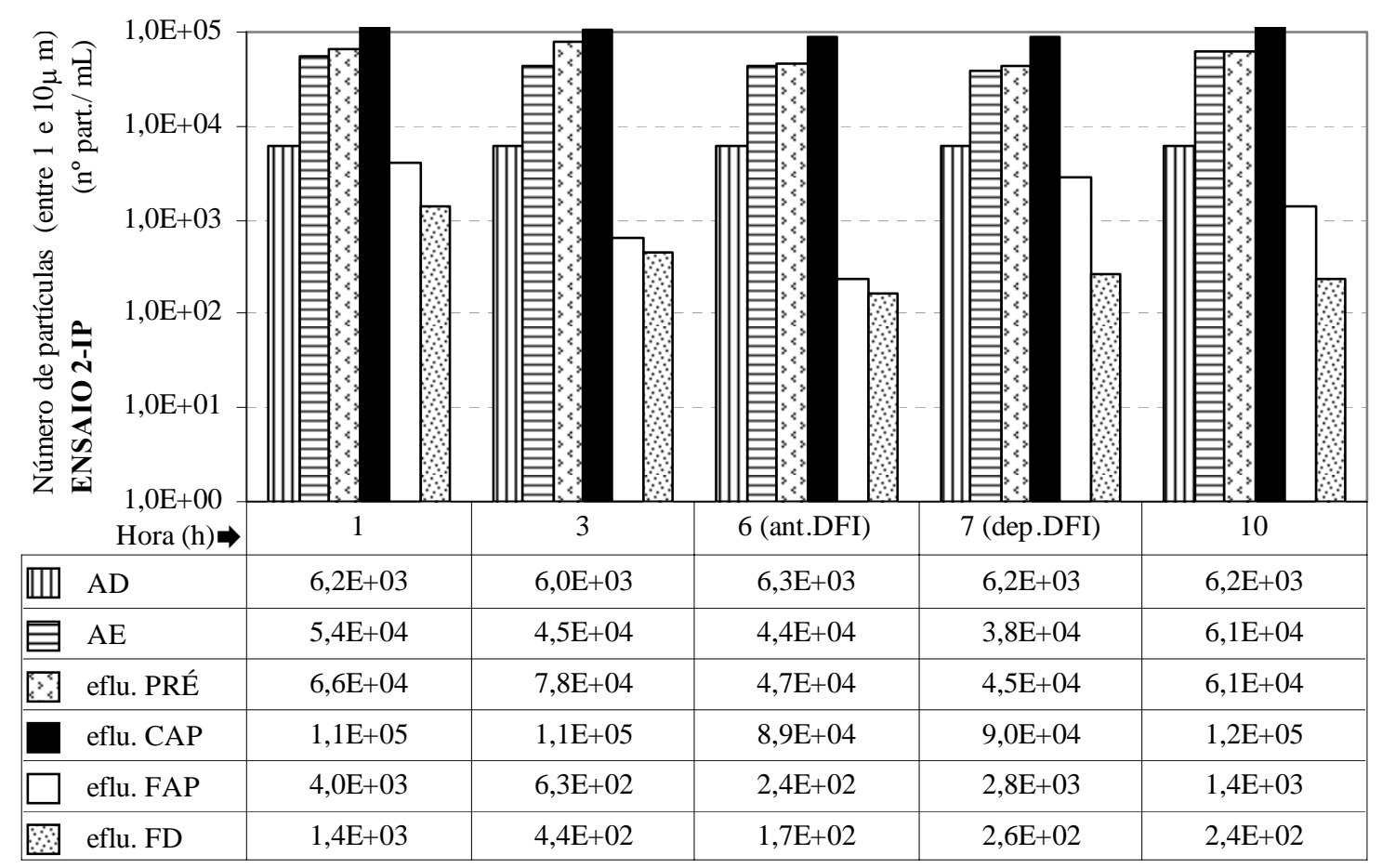

Figura 5.6.14 - Número de partículas (entre 1 e $10 \mu \mathrm{m}$ ) nas águas de diluição e de estudo e nos efluentes de cada processo de tratamento para diferentes tempos de amostragem do ENSAIO 2-IP 


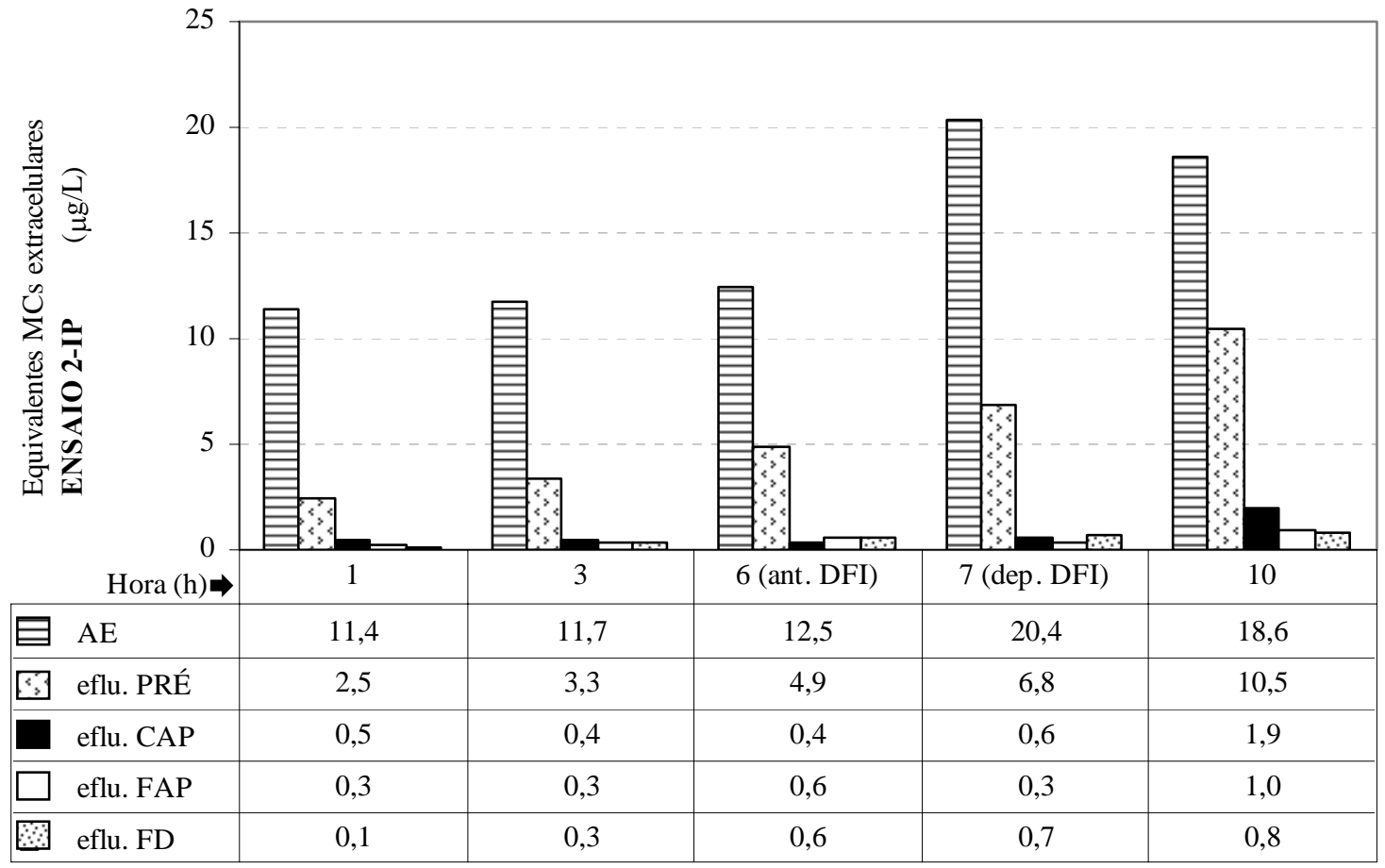

Figura 5.6.15 - Concentração de microcistinas - MCs extracelulares na água de estudo e nos efluentes de cada processo de tratamento para diferentes tempos de amostragem do ENSAIO 2-IP

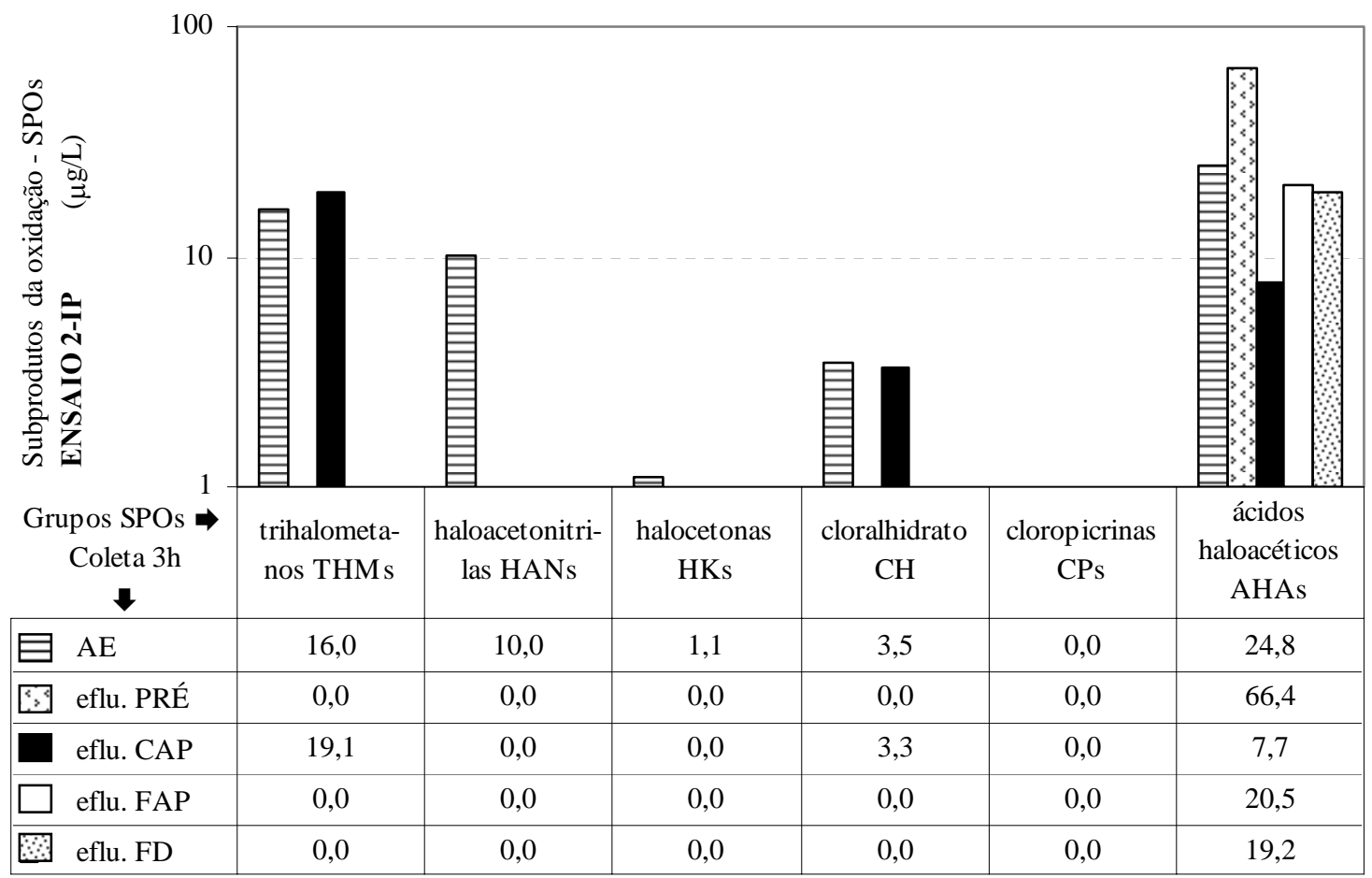

Figura 5.6.16 - Concentração de subprodutos organohalogenados - SPOs formados na água de estudo e nos efluentes de cada processo de tratamento para amostragem de $6 \mathrm{~h}$ do ENSAIO 2-IP 
Tabela 5.6.5 - Resumo das condições de funcionamento e dos parâmetros de desempenho para os controles operacional e qualitativo do ENSAIO3-IP (em instalação piloto)

ENSAIO3-IP: Sistema PRÉ $\rightarrow$ MR $\rightarrow$ FAP $\rightarrow$ FD

\begin{tabular}{l|l|l|l} 
TC-PRÉ $=35 \mathrm{~min}$ & TC-MR $=55 \mathrm{~s}$ & TxF-FAP $=120 \mathrm{~m}^{3} / \mathrm{m}^{2} . \mathrm{d}$ & TxF-FD $=180 \mathrm{~m}^{3} / \mathrm{m}^{2} . \mathrm{d}$
\end{tabular}

PARÂMETROS CONTROLE OPERACIONAL: DSA: 5 a 5,5 mg/L; DHS: 1 a 1,25 mg/L; pH da AC: 6,3 a 6,5; potencial zeta da AC: -6,7 a -14,2 mV; DCL: 2,5 mg/L; cloro residual do efluente da pré-cloração: 0,54 a 0,9 mg/L, temperatura: 19 a $22^{\circ} \mathrm{C}$; DFI realizada na $6^{\mathrm{a}} \mathrm{h}$, duração do ensaio: $10 \mathrm{~h}$

\begin{tabular}{|c|c|c|c|c|c|}
\hline \multirow{2}{*}{$\begin{array}{c}\text { PARÂMETROS } \\
\text { CONTROLE } \\
\text { QUALITATIVO }\end{array}$} & \multicolumn{5}{|c|}{ Águas de diluição - AD, de estudo - AE e Efluentes } \\
\hline & $\mathrm{AD}$ & $\mathrm{AE}$ & PRÉ & FAP & FD \\
\hline $\mathrm{pH}$ & 6,3 a 6,9 & 6,4 a 6,9 & 6,4 a 6,6 & 6,2 a 6,6 & 6,2 a 7,3 \\
\hline Potencial Zeta (mV) & $-3,2$ a $-2,2$ & 32,0 a $-29,8$ & - & $-3,1$ a $-2,0$ & $-2,2 \mathrm{a}-2,0$ \\
\hline $\begin{array}{c}\text { Carbono orgânico total - COT } \\
(\text { mg C / L) }\end{array}$ & - & 2,2 a 3,0 & 2,1 a 3,5 & 2,0 a 2,3 & 1,9 a 2,7 \\
\hline Absorvância $\lambda=254 \mathrm{~nm}$ & - & 0,025 a 0,031 & 0,024 a 0,029 & 0,016 a 0,018 & 0,016 a 0,032 \\
\hline $\begin{array}{l}\text { Oxigênio dissolvido - OD } \\
(\mathrm{mg} / \mathrm{L})\end{array}$ & 7,6 a 8,6 & 7,5 a 8,5 & 7,8 a 8,6 & 7,8 a 8,6 & 7,6 a 8,8 \\
\hline $\begin{array}{l}\text { Condutividade elétrica } \\
(\mu \mathrm{S} / \mathrm{cm})\end{array}$ & 16,5 a 17,2 & 25,5 a 26,8 & 24,9 a 27,6 & 27,9 a 30,4 & 28,7 a 30,1 \\
\hline Dureza $\left(\mathrm{mgCaCO}_{3} / \mathrm{L}\right)$ & 5 a 6 & 8 a 9 & 9 & 8 a 10 & 7 a 10 \\
\hline Turbidez $^{(*)}$ (uT) & - & 2,3 a 2,8 & 1,4 a 1,8 & 0,3 a 1,2 & 0,3 a 0,4 \\
\hline Turbidez $^{(* *)}$ (uT) & 0,5 a 0,7 & 2,2 a 3,0 & 0,03 a 0,4 & 2,2 a 2,8 & 0,04 a 0,1 \\
\hline
\end{tabular}

TC: tempo médio de contato; TxF: taxa média de filtração; TCv: tempo médio de contato em vazio; MR: mistura rápida; FAP: filtro ascendente de pedregulho; PRÉ: pré-cloração; FD: filtro descendente; DSA: dosagem de sulfato de alumínio $\mathrm{Al}_{2}\left(\mathrm{SO}_{4}\right)_{3} \times 14,3 \mathrm{H}_{2} \mathrm{O}$ /L; DHS: dosagem de hidróxido de sódio; AC: água coagulada; AD: água de diluição; AE: água de estudo; DFI: descarga de fundo intermediária; $\left.{ }^{(* *}\right)$ : leitura em turbidímetro de escoamento contínuo; $\left({ }^{*}\right)$ : leitura em turbidímetro de bancada 2100P HACH.

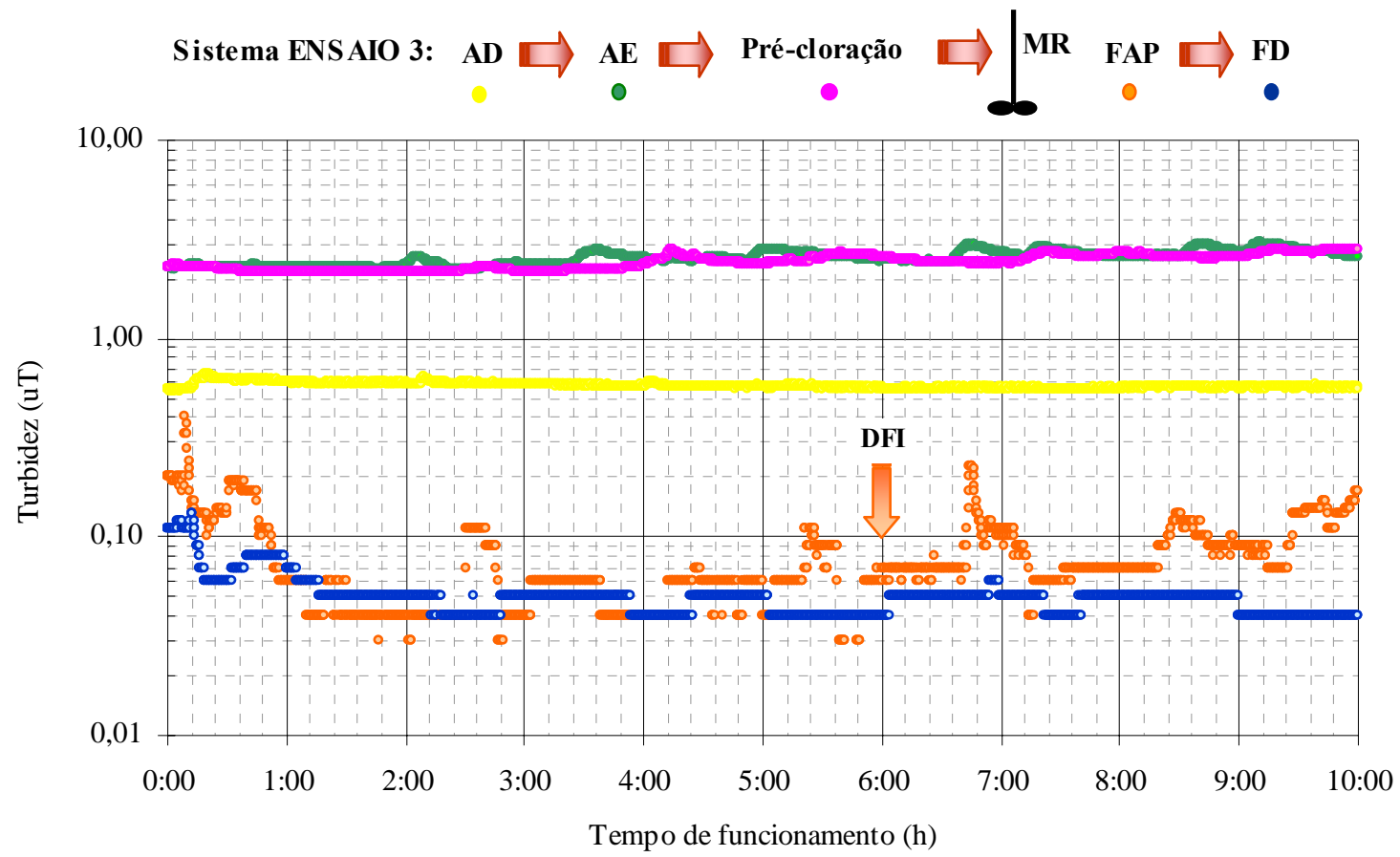

Figura 5.6.17 - Variação dos valores de turbidez em função do tempo nas águas de diluição e de estudo e nos efluentes de cada processo de tratamento do ENSAIO 3-IP 


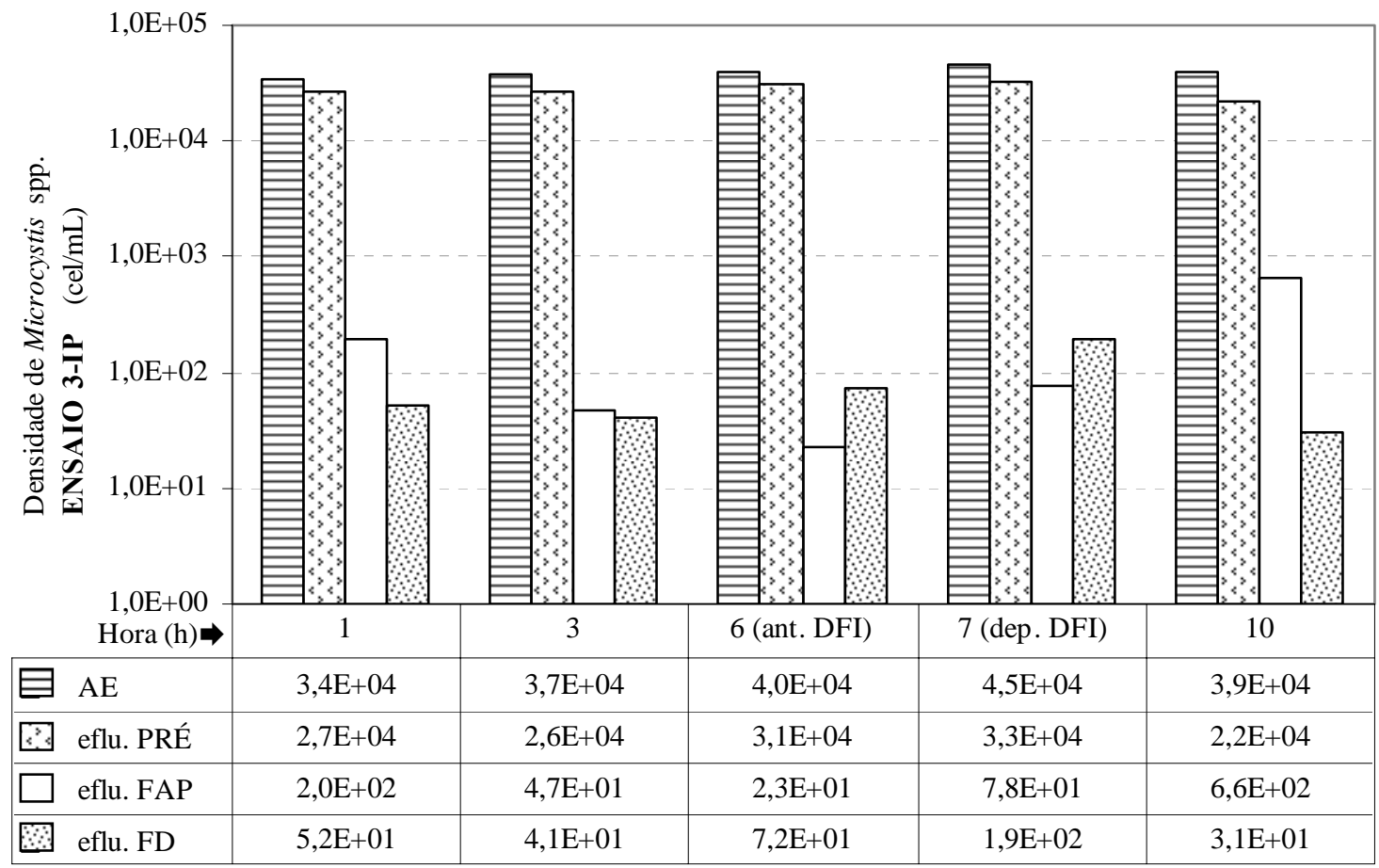

Figura 5.6.18 - Densidade de Microcystis spp. $\left(\mathrm{E}+0 \mathrm{x}=10^{\mathrm{x}}\right)$ na água de estudo e nos efluentes de cada processo de tratamento para diferentes tempos de amostragem do ENSAIO 3-IP

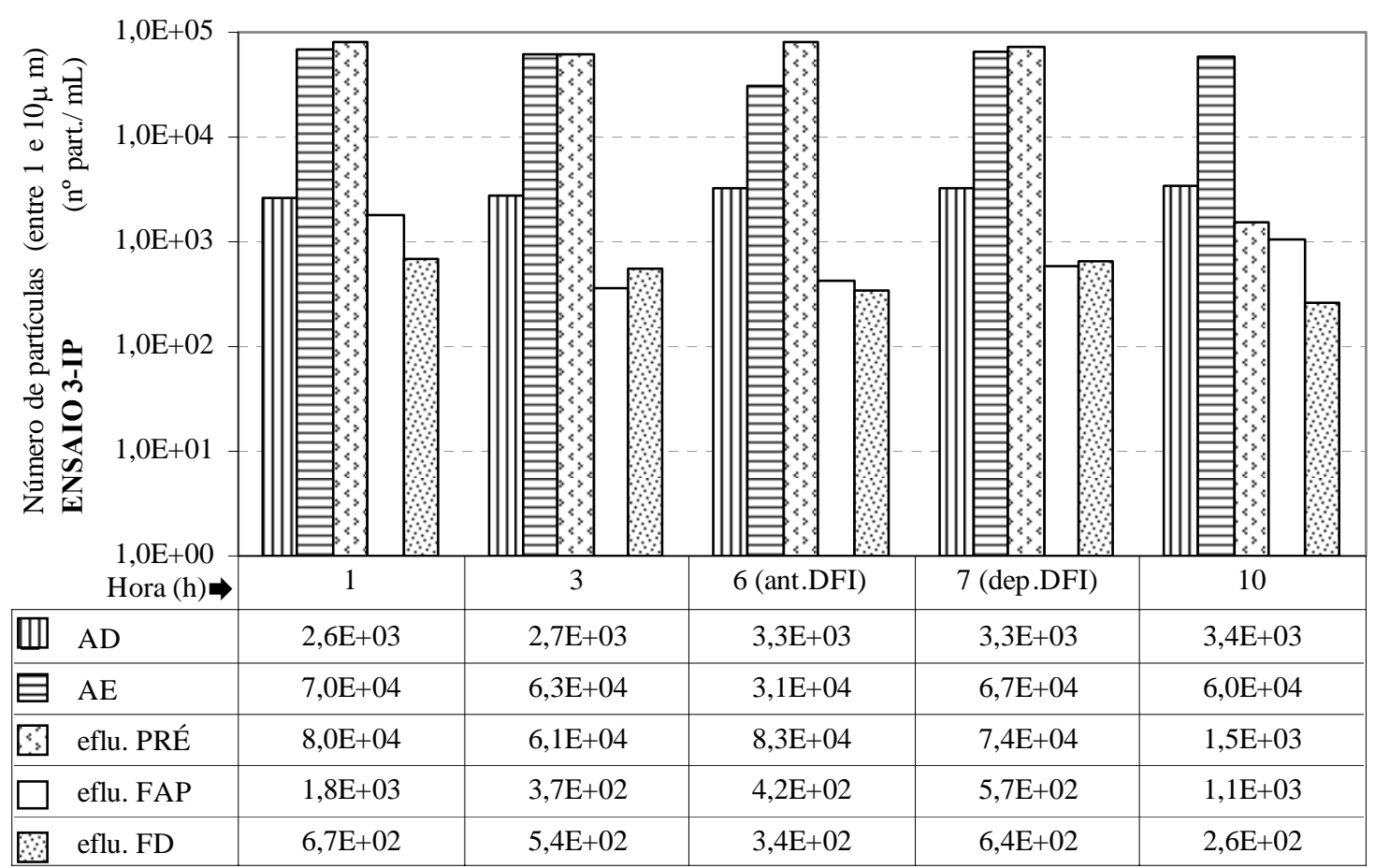

Figura 5.6.19 - Número de partículas (entre 1 e $10 \mu \mathrm{m}$ ) nas águas de diluição e de estudo e nos efluentes de cada processo de tratamento para diferentes tempos de amostragem do ENSAIO 3-IP 


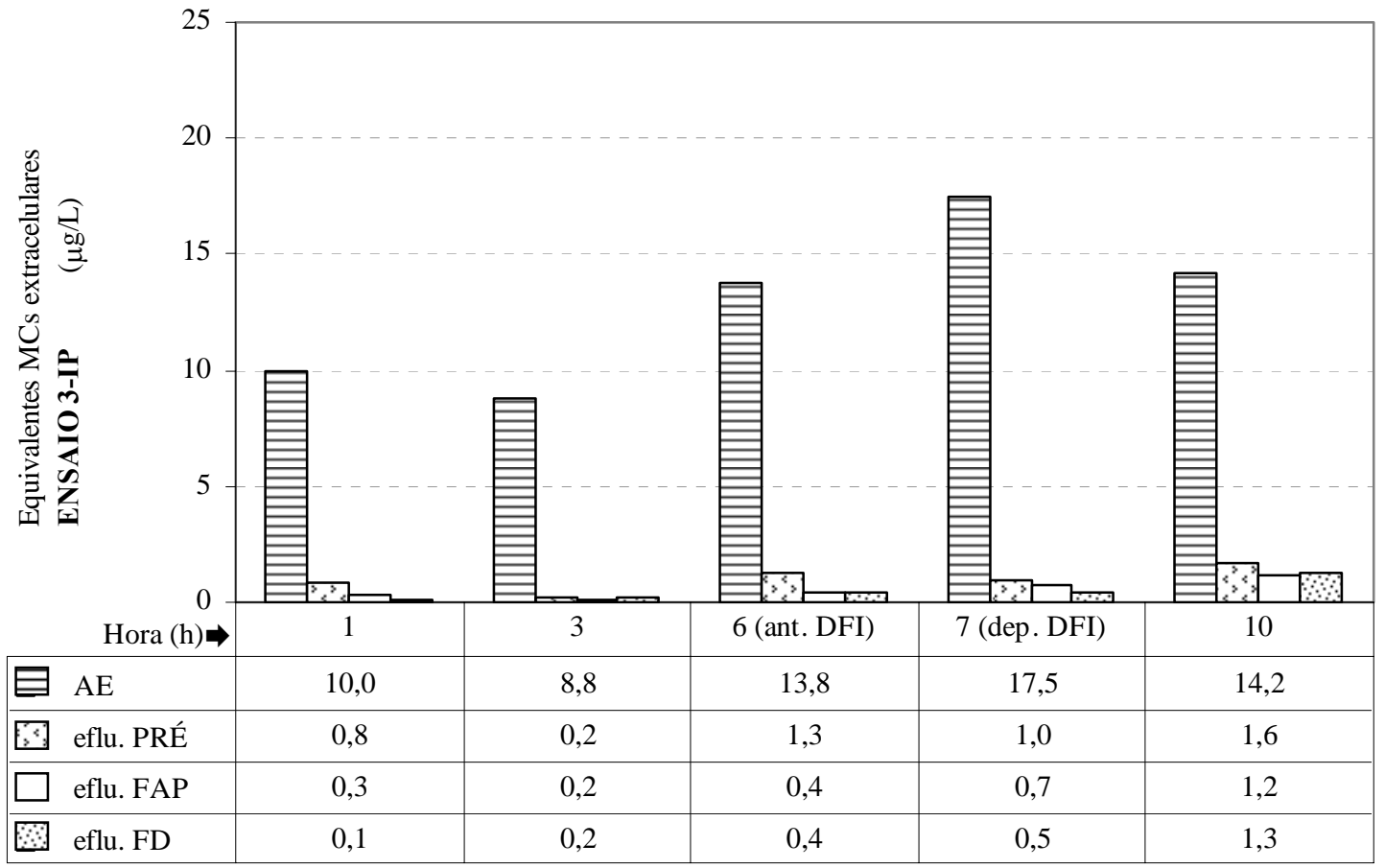

Figura 5.6.20 - Concentração de microcistinas - MCs extracelulares na água de estudo e nos efluentes de cada processo de tratamento para diferentes tempos de amostragem do ENSAIO 3-IP

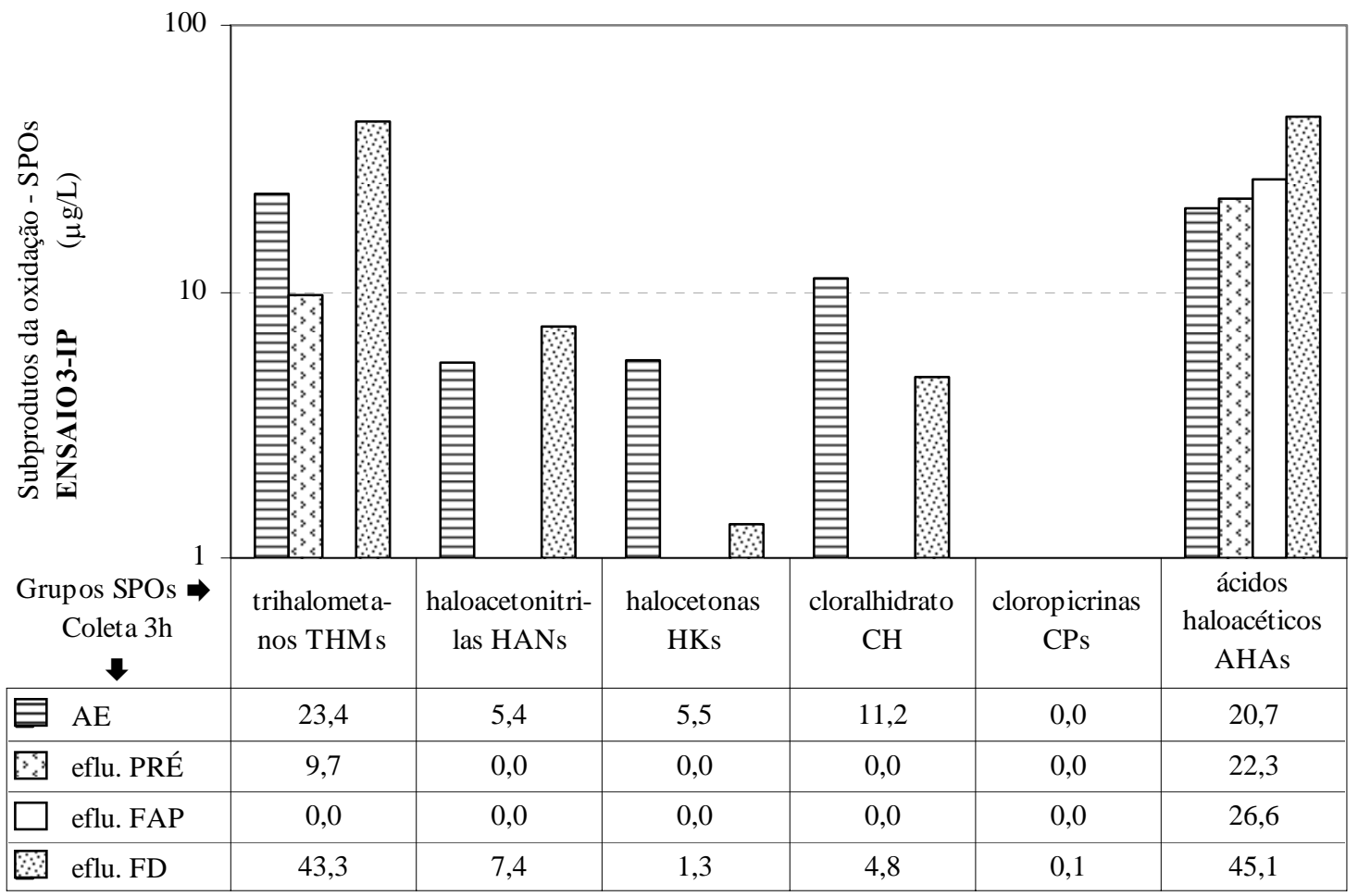

Figura 5.6.21 - Concentração de subprodutos organohalogenados - SPOs formados na água de estudo e nos efluentes de cada processo de tratamento para amostragem de $6 \mathrm{~h}$ do ENSAIO 3-IP 
Tabela 5.6.6 - Resumo das condições de funcionamento e dos parâmetros de desempenho para os controles operacional e qualitativo do ENSAIO4-IP (em instalação piloto)

ENSAIO4-IP: Sistema MR $\rightarrow$ FAP $\rightarrow$ FD $\rightarrow$ PÓS e FCAG (simultanemanete)

\begin{tabular}{c|c|c|c|c}
\hline TC-MR $=50 \mathrm{~s}$ & $\begin{array}{c}\text { TxF-FAP }=120 \\
\mathrm{~m}^{3} / \mathrm{m}^{2} . \mathrm{d}\end{array}$ & $\begin{array}{c}\text { TxF-FD }=180 \\
\mathrm{~m}^{3} / \mathrm{m}^{2} . \mathrm{d}\end{array}$ & TC-PÓS $=10 \mathrm{~min}$ & TCv FCAG $=12 \mathrm{~min}$ \\
\hline
\end{tabular}

PARÂMETROS CONTROLE OPERACIONAL: DSA: 5 a 7 mg/L; DHS: 1 a 1,5 mg/L; pH da AC: 6,0 a 7,4; potencial zeta da AC: -13,0 a -4,1 mV; cloro residual do efluente da pós-cloração: 1,1 a 2,1 mg/L, temperatura: 18 a $20{ }^{\circ} \mathrm{C}$; DFI realizada na $6 \mathrm{a}$, duração do ensaio: $10 \mathrm{~h}$

\begin{tabular}{|c|c|c|c|c|c|c|}
\hline \multirow{2}{*}{$\begin{array}{l}\text { PARÂMETROS } \\
\text { CONTROLE } \\
\text { QUALITATIVO }\end{array}$} & \multicolumn{6}{|c|}{ Águas de diluição - AD, de estudo - AE e Efluentes } \\
\hline & $\mathrm{AD}$ & $\mathrm{AE}$ & FAP & FD & PÓS & FCAG \\
\hline $\mathrm{pH}$ & 7,4 & 6,8 a 7,3 & 7,1 & 6,9 & 6,7 & 8,4 \\
\hline Potencial Zeta (mV) & $-3,2$ a $-2,6$ & $\begin{array}{c}-32,6 \mathrm{a}- \\
20,7 \\
\end{array}$ & $-3,6$ a $-2,0$ & $-2,0$ & - & $-2,0$ \\
\hline $\begin{array}{l}\text { Carbono orgânico total - COT } \\
(\mathrm{mg} \mathrm{C} \mathrm{/} \mathrm{L)}\end{array}$ & - & 2,21 a 2,85 & 1,6 a 2,74 & 1,53 a 1,98 & 1,62 a 2,05 & 1,10 a 1,37 \\
\hline Absorvância $\lambda=254 \mathrm{~nm}$ & - & $\begin{array}{c}0,023 \text { a } \\
0,03\end{array}$ & $\begin{array}{c}0,013 \text { a } \\
0,032\end{array}$ & $\begin{array}{c}0,013 \mathrm{a} \\
0,016\end{array}$ & $\begin{array}{l}0,02 \mathrm{a} \\
0,022\end{array}$ & $\begin{array}{c}0,003 \text { a } \\
0,006\end{array}$ \\
\hline $\begin{array}{l}\text { Oxigênio dissolvido - OD } \\
(\mathrm{mg} / \mathrm{L})\end{array}$ & 7,9 a 8,8 & 7,8 a 8,7 & 8,1 a 9,1 & 8,1 a 8,8 & 7,9 а 9,2 & 7,3 a 8,6 \\
\hline $\begin{array}{c}\text { Condutividade elétrica } \\
(\mu \mathrm{S} / \mathrm{cm})\end{array}$ & 16,0 a 18,4 & 21,4 a 25,6 & 24,5 a 26,8 & 23 a 27 & 24,9 a 33,8 & 21,2 a 26,6 \\
\hline Dureza $\left(\mathrm{mgCaCO}_{3} / \mathrm{L}\right)$ & 5 a 7 & 6 a 8 & 7 a 8 & 5 a 7 & 9 а 11 & 5 a 8 \\
\hline Turbidez $^{(*)}$ (uT) & - & 4,1 a 5,6 & 0,4 a 3,2 & 0,3 a 0,5 & 0,3 a 0,7 & 0,4 a 0,8 \\
\hline Turbidez $^{(* *)}$ (uT) & 0,2 а 0,37 & 2,3 а 3,2 & 0,03 а 2,1 & 0,04 a 0,07 & 0,05 a 0,07 & 0,01 a 0,07 \\
\hline
\end{tabular}

TC: tempo médio de contato; TxF: taxa média de filtração; TCv: tempo médio de contato em vazio; MR: mistura rápida; FAP: filtro ascendente de pedregulho; PÓS: pós-cloração; FD: filtro descendente; FCAG: filtro com carvão ativado granular; DSA: dosagem de sulfato de alumínio $\mathrm{Al}_{2}\left(\mathrm{SO}_{4}\right)_{3} \times 14,3 \mathrm{H}_{2} \mathrm{O} / \mathrm{L}$; DHS: dosagem de hidróxido de sódio; AC: água coagulada; AD: água de diluição; AE: água de estudo; DFI: descarga de fundo intermediária; $\left(^{* *}\right)$ : leitura em turbidímetro de escoamento contínuo; (*): leitura em turbidímetro de bancada 2100P HACH.

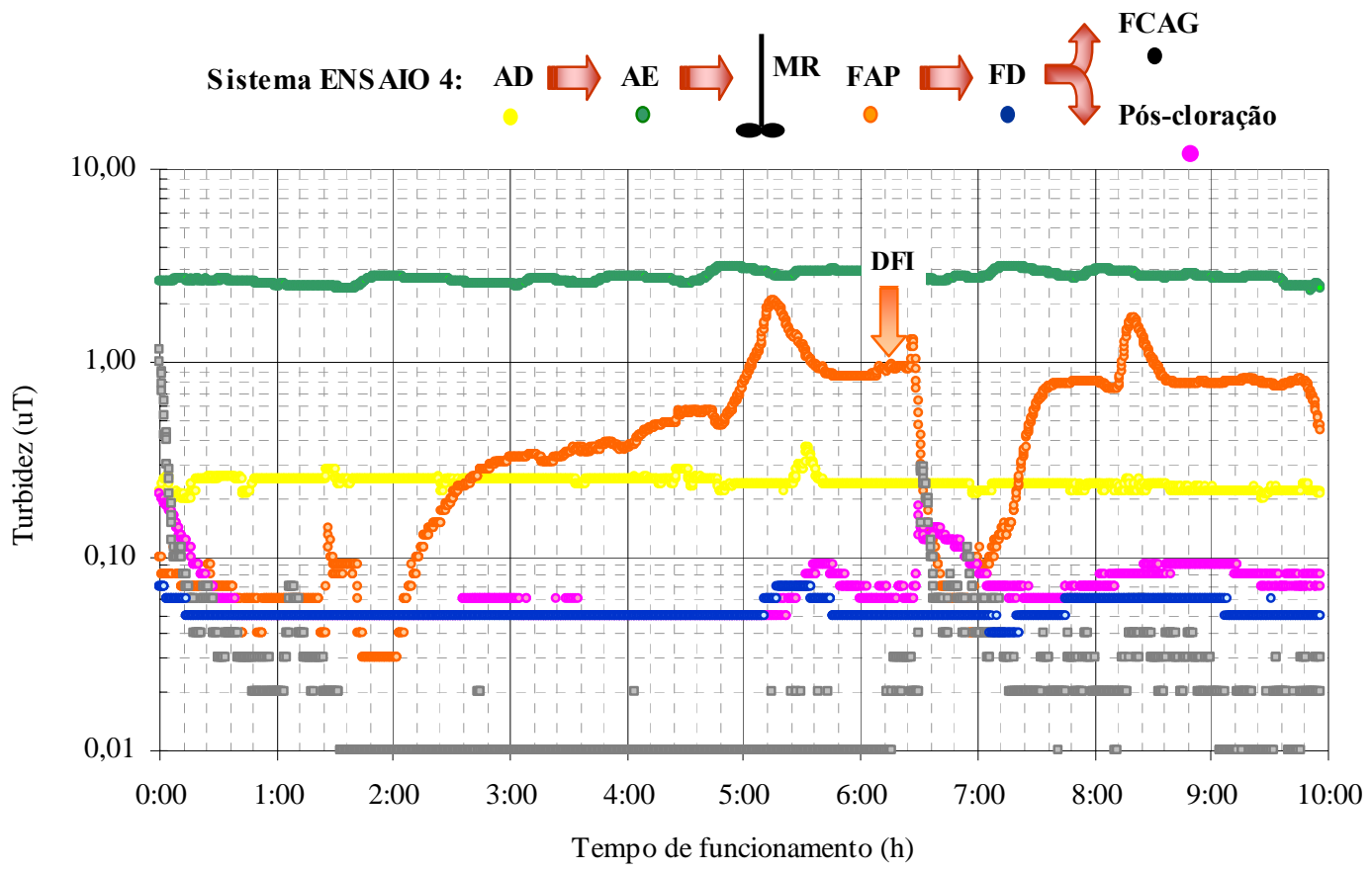

Figura 5.6.22 - Variação dos valores de turbidez em função do tempo nas águas de diluição e de estudo e nos efluentes de cada processo de tratamento do ENSAIO 4-IP (\#)

(\#) : Ensaio com problemas operacionais. 


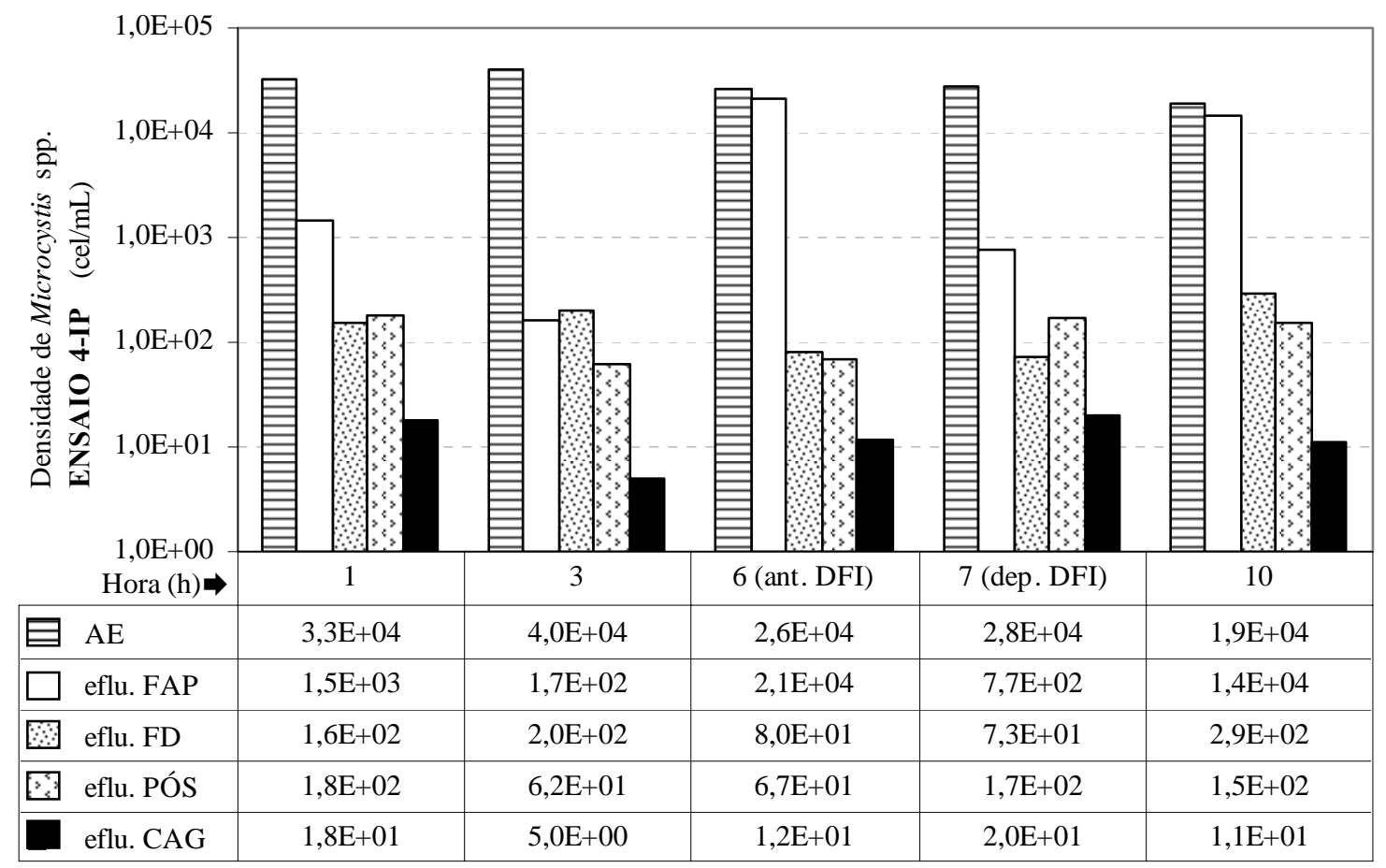

Figura 5.6.23 - Densidade de Microcystis spp. $\left(E+0 \mathrm{x}=10^{\mathrm{x}}\right)$ na água de estudo e nos efluentes de cada processo de tratamento para diferentes tempos de amostragem do ENSAIO 4-IP (\#)

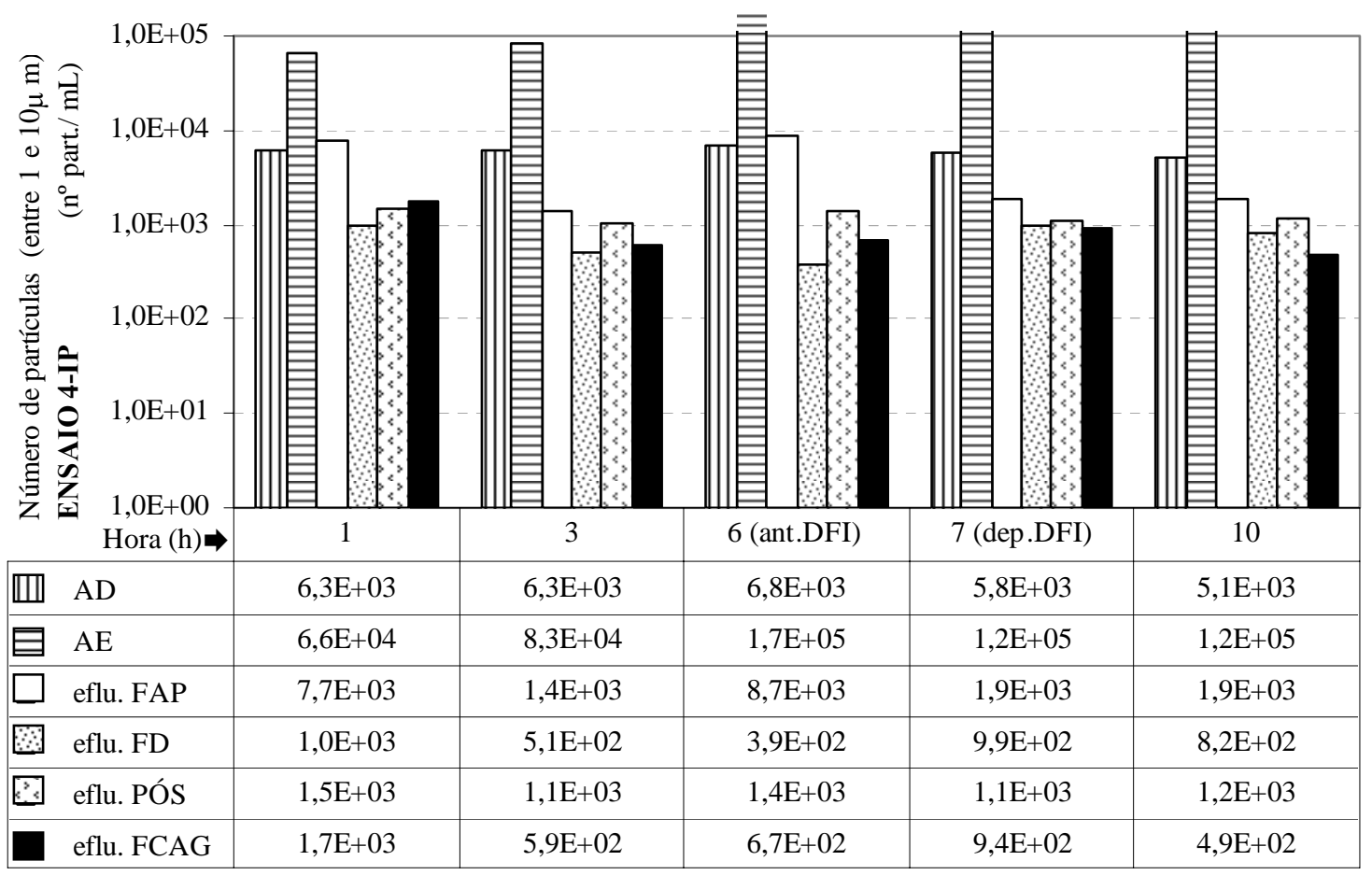

Figura 5.6.24 - Número de partículas (entre 1 e $10 \mu \mathrm{m}$ ) nas águas de diluição e de estudo e nos efluentes de cada processo de tratamento para diferentes tempos de amostragem do ENSAIO 4-IP (\#)

(\#) : Ensaio com problemas operacionais. 


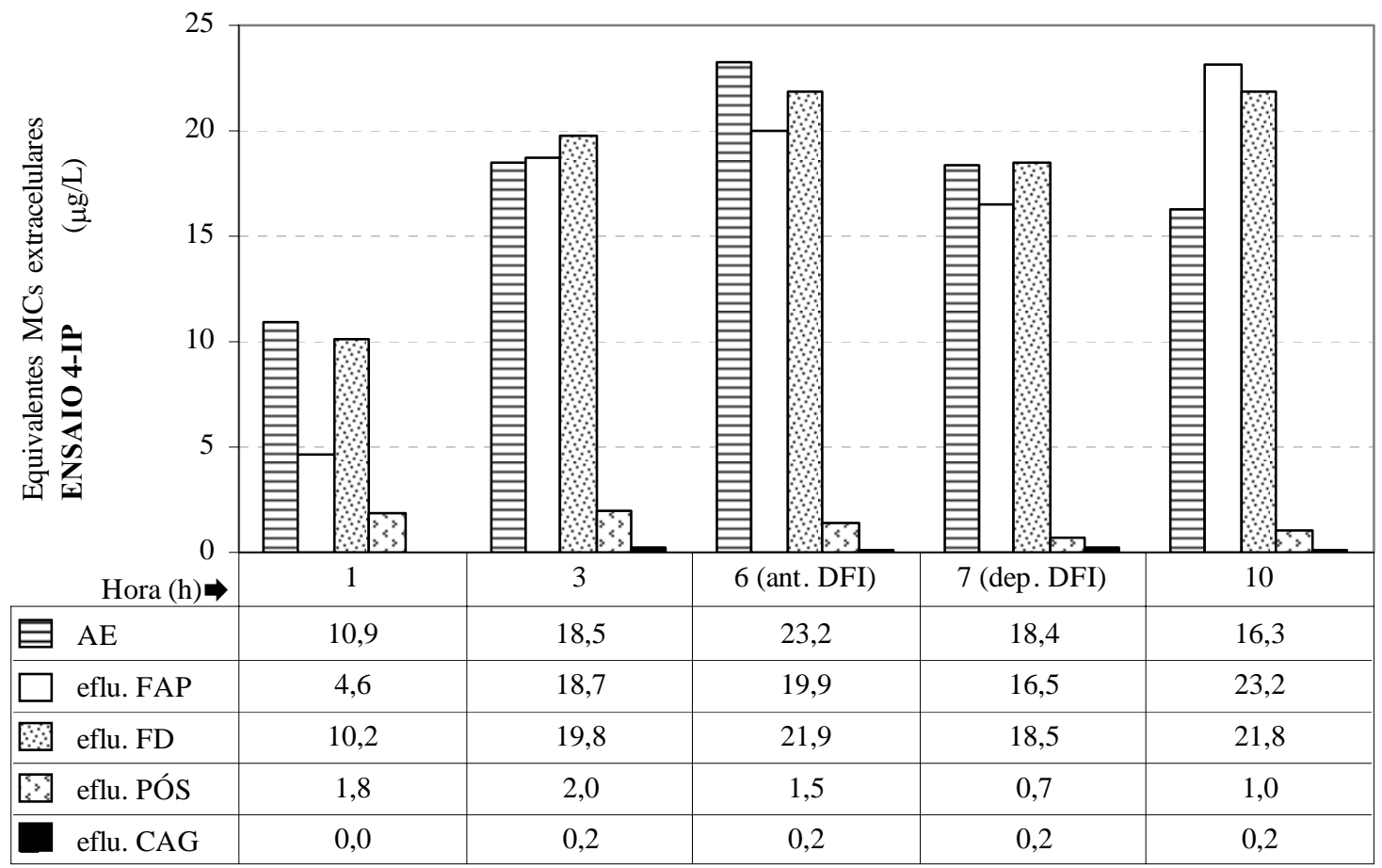

Figura 5.6.25 - Concentração de microcistinas - MCs extracelulares na água de estudo e nos efluentes de cada processo de tratamento para diferentes tempos de amostragem do ENSAIO 4-IP (\#)

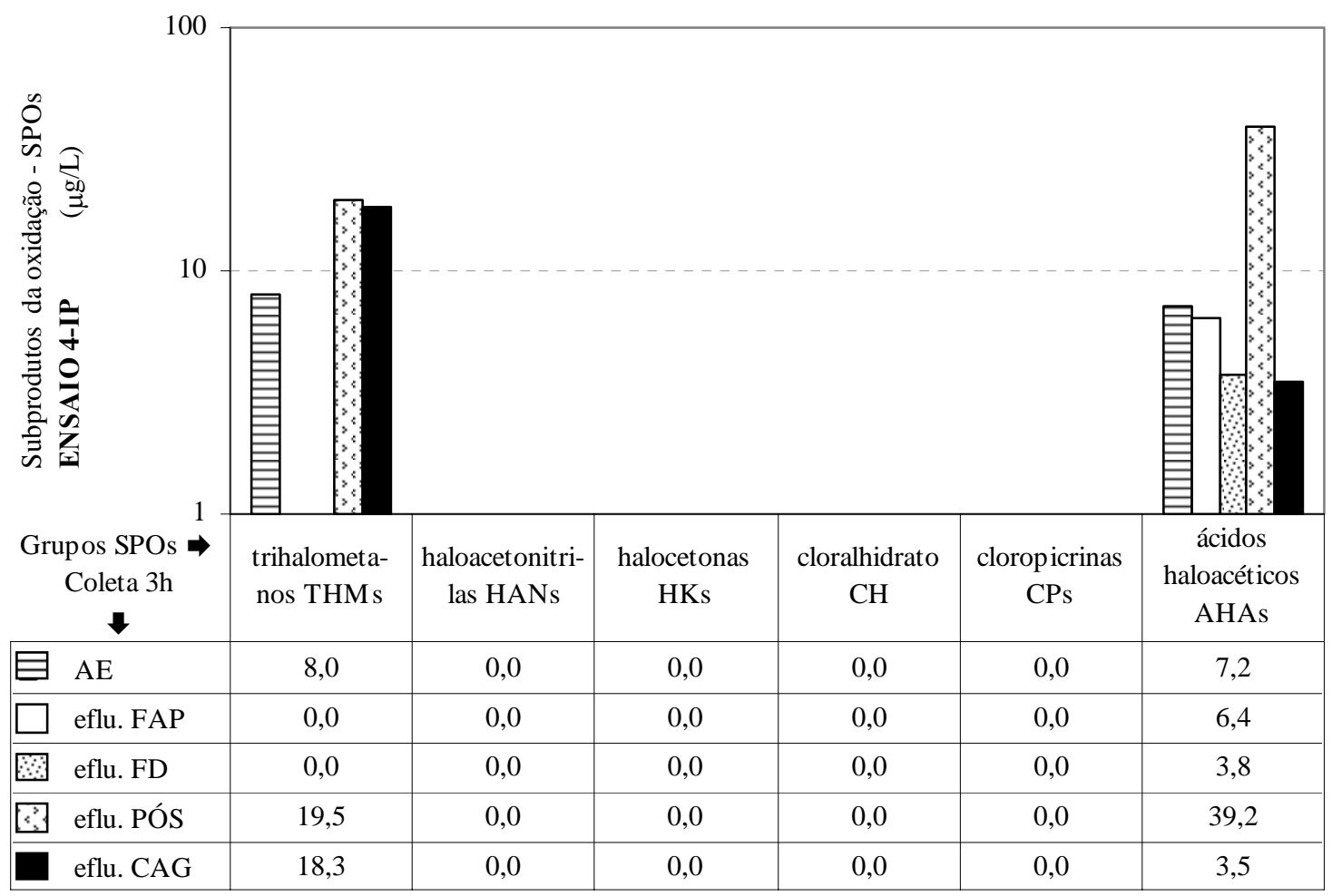

Figura 5.6.26 - Concentração de subprodutos organohalogenados - SPOs formados na água de estudo e nos efluentes de cada processo de tratamento para amostragem de $6 \mathrm{~h}$ do ENSAIO 4-IP (\#)

(\#) : Ensaio com problemas operacionais. 
Tabela 5.6.7 - Resumo das condições de funcionamento e dos parâmetros de desempenho para os controles operacional e qualitativo do ENSAIO5-IP (em instalação piloto)

ENSAIO5-IP: Sistema MR $\rightarrow$ FAP $\rightarrow$ FD $\rightarrow$ PÓS e FCAG (simultanemanete)

\begin{tabular}{c|c|c|c|c}
\hline TC-MR = 50 s & $\begin{array}{c}\text { TxF-FAP }=120 \\
\mathrm{~m}^{3} / \mathrm{m}^{2} . \mathrm{d}\end{array}$ & $\begin{array}{c}\text { TxF-FD }=180 \\
\mathrm{~m}^{3} / \mathrm{m}^{2} . \mathrm{d}\end{array}$ & TC-PÓS $=10 \mathrm{~min}$ & TCv FCAG = $12 \mathrm{~min}$ \\
\hline
\end{tabular}

PARÂMETROS CONTROLE OPERACIONAL: DSA: 5 a 7 mg/L; DHS: 1 a 1,5 mg/L; pH da AC: 6,4 a 6,9; potencial zeta da AC: $-12,0$ a -5,2 mV; cloro residual do efluente da pós-cloração: 0,3 a 1,5 mg/L, temperatura: 18,5 a $22{ }^{\circ} \mathrm{C}$; DFI realizada na $6^{\mathrm{a}} \mathrm{h}$, duração do ensaio: $10 \mathrm{~h}$

\begin{tabular}{|c|c|c|c|c|c|c|}
\hline \multirow{2}{*}{$\begin{array}{l}\text { PARÂMETROS } \\
\text { CONTROLE } \\
\text { QUALITATIVO }\end{array}$} & \multicolumn{6}{|c|}{ Águas de diluição - AD, de estudo - AE e Efluentes } \\
\hline & $\mathrm{AD}$ & $\mathrm{AE}$ & FAP & FD & PÓS & FCAG \\
\hline $\mathrm{pH}$ & 6,6 a 6,9 & 6,6 a 7,4 & 6,6 a 6,9 & 6,6 a 6,8 & 6,6 a 7,1 & 9,3 а 9,5 \\
\hline Potencial Zeta (mV) & $\begin{array}{l}-5,0 \text { a } \\
-2,06\end{array}$ & $\begin{array}{c}-35,2 \mathrm{a} \\
-31,3 \\
\end{array}$ & $-2,1$ a $-2,0$ & $-2,4$ a $-1,9$ & - & $-1,9$ \\
\hline $\begin{array}{l}\text { Carbono orgânico total - COT } \\
\text { (mg C / L) }\end{array}$ & - & 2,45 a 4,31 & 1,17 a 1,56 & 1,17 a 1,59 & 1,18 a 1,41 & 0,81 a 2,72 \\
\hline Absorvância $\lambda=254$ nm & - & $\begin{array}{c}0,022 \mathrm{a} \\
0,035\end{array}$ & $\begin{array}{c}0,012 \mathrm{a} \\
0,019\end{array}$ & $\begin{array}{c}0,012 \text { a } \\
0,027\end{array}$ & $\begin{array}{c}0,015 \mathrm{a} \\
0,026\end{array}$ & $\begin{array}{c}0,002 \mathrm{a} \\
0,009\end{array}$ \\
\hline $\begin{array}{l}\text { Oxigênio dissolvido - OD } \\
(\mathrm{mg} / \mathrm{L})\end{array}$ & 7,3 a 8,8 & 7,3 a 8,7 & 8,1 & 6,9 a 8,8 & 7,5 a 9,2 & 6,2 a 8,4 \\
\hline $\begin{array}{c}\text { Condutividade elétrica } \\
(\mu \mathrm{S} / \mathrm{cm})\end{array}$ & 14,6 a 14,8 & 20,1 a 22,3 & 24,8 a 28,5 & 26,2 a 28,0 & 27,2 a 36,0 & 26,8 a 53,2 \\
\hline Dureza $\left(\mathrm{mgCaCO}_{3} / \mathrm{L}\right)$ & 5 a 6 & 5 a 7 & 5 a 7 & 5 a 6 & 6 a 8 & 6 a 14 \\
\hline Turbidez $^{(*)}$ (uT) & - & - & 0,30 a 0,42 & 0,35 a 0,40 & 0,34 a 0,43 & 0,36 a 0,57 \\
\hline Turbidez $^{(* *)}$ (uT) & 0,08 а 0,28 & 1,97 а 2,62 & 0,03 а 0,92 & 0,05 а 0,29 & 0,03 а 0,07 & 0,01 a 0,07 \\
\hline
\end{tabular}

TC: tempo médio de contato; TxF: taxa média de filtração; TCv: tempo médio de contato em vazio; MR: mistura rápida; FAP: filtro ascendente de pedregulho; PÓS: pós-cloração; FD: filtro descendente; FCAG: filtro com carvão ativado granular; DSA: dosagem de sulfato de alumínio $\mathrm{Al}_{2}\left(\mathrm{SO}_{4}\right)_{3} \times 14,3 \mathrm{H}_{2} \mathrm{O} / \mathrm{L}$; DHS: dosagem de hidróxido de sódio; AC: água coagulada; AD: água de diluição; AE: água de estudo; DFI: descarga de fundo intermediária; $\left.{ }^{* *}\right)$ : leitura em turbidímetro de escoamento contínuo; (*): leitura em turbidímetro de bancada 2100P HACH.

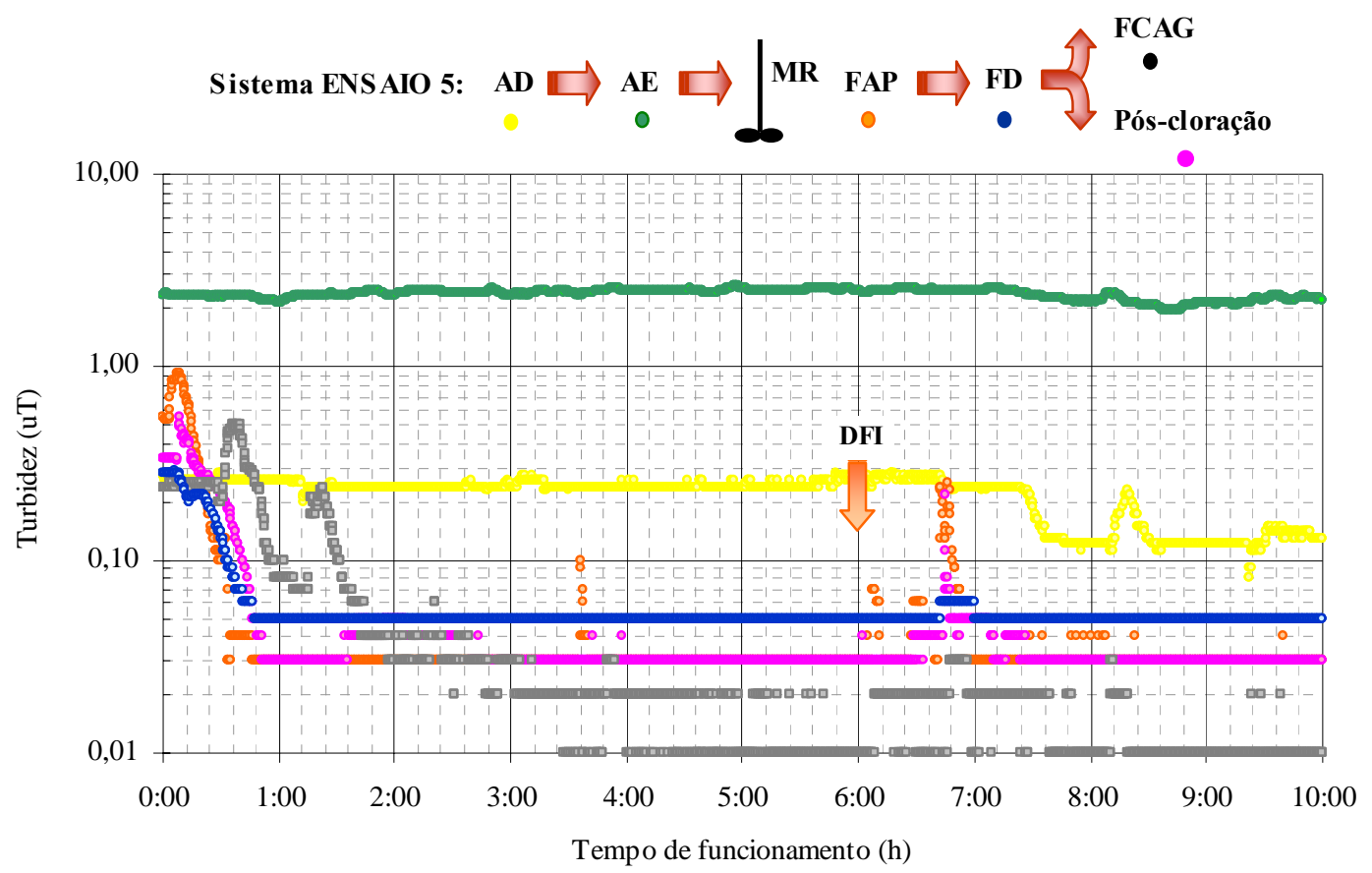

Figura 5.6.27 - Variação dos valores de turbidez em função do tempo nas águas de diluição e de estudo e nos efluentes de cada processo de tratamento do ENSAIO 5-IP 


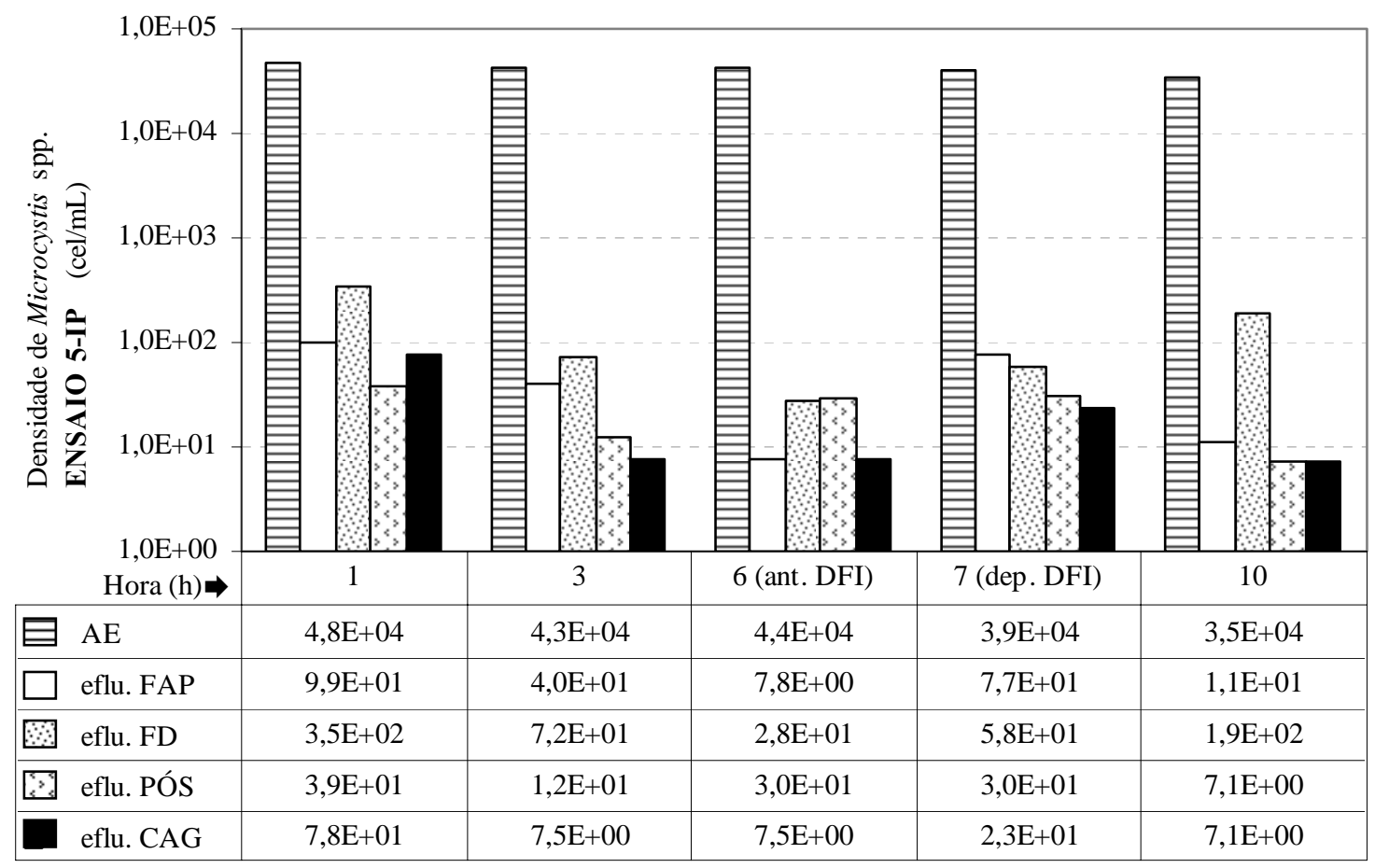

Figura 5.6.28 - Densidade de Microcystis spp. $\left(\mathrm{E}+0 \mathrm{x}=10^{\mathrm{x}}\right)$ na água de estudo e nos efluentes de cada processo de tratamento para diferentes tempos de amostragem do ENSAIO 5-IP

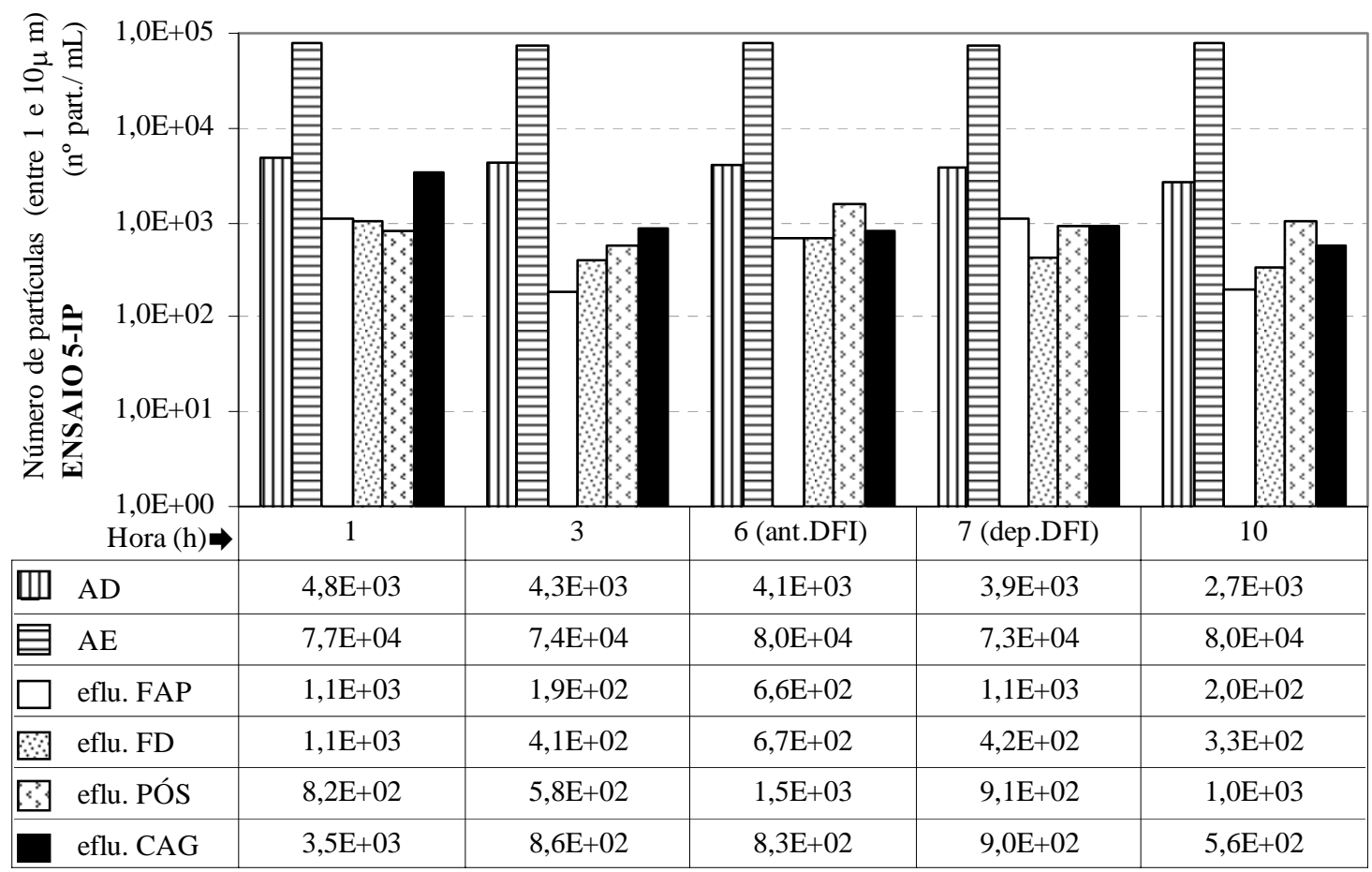

Figura 5.6.29 - Número de partículas (entre 1 e $10 \mu \mathrm{m}$ ) nas águas de diluição e de estudo e nos efluentes de cada processo de tratamento para diferentes tempos de amostragem do ENSAIO 5-IP 


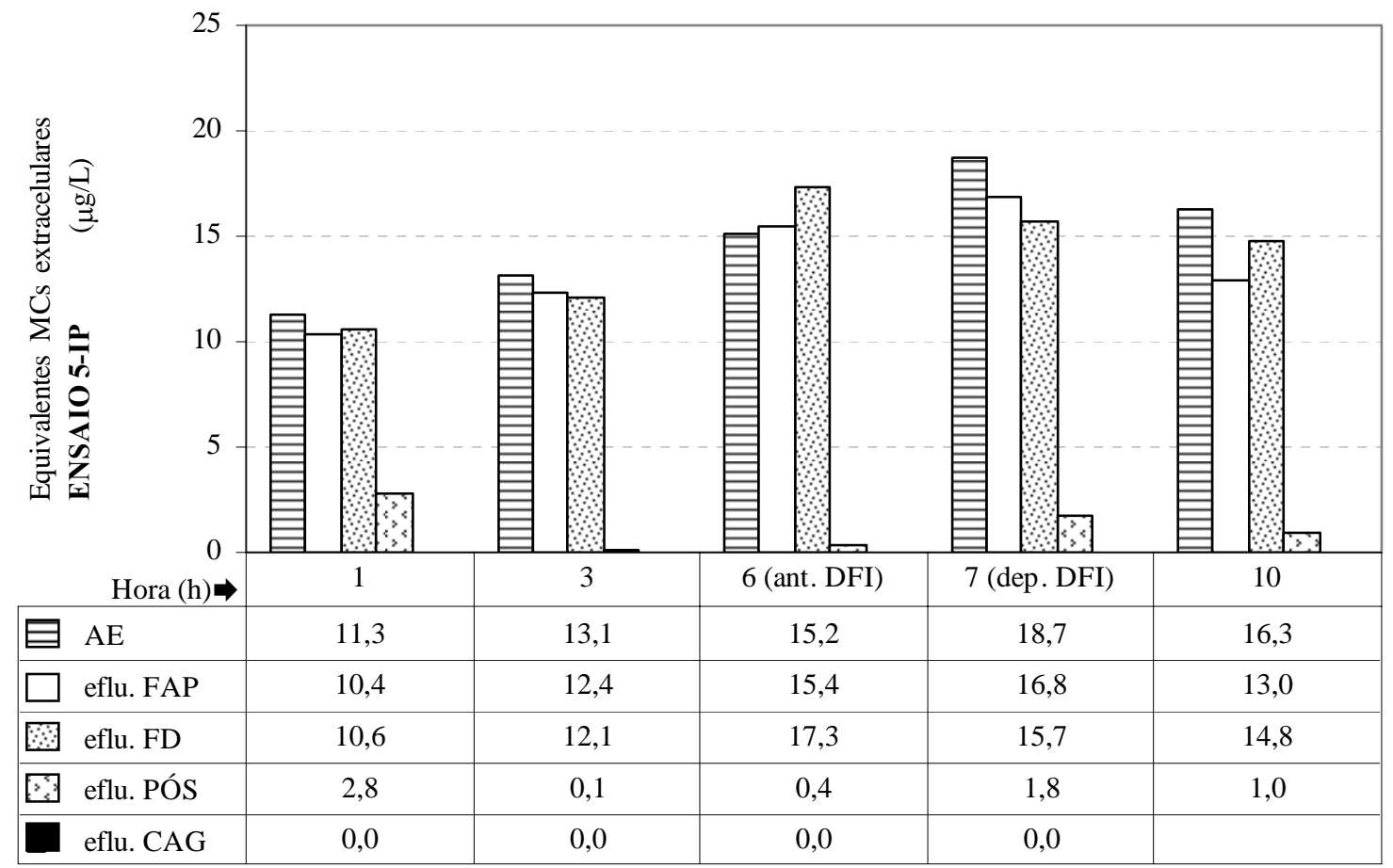

Figura 5.6.30 - Concentração de microcistinas - MCs extracelulares na água de estudo e nos efluentes de cada processo de tratamento para diferentes tempos de amostragem do ENSAIO 5-IP

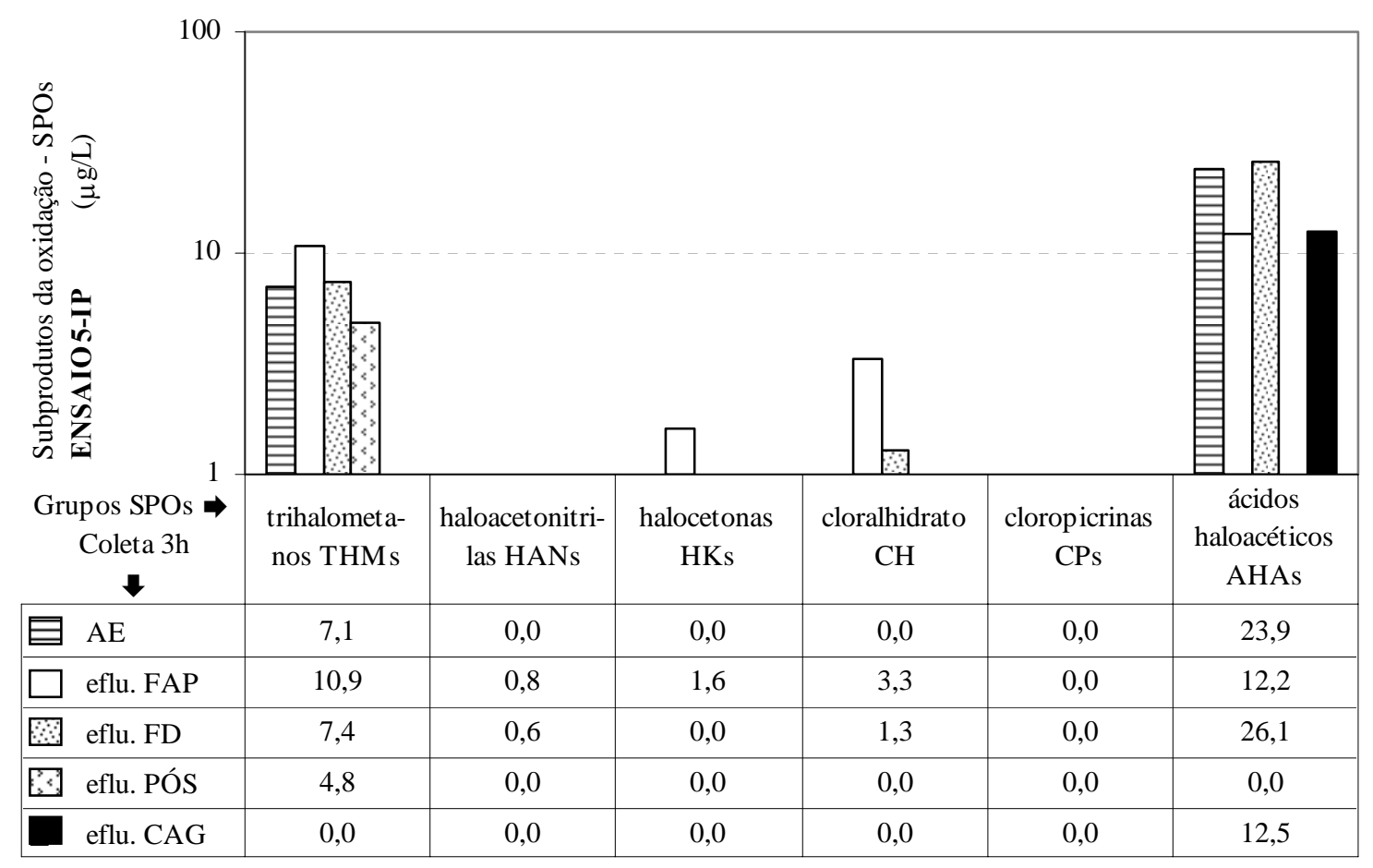

Figura 5.6.31 - Concentração de subprodutos organohalogenados - SPOs formados na água de estudo e nos efluentes de cada processo de tratamento para amostragem de $6 \mathrm{~h}$ do ENSAIO 5-IP 
Tabela 5.6.8 - Resumo das condições de funcionamento e dos parâmetros de desempenho para os controles operacional e qualitativo do ENSAIO 6-IP (em instalação piloto)

\section{ENSAIO6-IP: Sistema MR $\rightarrow$ FAP $\rightarrow$ INTER $\rightarrow$ FD $\rightarrow$ FCAG}

\begin{tabular}{c|c|c|c|c}
\hline TC-MR $=50 \mathrm{~s}$ & $\begin{array}{c}\text { TxF-FAP }=120 \\
\mathrm{~m}^{3} / \mathrm{m}^{2} . \mathrm{d}\end{array}$ & TC-INTER $=44 \mathrm{~min}$ & $\begin{array}{c}\text { TxF-FD }=180 \\
\mathrm{~m}^{3} / \mathrm{m}^{2} . \mathrm{d}\end{array}$ & TCv FCAG $=12 \mathrm{~min}$ \\
\hline
\end{tabular}

PARÂMETROS CONTROLE OPERACIONAL: DSA: 6 a 7 mg/L; DHS: 1 a 1,5 mg/L; pH da AC: 6,4 a 6,8; potencial zeta da AC: $-1,8$ a -0,3 mV; cloro residual do efluente da intercloração (mantido próximo de 0,5 mg/L): 0,2 a 1,0 mg/L, temperatura: 19,0 a $22{ }^{\circ} \mathrm{C}$; DFI realizada na $6^{\mathrm{a}} \mathrm{h}$, duração do ensaio: $10 \mathrm{~h}$

\begin{tabular}{|c|c|c|c|c|c|c|}
\hline \multirow{2}{*}{$\begin{array}{l}\text { PARÂMETROS } \\
\text { CONTROLE } \\
\text { QUALITATIVO }\end{array}$} & \multicolumn{6}{|c|}{ Águas de diluição - AD, de estudo - AE e Efluentes } \\
\hline & $\mathrm{AD}$ & $\mathrm{AE}$ & FAP & INTER & FD & FCAG \\
\hline $\mathrm{pH}$ & 6,8 a 6,9 & 6,7 a 7,0 & 6,6 a 6,9 & 6,6 a 6,8 & 6,7 a 6,8 & 7,5 a 7,9 \\
\hline Potencial Zeta (mV) & $-2,9$ a $-2,2$ & $\begin{array}{l}-25,0 \mathrm{a} \\
-13,5\end{array}$ & $-2,2$ a $-2,0$ & - & $-2,1$ a $-1,9$ & $-2,1$ a $-2,0$ \\
\hline $\begin{array}{c}\text { Carbono orgânico total - COT } \\
(\mathrm{mg} \mathrm{C} / \mathrm{L})\end{array}$ & - & 1,14 a 1,50 & 0,94 a 1,28 & 1,03 a 1,21 & 1,03 a 1,33 & 0,74 а 1,70 \\
\hline Absorvância $\lambda=254 \mathrm{~nm}$ & - & $\begin{array}{c}0,011 \mathrm{a} \\
0,019\end{array}$ & $\begin{array}{l}0,07 \mathrm{a} \\
0,012\end{array}$ & $\begin{array}{c}0,012 \mathrm{a} \\
0,015\end{array}$ & $\begin{array}{c}0,013 \mathrm{a} \\
0,016\end{array}$ & $\begin{array}{c}0,014 \mathrm{a} \\
0,029\end{array}$ \\
\hline $\begin{array}{c}\text { Oxigênio dissolvido - OD } \\
(\mathrm{mg} / \mathrm{L})\end{array}$ & 7,3 a 7,9 & 7,5 a 7,9 & 7,6 a 8,3 & 7,6 a 8,2 & 7,3 a 7,9 & 5,7 a 7,6 \\
\hline $\begin{array}{c}\text { Condutividade elétrica } \\
(\mu \mathrm{S} / \mathrm{cm})\end{array}$ & 14,6 a 14,9 & 14,8 a 15,3 & 19,4 a 20,6 & 23,2 a 25,4 & 23,4 a 25,5 & 22,4 a 39,6 \\
\hline Dureza $\left(\mathrm{mgCaCO}_{3} / \mathrm{L}\right)$ & 4 a 5 & 4 a 6 & 4 a 5 & 4 a 6 & 4 a 7 & 4 а 9 \\
\hline Turbidez $^{(*)}$ (uT) & - & 2,4 a 4,2 & 0,27 a 0,35 & 0,30 a 0,77 & 0,31 a 0,51 & 0,34 a 0,50 \\
\hline Turbidez $^{(* *)}$ (uT) & 0,13 & 2,2 a 5,5 & 0,03 a 0,6 & 0,02 a 0,16 & 0,02 a 0,08 & 0,05 a 0,11 \\
\hline $\begin{array}{l}\text { TC: tempo médio de contato; Tx } \\
\text { filtro ascendente de pedregulho; } \\
\text { DSA: dosagem de sulfato de alur } \\
\text { água de diluição; AE: água de } \\
\text { contínuo; }(*) \text { leitura em turbidín }\end{array}$ & $\begin{array}{l}\text { a média } \\
\mathrm{R}: \text { interc } \\
\mathrm{Al}_{2}\left(\mathrm{SO}_{4}\right)_{3} \\
\text {; } \mathrm{DFI}: \mathrm{d}\end{array}$ & $\begin{array}{l}\text { ração; TCv: } \\
\text { io; FD: filtr } \\
\mathrm{H}_{2} \mathrm{O} / \mathrm{L} ; \mathrm{D} \\
\text { ga de fundo }\end{array}$ & $\begin{array}{l}\text { npo médio de } \\
\text { o descendente } \\
\text { dosagem de l }\end{array}$ & $\begin{array}{l}\text { ontato em vaz } \\
\text { FCAG: filtro } \\
\text { dróxido de só }\end{array}$ & $\begin{array}{l}\text {; MR: mistura } \\
\text { m carvão ativa } \\
\text {; AC: água coa }\end{array}$ & $\begin{array}{l}\text { ápida; FAP: } \\
\text { do granular; } \\
\text { gulada; AD: } \\
\text { escoamento }\end{array}$ \\
\hline
\end{tabular}

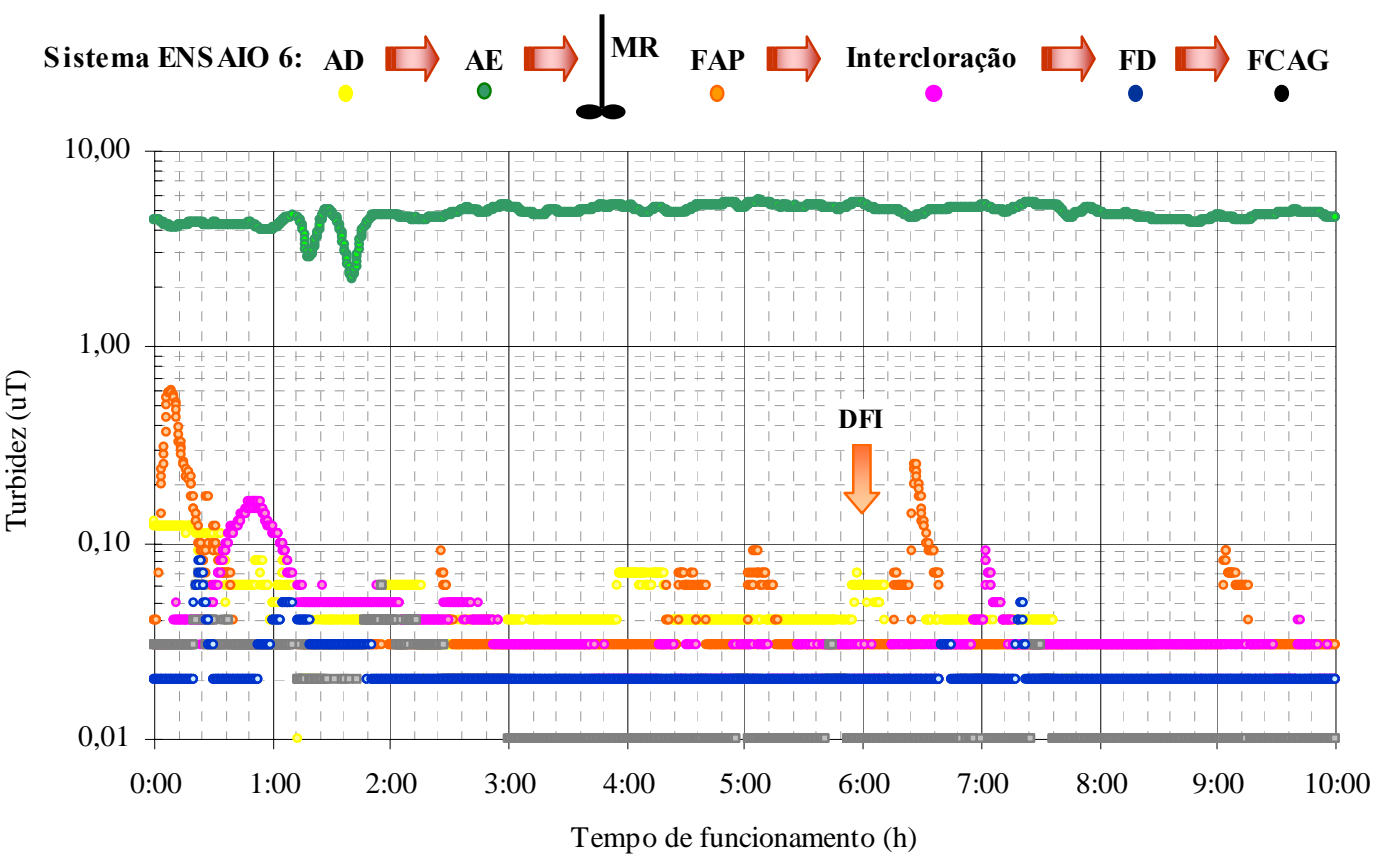

Figura 5.6.32 - Variação dos valores de turbidez em função do tempo nas águas de diluição e de estudo e nos efluentes de cada processo de tratamento do ENSAIO 6-IP 


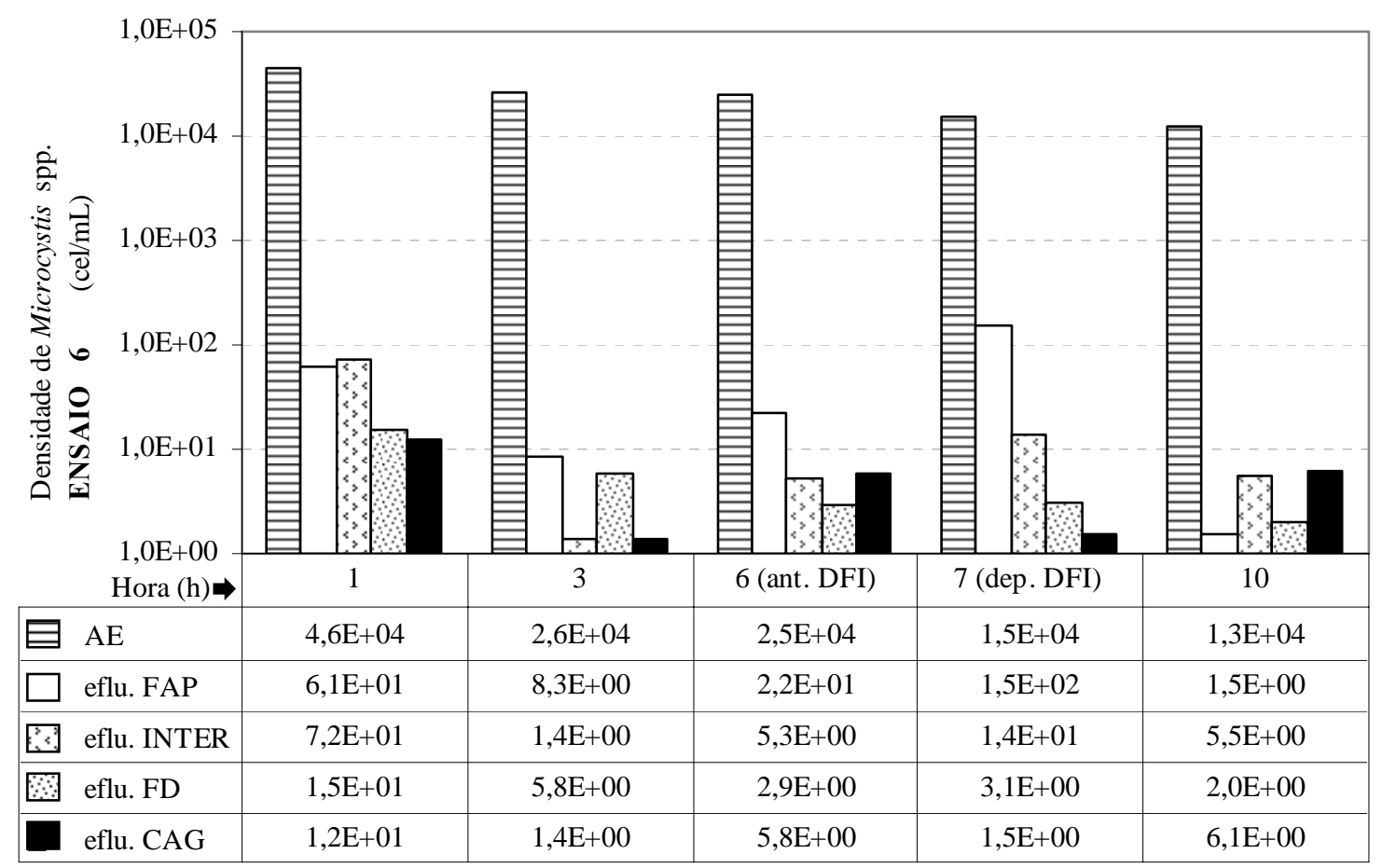

Figura 5.6.33 - Densidade de Microcystis spp. $\left(E+0 x=10^{\mathrm{x}}\right)$ na água de estudo e nos efluentes de cada processo de tratamento para diferentes tempos de amostragem do ENSAIO 6-IP

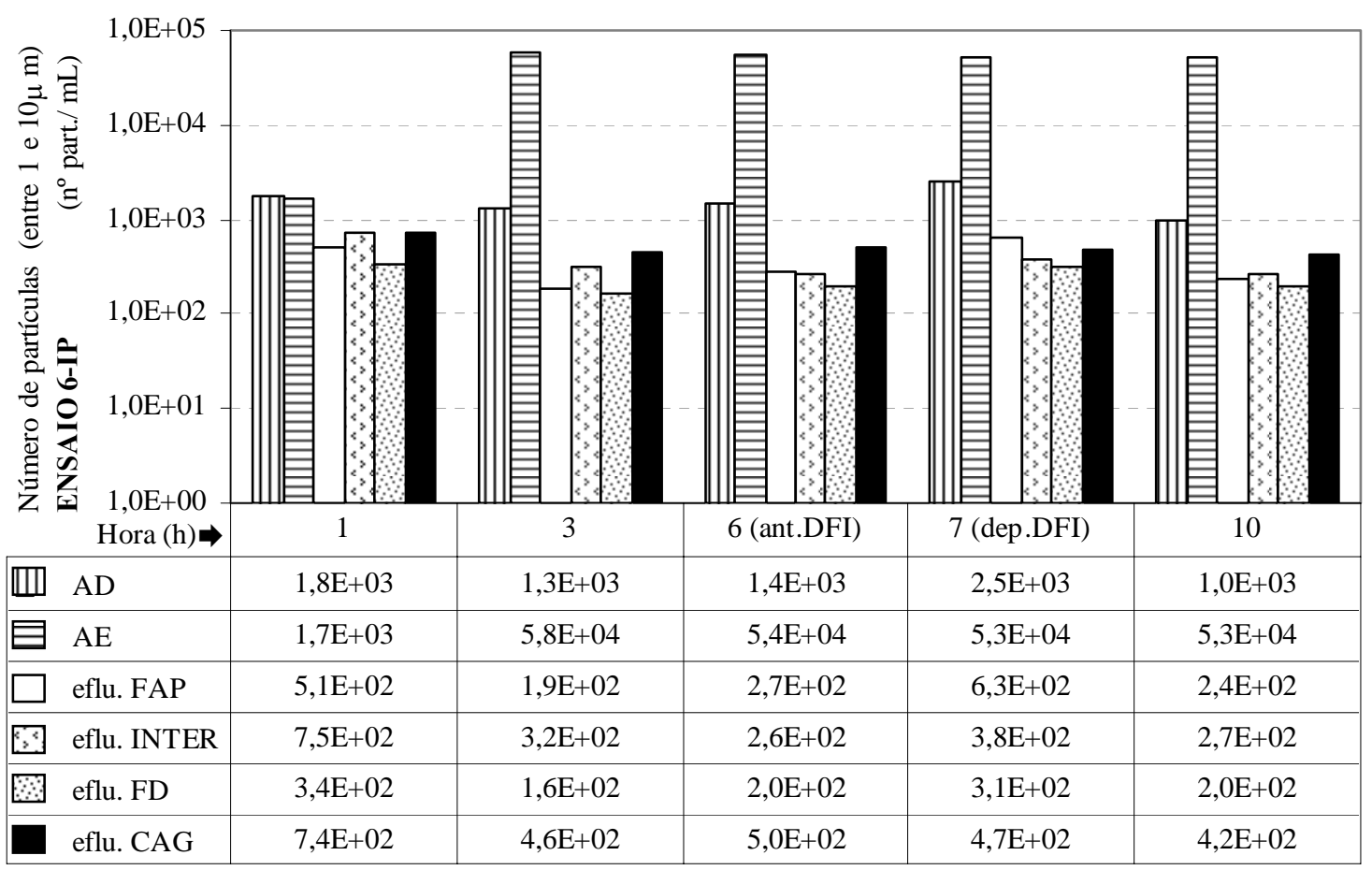

Figura 5.6.34 - Número de partículas (entre 1 e $10 \mu \mathrm{m}$ ) nas águas de diluição e de estudo e nos efluentes de cada processo de tratamento para diferentes tempos de amostragem do ENSAIO 6-IP 


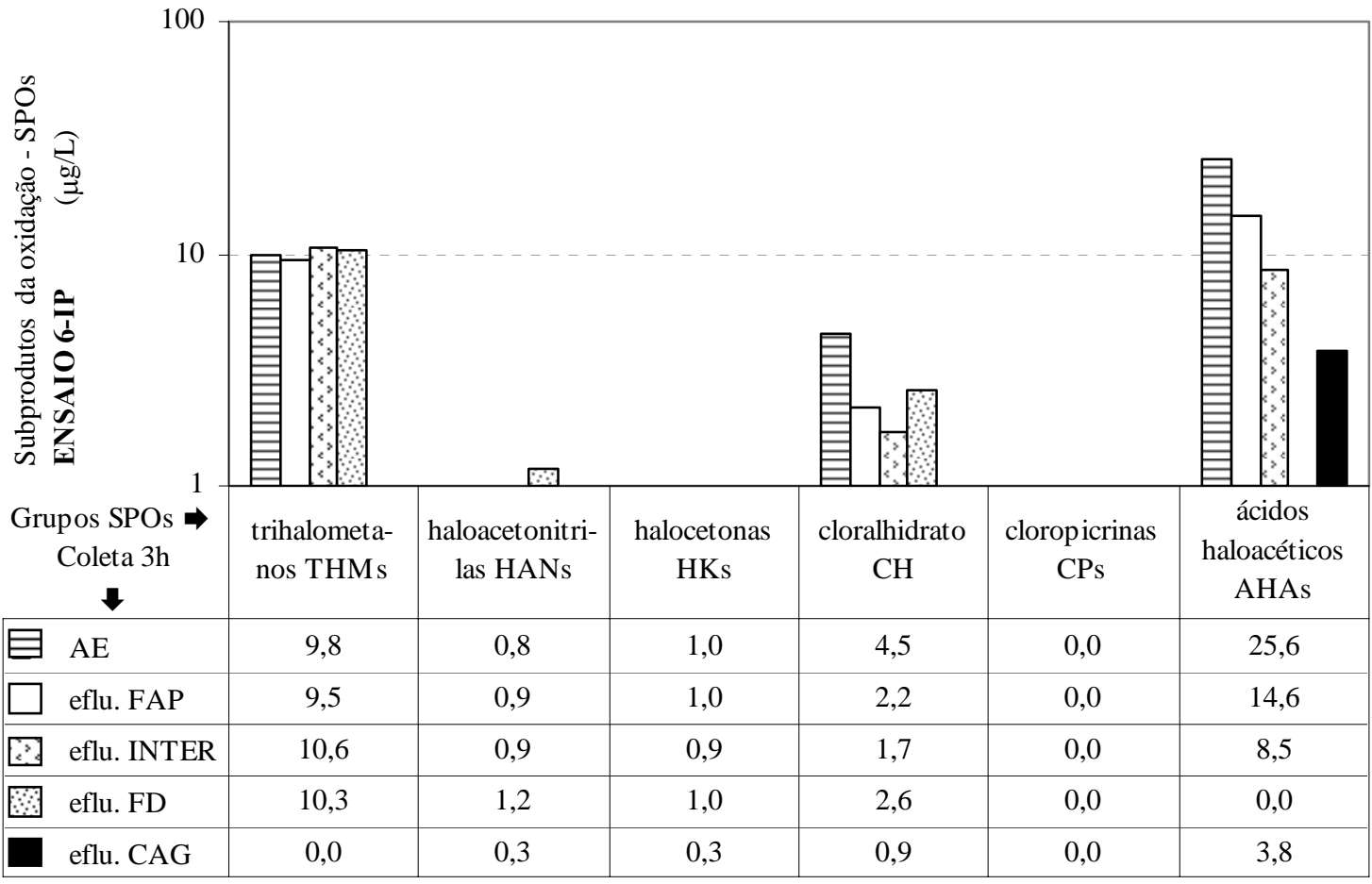

Figura 5.6.35 - Concentração de subprodutos organohalogenados - SPOs formados na água de estudo e nos efluentes de cada processo de tratamento para amostragem de $6 \mathrm{~h}$ do ENSAIO 6-IP

Tabela 5.6.9 - Resumo das condições de funcionamento e dos parâmetros de desempenho para os controles operacional e qualitativo do ENSAIO 7-IP (em instalação piloto)

ENSAIO7-IP: Sistema CAP $\rightarrow$ MR $\rightarrow$ FAP $\rightarrow$ FD

TC-CAP $=35 \mathrm{~min}$

$\mathrm{TC}-\mathrm{MR}=55 \mathrm{~s}$

TxF-FAP $=120 \mathrm{~m}^{3} / \mathrm{m}^{2} . \mathrm{d}$

TxF-FD $=180 \mathrm{~m}^{3} / \mathrm{m}^{2} \cdot \mathrm{d}$

PARÂMETROS CONTROLE OPERACIONAL: DSA: 5 a 5,5 mg/L; DHS: 1 a 1,25 mg/L; pH da AC: 6,3 a 6,5; potencial zeta da AC: -6,7 a -14,2 mV; DCL: 2,5 mg/L; cloro residual do efluente da pré-cloração: 0,54 a 0,9 mg/L, temperatura: 19 a $22{ }^{\circ} \mathrm{C}$; DFI realizada na $6^{\mathrm{a}} \mathrm{h}$, duração do ensaio: $6 \mathrm{~h}$

\begin{tabular}{|c|c|c|c|c|c|}
\hline \multirow{2}{*}{$\begin{array}{c}\text { PARÂMETROS } \\
\text { CONTROLE } \\
\text { QUALITATIVO }\end{array}$} & \multicolumn{5}{|c|}{ Águas de diluição - AD, de estudo - AE e Efluentes } \\
\hline & $\mathrm{AD}$ & $\mathrm{AE}$ & PRÉ & FAP & FD \\
\hline $\mathrm{pH}$ & 6,3 a 6,9 & 6,4 a 6,9 & 6,4 a 6,6 & 6,2 a 6,6 & 6,2 a 7,3 \\
\hline Potencial Zeta $(\mathrm{mV})$ & $-3,2$ a $-2,2$ & $-32,0$ a $-29,8$ & - & $-3,1$ a $-2,0$ & $-2,2$ a $-2,0$ \\
\hline $\begin{array}{c}\text { Carbono orgânico total - COT } \\
(\mathrm{mg} \mathrm{C} / \mathrm{L})\end{array}$ & - & 2,2 a 3,0 & 2,1 a 3,5 & 2,0 a 2,3 & 1,9 a 2,7 \\
\hline Absorvância $\lambda=254 \mathrm{~nm}$ & - & 0,025 a 0,031 & 0,024 a 0,029 & 0,016 a 0,018 & 0,016 a 0,032 \\
\hline $\begin{array}{c}\text { Oxigênio dissolvido - OD } \\
(\mathrm{mg} / \mathrm{L})\end{array}$ & 7,6 a 8,6 & 7,5 a 8,5 & 7,8 a 8,6 & 7,8 a 8,6 & 7,6 a 8,8 \\
\hline $\begin{array}{c}\text { Condutividade elétrica } \\
(\mu \mathrm{S} / \mathrm{cm})\end{array}$ & 16,5 a 17,2 & 25,5 a 26,8 & 24,9 a 27,6 & 27,9 a 30,4 & 28,7 a 30,1 \\
\hline Dureza $\left(\mathrm{mgCaCO}_{3} / \mathrm{L}\right)$ & 5 a 6 & 8 a 9 & 9 & 8 a 10 & 7 a 10 \\
\hline Turbidez $^{(*)}$ (uT) & - & 2,3 a 2,8 & 1,4 a 1,8 & 0,3 a 1,2 & 0,3 a 0,4 \\
\hline Turbidez $^{(* *)}$ (uT) & 0,5 a 0,7 & 2,2 a 3,0 & 0,03 a 0,4 & 2,2 a 2,8 & 0,04 a 0,1 \\
\hline
\end{tabular}

TC: tempo médio de contato; TxF: taxa média de filtração; TCv: tempo médio de contato em vazio; MR: mistura rápida; FAP: filtro ascendente de pedregulho; PRÉ: pré-cloração; FD: filtro descendente; DSA: dosagem de sulfato de alumínio $\mathrm{Al}_{2}\left(\mathrm{SO}_{4}\right)_{3} \times 14,3 \mathrm{H}_{2} \mathrm{O} / \mathrm{L}$; DHS: dosagem de hidróxido de sódio; AC: água coagulada; $\mathrm{AD}$ : água de diluição; AE: água de estudo; DFI: descarga de fundo intermediária; $\left({ }^{* *}\right)$ : leitura em turbidímetro de escoamento contínuo; $\left(^{*}\right)$ : leitura em turbidímetro de bancada 2100P HACH. 


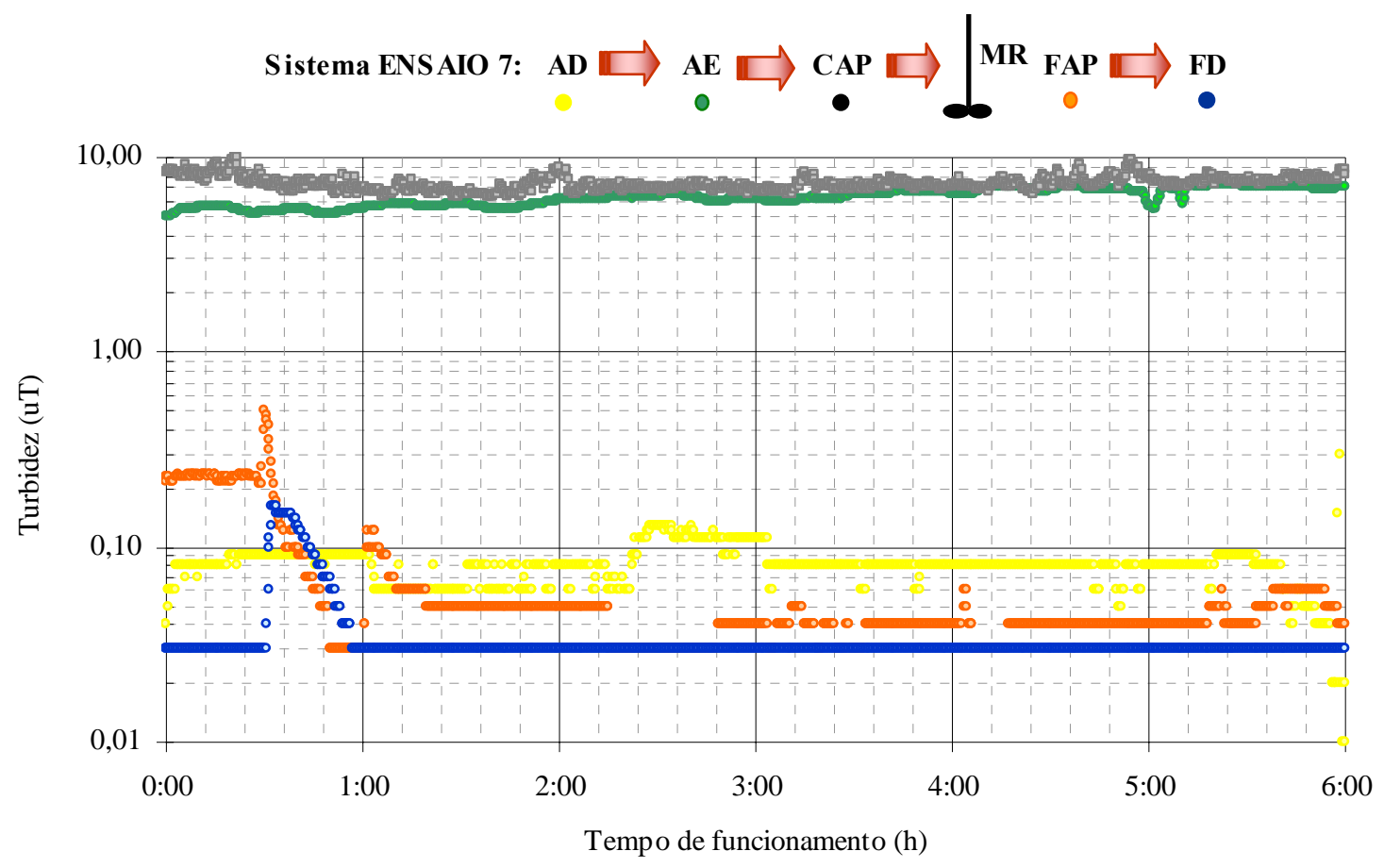

Figura 5.6.36 - Variação dos valores de turbidez em função do tempo nas águas de diluição e de estudo e nos efluentes de cada processo de tratamento do ENSAIO 7-IP

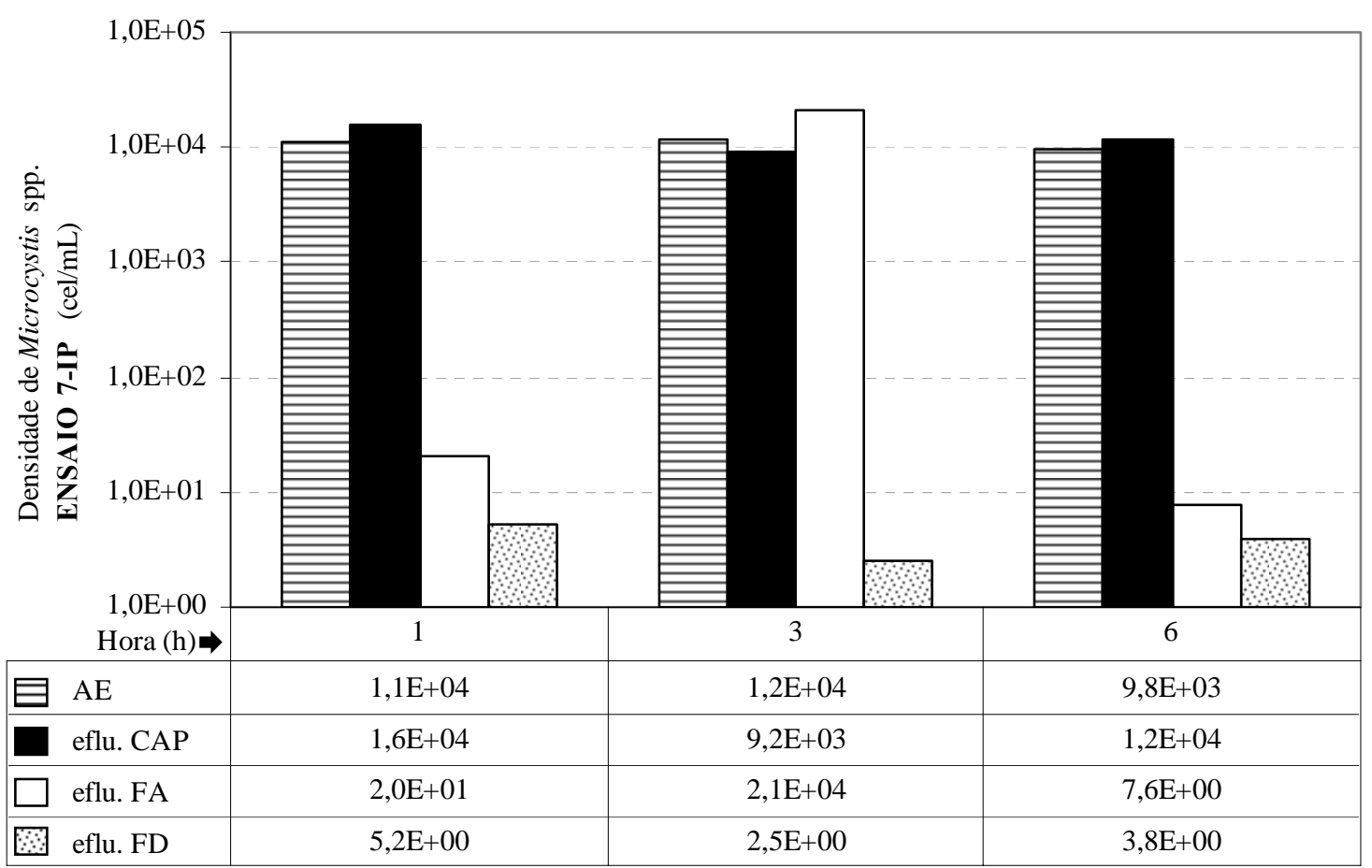

Figura 5.6.37 - Densidade de Microcystis spp. $\left(E+0 x=10^{\mathrm{x}}\right)$ na água de estudo e nos efluentes de cada processo de tratamento para diferentes tempos de amostragem do ENSAIO 7-IP 


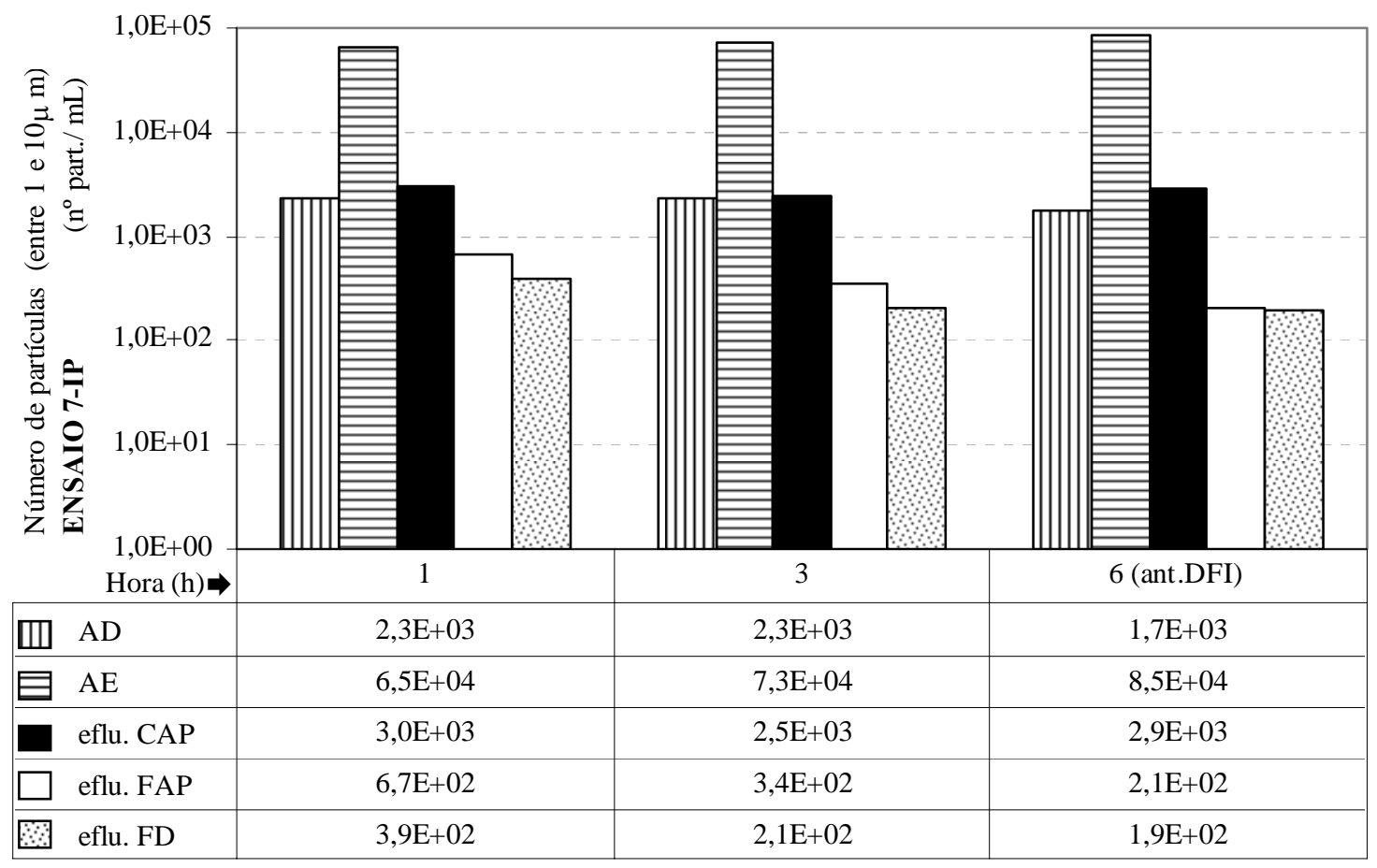

Figura 5.6.38 - Número de partículas (entre 1 e $10 \mu \mathrm{m}$ ) nas águas de diluição e de estudo e nos efluentes de cada processo de tratamento para diferentes tempos de amostragem do ENSAIO 7-IP

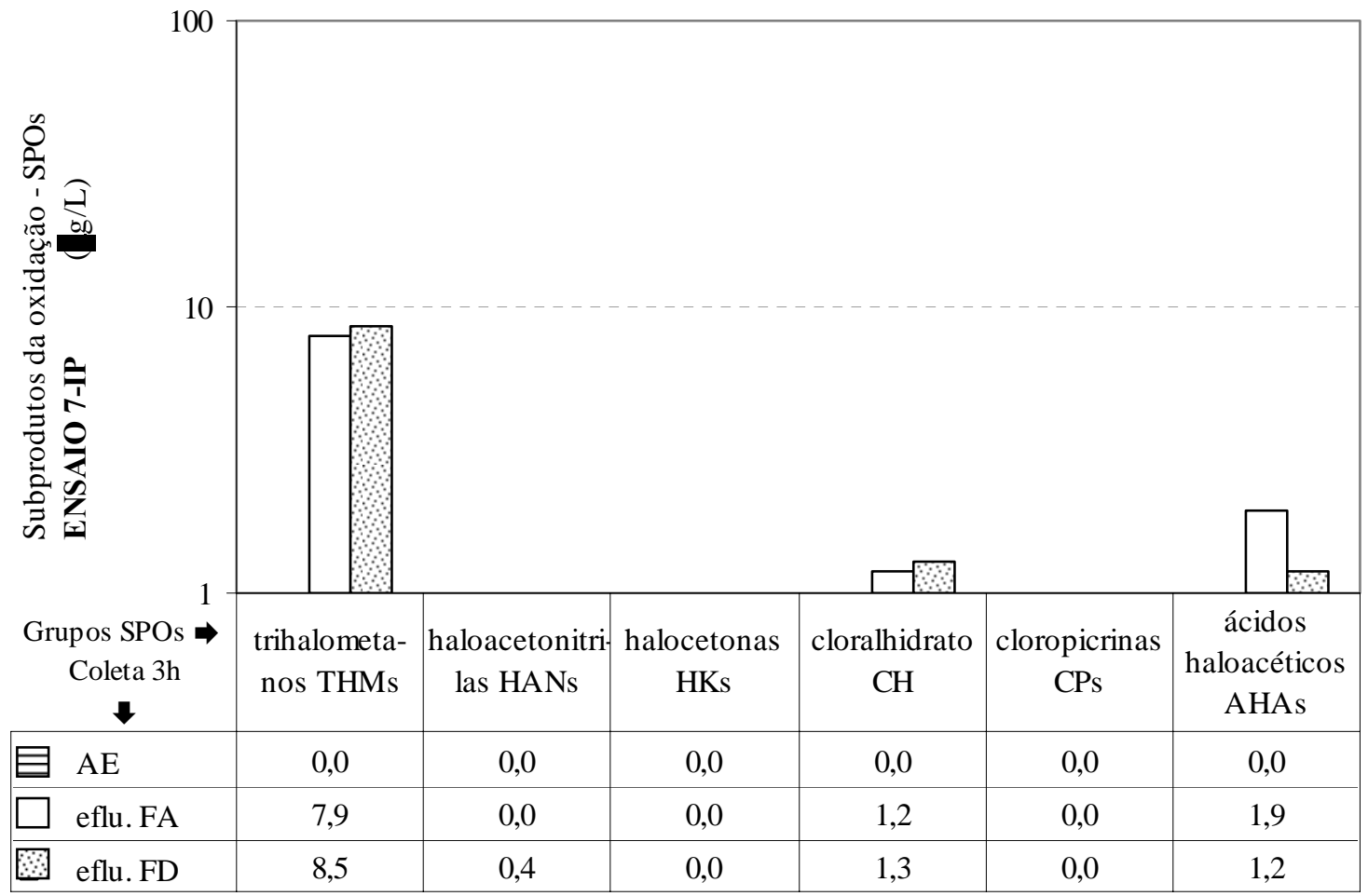

Figura 5.6.39 - Concentração de subprodutos organohalogenados - SPOs formados na água de estudo e nos efluentes de cada processo de tratamento para amostragem de $6 \mathrm{~h}$ do ENSAIO 7-IP 
Tabela 5.6.10 - Resumo das condições de funcionamento e dos parâmetros de desempenho para os controles operacional e qualitativo do ENSAIO 8-IP (em instalação piloto)

\begin{tabular}{c|c|c|c|c}
\hline \multicolumn{4}{c}{ ENSAIO8-IP: Sistema PRÉ $\rightarrow$ CAP $\rightarrow$ MR $\rightarrow$ FAP $\rightarrow$ FD } \\
\hline $\begin{array}{c}\text { TC-PRÉ }=35 \\
\text { min }\end{array}$ & TC-CAP $=20 \mathrm{~min}$ & TC-MR $=60 \mathrm{~s}$ & $\begin{array}{c}\text { TxF-FAP }=120 \\
\mathrm{~m}^{3} / \mathrm{m}^{2} . \mathrm{d}\end{array}$ & $\begin{array}{c}\text { TxF-FD }=180 \\
\mathrm{~m}^{3} / \mathrm{m}^{2} . \mathrm{d}\end{array}$ \\
\hline
\end{tabular}

PARÂMETROS CONTROLE OPERACIONAL: DSA: 5 a 7 mg/L; DHS: 1 a 1,5 mg/L; pH da AC: 6,9 a 7,0; cloro residual do efluente da i pré-oxidação: 0,05 a 0,20 mg/L, DCAP: $20 \mathrm{mg} / \mathrm{L}$; temperatura: 21 a 22,5 ${ }^{\circ} \mathrm{C}$; DFI realizada na $6^{\mathrm{a}} \mathrm{h}$, duração do ensaio: $6 \mathrm{~h}$

\begin{tabular}{|c|c|c|c|c|c|c|}
\hline \multirow{2}{*}{$\begin{array}{c}\text { PARÂMETROS } \\
\text { CONTROLE } \\
\text { QUALITATIVO }\end{array}$} & \multicolumn{6}{|c|}{ Águas de diluição - AD, de estudo - AE e Efluentes } \\
\hline & $\mathrm{AD}$ & $\mathrm{AE}$ & PRÉ & CAP & FAP & FD \\
\hline $\mathrm{pH}$ & 6,9 a 7,1 & 7,0 a 7,2 & 6,8 a 7,1 & 6,9 a 7,5 & 6,7 a 7,1 & 6,7 a 7,1 \\
\hline Potencial Zeta (mV) & $-4,1$ a $-2,5$ & $\begin{array}{l}-34,6 \mathrm{a} \\
-24,9 \mathrm{a}\end{array}$ & - & - & $-2,5$ a $-1,2$ & $-2,1$ a $-1,8$ \\
\hline $\begin{array}{l}\text { Carbono orgânico total - COT } \\
\text { (mg C / L) }\end{array}$ & - & 1,45 a 4,48 & 1,48 a 3,99 & 1,75 a 4,3 & 0,63 a 2,39 & 0,68 a 2,27 \\
\hline Absorvância $\lambda=254$ nm & - & $\begin{array}{c}0,026 \mathrm{a} \\
0,033\end{array}$ & $\begin{array}{c}0,015 \mathrm{a} \\
0,033\end{array}$ & $\begin{array}{c}0,015 \text { a } \\
0,026\end{array}$ & $\begin{array}{c}0,007 \text { a } \\
0,013\end{array}$ & $\begin{array}{c}0,005 \text { a } \\
0,012\end{array}$ \\
\hline $\begin{array}{c}\text { Oxigênio dissolvido - OD } \\
(\mathrm{mg} / \mathrm{L})\end{array}$ & 7,3 a 8,1 & 7,4 a 8,1 & 7,3 a 8,0 & 7,0 a 7,9 & 7,6 a 8,4 & 7,2 a 8,2 \\
\hline $\begin{array}{c}\text { Condutividade elétrica } \\
(\mu \mathrm{S} / \mathrm{cm})\end{array}$ & 17,4 a 17,9 & 24,3 a 24,9 & 24,3 a 25 & 25,3 a 25,6 & 18,9 a 29,8 & 21,1 a 30,1 \\
\hline Dureza $\left(\mathrm{mgCaCO}_{3} / \mathrm{L}\right)$ & 6 a 7 & 7 а 9 & 7 а 9 & 7 а 9 & 7 а 9 & 8 a a10 \\
\hline Turbidez $^{(*)}$ (uT) & - & 2,4 a 4,0 & 1,7 a 2,6 & 1,5 a 4,0 & 0,3 a 0,4 & 0,3 a 0,4 \\
\hline Turbidez $^{(* *)}$ (uT) & 0,7 a 0,9 & 2,3 a 3,6 & 2,3 a 3,3 & 2,8 a 4,7 & 0,03 a 0,5 & 0,04 a 0,2 \\
\hline
\end{tabular}

TC: tempo médio de contato; TxF: taxa média de filtração; TCv: tempo médio de contato em vazio; MR: mistura rápida; FAP: filtro ascendente de pedregulho; PRÉ: pré-cloração; FD: filtro descendente; CAP: carvão ativado em pó; DSA: dosagem de sulfato de alumínio $\mathrm{Al}_{2}(\mathrm{SO} 4)_{3} \times 14,3 \mathrm{H}_{2} \mathrm{O} / \mathrm{L}$; DHS: dosagem de hidróxido de sódio; AC: água coagulada; $\mathrm{AD}$ : água de diluição; AE: água de estudo; DFI: descarga de fundo intermediária; (*): leitura em turbidímetro de bancada 2100P HACH; (**): leitura em turbidímetro de escoamento contínuo.

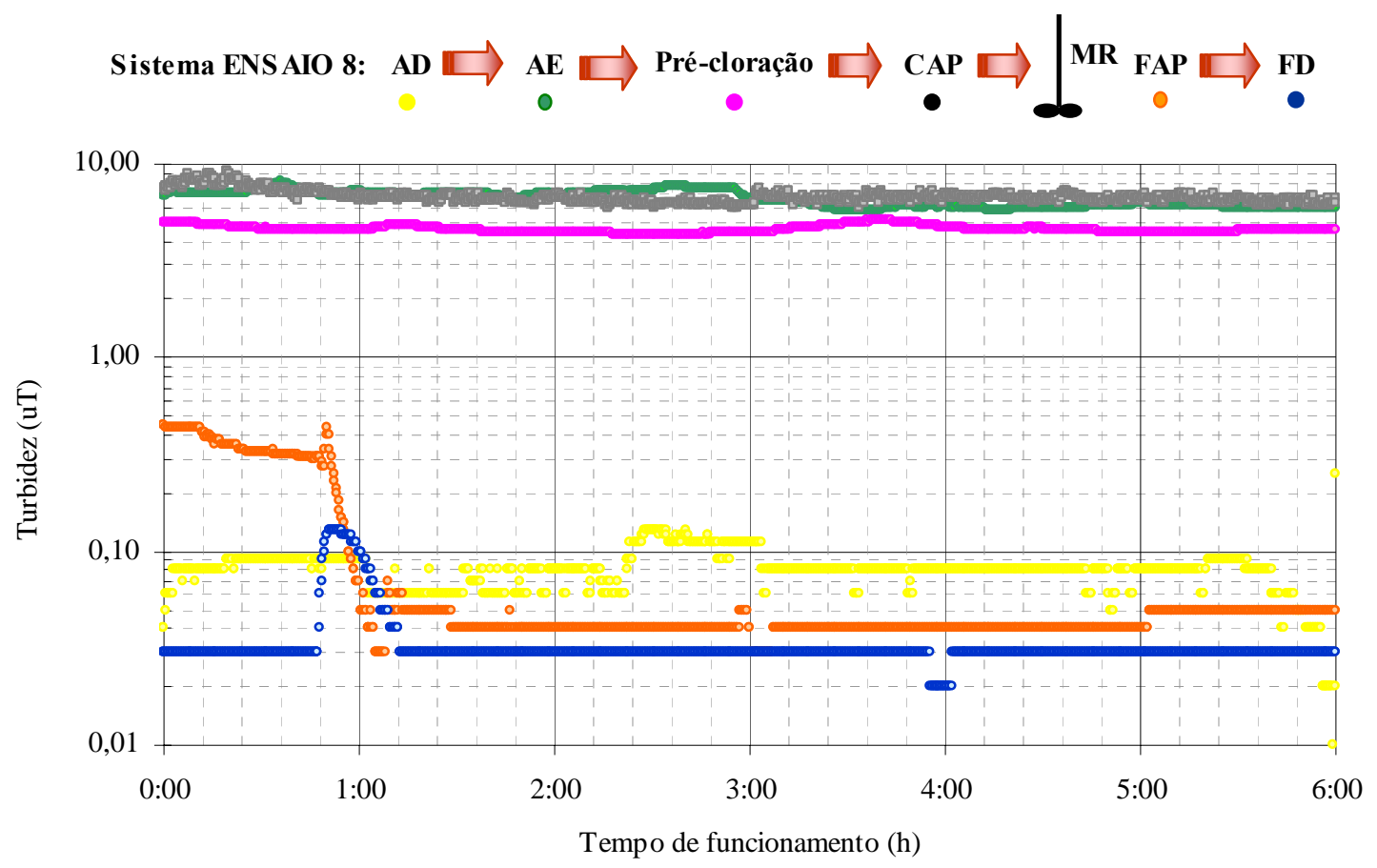

Figura 5.6.40 - Variação dos valores de turbidez em função do tempo nas águas de diluição e de estudo e nos efluentes de cada processo de tratamento do ENSAIO 8-IP 


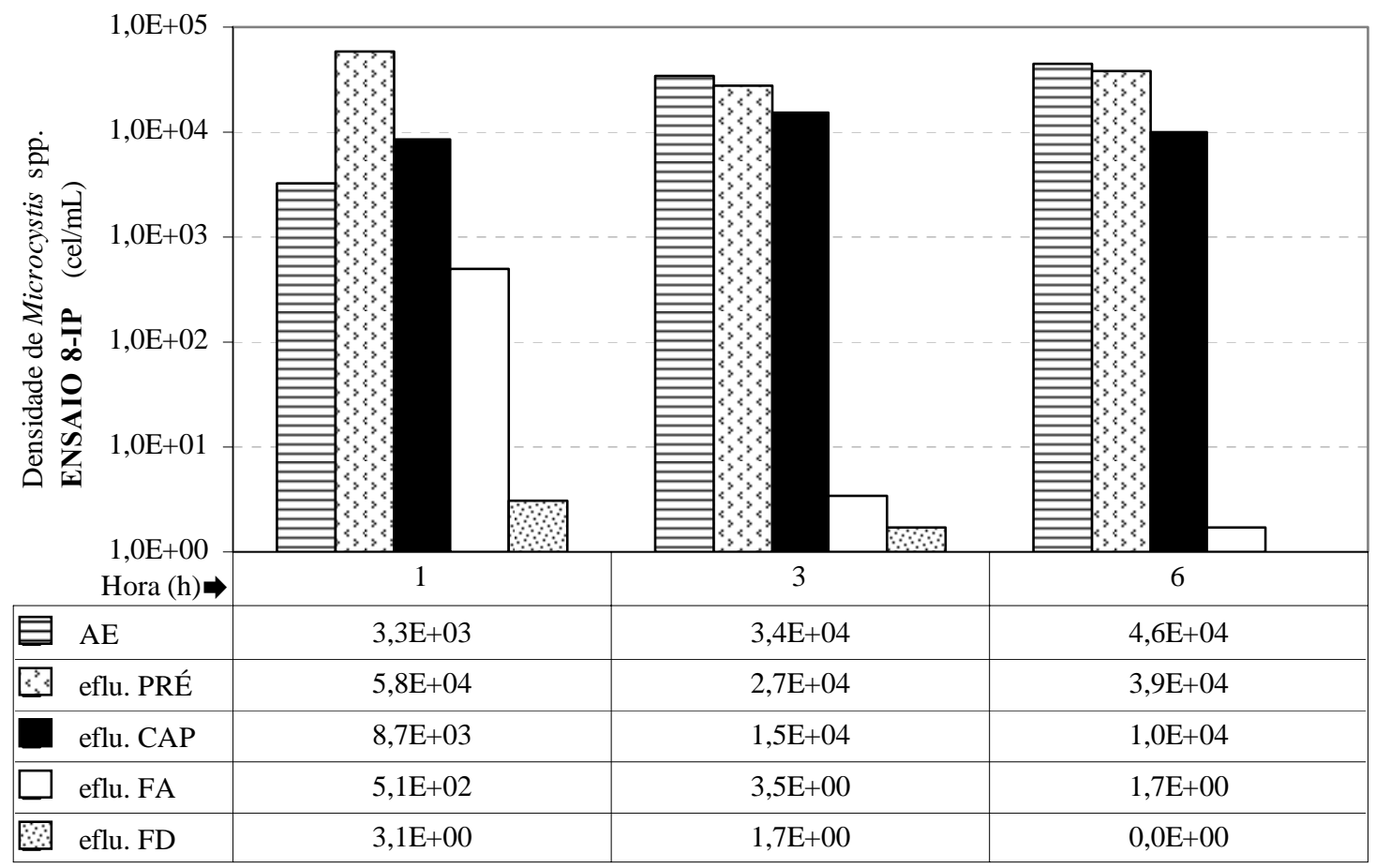

Figura 5.6.41 - Densidade de Microcystis spp. $\left(\mathrm{E}+0 \mathrm{x}=10^{\mathrm{x}}\right)$ na água de estudo e nos efluentes de cada processo de tratamento para diferentes tempos de amostragem do ENSAIO 8-IP

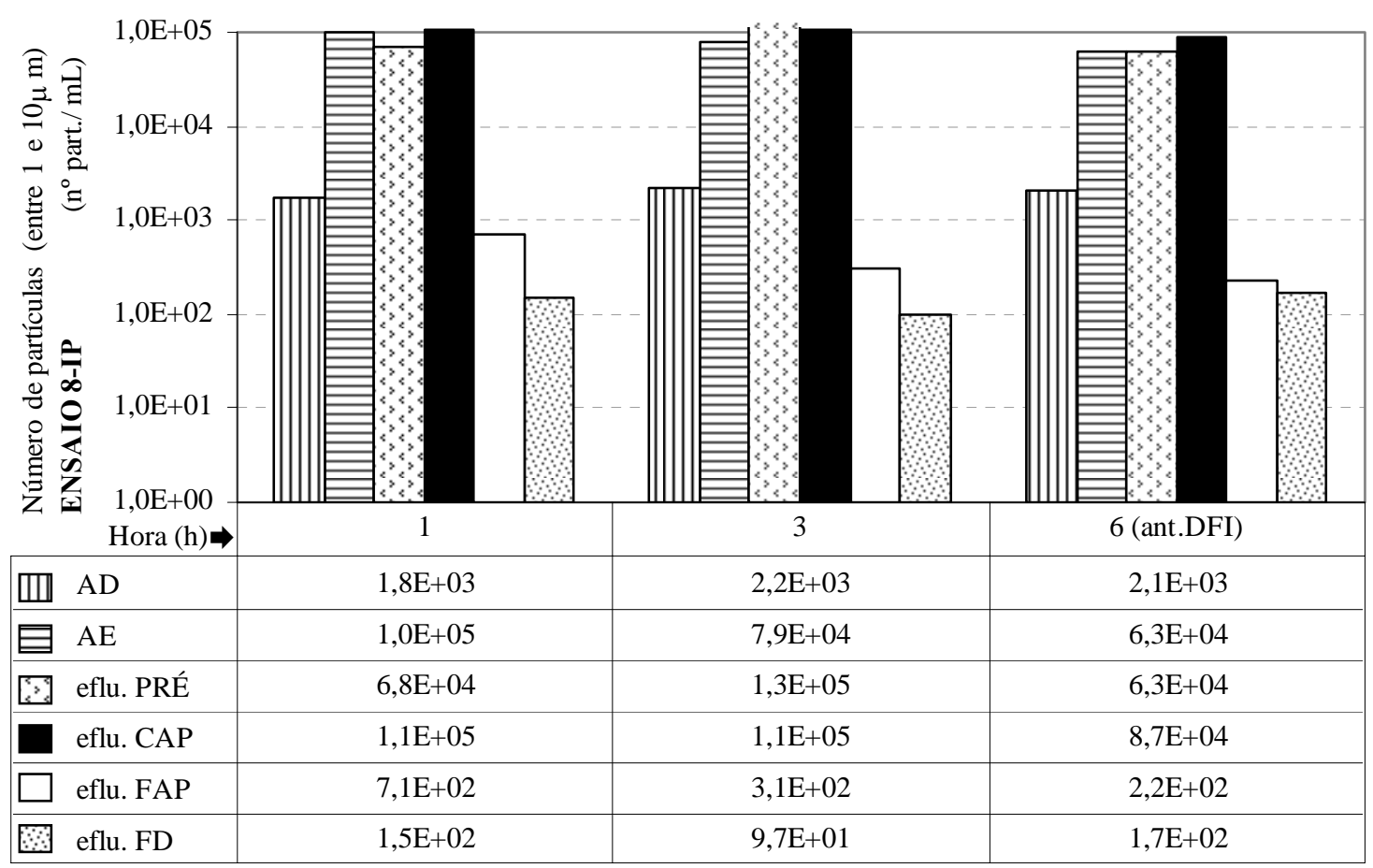

Figura 5.6.42 - Número de partículas (entre 1 e $10 \mu \mathrm{m}$ ) nas águas de diluição e de estudo e nos efluentes de cada processo de tratamento para diferentes tempos de amostragem do ENSAIO 8-IP 


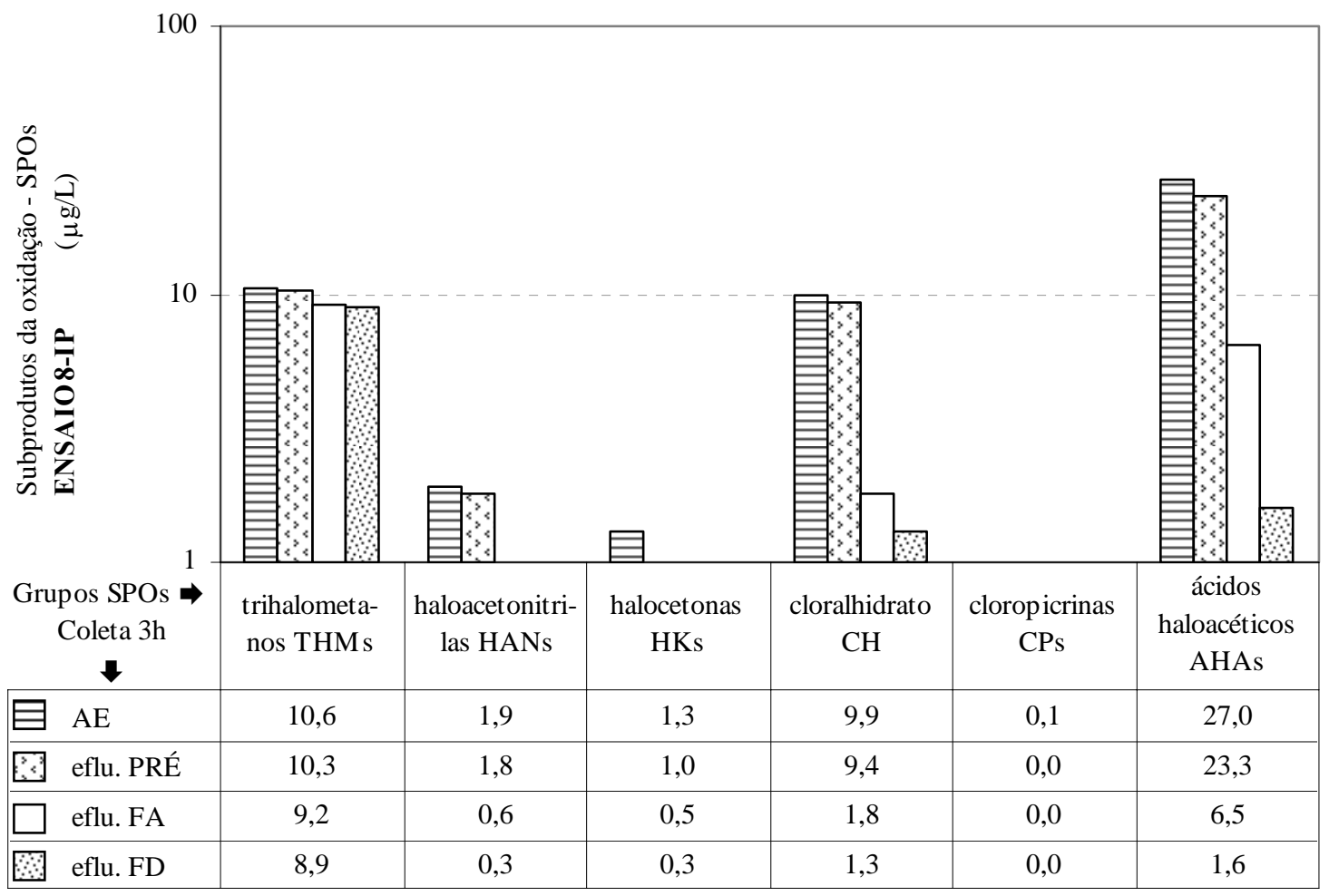

Figura 5.6.43 - Concentração de subprodutos organohalogenados - SPOs formados na água de estudo e nos efluentes de cada processo de tratamento para amostragem de $6 \mathrm{~h}$ do ENSAIO 8-IP

\subsubsection{Remoção de células de Microcystis spp.}

Na Tabela 5.6.11 são compilados os valores (mínimo e máximo) de densidade de Microcystis spp. e as respectivas eficiências médias (parcial e acumulada) observados para os efluentes de cada processo nos ensaios 1 a 6 .

De acordo com esses dados, para as águas de estudo empregadas nos ensaios, com densidade de $M$. spp. entre 2 e $5 \times 10^{4} \mathrm{cel} / \mathrm{mL}$, as eficiências médias parciais obtidas referentes à remoção de células de $M$. spp. variaram entre 29 e 31 \% para a pré-oxidação e entre 46 e 100 \% para a filtração ascendente em pedregulho. Porém, vale ressaltar que todos os efluentes do FA apresentaram remoção total superior a 99,5 \%, com exceção do ensaio 4, devido à ocorrência de problemas operacionais no sistema de dosagem e controle do pH de coagulação. Este fato ressalta a importância das condições de coagulação química na eficiência de sistemas que utilizam a tecnologia de filtração direta, conforme já verificado nos ensaios de bancada já apresentados, uma vez que no ensaio 4, a remoção de células intactas foi significativamente menor, chegando a valores de até $19 \%$.

Por outro lado, esse desarranjo possibilitou também, a constatação da segurança complementar oferecida pelos sistemas de dupla filtração, uma vez que nesse caso, o FD foi 
capaz de assegurar a qualidade do efluente final em relação a esse aspecto, resultando em eficiência média total de 99,4\%.

As eficiências parciais dos processos de inter e pós-oxidação e filtração em CAG não puderam ser efetivamente avaliadas devido à baixa densidade de $M$. spp. nos efluentes do FAP.

Tabela 5.6.11 - Valores mínimo e máximo de densidade de Microcystis spp. e eficiências médias parcial e acumulada observados nos ENSAIOS 1 a 6

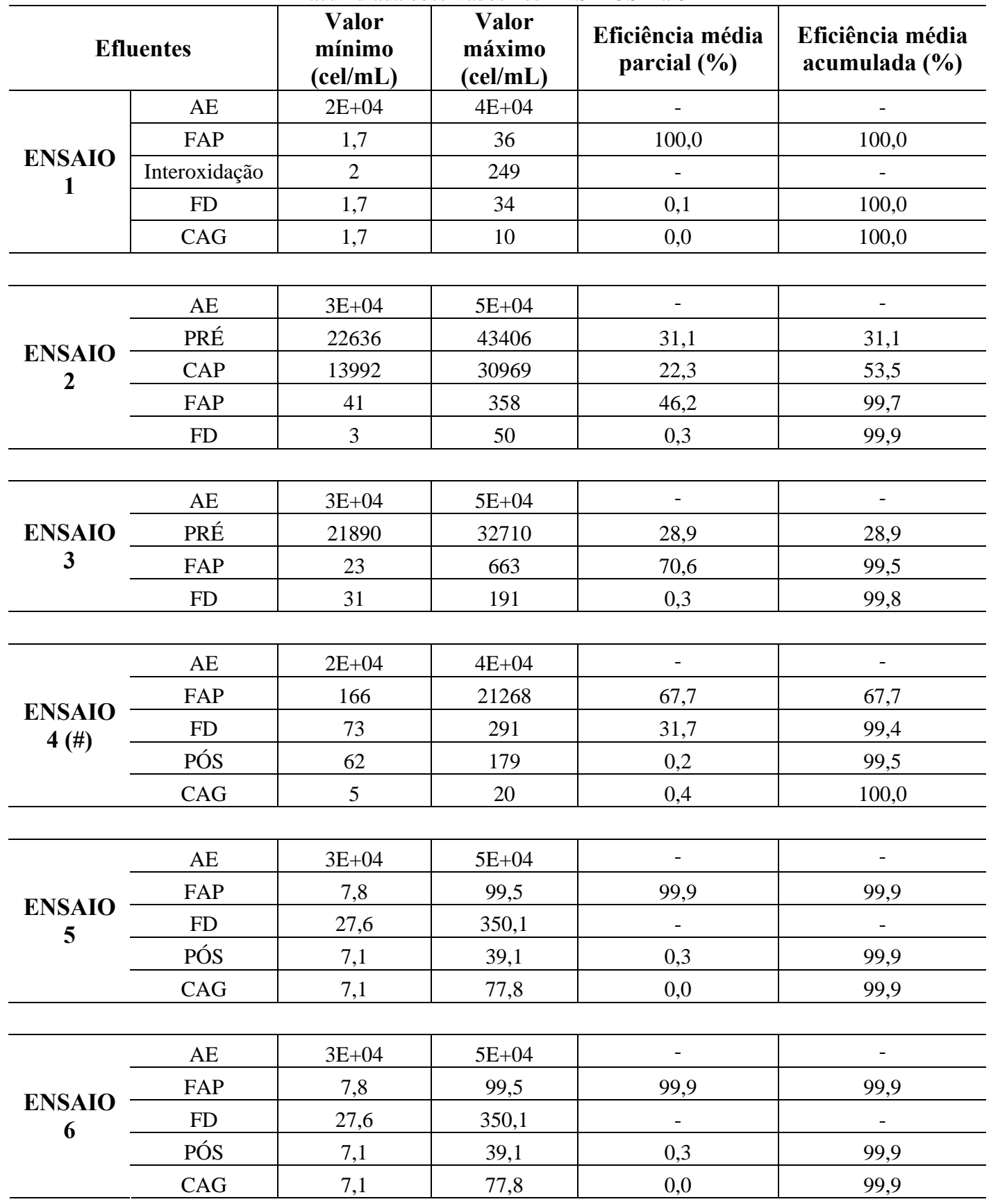

(\#) : Ensaio com problemas operacionais. 
Os resultados compilados dos ensaios 7 e 8 apresentaram alguns valores discrepantes e por isso, não foram incluídos na Tabela 5.6.11. A inconsistência de dados observada pode estar relacionada à presença de formas coloniais e de outros gêneros fitoplanctônicos na amostra, pois essas águas de estudo foram preparadas com material coletado em manancial eutrofizado - reservatório de Barra Bonita - SP.

Os resultados obtidos nesse estudo inferem que a eficiência da remoção de células de $M$. spp. está fortemente relacionada às condições de coagulação química e ao contrário do que foi constatado por PETRUSEVSKY et.al.(1996), parece não sofrer influência do emprego da pré-oxidação. Segundo os autores, eficiências da ordem de 90 \%, comumente atingidas por filtração direta, passaram a valores maiores que 99 \% após pré-oxidação com permanganato de potássio e adição de polímero.

DRIKAS et. al. (2001) simularam o tratamento por ciclo completo e obteve eficiências de remoções de células de microalgas entre 70 e $83 \%$ em experimentos de bancada e superiores a 99,9 \% em escala piloto, valores similares aos obtidos nesse estudo.

Os resultados obtidos de densidade de Microcystis spp. nos efluentes do filtro ascendete de pedregulho - FAP e do filtro descendente de areia - FD mostraram que a concepção de dupla filtração utilizada (composição e espessura do material granular e taxas de filtração) e operação adequada do sistema, mediante aplicação de condições selecionadas de coagulação química, foi bastante eficiente em relação à remoção de células de Microcystis spp. e, consequentemente, de microcistinas intracelulares.

\subsubsection{Remoção de partículas com tamanhos entre 1 e $10 \mu \mathrm{m}$}

Com relação às medidas de distribuição de partículas, foram considerados os tamanhos de 1, 2, 4, 6, 8, 10, 15 e >20 $\mu \mathrm{m}$. Para todas as águas de estudo - AEs empregadas nos ensaios em IP, os somatórios do número de partículas com tamanhos entre 1 e $10 \mu \mathrm{m}$, faixa associada ao tamanho das células de Microcystis spp. (Figura 5.1.2), representaram porcentagens superiores a $97 \%$ do total de partículas, conforme pode ser observado na tabela típica de resultadosTabela 5.6.12. 
Tabela 5.6.12 - Tabela típica de dados de partículas para amostra coletada na $1^{\mathrm{a}}$ hora do ENSAIO 1

\begin{tabular}{c|c|c}
\hline Tamanhos $(\boldsymbol{\mu m})$ & AE Ensaio 1 coleta: $\mathbf{~ h ~}$ & $\mathbf{\%}$ \\
\hline 1 & 19133,9 & 29,5 \\
\hline 2 & 32496,9 & 50,1 \\
\hline 4 & 10748,3 & 16,6 \\
\hline 6 & 864,1 & 1,3 \\
\hline 8 & 373,6 & 0,6 \\
\hline 10 & 376,4 & 0,6 \\
\hline 15 & 256,5 & 0,4 \\
\hline 20 & 586,3 & 0,9 \\
\hline $\mathbf{1 ~ a ~ 1 0}$ & $\mathbf{6 , 3 6 E}+\mathbf{0 4}$ & $\mathbf{9 8 , 1}$ \\
\hline$>\mathbf{1 0}$ & $1,2 \mathrm{E}+03$ & 1,9 \\
\hline total & $6,5 \mathrm{E}+04$ & 100,0 \\
\hline
\end{tabular}

Na Tabela 5.6 .13 são apresentados os valores e eficiências (mínimo e máximo) dos somatórios do número de partículas com tamanhos entre 1 e $10 \mu \mathrm{m}$ observados para os efluentes de cada processo nos ensaios 1 a 8. De acordo com esses dados, os somatórios do número de partículas para as AEs resultaram entre 3 e $7 \times 10^{4}$ e as eficiências mímima e máxima referentes à remoção de partículas no FAP foram de 92,6 e 99,5 \% , respectivamente, valores similares aos obtidos para densidade de células de $M$. spp., entre 2 e $5 \times 10^{4} \mathrm{cel} / \mathrm{mL}$ para as AEs e remoção média superior a 99,5 \% para o FAP, considerando a necessidade de prepração prévia das amostras (diluição para medição de partículas e concentração para densidade de células). Assim, de acordo com os resultados de filtração direta obtidos nos ensaios de bancada, que apresentou correlação entre os parâmetros densidade de células de $M$. spp. e número de partículas com tamanhos entre 1 e $10 \mu \mathrm{m}$ de 0,87, pôde-se constatar, também nos ensaios realizados em IP, a aplicabilidade do uso deste parâmetro físico como estimativa da densidade de células de $M$. spp. devido à correlação entre os dados, rapidez e simplicidade de medida. 
Tabela 5.6.13 - Valores mínimo e máximo de patículas (com tamanhos entre 1 e 10 m) / mL e de eficiência

\begin{tabular}{|c|c|c|c|c|c|}
\hline \multicolumn{2}{|c|}{ Efluentes } & \multirow{2}{*}{$\begin{array}{c}\text { Valor mínimo } \\
\text { (parts. }^{* * k} / \mathbf{m L} \text { ) }\end{array}$} & \multirow{2}{*}{$\begin{array}{c}\begin{array}{l}\text { Valor máximo } \\
\left(\text { parts. }^{* *} / \mathbf{m L}\right)\end{array} \\
9 \mathrm{E}+04\end{array}$} & \multirow{2}{*}{$\begin{array}{c}\begin{array}{c}\text { Eficiência } \\
\text { mínima } \\
\text { acumulada } \\
(\%)\end{array} \\
-\end{array}$} & \multirow{2}{*}{$\begin{array}{c}\begin{array}{c}\text { Eficiência } \\
\text { máxima }\end{array} \\
\begin{array}{c}\text { acumulada } \\
(\%)\end{array} \\
-\end{array}$} \\
\hline \multirow{5}{*}{$\begin{array}{c}\text { ENSAIO } \\
1\end{array}$} & $\mathrm{AE}$ & & & & \\
\hline & FAP & $1,74 \mathrm{E}+02$ & $3,48 \mathrm{E}+02$ & 99,5 & 99,7 \\
\hline & Interoxidação & $4,07 \mathrm{E}+02$ & $1,87 \mathrm{E}+03$ & 97,1 & 99,4 \\
\hline & FD & $1,89 \mathrm{E}+02$ & $3,51 \mathrm{E}+02$ & 99,5 & 99,8 \\
\hline & CAG & $3,46 \mathrm{E}+02$ & $1,48 \mathrm{E}+03$ & 97,9 & 99,6 \\
\hline
\end{tabular}

\begin{tabular}{|c|c|c|c|c|c|}
\hline \multirow{3}{*}{$\begin{array}{c}\text { ENSAIO } \\
2\end{array}$} & $\mathrm{AE}$ & $4 \mathrm{E}+04$ & $6 \mathrm{E}+04$ & - & - \\
\hline & FAP & $2,41 \mathrm{E}+02$ & $3,99 \mathrm{E}+03$ & 92,6 & 99,5 \\
\hline & FD & $1,66 \mathrm{E}+02$ & 1,37E+03 & 97,5 & 99,6 \\
\hline \multirow{3}{*}{$\begin{array}{c}\text { ENSAIO } \\
\mathbf{3}\end{array}$} & $\mathrm{AE}$ & $3 E+04$ & $7 E+04$ & - & - \\
\hline & FAP & $3,67 \mathrm{E}+02$ & $1,80 \mathrm{E}+03$ & 97,4 & 99,4 \\
\hline & FD & $2,56 \mathrm{E}+02$ & $6,73 E+02$ & 98,9 & 99,6 \\
\hline \multirow{5}{*}{$\begin{array}{c}\text { ENSAIO } \\
4(\#)\end{array}$} & $\mathrm{AE}$ & $7 E+04$ & $2 \mathrm{E}+05$ & - & - \\
\hline & FAP & $1,39 E+03$ & $8,73 E+03$ & 88,3 & 98,5 \\
\hline & FD & $3,88 \mathrm{E}+02$ & $9,98 \mathrm{E}+02$ & 98,5 & 99,8 \\
\hline & PÓS & $1,05 E+03$ & $1,48 \mathrm{E}+03$ & 97,8 & 99,2 \\
\hline & $\mathrm{CAG}$ & $4,89 \mathrm{E}+02$ & $1,73 \mathrm{E}+03$ & 97,4 & 99,6 \\
\hline \multirow{5}{*}{$\begin{array}{c}\text { ENSAIO } \\
5\end{array}$} & $\mathrm{AE}$ & $7 \mathrm{E}+04$ & $8 \mathrm{E}+04$ & - & - \\
\hline & FAP & $1,95 \mathrm{E}+02$ & $1,12 \mathrm{E}+03$ & 98,5 & 99,8 \\
\hline & FD & $3,33 E+02$ & $6,68 \mathrm{E}+02$ & 99,2 & 99,6 \\
\hline & PÓS & $4,99 \mathrm{E}+02$ & $1,02 \mathrm{E}+03$ & 98,7 & 99,4 \\
\hline & CAG & $5,58 \mathrm{E}+02$ & $8,98 \mathrm{E}+02$ & 98,8 & 99,3 \\
\hline \multirow{5}{*}{$\begin{array}{c}\text { ENSAIO } \\
6\end{array}$} & $\mathrm{AE}$ & $5 E+04$ & $6 \mathrm{E}+04$ & - & - \\
\hline & FAP & $1,87 \mathrm{E}+02$ & $6,26 \mathrm{E}+02$ & 98,8 & 99,7 \\
\hline & FD & $2,58 \mathrm{E}+02$ & $7,47 \mathrm{E}+02$ & 98,8 & 99,5 \\
\hline & PÓS & $1,63 \mathrm{E}+02$ & $3,42 \mathrm{E}+02$ & 99,4 & 99,7 \\
\hline & CAG & $4,24 \mathrm{E}+02$ & $7,37 \mathrm{E}+02$ & 98,8 & 99,2 \\
\hline \multirow{3}{*}{$\begin{array}{c}\text { ENSAIO } \\
7\end{array}$} & $\mathrm{AE}$ & $6 \mathrm{E}+04$ & $8 \mathrm{E}+04$ & - & - \\
\hline & FAP & $2,10 \mathrm{E}+02$ & $6,66 \mathrm{E}+02$ & 99,0 & 99,8 \\
\hline & FD & $1,91 \mathrm{E}+02$ & $3,90 \mathrm{E}+02$ & 99,4 & 99,8 \\
\hline \multirow{3}{*}{$\begin{array}{c}\text { ENSAIO } \\
8\end{array}$} & $\mathrm{AE}$ & $6 \mathrm{E}+04$ & $1 \mathrm{E}+05$ & - & - \\
\hline & FAP & $2,23 E+02$ & $7,11 \mathrm{E}+02$ & 99,3 & 99,6 \\
\hline & FD & $9,67 \mathrm{E}+01$ & $1,67 \mathrm{E}+02$ & 99,7 & 99,9 \\
\hline
\end{tabular}

(\#) : Ensaio com problemas operacionais.

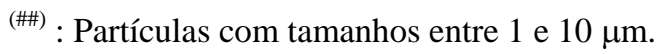




\subsubsection{Remoção de microcistinas - MCs}

Devido à elevada eficiência da filtração ascendente em pedregulho - FAP na remoção de células de Microcystis spp. e densidade empregada nas AEs-2, os efluentes dos processos de tratamento apresentaram concentrações de MCs intracelulares inferiores ao limite de detecção do método cromatográfico. A concentração média de MCs intracelulares nas AEs-2 foi da ordem de $10 \mu \mathrm{g} / \mathrm{L}$.

Na Tabela 5.6.14 são compilados os valores (mínimo e máximo) de concentração residual e de eficiências de remoção de microcistinas - MCs extracelulares, além de eficiências (parcial e acumulada) resultantes para os efluentes de cada processo nos ensaios 1 a 5. De acordo com esses dados, para as águas de estudo empregadas nos ensaios, com concentração de MCs extracelulares entre 6 e $23 \mu \mathrm{g} / \mathrm{L}$ as eficiências médias parciais obtidas referentes à remoção de MCs foram de:

- 93\% para a pré-oxidação, quando seguida de tratamento por filtração ascendente em pedregulho (ensaio 3) e relativamente menor, de 64\%, quando submetida a tratamento subseqüente por adsorção com carvão ativado em pó - CAP (ensaio 2), devido ao controle da dosagem de cloro a fim de que o residual resultasse mínimo;

- $46 \%$ para a interoxidação (ensaio 1) e entre $89 \%$ (ensaio 4) e 83\%(ensaio 5) para a pósoxidação, com valores absolutos correspondentes para o último processo, entre 0,1 e 2,8 $\mu \mathrm{g} / \mathrm{L}$ e portanto, superiores ao valor limitado pela Portaria MS 518/2004 de 1,0 $\mu \mathrm{g} / \mathrm{L}$;

- 3,3 a 27\% para a filtração ascendente em pedregulho e entre 0,6 e 13 \% para a filtração descendente em areia, o que comprova a baixa eficiência da filtração direta em relação a esse aspecto, conforme dados da literatura;

- 8 a 97\% para a adsorção com carvão ativado granular - CAG utilizado como póstratamento, porém, com produção de efluentes com concentrações residuais de MCs aceitáveis pela referida Portaria.

As variações de concentração de MCs nas águas de estudo durante os ensaios deveram-se à necessidade de acionamento periódico do sistema de agitação dos tanques de dosagem de suspensão de células e extrato de MCs o que ocasionou, por vezes, a entrada de ar na tubulação de dosagem, sendo necessário realizar constantes ajustes no sistema. 
Tabela 5.6.14 - Valores mínimo e máximo de concentração de microcistinas - MCs extracelulares e de eficiência e valores médios de eficiências parcial e acumulada dos ENSAIOS 1 a 5

\begin{tabular}{|c|c|c|c|c|c|c|c|}
\hline \multicolumn{2}{|c|}{ Efluentes } & $\begin{array}{c}\text { Valor } \\
\text { mínimo } \\
(\mu \mathrm{g} / \mathrm{L})\end{array}$ & $\begin{array}{c}\text { Valor } \\
\text { máximo } \\
(\mu \mathrm{g} / \mathrm{L})\end{array}$ & $\begin{array}{c}\text { Eficiência } \\
\text { mínima } \\
(\%)\end{array}$ & $\begin{array}{c}\text { Eficiência } \\
\text { máxima } \\
(\%)\end{array}$ & $\begin{array}{l}\text { Eficiência } \\
\text { média } \\
\text { parcial } \\
(\%)\end{array}$ & $\begin{array}{c}\text { Eficiência } \\
\text { média } \\
\text { acumulada } \\
(\%)\end{array}$ \\
\hline \multirow{5}{*}{$\begin{array}{c}\text { ENSAIO } \\
1\end{array}$} & $\mathrm{AE}$ & 6,0 & 18,3 & - & - & - & - \\
\hline & FAP & 3,5 & 23,9 & 7,8 & 41,5 & 26,3 & 26,3 \\
\hline & INTER & 2,6 & 10,6 & 10,0 & 85,4 & 46,2 & 59,4 \\
\hline & FD & 3,0 & 6,9 & 1,3 & 31,1 & 13,4 & 66,2 \\
\hline & CAG & 0,1 & 0,9 & 15,1 & 56,8 & 30,1 & 96,3 \\
\hline \multirow{5}{*}{$\begin{array}{c}\text { ENSAIO } \\
2\end{array}$} & $\mathrm{AE}$ & 11,4 & 20,4 & - & - & - & - \\
\hline & PRÉ & 2,5 & 10,5 & 43,3 & 78,3 & 64,0 & 64,0 \\
\hline & CAP & 0,4 & 1,9 & 17,2 & 46,3 & 31,0 & 95,1 \\
\hline & FAP & 0,3 & 1,0 & 1,1 & 5,3 & 2,5 & 96,7 \\
\hline & FD & 0,1 & 0,8 & 0,0 & 1,8 & 0,9 & 96,9 \\
\hline \multirow{4}{*}{$\begin{array}{c}\text { ENSAIO } \\
\mathbf{3}\end{array}$} & $\mathrm{AE}$ & 8,8 & 17,5 & - & - & - & - \\
\hline & PRÉ & 0,2 & 1,6 & 88,4 & 97,4 & 92,5 & 92,5 \\
\hline & FAP & 0,2 & 1,2 & 0,9 & 6,0 & 3,3 & 95,8 \\
\hline & FD & 0,1 & 1,3 & 0,1 & 1,7 & 1,1 & 96,2 \\
\hline \multirow{5}{*}{$\begin{array}{c}\text { ENSAIO } \\
4(\#)\end{array}$} & $\mathrm{AE}$ & 10,9 & 23,2 & - & - & - & - \\
\hline & FAP & 4,6 & 23,2 & 10,2 & 57,5 & 27,3 & 27,3 \\
\hline & FD & 10,2 & 21,9 & 0,0 & 0,0 & - & 27,3 \\
\hline & PÓS & 0,7 & 2,0 & 76,6 & 96,0 & 88,7 & 91,2 \\
\hline & CAG & 0,0 & 0,2 & 92,9 & 99,1 & 96,7 & 99,2 \\
\hline \multirow{5}{*}{$\begin{array}{c}\text { ENSAIO } \\
5\end{array}$} & $\mathrm{AE}$ & 11,3 & 18,7 & - & - & - & - \\
\hline & FAP & 10,4 & 16,8 & 5,7 & 20,3 & 11,0 & 11,0 \\
\hline & FD & 10,6 & 17,3 & 2,1 & 6,1 & 4,1 & 11,0 \\
\hline & PÓS & 0,1 & 2,8 & 68,9 & 97,7 & 83,4 & 91,3 \\
\hline & CAG & 0,0 & 0,0 & 83,6 & 99,9 & 91,9 & 99,8 \\
\hline
\end{tabular}

(\#) : Ensaio com problemas operacionais.

Como era esperada, a filtração direta em FAP, seguida ou não de FD, não foi eficiente para a remoção de microcistinas extracelulares presentes na água em estudo, tendo resultado em eficiência máxima de $27 \%$ e produzido efluentes com residuais bem superiores ao limitado pela Portaria MS 518/2004. A aplicação da oxidação com cloro tanto na inter como na pré-oxidação, mantendo-se um residual relativamente baixo (valor máximo desejável da ordem de $0,1 \mathrm{mg} / \mathrm{L}$ ) devido à etapa posterior de tratamento por adsorção com CAG e CAP, nos ensaios 1 e 2, respectivamente, produziram efluentes finais com qualidade aceitável sob esse aspecto.

Embora a aplicação da pré-oxidação com dosagens mais elevadas (ensaio 3), mantendo-se um residual da ordem de $1 \mathrm{mg} / \mathrm{L}$, tenha mostrado ser relativamente eficiente, 
esse processo deve ser empregado com precaução, devendo-se verificar preliminarmente, a formação de subprodutos organohalogenados para cada caso, uma vez que as condições do estudo em questão não foram favoráveis à formação desses compostos.

O processo de tratamento por adsorção com CAG, utilizado como pós-tratamento, mostrou ser bastante eficiente para assegurar a qualidade dos efluentes finais dos sistemas testados (ensaios 1, 4 e 5), especialmente, com relação à remoção de MCs extracelulares. Nos ensaios 4 e 5, os efluentes da filtração direta com concentrações de MCs entre 10 e 22 $\mu \mathrm{g} / \mathrm{L}$, tiveram sua concentração reduzida, consistentemente, para valores inferiores a 1,0 $\mu \mathrm{g} / \mathrm{L}$ após adsorção em filtro de CAG.

\subsubsection{Formação de subprodutos organohalogenados da oxidação}

SALES (2005) comparou a eficiência da dupla filtração - DF constituída de 4 sistemas diferentes de DF para remoção de cianobactérias (90 \% de Cylindrospermopsis racirborskii e Plancktotrix aghardii) presentes na água do lago Gavião (Fortaleza, CE, Brasil) em situações com e sem pré-oxidação e interoxidação, utilizando cloro, dióxido de cloro e permanganato de potássio e pós-cloração, além da formação de subprodutos (trihalometanos totais e ácidos haloacéticos).

A unidade DF 1 não foi submetida à pré-oxidação ou interoxidação, sendo usada a pós-cloração da água filtrada final (efluente do filtro descendente), com dosagem de cloro livre aplicada de $5 \mathrm{mg} / \mathrm{L}$ e tempo de contato de 24 h; a unidade DF 2 recebeu cloro como pré e interoxidante, com dosagem aplicada de $2 \mathrm{mg} / \mathrm{L}$; a unidade DF 3 recebeu dióxido de cloro como pré e interoxidante, com dosagem aplicada de $1 \mathrm{mg} / \mathrm{L}$; a unidade DF 4 recebeu permanganato de potássio como pré e interoxidante, com dosagem de 0,25 mg/L. Nessas três unidades (DF2, DF3 e DF4), a água filtrada também foi submetida à pós-cloração com dosagem de cloro livre aplicada de $5 \mathrm{mg} / \mathrm{L}$, com tempo de contato de $24 \mathrm{~h}$. As taxas de filtração foram de aproximadamente $185 \mathrm{~m} / \mathrm{d}$ no filtro ascendente e de $325 \mathrm{~m} / \mathrm{d}$ no filtro descendente.

Na Tabela 5.6.15 são apresentados os dados de uma carreira de estudo, na qual foi empregada a pré-oxidação, seguida da coagulação com $25 \mathrm{mg} / \mathrm{L}$ de hidróxicloreto de alumínio e 0,5 mg/L de polímero catiônico de elevada carga. A turbidez da água bruta manteve-se aproximadamente constante e igual 10 uT e a concentração de cianobactérias foi da ordem de $4,4 \times 10^{5} \mathrm{cel} / \mathrm{mL}$. 
Tabela 5.6.15 - Dados de funcionamento da instalação piloto de dupla filtração de água eutrofizada com préoxidação e pós-cloração FONTE: SALES (2005)

\begin{tabular}{|c|c|c|c|c|c|c|}
\hline \multirow{2}{*}{$\begin{array}{l}\text { Unidade de } \\
\text { Dupla } \\
\text { Filtração }\end{array}$} & \multicolumn{2}{|c|}{$\begin{array}{l}\text { Densidade de Cianobactérias } \\
\text { (cel/mL) }\end{array}$} & \multicolumn{2}{|c|}{ Turbidez (uT) } & \multirow[b]{2}{*}{$\begin{array}{c}\mathrm{AHA}(*) \\
(\mu \mathrm{g} / \mathrm{L})\end{array}$} & \multirow{2}{*}{$\begin{array}{c}\text { TTHM } \\
(* *) \\
(\mu \mathrm{g} / \mathrm{L})\end{array}$} \\
\hline & $\begin{array}{l}\text { Efluente do } \\
\text { Filtro } \\
\text { Ascendente } \\
\end{array}$ & $\begin{array}{l}\text { Efluente do } \\
\text { Filtro } \\
\text { Descendente }\end{array}$ & $\begin{array}{l}\text { Efluente do } \\
\text { Filtro } \\
\text { Ascendente } \\
\end{array}$ & $\begin{array}{c}\text { Efluente do } \\
\text { Filtro } \\
\text { Descendente }\end{array}$ & & \\
\hline DF 1 & $8,0 \times 10^{3}$ & $4,2 \times 10^{3}$ & 1,9 & 0,53 & 177 & 67 \\
\hline DF 2 & $8,4 \times 10^{3}$ & $1,9 \times 10^{3}$ & 2,2 & 0,54 & 187 & 52 \\
\hline DF 3 & $6,5 \times 10^{3}$ & $1,2 \times 10^{3}$ & 2,4 & 0,73 & 226 & 58 \\
\hline DF 4 & $2,7 \times 10^{3}$ & $5,9 \times 10^{3}$ & 0,54 & 0,47 & 173 & 42 \\
\hline
\end{tabular}

(*) ácidos haloacéticos após aplicação de $5 \mathrm{mg} / \mathrm{L}$ de cloro livre e tempo de contato de $24 \mathrm{~h}$

(**) trihalometanos totais após aplicação de $5 \mathrm{mg} / \mathrm{L}$ de cloro livre e tempo de contato de $24 \mathrm{~h}$

Na Tabela 5.6.16 são apresentados os dados de outra carreira de estudo, na qual foi empregada a interoxidação, seguida da coagulação com 25 mg/L de hidróxicloreto de alumínio e 0,5 mg/L de polímero catiônico de elevada carga. A turbidez da água bruta manteve-se aproximadamente constante e igual 11 uT e a concentração de cianobactérias foi da ordem de $3,1 \times 10^{5} \mathrm{cel} / \mathrm{mL}$.

Tabela 5.6.16 - Dados de funcionamento da instalação piloto de dupla filtração de água eutrofizada com interoxidação e pós-cloração FONTE: SALES (2005)

\begin{tabular}{|c|c|c|c|c|c|c|}
\hline \multirow{2}{*}{$\begin{array}{c}\text { Unidade de } \\
\text { Dupla } \\
\text { Filtração }\end{array}$} & \multicolumn{2}{|c|}{$\begin{array}{c}\text { Densidade de Cianobactérias } \\
\text { (cel/mL) }\end{array}$} & \multicolumn{2}{|c|}{ Turbidez (uT) } & \multirow[b]{2}{*}{$\begin{array}{c}\underset{(\mu \mathrm{g} / \mathrm{L})}{\mathrm{AHA}}(*) \\
\end{array}$} & \multirow{2}{*}{$\begin{array}{c}\text { TTHM } \\
(* *) \\
(\mu \mathrm{g} / \mathrm{L})\end{array}$} \\
\hline & $\begin{array}{l}\text { Efluente do } \\
\text { Filtro } \\
\text { Ascendente }\end{array}$ & $\begin{array}{c}\text { Efluente do } \\
\text { Filtro } \\
\text { Descendente }\end{array}$ & $\begin{array}{l}\text { Efluente do } \\
\text { Filtro } \\
\text { Ascendente }\end{array}$ & $\begin{array}{c}\text { Efluente do } \\
\text { Filtro } \\
\text { Descendente }\end{array}$ & & \\
\hline DF1 & $6,9 \times 10^{3}$ & $7,3 \times 10^{3}$ & 1,9 & 0,34 & 237 & 69 \\
\hline DF2 & $5,0 \times 10^{3}$ & $2,1 \times 10^{2}$ & 1,5 & 0,28 & 154 & 60 \\
\hline DF3 & $3,2 \times 10^{3}$ & $3,5 \times 10$ & 1,3 & 0,30 & 52 & 58 \\
\hline DF4 & $6,6 \times 10^{3}$ & $9,2 \times 10$ & 1,7 & 0,29 & 157 & 109 \\
\hline
\end{tabular}

(*) ácidos haloacéticos após aplicação de $5 \mathrm{mg} / \mathrm{L}$ de cloro livre e tempo de contato de $24 \mathrm{~h}$

(**) trihalometanos totais após aplicação de $5 \mathrm{mg} / \mathrm{L}$ de cloro livre e tempo de contato de $24 \mathrm{~h}$

De acordo com as Tabelas 5.6.15 e 5.6.16, a menor concentração de ácidos haloacéticos e de trihalometanos na água clorada final ocorreu com o efluente da unidade DF3, na qual foi usado o dióxido de cloro (1 mg/L) como interoxidante. Isso deve ter sido resultado da menor concentração de cianobactérias no efluente do filtro descendente dessa unidade de dupla filtração, situação para a qual segundo o padrão da USEPA (1999), seria atendido o valor limite de AHA, de $60 \mu \mathrm{g} / \mathrm{L}$.

Conforme avaliação realizada e resultados apresentados no Item 5.2.3, era prevista a formação de pequenas quantidades de subprodutos organohalogenados da oxidação - SPOs, uma vez que para as condições máximas de formação, o emprego de água de estudo com 1,4 $\times 10^{5} \mathrm{cel} / \mathrm{mL}$ de Microcystis spp. resultou em concentrações de $31 \mu \mathrm{g} / \mathrm{L}$ de THMs, valor inferior ao limitado pela Portaria MS/518/2004, de 0,1 mg/L.

Em relação aos ensaios em IP, pôde-se verificar que no sistema do ensaio 1, caracterizado pela remoção prévia de matéria orgânica seguida de interoxidação, a formação 
de SPOs resultou inferior (com THMs $=12,8 \mu \mathrm{g} / \mathrm{L}$ e AHAs $=0,8 \mu \mathrm{g} / \mathrm{L}$ ) à formada nos sistemas em que foram empregados a pré-oxidação, sem remoção prévia de matéria orgânica: ensaio 2 (AHAs = 19,2 $\mu \mathrm{g} / \mathrm{L}$ ) e ensaio 3 (com THMs $=43,3 \mu \mathrm{g} / \mathrm{L}$ e AHAs $=45,1$ $\mu \mathrm{g} / \mathrm{L})$.

\subsubsection{Testes de toxicidade aguda com dafinídeos e biomonitoramento com peixes}

Em geral, Ceriodaphnia silvestrii foi mais sensível do que Ceriodaphnia dubia, devido aos efeitos deletérios causados pela AE e efluentes da pré-oxidação - PRE e da adsorção com carvão ativado pulverizado - CAP. Os efluentes dos FAP e FD causaram efeitos tóxicos aos dafinídeos, durante o experimento, mostrando a ineficiência de tais processos para a remoção de compostos tóxicos.

Apesar da baixa concentração de MCs nas águas de estudo, como citado anteriormente, a AE preparada com amostras de floração natural de Barra Bonita causou efeitos de toxicidade aguda aos dafinídeos, ao contrário da AE preparada com a linhagem NPLJ-4 de Microcystis spp.. Resultado similar foi obtido por OKUMURA et. al. (2006), que analisaram os efeitos tóxicos agudos a dafinídeos (Ceriodaphnia silvestrii, Ceriodaphnia dubia e Daphnia similis) de extratos brutos da linhagem NPLJ-4 e de florações de cianobactérias (sendo Microcystis spp. dominantes) dos reservatórios de Barra Bonita e Ibitinga, SP. Segundo os autores, os extratos das florações apresentaram concentrações inferiores ao limite de detecção de MCs por imunoensaio ELISA, porém maior toxicidade do que a linhagem. Os autores atribuíram ao efeito combinado de diferentes compostos (cianotoxinas, metais e hidrocarbonetos aromáticos policíclicos) a maior toxicidade dos extratos brutos dos reservatórios.

Devido às condições otimizadas de coagulação química, a concentração residual de alumínio, proveniente do sulfato de alumínio usado como coagulante, resultou inferior ao limite de detecção do método em todas as análises realizadas. As concentrações de trihalometanos resultaram inferiores ao valor máximo permitido de $0,1 \mathrm{mg} / \mathrm{L}$ em água potável para consumo humano (Portaria 518/MS 2004).

De um modo geral, observou-se que os efeitos deletérios aos dafinídeos parecem ter sido causados mais por outros compostos tóxicos dos processos de tratamento do que propriamente por Microcystis spp. e MCs. Este fato pode ser evidenciado pelo teste realizado com efluentes dos ensaios 5 a 8 antes (4 - $6 \mathrm{mg} \mathrm{CaCO}_{3} / \mathrm{L}$ ) e após (40 - $48 \mathrm{mg} \mathrm{CaCO}_{3} / \mathrm{L}$ ) ajuste da dureza para a faixa de cultivo dos organismos, o que resultou na redução da toxicidade (Figura 5.6.44). 
Para o ajuste da dureza, foram acrescentadas soluções específicas (sulfato de cálcio, cloreto de potássio, bicarbonato de sódio e sulfato de magnésio) às amostras e mantidas sob agitação por 1 h, o que também pode ter contribuído para diminuição dos efeitos dos possíveis SPOs.

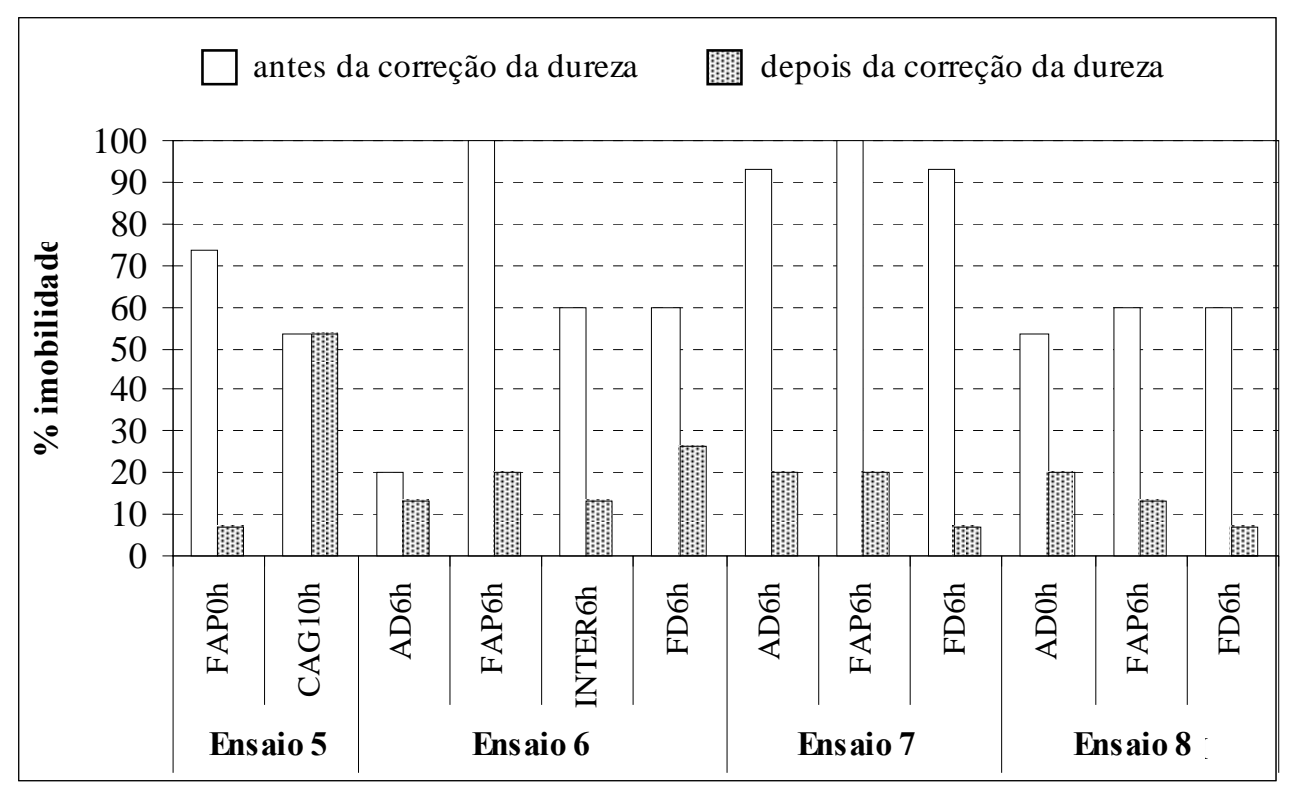

Figura 5.6.44 - \% imobilidade de Ceriodaphnia silvestrii para efluentes de processos de tratamento em diferentes tempos de amostragens dos Ensaios 5, 6, 7 e 8 - em IP, antes e após correção da dureza

A dureza da água pode promover efeitos adversos sobre os organismos submetidos a testes de toxicidade, quando seus valores diferirem daqueles da água de manutenção dos cultivos (CETESB, 1986). A água de cultivo dos dafinídeos apresenta dureza entre 40 e 48 $\mathrm{mg} \mathrm{CaCO}_{3} / \mathrm{L}$, enquanto a dureza das amostras de água dos ensaios foi de 3 a $14 \mathrm{mg}$ $\mathrm{CaCO}_{3} / \mathrm{L}$. Contudo, as duas faixas estão dentro da faixa de água mole ou branda, $\leq 50 \mathrm{mg} / \mathrm{L}$ $\mathrm{CaCO}_{3}$ (DI BERNARDO, 1993).

Desta forma, pôde-se constatar que a aplicação de testes de toxicidade aguda com dafinídeos, como ferramenta para avaliar a eficiência de processos de tratamento de água para remoção de células e toxinas de cianobactérias, requer a realização de estudos adicionais.

Em relação aos peixes, não foi observada mortalidade de Danio rerio, possivelmente devido ao curto período de exposição, de 10 a 12 horas, uma vez que a toxicidade aguda (letalidade) para peixes é avaliada em até 96 h de exposição. Assim, foram realizadas observações de respostas locomotoras dos peixes durante os ensaios 1 a 6 em IP (Tabela 5.6.17). Peixes não foram expostos nos ensaios 7 e 8. 


\begin{tabular}{|c|c|c|c|c|c|c|c|c|}
\hline Ensaio & $\begin{array}{c}\mathrm{n}^{\circ} \mathrm{de} \\
\text { peixes }\end{array}$ & $\begin{array}{l}\text { Tempo de } \\
\text { exposição }\end{array}$ & \multicolumn{6}{|c|}{ Efluentes } \\
\hline \multirow[t]{2}{*}{1} & 20 & $12 \mathrm{~h}$ & $\mathrm{AD}$ & $\mathrm{AE}$ & FAP & INTER & FD & CAG \\
\hline & & & $\mathrm{H}, \mathrm{a}, \mathrm{s}, \mathrm{f}$ & $\mathrm{H}, \mathrm{h}, \mathrm{a}, \mathrm{f}, \mathrm{s}$ & $\mathrm{H}, \mathrm{h}, \mathrm{a}, \mathrm{s}, \mathrm{f}$ & H, h, s & $\mathrm{H}, \mathrm{s}, \mathrm{r}$ & $\mathrm{s}, \mathrm{C}$ \\
\hline \multirow[t]{2}{*}{2} & 20 & $10 \mathrm{~h}$ & $\mathrm{AD}$ & $\mathrm{AE}$ & PRE & CAP & FAP & FD \\
\hline & & & $\mathrm{a}, \mathrm{s}, \mathrm{r}$ & $\mathrm{m}^{\mathrm{s}}$ & $\mathrm{s}$ & $\mathrm{a}, \mathrm{r}, \mathrm{s}, \mathrm{f}$ & $\mathrm{s}, \mathrm{f}$ & $s, f$ \\
\hline \multirow[t]{2}{*}{3} & 15 & $10 \mathrm{~h}$ & $\mathrm{AD}$ & $\mathrm{AE}$ & PRE & FAP & FD & \\
\hline & & & $\mathrm{a}, \mathrm{s}, \mathrm{f}, \mathrm{r}$ & $\mathrm{h}, \mathrm{a}, \mathrm{s}, \mathrm{f}, \mathrm{r}$ & $\mathrm{s}, \mathrm{f}, \mathrm{r}$ & $h, s, f, r$ & $\mathrm{~s}, \mathrm{f}$ & \\
\hline \multirow[t]{2}{*}{4} & 15 & $10 \mathrm{~h}$ & $\mathrm{AD}$ & $\mathrm{AE}$ & FAP & FD & POS & CAG \\
\hline & & & $\mathrm{a}, \mathrm{s}, \mathrm{f}, \mathrm{r}$ & $\mathrm{a}, \mathrm{s}, \mathrm{f}, \mathrm{r}$ & $\mathrm{s}, \mathrm{f}, \mathrm{r}$ & $\mathrm{a}, \mathrm{s}, \mathrm{f}, \mathrm{r}$ & $\mathrm{s}, \mathrm{f}, \mathrm{r}$ & $\mathrm{s}, \mathrm{f}, \mathrm{r}$ \\
\hline \multirow[t]{2}{*}{5} & 20 & $10 \mathrm{~h}$ & $\mathrm{AD}$ & $\mathrm{AE}$ & FAP & FD & POS & CAG \\
\hline & & & $\mathrm{s}, \mathrm{f}, \mathrm{r}$ & $\mathrm{S}$ & $\mathrm{s}, \mathrm{f}, \mathrm{r}$ & $\mathrm{s}$ & $\mathrm{s}, \mathrm{f}, \mathrm{r}$ & $\mathrm{s}, \mathrm{f}, \mathrm{r}$ \\
\hline \multirow[t]{2}{*}{6} & 20 & $10 \mathrm{~h}$ & $\mathrm{AD}$ & $\mathrm{AE}$ & FAP & INTER & FD & CAG \\
\hline & & & $\mathrm{a}, \mathrm{s}, \mathrm{f}, \mathrm{r}$ & $\mathrm{H}, \mathrm{a}, \mathrm{s}, \mathrm{r}$ & $\mathrm{a}, \mathrm{f}, \mathrm{r}$ & $\mathrm{a}, \mathrm{s}, \mathrm{f}, \mathrm{r}$ & $\mathrm{a}, \mathrm{s}, \mathrm{f}, \mathrm{r}$ & $\mathrm{s}, \mathrm{r}$ \\
\hline
\end{tabular}

\$ : em decorrência do oxidante (da pré-cloração) e não adição de tiosulfato de sódio para neutralizar o efeito do cloro.

Segundo normas padronizadas (ABNT, 2004b), ensaios com peixes devem ser conduzidos em temperatura de 23 a $27^{\circ} \mathrm{C}$. No entanto, muitas vezes, durante os ensaios, a temperatura ficou abaixo de $23^{\circ} \mathrm{C}$, uma vez que foram realizados durante a noite e a madrugada, no inverno. Tal fato pode ter influenciado nas respostas observadas dos peixes.

AMADO et. al. (2006) analisaram os efeitos da microcistina sobre DNA, enzimas antioxidantes e atividade locomotora de $D$. rerio. Os peixes foram distribuídos em quatro grupos: controle; expostos ao extrato liofilizado de Aphanotece sp, uma cianobactéria não toxigênica; e expostos ao extrato liofilizado da cianobactéria Microcystis aeruginosa (RST9501) em duas concentrações de microcistina. Após 24 h de teste, os animais foram submetidos ao teste em campo aberto que avalia a atividade locomotora. Os autores observaram que os animais do grupo exposto à maior concentração de microcistina (50 $\mu \mathrm{g} / \mathrm{L})$ tiveram sua atividade locomotora diminuída em relação aos animais dos grupos controle e exposto à cianobactéria não toxigênica.

Embora existam muitos estudos na área de toxicologia aquática comportamental, essa área está ainda nos estágios iniciais de desenvolvimento. Há carência de espécies-teste ou técnicas padronizadas e toda informação disponível sobre comportamento normal de organismos aquáticos é ainda insuficiente.

No presente trabalho, a ausência de informações comportamentais normais da espécie e a obtenção de respostas comportamentais dos peixes durante os ensaios em IP, por observações diretas, dificultaram sobremaneira a avaliação da aplicabilidade de biomonitoramento com peixes Danio rerio, e não foi possível obter associações e respostas diretas e conclusivas sobre sua aplicabiliadde. 


\section{CONCLUSÕES}

- O desenvolvimento de culturas de cepa toxigênica de Microcystis spp. sob condições controladas em micro, meso e macrocosmos, possibilitou o controle das características das AEs nos experimentos realizados nas fases 1 e 2, especialmente com relação à densidade de células de Microcystis spp. e concentração de microcistinas - MCs, favorecendo assim, a avaliação comparativa entre as eficiências obtidas nos variados processos de tratamento pesquisados;

Em relação à caracterização química e toxicológica de possíveis subprodutos de Microcystis spp.:

- As análises de microcistinas - MCs por HPLC-PDA permitiram concluir que embora os valores de índice de similaridade obtidos entre os espectros de UV a $238 \mathrm{~nm}$ dos picos da principal MC dos extratos e do padrão de MC-LR tenham resultados elevados, os tempos de retenção dos picos correspondentes às MCs dos extratos foram bem diferentes dos tempos de retenção obtidos pelo pico do padrão de MC -LR;

- A análise do extrato de microcistinas - MCs por MS-ESI no modo positivo revelou um espectro com $[\mathrm{M}+\mathrm{H}]^{+}$a $\mathrm{m} / \mathrm{z}$ 1037,8, indicando tratar-se de outro tipo de MC pois o espectro do padrão de MC-LR apresentou $[\mathrm{M}+\mathrm{H}]^{+}$a $\mathrm{m} / \mathrm{z}$ 995,7;

- Os valores das DL50 24h via intraperitonial (i.p) em camundongos encontrados nos testes de toxicidade aguda foram de $13,7 \mathrm{mg} / \mathrm{kg}$ p.c. de extrato seco e de $24,2 \mu \mathrm{g} / \mathrm{kg}$ p.c. de MCs totais estimada e revelaram a elevada toxicidade da cepa NPLJ-4 segundo classificação proposta por LAWTON et. al. (1994b);

- As concentrações calculadas de MCs no material seco utilizado para preparação de extratos com diferentes concentrações resultaram entre 1,64 e 1,86 $\mu \mathrm{g} / \mathrm{mg}$ p.s. ( $\mu \mathrm{g}$ de MCs totais / mg do material seco), o que condiz com a classificação proposta por LAWTON et. al. (1994b);

- O potencial de formação de trihalometanos - PFTHMs de 7 dias, para a água de estudo AE-A com $1,4 \times 10^{5} \mathrm{cel} / \mathrm{mL}$ de Microcystis spp. foi de $31 \mu \mathrm{g} / \mathrm{L}$, valor inferior ao limitado pela Portaria MS/518/2004, de 0,1 mg/L; 
- O potencial de formação de trihalometanos - PFTHMs de 3 e 7 dias, para a água de estudo AE-B com 5,5 × $10^{5}$ cel/mL de Microcystis spp. foi de 129 e $183 \mu \mathrm{g} / \mathrm{L}$, respectivamente, valores superiores ao limitado pela Portaria MS 518/2004, o que pode indicar uma ordem de grandeza da relação entre a densidade de Microcystis spp. e a formação máxima de THMs;

- A tendência de formação preferencial dos subprodutos organohalogenados - SPOs mais significativos foi mantida, seguindo proporções diretas e bem definidas em relação à densidade de Microcystis spp. (1,4 : 5,5). Esse fato comprova a hipótese de que os organismos fitoplanctônicos também se constituem em potenciais precursores de SPOs;

Em relação aos ensaios de filtração direta realizados em bancada:

- Nos ensaios de filtração direta em bancada, os resultados obtidos nos ensaios da série G, com emprego do coagulante tipo 7 (solução comercial de sulfato de alumínio com 7,2 \% de $\mathrm{Al}_{2} \mathrm{O}_{3}$ ), possibitaram a obtenção de boas correlações entre os valores de turbidez, número de partículas com tamanhos entre 1 e $10 \mu \mathrm{m}$ e densidade de Microcystis spp., mesmo para efluentes produzidos nos ensaios de bancada sob condições diversas de coagulação química;

- Com a representação dos resultados dos ensaios da série G em forma de diagramas de coagulação química para potencial zeta da água coagulada (mV), turbidez (uT), número de partículas (1 e $10 \mu \mathrm{m}) / \mathrm{mL}$, densidade de Microcystis spp. (cel/mL) e alumínio residual do efluente filtrado pôde-se distinguir 4 regiões de eficiência bem definidas, o que proporcionou maior segurança na seleção das condições de coagulação nos ensaios em instalação piloto;

Em relação aos ensaios de oxidação realizados em bancada:

- Nos ensaios de oxidação em bancada, embora os dados de remoção de células de Microcystis spp., de absorvância 254 nm e de carbono orgânico total no ensaio de oxidação da série A não sejam indicativos de elevada eficiência em relação a esses aspectos, os ensaios da série B revelaram que a ação oxidante, especialmente do cloro, pode ser relativamente efetiva na degradação de MCs;

- Para a situação 1 de oxidação: pré-oxidação seguida de adsorção com carvão ativado pulverizado - CAP, com produção de residuais próximos de zero ao final de 30 minutos 
de contato, as dosagens de cloro, dióxido de cloro e permanganato de potássio, passíveis de aplicação, foram de 1,0; 0,25 e 0,25 mg/L; e resultaram em eficiências de remoção de MCs da ordem de 84, 34 e $13 \%$, respectivamente.

- Para a situação 2 de oxidação: pré-oxidação seguida de filtração direta, com produção de residuais aceitáveis segundo legislações vigentes para o tempo de contato previsto de 60 min, as dosagens de cloro, dióxido de cloro e permanganato de potássio, foram de 2,5; 0,5 e 0,5 mg/L; correspondentes em eficiências de remoção de MCs de 97, 46 e 50 \%, respectivamente;

Em relação aos ensaios de adsorção realizados em bancada:

- Nos ensaios de adsorção em bancada, a determinação dos índices de iodo e de azul de metileno como estimativa dos volumes de micro e mesoporos, respectivamente, indicou ser uma ferramenta eficiente e de simples execução para controle da qualidade dos carvões ativados destinados ao uso em sistemas de tratamento de águas para consumo humano;

- Pôde-se constatar a predominância de microporos nos carvões ativados selecionados no estudo, fato confirmado pelos resultados de número de iodo relativamente elevado e índice de azul de metileno de medianos a baixo. Desta forma, relações estabelecidas em trabalhos citados entre a capacidade adsortiva dos carvões ativados para MC-LR e o volume de mesoporos e entre o índice de azul de metileno e o volume de mesoporos puderam ser verificadas;

- Comparando-se os resultados obtidos no experimento e os dados reportados na literatura citada, pôde-se verificar a baixa capacidade adsortiva dos carvões nacionais selecionados para remoção de microcistina não purificada, tendo resultado em valores de capacidade máxima de adsorção de MC da ordem de 3,0 $\mu \mathrm{g} / \mathrm{mg}$ para o carvão ativado granular CAG1 e da ordem de $10 \mu \mathrm{g} / \mathrm{mg}$ para o carvão ativado pulverizado CAP6;

Em relação aos ensaios em instalação piloto - IP:

- Nos ensaios em instalação piloto - IP, para as águas de estudo tipo 2 AEs-2 empregadas nos ensaios, com densidade de $M$. spp. entre 2 e $5 \times 10^{4} \mathrm{cel} / \mathrm{mL}$, as eficiências médias parciais obtidas referentes à remoção de células de $M$. spp. variaram entre 29 e 31 \% para a pré-oxidação e entre 46 e 100 \% para a filtração ascendente em pedregulho. Porém, vale ressaltar que todos os efluentes do FAP apresentaram remoção total superior a 99,5 
\%, com exceção do ensaio 4, devido à ocorrência de problemas operacionais no sistema de dosagem e controle do pH de coagulação;

- Os resultados obtidos de densidade de Microcystis spp. nos efluentes do filtro ascendete de pedregulho - FAP e do filtro descendente de areia - FD mostraram que a concepção de dupla filtração utilizada (composição e espessura do material granular e taxas de filtração) e operação adequada do sistema, mediante aplicação de condições selecionadas de coagulação química, foi bastante eficiente em relação à remoção de células de Microcystis spp. e, consequentemente, de microcistinas intracelulares;

- Os somatórios do número de partículas com tamanhos entre 1 e $10 \mu \mathrm{m}$ para as AEs resultaram entre 3 e $7 \times 10^{4}$ e as eficiências mímima e máxima referentes à remoção de partículas no FAP foram de 92,6 e 99,5 \% , respectivamente, podendo-se comprovar a aplicabilidade do uso deste parâmetro como estimativa da densidade de células de $M$. spp. (entre 2 e $5 \times 10^{4} \mathrm{cel} / \mathrm{mL}$ para as AEs e remoção média superior a 99,5 \% para o FAP), devido à boa correlação entre os dados, rapidez e simplicidade de medida;

- A filtração direta em FAP, seguida ou não de FD, não foi eficiente para a remoção de microcistinas - MCs extracelulares presentes na água em estudo, tendo resultado em eficiência máxima de $27 \%$ e produzido efluentes com residuais bem superiores ao limitado pela Portaria MS 518/2004. A aplicação da oxidação com cloro tanto na inter como na pré-oxidação, mantendo-se um residual relativamente baixo (valor máximo desejável da ordem de $0,1 \mathrm{mg} / \mathrm{L}$ ) devido à etapa posterior de tratamento por adsorção com carvões ativados granular - CAG e pulverizado - CAP, nos ensaios 1 e 2, respectivamente, produziram efluentes finais com qualidade aceitável sob esse aspecto;

- Embora a aplicação da pré-oxidação com dosagens mais elevadas (ensaio 3) mantendose um residual da ordem de $1 \mathrm{mg} / \mathrm{L}$ tenha mostrado ser relativamente eficiente na degradação de MCs extracelulares, esse processo deve ser empregado com precaução, devendo-se verificar preliminarmente, a formação de subprodutos organohalogenados para cada caso, uma vez que as condições do estudo em questão não foram favoráveis à formação desses compostos;

- O processo de tratamento por adsorção com carvão ativado granular - CAG, utilizado como pós-tratamento, mostrou ser bastante eficiente para assegurar a qualidade dos efluentes finais dos sistemas testados (ensaios 1, 4 e 5), especialmente, com relação à remoção de MCs extracelulares. Nos ensaios 4 e 5, os efluentes da filtração direta com 
concentrações de MCs entre 10 e $22 \mu \mathrm{g} / \mathrm{L}$, tiveram sua concentração reduzida, consistentemente, para valores inferiores a 1,0 $\mu \mathrm{g} / \mathrm{L}$ após adsorção em filtro de CAG;

- Pôde-se verificar que no sistema do ensaio 1 , caracterizado pela remoção prévia de matéria orgânica seguida de interoxidação, a formação de subprodutos organohalogenados - SPOs resultou inferior $(\mathrm{com}$ THMs $=12,8 \mu \mathrm{g} / \mathrm{L}$ e AHAs $=0,8$ $\mu \mathrm{g} / \mathrm{L}$ ) à formada nos sistemas em que foram empregados a pré-oxidação: ensaio 2 $($ AHAs $=19,2 \mu \mathrm{g} / \mathrm{L})$ e ensaio $3($ com THMs $=43,3 \mu \mathrm{g} / \mathrm{L}$ e AHAs $=45,1 \mu \mathrm{g} / \mathrm{L})$;

Em relação à aplicabilidade de testes de toxicidade com dafinídeos e Danio rerio:

- Com relação à aplicabilidade de testes de toxicidade aguda com dafinídeos na avaliação qualitativa do desempenho dos processos empregados, pôde-se observar que, em geral, as águas de estudo empregadas não apresentaram efeitos tóxicos aos dafinídeos;

- Os efluentes da filtração direta em bancada e a água filtrada na ETASC 2, utilizada para compor as águas de estudo - AEs, causaram toxicidade aguda aos dafinídeos, provavelmente, devido à concentração residual de alumínio ou impurezas resultantes do processo de coagulação química emprgada na ETASC - 2. Porém, ensaios de caráter proscpectivo utilizando filtros de laboratório com carvão ativado granular como póstratamento, mostraram ser eficientes para a remoção da toxicidade;

- Em geral, Ceriodaphnia silvestrii indicou ser mais sensível do que Ceriodaphnia dubia.

- Apesar da baixa concentração de microcistinas - MCs nas águas de estudo tipo 3 AE -3, preparada com amostras de floração natural de Barra Bonita, causou efeitos de toxicidade aguda aos dafinídeos, ao contrário de AE-1 e AE-2, preparadas com a linhagem toxigênica de Microcystis spp. NPLJ-4;

- Os resultados globais indicam que os efeitos deletérios aos dafinídeos parecem ter sido causados mais por outros compostos tóxicos dos processos de tratamento do que propriamente por Microcystis spp. e MCs;

- A ausência de informações comportamentais normais da espécie e a obtenção de respostas comportamentais dos peixes durante os ensaios em IP, por observações diretas, dificultaram sobremaneira a avaliação da aplicabilidade de biomonitoramento com peixes Danio rerio, e não foi possível obter associações e respostas diretas e conclusivas sobre sua aplicabiliadde. 


\section{RECOMENDAÇÕES}

- Os resultados obtidos no estudo de caracterização química e toxicológica revelaram sobretudo, a importância e necessidade da realização de testes de toxicidade com organismos como complemento às sofisticadas técnicas qualitativas e quantitativas, por possibilitar a aquisição de importantes informações sobre a potencialidade tóxica de uma amostra, especialmente nos casos em que os padrões dessas toxinas não são comercialmente disponíveis;

- A determinação do potencial de formação de subprodutos organohalogenados - PFSPO é uma ferramenta importante a ser utilizada no tratamento de água para consumo humano pois possibilita a previsão qualitativa e quantitativa dos possíveis subprodutos formados após oxidação, variando-se as condições de aplicação do processo, para águas contendo diferentes composições de matéria orgânica e principalmente, os riscos associados à sua presença em águas para consumo humano;

- Nos ensaios de filtração direta em bancada, a avaliação da qualidade dos efluentes por meio da determinação da densidade de Microcystis spp. e da distribuição de partículas, refletiu com maior precisão a perda de eficiência ocorrida para diversas condições, o que indica a necessidade e importância do emprego de parâmetros mais diretos em relação aos comumente utilizados, como turbidez e cor, para avaliação do desempenho das tecnologias de tratamento;

- Com a conclusão da caracterização dos carvões ativados, ressaltou-se a importância da realização de outras análises, além das regulamentadas pela legislação brasileira, devido à necessidade cada vez mais premente, de remoção de contaminantes específicos presentes em águas destinadas ao consumo humano;

- De acordo com os resultados da caracterização prévia realizada com baixos valores de IAM, os volumes de mesoporos foram reduzidos e como era esperado, constatou-se, a baixa capacidade adsortiva dos carvões selecionados para microcistinas - MCs não purificadas. Desta forma, ressalta-se a a necessidade de estudos relativos à otimização das condições de produção dos carvões ativados produzidos no Brasil.

- Visto que a filtração direta em FAP, seguida ou não de FD, não foi eficiente para a remoção de microcistinas - MCs extracelulares presentes na água em estudo, tendo produzido efluentes com residuais bem superiores ao limitado pela Portaria MS 
518/2004, é de fundamental importância a realização de investigações de outros processos alternativos a serem adicionados aos sistemas de tratamento já existentes.

- Os efeitos deletérios aos dafinídeos causados por outros compostos tóxicos dos processos de tratamento ou por efeito combinado de diferentes compostos indicam a necessidade da realização de estudos adicionais em relação a sua aplicabilidade. 


\section{ANEXO A: LIMPEZA DE VIDRARIAS}

\section{* Procedimento utilizado para limpeza de vidrarias}

1 Descartar os resíduos de cultura em recipientes destinados ao armazenamento e posterior tratamento com água sanitária ou oxidante similar;

2 Colocar a vidraria por 6h em água sanitária 5 \%;

3 Enxaguar a vidraria em água corrente e colocá-la por 6 h em extram ou solução de $\mathrm{NaOH} 5 \%$;

4 Enxaguar a vidraria em água corrente e colocá-la por 6 h em solução de HCl 5 \%;

5 Enxaguar a vidraria em água corrente por 7 vezes e em seguida em água destilada por 3 vezes, secar e tapar com filme de PVC ou papel alumínio.

\section{ANEXO B: PREPARAÇÃO DO MEIO ASM-1}

\section{* Procedimento utilizado para preparação do meio ASM-1}

1 preparar as soluções $A, B, C$ e $D$, conforme plannilha apresentada a seguir;

2 compor a solução ASM-1 seguindo a proporção:

1L de ASM-1: $20 \mathrm{~mL}$ de $\mathrm{A}+2 \mathrm{~mL}$ de $\mathrm{B}+0,1 \mathrm{~mL}$ de $\mathrm{C}+0,4 \mathrm{~mL}$ de $\mathrm{D}$

3 ajustar o pH para 8 a 8,05 com soluções de $\mathrm{NaOH} 4 \mathrm{M}$ (ajuste grosso) e 0,3 M (ajuste fino) e $\mathrm{HCl} 1 \mathrm{~N}$;

4 distribuir o meio em tubos de ensaio e erlenmeyers com volumes correspondentes a $90 \%$ do volume total da cultura e fechar com tampões de gaze e algodão;

5 cobrir o tampão com papel alumínio e prender com fita crepe;

6 autoclavar (1 atm e $120^{\circ} \mathrm{C}$ ) por 15 a $20 \mathrm{~min}$;

7 esperar esfriar e utilizá-lo no mínimo 6 h depois. 
Apresenta-se a seguir a planilha contendo a composição das soluções para preparação do meio ASM-1 e a previsão da quantidade de nutrientes requerida para a produção de 1,0; 100; 1000 e $2000 \mathrm{~L}$.

Planilha - Quantidade de produtos químicos para meio ASM-1

1L de ASM-1: $20 \mathrm{~mL}$ de A + $2 \mathrm{~mL}$ de $B+0,1 \mathrm{~mL}$ de $\mathrm{C}+0,4 \mathrm{~mL}$ de $D$

\begin{tabular}{|c|c|c|c|c|c|c|}
\hline \multirow[b]{2}{*}{ Solução estoque } & \multirow[b]{2}{*}{ Produto químico } & \multicolumn{5}{|c|}{ Peso (g) } \\
\hline & & Peso (g) & $\begin{array}{c}\mathbf{P} / 1 \mathbf{L} \\
(\mathrm{g})\end{array}$ & $\begin{array}{c}\mathrm{P} / 100 \mathrm{~L} \\
(\mathrm{~g})\end{array}$ & $\begin{array}{c}\text { P/ 1000L } \\
(\mathrm{g})\end{array}$ & $\begin{array}{l}\text { P/ 2000L } \\
\text { (g) }\end{array}$ \\
\hline \multirow{2}{*}{$\begin{array}{c}\text { A } \\
\text { vol completo } \\
(\mathrm{mL})\end{array}$} & $\mathrm{NaNO}_{3}$ & 1,7 & 0,17 & 17 & 170 & 340 \\
\hline & $\mathrm{MgCl}_{2} \cdot 6 \mathrm{H}_{2} \mathrm{O}$ & 0,41 & 0,041 & 4,1 & 41 & 82 \\
\hline 200 & $\mathrm{MgSO}_{4} \cdot 7 \mathrm{H}_{2} \mathrm{O}$ & 0,49 & 0,049 & 4,9 & 49 & 98 \\
\hline $10 \%$ & $\mathrm{CaCl} .2 \mathrm{H}_{2} \mathrm{O}$ & 0,29 & 0,029 & 2,9 & 29 & 58 \\
\hline \multirow{2}{*}{$\begin{array}{c}\text { B } \\
\text { vol completo } \\
(\mathrm{mL})\end{array}$} & $\mathrm{K}_{2} \mathrm{HPO}_{4}$ ou & 0,87 & 0,0174 & 1,74 & 17,4 & 34,8 \\
\hline & $\begin{array}{c}\mathrm{K}_{2} \mathrm{HPO} 4.3 \mathrm{H}_{2} \mathrm{O} \\
\mathrm{Na}_{2} \mathrm{HPO} 4.12 \mathrm{H}_{2} \mathrm{O}\end{array}$ & 1,14 & 0,0228 & 2,28 & 22,8 & 45,6 \\
\hline 100 & ou & 1,78 & 0,0356 & 3,56 & 35,6 & 71,2 \\
\hline $2 \%$ & $\mathrm{Na}_{2} \mathrm{HPO} 4.7 \mathrm{H}_{2} \mathrm{O}$ & 1,33 & 0,0266 & 2,66 & 26,6 & 53,2 \\
\hline \multirow{7}{*}{$\begin{array}{c}\mathbf{C} \\
\text { vol completo } \\
(\mathbf{m L}) \\
100 \\
0,10 \%\end{array}$} & $\mathrm{H}_{3} \mathrm{BO}_{3}$ & 2,48 & 0,00248 & 0,248 & 2,48 & 4,96 \\
\hline & $\mathrm{MnCl}_{2} \cdot 4 \mathrm{H}_{2} \mathrm{O}$ & 1,39 & 0,00139 & 0,139 & 1,39 & 2,78 \\
\hline & $\mathrm{FeCl}_{3} \cdot 6 \mathrm{H}_{2} \mathrm{O}$ & 1,08 & 0,00108 & 0,108 & 1,08 & 2,16 \\
\hline & $\mathrm{ZnCl}_{2}$ & 0,335 & 0,000335 & 0,0335 & 0,335 & 0,67 \\
\hline & $\mathrm{CoCl}_{2} \cdot 6 \mathrm{H}_{2} \mathrm{O}$ & 0,019 & 0,000019 & 0,0019 & 0,019 & 0,038 \\
\hline & $\mathrm{CuCl}$ ou & 0,0014 & 0,0000014 & 0,00014 & 0,0014 & 0,0028 \\
\hline & $\mathrm{CuCl} \cdot 2 \mathrm{H}_{2} \mathrm{O}$ & 0,0013 & 0,0000013 & 0,00013 & 0,0013 & 0,0026 \\
\hline $\begin{array}{c}\mathrm{D} \\
\text { vol completo } \\
(\mathrm{mL}) \\
100\end{array}$ & EDTA.Na ${ }_{2}$ & 1,86 & 0,00744 & 0,744 & 7,44 & 14,88 \\
\hline
\end{tabular}

\section{ANEXO C: ANÁLISE DE CLOROFILA-A}

- Procedimento para determinação da concentração de clorofila-a e feofitina-a com extração em solução de acetona $90 \%$ a frio

1 filtrar, em ambiente com baixa incidência de luz, o volume preestabelecido de amostra em filtro de fibra de vidro com tamanho dos poros $\leq 0,7 \mu \mathrm{m}$, no caso 0,45 $\mu \mathrm{m}$, diâmetro de 47 mm, sob pressão máxima de vácuo da ordem de 20 kPa;

Obs: a determinação deve ser feita pelo menos em réplica;

2 retirar o excesso de umidade do filtro, colocando-o por período suficiente (cerca de 6 h) sobre papel absorvente em ambiente com baixa incidência de luz; 

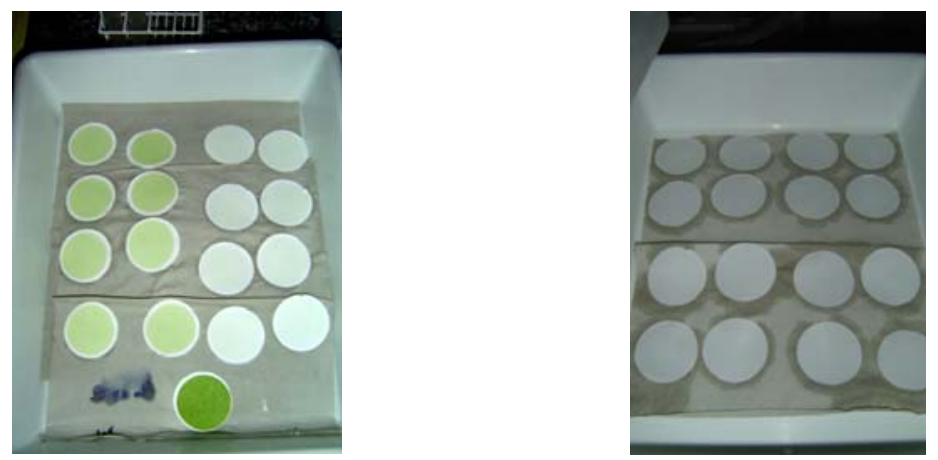

Preparação dos filtros para extração

3 cortar e macerar o filtro em cadinho de porcelana, colocando-se inicialmente, cerca de $3 \mathrm{~mL}$ e não mais do que $6 \mathrm{~mL}$ de solução de acetona $90 \%$ até dissolução total do filtro;

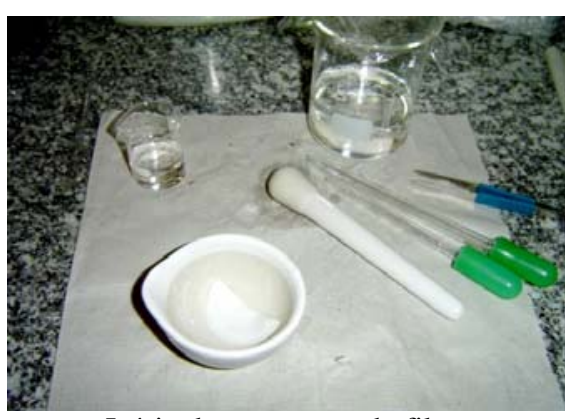

Início da maceração do filtro

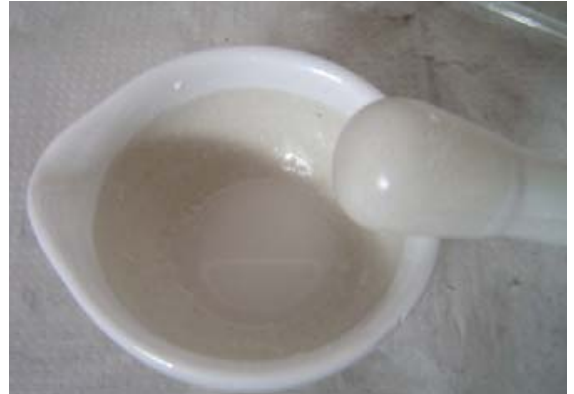

Final da maceração do filtro

4 transferir a suspensão para o tubo de centrífuga e completar com o solvente até o volume final fixado no caso igual a 12,0 mL;
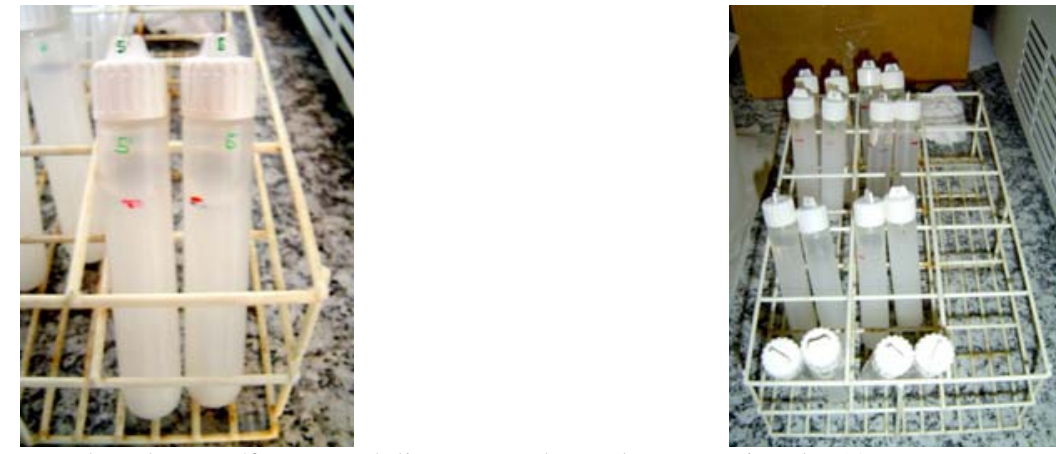

Tubos de centrífuga em réplica com volume do extrato igual a $12 \mathrm{~mL}$

5 guardar na geladeira a $4^{\circ} \mathrm{C}$ em caixa fechada para proteção contra incidência de luz, por tempo de extração preestabelecido;

6 centrifugar durante 15 minutos com rotação preestabelecida e em seguida, transferir o sobrenadante em frasco inerte fechado e escuro; 


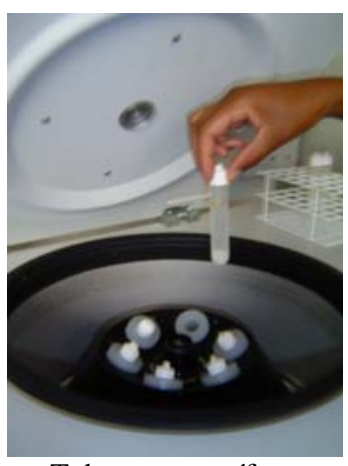

Tubos na centrífuga

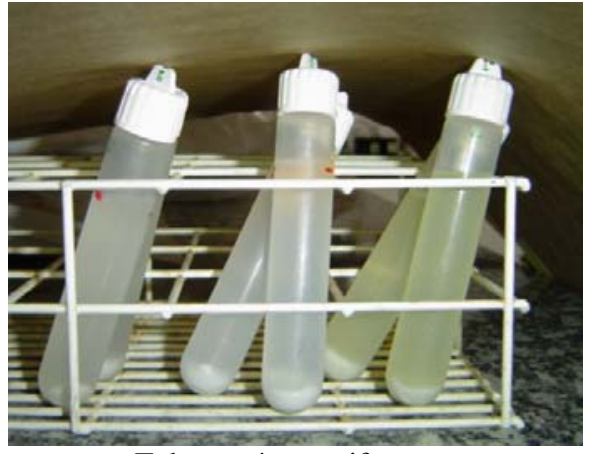

Tubos após centrifugação

7 fazer a leitura de absorbância na cubeta de quartzo, com comprimento ótico de 10 mm, em espectrofotômetro previamente zerado com o solução de acetona $90 \%$, regulado para passo ótico de $1 \mathrm{~nm}$, nos comprimentos de onda de 665 e $750 \mathrm{~nm}$;

Obs: se o valor de absorbância no comprimento de onda de $750 \mathrm{~nm}$ resultar> 0,005 unidades de absorção - UA, a amostra deve ser centrifugada ou filtrada para reduzir a interferência da turbidez na leitura

8 para determinação da concentração de feofitina-a, deve-se em seguida, acidificar a amostra com solução de $\mathrm{HCl}$ 0,1 $N$ de forma que o $\mathrm{pH}$ resulte entre 2,3 a 2,8 (aproximadamente $30 \mu \mathrm{L}$ ), esperar cerca de 30 segundos para completar a reação e fazer a nova leitura de absobância nos comprimentos de onda de 665 e 750 nm em até 3 minutos.

\section{* Procedimento para determinação da concentração de clorofila-a e feofitina-a com extração em solução de etanol $80 \%$ a quente}

1 filtrar, em ambiente com baixa incidência de luz, o volume preestabelecido de amostra em filtro de fibra de vidro com tamanho dos poros $\leq 0,7 \mu \mathrm{m}$, no caso $0,45 \mu \mathrm{m}$, diâmetro de $47 \mathrm{~mm}$, sob pressão máxima de vácuo da ordem de 20 kPa;

Obs: a determinação deve ser feita pelo menos em réplica;

2 retirar o excesso de umidade do filtro, colocando-o por período suficiente (cerca de $6 \mathrm{~h}$ ) sobre papel absorvente em ambiente com baixa incidência de luz;

3 colocar os filtros, (dobrados ao meio) nos tubos de centrifuga, completar com o solvente até o volume final fixado no caso igual a 10,0 $\mathrm{mL}$ e envolver em papel alumínio para proteção contra incidência de luz; 


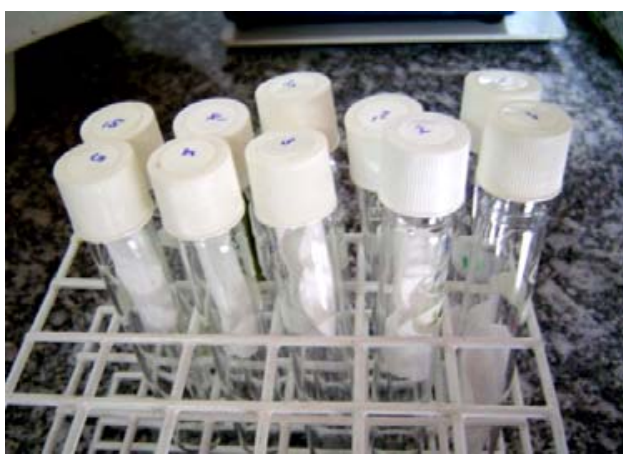

Filtros dobrados ao meio nos tubos de centrifuga

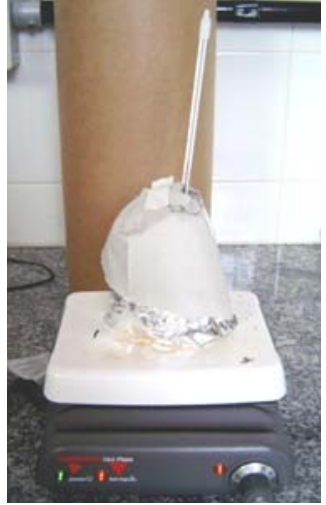

Aquecimento das amostras devidamente envoltas em papel alumínio

4 levar os tubos de centrifuga tapados, ao banho-maria à temperatura de $75^{\circ} \mathrm{C}$ durante 5 minutos;

5 resfriar em água corrente ou para uma melhor extração, realizar choque térmico com gelo e guardar na geladeira a $4^{\circ} \mathrm{C}$ em caixa fechada para proteção contra incidência de luz, por tempo de extraçãopreestabelecido, no caso, 16 h;

6 fazer a leitura de absorbância na cubeta de quartzo, com comprimento ótico de 10 mm, em espectrofotômetro previamente zerado com o solução de etanol 80 \%, regulado para passo ótico de $1 \mathrm{~nm}$, nos comprimentos de onda de 665 e $750 \mathrm{~nm}$;

Obs: se o valor de absorbância no comprimento de onda de $750 \mathrm{~nm}$ resultar $>0,005$ unidades de absorção - UA, a amostra deve ser centrifugada ou filtrada para reduzir a interferência da turbidez na leitura

7 para determinação da concentração de feofitina-a, deve-se em seguida, acidificar a amostra com solução de $\mathrm{HCl}$ 0,1 $\mathrm{N}$ de forma que o $\mathrm{pH}$ resulte entre 2,3 a 2,8 (aproximadamente $30 \mu \mathrm{L}$ ), esperar cerca de 30 segundos para completar a reação $e$ fazer a nova leitura de absobância nos comprimentos de onda de 665 e 750 nm em até 3 minutos. 


\section{ANEXO D: ANÁLISE DE ALUMÍNIO RESIDUAL}

* Procedimento para determinação da concentração de alumínio do padrão ou da amostra

1 colocar $25 \mathrm{~mL}$ de amostra em um balão volumétrico de $50 \mathrm{~mL}$;

2 adicionar $1 \mathrm{~mL}$ de $\mathrm{H}_{2} \mathrm{SO}_{4}-0,02 \mathrm{~N}$ e agitar;

3 adicionar $1 \mathrm{~mL}$ de ácido ascórbico e agitar;

4 adicionar $10 \mathrm{~mL}$ de tampão e agitar;

5 adicionar $5 \mathrm{~mL}$ de solução indicadora de Eriocromo Cyanine e agitar;

6 completar o volume em $50 \mathrm{~mL}$ de água destilada;

7 esperar 5 a 10 minutos;

8 fazer a leitura de absorbância na cubeta de quartzo, com comprimento ótico de 10 $\mathrm{mm}$, em espectrofotômetro previamente zerado com o branco e confirmado com um padrão preparado, regulado para passo ótico de $1 \mathrm{~nm}$, no comprimento de onda de 535 $n m$;

Obs1: A leitura deve ser feita no máximo em 15 minutos;

Obs2: O resultado é expresso em $\mathrm{mg} / \mathrm{L}$ de $\mathrm{Al}$;

Obs3: para construção da curva padrão, seguir a metodologia acima, substituindo no passo $n^{\circ} 1$ a amostra pelo padrão.
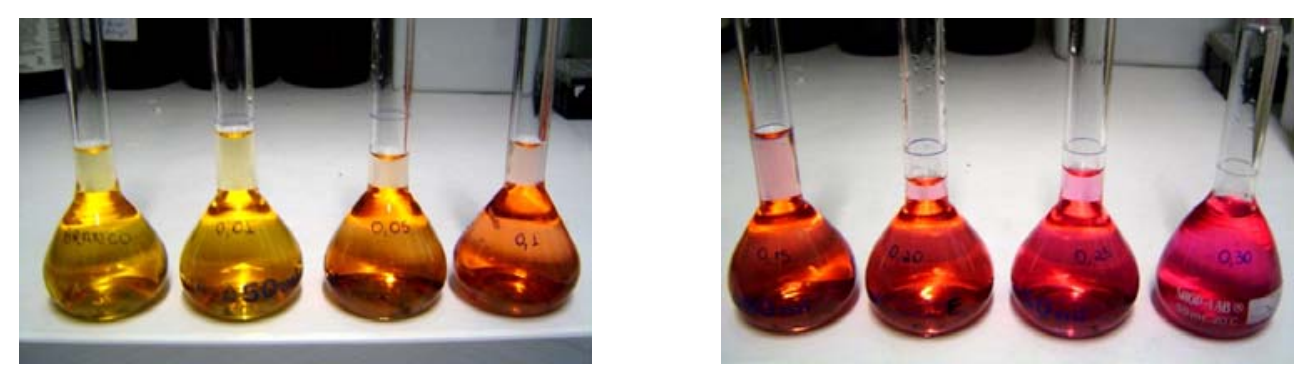

Soluções padrões preparados com concentrações de 0,01; 0,05; 0,10; 0,15; 0,20; 0,25 e 0,30 mg/L para construção da curva de $\mathrm{Al}$ 


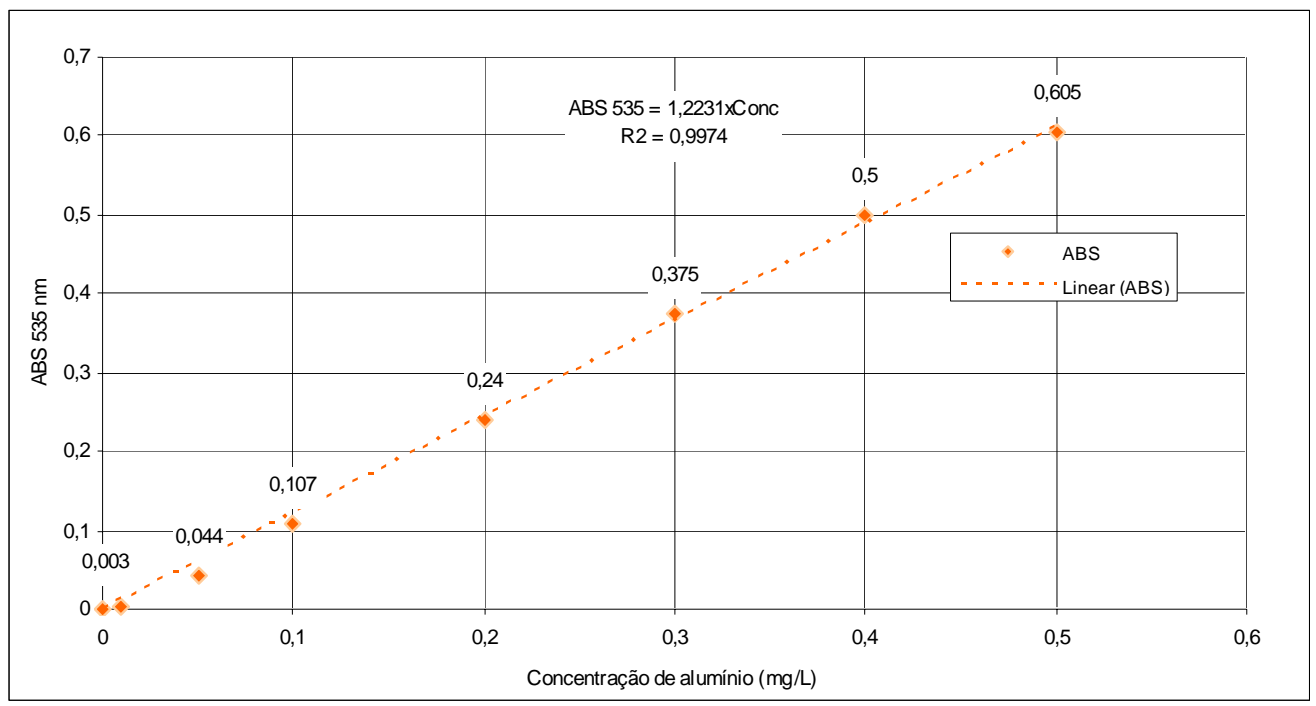

Curva de Alumínio resultante

* Procedimento para preparação do padrão para confirmação das condições de análise de alumínio

1 colocar $2 \mathrm{~mL}$ da solução padrão de alumínio em um balão de $50 \mathrm{~mL}$;

2 efetuar o procedimento normal para determinação da concentração de alumínio. $O$ resultado da leitura deste padrão deve ser $0,20 \mathrm{mg} / \mathrm{L}$ de Al.

* Procedimento para lavagem dos balóes volumétricos utilizados na análise de alumínio

1 lavar com solução de ácido clorídrico $\mathrm{HCl}$ 1:1;

2 enxaguar 7 vezes com água corrente e 3 vezes com água destilada ou deionizada.

12 ANEXO E: RESULTADOS COMPLEMENTARES (PARÂMETROS DE

CONTROLE OPERACIONAL E DE DESEMPENHO E TESTES

ECOTÓXICOLÓGICOS COM MICROCRUSTÁCEOS) DOS ENSAIOS EM

INSTALAÇÃO PILOTO - FASES 2 E 3 
Tabela 5.6.1 - Parâmetros de controle - operação do ENSAIO 1-IP (em instalação piloto): temperatura, pH, potencial zeta e residual de cloro livre das águas de diluição e de estudo e efluentes

\begin{tabular}{|c|c|c|c|c|c|c|c|c|c|c|c|c|c|c|c|}
\hline & $\mathrm{t}\left({ }^{\circ} \mathrm{C}\right)$ & $\mathrm{pH}$ & $\mathrm{Pz}(\mathrm{mV})$ & $\mathrm{pH}$ & $\mathrm{Pz}(\mathrm{mV})$ & $\mathrm{pH}$ & $\mathrm{Pz}(\mathrm{mV})$ & $\mathrm{pH}$ & $\mathrm{Pz}(\mathrm{mV})$ & $\mathrm{pH}$ & $\begin{array}{l}\begin{array}{c}\text { Cl res. } \\
(\mathrm{mg} / \mathrm{L})\end{array} \\
\end{array}$ & $\mathrm{pH}$ & $\mathrm{Pz}(\mathrm{mV})$ & $\mathrm{pH}$ & $\mathrm{Pz}(\mathrm{mV})$ \\
\hline Hora (h) & \multicolumn{3}{|c|}{$\mathrm{AD}$} & \multicolumn{2}{|c|}{$\mathrm{AE}$} & \multicolumn{2}{|c|}{ AC } & \multicolumn{2}{|c|}{ FAP } & \multicolumn{2}{|c|}{ INTER } & \multicolumn{2}{|c|}{ FD } & \multicolumn{2}{|c|}{ FCAG } \\
\hline 1 & 22,00 & 6,62 & $-1,20$ & 6,85 & $-34,80$ & 6,40 & $-6,40$ & 6,39 & - & 6,31 & 0,10 & 6,26 & - & & - \\
\hline 3 & 20,50 & 6,46 & - & 6,58 & $-32,50$ & 6,42 & $-3,90$ & - & - & 6,47 & 0,24 & 6,47 & - & 9,31 & - \\
\hline 6 (ant.) & 22,00 & 6,82 & - & 6,93 & - & 6,29 & 1,50 & 6,34 & - & 6,39 & 0,20 & 6,34 & - & 8,96 & - \\
\hline 7 (dep.) & 23,00 & 6,43 & $-1,50$ & & - & 6,42 & 1,70 & - & - & 6,42 & 0,78 & 6,43 & - & 9,03 & - \\
\hline 9 & 24,00 & 6,26 & - & 7,29 & - & 6,34 & 3,10 & 6,16 & - & 6,20 & 0,46 & 6,31 & - & 8,76 & - \\
\hline 12 & 24,50 & 6,29 & - & 6,47 & $-35,10$ & 6,56 & $-3,20$ & 6,23 & - & 6,21 & 0,32 & 6,45 & - & 8,78 & - \\
\hline MÍNIMO & 20,5 & 6,3 & $-1,5$ & 6,5 & $-35,1$ & 6,3 & $-6,4$ & 6,2 & - & 6,2 & 0,1 & 6,3 & - & 8,8 & - \\
\hline MÁXIMO & 24,5 & 6,8 & $-1,2$ & 7,3 & $-32,5$ & 6,6 & 3,1 & 6,4 & - & 6,5 & 0,8 & 6,5 & - & 9,3 & - \\
\hline
\end{tabular}

Tabela 5.6.2 - Parâmetros de controle - desempenho do ENSAIO 1-IP (em instalação piloto): carbono orgânico total, absorvância 254, oxigênio dissolvido, condutividade elétrica, dureza e turbidez das águas de diluição e de estudo e dos efluentes de cada processo de tratamento para diferentes tempos de amostragem

\begin{tabular}{|c|c|c|c|c|c|c|c|c|c|c|c|c|c|c|c|c|c|c|}
\hline \multirow[b]{2}{*}{ Hora (h) } & \multicolumn{6}{|c|}{ Carbono orgânico total - COT (mg/L) } & \multicolumn{6}{|c|}{ absorvância 254} & \multicolumn{6}{|c|}{ Oxigênio dissolvido - OD (mg/L) } \\
\hline & $\mathrm{AD}$ & $\mathrm{AE}$ & FAP & INTER & FD & FCAG & $\mathrm{AD}$ & $\mathrm{AE}$ & FAP & INTER & FD & FCAG & $\mathrm{AD}$ & $\mathrm{AE}$ & FAP & INTER & FD & FCAG \\
\hline 1 & - & 2,419 & 1,165 & 1,356 & 1,106 & 1,231 & - & 0,030 & 0,017 & 0,023 & 0,02 & 0,011 & $7,3(8,0)$ & $7,3(7,8)$ & $7,8(8,2)$ & $7,6(8,3)$ & $7,6(8,4)$ & $6,7(6,7)$ \\
\hline 3 & - & 1,651 & 1,085 & 1,993 & 1,357 & 0,968 & - & 0,032 & 0,017 & 0,046 & 0,02 & 0,007 & 7,5 & 7,7 & 7,7 & 7,8 & 7,7 & 7,2 \\
\hline 6 (ant.) & - & 1,541 & 1,046 & 1,083 & 1,097 & 0,436 & - & 0,032 & 0,018 & 0,021 & 0,019 & 0,007 & $7,3(7,8)$ & $7,4(7,7)$ & $7,5(8,0)$ & $7,7(8,0)$ & $7,3(8,3)$ & $7,4(7,5)$ \\
\hline 7 (dep.) & - & 1,311 & 1,012 & 1,002 & 0,985 & 0,402 & - & 0,027 & 0,016 & 0,02 & 0,021 & 0,006 & 7,4 & 7,0 & 7,7 & 7,4 & 7,3 & 6,7 \\
\hline 9 & - & 1,627 & 2,386 & 1,187 & 1,164 & 0,543 & - & 0,026 & 0,015 & 0,02 & 0,02 & 0,006 & 7,4 & 7,3 & 7,2 & 7,2 & 7,4 & 6,6 \\
\hline 12 & - & 1,391 & 1,691 & 1,052 & 0,973 & 0,381 & - & 0,028 & 0,015 & 0,02 & 0,019 & 0,006 & $7,0(7,7)$ & $7,0(7,7)$ & $7,0(7,5)$ & $7,3(7,8)$ & $7,1(7,5)$ & $6,6(6,9)$ \\
\hline MÍNIMO & - & 1,311 & 1,012 & 1,002 & 0,973 & 0,381 & - & 0,026 & 0,015 & 0,02 & 0,019 & 0,006 & 7,4 & 7,0 & 7,2 & 7,2 & 7,3 & 6,6 \\
\hline \multirow[t]{2}{*}{ MÁXIMO } & - & 2,419 & 2,386 & 1,993 & 1,357 & 1,231 & - & 0,032 & 0,018 & 0,046 & 0,021 & 0,011 & 7,5 & 7,7 & 7,7 & 7,8 & 7,7 & 7,2 \\
\hline & \multicolumn{6}{|c|}{ Condutividade elétrica $(\mu \mathrm{S} / \mathrm{cm})$} & \multicolumn{6}{|c|}{ Dureza $\left(\mathrm{mgCaCO}_{3} / \mathrm{L}\right)$} & \multicolumn{6}{|c|}{ Turbidez $^{(*)}$ (uT) } \\
\hline Hora (h) & $\mathrm{AD}$ & $\mathrm{AE}$ & FAP & INTER & FD & FCAG & $\mathrm{AD}$ & $\overline{\mathrm{AE}}$ & FAP & INTER & FD & FCAG & $\mathrm{AD}$ & $\mathrm{AE}$ & FAP & INTER & FD & FCAG \\
\hline 1 & 20,5 & 25,1 & 29,6 & 28,5 & 24,4 & 23,4 & 7 & 9 & 9 & 8 & 8 & 9 & - & 3,74 & 0,23 & 0,36 & 0,19 & 0,34 \\
\hline 3 & 20,3 & 24,7 & 29,8 & 30,4 & 30,7 & 32,4 & - & - & - & - & - & - & - & 4,21 & 0,20 & 1,80 & 0,18 & 0,21 \\
\hline 6 (ant.) & 20,2 & 25,6 & 30,5 & 31,3 & 30,6 & 32,7 & 6 & 7 & 7 & 8 & 9 & 10 & - & 3,11 & 0,23 & 0,28 & 0,30 & 0,25 \\
\hline 7 (dep.) & 20 & 24,7 & 29,4 & 32,1 & 30,4 & 33,7 & 6 & 8 & 8 & 10 & 8 & 9 & - & 2,54 & 0,20 & 0,25 & 0,24 & 0,31 \\
\hline 9 & 19,8 & 24,8 & 30,2 & 31,5 & 31,6 & 34,1 & - & - & - & - & - & - & - & 2,41 & 0,19 & 0,25 & 0,24 & 0,28 \\
\hline 12 & 19,7 & 25,2 & 29,7 & 32,2 & 32,2 & 31,9 & 6 & 8 & 8 & 8 & 8 & 9 & - & 2,49 & 0,19 & 0,29 & 0,22 & 0,19 \\
\hline MÍNIMO & 19,7 & 24,7 & 29,4 & 28,5 & 24,4 & 23,4 & 6 & 7 & 7 & 8 & 8 & 9 & - & 2,41 & 0,19 & 0,25 & 0,18 & 0,19 \\
\hline MÁXIMO & 20,5 & 25,6 & 30,5 & 32,2 & 32,2 & 34,1 & 7 & 9 & 9 & 10 & 9 & 10 & - & 4,21 & 0,23 & 1,80 & 0,30 & 0,34 \\
\hline
\end{tabular}

AD: águ de diluição; AE: água de estudo; Efluentes: FAP: filtro ascendente de pedregulho, INTER: intercloração, FD: filtração descendente, FCAG: filtro com carvão ativado granular; $\left.*^{*}\right)$ : leitura em turbidímetro de bancada 2100P HACH; OD: método de Winkler (sonda Horiba U-10); ant.: antes da DFI; dep.: depois da DFI. 
Tabela 5.6.3 - Resultados dos testes ecotoxicológicos com microcrustáceos (Ceriodaphnia dúbia - CD e Ceriodaphnia silvestri - CS) - ENSAIO 1-IP (em instalação piloto): total indivíduos imóveis / total indivíduos expostos, imobilidade, $\mathrm{pH}$, condutividade e dureza das águas de diluição e de estudo e efluentes ENSAIO1-IP: Sistema MR $\rightarrow$ FAP $\rightarrow$ INTER $\rightarrow$ FD $\rightarrow$ FCAG

\begin{tabular}{|c|c|c|c|c|c|c|c|c|c|c|c|c|c|c|c|c|c|c|c|}
\hline \multicolumn{2}{|c|}{$\begin{array}{l}\text { Início: 08abr06 } \\
\text { Fim: 10/abr/06 } \\
\end{array}$} & \multicolumn{6}{|c|}{$\begin{array}{c}\text { Réplicas } \\
\text { (ind. Imóveis / total ind. expostos) } \\
\end{array}$} & \multirow{2}{*}{\multicolumn{2}{|c|}{$\begin{array}{l}\text { Total ind. imóveis / } \\
\text { total ind. expostos }\end{array}$}} & \multirow{2}{*}{\multicolumn{2}{|c|}{ \% imobilidade }} & \multirow{2}{*}{\multicolumn{3}{|c|}{$\mathrm{pH}$}} & \multirow{2}{*}{\multicolumn{3}{|c|}{$\begin{array}{l}\text { Condutividade } \\
(\mu \mathrm{S} / \mathrm{cm})\end{array}$}} & \multirow{2}{*}{\multicolumn{2}{|c|}{$\begin{array}{c}\text { Dureza } \\
(\mathrm{mg} \mathrm{CaCO3} / \mathrm{L})\end{array}$}} \\
\hline \multirow{2}{*}{$\begin{array}{c}\text { Hora } \\
(\mathrm{h})\end{array}$} & \multirow{2}{*}{ Amostra } & \multicolumn{3}{|c|}{ C. dúbia CD } & \multicolumn{3}{|c|}{ C. silvestrii CS } & & & & & & & & & & & & \\
\hline & & 1 & 2 & 3 & 1 & 2 & 3 & CD & CS & $\mathrm{CD}$ & CS & início & fim & - & início & $\mathrm{CD}$ & $\mathrm{CS}$ & início & fim \\
\hline \multirow{7}{*}{1} & ontrole & C & $0 / 5$ & $0 / 5$ & $0 / 5$ & $0 / 5$ & $1 / 5$ & $0 / 15$ & $1 / 15$ & 0 & 6,67 & 7,10 & 7,10 & - & - & - & - & & 40 \\
\hline & $\mathrm{AD}$ & $4 / 5$ & $3 / 5$ & $3 / 5$ & $5 / 5$ & $5 / 5$ & $4 / 5$ & $10 / 15$ & $14 / 15$ & 66,67 & 93,33 & - & 6,50 & - & - & - & - & 7 & - \\
\hline & $\mathrm{AE}$ & $0 / 5$ & $0 / 5$ & $0 / 5$ & $0 / 5$ & $0 / 5$ & $1 / 5$ & $0 / 15$ & $1 / 15$ & 0 & 6,67 & - & 6,65 & - & - & - & - & 9 & 8 \\
\hline & FAP & $5 / 5$ & $5 / 5$ & $5 / 5$ & $4 / 5$ & $4 / 5$ & $4 / 5$ & $15 / 15$ & $12 / 15$ & 100 & 80 & - & 3,71 & - & - & - & - & 9 & 8 \\
\hline & INTER & $1 / 5$ & $0 / 5$ & $2 / 5$ & $3 / 5$ & $5 / 5$ & $4 / 5$ & $3 / 15$ & $12 / 15$ & 20 & 80 & - & 6,32 & - & - & - & - & 8 & 10 \\
\hline & FD & $7 / 10$ & $5 / 5$ & $5 / 5$ & $5 / 5$ & $5 / 5$ & $5 / 5$ & $17 / 20$ & $15 / 15$ & 85 & 100 & - & 6,33 & - & - & - & - & 8 & 10 \\
\hline & CAG & $0 / 5$ & $0 / 5$ & $0 / 5$ & $0 / 5$ & $0 / 5$ & $0 / 5$ & $0 / 15$ & $0 / 15$ & 0 & 0 & - & 7,15 & - & - & - & - & 9 & 10 \\
\hline \multirow{6}{*}{$\begin{array}{c}6 \\
\text { (ant.) }\end{array}$} & $\mathrm{AD}$ & $4 / 5$ & - & $4 / 5$ & $3 / 5$ & $4 / 5$ & $5 / 5$ & $8 / 10$ & $12 / 15$ & 80 & 80 & - & 6,45 & - & - & - & - & 6 & - \\
\hline & $\mathrm{AE}$ & $0 / 5$ & $0 / 5$ & $0 / 5$ & $0 / 5$ & $0 / 5$ & $1 / 5$ & $0 / 15$ & $1 / 15$ & 0 & 6,67 & - & 6,70 & - & - & - & - & 7 & - \\
\hline & FAP & $5 / 5$ & $5 / 5$ & $5 / 5$ & $4 / 5$ & $3 / 5$ & $3 / 5$ & $15 / 15$ & $10 / 15$ & 100 & 66,67 & - & 6,42 & - & - & - & - & 7 & - \\
\hline & INTER & $0 / 5$ & $0 / 5$ & $0 / 5$ & $0 / 5$ & $0 / 5$ & $0 / 5$ & $0 / 15$ & $0 / 15$ & 0 & 0 & - & 6,64 & - & - & - & - & 8 & - \\
\hline & FD & $0 / 5$ & $0 / 5$ & $2 / 5$ & $1 / 5$ & $0 / 5$ & $0 / 5$ & $2 / 15$ & $1 / 15$ & 13,33 & 6,67 & - & 6,54 & - & - & - & - & 9 & - \\
\hline & CAG & $0 / 5$ & $0 / 5$ & $0 / 5$ & $0 / 5$ & $0 / 5$ & $0 / 5$ & $0 / 15$ & $0 / 15$ & 0 & 0 & - & 6,96 & - & - & - & - & 10 & - \\
\hline \multirow{6}{*}{12} & $\mathrm{AD}$ & $4 / 5$ & $5 / 5$ & $5 / 5$ & $5 / 5$ & $5 / 5$ & $4 / 5$ & $14 / 15$ & $14 / 15$ & 93,33 & 93,33 & - & 6,36 & - & - & - & - & 6 & 8 \\
\hline & $\mathrm{AE}$ & $0 / 5$ & $0 / 5$ & $0 / 5$ & $0 / 5$ & $0 / 5$ & $0 / 5$ & $0 / 15$ & $0 / 15$ & 0 & 0 & - & 6,70 & - & - & - & - & 8 & 8 \\
\hline & FAP & $4 / 5$ & $3 / 5$ & $5 / 5$ & $4 / 5$ & $4 / 5$ & $5 / 5$ & $12 / 15$ & $13 / 15$ & 80 & 86,67 & - & 7,28 & - & - & - & - & 8 & 8 \\
\hline & INTER & $0 / 5$ & $0 / 5$ & $0 / 5$ & $1 / 5$ & $1 / 5$ & $2 / 5$ & $0 / 15$ & $4 / 15$ & 0 & 26,67 & - & 6,38 & - & - & - & - & 8 & 10 \\
\hline & FD & $0 / 5$ & $0 / 5$ & $0 / 5$ & $1 / 5$ & $1 / 5$ & $0 / 5$ & $0 / 15$ & $2 / 15$ & 0 & 13,33 & - & 6,73 & - & - & - & - & 8 & 10 \\
\hline & CAG & $0 / 5$ & $0 / 5$ & $0 / 5$ & $0 / 5$ & $0 / 5$ & $0 / 5$ & $0 / 15$ & $0 / 15$ & 0 & 0 & - & 6,93 & - & - & - & - & 9 & 10 \\
\hline
\end{tabular}


Tabela 5.6.4 - Parâmetros de controle - operação do ENSAIO 2-IP (em instalação piloto): temperatura, pH, potencial zeta e residual de cloro livre das águas de diluição e de estudo e efluentes

\begin{tabular}{|c|c|c|c|c|c|c|c|c|c|c|c|c|c|c|c|}
\hline & $\mathrm{t}\left({ }^{\circ} \mathrm{C}\right)$ & $\mathrm{pH}$ & $\mathrm{Pz}(\mathrm{mV})$ & $\mathrm{pH}$ & $\mathrm{Pz}(\mathrm{mV})$ & $\mathrm{pH}$ & $\begin{array}{l}\text { Cl res. } \\
(\mathrm{mg} / \mathrm{L})\end{array}$ & $\mathrm{pH}$ & $\mathrm{Pz}(\mathrm{mV})$ & $\mathrm{pH}$ & $\mathrm{Pz}(\mathrm{mV})$ & $\mathrm{pH}$ & $\mathrm{Pz}(\mathrm{mV})$ & $\mathrm{pH}$ & $\mathrm{Pz}(\mathrm{mV})$ \\
\hline Hora (h) & \multicolumn{3}{|c|}{$\mathrm{AD}$} & \multicolumn{2}{|c|}{$\mathrm{AE}$} & \multicolumn{2}{|c|}{ PRÉ } & \multicolumn{2}{|c|}{ CAP } & \multicolumn{2}{|c|}{$\mathrm{AC}$} & \multicolumn{2}{|c|}{ FAP } & \multicolumn{2}{|c|}{ FD } \\
\hline 1 & 22,5 & 6,99 & $-2,50$ & 7,02 & $-28,80$ & 6,78 & 0,20 & 6,87 & - & 6,92 & $-26,60$ & 6,74 & $-2,00$ & 6,68 & $-1,80$ \\
\hline 3 & - & 6,88 & - & - & $-34,60$ & 6,98 & 0,15 & 7,48 & - & 6,97 & $-24,00$ & 6,88 & $-1,20$ & - & $-2,00$ \\
\hline 6 (ant.) & - & 6,86 & $-3,00$ & 7,24 & $-26,10$ & 7,09 & 0,06 & 7,09 & - & 6,96 & $-25,20$ & 6,86 & $-2,50$ & 6,88 & $-2,10$ \\
\hline 7 (dep.) & 21,0 & 7,06 & - & - & $-31,30$ & 7,01 & 0,05 & 6,99 & - & 6,96 & $-21,40$ & 6,86 & - & - & - \\
\hline 10 & - & 7,00 & $-4,10$ & 7,01 & $-24,90$ & 6,97 & 0,10 & 7,22 & - & 6,96 & $-21,70$ & 7,09 & $-2,00$ & 7,13 & $-2,00$ \\
\hline MÍNIMO & 21,0 & 6,9 & $-4,1$ & 7,0 & $-34,6$ & 6,8 & 0,05 & 6,9 & - & 6,9 & $-26,6$ & 6,7 & $-2,5$ & 6,7 & $-2,1$ \\
\hline MÁXIMO & 22,5 & 7,1 & $-2,5$ & 7,2 & $\begin{array}{l}-24,9 \\
\end{array}$ & 7,1 & 0,20 & 7,5 & - & 7,0 & $-21,4$ & 7,1 & $-1,2$ & 7,1 & $-1,8$ \\
\hline
\end{tabular}

Tabela 5.6.5 - Parâmetros de controle - desempenho do ENSAIO 2-IP (em instalação piloto): carbono orgânico total, absorvância 254, oxigênio dissolvido, condutividade elétrica, dureza e turbidez das águas de diluição e de estudo e dos efluentes de cada processo de tratamento para diferentes tempos de amostragem

\begin{tabular}{|c|c|c|c|c|c|c|c|c|c|c|c|c|c|c|c|c|c|c|}
\hline \multirow[b]{2}{*}{ Hora (h) } & \multicolumn{6}{|c|}{ Carbono orgânico total - COT (mg/L) } & \multicolumn{6}{|c|}{ absorvância 254} & \multicolumn{6}{|c|}{ Oxigênio dissolvido - OD (mg/L) } \\
\hline & $\mathrm{AD}$ & $\overline{\mathrm{AE}}$ & PRÉ & CAP & FAP & FD & $\mathrm{AD}$ & $\mathrm{AE}$ & PRÉ & CAP & FAP & FD & $\mathrm{AD}$ & $\mathrm{AE}$ & PRÉ & CAP & FAP & FD \\
\hline 1 & - & 2,726 & 3,073 & 4,303 & 0,849 & - & - & 0,027 & 0,029 & 0,016 & 0,013 & 0,012 & $7,4(8,1)$ & $7,5(8,0)$ & $7,7(7,3)$ & $7,8(7,0)$ & $7,6(7,9)$ & $7,2(7,5)$ \\
\hline 3 & - & 1,9 & 2,551 & 1,748 & 0,627 & 0,774 & - & 0,026 & 0,015 & 0,026 & 0,007 & 0,008 & 7,4 & 7,5 & 7,7 & 7,7 & 7,7 & 7,7 \\
\hline 6 (ant.) & - & 2,122 & 1,477 & 3,959 & 0,634 & 0,795 & - & 0,031 & 0,030 & 0,017 & 0,007 & 0,012 & $7,4(8,0)$ & $7,4(8,0)$ & $7,7(8,2)$ & $7,6(7,5)$ & $7,7(8,3)$ & $7,3(8,2)$ \\
\hline 7 (dep.) & - & 1,446 & 2,098 & 3,504 & 0,701 & 0,682 & - & 0,028 & 0,031 & 0,015 & 0,009 & 0,005 & 7,3 & 7,5 & 7,7 & 7,8 & 7,8 & 7,8 \\
\hline 10 & - & 4,482 & 3,987 & - & 2,393 & 2,268 & - & 0,033 & 0,033 & 0,021 & 0,008 & 0,008 & $7,5(8,0)$ & $7,5(8,1)$ & $7,8(8,0)$ & $7,9(7,1)$ & $8,0(8,4)$ & $7,9(8,1)$ \\
\hline MÍNIMO & - & 1,446 & 1,477 & 1,748 & 0,627 & 0,682 & - & 0,026 & 0,015 & 0,015 & 0,007 & 0,005 & 7,3 & 7,4 & 7,3 & 7,0 & 7,6 & 7,2 \\
\hline \multirow[t]{2}{*}{ MÁXIMO } & - & 4,482 & 3,987 & 4,303 & 2,393 & 2,268 & - & 0,033 & 0,033 & 0,026 & 0,013 & 0,012 & 8,1 & 8,1 & 8,0 & 7,9 & 8,4 & 8,2 \\
\hline & \multicolumn{6}{|c|}{ Condutividade elétrica $(\mu \mathrm{S} / \mathrm{cm})$} & \multicolumn{6}{|c|}{ Dureza $\left(\mathrm{mgCaCO}_{3} / \mathrm{L}\right)$} & \multicolumn{6}{|c|}{ Turbidez $^{(*)}$ (uT) } \\
\hline Hora (h) & $\mathrm{AD}$ & $\mathrm{AE}$ & PRÉ & CAP & FAP & FD & $\mathrm{AD}$ & $\mathrm{AE}$ & PRÉ & CAP & FAP & FD & $\mathrm{AD}$ & $\mathrm{AE}$ & PRÉ & $\overline{\mathrm{CAP}}$ & FAP & FD \\
\hline 1 & 17,6 & 24,7 & 24,5 & 25,3 & 18,9 & 21,1 & 7,0 & 8,0 & 8,0 & 8 & 7 & 10 & - & 2,54 & 2,55 & 2,90 & 0,43 & 0,36 \\
\hline 3 & 17,4 & 24,8 & 25 & 25,3 & 29,2 & 28,4 & 7,0 & 7,0 & 8,0 & 9 & 8 & 9 & - & 2,37 & 2,38 & 1,49 & 0,31 & 0,34 \\
\hline 6 (ant.) & 17,4 & 24,5 & 24,7 & 25,6 & 29 & 29,5 & 6,0 & 8,0 & 7,0 & 7 & 8 & 8 & - & 2,40 & 1,96 & 3,03 & 0,31 & 0,29 \\
\hline 7 (dep.) & 17,6 & 24,3 & 24,4 & 25,5 & 29,8 & 29,6 & 6,0 & 9,0 & 7,0 & 8 & 8 & 9 & - & 2,52 & 1,66 & 3,10 & 0,35 & 0,30 \\
\hline 10 & 17,9 & 24,9 & 24,3 & 25,6 & 29,5 & 30,1 & 6,0 & 9,0 & 9,0 & 9 & 9 & 8 & - & 3,99 & 2,24 & 3,95 & 0,39 & 0,31 \\
\hline MÍNIMO & 17,4 & 24,3 & 24,3 & 25,3 & 18,9 & 21,1 & 6 & 7 & 7 & 7 & 7 & 8 & - & 2,37 & 1,66 & 1,49 & 0,31 & 0,29 \\
\hline MÁXIMO & 17,9 & 24,9 & 25 & 25,6 & 29,8 & 30,1 & 7 & 9 & 9 & 9 & 9 & 10 & - & 3,99 & 2,55 & 3,95 & 0,43 & 0,36 \\
\hline
\end{tabular}

AD: água de diluição; AE: água de estudo; Efluentes: PRÉ: pré-cloração, CAP: carvão ativado em pó, FAP: filtro ascendente de pedregulho, FD: filtração descendente. (*): leitura em turbidímetro de bancada 2100P HACH; OD: método de Winkler (sonda Horiba U-10); ant.: antes da DFI; dep.: depois da DFI. 
Tabela 5.6.6 - Resultados dos testes ecotoxicológicos com microcrustáceos (Ceriodaphnia dúbia - CD e Ceriodaphnia silvestri - CS) - ENSAIO 2-IP (em instalação piloto): total indivíduos imóveis / total indivíduos expostos, imobilidade, $\mathrm{pH}$, condutividade e dureza das águas de diluição e de estudo e efluentes

ENSAIO2-IP: Sistema PRÉ $\rightarrow$ CAP $\rightarrow$ MR $\rightarrow$ FAP $\rightarrow$ FD

\begin{tabular}{|c|c|c|c|c|c|c|c|c|c|c|c|c|c|c|c|c|c|c|}
\hline \multirow{2}{*}{\multicolumn{2}{|c|}{$\begin{array}{c}\text { Início: 30mai06 } \\
\text { Fim: 01jun06 }\end{array}$}} & \multirow{2}{*}{\multicolumn{6}{|c|}{$\begin{array}{c}\text { Réplicas } \\
\text { (ind. Imóveis / total ind. expostos) }\end{array}$}} & \multirow{3}{*}{\multicolumn{2}{|c|}{$\begin{array}{l}\text { Total ind. imóveis / } \\
\text { total ind. expostos }\end{array}$}} & \multirow{3}{*}{\multicolumn{2}{|c|}{ \% imobilidade }} & \multirow{3}{*}{\multicolumn{3}{|c|}{$\mathrm{pH}$}} & \multirow{3}{*}{\multicolumn{3}{|c|}{$\begin{array}{l}\text { Condutividade } \\
\qquad(\mu \mathrm{S} / \mathrm{cm})\end{array}$}} & \multirow{4}{*}{$\begin{array}{c}\begin{array}{c}\text { Dureza } \\
\left(\mathrm{mg} \mathrm{CaCO}_{3} / \mathrm{L}\right)\end{array} \\
\text { fim }\end{array}$} \\
\hline & & & & & & & & & & & & & & & & & & \\
\hline \multirow{2}{*}{$\begin{array}{c}\text { Hora } \\
\text { (h) }\end{array}$} & \multirow{2}{*}{ Amostra } & \multicolumn{3}{|c|}{ C. dúbia CD } & \multicolumn{3}{|c|}{ C. silvestrii CS } & & & & & & & & & & & \\
\hline & & 1 & 2 & 3 & 1 & 2 & 3 & CD & CS & CD & CS & início & CD & CS & início & CD & CS & \\
\hline \multicolumn{2}{|c|}{ Controle } & $1 / 5$ & $0 / 5$ & $1 / 5$ & $0 / 5$ & $0 / 5$ & $0 / 5$ & $2 / 15$ & $0 / 15$ & 13,33 & 0 & 7,11 & 7,70 & 7,68 & 160,0 & 185,1 & 182,9 & 48 \\
\hline \multirow{6}{*}{1} & $\mathrm{AD}$ & $5 / 5$ & $5 / 5$ & $4 / 5$ & $5 / 5$ & $5 / 5$ & $5 / 5$ & $14 / 15$ & $15 / 15$ & 93,33 & 100 & 6,78 & 6,90 & 6,72 & 28,1 & 31,2 & 30,7 & 6 \\
\hline & $\mathrm{AE}$ & $0 / 5$ & $0 / 5$ & $1 / 5$ & $0 / 5$ & $0 / 5$ & $0 / 5$ & $1 / 15$ & $0 / 15$ & 6,67 & 0 & 6,96 & - & - & 41,3 & - & - & 8 \\
\hline & PRÉ & $0 / 5$ & $0 / 5$ & $5 / 5$ & $5 / 5$ & $0 / 5$ & $0 / 5$ & $5 / 15$ & $5 / 15$ & 33,33 & 33,33 & 6,94 & 6,72 & 6,74 & 41,2 & 46,2 & 44,4 & 8 \\
\hline & CAP & $0 / 5$ & $0 / 5$ & $0 / 5$ & $0 / 5$ & $0 / 5$ & $0 / 5$ & $0 / 15$ & $0 / 15$ & 0 & 0 & 7,03 & - & - & 42,1 & - & - & 8 \\
\hline & FAP & $1 / 5$ & $0 / 5$ & $0 / 5$ & $0 / 5$ & $0 / 5$ & $0 / 5$ & $1 / 15$ & $0 / 15$ & 6,67 & 0 & 6,72 & - & - & 37,7 & 54,7 & 40,5 & 8 \\
\hline & FD & $3 / 5$ & $0 / 5$ & $2 / 5$ & $0 / 5$ & $0 / 5$ & $0 / 5$ & $5 / 15$ & $0 / 15$ & 33,33 & 0 & 6,84 & 6,73 & - & 35,3 & 39,5 & 40,1 & 6 \\
\hline \multirow{6}{*}{$\begin{array}{c}6 \\
\text { (ant.) }\end{array}$} & $\mathrm{AD}$ & $5 / 5$ & $4 / 5$ & $4 / 5$ & $4 / 5$ & $4 / 5$ & $3 / 5$ & $13 / 15$ & $11 / 15$ & 86,67 & 73,33 & 6,73 & 6,75 & 6,75 & 26,1 & 31,3 & 31,0 & 6 \\
\hline & $\mathrm{AE}$ & $0 / 5$ & $0 / 5$ & $0 / 5$ & $0 / 5$ & $0 / 5$ & $0 / 5$ & $0 / 15$ & $0 / 15$ & 0 & 0 & 6,97 & - & - & 43,5 & - & - & 8 \\
\hline & PRÉ & $0 / 5$ & $0 / 5$ & $5 / 5$ & $5 / 5$ & $0 / 5$ & $0 / 5$ & $5 / 15$ & $5 / 15$ & 33,33 & 33,33 & 6,95 & 6,95 & 6,84 & 42,4 & 47,4 & 49,6 & 8 \\
\hline & CAP & $1 / 5$ & $0 / 5$ & $0 / 5$ & $0 / 5$ & $0 / 5$ & $0 / 5$ & $1 / 15$ & $0 / 15$ & 6,67 & 0 & 6,97 & - & - & 42,4 & - & - & 8 \\
\hline & FAP & $0 / 5$ & $0 / 5$ & $0 / 5$ & $0 / 5$ & $0 / 5$ & $0 / 5$ & $0 / 15$ & $0 / 15$ & 0 & 0 & 7,19 & - & - & 47,6 & 53,0 & 52,5 & 8 \\
\hline & FD & $0 / 5$ & $1 / 5$ & $0 / 5$ & $0 / 5$ & $0 / 5$ & $0 / 5$ & $1 / 15$ & $0 / 15$ & 6,67 & 0 & 6,84 & 6,94 & - & 48,1 & 53,4 & - & 8 \\
\hline \multirow{2}{*}{$\begin{array}{c}7 \\
\text { (dep) }\end{array}$} & FAP & $1 / 5$ & $5 / 5$ & $2 / 5$ & $0 / 5$ & $0 / 5$ & $0 / 5$ & $8 / 15$ & $0 / 15$ & 53,33 & 0 & 6,87 & 6,70 & - & 51,1 & 54,4 & 52,0 & 10 \\
\hline & FD & $0 / 5$ & $0 / 5$ & $5 / 5$ & $0 / 5$ & $0 / 5$ & $0 / 5$ & $5 / 15$ & $0 / 15$ & 33,33 & 0 & 7,25 & 6,77 & - & 49,9 & 55,6 & 50,6 & 8 \\
\hline \multirow{6}{*}{10} & $\mathrm{AD}$ & $2 / 5$ & $4 / 5$ & $4 / 5$ & $4 / 5$ & $4 / 5$ & $5 / 5$ & $10 / 15$ & $13 / 15$ & 66,67 & 86,67 & 6,75 & 6,78 & 6,70 & 24,7 & 31,4 & 31,0 & 6 \\
\hline & $\mathrm{AE}$ & $0 / 5$ & $0 / 5$ & $0 / 5$ & $0 / 5$ & $0 / 5$ & $0 / 5$ & $0 / 15$ & $0 / 15$ & 0 & 0 & 6,99 & - & - & 43,0 & - & - & 8 \\
\hline & PRÉ & $0 / 5$ & $0 / 5$ & $0 / 5$ & $0 / 5$ & $0 / 5$ & $0 / 5$ & $0 / 15$ & $0 / 15$ & 0 & 0 & 7,01 & 7,02 & 6,97 & 42,1 & 47,9 & 49,8 & 8 \\
\hline & CAP & $0 / 5$ & $0 / 5$ & $0 / 5$ & $0 / 5$ & $0 / 5$ & $0 / 5$ & $0 / 15$ & $0 / 15$ & 0 & 0 & 7,08 & - & - & 43,7 & - & - & 8 \\
\hline & FAP & $1 / 5$ & $3 / 5$ & $2 / 5$ & $0 / 5$ & $0 / 5$ & $0 / 5$ & $6 / 15$ & $0 / 15$ & 40 & 0 & 6,61 & 6,80 & - & 48,6 & 43,6 & 55,0 & 8 \\
\hline & FD & $1 / 5$ & $2 / 5$ & $1 / 5$ & $0 / 5$ & $0 / 5$ & $0 / 5$ & $4 / 15$ & $0 / 15$ & 26,67 & 0 & 7,07 & 7,05 & - & 47,6 & 56,5 & 54,7 & 8 \\
\hline
\end{tabular}


Tabela 5.6.7 - Parâmetros de controle - operação do ENSAIO 3-IP (em instalação piloto): temperatura, pH, potencial zeta e residual de cloro livre das águas de diluição e de estudo e efluentes

\begin{tabular}{|c|c|c|c|c|c|c|c|c|c|c|c|c|c|}
\hline & $\mathrm{t}\left({ }^{\circ} \mathrm{C}\right)$ & $\mathrm{pH}$ & $\mathrm{Pz}(\mathrm{mV})$ & $\mathrm{pH}$ & $\mathrm{Pz}(\mathrm{mV})$ & $\mathrm{pH}$ & $\begin{array}{l}\mathrm{Cl} \text { res. } \\
(\mathrm{mg} / \mathrm{L})\end{array}$ & $\mathrm{pH}$ & $\mathrm{Pz}(\mathrm{mV})$ & $\mathrm{pH}$ & $\mathrm{Pz}(\mathrm{mV})$ & $\mathrm{pH}$ & $\mathrm{Pz}(\mathrm{mV})$ \\
\hline Hora (h) & \multicolumn{3}{|c|}{$\overline{A D}$} & \multicolumn{2}{|c|}{$\frac{1}{\mathrm{AE}}$} & \multicolumn{2}{|c|}{ PRÉ } & \multicolumn{2}{|c|}{$\frac{1}{A C}$} & \multicolumn{2}{|c|}{ FAP } & \multicolumn{2}{|c|}{$\frac{1}{\mathrm{FD}}$} \\
\hline 1 & 22,0 & 6,91 & $-2,50$ & 6,87 & $-32,00$ & 6,60 & 0,68 & 6,40 & $-10,30$ & 6,58 & $-3,10$ & 7,30 & $-2,20$ \\
\hline 3 & - & - & - & - & - & - & 0,90 & 6,30 & $-6,70$ & & - & - & - \\
\hline 6 (ant.) & - & - & $-3,20$ & 6,57 & $-29,80$ & 6,59 & 0,79 & 6,45 & $-9,90$ & 6,48 & $-2,00$ & 6,45 & $-2,10$ \\
\hline 7 (dep.) & 20,0 & 6,34 & $-2,30$ & & - & - & 0,68 & 6,39 & $-11,00$ & & $-2,00$ & & $-2,00$ \\
\hline 10 & 19,0 & & $-2,20$ & 6,4 & $-32,00$ & 6,36 & 0,54 & 6,30 & $-14,20$ & 6,19 & $-2,00$ & 6,20 & $-2,10$ \\
\hline MÍNIMO & 19,0 & 6,3 & $-3,2$ & 6,4 & $-32,0$ & 6,4 & 0,54 & 6,3 & $-14,2$ & 6,2 & $-3,1$ & 6,2 & $-2,2$ \\
\hline MÁXIMO & 22,0 & 6,9 & $-2,2$ & 6,9 & $-29,8$ & 6,6 & 0,90 & 6,5 & $-6,7$ & 6,6 & $-2,0$ & 7,3 & $-2,0$ \\
\hline
\end{tabular}

Tabela 5.6.8 - Parâmetros de controle - desempenho do ENSAIO 3-IP (em instalação piloto): carbono orgânico total, absorvância 254, oxigênio dissolvido, condutividade elétrica, dureza e turbidez das águas de diluição e de estudo e dos efluentes de cada processo de tratamento para diferentes tempos de amostragem

\begin{tabular}{|c|c|c|c|c|c|c|c|c|c|c|c|c|c|c|c|}
\hline & \multicolumn{5}{|c|}{ Carbono orgânico total - COT (mg/L) } & \multicolumn{5}{|c|}{ absorvância 254} & \multicolumn{5}{|c|}{ Oxigênio dissolvido - OD (mg/L) } \\
\hline Hora (h) & $\mathrm{AD}$ & $\overline{\mathrm{AE}}$ & PRÉ & FAP & FD & $\mathrm{AD}$ & $\mathrm{AE}$ & PRÉ & FAP & $\overline{F D}$ & $\overline{\mathrm{AD}}$ & $\mathrm{AE}$ & PRÉ & FAP & FD \\
\hline 1 & - & 3,031 & 2,857 & 2,26 & 1,918 & - & 0,025 & 0,024 & 0,018 & 0,032 & $7,7(8,5)$ & $7,6(8,4)$ & $7,8(8,2)$ & $7,8(8,3)$ & $7,6(8,0)$ \\
\hline 3 & - & 2,156 & 2,617 & 2,151 & 2,071 & - & 0,028 & 0,025 & 0,018 & 0,017 & 7,7 & 7,6 & 7,8 & 7,8 & 7,6 \\
\hline 6 (ant.) & - & 3,011 & 3,467 & 2,108 & 2,669 & - & 0,029 & 0,029 & 0,016 & 0,017 & $7,6(8,4)$ & $7,5(8,5)$ & $7,9(8,6)$ & $7,9(8,6)$ & $7,9(8,5)$ \\
\hline 7 (dep.) & - & 2,683 & 2,609 & 2,006 & 1,976 & - & 0,029 & 0,029 & 0,016 & 0,016 & 7,6 & 7,6 & 7,8 & 8,1 & 8,0 \\
\hline 10 & - & 2,722 & 2,144 & 2,088 & 1,87 & - & 0,031 & 0,028 & 0,019 & 0,017 & $7,8(8,6)$ & $7,9(8,4)$ & $8,1(8,6)$ & $8,4(8,9)$ & $8,3(8,8)$ \\
\hline MÍNIMO & - & 2,156 & 2,144 & 2,006 & 1,87 & - & 0,025 & 0,024 & 0,016 & 0,016 & 7,6 & 7,5 & 7,8 & 7,8 & 7,6 \\
\hline \multirow[t]{2}{*}{ MÁXIMO } & - & 3,031 & 3,467 & 2,26 & 2,669 & - & 0,031 & 0,029 & 0,019 & 0,032 & 8,6 & 8,5 & 8,6 & 8,6 & 8,8 \\
\hline & \multicolumn{5}{|c|}{ Condutividade elétrica $(\mu \mathrm{S} / \mathrm{cm})$} & \multicolumn{5}{|c|}{ Dureza $\left(\mathrm{mgCaCO}_{3} / \mathrm{L}\right)$} & \multicolumn{5}{|c|}{ Turbidez $^{(*)}(\mathrm{uT})$} \\
\hline Hora (h) & $\mathrm{AD}$ & $\mathrm{AE}$ & PRÉ & FAP & FD & $\mathrm{AD}$ & $\mathrm{AE}$ & PRÉ & FAP & FD & $\mathrm{AD}$ & $\mathrm{AE}$ & PRÉ & FAP & FD \\
\hline 1 & 16,9 & 25,9 & 24,9 & 27,9 & 28,7 & 6,0 & 9,0 & 9,0 & 8 & 7 & - & 2,64 & 1,80 & 0,46 & 0,36 \\
\hline 3 & 16,5 & 25,5 & 26,1 & 29,7 & 30,0 & 5,0 & 8,0 & 9,0 & 9 & 10 & - & 2,74 & 1,77 & 0,33 & 0,42 \\
\hline 6 (ant.) & 17,2 & 25,9 & 26,7 & 30,4 & 29,8 & 6,0 & 9,0 & 9,0 & 9 & 10 & - & 2,80 & 1,37 & 0,39 & 0,35 \\
\hline 7 (dep.) & 17,2 & 26,1 & 27,6 & 29,3 & 30,1 & - & - & - & - & - & - & 2,83 & 1,75 & 0,33 & 0,33 \\
\hline 10 & 16,8 & 26,8 & 26,9 & 30,4 & 29,6 & 6,0 & 9,0 & 9,0 & 10 & 10 & - & 2,29 & 1,74 & 1,16 & 0,41 \\
\hline MÍNIMO & 16,5 & 25,5 & 24,9 & 27,9 & 28,7 & 5 & 8 & 9 & 8 & 7 & - & 2,29 & 1,37 & 0,33 & 0,33 \\
\hline MÁXIMO & 17,2 & 26,8 & 27,6 & 30,4 & 30,1 & 6 & 9 & 9 & 10 & 10 & - & 2,83 & 1,80 & 1,16 & 0,42 \\
\hline
\end{tabular}

AD: água de diluição; AE: água de estudo; Efluentes: PRÉ: pré-cloração, FAP: filtro ascendente de pedregulho, FD: filtração descendente. (*): leitura em turbidímetro de bancada 2100P HACH; OD: método de Winkler (sonda Horiba U-10); ant.: antes da DFI; dep.: depois da DFI. 
Tabela 5.6.9 - Resultados dos testes ecotoxicológicos com microcrustáceos (Ceriodaphnia dúbia - CD e Ceriodaphnia silvestri - CS) - ENSAIO 3-IP (em instalação piloto): total indivíduos imóveis / total indivíduos expostos, imobilidade, $\mathrm{pH}$, condutividade e dureza das águas de diluição e de estudo e efluentes ENSAIO3-IP: Sistema PRÉ $\rightarrow$ MR $\rightarrow$ FAP $\rightarrow$ FD

\begin{tabular}{|c|c|c|c|c|c|c|c|c|c|c|c|c|c|c|c|c|c|c|}
\hline \multirow{2}{*}{\multicolumn{2}{|c|}{$\begin{array}{c}\text { Início: 31mai06 } \\
\text { Fim: 02jun06 }\end{array}$}} & \multirow{2}{*}{\multicolumn{6}{|c|}{$\begin{array}{c}\text { Réplicas } \\
\text { (ind. Imóveis / total ind. expostos) }\end{array}$}} & \multirow{3}{*}{\multicolumn{2}{|c|}{$\begin{array}{l}\text { Total ind. imóveis / } \\
\text { total ind. expostos }\end{array}$}} & \multirow{3}{*}{\multicolumn{2}{|c|}{ \% imobilidade }} & \multirow{3}{*}{\multicolumn{3}{|c|}{$\mathrm{pH}$}} & \multirow{3}{*}{\multicolumn{3}{|c|}{$\begin{array}{l}\text { Condutividade } \\
\text { ( } \mu \mathrm{S} / \mathrm{cm})\end{array}$}} & \multirow{4}{*}{$\begin{array}{c}\left.\begin{array}{c}\text { Dureza } \\
(\mathrm{mg} \mathrm{CaCO}\end{array} / \mathrm{L}\right) \\
\text { fim }\end{array}$} \\
\hline & & & & & & & & & & & & & & & & & & \\
\hline \multirow{2}{*}{$\begin{array}{l}\text { Hora } \\
(\mathrm{h})\end{array}$} & \multirow{2}{*}{ Amostra } & \multicolumn{3}{|c|}{ C. dúbia CD } & \multicolumn{3}{|c|}{ C. silvestrii CS } & & & & & & & & & & & \\
\hline & & 1 & 2 & 3 & 1 & 2 & 3 & CD & CS & CD & CS & início & $\mathrm{CD}$ & CS & início & CD & CS & \\
\hline \multicolumn{2}{|c|}{ Controle } & $0 / 5$ & $1 / 5$ & $2 / 5$ & $0 / 5$ & $1 / 5$ & $1 / 5$ & $3 / 15$ & $2 / 15$ & 20 & 13,33 & 7,11 & 7,64 & 7,70 & 160,0 & 180,7 & 179,5 & 48 \\
\hline \multirow{5}{*}{1} & $\mathrm{AD}$ & $0 / 5$ & $1 / 5$ & $1 / 5$ & $0 / 5$ & $1 / 5$ & $0 / 5$ & $2 / 15$ & $1 / 15$ & 13,33 & 6,67 & 6,49 & 6,87 & 6,74 & 23,4 & 32,1 & 30,1 & 6 \\
\hline & $\mathrm{AE}$ & $0 / 5$ & $0 / 5$ & $0 / 5$ & $0 / 5$ & $0 / 5$ & $0 / 5$ & $0 / 15$ & $0 / 15$ & 0 & 0 & 6,94 & 6,93 & 6,96 & 43,8 & 52,5 & 51,2 & 8 \\
\hline & PRÉ & $0 / 5$ & $0 / 5$ & $0 / 5$ & $0 / 5$ & $0 / 5$ & $0 / 5$ & $0 / 15$ & $0 / 15$ & 0 & 0 & 6,91 & 6,86 & 6,81 & 43,1 & 48,5 & 49,2 & 8 \\
\hline & FAP & $0 / 5$ & $2 / 5$ & $0 / 5$ & $4 / 5$ & $0 / 5$ & $0 / 5$ & $2 / 15$ & $4 / 15$ & 13,33 & 26,67 & 6,84 & 7,03 & 6,90 & 49,2 & 54,9 & 51,6 & 8 \\
\hline & FD & $0 / 5$ & $0 / 5$ & $0 / 5$ & $0 / 5$ & $0 / 5$ & $0 / 5$ & $0 / 15$ & $0 / 15$ & 0 & 0 & 7,12 & 7,10 & 7,05 & 51,3 & 56,0 & 55,5 & 10 \\
\hline \multirow{5}{*}{$\begin{array}{c}6 \\
\text { (ant.) }\end{array}$} & $\mathrm{AD}$ & $0 / 5$ & $2 / 5$ & $2 / 5$ & $1 / 5$ & $0 / 5$ & $0 / 5$ & $4 / 15$ & $1 / 15$ & 26,67 & 6,67 & 6,58 & 6,79 & 6,80 & 25,8 & 32,8 & 31,5 & 6 \\
\hline & $\mathrm{AE}$ & $0 / 5$ & $0 / 5$ & $0 / 5$ & $0 / 5$ & $0 / 5$ & $0 / 5$ & $0 / 15$ & $0 / 15$ & 0 & 0 & 6,98 & 6,94 & 6,89 & 45,7 & 52,4 & 51,5 & 10 \\
\hline & PRÉ & $0 / 5$ & $1 / 5$ & $1 / 5$ & $0 / 5$ & $0 / 5$ & $0 / 5$ & $2 / 15$ & $0 / 15$ & 13,33 & 0 & 6,95 & 6,81 & 6,89 & 43,9 & 48,7 & 47,4 & 8 \\
\hline & FAP & $0 / 5$ & $0 / 5$ & $2 / 5$ & $0 / 5$ & $0 / 5$ & $0 / 5$ & $2 / 15$ & $0 / 15$ & 13,33 & 0 & 6,78 & 6,96 & 7,01 & 50,9 & 56,3 & 52,7 & 10 \\
\hline & FD & $0 / 5$ & $0 / 5$ & $1 / 5$ & $0 / 5$ & $0 / 5$ & $0 / 5$ & $1 / 15$ & $0 / 15$ & 6,67 & 0 & 7,04 & 7,07 & 6,98 & 51,5 & 56,4 & 55,8 & 10 \\
\hline \multirow{2}{*}{$\begin{array}{c}7 \\
\text { (dep) } \\
\end{array}$} & FAP & $0 / 5$ & $0 / 5$ & $0 / 5$ & $0 / 5$ & $0 / 5$ & $0 / 5$ & $0 / 15$ & $0 / 15$ & 0 & 0 & 7,06 & 7,05 & 6,87 & 50,7 & 57,0 & 55,6 & 10 \\
\hline & FD & $2 / 5$ & $0 / 5$ & $1 / 5$ & $0 / 5$ & $0 / 5$ & $0 / 5$ & $3 / 15$ & $0 / 15$ & 20 & 0 & 7,05 & 7,00 & 6,90 & 52,3 & 55,3 & 55,4 & 8 \\
\hline \multirow{5}{*}{10} & $\mathrm{AD}$ & $0 / 5$ & $0 / 5$ & $0 / 5$ & $0 / 5$ & $0 / 5$ & $0 / 5$ & $0 / 15$ & $0 / 15$ & 0 & 0 & 6,62 & 6,76 & 6,80 & 23,6 & - & 30,1 & 6 \\
\hline & $\mathrm{AE}$ & $0 / 5$ & $0 / 5$ & $0 / 5$ & $0 / 5$ & $0 / 5$ & $0 / 5$ & $0 / 15$ & $0 / 15$ & 0 & 0 & 7,04 & 6,94 & 6,86 & 44,0 & 51,7 & 51,6 & 8 \\
\hline & PRÉ & $0 / 5$ & $0 / 5$ & $0 / 5$ & $1 / 5$ & $0 / 5$ & $0 / 5$ & $0 / 15$ & $1 / 15$ & 0 & 6,67 & 7,00 & 6,95 & 6,86 & 44,9 & 49,2 & 47,9 & 8 \\
\hline & FAP & $1 / 5$ & $3 / 5$ & $2 / 5$ & $0 / 5$ & $0 / 5$ & $0 / 5$ & $6 / 15$ & $0 / 15$ & 40 & 0 & 6,81 & 6,93 & 6,92 & 48,8 & 55,6 & 54,4 & 10 \\
\hline & FD & $1 / 5$ & $2 / 5$ & $3 / 5$ & $0 / 5$ & $0 / 5$ & $1 / 5$ & $6 / 15$ & $1 / 15$ & 40 & 6,67 & 6,90 & 6,96 & 6,88 & 51,5 & 55,8 & 55,9 & 10 \\
\hline
\end{tabular}


Tabela 5.6.10 - Parâmetros de controle - operação do ENSAIO 4-IP (em instalação piloto): temperatura, pH, potencial zeta e residual de cloro livre das águas de diluição e de estudo e

\begin{tabular}{|c|c|c|c|c|c|c|c|c|c|c|c|c|c|c|c|}
\hline & $\mathrm{t}\left({ }^{\circ} \mathrm{C}\right)$ & $\mathrm{pH}$ & $\mathrm{Pz}(\mathrm{mV})$ & $\mathrm{pH}$ & $\mathrm{Pz}(\mathrm{mV})$ & $\mathrm{pH}$ & $\mathrm{Pz}(\mathrm{mV})$ & $\mathrm{pH}$ & $\mathrm{Pz}(\mathrm{mV})$ & $\mathrm{pH}$ & $\mathrm{Pz}(\mathrm{mV})$ & $\mathrm{pH}$ & $\begin{array}{l}\mathrm{Cl} \text { res. } \\
(\mathrm{mg} / \mathrm{L})\end{array}$ & $\mathrm{pH}$ & $\mathrm{Pz}(\mathrm{mV})$ \\
\hline Hora (h) & \multicolumn{3}{|c|}{$\mathrm{AD}$} & \multicolumn{2}{|c|}{$\overline{\mathrm{AE}}$} & \multicolumn{2}{|c|}{$\frac{1}{\mathrm{AC}}$} & \multicolumn{2}{|c|}{$\frac{1}{\text { FAP }}$} & \multicolumn{2}{|c|}{$\overline{F D}$} & \multicolumn{2}{|c|}{ PÓS } & \multicolumn{2}{|c|}{ FCAG } \\
\hline 1 & 19,00 & 7,40 & $-3,20$ & 6,80 & $-20,70$ & 6,80 & $-5,20$ & 7,06 & $-2,00$ & 6,90 & $-2,00$ & 6,70 & 1,63 & - & - \\
\hline 3 & - & - & - & - & - & 6,00 & $-4,10$ & - & - & - & - & - & 1,09 & - & - \\
\hline 6 (ant.) & 20,00 & & $-2,60$ & 7,27 & $-32,60$ & 7,40 & $-5,40$ & & $-3,60$ & - & $-2,00$ & - & 1,20 & 8,41 & $-2,00$ \\
\hline 7 (dep.) & - & - & - & - & - & 7,00 & $-13,00$ & - & - & - & - & - & 2,09 & - & - \\
\hline 10 & 18,00 & - & - & - & - & 7,00 & - & - & - & - & - & - & 1,87 & - & - \\
\hline MÍNIMO & 18,0 & 7,4 & $-3,2$ & 6,8 & $-32,6$ & 6,0 & $-13,0$ & 7,1 & $-3,6$ & 6,9 & $-2,0$ & 6,7 & 1,1 & 8,4 & $-2,0$ \\
\hline MÁXIMO & 20,0 & 7,4 & $-2,6$ & 7,3 & $-20,7$ & 7,4 & $-4,1$ & 7,1 & $-2,0$ & 6,9 & $-2,0$ & 6,7 & 2,1 & 8,4 & $-2,0$ \\
\hline
\end{tabular}

Tabela 5.6.11 - Parâmetros de controle - desempenho do ENSAIO 4-IP (em instalação piloto): carbono orgânico total, absorvância 254, oxigênio dissolvido, condutividade elétrica, dureza e turbidez das águas de diluição e de estudo e dos efluentes de cada processo de tratamento para diferentes tempos de amostragem

\begin{tabular}{|c|c|c|c|c|c|c|c|c|c|c|c|c|c|c|c|c|c|c|}
\hline & \multicolumn{6}{|c|}{ Carbono orgânico total - COT (mg/L) } & \multicolumn{6}{|c|}{ absorvância 254} & \multicolumn{6}{|c|}{ Oxigênio dissolvido - OD (mg/L) } \\
\hline Hora (h) & $\mathrm{AD}$ & $\mathrm{AE}$ & FAP & FD & PÓS & FCAG & $\overline{\mathrm{AD}}$ & $\overline{\mathrm{AE}}$ & FAP & FD & PÓS & FCAG & $\overline{\mathrm{AD}}$ & $\overline{\mathrm{AE}}$ & $\overline{\text { FAP }}$ & $\overline{F D}$ & PÓS & FCAG \\
\hline 1 & - & 2,775 & 1,774 & 1,812 & 1,754 & 1,238 & - & 0,024 & 0,013 & 0,015 & 0,02 & 0,004 & $8,0(8,8)$ & $7,9(8,6)$ & $8,1(8,6)$ & $8,4(8,7)$ & $8,3(9,0)$ & $7,3(7,5)$ \\
\hline 3 & - & 2,214 & 1,865 & 1,982 & 1,844 & 1,37 & - & 0,026 & 0,013 & 0,016 & 0,021 & 0,004 & 7,9 & 7,8 & 8,2 & 8,1 & 7,9 & 7,3 \\
\hline 6 (ant.) & - & 2,847 & 2,739 & 1,807 & 2,054 & 1,245 & - & 0,027 & 0,032 & 0,015 & 0,022 & 0,005 & $8,5(8,5)$ & $8,5(8,5)$ & $8,4(8,4)$ & $8,5(8,4)$ & $8,5(8,4)$ & $7,9(7,8)$ \\
\hline 7 (dep.) & - & 2,528 & 1,597 & 1,585 & 1,83 & 1,188 & - & 0,03 & 0,014 & 0,013 & 0,021 & 0,003 & 8,5 & 8,5 & 9,1 & 8,6 & 8,8 & 8,6 \\
\hline 10 & - & 2,52 & 2,372 & 1,525 & 1,617 & 1,103 & - & 0,023 & 0,02 & 0,013 & 0,02 & 0,006 & $8,0(8,6)$ & $8,0(8,7)$ & $8,4(8,9)$ & $8,3(8,8)$ & $8,1(9,2)$ & $8,0(8,4)$ \\
\hline MÍNIMO & - & 2,214 & 1,597 & 1,525 & 1,617 & 1,103 & - & 0,023 & 0,013 & 0,013 & 0,02 & 0,003 & 7,9 & 7,8 & 8,1 & 8,1 & 7,9 & 7,3 \\
\hline \multirow[t]{2}{*}{ MÁXIMO } & - & 2,847 & 2,739 & 1,982 & 2,054 & 1,37 & - & 0,03 & 0,032 & 0,016 & 0,022 & 0,006 & 8,8 & 8,7 & 9,1 & 8,8 & 9,2 & 8,6 \\
\hline & \multicolumn{6}{|c|}{ Condutividade elétrica $(\mu \mathrm{S} / \mathrm{cm})$} & \multicolumn{6}{|c|}{ Dureza $\left(\mathrm{mgCaCO}_{3} / \mathrm{L}\right)$} & \multicolumn{6}{|c|}{ Turbidez $^{(*)}(\mathrm{uT})$} \\
\hline Hora (h) & $\mathrm{AD}$ & $\mathrm{AE}$ & FAP & FD & PÓS & FCAG & $\mathrm{AD}$ & $\mathrm{AE}$ & FAP & FD & PÓS & FCAG & $\mathrm{AD}$ & $\mathrm{AE}$ & FAP & FD & PÓS & FCAG \\
\hline 1 & 18,38 & 25,6 & 24,50 & 23,0 & 24,9 & 21,2 & 5 & 6 & 7 & 5 & 11 & 5 & - & 4,55 & 0,87 & 0,33 & 0,40 & 0,45 \\
\hline 3 & 16,41 & 23,6 & 24,50 & 25,1 & 29,3 & 23,7 & 5 & 7 & 7 & 7 & 9 & 7 & - & 4,23 & 0,37 & 0,32 & 0,52 & 0,37 \\
\hline 6 (ant.) & 16,04 & 21,4 & 26,50 & 26,4 & 31,9 & 26,6 & 6 & 8 & 8 & 7 & 9 & 6 & - & 4,50 & 3,19 & 0,40 & 0,78 & 0,83 \\
\hline 7 (dep.) & 16,38 & 23,8 & 26,20 & 26,7 & 33,8 & 25,7 & & & 8 & 6 & 10 & 7 & - & 4,09 & 0,47 & 0,35 & 0,42 & 0,39 \\
\hline 10 & 16,24 & 23,0 & 26,80 & 27,0 & 33,8 & 26,4 & 7 & 6 & 7 & 7 & 11 & 8 & - & 5,63 & 2,36 & 0,40 & 0,52 & 0,38 \\
\hline MÍNIMO & 16,04 & 21,4 & 24,5 & 23,0 & 24,9 & 21,2 & 5 & 6 & 7 & 5 & 9 & 5 & - & 4,09 & 0,37 & 0,32 & 0,40 & 0,37 \\
\hline MÁXIMO & 18,38 & 25,6 & 26,8 & 27,0 & 33,8 & 26,6 & 7 & 8 & 8 & 7 & 11 & 8 & - & 5,63 & 3,19 & 0,40 & 0,78 & 0,83 \\
\hline
\end{tabular}

AD: água de diluição; AE: água de estudo; Efluentes: FAP: filtro ascendente de pedregulho, INTER: intercloração, FD: filtração descendente, FCAG: filtro com carvão ativado granular; ${ }^{*}$ ): leitura em turbidímetro de bancada 2100P HACH; OD: método de Winkler (sonda Horiba U-10); ant.: antes da DFI; dep.: depois da DFI. 
Tabela 5.6.12 - Resultados dos testes ecotoxicológicos com microcrustáceos (Ceriodaphnia dúbia - CD e Ceriodaphnia silvestri - CS) - ENSAIO 4-IP (em instalação piloto): total indivíduos imóveis / total indivíduos expostos, imobilidade, $\mathrm{pH}$, condutividade e dureza das águas de diluição e de estudo e efluentes ENSAIO4-IP: Sistema MR $\rightarrow$ FAP $\rightarrow$ FD $\rightarrow$ PÓS e FCAG (simultaneamente)

\begin{tabular}{|c|c|c|c|c|c|c|c|c|c|c|c|c|c|c|c|c|c|c|}
\hline \multirow{2}{*}{\multicolumn{2}{|c|}{$\begin{array}{c}\text { Início: 03jun06 } \\
\text { Fim: 05jun06 }\end{array}$}} & \multirow{2}{*}{\multicolumn{6}{|c|}{$\begin{array}{c}\text { Réplicas } \\
\text { (ind. Imóveis / total ind. expostos) }\end{array}$}} & \multirow{3}{*}{\multicolumn{2}{|c|}{$\begin{array}{l}\text { Total ind. imóveis / } \\
\text { total ind. expostos }\end{array}$}} & \multirow{3}{*}{\multicolumn{2}{|c|}{ \% imobilidade }} & \multirow{3}{*}{\multicolumn{3}{|c|}{$\mathrm{pH}$}} & \multirow{3}{*}{\multicolumn{3}{|c|}{$\begin{array}{l}\text { Condutividade } \\
(\mu \mathrm{S} / \mathrm{cm})\end{array}$}} & \multirow{4}{*}{$\begin{array}{c}\begin{array}{c}\text { Dureza } \\
\left(\mathrm{mg} \mathrm{CaCO}_{3} / \mathrm{L}\right)\end{array} \\
\text { fim }\end{array}$} \\
\hline & & & & & & & & & & & & & & & & & & \\
\hline \multirow{3}{*}{$\begin{array}{c}\text { Hora } \\
(\mathrm{h})\end{array}$} & \multirow{3}{*}{ Amostra } & \multicolumn{3}{|c|}{ C. dúbia CD } & \multicolumn{3}{|c|}{ C. silvestrii CS } & & & & & & & & & & & \\
\hline & & 1 & 2 & 3 & 1 & 2 & 3 & $\mathrm{CD}$ & CS & $\mathrm{CD}$ & CS & início & CD & CS & início & $\mathrm{CD}$ & CS & \\
\hline & & 1 & 2 & 3 & 1 & 2 & 3 & $\mathrm{CD}$ & $\mathrm{CS}$ & $\mathrm{CD}$ & $\mathrm{CS}$ & início & $\mathrm{CD}$ & CS & início & $\mathrm{CD}$ & CS & fim \\
\hline \multicolumn{2}{|c|}{ Controle } & $0 / 5$ & $1 / 5$ & $2 / 5$ & $4 / 5$ & $1 / 5$ & $2 / 5$ & $3 / 15$ & $7 / 15$ & 20 & 46,67 & 7,41 & 7,76 & 7,78 & 160,0 & 179,4 & 181,0 & 46 \\
\hline \multirow{6}{*}{1} & $\mathrm{AD}$ & $4 / 5$ & $1 / 5$ & $2 / 5$ & $1 / 5$ & $1 / 5$ & $0 / 5$ & $7 / 15$ & $2 / 15$ & 46,67 & 13,33 & 6,42 & 6,88 & 6,78 & 22,7 & 26,8 & 26,7 & 6 \\
\hline & $\mathrm{AE}$ & $1 / 5$ & $1 / 5$ & $2 / 5$ & $1 / 5$ & $1 / 5$ & $2 / 5$ & $4 / 15$ & $4 / 15$ & 26,67 & 26,67 & 6,85 & 6,95 & 6,91 & 32,8 & 35,9 & 31,5 & 10 \\
\hline & FAP & $4 / 5$ & $4 / 5$ & $5 / 5$ & $5 / 5$ & $5 / 5$ & $0 / 5$ & $13 / 15$ & $10 / 15$ & 86,67 & 66,67 & 6,54 & 6,83 & 6,41 & 29,2 & 27,5 & 30,0 & 6 \\
\hline & FD & $2 / 5$ & $3 / 5$ & $5 / 5$ & $1 / 5$ & $0 / 5$ & $2 / 5$ & $10 / 15$ & $3 / 15$ & 66,67 & 20 & 6,73 & 6,65 & 6,72 & 41,2 & 39,9 & 42,7 & 10 \\
\hline & PÓS & $3 / 5$ & $3 / 5$ & $4 / 5$ & $1 / 5$ & $3 / 5$ & $2 / 5$ & $10 / 15$ & $6 / 15$ & 66,67 & 40 & 7,07 & 6,91 & 6,89 & 51,3 & 50,5 & 51,4 & 10 \\
\hline & FCAG & $5 / 5$ & $4 / 5$ & $4 / 5$ & $5 / 5$ & $3 / 5$ & $5 / 5$ & $13 / 15$ & $13 / 15$ & 86,67 & 86,67 & 7,31 & 7,20 & 6,48 & 36,1 & 35,1 & 37,7 & 10 \\
\hline \multirow{6}{*}{$\begin{array}{c}6 \\
\text { (ant.) }\end{array}$} & $\mathrm{AD}$ & $1 / 5$ & $2 / 5$ & $1 / 5$ & $1 / 5$ & $1 / 5$ & $1 / 5$ & $4 / 15$ & $3 / 15$ & 26,67 & 20 & 6,45 & 6,77 & 6,77 & 21,3 & 26,4 & 28,4 & 8 \\
\hline & $\mathrm{AE}$ & $0 / 5$ & $5 / 5$ & $2 / 5$ & $3 / 5$ & $0 / 5$ & $1 / 5$ & $7 / 15$ & $4 / 15$ & 46,67 & 26,67 & 6,98 & 6,95 & 6,96 & 34,5 & 39,3 & 35,0 & 8 \\
\hline & FAP & $4 / 5$ & $3 / 5$ & $5 / 5$ & $1 / 5$ & $1 / 5$ & $1 / 5$ & $12 / 15$ & $3 / 15$ & 80 & 20 & 6,65 & 4,22 & 6,75 & 41,4 & 65,2 & 41,1 & 8 \\
\hline & FD & $5 / 5$ & $5 / 5$ & $5 / 5$ & $5 / 5$ & $4 / 5$ & $5 / 5$ & $15 / 15$ & $14 / 15$ & 100 & 93,33 & 6,70 & 6,86 & 5,25 & 41,2 & 40,8 & 39,6 & 10 \\
\hline & PÓS & $1 / 5$ & $2 / 5$ & $1 / 5$ & $2 / 5$ & $2 / 5$ & $1 / 5$ & $4 / 15$ & $5 / 15$ & 26,67 & 33,33 & 6,94 & 6,96 & 6,92 & 55,8 & 52,8 & 54,6 & 10 \\
\hline & FCAG & $3 / 5$ & $4 / 5$ & $4 / 5$ & $4 / 5$ & $5 / 5$ & $5 / 5$ & $11 / 15$ & $14 / 15$ & 73,33 & 93,33 & 8,71 & 7,13 & 7,19 & 40,3 & 37,7 & 40,6 & 8 \\
\hline \multirow{4}{*}{$\begin{array}{c}7 \\
\text { (dep) }\end{array}$} & FAP & $4 / 5$ & $3 / 5$ & $5 / 5$ & $2 / 5$ & $3 / 5$ & $4 / 5$ & $12 / 15$ & $9 / 15$ & 80 & 60 & 6,61 & 6,78 & 6,78 & 42,5 & 36,6 & 41,8 & 8 \\
\hline & FD & $2 / 5$ & $4 / 5$ & $4 / 5$ & $3 / 5$ & $4 / 5$ & $3 / 5$ & $10 / 15$ & $10 / 15$ & 66,67 & 66,67 & 6,77 & 6,82 & 6,81 & 41,4 & 40,7 & 46,0 & 10 \\
\hline & PÓS & $4 / 5$ & $3 / 5$ & $2 / 5$ & $0 / 5$ & $1 / 5$ & $0 / 5$ & $9 / 15$ & $1 / 15$ & 60 & 6,67 & 6,95 & 6,97 & 6,92 & 60,7 & 57,2 & 55,7 & 16 \\
\hline & FCAG & $4 / 5$ & $3 / 5$ & $5 / 5$ & $5 / 5$ & $4 / 5$ & $5 / 5$ & $12 / 15$ & $14 / 15$ & 80 & 93,33 & 8,35 & 7,12 & 7,02 & 40,9 & 40,4 & 36,1 & - \\
\hline \multirow{6}{*}{10} & $\mathrm{AD}$ & $3 / 5$ & $1 / 5$ & $1 / 5$ & $2 / 5$ & $1 / 5$ & $1 / 5$ & $5 / 15$ & $4 / 15$ & 33,33 & 26,67 & 6,53 & 6,74 & 6,76 & 21,3 & 27,0 & 26,0 & 6 \\
\hline & $\mathrm{AE}$ & $1 / 5$ & $1 / 5$ & $3 / 5$ & $1 / 5$ & $2 / 5$ & $2 / 5$ & $5 / 15$ & $5 / 15$ & 33,33 & 33,33 & 6,90 & 6,96 & 6,97 & 34,4 & 37,5 & 35,6 & 8 \\
\hline & FAP & $4 / 5$ & $2 / 5$ & $4 / 5$ & $3 / 5$ & $4 / 5$ & $1 / 5$ & $10 / 15$ & $8 / 15$ & 66,67 & 53,33 & 6,98 & 6,81 & 6,76 & 42,1 & 42,8 & 40,7 & 8 \\
\hline & FD & $4 / 5$ & $4 / 5$ & $5 / 5$ & $3 / 5$ & $5 / 5$ & $5 / 5$ & $13 / 15$ & $13 / 15$ & 86,67 & 86,67 & 6,75 & - & 6,83 & 44,2 & 39,1 & 40,9 & 10 \\
\hline & PÓS & $4 / 5$ & $4 / 5$ & $4 / 5$ & $2 / 5$ & $0 / 5$ & $0 / 5$ & $12 / 15$ & $2 / 15$ & 80 & 13,33 & 6,85 & 6,95 & 6,86 & 60,7 & 60,7 & 59,5 & 14 \\
\hline & FCAG & $5 / 5$ & $5 / 5$ & $5 / 5$ & $4 / 5$ & $4 / 5$ & $5 / 5$ & $15 / 15$ & $13 / 15$ & 100 & 86,67 & 8,29 & 6,96 & 7,10 & 41,3 & 43,4 & 39,8 & 8 \\
\hline
\end{tabular}


Tabela 5.6.13 - Parâmetros de controle - operação do ENSAIO 5-IP (em instalação piloto): temperatura, pH, potencial zeta e residual de cloro livre das águas de diluição e de estudo e

\begin{tabular}{|c|c|c|c|c|c|c|c|c|c|c|c|c|c|c|c|}
\hline & $\mathrm{t}\left({ }^{\circ} \mathrm{C}\right)$ & $\mathrm{pH}$ & $\mathrm{Pz}(\mathrm{mV})$ & $\mathrm{pH}$ & $\mathrm{Pz}(\mathrm{mV})$ & $\mathrm{pH}$ & $\mathrm{Pz}(\mathrm{mV})$ & $\mathrm{pH}$ & $\mathrm{Pz}(\mathrm{mV})$ & $\mathrm{pH}$ & $\mathrm{Pz}(\mathrm{mV})$ & $\mathrm{pH}$ & $\begin{array}{l}\text { Cl res. } \\
\text { (mg/L) }\end{array}$ & $\mathrm{pH}$ & $\mathrm{Pz}(\mathrm{mV})$ \\
\hline Hora (h) & \multicolumn{3}{|c|}{$\mathrm{AD}$} & \multicolumn{2}{|c|}{$\mathrm{AE}$} & \multicolumn{2}{|c|}{$\mathrm{AC}$} & \multicolumn{2}{|c|}{$\frac{1}{\text { FAP }}$} & \multicolumn{2}{|c|}{ FD } & \multicolumn{2}{|c|}{ PÓS } & \multicolumn{2}{|c|}{ FCAG } \\
\hline 1 & 18,50 & 6,70 & $-5,00$ & 6,60 & $-33,00$ & 6,40 & $-8,80$ & 6,60 & $-2,10$ & 6,80 & $-1,90$ & 7,07 & 0,37 & 9,50 & $-1,90$ \\
\hline 3 & 22,00 & 6,88 & - & 7,40 & $-31,30$ & 6,70 & $-12,00$ & 6,85 & $-2,00$ & 6,84 & $-2,00$ & 6,90 & 0,29 & - & - \\
\hline 6 (ant.) & 21,50 & 6,57 & $-2,00$ & 7,20 & $-33,60$ & 6,90 & $-6,20$ & 6,55 & $-2,10$ & 6,64 & $-2,00$ & 6,57 & 1,40 & 9,30 & $-1,90$ \\
\hline 7 (dep.) & - & - & - & & $-35,20$ & 6,88 & $-12,00$ & - & - & - & - & - & 0,98 & - & - \\
\hline 10 & 20,00 & 6,80 & - & 7,10 & $-35,00$ & 6,85 & $-5,20$ & 6,88 & $-2,10$ & 6,74 & $-2,40$ & 7,01 & 1,51 & - & - \\
\hline MÍNIMO & 18,5 & 6,6 & $-5,0$ & 6,6 & $-35,2$ & 6,4 & $-12,0$ & 6,6 & $-2,1$ & 6,6 & $-2,4$ & 6,6 & 0,3 & 9,3 & $-1,9$ \\
\hline MÁXIMO & 22,0 & 6,9 & $-2,0$ & 7,4 & $-31,3$ & 6,9 & $-5,2$ & 6,9 & $-2,0$ & 6,8 & $-1,9$ & 7,1 & 1,5 & 9,5 & $-1,9$ \\
\hline
\end{tabular}

Tabela 5.6.14 - Parâmetros de controle - desempenho do ENSAIO 5-IP (em instalação piloto): carbono orgânico total, absorvância 254, oxigênio dissolvido, condutividade elétrica, dureza e turbidez das águas de diluição e de estudo e dos efluentes de cada processo de tratamento para diferentes tempos de amostragem

\begin{tabular}{|c|c|c|c|c|c|c|c|c|c|c|c|c|c|c|c|c|c|c|}
\hline & \multicolumn{6}{|c|}{ Carbono orgânico total - COT (mg/L) } & \multicolumn{6}{|c|}{ absorvância 254} & \multicolumn{6}{|c|}{ Oxigênio dissolvido - OD (mg/L) } \\
\hline Hora (h) & $\mathrm{AD}$ & $\mathrm{AE}$ & FAP & FD & PÓS & FCAG & $\overline{\mathrm{AD}}$ & $\overline{\mathrm{AE}}$ & FAP & FD & PÓS & FCAG & $\mathrm{AD}$ & $\overline{\mathrm{AE}}$ & FAP & FD & PÓS & $\overline{\text { FCAG }}$ \\
\hline 1 & - & 2,9 & 1,221 & 1,222 & 1,198 & 0,971 & - & 0,022 & 0,012 & 0,012 & 0,017 & 0,002 & 7,70 & 7,72 & 8,00 & 7,5 & 8,22 & 6,22 \\
\hline 3 & - & 3,113 & 1,173 & 1,171 & 1,24 & 0,883 & - & 0,023 & 0,012 & 0,012 & 0,024 & 0,007 & 7,83 & 7,92 & 8,05 & 7,85 & 7,93 & 7,34 \\
\hline 6 (ant.) & - & 2,447 & 1,254 & 1,337 & 1,181 & 2,719 & - & 0,035 & 0,018 & 0,027 & 0,022 & 0,008 & 7,51 & 7,69 & 7,33 & 7,31 & 7,51 & 7,05 \\
\hline 7 (dep.) & - & 2,963 & 1,563 & 1,586 & 1,413 & 1,096 & - & 0,03 & 0,014 & 0,012 & 0,015 & 0,008 & 7,25 & 7,32 & 7,35 & 6,94 & 7,67 & 7,09 \\
\hline 10 & - & 4,311 & 1,558 & 1,411 & 1,3 & 0,811 & - & 0,029 & 0,019 & 0,019 & 0,026 & 0,009 & 7,90 & 8,06 & 8,14 & 7,98 & 8,71 & 8,39 \\
\hline MÍNIMO & - & 2,447 & 1,173 & 1,171 & 1,181 & 0,811 & - & 0,022 & 0,012 & 0,012 & 0,015 & 0,002 & 7,3 & 7,3 & 8,1 & 6,9 & 7,5 & 6,2 \\
\hline \multirow[t]{2}{*}{ MÁXIMO } & - & 4,311 & 1,563 & 1,586 & 1,413 & 2,719 & - & 0,035 & 0,019 & 0,027 & 0,026 & 0,009 & 8,8 & 8,7 & 8,1 & 8,8 & 9,2 & 8,4 \\
\hline & \multicolumn{6}{|c|}{ Condutividade elétrica $(\mu \mathrm{S} / \mathrm{cm})$} & \multicolumn{6}{|c|}{ Dureza $\left(\mathrm{mgCaCO}_{3} / \mathrm{L}\right)$} & \multicolumn{6}{|c|}{ Turbidez $^{(*)}(\mathrm{uT})$} \\
\hline Hora (h) & $\mathrm{AD}$ & $\mathrm{AE}$ & FAP & FD & PÓS & FCAG & $\mathrm{AD}$ & $\mathrm{AE}$ & FAP & FD & PÓS & FCAG & $\mathrm{AD}$ & $\mathrm{AE}$ & FAP & FD & PÓS & FCAG \\
\hline 1 & 14,82 & 20,8 & 24,80 & 26,2 & 27,2 & 53,2 & 5 & 6 & 5 & 6 & 8 & 14 & - & - & 0,42 & 0,38 & 0,43 & 0,39 \\
\hline 3 & 14,62 & 22,2 & 27,5 & 28 & 34,1 & 29,9 & 5 & 6 & 6 & 6 & 7 & 6 & - & - & 0,30 & 0,40 & 0,35 & 0,36 \\
\hline 6 (ant.) & 14,75 & 20,1 & 28 & 27,8 & 29,4 & 33,5 & 6 & 7 & 7 & 6 & 7 & 7 & - & - & 0,36 & 0,40 & 0,34 & 0,57 \\
\hline 7 (dep.) & 14,77 & 22,3 & 28,5 & 27,5 & 32 & 28,9 & 6 & 7 & 7 & 6 & 7 & 6 & - & - & 0,34 & 0,35 & 0,37 & 0,40 \\
\hline 10 & 14,77 & 21,5 & 26,7 & 26,2 & 36 & 26,8 & 5 & 5 & 5 & 5 & 6 & 6 & - & - & 0,35 & 0,38 & 0,43 & 0,50 \\
\hline MÍNIMO & 14,62 & 20,1 & 24,8 & 26,2 & 27,2 & 26,8 & 5 & 5 & 5 & 5 & 6 & 6 & - & - & 0,30 & 0,35 & 0,34 & 0,36 \\
\hline MÁXIMO & 14,82 & 22,3 & 28,5 & 28 & 36 & 53,2 & 6 & 7 & 7 & 6 & 8 & 14 & - & - & 0,42 & 0,40 & 0,43 & 0,57 \\
\hline
\end{tabular}

AD: água de diluição; AE: água de estudo; Efluentes: FAP: filtro ascendente de pedregulho, PÓS: pós-cloração, FD: filtracão descendente, FCAG: filtro com carvão ativado granular; (*): leitura em turbidímetro de bancada 2100P HACH; OD: método de Winkler (sonda Horiba U-10); ant.: antes da DFI; dep.: depois da DF 
Tabela 5.6.15 - Resultados dos testes ecotoxicológicos com microcrustáceos (Ceriodaphnia dúbia - CD e Ceriodaphnia silvestri - CS) - ENSAIO 5-IP (em instalação piloto): total indivíduos imóveis / total indivíduos expostos, imobilidade, $\mathrm{pH}$, condutividade e dureza das águas de diluição e de estudo e efluentes ENSAIO5-IP: Sistema MR $\rightarrow$ FAP $\rightarrow$ FD $\rightarrow$ PÓS e FCAG (simultaneamente)

\begin{tabular}{|c|c|c|c|c|c|c|c|c|c|c|c|c|c|c|c|c|c|}
\hline \multicolumn{2}{|c|}{\begin{tabular}{|l} 
Início: 25jul06 \\
Fim: 27jul06 \\
\end{tabular}} & \multicolumn{6}{|c|}{$\begin{array}{l}\text { Réplicas lote CD 08,14, 18/7 e CS 12/07 } \\
\text { (ind. Imóveis / total ind. expostos) }\end{array}$} & \multirow{2}{*}{\multicolumn{2}{|c|}{$\begin{array}{l}\text { Total ind. imóveis / } \\
\text { total ind. expostos }\end{array}$}} & \multirow{2}{*}{\multicolumn{2}{|c|}{ \% imobilidade }} & \multirow{2}{*}{\multicolumn{2}{|c|}{$\mathrm{pH}$}} & \multirow{2}{*}{\multicolumn{2}{|c|}{$\begin{array}{l}\text { Condutividade } \\
(\mu \mathrm{S} / \mathrm{cm})\end{array}$}} & \multirow{2}{*}{\multicolumn{2}{|c|}{$\begin{array}{c}\text { Dureza } \\
\left(\mathrm{mg} \mathrm{CaCO}_{3} / \mathrm{L}\right)\end{array}$}} \\
\hline \multirow{2}{*}{$\begin{array}{c}\text { Hora } \\
\text { (h) }\end{array}$} & \multirow{2}{*}{ Amostra } & \multicolumn{3}{|c|}{ C. dúbia CD } & \multicolumn{3}{|c|}{ C. silvestrii CS } & & & & & & & & & & \\
\hline & & 1 & 2 & 3 & 1 & 2 & 3 & $\mathrm{CD}$ & $\mathrm{CS}$ & $\mathrm{CD}$ & $\mathrm{CS}$ & início & fim & início & fim & início & fim \\
\hline \multirow{7}{*}{1} & ontrole & $0 / 5$ & $0 / 5$ & $0 / 5$ & $0 / 5$ & $0 / 5$ & $0 / 5$ & $0 / 15$ & $0 / 15$ & 0 & 0 & 7,38 & 7,76 & 160,0 & 196,7 & 44 & - \\
\hline & $\mathrm{AD}$ & $4 / 5$ & $1 / 5$ & $3 / 5$ & $1 / 5$ & $1 / 5$ & $1 / 5$ & $8 / 15$ & $3 / 15$ & 53,33 & 20 & 6,94 & 7,39 & 14,82 & 40,5 & 5 & - \\
\hline & $\mathrm{AE}$ & $0 / 5$ & $0 / 5$ & $0 / 5$ & $0 / 5$ & $0 / 5$ & $0 / 5$ & $0 / 15$ & $0 / 15$ & 0 & 0 & 7,08 & 7,08 & 20,8 & 38,2 & 6 & 8 \\
\hline & FAP & $4 / 5$ & $4 / 5$ & $4 / 5$ & $4 / 5$ & $2 / 5$ & $5 / 5$ & $12 / 15$ & $11 / 15$ & 80 & 73,33 & 6,86 & 6,87 & 24,8 & 44,2 & 5 & 8 \\
\hline & FD & $3 / 5$ & $3 / 5$ & $3 / 5$ & $1 / 5$ & $1 / 5$ & $0 / 5$ & $9 / 15$ & $2 / 15$ & 60 & 13,33 & 6,84 & 6,88 & 26,2 & 43,1 & 6 & 8 \\
\hline & PÓS & $1 / 5$ & $1 / 5$ & $1 / 5$ & - & $0 / 5$ & $0 / 5$ & $3 / 15$ & $0 / 10$ & 20 & 0 & 7,18 & 7,00 & 27,2 & 53,7 & 8 & 8 \\
\hline & FCAG & $2 / 5$ & $1 / 5$ & $1 / 5$ & $1 / 5$ & $1 / 5$ & $1 / 5$ & $4 / 15$ & $3 / 15$ & 26,67 & 20 & 8,45 & 7,88 & 53,2 & 86,3 & 14 & 16 \\
\hline \multirow{6}{*}{$\begin{array}{c}6 \\
\text { (ant.) }\end{array}$} & $\mathrm{AD}$ & $1 / 5$ & $2 / 5$ & $3 / 5$ & $1 / 5$ & $0 / 5$ & $0 / 5$ & $6 / 15$ & $1 / 15$ & 40 & 6,67 & 6,95 & 7,38 & 14,75 & 40,0 & 6 & 12 \\
\hline & $\mathrm{AE}$ & $0 / 5$ & $0 / 5$ & $2 / 5$ & $1 / 5$ & $1 / 5$ & $0 / 5$ & $2 / 15$ & $2 / 15$ & 13,33 & 13,33 & 7,10 & 7,04 & 20,1 & 38,7 & 7 & 8 \\
\hline & FAP & $1 / 5$ & $1 / 5$ & $0 / 5$ & $0 / 5$ & $0 / 5$ & $0 / 5$ & $2 / 15$ & $0 / 15$ & 13,33 & 0 & 6,76 & 6,80 & 28,0 & 48,1 & 7 & 8 \\
\hline & FD & $0 / 5$ & $4 / 5$ & $1 / 5$ & $0 / 5$ & $0 / 5$ & $0 / 5$ & $5 / 15$ & $0 / 15$ & 33,33 & 0 & 6,83 & 6,85 & 27,8 & 46,4 & 6 & 8 \\
\hline & PÓS & $2 / 5$ & $2 / 5$ & $1 / 5$ & - & $0 / 5$ & $0 / 5$ & $5 / 15$ & $0 / 10$ & 33,33 & 0 & 7,03 & 6,88 & 29,4 & 62,7 & 7 & 10 \\
\hline & FCAG & $3 / 5$ & $1 / 5$ & $1 / 5$ & $3 / 5$ & $2 / 5$ & $2 / 5$ & $5 / 15$ & $7 / 15$ & 33,33 & 46,67 & 8,30 & 7,48 & 33,5 & 49,3 & 7 & 10 \\
\hline \multirow{4}{*}{$\begin{array}{c}7 \\
\text { (dep) }\end{array}$} & FAP & $1 / 5$ & $2 / 5$ & $2 / 5$ & $0 / 5$ & $0 / 5$ & $0 / 5$ & $5 / 15$ & $0 / 15$ & 33,33 & 0 & 6,75 & 6,84 & 28,5 & 47,7 & 7 & 8 \\
\hline & FD & $0 / 5$ & $0 / 5$ & $1 / 5$ & $1 / 5$ & $0 / 5$ & $0 / 5$ & $1 / 15$ & $1 / 15$ & 6,67 & 6,67 & 6,78 & 6,86 & 27,5 & 46,5 & 6 & 8 \\
\hline & PÓS & $3 / 5$ & $5 / 5$ & $5 / 5$ & $4 / 5$ & $5 / 5$ & - & $13 / 15$ & $9 / 10$ & 86,67 & 90 & 8,30 & 7,45 & 32,0 & 48,4 & 7 & 12 \\
\hline & FCAG & $2 / 5$ & $2 / 5$ & $1 / 5$ & $0 / 5$ & $0 / 5$ & $1 / 5$ & $5 / 15$ & $1 / 15$ & 33,33 & 6,67 & 6,96 & 6,92 & 28,9 & 58,4 & 6 & 10 \\
\hline \multirow{6}{*}{10} & $\mathrm{AD}$ & $4 / 5$ & $2 / 5$ & $2 / 5$ & $1 / 5$ & $1 / 5$ & $2 / 5$ & $8 / 15$ & $4 / 15$ & 53,33 & 26,67 & 6,90 & 7,35 & 14,77 & 40,6 & 5 & - \\
\hline & $\mathrm{AE}$ & $1 / 5$ & $0 / 5$ & $0 / 5$ & $1 / 5$ & $1 / 5$ & $0 / 5$ & $1 / 15$ & $2 / 15$ & 6,67 & 13,33 & 7,12 & 7,03 & 21,5 & 38,4 & 5 & 10 \\
\hline & FAP & $4 / 5$ & $5 / 5$ & $5 / 5$ & $3 / 5$ & $3 / 5$ & $5 / 5$ & $14 / 15$ & $11 / 15$ & 93,33 & 73,33 & 6,64 & 6,83 & 26,7 & 44,7 & 5 & 8 \\
\hline & FD & $3 / 5$ & $3 / 5$ & $1 / 5$ & $1 / 5$ & $0 / 5$ & $0 / 5$ & $7 / 15$ & $1 / 15$ & 46,67 & 6,67 & 6,77 & 6,87 & 26,2 & 44,5 & 5 & 8 \\
\hline & PÓS & $0 / 5$ & $1 / 5$ & $1 / 5$ & $1 / 5$ & - & $0 / 5$ & $2 / 15$ & $1 / 10$ & 13,33 & 10 & 7,13 & 6,84 & 36,0 & 60,9 & 6 & 10 \\
\hline & FCAG & $5 / 5$ & $4 / 5$ & $3 / 5$ & $3 / 5$ & $2 / 5$ & $3 / 5$ & $12 / 15$ & $8 / 15$ & 80 & 53,33 & 7,93 & 7,36 & 26,8 & 48,4 & 6 & 10 \\
\hline
\end{tabular}


Tabela 5.6.16 - Parâmetros de controle - operação do ENSAIO 6-IP (em instalação piloto): temperatura, pH, potencial zeta e residual de cloro livre das águas de diluição e de estudo e

\begin{tabular}{|c|c|c|c|c|c|c|c|c|c|c|c|c|c|c|c|}
\hline & $\mathrm{t}\left({ }^{\circ} \mathrm{C}\right)$ & $\mathrm{pH}$ & $\mathrm{Pz}(\mathrm{mV})$ & $\mathrm{pH}$ & $\mathrm{Pz}(\mathrm{mV})$ & $\mathrm{pH}$ & $\mathrm{Pz}(\mathrm{mV})$ & $\mathrm{pH}$ & $\mathrm{Pz}(\mathrm{mV})$ & $\mathrm{pH}$ & $\begin{array}{l}\text { Cl res. } \\
\text { (mg/L) }\end{array}$ & $\mathrm{pH}$ & $\mathrm{Pz}(\mathrm{mV})$ & $\mathrm{pH}$ & $\mathrm{Pz}(\mathrm{mV})$ \\
\hline Hora (h) & \multicolumn{3}{|c|}{$\mathrm{AD}$} & \multicolumn{2}{|c|}{$\mathrm{AE}$} & \multicolumn{2}{|c|}{$\mathrm{AC}$} & \multicolumn{2}{|c|}{$\frac{1}{\text { FAP }}$} & \multicolumn{2}{|c|}{ INTER } & \multicolumn{2}{|c|}{ FD } & \multicolumn{2}{|c|}{ FCAG } \\
\hline 1 & 22,00 & 6,80 & $-2,30$ & 6,84 & $-25,00$ & 6,70 & $-1,30$ & 6,71 & $-2,00$ & 6,70 & 1,00 & 6,72 & $-2,10$ & 7,50 & $-2,10$ \\
\hline 3 & 21,00 & 6,89 & - & 6,9 & $-23,70$ & 6,40 & $-0,30$ & 6,59 & $-2,00$ & 6,61 & 0,48 & 6,70 & - & 7,89 & - \\
\hline 6 (ant.) & 21,00 & 6,81 & $-2,90$ & 6,8 & $-17,70$ & 6,80 & $-1,30$ & 6,70 & $-2,10$ & 6,76 & 0,20 & 6,76 & $-2,00$ & 7,80 & $-2,00$ \\
\hline 7 (dep.) & 20,50 & 6,83 & - & 6,74 & - & 6,48 & $-0,70$ & 6,72 & $-2,20$ & 6,77 & 0,33 & - & - & - & - \\
\hline 10 & 19,00 & 6,90 & $-2,20$ & 6,95 & $-13,50$ & 6,82 & $-1,80$ & 6,88 & $-2,00$ & 6,82 & 0,20 & 6,80 & $-1,90$ & 7,85 & - \\
\hline MÍNIMO & 19,0 & 6,8 & $-2,9$ & 6,7 & $-25,0$ & 6,4 & $-1,8$ & 6,6 & $-2,2$ & 6,6 & 0,2 & 6,7 & $-2,1$ & 7,5 & $-2,1$ \\
\hline MÁXIMO & 22,0 & 6,9 & $-2,2$ & 7,0 & $-13,5$ & 6,8 & $-0,3$ & 6,9 & $-2,0$ & 6,8 & 1,0 & 6,8 & $-1,9$ & 7,9 & $-2,0$ \\
\hline
\end{tabular}

Tabela 5.6.17 - Parâmetros de controle - desempenho do ENSAIO 6-IP (em instalação piloto): carbono orgânico total, absorvância 254, oxigênio dissolvido, condutividade elétrica, dureza e turbidez das águas de diluição e de estudo e dos efluentes de cada processo de tratamento para diferentes tempos de amostragem

\begin{tabular}{|c|c|c|c|c|c|c|c|c|c|c|c|c|c|c|c|c|c|c|}
\hline \multirow[b]{2}{*}{ Hora (h) } & \multicolumn{6}{|c|}{ Carbono orgânico total - COT (mg/L) } & \multicolumn{6}{|c|}{ absorvância 254} & \multicolumn{6}{|c|}{ Oxigênio dissolvido - OD (mg/L) } \\
\hline & $\mathrm{AD}$ & $\mathrm{AE}$ & FAP & INTER & FD & FCAG & $\mathrm{AD}$ & $\overline{\mathrm{AE}}$ & FAP & INTER & FD & FCAG & $\mathrm{AD}$ & $\mathrm{AE}$ & FAP & INTER & FD & FCAG \\
\hline 1 & - & 1,379 & 0,943 & 1,074 & 1,224 & 1,696 & - & 0,012 & 0,01 & 0,015 & 0,016 & 0,029 & 7,33 & 7,50 & 7,78 & 7,64 & 7,34 & 5,71 \\
\hline 3 & - & 1,4 & 1,211 & 1,205 & 1,12 & 1,063 & - & 0,019 & 0,007 & 0,015 & 0,015 & 0,022 & 7,40 & 7,57 & 7,72 & 7,62 & 7,70 & 7,22 \\
\hline 6 (ant.) & - & 1,327 & 0,19 & 1,129 & 1,33 & 1,008 & - & 0,011 & 0,007 & 0,012 & 0,014 & 0,019 & 7,56 & 7,70 & 7,58 & 7,64 & 7,67 & 7,31 \\
\hline 7 (dep.) & - & 1,498 & 1,276 & 1,033 & 1,032 & 0,738 & - & 0,013 & 0,012 & 0,014 & 0,013 & 0,014 & 7,65 & 7,67 & 7,93 & 7,81 & 7,90 & 7,50 \\
\hline 10 & - & 1,139 & 1,044 & 1,149 & 1,036 & 0,777 & - & 0,014 & 0,009 & 0,014 & 0,014 & 0,018 & 7,90 & 7,85 & 8,28 & 8,17 & 7,73 & 7,62 \\
\hline MÍNIMO & - & 1,139 & 0,943 & 1,033 & 1,032 & 0,738 & - & 0,011 & 0,007 & 0,012 & 0,013 & 0,014 & 7,3 & 7,5 & 7,6 & 7,6 & 7,3 & 5,7 \\
\hline \multirow[t]{2}{*}{ MÁXIMO } & - & 1,498 & 1,276 & 1,205 & 1,33 & 1,696 & - & 0,019 & 0,012 & 0,015 & 0,016 & 0,029 & 7,9 & 7,9 & 8,3 & 8,2 & 7,9 & 7,6 \\
\hline & \multicolumn{6}{|c|}{ Condutividade elétrica $(\mu \mathrm{S} / \mathrm{cm})$} & \multicolumn{6}{|c|}{ Dureza $\left(\mathrm{mgCaCO}_{3} / \mathrm{L}\right)$} & \multicolumn{6}{|c|}{ Turbidez $^{(*)}(\mathrm{uT})$} \\
\hline Hora (h) & $\mathrm{AD}$ & $\mathrm{AE}$ & FAP & INTER & FD & FCAG & $\mathrm{AD}$ & $\mathrm{AE}$ & FAP & INTER & FD & FCAG & $\mathrm{AD}$ & $\mathrm{AE}$ & FAP & INTER & FD & FCAG \\
\hline 1 & 14,59 & 15,25 & 19,42 & 23,2 & 25,5 & 39,6 & 5 & 6 & 5 & 6 & 7 & 9 & - & - & 0,33 & 0,77 & 0,48 & 0,40 \\
\hline 3 & 14,75 & 14,96 & 19,45 & 24,9 & 25,2 & 25,5 & 4 & 5 & 5 & 5 & 5 & 6 & - & - & 0,3 & 0,3 & 0,3 & 0,5 \\
\hline 6 (ant.) & 14,83 & 15,14 & 20,6 & 24,7 & 25,1 & 26,5 & 4 & 5 & 4 & 4 & 4 & 4 & - & - & 0,28 & 0,35 & 0,50 & 0,38 \\
\hline 7 (dep.) & 14,85 & 15,16 & 20,3 & 25,4 & 24,4 & 25,7 & - & - & 4 & 4 & 4 & 4 & - & - & 0,4 & 0,4 & 0,4 & 0,5 \\
\hline 10 & 14,74 & 14,8 & 19,5 & 24,0 & 23,4 & 22,4 & 4 & 4 & 4 & 4 & 4 & 4 & - & - & 0,3 & 0,3 & 0,4 & 0,3 \\
\hline MÍNIMO & 14,59 & 14,83 & 19,42 & 23,2 & 23,4 & 22,4 & 4 & 4 & 4 & 4 & 4 & 4 & - & - & 0,27 & 0,30 & 0,31 & 0,34 \\
\hline MÁXIMO & 14,85 & 15,25 & 20,6 & 25,4 & 25,5 & 39,6 & 5 & 6 & 5 & 6 & 7 & 9 & - & - & 0,35 & 0,77 & 0,50 & 0,50 \\
\hline
\end{tabular}

AD: água de diluição; AE: água de estudo; Efluentes: FAP: filtro ascendente de pedregulho, INTER: intercloração, FD: filtração descendente, FCAG: filtro com carvão ativado granular; (*): leitura em

turbidímetro de bancada 2100P HACH; OD: método de Winkler (sonda Horiba U-10); ant.: antes da DFI; dep.: depois da DFI. 
Tabela 5.6.18 - Resultados dos testes ecotoxicológicos com microcrustáceos (Ceriodaphnia dúbia - CD e Ceriodaphnia silvestri - CS) - ENSAIO 6-IP (em instalação piloto): total indivíduos imóveis / total indivíduos expostos, imobilidade, $\mathrm{pH}$, condutividade e dureza das águas de diluição e de estudo e efluentes ENSAIO6-IP: Sistema MR $\rightarrow$ FAP $\rightarrow$ INTER $\rightarrow$ FD $\rightarrow$ FCAG

\begin{tabular}{|c|c|c|c|c|c|c|c|c|c|c|c|c|c|c|c|c|c|}
\hline \multicolumn{2}{|c|}{$\begin{array}{c}\text { Início: 26jul06 } \\
\text { Fim: 28jul06 }\end{array}$} & \multicolumn{6}{|c|}{$\begin{array}{l}\text { Réplicas lote CD 14/07 e CS 18/07 } \\
\text { (ind. Imóveis / total ind. expostos) }\end{array}$} & \multirow{2}{*}{\multicolumn{2}{|c|}{$\begin{array}{l}\text { Total ind. imóveis / } \\
\text { total ind. expostos }\end{array}$}} & \multirow{2}{*}{\multicolumn{2}{|c|}{ \% imobilidade }} & \multirow{2}{*}{\multicolumn{2}{|c|}{$\mathrm{pH}$}} & \multirow{2}{*}{\multicolumn{2}{|c|}{$\begin{array}{l}\text { Condutividade } \\
\qquad(\mu \mathrm{S} / \mathrm{cm})\end{array}$}} & \multirow{2}{*}{\multicolumn{2}{|c|}{$\begin{array}{c}\text { Dureza } \\
\left(\mathrm{mg} \mathrm{CaCO}_{3} / \mathrm{L}\right)\end{array}$}} \\
\hline \multirow{2}{*}{$\begin{array}{c}\text { Hora } \\
(\mathrm{h})\end{array}$} & \multirow{2}{*}{ Amostra } & \multicolumn{3}{|c|}{ C. dúbia CD } & \multicolumn{3}{|c|}{ C. silvestrii CS } & & & & & & & & & & \\
\hline & & 1 & 2 & 3 & 1 & 2 & 3 & $\mathrm{CD}$ & $\mathrm{CS}$ & $\mathrm{CD}$ & $\mathrm{CS}$ & início & fim & início & fim & início & fim \\
\hline \multicolumn{2}{|c|}{ Controle } & $0 / 5$ & $0 / 5$ & $0 / 5$ & $0 / 5$ & $0 / 5$ & $0 / 5$ & $0 / 15$ & $0 / 15$ & 0 & 0 & 7,38 & 7,82 & 160,0 & 186,5 & 44 & - \\
\hline \multirow{6}{*}{1} & $\mathrm{AD}$ & $2 / 5$ & $1 / 5$ & $0 / 5$ & $0 / 5$ & $1 / 5$ & $4 / 15$ & $1 / 15$ & 26,67 & 6,67 & 6,82 & 7,29 & 14,59 & 36,5 & 5 & 12 & 12 \\
\hline & $\mathrm{AE}$ & $5 / 5$ & $2 / 5$ & $0 / 5$ & $0 / 5$ & $0 / 5$ & $9 / 15$ & $0 / 15$ & 60 & 0 & 6,90 & 6,88 & 15,25 & 28,8 & 6 & - & - \\
\hline & FAP & $5 / 5$ & $5 / 5$ & $5 / 5$ & $5 / 5$ & $5 / 5$ & $15 / 15$ & $15 / 15$ & 100 & 100 & 6,75 & 6,72 & 19,42 & 31,1 & 5 & 6 & 6 \\
\hline & INTER & $5 / 5$ & $5 / 5$ & $5 / 5$ & $4 / 5$ & $4 / 5$ & $15 / 15$ & $13 / 15$ & 100 & 86,67 & 6,90 & 6,87 & 23,2 & 42,6 & 6 & - & - \\
\hline & FD & $5 / 5$ & $3 / 5$ & $2 / 5$ & $2 / 5$ & $3 / 5$ & $13 / 15$ & $7 / 15$ & 86,67 & 46,67 & 6,98 & 6,90 & 25,5 & 41,5 & 7 & - & - \\
\hline & CAG & $1 / 5$ & $0 / 5$ & $0 / 5$ & $0 / 5$ & $0 / 5$ & $3 / 15$ & $0 / 15$ & 20 & 0 & 7,88 & 7,43 & 39,6 & 68,6 & 9 & 14 & 14 \\
\hline \multirow{6}{*}{$\begin{array}{c}6 \\
\text { (ant.) }\end{array}$} & $\mathrm{AD}$ & $3 / 5$ & $3 / 5$ & $0 / 5$ & $3 / 5$ & $0 / 5$ & $8 / 15$ & $3 / 15$ & 53,33 & 20 & 6,84 & 7,21 & 14,83 & 33,0 & 4 & - & - \\
\hline & $\mathrm{AE}$ & $4 / 5$ & $2 / 5$ & $0 / 5$ & $0 / 5$ & $0 / 5$ & $9 / 15$ & $0 / 15$ & 60 & 0 & 6,88 & 6,85 & 15,14 & 27,8 & 5 & - & - \\
\hline & FAP & $5 / 5$ & $3 / 5$ & $5 / 5$ & $5 / 5$ & $5 / 5$ & $13 / 15$ & $15 / 15$ & 86,67 & 100 & 6,83 & 6,74 & 20,6 & 32,8 & 4 & 8 & 8 \\
\hline & INTER & $4 / 5$ & $4 / 5$ & $3 / 5$ & $3 / 5$ & $3 / 5$ & $13 / 15$ & $9 / 15$ & 86,67 & 60 & 6,90 & 6,98 & 24,7 & 39,9 & 4 & 8 & 8 \\
\hline & FD & $3 / 5$ & $3 / 5$ & $3 / 5$ & $4 / 5$ & $2 / 5$ & $9 / 15$ & $9 / 15$ & 60 & 60 & 6,94 & 6,96 & 25,1 & 40,0 & 4 & 8 & 8 \\
\hline & CAG & $2 / 5$ & $0 / 5$ & $0 / 5$ & $0 / 5$ & $2 / 5$ & $4 / 15$ & $2 / 15$ & 26,67 & 13,33 & 7,56 & 7,32 & 26,5 & 47,9 & 4 & 10 & 10 \\
\hline \multirow{4}{*}{$\begin{array}{c}7 \\
\text { (dep) }\end{array}$} & FAP & $5 / 5$ & $5 / 5$ & $5 / 5$ & $5 / 5$ & $5 / 5$ & $15 / 15$ & $15 / 15$ & 100 & 100 & 6,71 & 6,68 & 20,3 & 31,6 & 4 & 6 & 6 \\
\hline & INTER & $4 / 5$ & $4 / 5$ & $3 / 5$ & $3 / 5$ & $3 / 5$ & $11 / 15$ & $9 / 15$ & 73,33 & 60 & 6,82 & 6,90 & 25,4 & 40,9 & 4 & 8 & 8 \\
\hline & FD & $3 / 5$ & $5 / 5$ & $3 / 5$ & $2 / 5$ & $4 / 5$ & $11 / 15$ & $9 / 15$ & 73,33 & 60 & 6,95 & 6,89 & 24,4 & 40,2 & 4 & 8 & 8 \\
\hline & CAG & $2 / 5$ & $1 / 5$ & $0 / 5$ & $1 / 5$ & $1 / 5$ & $4 / 15$ & $2 / 15$ & 26,67 & 13,33 & 7,60 & 7,30 & 25,7 & 45,4 & 4 & 10 & 10 \\
\hline \multirow{6}{*}{10} & $\mathrm{AD}$ & $2 / 5$ & $2 / 5$ & $1 / 5$ & $0 / 5$ & $0 / 5$ & $7 / 15$ & $1 / 15$ & 46,67 & 6,67 & 6,96 & 7,30 & 14,74 & 33,0 & 4 & 10 & 10 \\
\hline & $\mathrm{AE}$ & $2 / 5$ & $1 / 5$ & $0 / 5$ & $0 / 5$ & $0 / 5$ & $4 / 15$ & $0 / 15$ & 26,67 & 0 & 6,80 & 6,90 & 14,83 & 27,4 & 4 & - & - \\
\hline & FAP & $5 / 5$ & $3 / 5$ & $0 / 5$ & $3 / 5$ & $5 / 5$ & $11 / 15$ & $8 / 15$ & 73,33 & 53,33 & 7,00 & 6,72 & 19,49 & 31,8 & 4 & 6 & 6 \\
\hline & INTER & $5 / 5$ & $5 / 5$ & $5 / 5$ & $4 / 5$ & $5 / 5$ & $14 / 15$ & $14 / 15$ & 93,33 & 93,33 & 6,8 & 6,92 & 24,0 & 40,2 & 4 & 8 & 8 \\
\hline & FD & $5 / 5$ & $4 / 5$ & $0 / 5$ & $3 / 5$ & $2 / 5$ & $13 / 15$ & $5 / 15$ & 86,67 & 33,33 & 7,10 & 7,04 & 23,4 & 38,6 & 4 & - & - \\
\hline & CAG & $1 / 5$ & $1 / 5$ & $0 / 5$ & $0 / 5$ & $0 / 5$ & $3 / 15$ & $0 / 15$ & 20 & 0 & 7,95 & 7,37 & 22,4 & 50,7 & 4 & 10 & 10 \\
\hline
\end{tabular}


Tabela 5.6.19 - Parâmetros de controle - operação do ENSAIO 7-IP (em instalação piloto): temperatura, pH, potencial zeta e residual de cloro livre das águas de diluição e de estudo e

\begin{tabular}{|c|c|c|c|c|c|c|c|c|c|c|c|c|c|}
\hline & $\mathrm{t}\left({ }^{\circ} \mathrm{C}\right)$ & $\mathrm{pH}$ & $\mathrm{Pz}(\mathrm{mV})$ & $\mathrm{pH}$ & $\mathrm{Pz}(\mathrm{mV})$ & $\mathrm{pH}$ & $\mathrm{Pz}(\mathrm{mV})$ & $\mathrm{pH}$ & $\mathrm{Pz}(\mathrm{mV})$ & $\mathrm{pH}$ & $\mathrm{Pz}(\mathrm{mV})$ & $\mathrm{pH}$ & $\mathrm{Pz}(\mathrm{mV})$ \\
\hline Hora (h) & \multicolumn{3}{|c|}{$\overline{A D}$} & \multicolumn{2}{|c|}{$\mathrm{AE}$} & \multicolumn{2}{|c|}{ CAP } & \multicolumn{2}{|c|}{ AC } & \multicolumn{2}{|c|}{ FAP } & \multicolumn{2}{|c|}{ FD } \\
\hline 1 & 25,0 & 6,57 & $-2,10$ & 6,69 & $-22,30$ & 6,69 & - & 6,43 & 0,30 & 6,16 & $-2,20$ & 6,11 & $-1,70$ \\
\hline 3 & 24,0 & 6,60 & $-2,40$ & 6,7 & $-27,70$ & 6,75 & - & 6,40 & $-2,00$ & 6,42 & $-1,90$ & 6,30 & $-1,80$ \\
\hline 6 (ant.) & - & 6,90 & $-2,80$ & 6,38 & $-25,20$ & 7,11 & - & 6,72 & 0,70 & 6,84 & - & - & - \\
\hline MÍNIMO & 24,0 & 6,6 & $-2,8$ & 6,4 & $-27,7$ & 6,7 & - & 6,4 & $-2,0$ & 6,2 & $-2,2$ & 6,1 & $-1,8$ \\
\hline MÁXIMO & 25,0 & 6,9 & $-2,1$ & 6,7 & $-22,3$ & 7,1 & - & 6,7 & 0,7 & 6,8 & $-1,9$ & 6,3 & $-1,7$ \\
\hline
\end{tabular}

Tabela 5.6.20 - Parâmetros de controle - desempenho do ENSAIO 7-IP (em instalação piloto): carbono orgânico total, absorvância 254, oxigênio dissolvido, condutividade elétrica, dureza e turbidez das águas de diluição e de estudo e dos efluentes de cada processo de tratamento para diferentes tempos de amostragem

\begin{tabular}{|c|c|c|c|c|c|c|c|c|c|c|c|c|c|c|c|}
\hline \multirow[b]{2}{*}{ Hora (h) } & \multicolumn{5}{|c|}{ Carbono orgânico total - COT (mg/L) } & \multicolumn{5}{|c|}{ absorvância 254} & \multicolumn{5}{|c|}{ Oxigênio dissolvido - OD (mg/L) } \\
\hline & $\mathrm{AD}$ & $\mathrm{AE}$ & CAP & FAP & FD & $\mathrm{AD}$ & $\mathrm{AE}$ & CAP & FAP & FD & $\mathrm{AD}$ & $\mathrm{AE}$ & CAP & FAP & FD \\
\hline 1 & - & 1,284 & 1,557 & 0,808 & 0,804 & - & 0,010 & $<\mathrm{LD}$ & 0,005 & 0,005 & 7,04 & 7,43 & 7,57 & 7,48 & 7,24 \\
\hline 3 & - & 2,029 & 0,722 & - & 0,968 & - & 0,017 & 0,004 & 0,074 & 0,006 & 6,86 & 7,55 & 7,26 & 8,96 & 7,09 \\
\hline 6 (ant.) & - & 1,296 & & 0,775 & 0,759 & - & 0,012 & 0,1 & 0,007 & 0,005 & 6,99 & 7,36 & 7,65 & 7,44 & 7,56 \\
\hline MÍNIMO & - & 1,284 & 0,722 & 0,775 & 0,759 & - & 0,01 & 0,004 & 0,005 & 0,005 & 6,9 & 7,4 & 7,0 & 7,6 & 7,2 \\
\hline \multirow[t]{2}{*}{ MÁXIMO } & - & 2,029 & 1,557 & 0,808 & 0,968 & - & 0,017 & 0,078 & 0,074 & 0,006 & 8,1 & 8,1 & 7,9 & 8,4 & 8,2 \\
\hline & \multicolumn{5}{|c|}{ Condutividade elétrica $(\mu \mathrm{S} / \mathrm{cm})$} & \multicolumn{5}{|c|}{ Dureza $\left(\mathrm{mgCaCO}_{3} / \mathrm{L}\right)$} & \multicolumn{5}{|c|}{ Turbidez $^{(*)}(\mathrm{uT})$} \\
\hline Hora (h) & $\mathrm{AD}$ & $\mathrm{AE}$ & CAP & FAP & FD & $\mathrm{AD}$ & $\mathrm{AE}$ & CAP & FAP & FD & $\mathrm{AD}$ & $\mathrm{AE}$ & CAP & FAP & FD \\
\hline 1 & 13,82 & 14,52 & 14,48 & 18,1 & 17,88 & 3 & 4 & 5 & 3 & 4 & - & - & - & 0,29 & 0,34 \\
\hline 3 & 14,54 & 14,64 & 14,72 & 18,66 & 18,02 & 5 & 5 & 5 & 6 & 5 & - & - & - & 0,4 & 0,3 \\
\hline 6 (ant.) & 14,04 & 14,7 & 14,96 & 18,54 & 17,8 & 5 & 4 & 4 & 5 & 4 & - & - & - & 0,34 & 0,32 \\
\hline MÍNIMO & 13,82 & 14,52 & 14,48 & 18,12 & 17,8 & 3 & 4 & 4 & 3 & 4 & - & - & - & 0,3 & 0,3 \\
\hline MÁXIMO & 14,54 & 14,7 & 14,96 & 18,66 & 18,02 & 5 & 5 & 5 & 6 & 5 & - & - & - & 0,4 & 0,3 \\
\hline
\end{tabular}

AD: água de diluição; AE: água de estudo; Efluentes: PRÉ: pré-cloração, CAP: carvão ativado em pó, FAP: filtro ascendente de pedregulho, FD: filtração descendente. (*): leitura em turbidímetro de bancada

2100P HACH; OD: método de Winkler (sonda Horiba U-10); ant.: antes da DFI; dep.: depois da DFI. 
Tabela 5.6.21 - Resultados dos testes ecotoxicológicos com microcrustáceos (Ceriodaphnia dúbia - CD e Ceriodaphnia silvestri - CS) - ENSAIO 7-IP (em instalação piloto): total indivíduos imóveis / total indivíduos expostos, imobilidade, $\mathrm{pH}$, condutividade e dureza das águas de diluição e de estudo e efluentes ENSAIO7-IP: Sistema CAP $\rightarrow$ MR $\rightarrow$ FAP $\rightarrow$ FD

\begin{tabular}{|c|c|c|c|c|c|c|c|c|c|c|c|c|c|c|c|c|c|}
\hline \multicolumn{2}{|c|}{$\begin{array}{c}\text { Início: 31jul06 } \\
\text { Fim: 02ago06 }\end{array}$} & \multicolumn{6}{|c|}{$\begin{array}{l}\text { Réplicas Lote CD } 18 \text { e 24/07 CS 18/07 } \\
\text { (ind. Imóveis / total ind. expostos) }\end{array}$} & \multirow{2}{*}{\multicolumn{2}{|c|}{$\begin{array}{l}\text { Total ind. imóveis / } \\
\text { total ind. expostos }\end{array}$}} & \multirow{2}{*}{\multicolumn{2}{|c|}{ \% imobilidade }} & \multirow{2}{*}{\multicolumn{2}{|c|}{$\mathrm{pH}$}} & \multirow{2}{*}{\multicolumn{2}{|c|}{$\begin{array}{l}\text { Condutividade } \\
(\mu \mathrm{S} / \mathrm{cm})\end{array}$}} & \multirow{2}{*}{\multicolumn{2}{|c|}{$\begin{array}{c}\text { Dureza } \\
\left(\mathrm{mg} \mathrm{CaCO}_{3} / \mathrm{L}\right)\end{array}$}} \\
\hline \multirow{2}{*}{$\begin{array}{l}\text { Hora } \\
\text { (h) }\end{array}$} & \multirow{2}{*}{ Amostra } & \multicolumn{3}{|c|}{ C. dúbia CD } & \multicolumn{3}{|c|}{ C. silvestrii CS } & & & & & & & & & & \\
\hline & & 1 & 2 & 3 & 1 & 2 & 3 & $\mathrm{CD}$ & $\mathrm{CS}$ & $\mathrm{CD}$ & $\mathrm{CS}$ & início & fim & início & fim & início & fim \\
\hline \multicolumn{2}{|c|}{ Controle } & $0 / 5$ & $0 / 5$ & $1 / 5$ & $0 / 5$ & $0 / 5$ & $0 / 5$ & $1 / 15$ & $0 / 15$ & 6,67 & 0 & 7,63 & 7,68 & 160,0 & 191,1 & 42 & - \\
\hline \multirow{5}{*}{1} & $\mathrm{AD}$ & $4 / 5$ & $3 / 5$ & $4 / 5$ & $5 / 5$ & $2 / 5$ & $2 / 5$ & $11 / 15$ & $9 / 15$ & 73,33 & 60 & 6,92 & 7,20 & 13,82 & 38,2 & 3 & - \\
\hline & $\mathrm{AE}$ & $0 / 5$ & $0 / 5$ & $0 / 5$ & $0 / 5$ & $0 / 5$ & $0 / 5$ & $0 / 15$ & $0 / 15$ & 0 & 0 & 6,88 & 6,92 & 14,52 & 29,7 & 4 & 8 \\
\hline & CAP & $0 / 5$ & $1 / 5$ & $0 / 5$ & $0 / 5$ & $0 / 5$ & $1 / 5$ & $1 / 15$ & $1 / 15$ & 6,67 & 6,67 & 7,00 & 6,98 & 14,48 & 29,6 & 5 & 7 \\
\hline & FAP & $5 / 5$ & $5 / 5$ & $5 / 5$ & $5 / 5$ & $5 / 5$ & $5 / 5$ & $15 / 15$ & $15 / 15$ & 100 & 100 & 6,68 & 6,67 & 18,12 & 33,7 & 3 & 7 \\
\hline & FD & $5 / 5$ & $5 / 5$ & $5 / 5$ & $5 / 5$ & $5 / 5$ & $4 / 5$ & $15 / 15$ & $14 / 15$ & 100 & 93,33 & 6,74 & 6,76 & 17,88 & 32,8 & 4 & 8 \\
\hline \multirow{5}{*}{3} & $\mathrm{AD}$ & $2 / 5$ & $3 / 5$ & $1 / 5$ & $1 / 5$ & $0 / 5$ & $0 / 5$ & $6 / 15$ & $1 / 15$ & 40 & 6,67 & 6,93 & 7,23 & 14,54 & 34,1 & 5 & 10 \\
\hline & $\mathrm{AE}$ & $0 / 5$ & $0 / 5$ & $0 / 5$ & $0 / 5$ & $0 / 5$ & $0 / 5$ & $0 / 15$ & $0 / 15$ & 0 & 0 & 6,82 & 6,92 & 14,64 & 29,1 & 5 & 8 \\
\hline & CAP & $0 / 5$ & $0 / 5$ & $0 / 5$ & $0 / 5$ & $0 / 5$ & $0 / 5$ & $0 / 15$ & $0 / 15$ & 0 & 0 & 6,98 & 6,86 & 14,72 & 30,4 & 5 & 7 \\
\hline & FAP & $5 / 5$ & $5 / 5$ & $5 / 5$ & $5 / 5$ & $5 / 5$ & $5 / 5$ & $15 / 15$ & $15 / 15$ & 100 & 100 & 6,55 & 6,71 & 18,66 & 32,8 & 6 & 7 \\
\hline & FD & $5 / 5$ & $5 / 5$ & $5 / 5$ & $5 / 5$ & $5 / 5$ & $5 / 5$ & $15 / 15$ & $15 / 15$ & 100 & 100 & 6,62 & 6,67 & 18,02 & 32,6 & 5 & 6 \\
\hline \multirow{5}{*}{6} & $\mathrm{AD}$ & $5 / 5$ & $4 / 5$ & $5 / 5$ & $5 / 5$ & $4 / 5$ & $5 / 5$ & $14 / 15$ & $14 / 15$ & 93,33 & 93,33 & 6,85 & 7,23 & 14,04 & 34,3 & 5 & - \\
\hline & $\mathrm{AE}$ & $2 / 5$ & $0 / 5$ & $1 / 5$ & $1 / 5$ & $0 / 5$ & $0 / 5$ & $3 / 15$ & $1 / 15$ & 20 & 6,67 & 6,91 & 6,96 & 14,70 & 29,3 & 4 & 8 \\
\hline & CAP & $1 / 5$ & $0 / 5$ & $1 / 5$ & $0 / 5$ & $0 / 5$ & $1 / 5$ & $2 / 15$ & $1 / 15$ & 13,33 & 6,67 & 7,04 & 6,94 & 14,96 & 30,4 & 4 & 7 \\
\hline & FAP & $5 / 5$ & $5 / 5$ & $5 / 5$ & $5 / 5$ & $5 / 5$ & $5 / 5$ & $15 / 15$ & $15 / 15$ & 100 & 100 & 6,63 & 6,70 & 18,54 & 30,4 & 5 & 8 \\
\hline & FD & $5 / 5$ & $5 / 5$ & $5 / 5$ & $4 / 5$ & $5 / 5$ & $5 / 5$ & $15 / 15$ & $14 / 15$ & 100 & 93,33 & 6,68 & 6,63 & 17,80 & 32,8 & 4 & 8 \\
\hline
\end{tabular}


Tabela 5.6.22 - Parâmetros de controle - operação do ENSAIO 8-IP (em instalação piloto): temperatura, pH, potencial zeta e residual de cloro livre das águas de diluição e de estudo e

\begin{tabular}{|c|c|c|c|c|c|c|c|c|c|c|c|c|c|c|c|}
\hline & $\mathrm{t}\left({ }^{\circ} \mathrm{C}\right)$ & $\mathrm{pH}$ & $\mathrm{Pz}(\mathrm{mV})$ & $\mathrm{pH}$ & $\mathrm{Pz}(\mathrm{mV})$ & $\mathrm{pH}$ & $\begin{array}{l}\text { Cl res. } \\
\text { (mg/L) }\end{array}$ & $\mathrm{pH}$ & $\mathrm{Pz}(\mathrm{mV})$ & $\mathrm{pH}$ & $\mathrm{Pz}(\mathrm{mV})$ & $\mathrm{pH}$ & $\mathrm{Pz}(\mathrm{mV})$ & $\mathrm{pH}$ & $\mathrm{Pz}(\mathrm{mV})$ \\
\hline Hora (h) & \multicolumn{3}{|c|}{$\mathrm{AD}$} & \multicolumn{2}{|c|}{$\mathrm{AE}$} & \multicolumn{2}{|c|}{ PRÉ } & \multicolumn{2}{|c|}{ CAP } & \multicolumn{2}{|c|}{ AC } & \multicolumn{2}{|c|}{ FAP } & \multicolumn{2}{|c|}{ FD } \\
\hline 1 & 22,5 & 6,99 & $-2,50$ & 7,02 & $-28,80$ & 6,78 & 0,20 & 6,87 & - & 6,92 & $-26,60$ & 6,74 & $-2,00$ & 6,68 & $-1,80$ \\
\hline 3 & - & 6,88 & - & - & $-34,60$ & 6,98 & 0,15 & 7,48 & - & 6,97 & $-24,00$ & 6,88 & $-1,20$ & - & $-2,00$ \\
\hline 6 (ant.) & - & 6,86 & $-3,00$ & 7,24 & $-26,10$ & 7,09 & 0,06 & 7,09 & - & 6,96 & $-25,20$ & 6,86 & $-2,50$ & 6,88 & $-2,10$ \\
\hline 7 (dep.) & 21,0 & 7,06 & - & - & $-31,30$ & 7,01 & 0,05 & 6,99 & - & 6,96 & $-21,40$ & 6,86 & - & - & - \\
\hline 10 & - & 7,00 & $-4,10$ & 7,01 & $-24,90$ & 6,97 & 0,10 & 7,22 & - & 6,96 & $-21,70$ & 7,09 & $-2,00$ & 7,13 & $-2,00$ \\
\hline MÍNIMO & 21,0 & 6,9 & $-4,1$ & 7,0 & $-34,6$ & 6,8 & 0,05 & 6,9 & - & 6,9 & $-26,6$ & 6,7 & $-2,5$ & 6,7 & $-2,1$ \\
\hline MÁXIMO & 22,5 & 7,1 & $-2,5$ & 7,2 & $-24,9$ & 7,1 & 0,20 & 7,5 & - & 7,0 & $-21,4$ & 7,1 & $-1,2$ & 7,1 & $-1,8$ \\
\hline
\end{tabular}

Tabela 5.6.23 - Parâmetros de controle - desempenho do ENSAIO 8-IP (em instalação piloto): carbono orgânico total, absorvância 254, oxigênio dissolvido, condutividade elétrica, dureza e turbidez das águas de diluição e de estudo e dos efluentes de cada processo de tratamento para diferentes tempos de amostragem

\begin{tabular}{|c|c|c|c|c|c|c|c|c|c|c|c|c|c|c|c|c|c|c|}
\hline \multirow[b]{2}{*}{ Hora $(\mathrm{h})$} & \multicolumn{6}{|c|}{ Carbono orgânico total - COT (mg/L) } & \multicolumn{6}{|c|}{ absorvância 254} & \multicolumn{6}{|c|}{ Oxigênio dissolvido - OD (mg/L) } \\
\hline & $\mathrm{AD}$ & $\mathrm{AE}$ & PRÉ & CAP & FAP & FD & $\mathrm{AD}$ & $\mathrm{AE}$ & PRÉ & CAP & FAP & FD & $\mathrm{AD}$ & $\mathrm{AE}$ & PRÉ & CAP & FAP & FD \\
\hline 1 & - & 1,284 & 1,557 & 0,808 & 0,804 & - & 0,010 & $<\mathrm{LD}$ & 0,005 & 0,005 & 7,04 & 7,43 & 7,57 & 7,48 & 7,24 & - & 1,284 & 1,557 \\
\hline 3 & - & 2,029 & 0,722 & - & 0,968 & - & 0,017 & 0,004 & 0,074 & 0,006 & 6,86 & 7,55 & 7,26 & 8,96 & 7,09 & - & 2,029 & 0,722 \\
\hline 6 (ant.) & - & 1,296 & & 0,775 & 0,759 & - & 0,012 & 0,1 & 0,007 & 0,005 & 6,99 & 7,36 & 7,65 & 7,44 & 7,56 & - & 1,296 & \\
\hline MÍNIMO & - & 1,284 & 0,722 & 0,775 & 0,759 & - & 0,01 & 0,004 & 0,005 & 0,005 & 6,9 & 7,4 & 7,0 & 7,6 & 7,2 & - & 1,284 & 0,722 \\
\hline \multirow[t]{2}{*}{ MÁXIMO } & - & 2,029 & 1,557 & 0,808 & 0,968 & - & 0,017 & 0,078 & 0,074 & 0,006 & 8,1 & 8,1 & 7,9 & 8,4 & 8,2 & - & 2,029 & 1,557 \\
\hline & \multicolumn{6}{|c|}{ Condutividade elétrica $(\mu \mathrm{S} / \mathrm{cm})$} & \multicolumn{6}{|c|}{ Dureza $\left(\mathrm{mgCaCO}_{3} / \mathrm{L}\right)$} & \multicolumn{6}{|c|}{ Turbidez $^{(*)}(\mathrm{uT})$} \\
\hline Hora (h) & $\mathrm{AD}$ & $\mathrm{AE}$ & PRÉ & CAP & FAP & FD & $\mathrm{AD}$ & $\mathrm{AE}$ & PRÉ & CAP & FAP & FD & $\mathrm{AD}$ & $\mathrm{AE}$ & PRÉ & CAP & FAP & FD \\
\hline 1 & 13,82 & 14,52 & 14,48 & 18,1 & 17,88 & 3 & 4 & 5 & 3 & 4 & - & - & - & 0,29 & 0,34 & 13,82 & 14,52 & 14,48 \\
\hline 3 & 14,54 & 14,64 & 14,72 & 18,66 & 18,02 & 5 & 5 & 5 & 6 & 5 & - & - & - & 0,4 & 0,3 & 14,54 & 14,64 & 14,72 \\
\hline 6 (ant.) & 14,04 & 14,7 & 14,96 & 18,54 & 17,8 & 5 & 4 & 4 & 5 & 4 & - & - & - & 0,34 & 0,32 & 14,04 & 14,7 & 14,96 \\
\hline MÍNIMO & 13,82 & 14,52 & 14,48 & 18,12 & 17,8 & 3 & 4 & 4 & 3 & 4 & - & - & - & 0,3 & 0,3 & 13,82 & 14,52 & 14,48 \\
\hline MÁXIMO & 14,54 & 14,7 & 14,96 & 18,66 & 18,02 & 5 & 5 & 5 & 6 & 5 & - & - & - & 0,4 & 0,3 & 14,54 & 14,7 & 14,96 \\
\hline
\end{tabular}

AD: água de diluição; AE: água de estudo; Efluentes: PRÉ: pré-cloração, CAP: carvão ativado em pó, FAP: filtro ascendente de pedregulho, FD: filtração descendente. (*): leitura em turbidímetro de bancada 2100P HACH; OD: método de Winkler (sonda Horiba U-10); ant.: antes da DFI; dep.: depois da DFI. 
Tabela 5.6.24 - Resultados dos testes ecotoxicológicos com microcrustáceos (Ceriodaphnia dúbia - CD e Ceriodaphnia silvestri - CS) - ENSAIO 8-IP (em instalação piloto): total indivíduos imóveis / total indivíduos expostos, imobilidade, $\mathrm{pH}$, condutividade e dureza das águas de diluição e de estudo e efluentes ENSAIO8-IP: Sistema PRÉ $\rightarrow$ CAP $\rightarrow$ MR $\rightarrow$ FAP $\rightarrow$ FD

\begin{tabular}{|c|c|c|c|c|c|c|c|c|c|c|c|c|c|c|c|c|c|}
\hline \multicolumn{2}{|c|}{$\begin{array}{c}\text { Início: } 23 \text { jul06 } \\
\text { Fim: } 25 \text { jul06 } \\
\end{array}$} & \multicolumn{6}{|c|}{$\begin{array}{l}\text { Réplicas Lote CD } 08 \text { e 14/07 e CS 12/07 } \\
\text { (ind. Imóveis / total ind. expostos) }\end{array}$} & \multirow{2}{*}{\multicolumn{2}{|c|}{$\begin{array}{l}\text { Total ind. imóveis / } \\
\text { total ind. expostos }\end{array}$}} & \multirow{2}{*}{\multicolumn{2}{|c|}{ \% imobilidade }} & \multirow{2}{*}{\multicolumn{2}{|c|}{$\mathrm{pH}$}} & \multirow{2}{*}{\multicolumn{2}{|c|}{$\begin{array}{l}\text { Condutividade } \\
\qquad(\mu \mathrm{S} / \mathrm{cm})\end{array}$}} & \multirow{2}{*}{\multicolumn{2}{|c|}{$\begin{array}{c}\text { Dureza } \\
\left(\mathrm{mg} \mathrm{CaCO}_{3} / \mathrm{L}\right)\end{array}$}} \\
\hline \multirow{2}{*}{$\begin{array}{l}\text { Hora } \\
(\mathrm{h})\end{array}$} & \multirow{2}{*}{ Amostra } & \multicolumn{3}{|c|}{ C. dúbia CD } & \multicolumn{3}{|c|}{ C. silvestrii CS } & & & & & & & & & & \\
\hline & & 1 & 2 & 3 & 1 & 2 & 3 & CD & CS & CD & CS & início & fim & início & fim & início & fim \\
\hline \multicolumn{2}{|c|}{ Controle } & $0 / 5$ & $1 / 5$ & $0 / 5$ & $0 / 5$ & $0 / 5$ & $0 / 5$ & $1 / 15$ & 0/15 & 6,67 & 0 & 7,40 & - & 160,0 & 264 & 44 & 64 \\
\hline \multirow{6}{*}{1} & $\mathrm{AD}$ & $5 / 5$ & $4 / 5$ & $5 / 5$ & $4 / 5$ & $2 / 5$ & $2 / 5$ & $14 / 15$ & $8 / 15$ & 93,33 & 53,33 & 6,92 & 7,03 & 13,80 & - & 5 & - \\
\hline & $\mathrm{AE}$ & $5 / 5$ & $4 / 5$ & $5 / 5$ & $5 / 5$ & $4 / 5$ & $5 / 5$ & $14 / 15$ & $14 / 15$ & 93,33 & 93,33 & 6,87 & 6,80 & 21,0 & 39,0 & 4 & 8 \\
\hline & PRÉ & $1 / 5$ & $0 / 5$ & $0 / 5$ & $3 / 5$ & $5 / 5$ & $5 / 5$ & $1 / 15$ & $13 / 15$ & 6,67 & 86,67 & 6,97 & 6,90 & 22,7 & 39,6 & 4 & 8 \\
\hline & CAP & $0 / 5$ & $1 / 5$ & $0 / 5$ & $5 / 5$ & $4 / 5$ & $4 / 5$ & $1 / 15$ & $13 / 15$ & 6,67 & 86,67 & 7,12 & 6,73 & 21,0 & 40,4 & 4 & 8 \\
\hline & FAP & $2 / 5$ & $3 / 5$ & $3 / 5$ & $5 / 5$ & $1 / 5$ & $4 / 5$ & $8 / 15$ & $10 / 15$ & 53,33 & 66,67 & 6,75 & 6,77 & 22,8 & 42,5 & 4 & 8 \\
\hline & FD & $4 / 5$ & $4 / 5$ & $5 / 5$ & $5 / 5$ & $5 / 5$ & $5 / 5$ & $13 / 15$ & $15 / 15$ & 86,67 & 100 & 6,67 & 6,80 & 23,3 & 43,7 & 3 & 10 \\
\hline \multirow{6}{*}{3} & $\mathrm{AD}$ & $3 / 5$ & $4 / 5$ & $3 / 5$ & $0 / 5$ & $3 / 5$ & $0 / 5$ & $10 / 15$ & $3 / 15$ & 66,67 & 20 & 6,80 & 7,09 & 13,75 & - & 4 & - \\
\hline & $\mathrm{AE}$ & $1 / 5$ & $0 / 5$ & $0 / 5$ & $1 / 5$ & $2 / 5$ & $2 / 5$ & $1 / 15$ & $5 / 15$ & 6,67 & 33,33 & 6,96 & 6,93 & 23,4 & 41,4 & 4 & 8 \\
\hline & PRÉ & $1 / 5$ & $0 / 5$ & $2 / 5$ & $2 / 5$ & $4 / 5$ & $5 / 5$ & $3 / 15$ & $11 / 15$ & 20 & 73,33 & 6,97 & 6,85 & 22,5 & 40,1 & 4 & 8 \\
\hline & CAP & $1 / 5$ & $0 / 5$ & $0 / 5$ & $4 / 5$ & $4 / 5$ & $3 / 5$ & $1 / 15$ & $11 / 15$ & 6,67 & 73,33 & 6,95 & 6,92 & 22,1 & 38,5 & 4 & 8 \\
\hline & FAP & $3 / 5$ & $0 / 5$ & $3 / 5$ & $4 / 5$ & $2 / 5$ & $3 / 5$ & $6 / 15$ & $9 / 15$ & 40 & 60 & 6,67 & 6,84 & 23,9 & 43,1 & 4 & - \\
\hline & FD & $5 / 5$ & $3 / 5$ & $5 / 5$ & $2 / 5$ & $3 / 5$ & $3 / 5$ & $13 / 15$ & $8 / 15$ & 86,67 & 53,33 & 6,70 & 6,82 & 23,7 & 43,5 & 4 & 10 \\
\hline \multirow{6}{*}{6} & $\mathrm{AD}$ & $3 / 5$ & $5 / 5$ & $5 / 5$ & $1 / 5$ & $1 / 5$ & $3 / 5$ & $13 / 15$ & $5 / 15$ & 86,67 & 33,33 & 6,87 & 7,10 & 14,04 & - & 3 & - \\
\hline & $\mathrm{AE}$ & $0 / 5$ & $0 / 5$ & $0 / 5$ & $2 / 5$ & $0 / 5$ & $2 / 5$ & $0 / 15$ & $4 / 15$ & 0 & 26,67 & 6,97 & 6,85 & 22,9 & 41,6 & 4 & 8 \\
\hline & PRÉ & $1 / 5$ & $0 / 5$ & $1 / 5$ & $4 / 5$ & $4 / 5$ & $3 / 5$ & $2 / 15$ & $11 / 15$ & 13,33 & 73,33 & 6,94 & 6,95 & 22,4 & 41,4 & 4 & 10 \\
\hline & CAP & $0 / 5$ & $0 / 5$ & $0 / 5$ & $5 / 5$ & $5 / 5$ & $5 / 5$ & $0 / 15$ & $15 / 15$ & 0 & 100 & 7,00 & - & 21,4 & 39,6 & 4 & 10 \\
\hline & FAP & $3 / 5$ & $4 / 5$ & $5 / 5$ & $3 / 5$ & $3 / 5$ & $3 / 5$ & $12 / 15$ & $9 / 15$ & 80 & 60 & 6,70 & 6,88 & 24,7 & 43,1 & 4 & 8 \\
\hline & FD & $5 / 5$ & $4 / 5$ & $4 / 5$ & $2 / 5$ & $3 / 5$ & $4 / 5$ & $13 / 15$ & $9 / 15$ & 86,67 & 60 & 6,76 & 6,77 & 24,3 & 42,2 & 4 & 8 \\
\hline
\end{tabular}




\section{REFERENCIAS BIBLIOGRÁFICAS}

AMADO, L.L.; SANTOS, L.C.; ACOSTA, D.; MORAES, T.B.; FERREIRA, J.L.R.; YUNES, J.S.; CERACITANO, L.A.; MONSERRAT, J.M (2006). Avaliação da toxicidade da microcistina sobre a geração de dano de DNA, a atividade locomotora e de enzimas antioxidantes no peixes Danio rereio (Teleostei, Cyprinidae). In: CONGRESSO BRASILEIRO DE ECOTOXICOLOGIA, 9., São Pedro. Resumos. São Paulo: Vida e Consciência, jul/2006. p.152.

AMARAL, S. F., GALVÃO, E. M. O. B., BERTOLOSSI, V. M., VIANNA, R. F. M., CEZAR, M. C. M., BRANDÃO, C. C. S. (2001). Filtração ascendente em pedregulho seguida de filtração descendente em areia (dupla filtração) aplicada ao tratamento de águas com presença de algas. In: 21ํ. Congresso Brasileiro de Engenharia Sanitária e Ambiental, João Pessoa, Brasil.

AMERICAN PUBLIC HELT ASSOCIATION; AMERICAN WATER WORKS ASSOCIATION; WATER ENVIROMENT FEDERATION - APHA, AWWA, WEF (1999). Standard methods for the examination of water and wastewater. 20 th edition. Washington. USA

AMERICAN SOCIETY FOR TESTING MATERIALS - ASTM (2000). Standards on Activated Carbon. Second Edition. Filadélfia, EEUU.

AMERICAN WATER WORKS ASSOCIATION, AMERICAN SOCIETY OF CIVIL ENGINEERS (1990) Water Treatment Plant Design 3rd Ed., McGraw-Hill Handbooks, USA.

ARAGÃO, M.A.; BURATINI, S.V. (2000). Caracterização da dureza de águas superficiais do Estado de São Paulo. In: ENCONTRO DE ECOTOXICOLOGIA, 6., 2000, São Carlos. Resumos. São Carlos: USP/IPEN/SETAC. p.126.

ARAR, E.J. (1997). Determination of Chlorophyll a, b, c1 and c2, and Pheophytin a in marine and freshwater phytoplankton by spectrophotometry. EPA metod 446.0. EPA.

ASSOCIAÇÃO BRASILEIRA DE NORMAS TECNICAS - ABNT (1991). Carvão ativado pulverizado para tratamento de água - especificações: EB - 2133. Rio de janeiro. 
ASSOCIAÇÃO BRASILEIRA DE NORMAS TECNICAS - ABNT (2004a). NBR 12713: Ecotoxicologia aquática - Toxicidade aguda - Método de ensaio com Daphnia spp (Cladocera, Crustácea). Rio de Janeiro, 21 p.

ASSOCIAÇÃO BRASILEIRA DE NORMAS TECNICAS - ABNT (2004b). NBR 15088: Ecotoxicologia aquática - Toxicidade aguda - Método de ensaio com peixes. Rio de Janeiro, $19 \mathrm{p}$.

ASSOCIAÇÃO BRASILEIRA DE NORMAS TECNICAS - ABNT (2005). NBR 13373: Ecotoxicologia aquática - Toxicidade crônica - Método de ensaio com Ceriodaphnia spp (Cladocera, Crustacea). Rio de Janeiro, 15p.

AYGUN A, YENISOY-KARAKAS S, DUMAN I. (2003). Production of granular activated carbon from fruit stones and nutshells and evaluation of their physical, chemical and adsorption properties. Microporous and mesoporous materials, vol. 66, n 2-3, p. 189-195, DEC 5.

AZEVEDO, S. M. F. O. (1998). Toxinas de Cianobactérias: causas e conseqüências para a saúde pública. Disponível em: www.medonline.com.br/med_ed/med3/microcis.htm.

AZEVEDO, S.M.F.O. (1996). “Toxic cyanobacteria and the Caruaru tragedy.” IV Simpósio da Sociedade Brasileira de Toxinologia. Livro de Resumos, pp. 84.

AZEVEDO, S.M.F.O. (2000). Cianobactérias e eutrofização. In: Seminário Internacional represa do Lobo - Broa - 30 anos de Pesquisa em Limnologia, Gerenciamento e Participação da Comunidade e Bases Científicas para o Gerenciamento da Eutrofização, 2000, São Carlos. Resumos. São Paulo: IIE/USP/UFSCar, dez/2000. p.20.

AZEVEDO, S.M.F.O.; VASCONCELOS, V.M. (2006). Toxinas de cianobactérias: causas e conseqüências para a saúde pública. In: Zagatto, P.A.; Bertoletti, E. (orgs.) Ecotoxicologia aquática - princípios e aplicações. São Carlos: RiMa. Capítulo 18, p.433-452.

BAÇAOUI, A.; YAACOUBI, A.; DAHBI, A.; BENNOUNA, C.; PHAN TAN LUU, R.; MALDONADO-HODAR, F. J.; RIVERA-UTRILLA, J.; MORENO-CASTILLA, C. (2001). Optimization of conditions for the preparation of activated carbons olive-waste cakes. Carbon, v. 39, p. 425-432. 
BARTON, S. S. (1987). The adsorption of methylene blue by active carbon. Carbon, v. 25, p. 343-350.

BOUVY, M.; MOLICA, R.; OLIVEIRA, S.; MARINHO, M. e BEKER, B. (1999). "Dynamics of a toxic cyanobacterial bloom (Cylindrospermopsis raciborskii) in a shallow reservoir in the semi-arid region of northeast Brazil.” Aquatic Microbial Ecology, 20, pp. 285-297.

BRANCO, S.M. (1986). Hidrobiologia aplicada à engenharia sanitária. 2.ed. CETESB, São Paulo, Brasil, 620p., 1986.

BRANDÃO, C. C.; AZEVEDO, S. M. F. O. (2001). Cianobactérias tóxicas: Impactos na saúde pública e processos de remoção em água para consumo humano. Ministério da Saúde, FUNASA (Ed). Brasília-DF, Brasil.

BRASIL. Ministério da Saúde. Portaria ${ }^{0}$ 518, de 25 de março de 2004. Estabelece os procedimentos e responsabilidades relativos ao controle e vigilância da qualidade da água para consumo humano e seu padrão de potabilidade, e dá outras providências, Brasília, 2004.

$\begin{array}{llll}\text { CARMICHAEL W. W. } & \text { W. }\end{array}$ http://www.wright.edu/biology/faculty/carmichael/labhome/labhome.htm

CARMICHAEL, W. W. (1992). Cyanobacteria secondary metabolites - the cyanotoxins. Journal of Applied Bacteriology, v.72, p.445-459.

CARMICHAEL, W. W. (1992). Cyanobacteria secondary metabolites - the cyanotoxins. Journal of Applied Bacteriology, v.72, p.445-459.

CARMICHAEL, W. W. (1994).The toxins of cyanobacteria. Scientific American, vol. 270,

CEZAR, M.C.M.; CARVALHO, R.P.M.; BRANDÃO, C.C.S. (2000). Efeito da coagulação química na (pré) filtração em pedregulho de águas com presença de algas, e seu potencial como pré-tratamento para a filtração rápida descendente. / Apresentado ao $21^{\circ}$.Congresso Interamericano de Engenharia Sanitária e Ambiental, Porto Alegre-RS.

CHORUS, I.; BARTRAM, J. (eds.). (1999). Toxic cyanobacteria in water - a guide to their public health consequences, monitoring and management. London: E \& FN Spon. 1999. 416p. 
CHOW, C.W.K.; HOUSE, J.; VELZEBOER, R.M.A.; DRIKAS, M.; BURCH, M.D.; STEFFENSEN, D.A. (1998). The effect of ferric chloride flocculation on cyanobacterial cells. Water Research, v.32, n.3, p.808-814.

CIESLINSKI, A.H. (2003). Ocorrência de microcistinas em mananciais utilizados para o abstecimento público e de centros de hemodiálise no Brasil. 81p. Dissertação (Mestrado) Universidade de Brasília, Brasília - DF, 2003.

CODD, G.A. (1995). Cyanobacterial toxins: occurrence, properties and biological significance. Watet Science and Technology, Oxford, v.32, n.4, p.149-156.

CODD, G.A. (2000). Cyanobacterial toxins, the perception of water quality, and the priorisation of eutrophication control. Ecological Engineering, Amsterdam, v.16, n.1, p.5160 , Oct.

CODD, G.A.; BELL, S.G.; BROOKS, W.P. (1989). Cyanobacterial toxins in waters. Water Science and Technology, n.21, p.1-13.

COMPANHIA DE TECNOLOGIA E SANEAMENTO AMBIENTAL - CETESB (1986). Desenvolvimento de métodos para o estabelecimento de critérios ecotoxicológicos. São Paulo, CETESB. v.1. 174 p. Relatório Técnico.

COMPANHIA DE TECNOLOGIA E SANEAMENTO AMBIENTAL - CETESB (1993). Água - Teste para avaliação da toxicidade aguda de cianofíceas (algas azuis). São Paulo, CETESB. 12p. Norma Técnica L5-025

COUTINHO, A.R.; BARBIERI, F.C.; PAVANI, P.A. (2000). Preparação de carvões ativados a partir de fibras de cellulose. In: $2^{\circ}$ Encontro brasileiro de adsorção, maio de 1998, Florianópolis, Santa Catarina. Anais de trabalhos apresentados, Leonel T. Pinto (editor), p. 139-144, Universidade Federal de Santa Catarina, SC, Brasil.

COYLE, S. M.; LAWTON, L. A. (1996). Development of an extraction procedure for the quantitative analysis of microcystins in cyanobacterial cells. Phycologia v.35 (6 Supplement p.57-61).

DEMOTT, W.R.; ZHANG, Q.T.X. \& CARMICHAEL, W.W. (1991). Effects of toxic cyanobacteria and purified toxins on the survival and feeding of a copepod and three species 
of Daphina. Limnol. Oceanogr., v.7, n.36, p.1346-1357.

DI BERNARDO, A. S. (2004) Desempenho de sistemas de dupla filtração no tratamento de água com turbidez elevada São Carlos, Tese de Doutorado, Escola de Engenharia de São Carlos da Universidade de São Paulo.

DI BERNARDO, L. (1995) Algas e suas influências na qualidade das águas e nas tecnologias de tratamento. ABES, Rio de Janeiro, 1995.

DI BERNARDO, L.; DANTAS, A. D. B. (2005). Métodos e Técnicas de Tratamento de Água - Volumes I e II RIMA EDITORA, São Carlos, Brasil.

DI BERNARDO, L.; DI BERNARDO, A.S.; TROFINO, J.C. (2000). Pré-oxidação com cloro e dióxido de cloro para remoção de algas em água de abastecimento. I Seminário Nacional de Microbiologia Aplicada ao Saneamento. Vitória.

DI BERNARDO, L.; ISAAC R. L. (2001). Upflow Direct Filtration - A Review. In: INTERNATIONAL CONFERENCE ON ADVANCES IN RAPID GRANULAR FILTRATION IN WATER AND WASTEWATER TREATMENT. London, 2001. Anais. UK.

DOMINGUES, D.F.; BERTOLETTI, E. (2006). Seleção, manutenção e cultivo de organismos aquáticos. In: Zagatto, P.A.; Bertoletti, E. (orgs.) Ecotoxicologia aquática princípios e aplicações. São Carlos: RiMa. Capítulo 7, p.153-184.

DONATI, C.; DRIKAS, M.; HAYES, R. E NEWCOMBE, G. (1994). Mycrocystin-LR adsorption by powdered activated carbon. Water Research, 28(8), pp. 1735-1742.

DOS SANTOS, A.C.A., CALIJURI, M.C., MORAES, E.M.; ADORNO, M.A.T.; FALCO, P.B.; CARVALHO, D.P.; DEBERDT, G.L.B.; BENASSI, S.F. (2003). Comparison of three methods for Chlorophyll determination: Spectrophotometry and Fluorimetry in samples containing pigment mixtures and spectrophotometry in samples with separate pigments through High Performance Liquid Chromatography. ACTA Limnologica Brasiliensis vol 15, $n^{0} 3$, pg 7-18.

DRIKAS, M.; CHOW, C.W.K.; HOUSE, J.; BURCH, M.D. (2001). Using coagulation, flocculation, and settling to remove toxic cyanobacteria. Journal of American Water Works 
Association, v.93, n.2, p.100-111.

DRISCOLL, JR, C.T.; BAKER, J.P.; BISOGNI, JR, J.J.; SCHOFIELD, C.L. Effect of aluminum on fish in dilute acidified water. Nature, v.284, n.13, p.161-164, 1980.

EIJCKELHOFF, C. \& DEKKER, J.P. (1997) A routine method to determine the chlorophyll a, pheophytin a ans carotene contents of isolated photosyntem II reaction center complexes. Photosynthessis Research v.52, pg 69-73.

EL-HENDAWY, A.-N. A. ; SAMRA, S.E.; GIRGIS, B.S. (2001). Adsorption characteristics of activated carbons obtained from corncobs. Colloids and Surfaces A: Physicochemical and Engineering Aspects. Vol. 180, p. 209-221.

ENVIRONMENT AGENCY (1998). The determination of microcystin algal toxins in raw and treated waters by high performance liquid chromatography / Methods for the Examination os Waters and Associated Materials, UK.

FALCONER, I.; HARDY, S.J.; HUMPAGE, A.R.; FROSCIO, S.M.; TOZER, G.J.; HAWKINS, P.R. (1999). Hepatic and renal toxicity of the blue-green alga (cyanobacterium) Cylindrospermopsis raciborskii in male swiss albino mice. Environmental Toxicology, v.1, n.14, p.143-150.

FALCONER, I.; HUMPAGE, A.R. (1998). Tumor promotion by cyanobacterial toxins. Phycologia, n.35, p.74-79.

FALCONER, I.R. (1991). Tumor promotion and liver injury caused by oral consumption of cyanobacteria. Environmental Toxicology and Water Quality, New York, v.6, n.2, p.177184, May.

FALCONER, I.R. (1999). An overview of problems caused by toxic blue-green algae (Cyanobacteria) in drinking water and recreational water. Environmental Toxicology, v.1, n.14, p.5-12.

FALCONER, I.R. BURCH, M.D.; STEFFENSEN, D.A.; CHOICE, M. \& COVERDALE, O.R. (1994). Toxicity of the blue-green algae (Cyanobacterium) Microcystis aeruginosa in drinking water to growing pigs, as an animal model for human injury and risk assessment. Environ. Toxicol. Water Qual. Inter., 9: 131-139. 
FALCONER, I.R.; RUNNEGAR, M.T.C.; BUCKLEY, T.; HUYN, V.L. e BRADSHAW, P. (1989). "Using activated carbon to remove toxicity from drinking water containing Cyanobacterial blooms.” Journal of The American Water Works Association, 81(2), pp. 102105.

FASTNER, J.; NEUMANN, U.; WIRSING, B.; WECKESSER, J.; WIEDNER, C.; NIXDORF, B.; CHORUS, I. (1999). Microcystins (hepatotox hepatopeptides) in german fresh water bodies. Environmental Toxicology, v.1, n.14, p.13-22, 1999.

FERRÃO-FILHO, A.S.; AZEVEDO, S.M.F.O. (2002). Effects of unicellular and colonial forms of Microcystis aeruginosa from laboratory culture and natural populations on tropical cladoceran. Aquat. Ecology, v.37, 23-35.

FERRÃO-FILHO, A.S.; MAGALHÃES, V.F.; BAPTISTA, D.F. (2006). Avaliação da toxicidade de Cylindrospermopsis raciborskii na atividade natatória de organismos aquáticos através de processamento de imagem. In: CONGRESSO BRASILEIRO DE ECOTOXICOLOGIA, 9, São Pedro. Resumos. São Paulo: Vida e Consciência, jul/2006. p.184-185.

FERREIRA, A. C. S.; MOTA FILHO, C. R.; PÁDUA, V. L. (2003). Relação entre turbidez e contagem do fitoplâncton na avaliação da qualidade da água para consumo humano. Apresentado ao $22^{\circ}$. Congresso Brasileiro de Engenharia Sanitária e Ambiental, Joinville SC, 2003.

FIGUEIREDO, D.R.; AZEITEIRO, U.M.; ESTEVES, S.M.; GOLÇALVES, F.J.M.; PEREIRA, M.J. (2004). Microcystin-producing blooms - a serius global public health issue. Ecotoxicology and Environmental Safety, v.59, p.151-163, 2004.

GEORGE, D. B.; BECK, S. G.; ADAMS, V. D.; MORGAN, E. L.; ROBERTS, R. O.; HOLLOWAY, C.; LOTT, R. C.; HOLT L. K. Alum sludge in the Aquatic Environment. AWWA Research Foundation and the American Waterworks Association, 1991.

GEORGE, D.B.; BERK, S.G.; ADAMS, V.D.; TING, R.S.; ROBERTS, R.O.; PARKS, L.H.; LOTT, R.C. Toxicity of alum sludge extracts to a freshwater alga, protozoan, fish, and marine bacterium. Archives of Environmental Contamination and Toxicology, v.29, p.149158, 1995. 
GUSMÃO, P. T. R. (2001). Utilização de Filtração direta ascendente como pré-tratamento para tratamento de água de abastecimento. São Carlos. 335 p. Tese de doutorado - Escola de Engenharia de São Carlos, Universidade de São Paulo.

HAMILTON, M.A.; RUSSO, R.C.; THURSTON, R.V. (1977). Trimmed Spearman-Karber method for estimating median lethal concentrations in toxicity bioassays. Environmental Science \& Technology, Easton, v.11, n.7, p.714-719.

HART, J.; FAWELL, J.K. E CROLL, B. (1998). "The fate of both intra- and extracellular toxins during drinking water treatment.” Water Supply, 16(1/2), pp. 611-616.

HAVAS, M. Aluminum bioaccumulation and toxicity to Daphnia magna in soft water at low pH. Canadian Journal of Fisheries and Aquatic Science, v.42, p.1741-1748, 1985.

HEINZE, R. Toxicity of the cyanobacterial toxin microcystin-LR to rats after 28 days intake with the drinking water. Environmental Toxicology, v.1, n.14, p.57-60, 1999.

HIMBERG, K.; KEIJOLA, A-M.; HIISVIRTA, L.; PYYSALO, H. E SIVONEN, K. (1989). "The effect of water treatment processes on the removal of hepatotoxins from Microcystis and Oscillatoria cyanobacteria: A laboratory study.” Water Research, 23(8), pp. 979-984.

HOHEN, R. C., GRIZZARD, T. J., SHAFFER, P. T. B. (1980). Algae as Sources of Trihalomethane Precursors JAWWA, vol. 72, n. 6, p: 344 - 350, Jun., USA.

HOLM-HANSEN, O. \& RIEMANN, B. (1978) Chlorophyll a determination: improvements in methodology. Oikos v.30 pg 438-447.

HUNN, J.B.; CLEVELAND, L.; LITTLE, E.E. Influence of $\mathrm{pH}$ and aluminum on developing brook trout in a low calcium water. Environmental Pollution, v.43, p.63-73, 1987.

JANSSENS, J.G. e BUEKENS, A. (1993). “Assessment of process selection for particle removal in surface water treatment.” Journal Water SRT - Aqua, 42(5), pp. 279-288.

JAPANESE INDUSTRIAL STANDARD - JIS K 1474. Test methods for activated carbon. Japanese Standards Association. Tokyo, 1991.

JARDIM, F.A., FONSECA, Y.M.F. E AZEVEDO, S.M.F.O. (1999). “A ocorrência de 
Microcystis viridis e Cylindrospermopsis raciborskii tóxicas em um manancial da COPASA - MG:” Anais da VIII Reunião Brasileira de Ficologia.

JOCHIMSEN, E.M.; CARMICHAEL, W.W.; AN, J.S.; CARDO, D.M.; COOKSON, S.T.; HOLMES, C.E.; ANTUNES, M.B.; MELO FILHO, D.A.; LYRA, T.M.; BARRETO, V.S.; AZEVEDO, S.M.; JARVIS, W.R. Liver failure and death after exposure to microcystins at a hemodialysis center in Brazil. The New England Journal of Medicine, v.338, p.873-878, 1998.

JUNGMANN, D. Toxic compounds isolated from Microcystis PCC7806 that are more active against Daphnia than two microcystins. Limnol. Oceanogr.,v.37, n.8, p.1777-1783, 1992.

KARNER, D.A.; STANDRIDGE, J.H.; HARRINGTON, G.W.; BARNUM, R.P. (2001). Microcystin algal toxins in source and finished drinking water. Journal of the American Water Works Association, p.72-81, August.

KEIJOLA, A-M.; HIMBERG, K.; ESALA, A.L.; SIVONEN, K. e HIISVIRTA, L. (1988). "Removal of cyanobacterial toxins in water treatment processes: Laboratory and pilot scale experiments.” Toxicity Assessment: An international Journal, 3, pp. 643-656.

KRISHNAMURTHY, T.; W. W. CARMICHAEL \& E. W. SARVER, 1986. Toxic peptides from freshwater Cyanobacteria (blue-green algae) I. Isolation, purification and characterization of peptides from Microcystis aeruginosa and Anabaena flos-aquae. Toxicon, vol $24 n^{\circ} .9865-873$.

KUIPER-GOODMAN, T. et. al. (1994). Microcystins in drinking water. In: STEFFENSEN, D.A.; NICHOLSON, B.C. (Ed.). Toxic cyanobacteria - a global perspective. Salisbury: Australian Centre for Quality Research. p.17-23.

KURODA, E. K. (2002) Avaliação da Filtração Direta Ascendente em Pedregulho como Pré-tratamento em Sistemas de Dupla Filtração São Carlos. 217 p. Dissertação (mestrado) Escola de Engenharia de São Carlos, Universidade de São Paulo.

KURODA, E. K.; ADORNO M. A. T.; RODRIGUES FILHO E.; DI BERNARDO, L. (2005). Caracterização da principal microcistina produzida pela cepa de Microcystis spp. empregada na avaliação de tecnologias de tratamento de águas para abastecimento. 28ํ.Reunião Anual da Sociedade Brasileira de Química. Poços de Caldas - MG. 
KURODA, E. K.; ADORNO M. A. T.; RODRIGUES FILHO E.; DI BERNARDO, L. (2006). Dados espectrométricos da principal microcistina produzida pela cepa de Microcystis spp. 29. Reunião Anual da Sociedade Brasileira de Química. Poços de Caldas - MG.

KURODA, E. K.; ALBUQUERQUE JR, E. C.; DI BERNARDO, L.; TROFINO, J. C. (2005)a. Caracterização e escolha do tipo de carvão ativado a ser empregado no tratamento de águas contendo microcistinas I-072. In: XXIII Congresso Brasileiro de Engenharia Sanitária e Ambiental, Campo Grande - MS, set.

KURODA, E. K.; DI BERNARDO, L. (2005)b. Determinação das condições de coagulação química para filtração direta com águas contendo células e subprodutos de cianobactérias I073. In: XXIII Congresso Brasileiro de Engenharia Sanitária e Ambiental, Campo Grande MS, set 2005.

KURODA, E. K.; DOS SANTOS, A. C. A.; QUEIROZ, L. A.; CALIJURI, M. C.; DI BERNARDO, L. (2005)c. Determinação de clorofila pelo método espectrofotométrico visando o monitoramento da eficiência do tratamento de águas para abastecimento. I-074. In: XXIII Congresso Brasileiro de Engenharia Sanitária e Ambiental, Campo Grande - MS, set 2005.

KURODA, E. K.; MINILLO, A.; ROCHA, O., RODRIGUES FILHO, E., DI BERNARDO, L. (2007). Avaliação da toxicidade aguda de uma cepa de Microcystis spp. por meio de testes com camundongos. Revista Brasileira de Engenharia Sanitária e Ambiental. (No prelo).

LALEZARY, S., PIIRBZARY, M., MCGUIRE, M. J. (1986) Oxidation of Five EarthyMusty Taste and Odor Compounds JAWWA, vol. 78, n. 3, p: 62-69, Mar. 1986, USA.

LAWTON, L.A. e COOD, G.A. (1991). "Cyanobacterial (Blue-green Algal) toxins and their significance in UK and European waters.” Journal IWEM, 5, pp. 460-465.

LAWTON, L.A., BEATTIE K. A.; HAWSER S. P., CAMPBELL, D. L., COOD G. A. (1994b). Evaluation of assay methods for the determination of cyanobacterial hepatotoxicity. In: CODD, G.A. et. al. (Ed.). Detection methods for cyanobacterial toxins. Cambridge: The Royal Society of Chemistry. p.111-116.

LAWTON, L.A.; EDWARDS, C., COOD G. A. (1994a). Extraction and high-performance 
liquid, chromatographic method for the determination of microcystins in raw and treated waters. Analysis, July 1994, vol.119.

LIN, S.; EVANS, R.L.; SCHNEPPER, D.; HILL, T. (1984). Evaluation of wastes from the East St. Louis water treatment plant and their impact on the Mississippi river. Illinois: State Water Survey Div., Champaign - National Technical Information Service-NTIS, ISWS/CIR160/84, 1984.

LLOYD, S.W. \& TUCKER, C.S. (1988) Comparison of three solvent systems for extraction of chlorophyll-a from fish pond phytoplankton communities. Journal of World Aquaculture Society, vol 19, no2, pg 36-40.

LOMBARDI, A.T.; VIEIRA, A.A.H. (1998). Copper and lead complexation by high molecular weight compounds produced by Synura sp. (Chysophyceae). Phycologia, v.37, p.34-39.

LORENZEN, C.J. (1965). A note on the chlorophyll and phaeophytin content of the chlorophyll maximum. Limnology and Oceanography v.10, pg 482-483.

LORENZEN, C.J. (1967). Determination of chlorophyll and pheo-pigments: spectrofotometric equations. Limnol. Oceanogr. V.12: p343.

MAGALHÃES, D.P.; BAPTISTA, D.; CUNHA, R. (2005) Sistema de biomonitoramento em tempo real para avaliação de efeito de substâncias químicas no comportamento natatório do peixe Danio rerio. Anais do XCBL - X Congresso Brasileiro de Limnologia, 24 a 29 de julho de 2005, Ilhéus, BA. CD-ROM.

MARKER, A.F.H. (1972) The use of acetone and methanol in the estimation of chlorophyll in the presence of pheophytin. Freshwater Biology v.2 pg361-385.

MARKER, A.F.H.; NUSH, E.A.; RAI, H \& RIEMAN, B. (1980) The measurements of photosynthetic pigments in freshwaters and standartization of methods: conclusions and recommendations. Arch. Hydrobiol. Beith. Ergbn Limnol. V.14 pg 91-106.

MATTHIENSEN A., BEATTIE K. A., YUNES J. S., KAYA, K., COOD G. A. (2000). [DLeu1] Microcystin-LR, from the cyanobacterium Microcystis RST 9501 and from a Microcystis bloom in the Patos Lagoon estuary, Brazil. Phytochemistry, 55, 383-387. 
MATTHIENSEN, A.; YUNES, J.S.; COOD, G.A. (1999). Ocorrência, distribuição e toxicidade de cianobactérias no Estuário da Lagoa dos Patos, RS. Revista Brasileira de Biologia, Rio de Janeiro, v.59, n.2, p.1-15.

MEANS III, E. G., MCGUIRE, M. J. (1984). AN EARLY WARNING SYSTEM FOR TASTE AND ODOR CONTROL JAWWA, vol. 76, n. 3, p: 77-83, Mar., USA.

MEGDA, C. R (1999). Filtração direta ascendente em pedregulho como pré-tratamento à filtração rápida descendente. São Carlos. 170 p. Dissertação (mestrado) - Escola de Engenharia de São Carlos, Universidade de São Paulo.

MERILUOTO, J.AND CODD, G. A., (2005). Cyanobacterial monitoring and cyanotoxin analysis. Åbo Akademi University Press.149 pp

MINILLO, A. (2005). Análise da distribuição, densidade e toxicidade de florações de cianobactérias e suas toxinas nos reservatórios do Médio e Baixo rio Tietê (SP) e relação com as características limnológicas do sistema. 400p. Tese (Doutorado em Ciências da Engenharia Ambiental) - Escola de Engenharia de São Carlos, Universidade de São Paulo, São Carlos, 2005.

MOED, J.R. \& HALLEGRAEFF, G.M. (1978) Some problems in the estimation of chlorophyll-a and pheo pigments from pre and postacidification: spectrophotometric measurements. Int. Rev. Gesamten Hydrobiol. V.63 pg787-800.

MOHAMED, Z.A.; CARMICHAEL, W.W.; AN, J.; EL-SHAROUNY, H.M. (1998). Activated Carbon Removal Efficiency of Microcystins in Aqueous Cell Extract of Microcystis aeruginosa and oscillatoria tenuis Strains Isolated from Egiptian Freshwaters. ed. England: John Wiley \& Sons. 197.

MONDARDO, R. I. (2004) Influência da Pré-oxidação na Tratabilidade das Águas Via Filtração Direta Descendente em Manancial com elevadas Concentrações de Microalgas e Cianobactérias, Dissertação de Mestrado em Engenharia Ambiental UFSC, Florianópolis, Brasil.

NG, C.; LOSSO, J.N.; MARSHALL, W.E.; RAO, R.M. (2002). Freundlich adsorption isotherms of agricultural by-product-based powdered activated carbons in geosmin-water system. Bioresource technology, v. 85, p. 131-135. 
NICHOLSON, B.C.; ROSITANO, J.; BURCH, M.D. (1994). Destruction of cyanobacterial peptide hepatotoxins by chlorine and chloramine. Water Research, v.28, n.6, p.1297-1303.

NIZAN, S.; DIMENTMAN, C. \& SHILO, M. (1986). Acute toxic effects of the cyanobacterium Microcystis aeruginosa on Daphnia magna. Limnol. Oceanogr., v.3, n.31, p.497-502, 1986.

NOGUEIRA, P.F.M. Consumo e influencia de polissacarideos excretados por Anabaena spiroides (Cyanophyceae) sobre a toxidade e bioacumulacao de cobre em Simocephalus serrulatus (Cladocera, Daphnidae). 2002. 51p. Dissertação (Mestrado em Ecologia e Recursos Naturais) - Centro de Ciências Biológicas e da Saúde, Universidade Federal de São Carlos, São Carlos, 2002.

NUSCH, E. A. (1980). Comparation of different methods for chlorophyll and phaeopigment determination. Arch. Hydrobiol. Beih. Stuttgart, 14: 14-36.

OKUMURA, D.T.; SOTERO-SANTOS, R.B.; TAKENAKA, R.A.; ROCHA, O. (2006). Evaluation of cyanobacteria toxicity in tropical reservoirs using crude extract bioassay with cladocerans. Ecotoxicology (no prelo).

OLIVEIRA, A. C. P. (2003). Efeitos de fatores físicos, químicos e biológicos no processo de degradação de e remoção de microcistinas. 147 p. Tese (Doutorado) - Centro de Ciências da Saúde, Universidade Federal do Rio de Janeiro.

OLIVEIRA, A.C.P.; SAMPAIO, G.F.; GÔMARA, G.A. (2003). Detecção de hepatotoxinas e neurotoxinas (toxinas de cianobactérias) no reservatório do Funil. In: CONGRESSO BRASILEIRO DE LIMNOLOGIA, 9., 2003, Juiz de Fora. Secções de painéis.

PASCHOALATO, C. F. P. R. (2005). Efeito da Pré-oxidação, Coagulação, Filtração e PósCloração na Formação de Subprodutos Orgânicos Halogenados. Tese de Doutorado; Escola de Engenharia de São Carlos - USP, São Carlos, Brasil.

PENDLETON, P.; SCHUMANN, R.; WONG, S. H.; (2001). Mycrocystin-LR adsorption by activated carbon. Journal of Colloid and Interface Science 240, 1-8.

PERSSON, P.E. (1996). Cyanobacteria and off-flavours. Phycology, v.35, p.168-71, 1996.

PETRUSEVSKY, N. A.; VAN BREEMEN, N. A.; ALAERTS, G. J. (1996). Effect of 
permanganate pre-treatment and coagulation with dual coagulants on algal removal in direct filtration. Journal Water SRT - Aqua, v.45, n.5, p.316-326.

PORRA, R. J. (2002). The chequered history of the development and use of simultaneous equations for the accurate determination of chlorophylls a and b. Photosynthesis Research v.73, pg 149-156.

RAI, H. (1980). Some problems in determination of photosynthetic planktonic pigments and their decomposition products. Arch. Hydrobiol. Bech. Stuttgart. v.14. p.3-13.

RAMAMOORTHY, S. (1988). Effect of $\mathrm{pH}$ on speciation and toxicity of aluminum to rainbow trout (Salmo gairdneri). Canadian Journal of Fisheries and Aquatic Science, v.45, n.4, p.634-642, 1988.

RATTNER, B.A.; HEATH, A.C. (1995). Environmental factors affecting contaminant toxicity in aquatic and terrestrial vertebrates. In: HOFFMAN, D.J.; RATTNER, B.A.; BURTON Jr., G. A.; CAIRNS Jr., J., eds. Handbook of Ecotoxicology. Boca Raton, Lewis Publishers.

REINIKAINEN, M.; KETOLA, M.; WALLS, M. (1994). Effects on the concentrations of toxic Microcystis aeruginosa and an alternative food on the survival of Daphnia pulex. Limnol. Oceanogr., v.2, n.39, p.424-432.

RINEHART, K.L.O; NAMIKOSHI, M.; CHOI, B.W. (1994). Struture and biosynthesis of toxins from blue-green algae (cyanobacteria). Journal of Applied Phycology, Dordrecht, v.6, n.2, p.159-176.

SÁ, J. C. (2002). Remoção de Microcystis aeruginosa e microcistina pelo processo de filtração lenta. Dissertação de Mestrado, Publicação PTARH.DM-48/02 Departamento de Engenharia Ambiental, Universidade de Brasília, DF, 115p.

SAKSHAUG, E. (1981). Problems in the methodology of studying phytoplankton. In MORRIS, I. (Ed) Physiological ecology of phytoplankton. Balckwell, Oxford. P 57-94.

SALES, M. V. (2005). Tratamento de Água Eutrofizada por Meio da Dupla Filtração e Oxidação. Universidade Federal do Ceará, Fortaleza, CE, Brasil.

SANT'ANNA, C.L. e AZEVEDO, M.T.P. (2000). "Contribution to the knowledge of 
potentially toxic Cyanobacteria from Brazil.” Nova Hedwigia. 71(3-4), pp. 359-385.

SARTORY, D.P. \& GROBBELAAR, J.U. (1984) The determination of algal chlorophyllous pigments by high performance liquid chromatography and spectrophotometry. Water Res. V.19 pg605-610.

SENS, M. L., DALSASSO, R. L., MELO FILHO, L. C., MONDARDO, R. I., SIMIONI, D. BÖEL, H., EMMENDOERFTER, M. (2003) Filtração Direta Descendente com Préfloculação em Meio Granular Expandido - Aspectos Hidráulicos e Produtivos - Relatório de Atividades do PROSAB - Programa de Pesquisa em Saneamento Básico - Edital 3 - Tema 1 - Técnicas de Baixo Custo para Potabilização de Águas: Filtração Direta Aplicada a Pequenas Comunidades - Continuidade - FINEP

SIMON, D. \& HELLIWELL, S. (1998). Extraction and quantification of chlorophyll a from freshwater green algae. Water Res. V.12, No7, pg2220-2223.

SINGER, P. C. Control of Disinfection By-Products in Drinking Water JEE-ASCE, vol. 120, n. 4, p: 727-744, Aug. 1994, USA.

SOTERO-SANTOS, R.B.; SOUZA E SILVA, C.R.; VERANI, N.F.; NONAKA, K.O.; ROCHA, O. Toxicity of a cyanobacteria bloom in Barra Bonita Reservoir (Middle Tietê River, São Paulo, Brazil). Ecotoxicol. Environ. Safe, v.64, p.163-170, 2006.

STEWART, A.J.; HILL, W.R.; HAM, K.D.; CHRISTENSEN, S.W.; BEAUCHAMP, J.J. Chlorine dynamics and ambient toxicity in receiving streams. Ecological Applications, v.6, n.2, p.458-471, 1996.

TAKENAKA, R.A.; SOTERO-SANTOS, R.M.B.; OKUMURA, D. T.; KURODA, E. K.; DI BERNARDO, L. (2005). Uso de bioensaios na avaliaçao de tecnologias de tratamento de água para a remoçao de células e toxinas de Microcystis spp. I-071. In: XXIII Congresso Brasileiro de Engenharia Sanitária e Ambiental, Campo Grande - MS, set 2005.

TAKENAKA, R.A.; SOTERO-SANTOS, R.M.B.; ROCHA, O. (2006). Water quality assessment by ecotoxicological and limnological methods in water supplies, southeast Brazil. Ecotoxicology, 15(1), 73-82.

THOSTRUP, L.; CHRISTOFFERSEN, K. (1999). Accumulation of microcystin in Daphnia 
magna feeding on toxic Microcystis. Arch. Hydrobiol., v.145, n.4, p.447-467, 1999.

TSUJI, K.; NAITO, S.; KONDO, F.; WATANABE, M.F.; SUZUKI, S.; NAKAZAWA, H.; SUZUKI, M.; SHIMADA, T.; HARADA, K. (1994). A clean-up method for analysis of trace amounts of microcystins in lake water. Toxicon, v. 32, no 10, pp. 1251-1259.

UENO, Y.; MAKITA, Y.; NAGATA, S.; TSUTSUMI, T.; YOSHIDA, F.; TAMURA, S.I.; SEKIJIMA, M.; TASHITO, F.; HARADA, T.; YOSHIDA, T. No chronic oral toxicity of a low dose of microcystin-LR, a cyanobacterial hepatotoxin, in female BALB/c mice. Environmental Toxicology, v.1, n.14, p.45-55, 1999.

UNITED STATES ENVIRONMENTAL PROTECTION AGENCY - USEPA (1995). Method 551.1. Determination of chlorination disinfection byproducts, chlorinated solvents, and halogenated pesticides/herbicides in drinking water by liquid-liquid extracion and gas chromatografhy with electron-capture detection. CD-ROM Review 1. Sept, Ohio, USA.

UNITED STATES ENVIRONMENTAL PROTECTION AGENCY - USEPA (1995). Method 552..2 Determination of haloacetic acids and dalapon in, in drinking water by liquid-liquid extracion, derivatization and gas chromatografhy with electron-capture detection. CD-ROM Review 1. Sept, Ohio, USA.

UNITED STATES ENVIRONMENTAL PROTECTION AGENCY - USEPA (1999). Alternative disinfectants and oxidants guidance manual. Washington.

UTHERMÖHL, H. (1958). On the perfecting of quantitative phytoplankton method. Int. Ass. Theor. Appl. Limnol. Commun. v.9

VASCONCELOS, V. (1991). Impacte de estirpes tóxicas e nao tóxicas da cianobactéria Microcystis aeruginosa em espécies zooplanctônicas. Revista de Biologia de la Universidade de Aveiro, v.4, p.211-221.

VASCONCELOS, V. (1999). Cyanobacterial toxins in Portugal: effects on aquatic animals and riskfor human health. Braziliam Journal of Medical and Biological Research, 32: 249254.

VASCONCELOS, V.M.; ARAÚJO, F.O. (1994). Cianobactérias: um risco para o ambiente e para a saúde humana. Portugal: Ministério da Saúde. 1994, 24p. 
VIEIRA, A.A.H. (2002). Produção e destino dos polissacarídeos extracelulares de origem algal em um reservatório eutrofizado do rio Tietê: estudos de processos. Reunião Brasileira de Ficologia, 9., 2002, Aracruz. Resumos. Aracruz: Sociedade Brasileira de Ficologia. p.35.

VLASKI, A.; VAN BREEMAN, A.N. E ALAERTS, G.J. (1996). Optimisation of coagulation conditions for the removal of cyanobacteria by dissolved air flotation or sedimentation. Journal Water SRT-Aqua, 45(5), pp. 253-261.

VLASKI, A; BREEMEN, A. N.; ALAERTS, G. J. F. R. (1994). Algae and water treatment in the Netherlands.- Problem Analysis and Treatment Strategies in Five Water Companies. IHE DELFT. TUDelft.

WARHURST, A. M.; McCONNACHIE, G. L.; POLLARD, S. J. T. (1997). Characterization and applications of activated carbon produced from moringa oleifera seed husk by synglestep steam pirolysis. Water Research, v. 31, n. 4, p. 759-766.

WEBB, P.A.; ORR, C. (1997). Analytical methods in fine particle technology. Micromeritics Instrument Corp., Norcross.

WIECHETECK, G., K. (2005). Remoção de Substâncias Húmicas em Tratamento de Água por Meio da Pré-oxidação e Dupla Filtração São Carlos, Tese de Doutorado, Escola de Engenharia de São Carlos da Universidade de São Paulo.

WOOD, L. W. (1985) Chloroform-Methanol Extraction of Chlorophyll a. Can. J. Fish. Aquat. Sci. 42:38-43.

YOO, R.S.; CARMICHAEL, W.W.; HOEHN, R.C. e HRUDEY, S.E. (1995). Cyanobacterial (Blue-Green Algal) toxins: A resource guide. AWWA Research Foundation and American Water Works Association. 229 p. 